\title{
IntechOpen
}

\section{Ecosystem and Biodiversity of Amazonia}

Edited by Heimo Juhani Mikkola

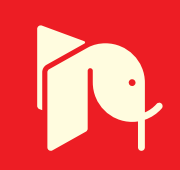





\section{Ecosystem and Biodiversity of Amazonia}

Edited by Heimo Juhani Mikkola 

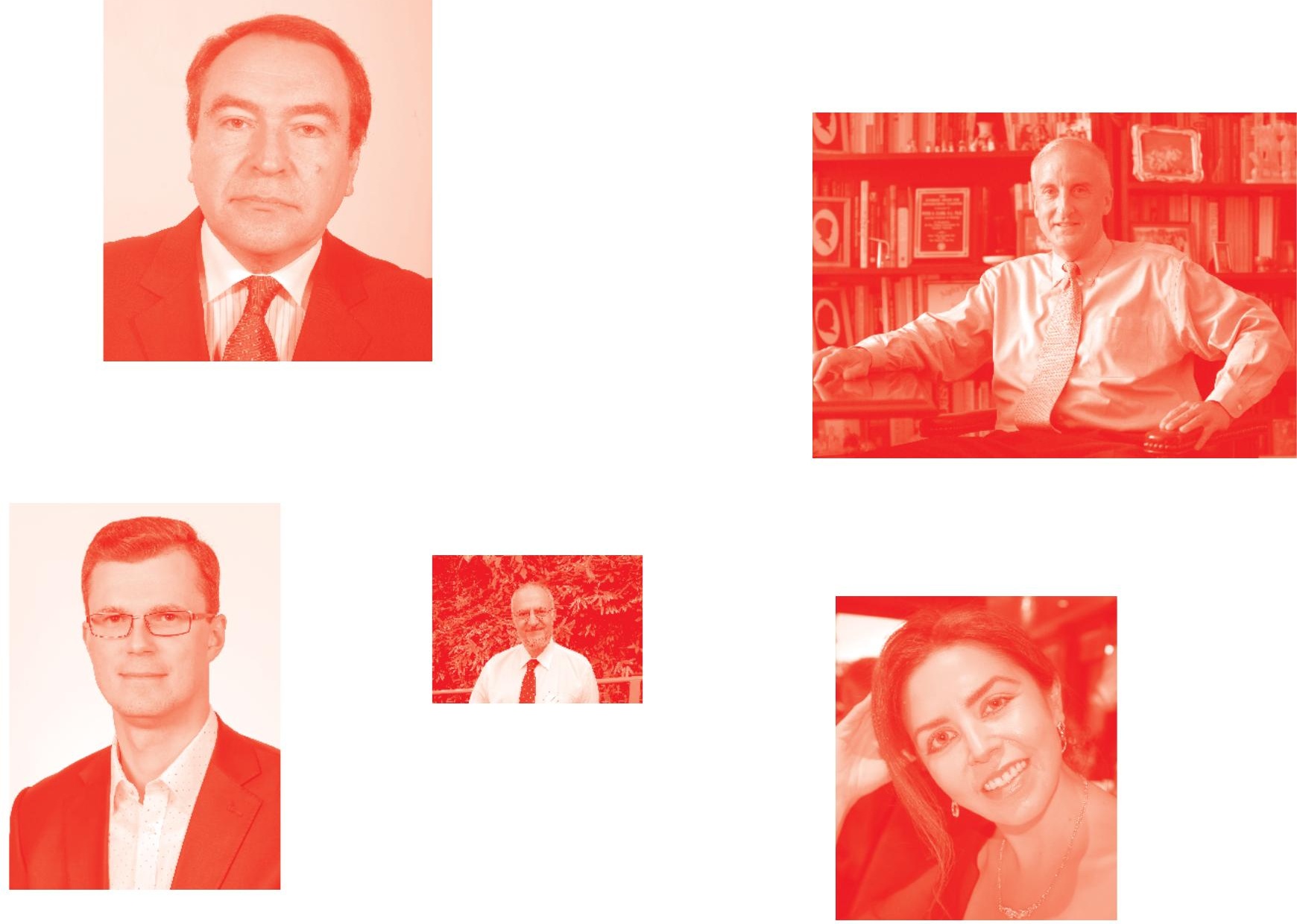

Supporting open minds since 2005
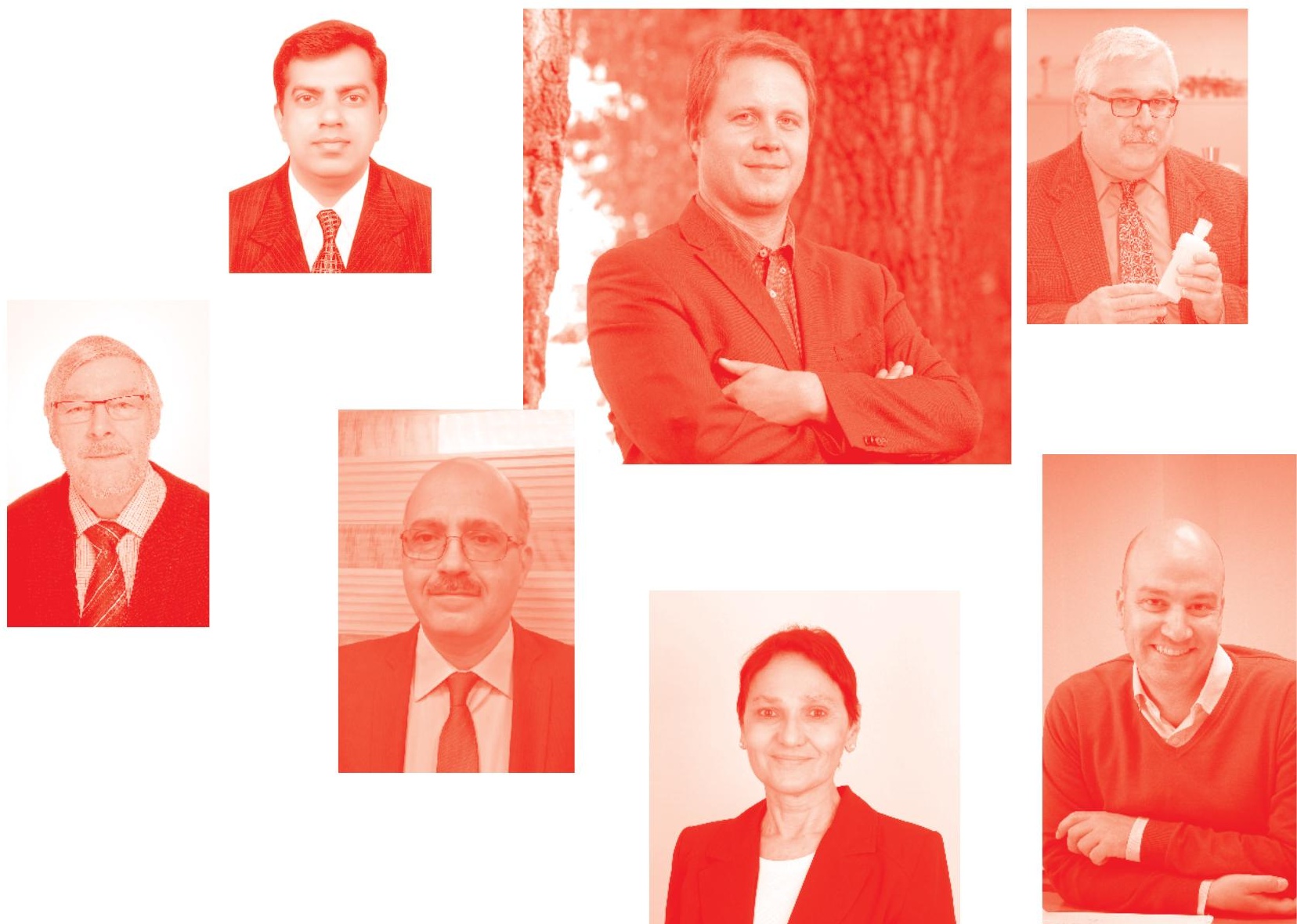
Ecosystem and Biodiversity of Amazonia

http: //dx . doi. org/10.5772/intechopen. 91089

Edited by Heimo Juhani Mikkola

\section{Contributors}

Gabriela N. Nicoleta Tenea, Pablo Jarrin-V, Lucia Yepez, Paola González Carvajal, Klaus Hilbert, Jens Soentgen, Natali Gomes Bordon, Niwton Leal Filho, Tony Vizcarra Bentos, Gelson Dias Dias Florentino, Lucieta Guerreiro G. Martorano, José Reinaldo Da Silva Cabral De Moraes, Sandro Augusto Lima dos Santos, Ires Paula de Andrade Miranda, Maria De Lourdes Pinheiro Ruivo, Hermes R. Luz, Thiago F. Martins, Sebastián Muñoz-Leal, Francisco B. Costa, Sérgio L. Gianizella, João Luiz H. Faccini, Marcelo B. Labruna, Alexandre Guida Navarro, Pedro Pablo Cardoso Castro, Niriva Ravena, Zoran Stiperski, Tomica Hruška, Anna Kanele, Claude François Béguin, Heimo Juhani Mikkola

\section{() The Editor(s) and the Author(s) 2021}

The rights of the editor(s) and the author(s) have been asserted in accordance with the Copyright, Designs and Patents Act 1988. All rights to the book as a whole are reserved by INTECHOPEN LIMITED. The book as a whole (compilation) cannot be reproduced, distributed or used for commercial or non-commercial purposes without INTECHOPEN LIMITED's written permission. Enquiries concerning the use of the book should be directed to INTECHOPEN LIMITED rights and permissions department (permissions@intechopen.com).

Violations are liable to prosecution under the governing Copyright Law .

\section{(cc) BY}

Individual chapters of this publication are distributed under the terms of the Creative Commons Attribution 3.๑ Unported License which permits commercial use, distribution and reproduction of the individual chapters, provided the original author(s) and source publication are appropriately acknowledged. If so indicated, certain images may not be included under the Creative Commons license. In such cases users will need to obtain permission from the license holder to reproduce the material. More details and guidelines concerning content reuse and adaptation can be found at http : //www . intechopen . com/copyright-policy . html .

Notice

Statements and opinions expressed in the chapters are these of the individual contributors and not necessarily those of the editors or publisher. No responsibility is accepted for the accuracy of information contained in the published chapters. The publisher assumes no responsibility for any damage or injury to persons or property arising out of the use of any materials, instructions, methods or ideas contained in the book.

First published in London, United Kingdom, 2021 by IntechOpen

IntechOpen is the global imprint of INTECHOPEN LIMITED, registered in England and Wales, registration number: 11086078 , 5 Princes Gate Court, London, SW7 2QJ, United Kingdom Printed in Croatia

British Library Cataloguing-in-Publication Data

A catalogue record for this book is available from the British Library

Additional hard and PDF copies can be obtained from orders@intechopen. com

Ecosystem and Biodiversity of Amazonia

Edited by Heimo Juhani Mikkola

p. $\mathrm{cm}$.

Print ISBN 978-1-83962-812-2

Online ISBN 978-1-83962-813-9

eBook (PDF) ISBN 978-1-83962-814-6 


\section{We are IntechOpen, \\ the world's leading publisher of Open Access books}

Built by scientists, for scientists

\section{$5,200+$}

Open access books available

156

Countries delivered to
$128,000+$

International authors and editors

Our authors are among the

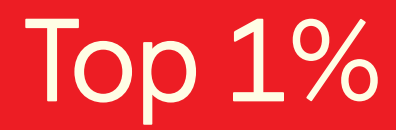

most cited scientists

Contributors from top 500 universities
$150 \mathrm{M}+$

$12.2 \%$

\section{Interested in publishing with us? \\ Contact book.department@intechopen.com}

Numbers displayed above are based on latest data collected.

For more information visit www.intechopen.com

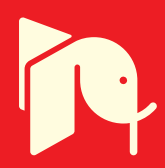





\section{Meet the editor}

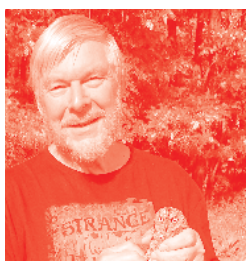

Heimo Mikkola, Ph.D., has more than 35 years of experience in sustainable development through working with growing responsibilities in international organizations, in particular the African Development Bank, European Union, United Nations System and the World Bank. Dr. Mikkola received his Ph.D. from the University of Kuopio, Finland. He has visited and worked in 133 countries (46 of those in Africa). In South America, he worked with the Food and Agriculture Organization of the United Nations in Colombia and Uruguay visiting also Brazil, Chile, Costa Rica, Cuba, Curaçao, Guadeloupe, Panama and Venezuela. Since 1988 Dr. Mikkola has been an adjunct professor at Eastern Finland University. Between 2010 and 2018, he served as a visiting professor at three different universities in Almaty, Kazakhstan and one in Bishkek, Kyrgyzstan. He has published more than 660 zoological papers and texts and has edited seven books. 



\section{Contents}

Preface

Section 1

Animal and Plant Diversity

Chapter 1

Diversity of the Owl Species in the Amazon Region

by Heimo Juhani Mikkola

Chapter 2

Microbiota of Wild Fruits from the Amazon Region of Ecuador:

Linking Diversity and Functional Potential of Lactic Acid Bacteria with Their Origin

by Gabriela N. Tenea, Pablo Jarrin-V and Lucia Yepez

Chapter 3

Ticks from the Brazilian Amazon: Species, Distribution and

Host-Relations

by Hermes R. Luz, Thiago F. Martins, Sebastián Muñoz-Leal, Francisco B. Costa, Sérgio L. Gianizella, João Luiz H. Faccini and Marcelo B. Labruna

Chapter 4

Ecology of the Seed Bank in the Amazon Rainforest

by Natali Gomes Bordon, Niwton Leal Filho and Tony Vizcarra Bentos

Chapter 5

The Nymph Architect of the Cicada Guyalna chlorogena:

Behaviours and Ecosystem

by Claude François Béguin

Section 2

Human Culture and History

Chapter 6

Shipibo Conibo and Chilean Diaguita Visual Art: Cognitive Technologies, Shamanism and Long-Distance Cultural Linkages by Paola González Carvajal 
From the "Terra Preta de Indio" to the "Terra Preta do Gringo":

A History of Knowledge of the Amazonian Dark Earths

by Klaus Hilbert and Jens Soentgen

Chapter 8

Ecology as Cosmology: Animal Myths of Amazonia

by Alexandre Guida Navarro

\section{Section 3}

Development Opportunities and Problems

Chapter 9

Bioeconomic Potential of Sustainability Indicators in a Ceramic

Production Center in the Western Amazon

by Gelson Dias Florentino, Lucieta Guerreiro Martorano,

Sandro Augusto Lima dos Santos, José Reinaldo da Silva Cabral de Moraes, Ires Paula de Andrade Miranda and Maria de Lourdes Pinheiro Ruivo

Chapter 10

Neo-Developmentalism and Regional Integration: IIRSA Impact in the

Environmental Agenda in the Amazon

by Pedro Pablo Cardoso Castro and Nirvia Ravena

Chapter 11

Social Changes in the Peruvian Amazon Due to Foreign Influence by Zoran Stiperski and Tomica Hruška

Chapter 12

Quilombo Communities and Opportunities for Market-Driven

Mechanisms for the Protection of the Amazon Forest

by Anna Kanele and Pedro Pablo Cardoso Castro 


\section{Preface}

"If humans continue to cut down the Amazon, the forest may start to die off in the 2030s, destabilising South America and the world."

David Attenborough in his book A Life on Our Planet [1].

The Amazon River is the largest in the world in terms of volume and second only to the Nile in length. The climate is very warm and humid resulting in the largest tropical rainforest, which represents more than half of the world's remaining rainforests [2]. It includes parts of eight South American countries: Bolivia, Brazil, Colombia, Ecuador, French Guiana, Guyana, Suriname and Venezuela. The Amazon basin covers roughly 634 million hectares, but only 529 million hectares are classified as primary forest [3]. The basin is named after the river, known in Spanish and Portuguese as 'Rio Amazonas'. That name was derived from a tribe of mighty women warriors, 'Amazons', in ancient Greek mythology [4] because back then several tribes in the region practiced headhunting for trophies [5].

The first humans migrated from Central America to the Amazon region some 13,000 years ago [6]. Francisco de Orellana was the first European to travel the length of the Amazon River [7] and found there a complex civilization in the 1540s. It is suggested that up to 10 million indigenous people lived in fortified settlements, creating ceremonial artworks and growing food in small fields. Unfortunately, that civilization was later devastated by the spread of diseases originating from Europe such as measles, smallpox and typhus.

The Amazon rainforest is an ecosystem with vertical layers differing in plants and wildlife. Trees form the forest canopy with the dense top layer shading the trees below. The next layer includes shade-tolerant shrubs that cover the lower herbaceous plants. All large mammals, many small mammals, and a few birds live at ground level, but most of the birds and all of the bats live among the upper layers. Various insects inhabit all layers, but most species inhabit the top layers. Many of the species and much of the ecology of this ecosystem remain unknown [8].

In this introduction, I attempt to answer several questions [cf. 3 and 9] about the Amazon region.

Are the Amazon rainforests Earth's lungs?

The Amazon rainforest is often referred to as the "lungs of the planet." It produces oxygen through photosynthesis in the daytime but absorbs a lot of oxygen at night via respiration. Therefore, the rainforest is not a real net producer of oxygen. It does, however, absorb carbon dioxide, which is a greenhouse gas; hence why the word 'lungs' is often used. Through transpiration, the rainforest releases large amounts of moisture into the atmosphere. This helps stabilize the global climate, generating rainfall at local, regional, and trans-continental scales [3]. Ricardo Galvão, former head of Brazil's National Institute for Space Research (INPE), rightly concluded: "If the Amazon is destroyed, it will be impossible to control global warming"[6]. 
What causes fires in the Amazon?

Fires result from either natural lightning or intentional setting by people. At least 75 percent of fires are due to human activities like farming and logging, which allow fires to spread from dry areas into the rainforest.

Shifting agriculture and cattle ranches are responsible for $80-85$ percent of deforestation in the Amazon [10]. Deforestation increases the vulnerability of rainforests to fire as it dries out the forest interior.

Climate change is largely contributing to this worsening situation, as it leads to increasing average temperatures and larger and more frequent fires during the dry season. If farmers, ranchers, and land speculators start fires, these fires can easily move to the rainforest. A vicious circle is taking place as fires also reinforce global warming [11].

According to INPE, 93,485 fires have been recorded in the Brazilian rainforest in 2020 prior to November, which is 25 percent more than in the same period in 2019 [12].

Why is the Amazon rainforest in danger?

Cattle ranching and soy plantations in massive landholdings of thousands of acres are the dominant drivers of deforestation in the Amazon. New threats emerge from palm oil plantations, illegal mining, and hydropower development [13]. Forest degradation due to unsustainable selective logging practices may not be the largest problem. It is more likely that accelerating deforestation is a real concern because it may affect the global climate. If climate warming continues, a large part of the Amazon could change from rainforest to savanna. This shift would mean huge economic and ecological consequences in the form of rainfall losses. Normally rain falls for 200 days each year, and total rainfall exceeds 80 inches per year [2]. Current rains feed the region that produces two-thirds of South America's GDP and their absence would trigger large carbon emissions from forest die-off. These emissions will further worsen climate change [3].

How much of the Amazon rainforest has been destroyed?

Brazil has the power to save the greatest rainforest - or destroy it [14]. It seems that South America's natural wonder may be perilously close to the tipping point beyond which its gradual transformation into something closer to the steppe cannot be stopped or reversed, even if people lay down their axes. An area equivalent in size to Turkey and bigger than that of Texas has been lost to logging, farming, mining, roads, dams, and other forms of "development." Between August 2017 and July 2018, Brazil lost $7900 \mathrm{~km}^{2}$ of Amazon forest and nearly a billion trees [15]. During the following reporting period of the INPE, the forest loss was $9205 \mathrm{~km}^{2}$ from August 2018 to July 2019. Due to soaring levels of illegal deforestation, the July 2020 figures from the Brazilian Amazon alone showed a 28 percent increase in the number of fires over the same period in the year before. The INPE recently reported that between August 2019 and July 2020 a total of $11,088 \mathrm{~km}^{2}$ of rainforest were lost in Brazil; this being the greatest deforestation rate since 2008 [16]. Now the World Wildlife Fund (WWF) calls for immediate emergency measures to be implemented to ban deforestation in the Amazon for five years [11].

How do we stop the global and Amazon deforestation? 
The restoration of forested land at a global scale is likely to be the most effective strategy to limit the rise of atmospheric carbon and mitigate climate change [17]. It is promising that some organizations around the world are planting trees at an unprecedented rate in a bid to combat global heating. For example, TreeSisters is planting 2.2 million trees each year across Africa as well as Brazil. The International Tree Foundation (ITF) is supporting local charities to work with local women to establish small nurseries of native trees at the forest fringe. These native trees are then planted directly into deforested areas. Women are the primary caretakers and can drive massive change; planting trees will make their lives better [18]. Although there is no doubt that the restoration of trees is a good strategy for climate change mitigation and wildlife conservation [17], it is important to decide the kinds of trees as well as how and where they are grown. In some contexts it has been shown that increasing tree cover can elevate fire risk if reforestation is achieved with singlespecies tree plantations, which decrease water supplies and can cause crop damage by wildlife. We must view restoration as a system and concentrate on restoring native forest ecosystems [19]. Avoiding forest fires if of utmost importance in the future, as smoke from burning forests in the Amazon has intensified glacier melt in Zongo Glacier in Bolivia fueling concern about a water crisis in South America [20]. Since the 1970s, the Peruvian Andes have lost nearly half their glacier-ice surface area. This impacts hundreds of thousands of people who use glacier water for agriculture and hydropower. In addition, the Patagonian ice fields between Chile and Argentina are melting at a very fast rate [6].

Who owns the Amazon rainforest? Why can't we just buy it?

Within the eight countries covering parts of the rainforest, the land is privately owned or held by indigenous people in legally formed territories. Some parts are owned by collectives or are government-controlled public lands and protected national parks. Attempts to buy the entire Amazon are not viable, but sovereign nations of the region could be financially assisted in setting aside some lands for conservation. It is shown that the protected status of indigenous lands is an effective measure against deforestation [21].

I want to thank Author Service Manager Sandra Maljavac at IntechOpen for all her efforts during the preparation and publication of this book. Without her active but friendly attitude, many important chapters would not have come to be.

Heimo Mikkola
University of Eastern Finland,
Kuopio, Finland 


\section{References}

[1] Attenborough D. A Life on Our Planet: My Witness Statement and a Vision for the Future. London: Ebury Publishing; 2020. 272 p

[2] Keen C. Amazon Basin. 1997. Available from: https://www. greatestplaces.org/notes/amazon.html [Accessed: October 19, 2020]

[3] Butler RA. The Amazon Rainforest: The World's Largest Rainforest. 2020. Available from: https://rainforests. mongabay.com/amazon/ [Accessed: October 19, 2020]

[4] Taylor I. Names and Their Histories: A Handbook of Historical Geography and Topographical Nomenclature. London: Rivingtons; 1898. ISBN 978-0-559-29668-0

[5] Anonymous. Amazon's head hunters and body shrinkers. The Week. 2012. Available from: https://theweek.com/ articles/478804/amazons-head-huntersbody-shrinkers [Accessed: January 20, 2012]

[6] Sandy M. The Tipping Point. Time Magazine. 2019;23(Sept.):67-79

[7] Smith A. Explorers of the Amazon. Chicago: University of Chicago Press; 1994. ISBN 978-0-226-76337-8

[8] Dinesen C. The Ecosystem of the Amazon Rainforest. 2017. Available from: https://sciencing.com/ecosystemamazon-rainforest-6495612.html [Accessed: September 15, 2020]

[9] Phillips D, Camargos D.

Scorched earth. How do we stop the Amazon burning? The Guardian. 2020;15(May):28-29

[10] Salisbury DS, Schmink M. Cows versus rubber: Changing livelihoods among Amazonian extractivist. Geoforum. 2007;38:1233-1249. DOI: 10.1016/j.geoforum.2007.03.005

[11] World Wildlife Fund. 2020 Forest Fires Globally Could be Worse Than 2019, WWF Warns. WWF Press Release, August 27. 2020

[12] BBC 2020. Amazon fires: Yearon-year numbers doubled in October. BBC News Online November 2, 2020. Available from: https://www.bbc.com/ news/world-latin-america-54779877

[13] Yale University 2020. The Amazon Basin Forest. Available from: https:// globalforestatlas.yale.edu/region/ amazon [Accessed: October 19, 2020]

[14] Anononymous. Deathwatch. The Economist. 2019;3(August):9

[15] Nova Xavantina \& Santarém. Briefing The Amazon. On the brink. The Economist. 2019;3(August):16-18

[16] BBC 2020. Brazil's Amazon: Deforestation 'surges to 12-year high. BBC News Online December 1, 2020. Available from: https://www.bbc.com/ news/world-latin-america-55130304

[17] Bastin J-F, Finegold Y, Garcia C, Mollicone D, Rezende M, Routh D, et al. The global tree restoration potential. Science. 2019;365:76-79

[18] Barkham P. Can trees save the planet? The Guardian Weekly. 2019;2019(June):21-25

[19] Chazdon R, Brancalion P. Restoring forests as a means to many ends. Science. 2019;365:24-25

[20] Gill V. Amazon fires intensify Andes glacier melt. BBC Reel. 2019 
[21] Valqui M, Feather C, Espinosa Lanos

R. Revealing the Hidden-Indigenous

Perspectives on Deforestation in the

Peruvian Amazon - The Causes and

the Solutions. Lima, Peru: AIDESEP

(Inter-Ethnic Association for the

Development of the Peruvian Amazon)

and Moreton-in-Marsh: FPP (Forest

Peoples Programme); 2015. 127 p 

Section 1

Animal and Plant

Diversity 



\title{
Diversity of the Owl Species in the Amazon Region
}

\author{
Heimo Juhani Mikkola
}

\begin{abstract}
The Amazon basin is the largest tropical rainforest in the world covering almost 40 per cent of the South American continent. For centuries, its vastness and inaccessibility have been protecting this area. The general belief is that the Amazonia region has unparalleled biodiversity which means that one in five of all bird species known in the globe lives in the Amazon Jungle. The author is testing this claim against the known occurrence of the world owl species. There are fewer owl species in Amazonia than expected namely 34 (against 54 expected). Two possible reasons are that our knowledge of the Amazon region species is still incomplete as may be indicated that new owl species have been found recently. The other reason could be that the rainforest is not after all the most wanted biotope for many of the owl species which often depend on the prey available in the bottom tier of the forest which is flooded during the wet season. Whatever the reason is, more detailed research is needed on all species of the Amazon region as there must be many new owls and other animal species out there waiting to be discovered. We have no idea how many of those new species have been or will be lost due to the rainforest destruction before they can be discovered. Therefore, it is necessary to stop deforestation in the Amazonia, be it due to forest logging, uncontrolled fires (often deliberately set) agriculture expansion or industrial development. Deforestation is not the only reason that the Amazon basin is changing. The rainforest suffers also from the global climate change when the higher temperatures reduce the rainfall in the tropical Atlantic region, causing drought and increasing the fire susceptibility of the rainforest. Luckily the owls are not so sensitive to surrounding forest cover as many other tropical forest-dependent bird species, like the large-bodied avian frugivores. Impacts of forest fragmentation on owls will need additional research.
\end{abstract}

Keywords: Amazonia, conservation, owl species, number of wildlife species, climate change

\section{Introduction}

The history of geology tells us that at one time Amazon River flowed westward when it was still inside the Gondwana continent and part of the proto-Congo River system [1]. Later the African and South American continents separated and the Atlantic Ocean widened enough to provide a moist and warm climate to the Amazon region. The rainforest formed during the Eocene era between 56 and 34 million years ago [2]. The Andes have formed 15 million years ago and some 5 million years later the Amazon River began to flow eastward [1].

Now the Amazon River is the largest of the world's rivers in terms of water volume discharged into the sea, carrying more than five times the volume of the Congo River 
or twelve times that of the Mississippi River [1]. The Amazon River basin covers almost 40 per cent of the South American continent and the main river is some 4080 miles long, second only to the River Nile in length [3]. The Amazon river and its 1100 tributaries have a drainage area covering 2.7 million square miles belonging to nine nations: (the percentage share of each nation is shown in brackets) Bolivia (7.7\%), Brazil (58.4\%), Colombia (7.1\%), Ecuador (1\%), French Guiana (1.4\%), Guyana (3.1\%), Peru (12.8\%), Surinam (2.5\%) and Venezuela (6.1\%) [4]. Even in this book, the percentages vary as the perceived extent of the Amazon depends on the definition. Often people as well include areas outside the basin and that biogeographic Amazon ranges 3-3.2 million sq. mi, of which just over 80 per cent is forested [1]. Whatever definition is used the Amazon basin has the world's largest rainforest, bigger than the next two largest rainforests - in the Congo River basin and Indonesia - combined. The moist broadleaf forest comprises an estimated 390 billion individual trees representing some 16,000 species [5]. Billions of trees pump daily huge quantities of water vapour into the atmosphere. A large part of this water rains down locally, but part of this moisture is carried in the air to other areas including the agricultural heartland of South America. It has been estimated that two-thirds of Brazil's national product comes from the areas that receive Amazon rainforest generated rainfall [1].

It was for a long time a general belief that the Amazon rainforest has been always only sparsely populated by the humans due to the poor soils. Recent archaeological findings, however, suggest that the Amazon was earlier densely populated and that up to 5 million people were living in the region in 1500 AD. However, by 1900, the population had fallen to one million and by the early 1980s, it was estimated to be less than 200,000. Indigenous civilizations were devastated by the spread of new diseases like smallpox and typhus after the arrival of the first Europeans, in 1542 and after [6]. The UK broadcaster BBC 4 presented evidence that the Amazon rainforest has been shaped by humans for at least 11,000 years through activities like forest gardening and'terra preta' indigenous soil management, instead of being only a pristine wilderness [7]. In recent decades the human population has accelerated and incoming people have introduced mechanised agriculture and integrated the region into the global economy. Large quantities of the Amazon-produced commodities like cattle beef and leather, timber, soy, oil and gas, and minerals are sold to China, Europe, Russia and the U.S. [1].

\begin{tabular}{lcccc}
\hline $\begin{array}{l}\text { Number of plants/and } \\
\text { animal group species }\end{array}$ & $\begin{array}{c}\text { Butler/Mongabay } \\
{[\mathbf{1}]}\end{array}$ & $\begin{array}{c}\text { Wikipedia } \\
{[2]}\end{array}$ & $\begin{array}{c}\text { WWF } \\
{[9]}\end{array}$ & $\begin{array}{c}\text { Ascent of the } \\
\text { Amazon [10] }\end{array}$ \\
\hline Plant species & 40,000 & $\begin{array}{c}\text { At least } \\
40,000\end{array}$ & 40,000 & $\mathrm{Na}$ \\
\hline Mammals & $430+$ & 427 & 427 & More than 1400 \\
\hline Birds & 1300 & 1294 & 1300 & 1500 \\
\hline Fishes & 3000 & 2200 & ca. 3000 & 2200 \\
\hline Reptiles & $400+$ & 378 & 378 & $\mathrm{Na}$ \\
\hline Amphibians & $1000+$ & 428 & Over 400 & More than 1000 \\
\hline Invertebrates & $\mathrm{Na}$ & 96,660 & $\mathrm{ca}$. & $\mathrm{Na}$ \\
& & $-128,843$ & 100,000 & \\
\hline Insects & $\mathrm{Na}$ & 2.5 million & $\mathrm{Na}$ & $90 \%$ of all animal \\
& & & &
\end{tabular}

$\mathrm{Na}=$ Not available.

Table 1.

Biodiversity of Amazonia plant and wildlife [1, 2, 9, 10]. 
The wet forests in Amazon have consistently higher species diversity than any comparable forests in Africa and Asia [8]. The Amazonia Region is home to a large collection of living plants (40,000 or more) and animal species in the world. However, Table 1 above shows considerable discrepancies in the stated species diversity.

The largest discrepancies seem to be in the numbers of mammals and amphibians whilst the number of birds and reptiles is relatively uniform. It is possible that the highest numbers represent the number of South American species in its entirety and not just in Amazonia.

It has been said that one in ten known species in the world occurs in the Amazon region and one in five of all bird species are found in the Amazon rainforest [11]. The author knows best "Owls of the World" [12] and compares here how these statements hold for the world owls.

\section{Material and methods}

The history of owls in the Amazon region is far less known than that of human history. Fossil records of the Amazon owls are very few if any [13] so we do not know what kind of owls lived in the region before the present species. Even today, Amazonian owl species are not well known, and few studies have focused on the species from the region (see [14-24]. In the nine countries sharing the Amazon basin the number of owl species is on average 22 species ranging from 13 to 30 per country (Table 2 ).

However, it is important to note that only part of the above-listed owl species lives in the Amazon basin of that country. In the following, the scientific names are in the same form as in the "Owls of the World" [34] to avoid the complicated taxonomic discussions. In Bolivia, the tropical lowland evergreen forests are found in all the Amazonian ecoregions of the country. They represent the habitat with the second highest diversity of owls, with the following species: Tyto furcata, Mecascops choliba, M. watsonii, M. hoyi, M. guatemalae, Pulsatrix perspicillata, Bubo virginianus, Strix chacoensis, S. virgata, Glaucidium brasilianum and Aegolius harrisii [25]. In Brazil, there are five owl species, which occur exclusively in this biome: Megascops watsonii, M. usta, M. roraimae, Glaucidium hardyi and Lophostrix cristata [26]. From Colombian 28 owl species 10 are found in the Amazon area of the country. This corresponds well with the fact that in the Amazon region Colombia represents 30\% of the national territory. Amazon species include Tyto furcata, Megascops choliba, $M$.

\begin{tabular}{lcc}
\hline Country & Number of owl species & Source of information \\
\hline Bolivia & 25 & {$[24]$} \\
\hline Brazil & 23 & {$[25]$} \\
\hline Colombia & 28 & {$[26]$} \\
\hline Ecuador & 28 & {$[27]$} \\
\hline French Guiana & 13 & {$[28]$} \\
\hline Guyana & 16 & {$[29]$} \\
\hline Peru & 30 & {$[30]$} \\
\hline Suriname & 15 & {$[31]$} \\
\hline Venezuela & 22 & {$[32]$} \\
\hline Average 22. & & \\
\hline
\end{tabular}

Table 2.

A total number of owl species listed in the 9 countries sharing the Amazon basin. Sources of information [25-33]. 
watsonii, Lophostrix cristata, Pulsatrix perspicillata, Pulsatrix melanota, Strix virgata, Strix huhula, Glaucidium brasilianum, and Athene cunicularia [27]. In Ecuador, the rather homogenous forests of the Amazon lowlands are home to nine species mostly distributed throughout the entire region including Tyto furcata, Megascops choliba, M. watsonii, Lophostrix cristata, Pulsatrix perspicillata, Strix virgata, Strix huhula, Glaucidium brasilianum, and Asio clamator [28].

Unfortunately, there is no available specific study on owls in Guyana, Peru and Venezuela. Also in the French Guiana and Surinam the total of 13 and 15 owl species sounds very small and it is equally not well defined which owls live in the Amazon basin of the country.

The occurrence of different owl species in the comparison of this chapter is based entirely on the latest known distribution maps $[12,13]$ and no new field research was undertaken in the region. Therefore, especially in the Andean region, it was not so easy to decide which "Pacific side" owls may or may not belong to the Amazonian fauna. As all these owl distribution maps are still in a state of flux so one can expect that the total numbers may hold up very well as any mistakes have most likely been made in both directions.

\section{Results}

There are some 268 owl species in the world [12] and as Table 3. shows that a new Pygmy Owl (yet to be validated) has been discovered by Luis Fabio Silveira, Curator of Birds at the Museum of Zoology, the University of São Paulo by its call during an ongoing expedition to the Neblina National Park area, in Brazil. Provisionally this

\begin{tabular}{l}
\hline 1. American Barn Owl Tyto furcata LC Stable \\
\hline 2. Tropical Screech Owl Megascops choliba LC Stable \\
\hline 3. Maria Koepcke's Screech Owl (Koepcke's Screech Owl) Megascops koepckeae LC Stable \\
\hline 4. Peruvian Screech Owl Megascops roboratus LC Stable \\
\hline 5. Rufescent Screech Owl Megascops ingens LC Decreasing \\
\hline 6. Cinnamon Screech Owl Megascops petersoni LC Stable \\
\hline 7. Cloud-forest Screech Owl Megascops marshalli NT Stable but in Bolivia classified as vulnerable [24] \\
\hline 8. Northern Tawny-bellied Screech Owl Megascops watsonii LC Stable \\
\hline 9. Southern Tawny-bellied Screech Owl Megascops usta Na \\
\hline 10. Roraima Screech Owl (Foothill Screech Owl) Megascops roraimae Na \\
\hline 11. Rio Napo Screech Owl Megascops napensis Na \\
\hline 12. White-throated Screech Owl Megascops albogularis LC Stable \\
\hline 13. Great Horned Owl Bubo virginianus LC Stable \\
\hline 14. Magellanic Horned Owl (Magellan Horned Owl or Lesser Horned Owl) Bubo magellanicus Na \\
\hline 15. Spectacled Owl Pulsatrix perspicillata LC Stable \\
\hline 16. Band-bellied Owl Pulsatrix melanota LC Stable \\
\hline 17. Mottled Owl Strix virgata LC Decreasing \\
\hline 18. Rufous-banded Owl Strix albitarsis LC Stable \\
\hline 19. Black-and-White Owl Strix nigrolineata LC Stable \\
\hline 20. Black-banded Owl Strix huhula LC Decreasing \\
\hline 21. Crested Owl Lophostrix cristata LC Stable \\
\hline
\end{tabular}


Diversity of the Owl Species in the Amazon Region

DOI: http://dx.doi.org/10.5772/intechopen.94977

22. Amazonian Pygmy Owl Glaucidium hardyi LC Stable

23. Ferruginous Pygmy Owl Glaucidium brasilianum LC Decreasing

24. 'Neblina Pygmy Owl' Glaucidium spp. Nov. [35] Na

25. Subtropical Pygmy Owl Glaucidium parkeri LC Stable

26. Andean Pygmy Owl Glaucidium jardinii LC Stable

27. Yungas Pygmy Owl Glaucidium bolivianum LC Decreasing

28. Chaco Pygmy Owl (Tucuman Pygmy Owl) Glaucidium tucumanum Na

29. Long-whiskered Owl (Long-whiskered Owlet) Xenoglaux loweryi EN

30. Burrowing Owl Athene cunicularia LC Decreasing

31. Buff-fronted Owl Aegolius harrisii LC Stable but in Ecuador ranked as vulnerable [27]

32. Stygian Owl Asio stygius LC Decreasing

33. Striped Owl Asio clamator LC Decreasing

34. Short-eared Owl Asio flammeus LC Decreasing

Note that all listed 'species' are not, yet, fully approved by the taxonomists. Known conservation status is indicated for those species listed to be in danger [36]. $C R=$ Critical; $E N=$ Endangered; $L C=$ Least concern; $N a=$ No conservation status given $; T T=$ Near-threatened and $V U=$ Vulnerable .

Table 3.

List and scientific names of Amazon region owl species [12, 13] (+one new species proposed after 2012 and referenced separately in the table).

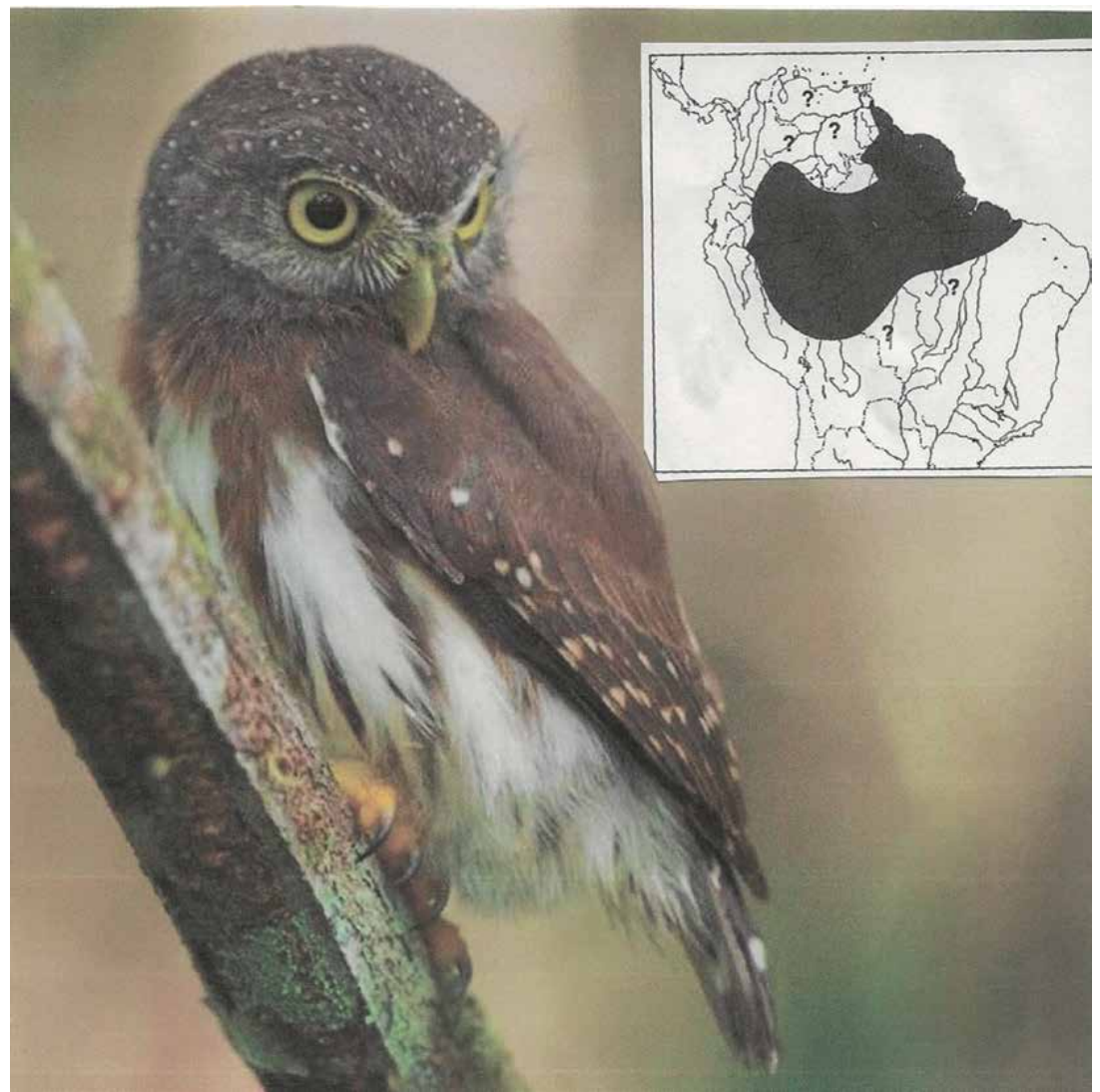

Figure 1.

Amazonian pygmy owl Glaucidium hardyi distribution map [from 34] with a scan of an excellent photo of Kurazo Okada from Macapá, Brazil. 
new owl has been named the 'Neblina Pygmy Owl' [35]. That brings the total of the world owl species to 269, so 34 species listed for Amazonia represent 12.6 per cent. Similarly, 88 owl species of the world lives in the Neotropical zone of the world. This is 32.7 per cent of the world species. Amazon Region owls make 38.6 per cent of the Neotropical owls, respectively $[12,13]$. There is only one owl species that has been nominated due to the region as Amazon Pygmy Owl Glaucidium hardyi. Its distribution map shows very well how difficult it is to know the exact limits of some species in the Amazon region (Figure 1). This tiny owl is difficult to observe in the rainforest canopy [12]. The latest book on Colombian owls [37] does not include this species, so the presented map extends a little too much to the west.

\section{Discussion}

Based on the assumption that one in five, i.e. 20 per cent of the world owl species should live in the Amazon Region we can see that the rainforest has twenty species less ( $34 v s$. 54) than expected. There can be at least two very distinct reasons for this. Firstly, we may not know, yet, all of the owl species living in the Amazon region. The practical limitations of calculating and identifying birds, especially night-time, mean that data collection is often very difficult if not impossible. This explanation is supported by the owl study difficulties summarised below:

\begin{tabular}{ll}
\hline Compared with other avian groups, owls are difficult to study & {$[13,38,39]$} \\
\hline Studying them is a challenge because......... & {$[13]$} \\
Owls are typically not covered by land bird monitoring programmes because of & {$[38]$} \\
\hline - they are uncommon & {$[13]$} \\
• their low densities & {$[38]$} \\
\hline - elusive behaviour & {$[38]$} \\
\hline - nocturnal habits & {$[13,38]$} \\
\hline - usually go unnoticed & {$[13]$} \\
- incomplete detectability or false absences & {$[39]$} \\
\hline - and live in places difficult to access & {$[13]$} \\
\hline
\end{tabular}

The second reason could be that the rainforest may not be the most ideal biotope for many of the owl species which often depend on the prey available in the bottom tier of the forest which is flooded during the wet season. The wet rainforest prey availability and catch-ability can be very different from the dry forest environment. In Ecuador, it has been noted that owl diversity is higher in forested ecosystems than in open areas and in humid forests than in dry forests. However, even in Ecuador the Pacific lowlands harbour more species than the Amazon lowlands [28] somewhat supporting my second reason. It gains further support at the end of the conclusions.

\section{Conclusions}

More detailed research is needed on all species of the Amazon region. Only a small percentage of the basin's plant life has been documented or studied for their potential medicinal value [40]. Much of the ecology of this ecosystem remains unknown, and one can suspect that there must be many new owls and other animal 
species out there waiting to be discovered. It may be the only area in the world where you can still hope to find a new owl species, as the recently found and not, yet, officially described new Glaucidium spp. Nov. owl shows (Table 3). Also, we will have no idea how many of those new species were or will be lost through rainforest destruction before they can be discovered. Therefore, stating the obvious, it is necessary to stop deforestation in the Amazon. South America's natural wonder may be perilously close to the tipping point beyond which its gradual transformation into something closer to steppe cannot be stopped or reversed, even if people lay down their axes. An area equivalent to the size of Turkey, and bigger than that of Texas has been lost to logging, farming, mining, roads, dams, and other forms of 'development'. Between only August 2017 and July 2018, Brazil lost 7900 km² of Amazon forest - nearly a billion trees - the highest rate of deforestation for a decade [41]. And in the following year in Brazil, alone, deforestation rose more than 88 per cent in June 2019 compared with the same month in 2018 [42]. Since then deforestation has again been steadily rising in the Brazilian Amazon, with deforestation alerts from August 2019 to July 2020 and is 33 per cent higher than in the same period of the previous year [43]. Unfortunately, it is not Brazil alone burning and deforesting the Amazon region. After two years in Colombia, I sadly concluded with my biologist wife that people in that country have very little respect for the forests and wildlife [44]. Since that time deforestation has increased especially in the Amazon region of the country. In 2017 alone, deforestation destroyed 60,300 hectares in Caquetá (one Amazon department) [45]. If current trends in the Amazon region continue, millions of extra tonnes of carbon dioxide will be released in the atmosphere with devastating long-term consequences. There will be immediate impacts like decimating biodiversity, and vital ecosystem destruction. The impact on regional economies could also be substantial due to the dramatic implications for regional rainfall, leading to drier conditions across South America's breadbasket and major urban areas [1]. Deforestation is not the only reason that the Amazon region is changing. Global climate change is having an important impact because the higher temperatures reduce the rainfall in the tropical Atlantic. This is causing regular drought periods over years thus increasing the susceptibility of the rainforest to fire [1]. This widespread devastation in the natural habitats is likely to have deleterious implications for the Amazon basin owl populations due to the sensitivity of many owl species to habitat disturbance [46]. A recent study in Ecuadorian owls found no relationship between species richness and the amount of surrounding forest cover [47] which tends to support my second hypothesis that the rainforest environment may not be the first choice of the owls. However, another concurrent study in Ecuador noted that the large-bodied frugivores birds in the same fragmented forests showed that frugivore richness corresponded strongly and positively to surrounding forest cover [48]. Clear discrepancies between different bird groups suggest that additional research is needed to evaluate how the impacts of forest fragmentation may vary among the bird guilds. 


\section{Author details}

Heimo Juhani Mikkola

University of Eastern Finland, Kuopio, Finland

*Address all correspondence to: heimomikkola@yahoo.co.uk

\section{IntechOpen}

(C) 2020 The Author(s). Licensee IntechOpen. This chapter is distributed under the terms of the Creative Commons Attribution License (http://creativecommons.org/licenses/ by/3.0), which permits unrestricted use, distribution, and reproduction in any medium, provided the original work is properly cited. (cc) BY 


\section{References}

[1] Butler, R.A. 2020. The Amazon Rainforest: The World's Largest Rainforest. https://rainforests. mongabay.com/amazon/ Accessed $18 / 10 / 2020$

[2] Wikipedia 2020. Amazon rainforest. https://en.wikipedia.org/wiki/Amazon_ Rainforest. Accessed 15/07/2020

[3] Keen, C. 1997. Amazon Basin. In Greatest Places Physical Geography. July 1997. https://www.greatestplaces. org/notes/amazon.html Accessed 18/10/2020.

[4] Coca-Castro, A., Raymondin, L., Bellfield, H. \& Hyman, G. 2013. Land use Status and Trends in Amazonia. https:// web.archive.org/web/201603191409931/ http://segamazonia.org/sites/default/ files/press_releases/land_use_status_ and_trends_in_amazonia.pdf Accessed $15 / 07 / 2020$

[5] Field Museum 2013. Field Museum scientist estimate 16,000 tree species in the Amazon. http://www. eurekalert.org/pub_releases/2013-10/ fm-fms101413.php Accessed 15/07/2020

[6] Smith, A. 1994. Explorers of the Amazon. University of Chicago Press, Chicago. ISBN 978-0-226-76337-8.

[7] BBC Four. 2011. Unnatural Histories - Amazon. http://www.bbc. co.uk/programmes/b0122njp.

[8] Turner, I.M. 2001. The ecology of trees in the tropical forest. Cambridge University Press, Cambridge. ISBN 0-521-801183-4

[9] WWF 2020. From the boa to leafcutter ant, and back to red piranha, Amazon wildlife comes in all shapes and sizes. https://wwf.panda.org/ knowledge_hub/where_we_work/ amazon/about_wildlife_amazon/ Accessed 15/07/2020
[10] Ascent of the Amazon 2020. Amazon Animals A-Z. https://www. ascentpftheamazon.com/learningresources/amazon-animals-a-to-z/ Accessed 15/07/2020

[11] World Wide Fund for Nature 2008. Amazon Rainforest, Amazon Plants, Amazon River Animals. http://www. worldwildlife.org/wildplaces/amazon/ index.cfm Accessed 15/07/2020

[12] Mikkola, H. 2013. Owls of the World. A Photographic Guide. $2^{\text {nd }}$ Revised Edition. - Bloomsbury/ Christopher Helm, London. 528 p.(ISBN: 978-1-4729-0593-2).(Also, in Canada and USA in 2014 by Firefly Books in Ontario and New York, ISBN13: 978-1-77085-274-7).

[13] Enriquez, P.L. (Ed.) 2017.

Neotropical Owls Diversity and Conservation. Springer International Publishing, AG. Cham, Switzerland. 670 p. (ISBN 978-3-319-57107-2). DOI 10.1007/978-3-319-57108-9.

[14] Barros, F.M. \& Cintra, R. 2009. The effects of forest structure on occurrence and abundance of three owl species (Aves: Strigidae) in the Central Amazon forest. Fortschr. Zool. 26(1): 85-96.

[15] Borges, S.H., Henriques, L.M. \& Carvalhaes, A. 2004. Density and habitat use by owls in two Amazonian forest types. J. Field. Ornithol. 75: 176-182.

[16] Mikkola, H. 2018. Again, a New Owl Species from Colombia - Santa Marta Screech Owl. Tyto March 2018: 6-10.

[17] Muñoz-Garcia, J., Castaño Vargas, C.C., Reyes-Bueno, S. \& RodríguezVillamil, D.R. 2019. Registros de reproducción y notas del cuidado parental de Ciccaba huhula en Colombia. Spizaetus 28: 15-20. 
[18] Padilla, O. 2019. Descripcíon de un evento de anidacíon del búho real (Bubo virginianus nacurutu Vieillot, 1817) y del búho moteado (Ciccaba virgata virgata Cassin, 1849) en Huila, Colombia. Intropica 14(1):1-8 DOI : 10.21676/23897864.2696.

[19] Penagos, A.P., Martínez, A. \& Rodríguez-Bolaños 2018. Nueve registro y ampliación de distribución del búho bicolor (Aegolius harrisii) en Colombia. Biota Colombiana 19(2): 140-146. DOI: 10.21068/c2018.v19n02a13.

[20] Restrepo Cardona, J.S., López Betancur, A. \& Córdoba-Córdoba, S. 2013. El Búho de Anteojos (Pulsatrix perspicillata) en Fragmentos de Bosque Seco del Valle de Río Cauca en Neira, Caldas, Colombia. Spizaetus 15: 19-24.

[21] Restrepo Cardona, J.S., López Betancur, A. \& Cano Castaño, N. 2015. Abundancia y nuevos registros de búhos simpátricos en Manizales y Villamaría (Caldas, Colombia). Bol. Cient. Mus. Hist. Nat. U. De Caldas 19(2): 220-229. DOI: $10.17151 / \mathrm{bccm} \cdot 2015.19 .2 .13$

[22] Restrepo Cardona, J.S., SáenzJiménez, F., Echeverry-Galvis, M.A., Marín-C, D. \& Poveda, J. 2019. Diet of the Great Horned Owl (Bubo virginianus) during the breeding season in the paramo of Laguna Corazón, Tolima, Colombia. Ornitologia Colombiana 17: 1-5 http:// associacioncolombianadeornitologia. org/ Accessed 15/02/2020

[23] Rodríguez-Villamil, D.R. 2018. Extensión de la distribución de Pulsatrix melanota (Strigidae) en el piedemonte llanero colombiano. Ornitología Colombiana 16: 1-6 http:// associacioncolombianadeornitologia. org/ Accessed 15/02/2020

[24] Seminario Moscol, L.E. \& Infante Castro, Y.I. 2018. Primer registro documentado de Búho Blanco y Negro (Ciccaba nigrolineata) en el bosque de
Suyo, Ayabaca, departamento de Piura, Perú. Boletín UNOP 13(1): 22-25.

[25] Méndez, D.R. 2017. The Owls of Bolivia. Chapter 5: 75-95. In: Enriquez, P.L. (Ed.) 2017. Neotropical Owls Diversity and Conservation. Springer International Publishing, AG. Cham, Switzerland. $670 \mathrm{p}$.

[26] Motta-Junior, J.C., Rocha Braga, A.C. \& Monteiro Granzinolli, M.A. 2017. The Owls of Brazil. Chapter 6: 97-158. In: Enriquez, P.L. (Ed.) 2017. Neotropical Owls Diversity and Conservation. Springer International Publishing, AG. Cham, Switzerland. $670 \mathrm{p}$.

[27] Chaparro-Herrera, S., CórdobaCórdoba, S., López-Ordoñez, J.P., Restrepo-Cardona, J.S. \& CortesHerrera, O. 2017. The Owls of Colombia. Chapter 9: 317-371. In: Enriquez, P.L. (Ed.) 2017. Neotropical Owls Diversity and Conservation. Springer International Publishing, AG. Cham, Switzerland. $670 \mathrm{p}$.

[28] Freile, J.F., Guevara, E.A., Pacheco, C. \& Santander, T. 2017. The Owls of Ecuador. Chapter 10:373-395. In: Enriquez, P.L. (Ed.) 2017. Neotropical Owls Diversity and Conservation. Springer International Publishing, AG. Cham, Switzerland. 670 p.

[29] Claessens, O., de Pracontal, N. \& Ingels, J. 2017. The Owls of French Guiana. Chapter 12: 419-445. In: Enriquez, P.L. (Ed.) 2017. Neotropical Owls Diversity and Conservation. Springer International Publishing, AG. Cham, Switzerland. 670 p.

[30] Wikipedia 2020. List of birds of Guyana https://en.wikipedia.org/wiki/ List_of_birds_of_Guyana Accessed 20/10/2020

[31] Wikipedia 2020. List of birds of Peru https://en.wikipedia.org/wiki/List_ of_birds_of_Peru Accessed 20/10/2020 
[32] Ramcharan, S. \& Ottema, O. 2017. The Owls of Surinam. Chapter 19: 633-644. In: Enriquez, P.L. (Ed.) 2017. Neotropical Owls Diversity and Conservation. Springer International Publishing, AG. Cham, Switzerland. $670 \mathrm{p}$.

[33] Wikipedia 2020. List of birds of Venezuela https://en.wikipedia. org/ wiki/List_of_birds_of_Venezuela. Accessed 20/10/2020

[34] König, C., Weick, F. \& Becking, J-H. 2011. Owls of the World. 2nd Reprinted Edition. - A\&C Black/ Christopher Helm, London.528 p. (ISBN: 978-0-7136-6548-2).

[35] BBC News 2018. A New Pygmy Owl species from Amazon. Amazon Discoveries 06/04/2018

[36] IUCN 2020. The IUCN Red List of Threatened Species. https://www. iucnredlist.org Accessed 20/10/2020

[37] Chaparro-Herrera, S., Enríquez, P.L. \& Lopera-Salazar, A. 2020. Búhos de Colombia Guía Ilustrada y Sonora. Puntoaparte Ltda, Bogota. 107 p.

[38] Fuller, M.A. \& Mosher, J.A. 1987. Raptor survey techniques. Pp. 37-65. In: Giron Pendleton, B.A., Millsap, B.A., Cline, K.W. \& Bird, D.M. (Eds.) 1987. Raptor management techniques manual. National Wildlife Federation, Washington, D.C., USA.

[39] Wintle, B.A., Kavanagh, R.P., McCarthy, M.A. \& Burgman, M.A. 2005. Estimating and dealing with detectability in occupancy surveys for forest owls and arboreal marsupials. Journal of Wildlife Management 69: 905-917.

[40] Dinesen Rogers, C. 2017. The Ecosystem of the Amazon Rainforest. https://sciencing.com/ecosystemamazon-rainforest-6495612.html Accessed 15/07/2020
[41] Anonymous 2019. Deathwatch for the Amazon. The threat of runaway deforestation. - The Economist, August 3 rd-9 2019.

[42] Deutsche Welle 2019. Brazil registers huge spike in Amazon deforestation. July 3, 2019. https://www.dw.com/en/ brazil-registers-huge-spike-in-amazondeforestation/a-494627773 Accessed $15 / 08 / 2020$

[43] WWF 2020. 2020 Forest Fires Globally Could be Worse Than 2019, WWF Warns. Press Release 10/19/2020. Accessed 20/10/2020

[44] Mikkola, H. \& Mikkola, K. 1978. Tragedy of Colombian nature. Suomen Luonto 37: 14-16 and 47 (In Finnish with summary in English).

[45] MINAMBIENTE 2017. Resultados. Monitoreo de la deforestación 2017. Gobierno de Colombia. http:// documentacion.ideam.gov.co/ openbiblio/bvirtual/02835/Resultados_ Monitoreo_Deforestacion_2017.pdf Accessed 15/02/2018

[46] Stotz, D., Fitzpatrick, J.W., Parker, T.A. \& Moskovits, D.K. (Eds.) 1996. Neotropical birds: ecology and conservation. The University of Chicago Press, Illinois, USA.

[47] Walter, S.T., Browne, L., Freile, J., Gonzáles, N., Loor, J., Darkes, M., Gillespie, T.W. \& Karubian, J. 2017. Nocturnal bird diversity in forest fragments in north-west Ecuador. Journal of Tropical Ecology 33: 357-364.

[48] Walter, S.T., Browne, L., Freile, J., Olivo, J., Gonzáles, M. \& Karubian, J. 2017. Landscape-level tree cover predicts species richness of large-bodied frugivorous birds in forest fragments. Biotropica 49: 838-847. 



\title{
Microbiota of Wild Fruits from the Amazon Region of Ecuador: Linking Diversity and Functional Potential of Lactic Acid Bacteria with Their Origin
}

\author{
Gabriela N. Tenea, Pablo Jarrin-V and Lucia Yepez
}

\begin{abstract}
Subtropical wild fruits are a reservoir of microbial diversity and represent a potential source of beneficial microorganisms. Wild fruits provide essential nutrients, minerals, and antioxidants that contribute to human health. Many of these wild fruits are used by indigenous peoples for medicine and food, but there is yet an unexplored potential in the study of their properties and benefits. Wild fruits from the Amazon region and their associated active substances or bacterial communities can prevent disease, provide appropriate nutrition, contribute to new sources of income, and improve lives. Despite its condition as a megabiodiverse country, Ecuador suffers from limited access to its genetic resources, and particularly for research. A total of 41 isolates were obtained from six wild Amazonian fruit species and were molecularly classified into the genera Lactiplantibacillus (31 isolates), Lactococcus (3 isolates), Weissella (3 isolates), and Enterococcus (1 isolate). Three isolates showed large divergence in sequence variability and were not identified by the taxonomic assignment algorithm. Inferred phylogenies on the 16S rRNA gene explained the relationship between lineages and their origin. Carbohydrate metabolism and antimicrobial profiles were evaluated, and the isolates were classified from a functional perspective. Antimicrobial profiles showed a wide-range spectrum against several Gram-positive and Gram-negative bacteria. To our knowledge, this is the first study assessing the diversity of LAB in native tropical fruits from the Amazon region of Ecuador and their promising functional properties. The obtained isolates and their assessed properties are valuable genetic resources to be further investigated for industrial and pharmaceutical applications.
\end{abstract}

Keywords: microbial diversity, Amazon region, lactic acid bacteria, fruit origin

\section{Introduction}

Lactic acid bacteria (LAB) are a versatile group of microorganisms and with a long history of use in fermented foods. LAB are distributed in diverse environments and are of considerable economic interest due to their "Food Grade Status" [1]. 
LAB have been extensively used as starter cultures, as probiotics, and in the production of inhibitory compounds. The latter has been considered as a new generation of antibiotics [2].

The growing number of people with lactose intolerance, allergy to cow's milk protein, or high cholesterol, which cannot consume dairy products, is affected by the lack of access to beneficial probiotic bacteria. Thus, fermented fruits or vegetables, which are an alternative source of probiotic bacteria, have received considerable attention from the consumers. The increasing trend for veganism or vegetarianism has promoted an increase in consumer interest for functional foods that contain beneficial bacteria [3].

When evaluating aspects of safety, taxonomy, and potential to produce pathogenic toxins and resistance to antibiotics, LAB have been recognized by the Food and Drug Administration (FDA) and the European Food Safety Authority (EFSA) as "generally recognized as safe" (GRAS) [4]. Although resistance genes in bacteria, including Lactobacillus, are located in transposable elements that can be transferred to other species, the US legislation has no guidelines that contemplate the potential development of resistance for microorganisms used in foods [5]. Alternatively, the European Food Safety Authority (EFSA) established guidelines that define the safety standards for microorganisms used "from farm to fork" [6]. The probiotics belonging to the species included in the category "qualified presumption of safety" (QPS) by EFSA show excellent safety records [4]. Undoubtedly, a full safety assessment of newly identified strains begins with proper identification and an in vitro evaluation of the potential risks [7].

Numerous research studies have attempted to design fermented foods based on fruits or vegetables with probiotic bacteria. LAB can display a remarkable degree of phenotypic and genotypic diversity, allowing them to survive in a variety of habitats and stress conditions. Most species in the LAB group are found colonizing the human or animal intestine but also in several fermented foods, vegetables, and fruits $[8,9,10]$.

The capacity to adapt to environmental changes depends on the genetic repertoire and the competency to use micronutrients along with the ability to counteract and overcome externally exerted physical-chemical challenges [11]. Despite an immeasurable arsenal of microbes, each plant or fruit harbors a distinctive microbiota that represents a remarkable niche to several LAB species [12]. However, the microbial composition in these environments is fluctuating and depends on intrinsic (physical and nutritional conditions) and extrinsic (environmental and harvesting conditions) parameters of the plant matrix [13]. Depending on the plant or fruit origin, the LAB species differ; thus, the Leuconostoc, Lactobacillus, Weissella, Enterococcus, and Pediococcus genera are those most frequently identified as epiphytes within the microbiota [14]. Although several species have been identified and characterized, the selection of new strains with valuable biotechnological properties remains a topic of interest [2].

Ecuador is known as a megabiodiverse country, where access to genetic resources for research is still deficient. Studies on the microbial diversity of unexplored niches and environments are of interest as these might lead to the identification of an endless number of species with unique characteristics and properties. It has been claimed that the microbial population present in raw plant material that has been originated from unexplored niches, differs among samples, as the plant matrix might carry a particular microbiota in a specific geographical region and at a specific time-point [15].

Recently, we proposed to investigate the microbiota associated with wild fruits; especially, to select and characterize strains of beneficial lactic acid bacteria [16]. Tropical forest fruits provide essential nutrients, minerals, and antioxidants that keep a healthy body and provide resilience to disease [17]. The physical and 
nutritional properties of fruits, together with the environmental and harvesting conditions of the plant matrix, may influence the final microbial community composition [2]. However, we hypothesize that the wild fruits from the Amazon region differ in their native availability of nutrients and physicochemical conditions, especially when compared to domesticated fruits from commercial crops. These substantial differences might influence the range of potential microbiota.

Wild tropical fruits are used for nutrition and medicine by the local inhabitants; yet, the lack of research makes this natural resource an yet unknown source of benefits to the food industry [18]. The prevention of diseases through appropriate nutrition with such fruits or the active substances extracted from such fruits or the products from the associated bacterial community can save lives and income [19]. The role of LAB isolated from fruits is not clearly understood; nonetheless, as they are naturally present on the surface of fruits, they produce antimicrobial compounds that might be used as a biological agent to control the growth of spoilage bacteria, and without changing the sensory properties of foods [20, 21]. Thus, we expected to find microorganisms with unique characteristics unlike those of the strains found in ordinary fermented materials, such as fermented milk or vegetables. Nonetheless, to use such strains as part of probiotic foods implies the application of numerous functional analyses to determine their susceptibility or resistance to antibiotics, capacity to prevent the growth of harmful bacteria by competitive exclusion, and production of organic compounds.

The resistance of LAB to antibiotics is a relevant biosafety issue. Some strains with intrinsic antibiotic resistance could be useful to restore the antibiotic resistance of the gut microbiota after antibiotic treatments [22]. Specific antibiotic resistance genes are carried by transposable elements and constitute a reservoir of resistance for potential food or gut pathogens, thus representing a major biosafety issue $[22,23]$. In this regard, special attention should be given to the presence of antibiotic resistance determinants and their potential mobility. Lactobacilli are usually sensitive to the cell wall-targeting penicillin and $\beta$-lactamase, but more resistant to cephalosporins. Also, some species are susceptible to low concentrations of several inhibitors of protein synthesis, such as chloramphenicol and tetracycline [22]. Some LABs are considered the most promising natural food preservatives, as they secrete antimicrobial substances (i.e. bacteriocins) that, when applied as crude-extracts to food, precipitated peptides that protect the products from deterioration by microbial activity [24]. LAB can also be used in the pharmaceutical industry to produce compounds such as esters, through the reduction of fructose, as the most abundant sugar present in fruits [25].

This research aimed to investigate the lactic acid bacteria diversity associated with the microecosystem of wild fruits from the Amazon region of Ecuador. We sought to find unique characteristics, unlike those of the strains found in ordinary fermented materials such as milk or vegetables. As a first step to select the most promising strains with superior functional properties, we present broad insights into this microenvironment. To our knowledge, this is the first study that assessed the diversity and functional properties of $\mathrm{LAB}$ in native tropical fruits from the Amazon region of Ecuador.

\section{Materials and methods}

\subsection{Sampling, isolation, and purification of lactic acid bacteria}

The source wild fruit samples were collected during the rainy season (April-July, 2014-2015) from the tropical forest of the Sucumbíos Province in the Amazon region of Ecuador (Figure 1). Several units of fruits from Chrysophyllum oliviforme, 


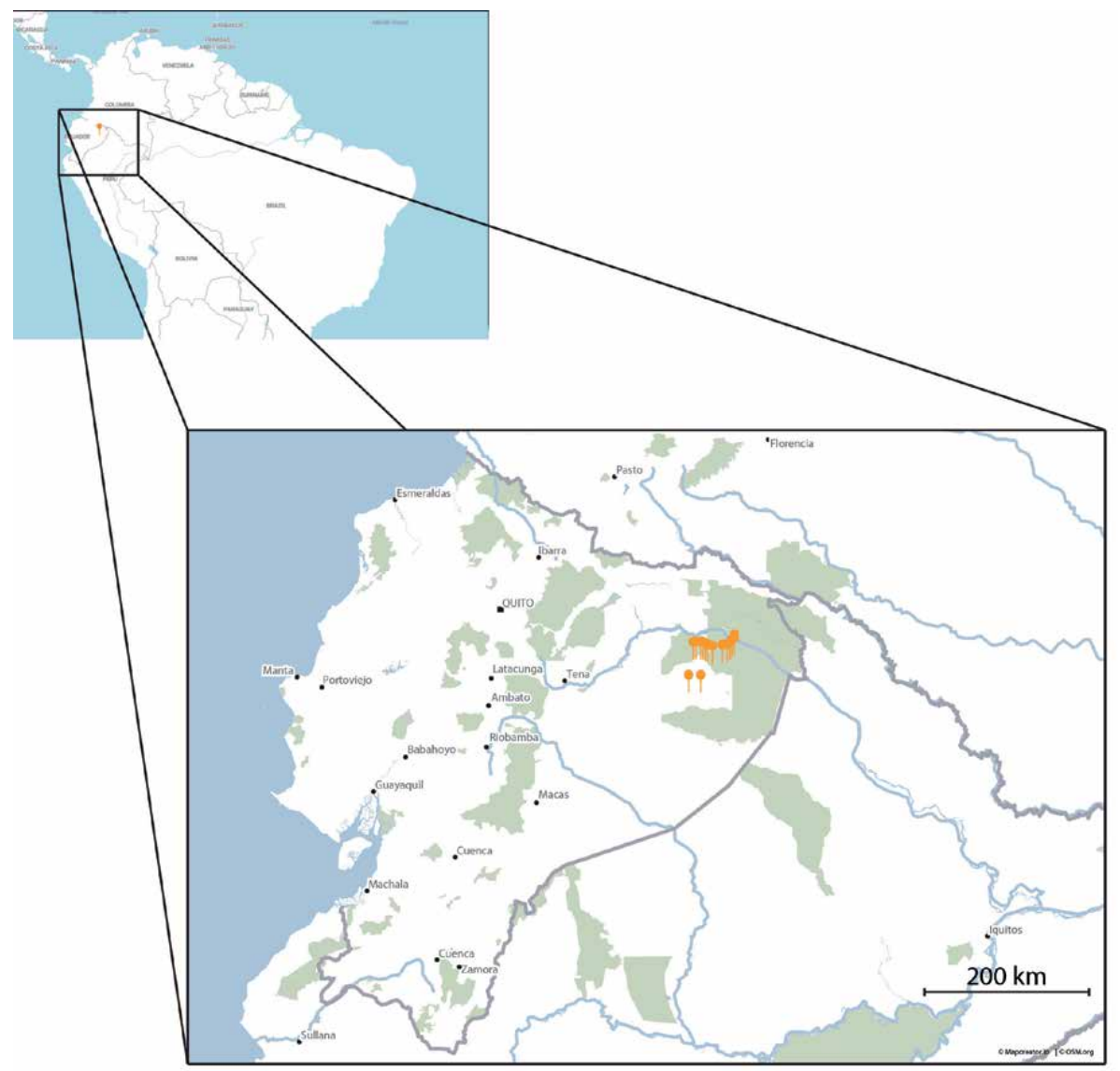

Figure 1.

Location of samples obtained for this study in the Amazon region of Ecuador. Colored areas represent national parks. Most of the samples were obtained in the areas adjacent to the Cuyabeno National Park.

Malus sp., Costus sp., Solanum stramofolium, Cheilocostus specious, and Theobroma grandiflorum were collected aseptically in sterile bags and stored at $4^{\circ} \mathrm{C}$ for transport to the laboratory. The fruit samples were washed with a $5 \%$ bleach solution for $5 \mathrm{~min}$, then twice with distillate water, smashed in small pieces, and transferred into Erlenmeyer flasks $(500 \mathrm{ml})$ that contained peptone water $(0.1 \%$, bacteriological peptone, Difco Detroit, MI, USA). Samples were incubated statically for up to 5 days at room temperature. MRS agar [26] plates containing $5 \mathrm{~g} / \mathrm{l} \mathrm{CaCO}_{3}$ were inoculated and incubated under anaerobic conditions $\left(37^{\circ} \mathrm{C}\right.$ for 72 hours $)$, and individual colonies were randomly selected and purified. The purified colonies $(<75$ colonies/each fruit) were Gram-stained, characterized by microscopic morphology, and tested for mobility, indole and catalase production, spore formation, and gas production from glucose [16]. The selected colonies were screened for their capacity to inhibit four bacterial pathogens (Section 2.4), resistance to bile (1\%), acidity ( $\mathrm{pH} 2.5-3.0)$, and temperature range $\left(15-45^{\circ} \mathrm{C}\right)$. A total of 41 isolates complying with these criteria were further selected and identified. Each isolate was assigned a collection code (UTN) and was stored at $-80^{\circ} \mathrm{C}$ in MRS medium containing $20 \%$ glycerol.

\subsection{Classification of isolates using 16S rRNA gene sequence analysis}

16S rRNA gene sequencing was used for taxonomical assignment (Macrogen Inc., Korea, custom service). The primers 27F 5' (AGA GTT TGA TCM TGG CTC 
AG) 3' and 1492R 5' (TAC GGY TAC CTTGTT ACG ACT T) 3' were used for the PCR amplification. The PCR reaction was performed with 20 ng of genomic DNA in a $30 \mu \mathrm{l}$ reaction mixture with EF-Taq (SolGent, Korea) and through the following protocol: activation of Taq polymerase at $95^{\circ} \mathrm{C}$ for 2 minutes, 35 cycles of $95^{\circ} \mathrm{C}$ for 1 minute, at $55^{\circ} \mathrm{C}$ and $72^{\circ} \mathrm{C}$ for 1 minute, finishing with 10 minutes at $72^{\circ} \mathrm{C}$. The amplification products were purified with a multiscreen filter plate (Millipore Corp., Bedford, MA, USA). The sequencing reaction was performed using a PRISM BigDye Terminator v3.1 cycle sequencing kit. The DNA samples containing the extension products were added to Hi-Di formamide (Applied Biosystems, Foster City, CA). The mixture was incubated at $95^{\circ} \mathrm{C}$ for 5 minutes, followed by 5 minutes on ice and then analyzed by an ABI Prism 3730XL DNA analyzer (Applied Biosystems, Foster City, CA).

A preliminary fast search of the sequences was conducted using the megablast algorithm on the $16 \mathrm{~S}$ ribosomal RNA database at NCBI, as implemented in Geneious Prime 2020.2.3 [27]. This first search was used to obtain a maximum of 100 hits and associated search quality parameters that provided an initial reference for taxonomic classification. A final taxonomic assignment was made by the RDP Bayesian classifier algorithm [28] with 100 bootstrap replicates and a K-mer of size 8, as implemented in the function "accurate, high-resolution sample inference from amplicon sequencing data" (assign Taxonomy) of the DADA2 package [29] in $\mathrm{R}$ [30]. The Genome Taxonomy Database [31] was used as the reference for the Bayesian classifier algorithm. A threshold for bootstrap values equal or over $80 \%$ was used to filter the taxonomic correspondences. The resulting final table of taxonomic assignments was used for downstream statistical analyses.

We used reference samples to root the inferred phylogenetic hypotheses and provide a comparison to the experimental samples used in this study. This reference samples were: KJ660075.1: Brachyspira_hampsonii; AJ276460.1: Enterococcus_faecalis; NR_114312.1: Weissella oryzae; NR_104573.1: Lactobacillus; LC063164.1: Weissella confusa; NR_029133.1: Lactobacillus.

LAB represent a small fraction of the autochthonous microbiota in the fruit and plant phyllosphere. However, due to the inherent limitations of in vitro cultures, the most frequent isolates often belong to the genera Lactobacillus, Leuconostoc, Weissella, Enterococcus, and Pediococcus [14]. More recently, based on conserved pairwise average amino acid identity, core genome phylogeny, physiological criteria, clade-specific signature genes, and ecology, Lactobacillaceae, and Leuconostocaceae were merged into Lactobacillaceae [32]. The genus Lactobacillus was split into 25 genera including Lactiplantibacillus, Fructiplantibacillus, Lactobacillus, among others. Thus, we allocate the study samples according to this new classification.

\subsection{Metabolic profile of the selected isolates}

The BBL Crystal anaerobe identification system (cat \# 245010, BD Company, US) is a miniaturized identification method for tests of fermentation, oxidation, degradation, and hydrolysis of diverse substrates. It also includes chromogen and fluorogenic linked substrates to detect enzymes that microbes metabolize. The results obtained after incubation of strips for 24 hours at $37^{\circ} \mathrm{C}$ were analyzed using the BBL Crystal analysis software (according to the manufacturer instructions). The results were qualitatively defined as negative (-) or positive $(+)$ according to the detected color. As a reference for the metabolic profile test, we used Lactobacillus plantarum ATCC8014 and Lactobacillus fermentum CNCM 1-2998 (Lacc), which were recovered from the commercial probiotic Lacteol Fort (Lactobacillus LB, Axcan Pharma, France). 


\subsection{Antibiotic susceptibility testing}

Susceptibility to several antibiotics was determined by commercial discs of Amoxicillin (AMX: $25 \mu \mathrm{g}$ ), Ampicillin (AM: $10 \mu \mathrm{g}$ ) Gentamicin (CN: $10 \mu \mathrm{g}$ ), Kanamycin (K: $30 \mu \mathrm{g})$, Amoxicillin/Clavulanic Acid (AMC: 20/10 $\mu \mathrm{g}$ ), Tetracycline (TE: $30 \mu \mathrm{g}$ ), and Cefuroxime (CXM: $30 \mu \mathrm{g}$ ). For the disk diffusion assay, we used concentrations recommended by the Scientific Committee on Animal Nutrition (discs provided by Merck) [12]. We used Escherichia coli ATCC 25922 as quality control. The microbiological breakpoints reported by the FEEDAP standards were used to categorize lactobacilli as susceptible or resistant [4]. Lactobacillus plantarum ATCC8014 and L. fermentum CNCM 1-2998 (Lacc) were used as a reference to the test. Results were qualified as R (resistance), I (intermediate), and S (susceptible).

\subsection{Antimicrobial spectrum of the selected isolates}

The antimicrobial spectrum of the selected isolates was determined against Gram-positive and Gram-negative bacteria, as previously described by Garzon et al. [33]. The indicator bacteria were: Salmonella enterica subsp. enterica (Kauffmann and Edwards) Le Minor and Popoff ATCC 51741, Salmonella enterica subsp. enterica serovar Abaetetuba ATCC35640, Escherichia coli ATCC25922, E. coli ATCC10536, Shigella sonnei ATCC25931, Streptococcus thermophilus ATCC19258, Enterobacter aerogenes UTNEag1 (laboratory collection), Salmonella UTNSm2 (laboratory collection), Shigella UTNShg1 (laboratory collection), and E. coli UTNEc1 (laboratory collection). LAB was grown in MRS broth at $34^{\circ} \mathrm{C}$ for $24-27$ hours and the supernatants were collected by centrifugation at $13,000 \mathrm{xg}$ for 20 minutes at $4^{\circ} \mathrm{C}$. The crude extract (CE) was recovered and filtered with a $0.22 \mu \mathrm{m}$ porosity syringe filter. The indicator strains $(100 \mu \mathrm{l})$ were grown in broth medium $(7 \log \mathrm{CFU} / \mathrm{ml})$ and mixed with $3.5 \mathrm{ml}$ of soft MRS agar $(0.75 \%)$. It was then overlaid on nutrient agar plates and incubated at $37^{\circ} \mathrm{C}$ for 2 hours. The $\mathrm{CE}$ of each strain $(100 \mu \mathrm{l})$ was transferred onto the reaction wells $(6 \mathrm{~mm})$ on overlaid agar, incubated at $37^{\circ} \mathrm{C}$ and subsequently examined for the presence of an inhibition zone at 48 hours. To rule out the possible inhibitory activity of organic acids, the $\mathrm{CE}$ was heated at $80^{\circ} \mathrm{C}$ for 10 minutes, the $\mathrm{pH}$ adjusted at 6.0 and the activity was determined. Lactobacillus plantarum ATCC8014 and L. fermentum CNCM 1-2998 (Lacc) were used as reference strains. MRS broth was used as a negative control. The experiments were run in triplicate and the mean value of the inhibition zone was determined. A numeric scale from zero to ten was included in the statistical analysis and the results were also qualitatively defined as narrow (inhibit less than 5 indicator strains) or broad activity (inhibit more than 5 indicator strains).

\subsection{Statistical and phylogenetic analyses}

The interpretation of the antibiogram results was assisted by the package AMR [34], which provided corresponding frequencies on the qualitative responses. The distances (Bray-Curtis) among samples were then projected in canonical space through a non-metric multidimensional scaling. Either putative genera of bacteria, assigned through the RDP Bayesian classifier algorithm [28], or the host plants were included as the grouping variable.

The metabolic profiling resulted in a matrix that could be interpreted in binary form, and from which it was possible to determine a set of distances (binary BrayCurtis) for classifying samples through a cluster analysis (unweighted pair group method with arithmetic averages, UPGMA). Ordination methods were carried out through vegan [35] and ggdendro [36] in $\mathrm{R}$ [30]. 
Sequences were aligned trough Clustal Omega, as implemented in Geneious Prime 2020.2.3 [27]. A proper substitution model was obtained through jModeltest v. 2.1.10 [37] and selected by a Bayesian information criterion. A phylogenic hypothesis was inferred by Bayesian inference with Mr. Bayes 3.2.6 [38]. The selected HKY85 model included a proportion of invariable sites and varying rates across sites with a discretized gamma distribution (HKY85 + I + G). The Bayesian analysis included 1.1 million generations and four chains per run. Hypotheses were sampled every 200 generations and the first $10 \%$ of these samples were discarded. The remaining $90 \%$ of the trees and parameters were respectively summarized in a $50 \%$ majority-rule consensus tree.

\section{Results and discussion}

\subsection{Wild fruits: A microenvironment of diverse lactic acid bacteria}

Out of 41 isolates, the most frequently observed genus was Lactiplantibacillus (31 isolates), followed by Lactococcus (3 isolates), Weissella (3 isolates), and Enterococcus (1 isolate). Three isolates showed large divergence and were not identified by the taxonomic assignment algorithm (i.e. UTN39, UTN41, and UTN88)

(Figure 2a). The former three isolates may represent unreported lineages or species. The presence of Lactococcus in plants or fruit is rare: thus, we only found few isolates belonging to such genus.

Isolates showed a remarkable distance to the outgroup reference samples, and most were included within a clade formed by Lactiplantibacillus, where they showed relatively small distances (i.e. small branch lengths). However, within this inclusive group of Lactiplantibacillus there was an ingroup with strong support (Bayesian posterior probabilities = 1) and formed by Weissella, Enterococcus, and Lactococcus. This paraphyletic ingroup, within a more inclusive group formed mostly by Lactiplantibacillus should be eventually resolved by the inclusion of additional molecular markers (Figure 2a). The paraphyletic ingroup contains samples that belong to the plant species Costus sp., which occurs exclusively to this clade (Figure 2b).

\subsection{The metabolic profile reveals the divergent properties of selected LAB}

LAB strains may present specific metabolic traits as a result of their microenvironmental origin (i.e. different species of fruits) and possess a unique portfolio of enzymes that allow them to metabolize various compounds found in the host plant or fruit matrices. We present a metabolic profile together with other properties that were analyzed in the obtained isolates (Figure 3). Within Lactiplantibacillus, the isolates showed a variable capacity to ferment sugars and hydrolyze esculin. These features were strain-dependent. Among the available isolates, UTN39 and UTN76 were the only two samples that metabolized ARG, while UTN37 and UTN39 hydrolyzed urea. The latter is a relevant characteristic for selecting probiotic strains [2]. Of particular relevance were the locations of UTN76 and UTN39 on the previously presented phylogenetic hypotheses (Figure 2); these two isolates showed large genetic distances relative to the other samples, or unique positions in clades that diagnose them as different or remarkable lineages. The observed patterns in the metabolic profile are rather complex. UTN37, UTN39, and UTN76 show noteworthy properties; they, however, differ in their response to other substrates (Figure 3); thus, the corresponding dendrogram, which results from clustering the observed metabolic profile, hints to four main groups of isolates (Figure 4). 


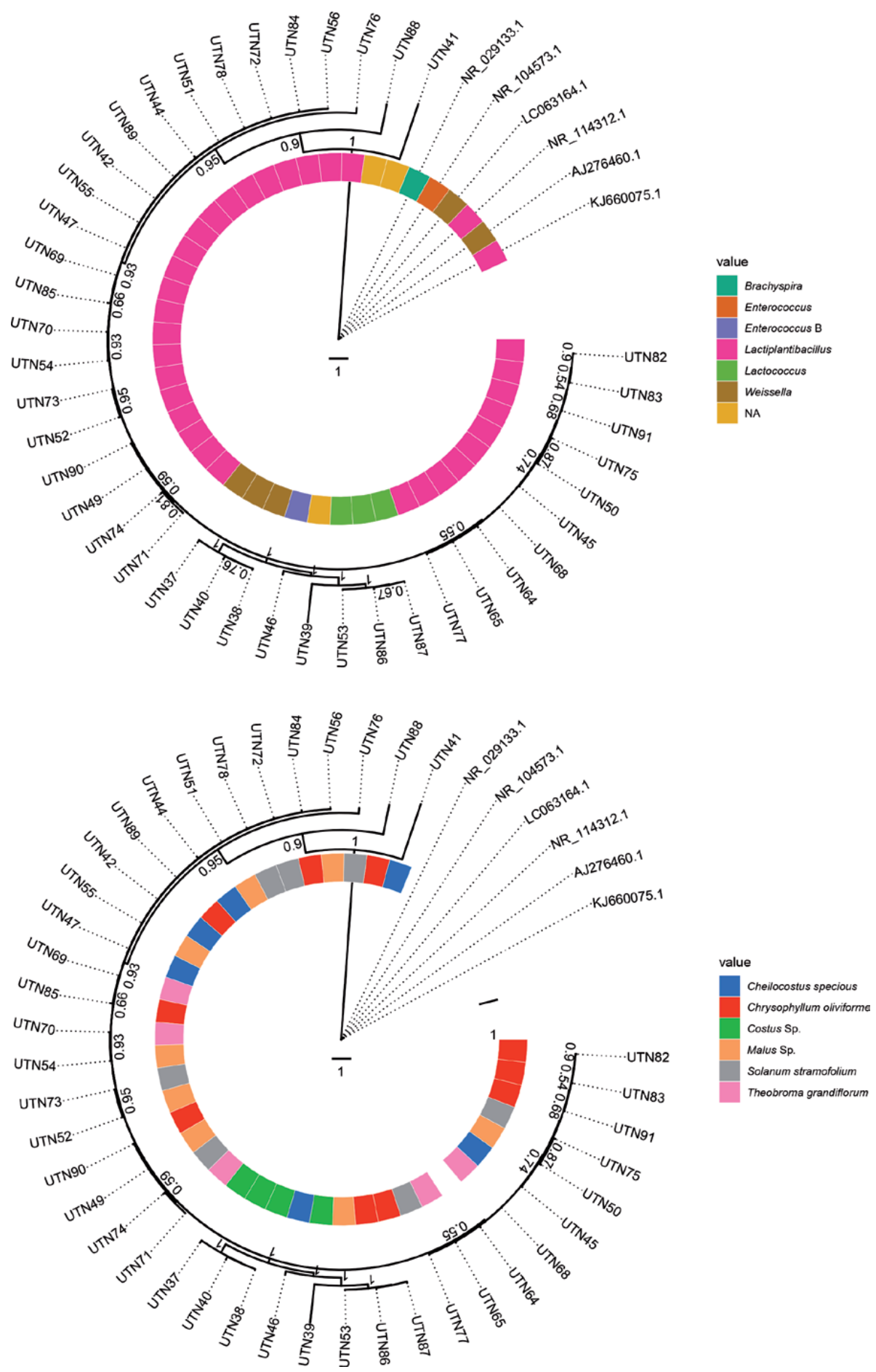

Figure 2.

(a) Phylogenetic hypothesis of the isolated samples and corresponding genera of bacteria. (b) The hypothesis with the corresponding host genera of plants. Branch support values are posterior probabilities from the applied Bayesian inference.

The ability to utilize the $\alpha$-galacto-oligosaccharides-family ( $\alpha \mathrm{GOS})$, d-melibiose $[\alpha-$ Gal- $(1 \rightarrow 6)$-Glu], as well as the raffinose-family oligosaccharide (RFO) d-raffinose, seems to be a common feature among all the tested isolates. On the 


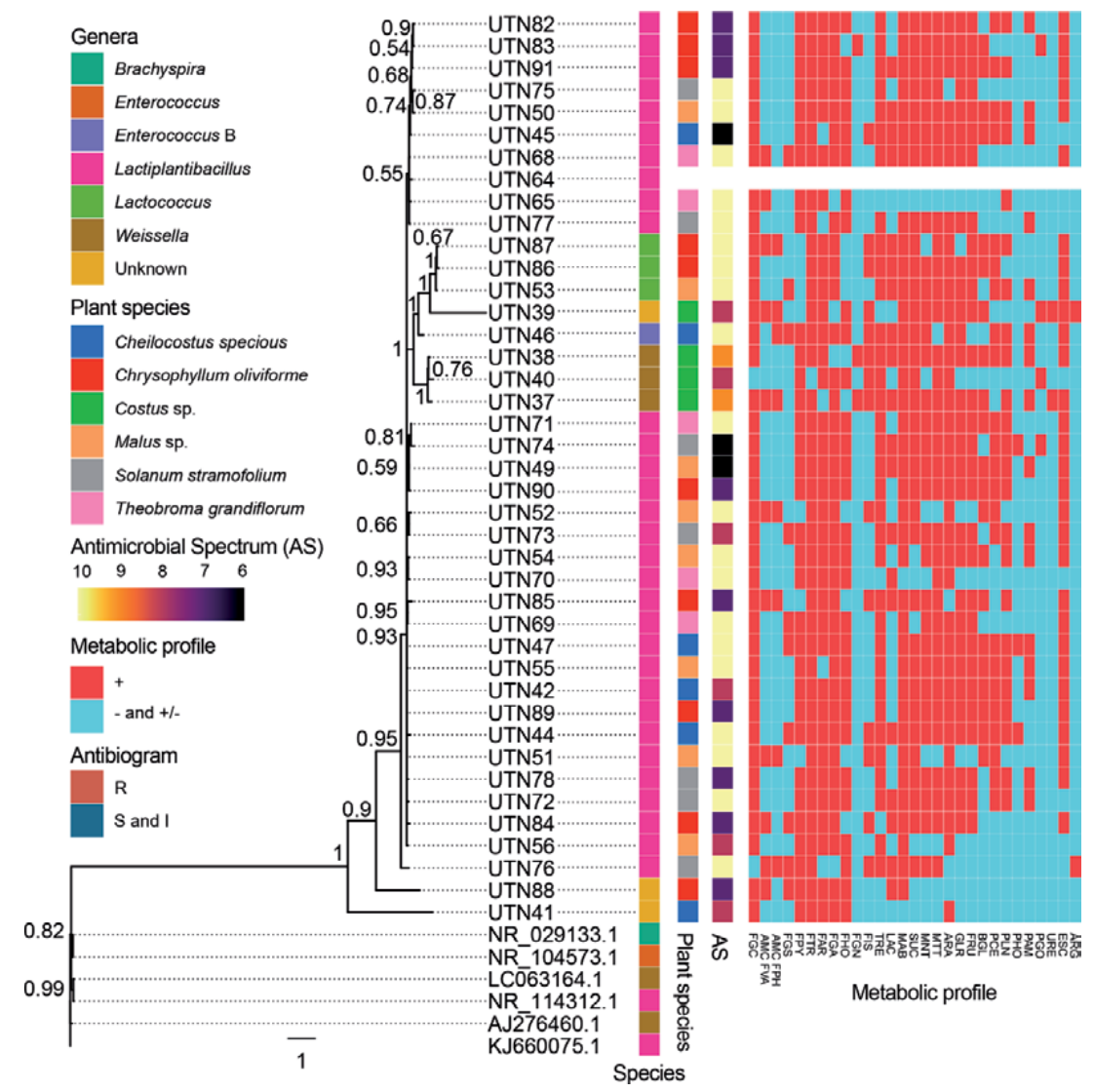

Figure 3.

Annotated phylogeny and heatmap showing the metabolic profiles of the LAB isolates. The phylogeny is an alternative depiction of the one shown in Figure 2 and serves as a reference to the profiles. The antimicrobial spectrum $(A S)$ is also presented for each isolate.

other hand, the metabolisms of the trisaccharide d-melezitose $(\alpha-$ Glu- $(1 \rightarrow 3)-\beta$ Fru- $(2 \rightarrow 1)-\alpha-$ Glu $)$ and the disaccharides d-trehalose $[\alpha-G l u-(1 \rightarrow 1)-\alpha-G l u]$ and d-turanose $(\alpha-$ Glu- $(1 \rightarrow 3)$ - $\alpha$-Fru $)$ were strain-specific and restricted mainly to the Lactoplantibacilaceae. Although not classified, in a distinct lineage near the base of the tree, and with relatively large genetic distances, the isolates UTN41 and UTN88 did not metabolize most of the oligosaccharide substrates. The dissimilarity of individual isolates was supported by the different use of glycerol, trehalose, and sucrose. UTN40 was in the same lineage group as UTN37 and UTN38; however, it showed a distinct metabolic and antibiotic pattern, being the only one with resistance to AM10 and CN10. The isolate UTN76 showed a similar metabolic pattern to UTN88, both were the only isolates that did not metabolize p-n-p- $\beta$-D-cellobioside, p-n-p-phosphate, and proline. The Lactococcus species (UTN53, UTN86, and UTN87) were grouped in the same clade but were different in both the metabolic and antibiotic profiles.

The results revealed the production of $\beta$-galactosidase, $\alpha$-glucosidase, $\beta$-glucosidase, and $\mathrm{p}-\mathrm{n}-\mathrm{p}-\alpha-\beta$-galactoside in some isolates. Although all isolates were originated from plants, there were differences in the utilization of mannitol and fructose. Previous studies have indicated that strains of L. plantarum, which were isolated from plant environments, often were able to metabolize these carbohydrates, and which has been considered as a fructophilic property [39]. 


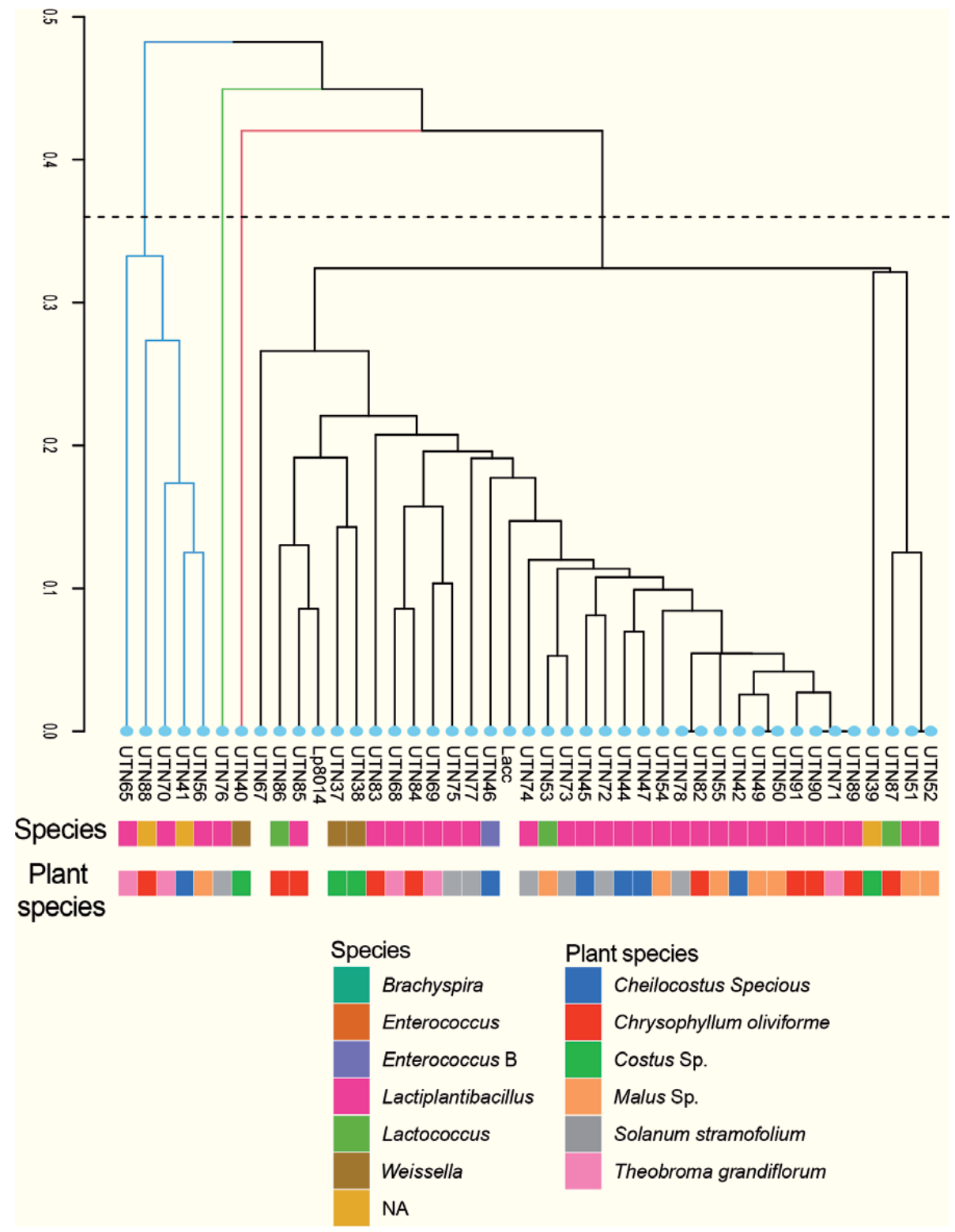

Figure 4.

Dendrogram from a cluster analysis on the metabolic profile for the obtained isolates. Four groups are possible to define at the established distance (dotted vertical line). The assigned species and the host plant species are represented as color codes.

\subsection{The antimicrobial profile reveals that inhibitory activity is related to microenvironmental origin}

AMX25 was the only antibiotic for which all isolates showed susceptibility, while all isolates showed innate resistance to MET5. Previous studies have indicated that Lactobacilli have a high natural resistance to metronidazole, as well as antibiotics that inhibit the synthesis of proteins such as chloramphenicol, erythromycin, clindamycin, and tetracyclines [40]. UTN41 was susceptible to almost all antibiotics. Among the Lactiplantibacillus genus, the isolates UTN76 and UTN88 were resistant to AMC30, and UTN84 and UTN89 were resistant to TE30. However, this relevant pattern did not show consistency with the fruit host, as the plant species 
Chrysophyllum oliviforme, which was the origin of the resistant samples, was also the origin of other isolates in Lactiplantibacillus, but which did not coincide in their resistance pattern (Figure 5). Another relevant aspect was that of UTN68 (Lactiplantibacillus), which originated from Theobroma grandifolium and UTN40 (Weissella) from Costus sp., which were the only isolates showing resistance to AM10 (Figure 5).

Although resistance to gentamicin and kanamycin is considered a health concern, the isolates that showed resistance to both antibiotics were control reference strains that were isolated from dairy and human intestine. In general, patterns in the antibiogram were broad and yet inconclusive, as the position of isolates and plant hosts in canonical space show that further evidence is necessary to establish definitive patterns of association (Figure 6). However, this is also evidence of large variability across samples, with no conclusive patterns in isolated species or their host plants.

Although antibiotic resistance is a criterium to be considered from a biosafety perspective, it has been shown that the probiotic strains of starter culture strains

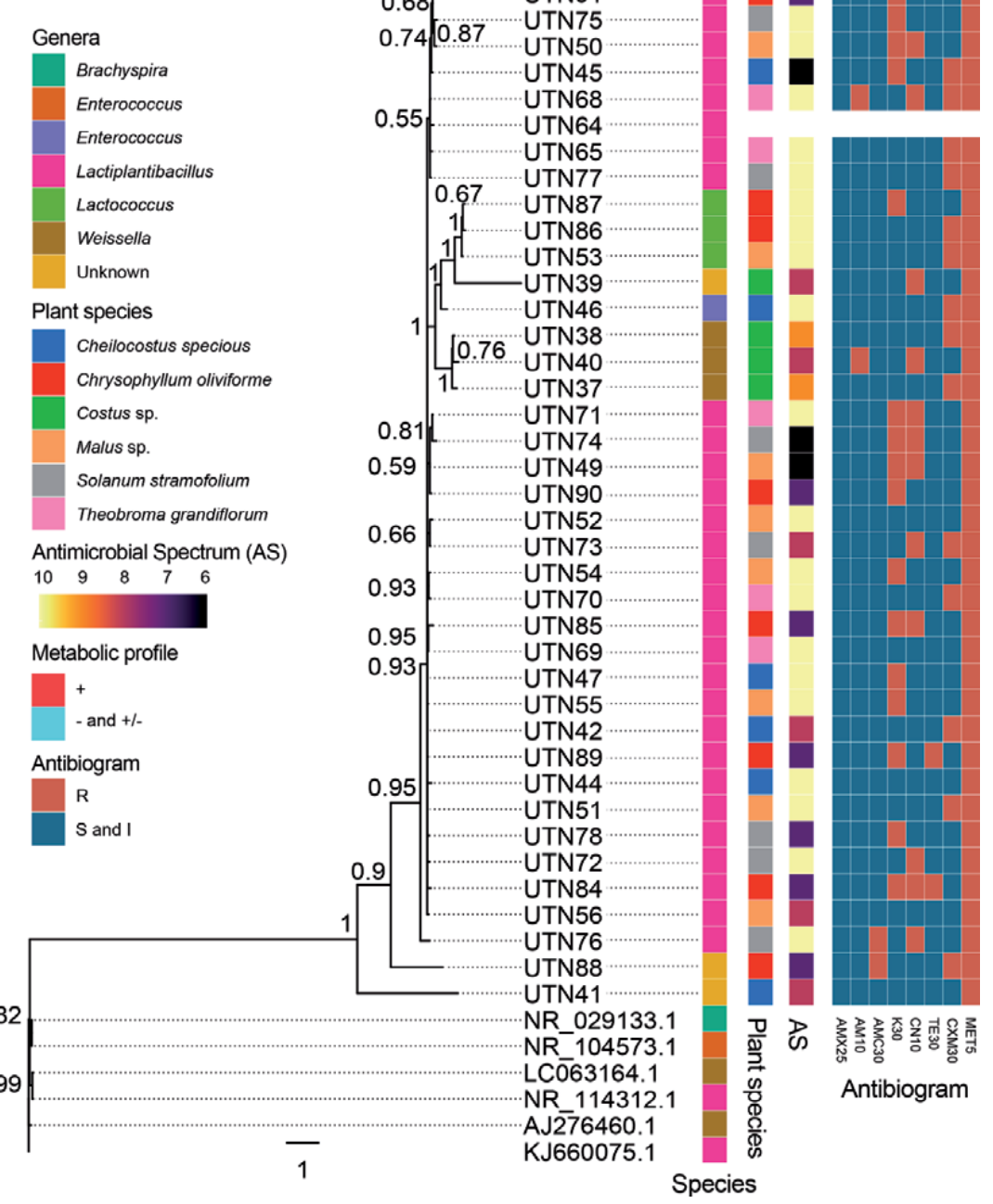

Figure 5.

Annotated phylogeny and heatmap showing antimicrobial profiles of the LAB isolates. 

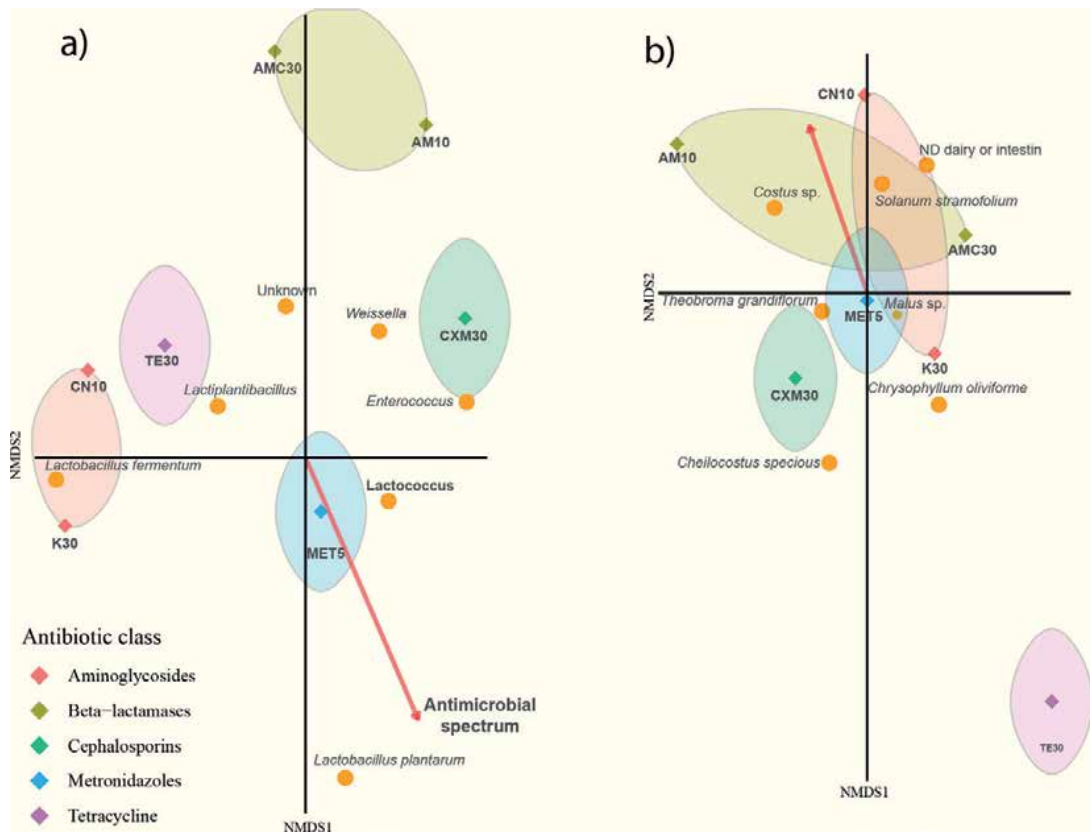

Figure 6.

Non-metric multidimensional scaling (NMDS) that represents, in two dimensions, the distances among isolates and host plants according to the observed pattern of antibiotic resistance. a) Tile for the spatial relationships in NMDS space between antibiotics and the studied bacterial isolates. b) Tile for spatial relationships in $N M D S$ space between antibiotics and the host plants of the studied bacterial isolates. Short distances among these objects in the canonical space represent strong associations of either resistance or susceptibility. The antimicrobial spectrum is shown here as a cofactor showing a directional trend. AMX25 was removed from this analysis as it was not informative (i.e. susceptibility as a zero-response constant). The colored areas facilitate the interpretation of the antibiotics position. L. fermentum and $\mathrm{L}$. plantarum were used as a reference in the tests.

are resistant to ampicillin, vancomycin, gentamicin, kanamycin, streptomycin, erythromycin, clindamycin, tetracyclines, and chloramphenicol $[4,7]$. Another study has reported that Lactobacilli isolated from fermented olives were resistant to cephalosporins, streptomycin, and kanamycin [41]. Overall, the observed pattern is for high variability or diversity in the response to antibiotics as there is considerable dispersion in the response within and among bacterial species or plant hosts (Figure 6). However, there were also isolates with unique resistance patterns, which will require a further inquiry into their molecular and physiological properties. Undoubtedly, a full safety assessment with a robust identification of the strains and an in vitro evaluation of the potential risks is needed; particularly if these are intended to be used as additives in food products.

It is known that some LAB strains produce a wide variety of anti-pathogenic compounds, like bacteriocins, ethanol, organic acids, diacetyl, acetaldehydes, hydrogen peroxide $\left(\mathrm{H}_{2} \mathrm{O}_{2}\right)$, and peptides $[42,43]$. When we analyzed the antimicrobial spectrum against ten Gram-negative and Gram-positive bacteria, including closely related species and pathogens such as Salmonella enterica, Shigella sonnei, Escherichia coli, Enterobacter, Staphylococcus aureus, we observed that the isolates showed high inhibitory potential, as none had values below six and were defined as broad-spectrum (Figures 3 and 4). The inhibitory effect of LAB strains may result from a combination of competition for metabolic substrates, growth suppression by organic acids, and bacteriocin secretion. Recently, we showed that some of the Lactobacilli strains inhibited Salmonella enterica subsp. enterica ATCC51741 and E. coli ATCC25922 at both the early and logarithmic stages of bacterial growth in vitro and ex vitro $[44,45,46]$. Also, we showed that one selected LAB strain from the 
Microbiota of Wild Fruits from the Amazon Region of Ecuador: Linking Diversity...

DOI: http://dx.doi.org/10.5772/intechopen.94179

Lactococcus genera harbored interesting functional properties to be used in starter culture formulations for dairy-based fermented food products [46].

\section{Conclusions}

The Amazon rainforest is a sizeable reservoir of plants, animals, and bacterial diversity. For Ecuador, the Amazon region could be a significant source of new bioproducts, based on the transformation of biodiversity [47]. Subtropical wild fruits have a relevant ethnobotanical significance, as they are mostly consumed by indigenous people as food or natural medicine; however, the bacterial microbiota of those fruits has not been assessed. In this research, we investigated the lactic acid bacteria diversity associated with several wild fruits collected from the Amazon region of Ecuador. Their remarkable inhibitory potential towards Gram-negative bacteria might be related to their capacity to produce various antimicrobial substances, that when applied to food products might prevent the growth of undesirable microorganisms. A better understanding of the metabolic capacity of these microorganisms will further complement our knowledge about the development of a novel starter or preservative culture for fruit- and vegetable-based foods. The prospective comparative exploration of the genomes of LAB strains from various plant or fruit origins would be of particular interest to provide information on their adaptations to different food-matrices and to further explore biotechnological applications.

Genotype-functional correlation studies contribute to the discovery of new biotechnological properties for several species. The results from the present study supported our hypothesis that LAB strains from wild fruits of the Amazon Region of Ecuador carry noteworthy characteristics that could be inherent to their ecological niches or environmental origin and that could be developed for biotechnological applications. Several strains were found capable of producing antimicrobials with high inhibitory potential against commensal and spoilage bacteria and are promissory natural food preservatives.

\section{Acknowledgements}

This research was financed by the Technical University of the North, Centre of Research (CUICYT)-Grant no. 01388/2014 and Grant 0179/2016. The authors gratefully acknowledge the generous technical support of Ulcuango M, Torres J., and Benavidez A. GNT was supported in part by the Prometeo Project of the Secretary for Higher Education, Science, Technology and Innovation (SENESCYT, 2014-2016).

\section{Conflict of interest}

The authors report no conflicts of interest. The authors are responsible for the content and writing of this article. 


\section{Author details}

Gabriela N. Tenea ${ }^{1 *}$, Pablo Jarrin- $\mathrm{V}^{2}$ and Lucia Yepez ${ }^{1}$

1 Biofood and Nutraceutics Research and Development Group, Technical University of the North, Ibarra, Ecuador, Av. 17 de Julio s-21 y José María Córdova, Barrio El Olivo, 100150, Ibarra, Ecuador

2 Population and Environment Research Group, Universidad Regional Amazónica Ikiam, Tena, Ecuador

*Address all correspondence to: gntenea@utn.edu.ec; gtenea@hotmail.com

\section{IntechOpen}

(C) 2020 The Author(s). Licensee IntechOpen. This chapter is distributed under the terms of the Creative Commons Attribution License (http://creativecommons.org/licenses/ by/3.0), which permits unrestricted use, distribution, and reproduction in any medium, provided the original work is properly cited. (cc) BY 
Microbiota of Wild Fruits from the Amazon Region of Ecuador: Linking Diversity...

DOI: http://dx.doi.org/10.5772/intechopen.94179

\section{References}

[1] Garcia EF, Luciano WA, Xavier DE, da Costa WC, de Sousa Oliveira K, Franco OL. et al. Identification of lactic acid bacteria in fruit pulp processing byproducts and potential probiotic properties of selected Lactobacillus strains. Frontiers in Microbiology. 2016;7: 1371. DOI: $10.3389 /$ fmicb.2016.01371

[2] Ruiz Rodríguez, LG, Aller K, Bru E, De Vuyst L, Hebert EM, Mozzi F. Enhanced mannitol biosynthesis by the fruit origin strain Fructobacillus tropaeoli CRL 2034. Applied Microbiology and Biotechnology. 2017;101:6165-6177. DOI: 10.1007/s00253-017-8395-1

[3] Szutowska J. Functional properties of lactic acid bacteria in fermented fruit and vegetable juices: a systematic literature review. European Food Research and Technology. 2020;246:357372. DOI: 10.1007/s00217-019-03425-7

[4] European Food Safety authority (EFSA). Guidance on the assessment of bacterial susceptibility to antimicrobials of human and veterinary importance. EFSA J. 2012: 10:2740-9.16. 732:1-15. DOI: $10.2903 /$ j.efsa.2008.732

[5] Mattia A, Merker R. Regulation of probiotic substances as ingredients in foods: Premarket approval or "generally recognized as safe" notification. Clinical Infectious Diseases. 2008; 46(supplement_2):S115-S118. DOI: $10.1086 / 523329$

[6] Laulund S, Wind A, Derkx PM, Zuliani V. Regulatory and safety requirements for food cultures. Microorganisms. 2017;5:E28. DOI: 10.3390/microorganisms5020028

[7] Fraqueza MJ. Antibiotic resistance of lactic acid bacteria isolated from dry-fermented sausages. International Journal of Food Microbiology. 2015, 212, 76-88. DOI: 10.1016/j. ijfoodmicro.2015.04.035
[8] Chao SH, Huang HY, Kang YH, Watanabe K, Tsai YC. The diversity of lactic acid bacteria in a traditional Taiwanese millet alcoholic beverage during fermentation. LWT - Food Sci and Technology. 2013;51:135-142. DOI: 10.1016/j.lwt. 2012.09.015

[9] Emerenini E, Afolabi O, Okolie P, Akintokun A. Isolation and molecular characterization of lactic acid bacteria isolated from fresh fruits and vegetables using nested PCR analysis. Brazilian Microbiology Research Journal. 2013;3:368-377. DOI: 10.9734/ BMRJ/2013/2520

[10] Mustopa AZ, Fatimah F. Diversity of Lactic acid bacteria Isolated from Indonesian traditional fermented foods. Microbiology Indonesia. 2014;8(2):4857. DOI: $10.5454 / \mathrm{mi} \cdot 8.2 .2$

[11] Barraclough T, Balbi K, Ellis R. Evolving concepts of bacterial species. Evolutionary Biology. 2012;39:148-157. DOI: $10.1007 / \mathrm{s} 11692-012-9181-8$

[12] Naeem M, Ilyas M, Haider S, Baig S, Saleem, M. Isolation characterization and identification of lactic acid bacteria from fruit juices and their efficacy against antibiotics. Pakistan Journal of Botany. 2012;44:323-328

[13] Di Cagno R, Filannino P, Gobbetti M. Vegetable and fruit fermentation by lactic acid bacteria. In: Mozzi F, Raya RR, Vignolo GM, editors. Biotechnology of Lactic Acid Bacteria: Novel Applications. Chichester:John Wiley \& Sons; 2015. p. 216-230. DOI: 10.1002/9781118868386.ch14

[14] Filannino P, Di Cagno R, and Gobbetti M. Metabolic and functional paths of lactic acid bacteria in plant foods: get out of the labyrinth. Current Opinion in Biotechnology. 2018;49: 64-72. DOI: 10.1016/j.copbio.2017.07.016 
[15] Samuni-Blank M, Izhaki I, Laviad S, Bar-Massada A, Gerchman Y, Halpern M. The role of abiotic environmental conditions and herbivory in shaping bacterial community composition in floral nectar. PLoS ONE. 2014;9:e99107. DOI: 10.1371/journal. pone.0099107

[16] Benavidez A, Ulcuango M, Yépez L, Tenea, GN. Assessment of the in vitro bioactive properties of lactic acid bacteria isolated from native ecological niches of Ecuador. Revista Argentina de Microbiologia. 2016;48:236-244. DOI: 10.1016/j.ram.2016.05.003

[17] Xing J, Wang G, Zhang Q, Liu X, $\mathrm{Gu}$ Z, Zhang H, Chen YQ, Chen W. Determining antioxidant activities of lactobacilli cell-free supernatants by cellular antioxidant assay: a comparison with traditional methods. PLoS ONE. 2015;10(3):e0119058. DOI: 10.1371/ journal.pone.0119058

[18] Khoo HE, Azlan A, Kong KW, Ismail A. Phytochemicals and medicinal properties of indigenous tropical fruits with potential for commercial development. Evidence-Based Complementary and Alternative Medicine. 2016;ID 7591951. DOI: 10.1155/2016/7591951

[19] Gul K, Singh AK, Jabeen R. Nutraceuticals and functional foods: The foods for the future world. Critical Reviews in Food Science and Nutrition. 2016;56(16):2617-2627. DOI: 10.1080/10408398.2014.903384

[20] Tenea GN, Hurtado P, Ortega C. Inhibitory effect of substances produced by native Lactococcus lactis strains of tropical fruits towards food pathogens. Preventive Nutrition and Food Science. 2018;23(3):260-268. DOI: $10.3746 /$ pnf.2018.23.3.260

[21] Tenea GN, Pozo Delgado T. Antimicrobial peptides from Lactobacillus plantarum UTNGt2 prevent harmful bacteria growth on fresh tomatoes. Journal of Microbiology and Biotechnology. 2019;29:1553-1560, DOI: $10.4014 / j m b .1904 .04063$

[22] Gueimonde M, Sánchez B, de Los Reyes-Gavilán GC, Margolles A. Antibiotic resistance in probiotic bacteria. Frontiers in Microbiology. 2013;4:202. DOI: 10.3389/

fmicb.2013.00202

[23] Ceapa C, Lambertb J, van Limptb K, Welse M, Smokvinaa T, Knol J, Kleerebezemd M. Phenotype profiling links genotype to carbohydrate utilization signatures in the species Lactobacillus rhamnosus. Applied Environmental Microbiology. 2015; DOI: 10.1128/AEM.00851-15

[24] Bali V, Panesar PS, Bera MB, Kennedy JF. Bacteriocins: Recent trends and potential applications. Critical Review in Food Science and Nutrition. 2016;56(5):817-34. DOI: 10.1080/10408398.2012.729231

[25] Saha BC. A low-cost medium for mannitol production by Lactobacillus intermedius NRRL B-3693. Applied Microbiology and Biotechnology. 2006;72:676-680. DOI: 10.1007/ s00253-006-0364-z

[26] De Man JC, Rogosa M, Sharpe E. A medium for the cultivation of lactobacilli. Journal of Applied Microbiology. 1960;23:130-155. DOI: 10.1111/j.1365-2672.1960.tb00188.x

[27] Kearse M, Moir R, Wilson A, Stones-Havas S, Cheung M, Sturrock S, Buxton S, Cooper A, Markowitz A, Duran D, Thierer, T, Ashton B, Meintjes P, Drummond A. Geneious Basic: an integrated and extendable desktop software platform for the organization and analysis of sequence data. Bioinformatics. 2012;28(12):16471649. DOI: $10.1093 /$ bioinformatics/ bts199 
[28] Wang Q, Garrity G, Tiedje J, Cole J. Naïve bayesian classifier for rapid assignment of rRNA Sequences into the new bacterial taxonomy. Applied and Environmental Microbiology. 2007;73(16):5261-5267. DOI: 10.1128/ aem.00062-07

[29] Callahan BJ, McMurdie PJ, Rosen MJ, Han AW, Johnson AJA, Holmes SP. DADA2: High-resolution sample inference from Illumina amplicon data. Nature Methods. 2020; 13:581-583. DOI: $10.1038 /$ nmeth.3869

[30] R Core Team R: A language and environment for statistical computing. R Foundation for Statistical Computing. Vienna, Austria. 2020. URL: https:// www.R-project.org/

[31] Alishum A. DADA2 formatted 16S rRNA gene sequences for both bacteria \& archaea (Version 3). Zenodo. 2020; DOI: 10.5281/zenodo.3951383

[32] Zheng J, Wittouck S, Salvetti E, Franz C, Harris H, Mattarelli P, O'Toole PW, Pot B, Vandamme P, Walter J., Watanabe K, Wuyts S, Felis GE, Gänzle MG, Lebeer S. A taxonomic note on the genus Lactobacillus: Description of 23 novel genera, emended description of the genus Lactobacillus Beijerinck 1901, and union of Lactobacillaceae and Leuconostocaceae. International journal of systematic and evolutionary microbiology. 2020;70(4):2782-2858. DOI: $10.1099 /$ ijsem.0.004107

[33] Garzón K, Ortega C, Tenea GN. Characterization of bacteriocinproducing lactic acid bacteria isolated from native fruits of Ecuadorian Amazon. Polish Journal of Microbiology. 2017; 66(4): 473-481. DOI: 10.5604/01.3001.0010.7037

[34] Berends MS, Luz CF et al. AMR An R Package for working with antimicrobial resistance data. bioRxiv. 2019. DOI: $10.1101 / 810622$
[35] Oksanen JF, Blanchet G, Friendly M, Kindt R, Legendre $P$, McGlinn D, Minchin PR, O'Hara RB, Simpson GL, Solymos P, Stevens HH, Szoecs E, Wagner H. Vegan: community ecology package. R package version 2.56. 2019. https://CRAN.R-project.org/ package $=$ vegan

[36] de Vries A, Ripley BD. ggdendro: Create dendrograms and tree diagrams using 'ggplot2'. R package version 0.1.21. 2020. https://CRAN.R-project.org/ package $=$ ggdendro

[37] Darriba D, Taboada GL, Doallo R Posada D. jModelTest 2: more models, new heuristics and parallel computing. Nature Methods. 2012;9(8):772

[38] Ronquist F, Huelsenbeck JP. MRBAYES 3: Bayesian phylogenetic inference under mixed models. Bioinformatics. 2003;19:1572-1574

[39] Gustaw, K., Michalak, M., Polak-Berecka, M. et al. Isolation and characterization of a new fructophilic Lactobacillus plantarum FPL strain from honeydew. Annals of Microbiology. 2018;68:459-470. DOI: 10.1007/s13213-018-1350-2

[40] Abriouel H, Casado Muñoz MD, Lerma LL, Perez Montoro B, Bockelman W, Pichner R, et al. New insights in antibiotic resistance of Lactobacillus species from fermented foods. Food Research International. 2015;78:465-481. DOI: 10.1016/j. foodres.2015.09.016

[41] Casado Muñoz MC, Benomar N, Lerma LL, Gálvez A, Abriouel H. Antibiotic resistance of Lactobacillus pentosus and Leuconostoc pseudomesenteroides isolated from naturally-fermented Aloreña table olives throughout fermentation process. International Journal of Food Microbiology. 2014;172:110-118. DOI: 10.1016/j.ijfoodmicro.2013.11.025 
[42] Venegas-Ortega MG, Flores-

Gallegos AC, Martínez-Hernández JL, Aguilar CN, Nevárez-Moorillón GV.

Production of bioactive peptides from lactic acid bacteria: a sustainable approach for healthier foods.

Comprehensive Review in Food Sciences and Food Safety. 2019;18:1039-1051.

DOI: 10.1111/1541-4337.12455

[43] Simons A, Alanout K, Duval RE. Bacteriocins, antimicrobial peptides from bacterial origin: overview of their biology and their impact against multidrug-resistant bacteria. Microorganisms. 2020;8:639. DOI: $10.3390 /$ microorganisms 8050639

[44] Tenea GN, Lara MI. Antimicrobial compounds produced by Weissella confusa Cys2-2 strain inhibit Gramnegative bacteria growth. CyTA Journal of Food. 2019;17(1):105-111. DOI: 10.1080/19476337.2018.1561520

[45] Tenea GN, Olmedo D, Ortega C. Peptide-based formulation from lactic acid bacteria Impairs the pathogen growth in Ananas comosus (Pineapple). Coatings. 2020;10: 457. DOI: 10.3390/ coatings10050457

[46] Tenea GN, Suárez J. Probiotic Potential and Technological Properties of Bacteriocinogenic Lactococcus lactis subsp. lactis UTNGt28 from a native Amazonian fruit as a yogurt starter culture. Microorganisms. 2020;8:733. DOI: $10.3390 /$ microorganisms 8050733

[47] Jarrín Valladares PS, Carrillo LT, Zamora G. The internal colony as a current issue: transformation of the human territory in the Amazonian region of Ecuador. Letras Verdes. 2016;20:22-43. DOI: 10.17141/ letrasverdes.20.2016.2063 


\title{
Ticks from the Brazilian Amazon: Species, Distribution and Host-Relations
}

\author{
Hermes R. Luz, Thiago F. Martins, Sebastián Muño-Leal, \\ Francisco B. Costa, Sérgio L. Gianizella, \\ João Luiz H. Faccini and Marcelo B. Labruna
}

\begin{abstract}
Ticks are important ectoparasites and can transmit a wide variety of pathogens to animals and humans worldwide. These ectoparasites are the most important vectors of diseases causing pathogens in domestic and wild animals, and the second for man. In Brazil, Spotted Fever is the only disease transmitted to humans by ticks, while for animals we can highlight babesiosis, ehrlichiosis and anaplasmosis.

Although ticks are found in all of Brazil's biomes, little is known about its diversity and host-relations in the Amazon biome. The existing gaps and the lack of research indicate that the diversity of ticks and their possible pathogens are underestimated in the Brazilian Amazon. Therefore, in order to guide the next studies in the Amazon biome, we present in this chapter a compilation of the records of hard ticks and soft ticks parasitizing wild and domestic animals, and humans. We present the general list of ticks for this biome, their distribution, hosts and importance for public health and veterinary. Finally, the ixodofauna found in the Brazilian Amazon and presented here does not match the vertebrate diversity of this biome, which is one of the largest on the planet. Therefore, more acarologists and epidemiologists are needed in this region.
\end{abstract}

Keywords: Ixodida, domestic animals, wild animals, humans, Amazon, Brazil

\section{Introduction}

The Amazon or Amazon Rainforest is the largest remnant of tropical forest in the world, occupying a region of approximately 6.7 million $/ \mathrm{km}^{2}$, covering nine countries in South America: Ecuador $(\cong 2 \%)$, Suriname $(\cong 2 \%)$, Bolivia $(\cong 4 \%)$, Venezuela $(\cong 4 \%)$, Guyana $(\cong 3 \%)$, French Guiana $(\cong 2 \%)$, Colombia $(\cong 10 \%)$,

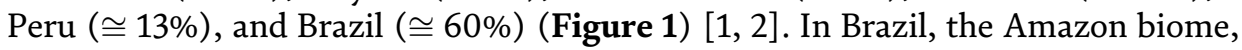
also known as "Legal Amazon" occupies approximately $49 \%$ of its territory, covering the states of Acre, Amapá, Amazonas, Mato Grosso, Pará, Rondônia, Roraima, Tocantins and Maranhão (Figure 1). The Brazilian Amazon is known for its high richness of landscapes composed of 23 ecoregions, whose main domain is the humid rainforest $(\cong 78 \%)$. Due to this heterogeneity, the Amazon has an immeasurable amount of essential habitats for the maintenance of flora and fauna, represented 

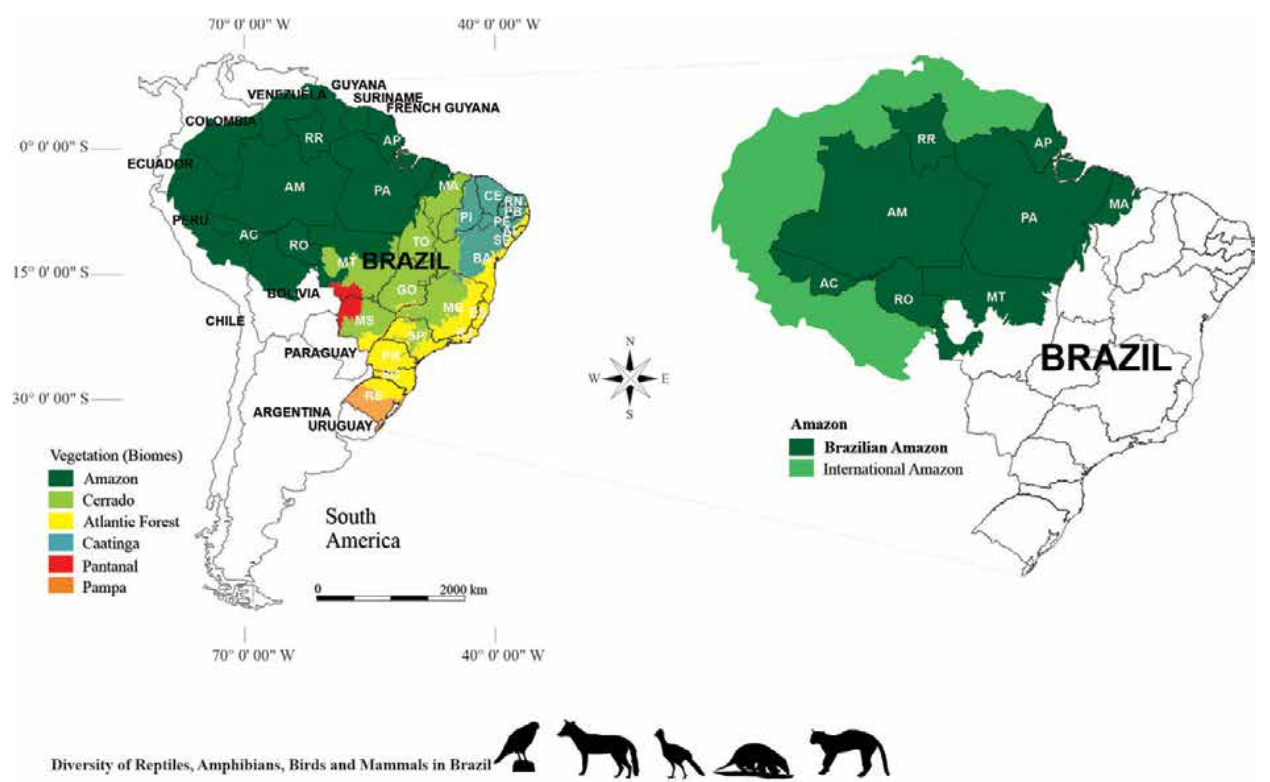
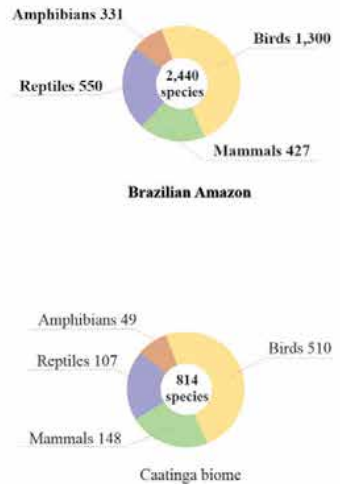
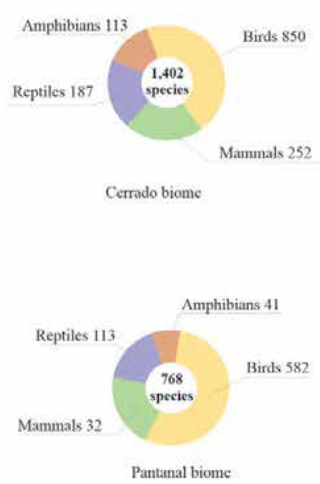
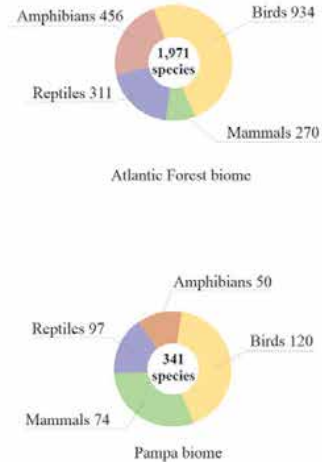

Figure 1.

Diversity of reptiles, amphibians, birds and mammals in Brazil, including the Brazilian Amazon.

with high biological diversity, which is regarded as the largest in the world $[3,4]$ The Amazon has approximately 45,000 species of flora (39,474 species) and fauna $(5,526$ species $)[2,5]$. However, even with this expressive diversity and the numerous faunal studies carried out in the region, there are still many gaps in the biological diversity of the Amazon. Due to its enormous extension and high degree of preservation (e.g., unexplored areas), new bioecological associations and new species are discovered every year. In the past 20 years, more than 1,200 new species have been described in the Amazon region from which we can highlight 16 birds, 39 mammals, 55 reptiles and $\cong 100$ amphibians [2]. However, anthropic action has negatively impacted the animal-forest relationships for decades, resulting in the extinction of ecologically demanding species and, at the same time, the appearance of opportunistic and/or generalist species [6].

Many domestic and wild animals are responsible for the maintenance and dispersion of ticks in nature. In addition, vertebrates act as amplifiers and/or reservoirs for viruses, protozoa and bacteria transmitted by these ectoparasites. The antropic action affects the population dynamics of both ticks and their wild hosts directly or indirectly, and consequently, the epidemiology of tick-borne diseases once restricted to wild fauna can reach domestic animal and humans interfaces [7]. Ticks are responsible for more than 100,000 cases of diseases in humans and animals 
worldwide [8], therefore a concern for public health professional. In Brazil, ticks are vectors of diseases such as babesiosis, ehrlichiosis, anaplasmosis and rickettsioses, including Brazilian Spotted Fever (BSF) $[9,10]$.

Ticks belong to the Sub-Class Acari, Super-Order Parasitiformes, Order Ixodida, and four families: Ixodidae, Argasidae, Nuttallielidae and Deinocrotonidae [11, 12], the latter extinct. Of these, only the Ixodidae and Argasidae families occur in Brazil, with nine genera and 75 species [11,13-16]. Ixodidae family is the most diverse with 51 species and five genera: Amblyomma (33 species), Ixodes (12 species), Rhipicephalus (two species), Haemaphysalis (three species) and Dermacentor (one species). Argasidae family is represented by 24 species and four genera: Ornithodoros (18 species), Antricola (three species), Argas (one species) and Nothoaspis (two species). In general, the immature stages (larvae and nymphs) of two or three host ticks feed on small mammals and birds, while adults exploit medium to large-sized hosts [17]. One-host species Dermacentor nitens and Rhipicephalus microplus, complete the life cycle mainly on large animals such as horses and cattle, respectively. Second Esser et al. [18] the diversity of ticks increases with the increase of diversity of hosts, inasmuch as these hematophagous arthropods rely on the hosts to complete their life cycles. Therefore, if we take into account the high diversity of hosts living in this biome and the amount of unexplored ecoregions, it is reasonable to infer that the diversity of ticks in the Amazon biome is insufficiently addressed. Thus, a review on the subject is necessary to point out the existing gaps and encourage new studies on ticks in the Brazilian Amazon.

\section{Hard ticks associated with amphibians and reptiles}

The class Amphibia includes the orders Anura, Caudata, Gymnophiona, whereas the class Reptilia includes the orders Squamata, Testudines and Crocodylia. There are 331 amphibian and 550 reptile species in the Brazilian Amazon (Figure 1), although that faunal records are far from complete $[2,19]$. Brazil has witnessed an increasing number of reports on tick parasitism of amphibians and reptiles over the past few years [20-24]. However, knowledge of this tick fauna as their hosts remains incomplete. To date, major tick-amphibian associations reported in Brazil are the ixodids Amblyomma dissimile, Amblyomma rotundatum, Amblyomma humerale, Amblyomma fuscum and Amblyomma goeldii [20-24], and the argasids Ornithodoros saraivai and Ornithodoros faccinii associated with species Cycloramphus boraceiensis and Thoropa miliaris, respectively [25, 26]. Occasional records on reptiles have also been reported for Ornithodoros mimon and Ornithodoros rietcorreai [22]. However, none of these argasids have been reported in the Amazon biome. Although the Brazilian Amazon has a high diversity of amphibians and reptiles, studies on ticks in association with these hosts are still rare, with a dominance of species $A$. dissimile, A. rotundatum and $A$. humerale [21-23, 27, 28].

The tick $A$. dissimile is constantly misidentified with the morphologically similar $A$. rotundatum. Recently, the distribution of $A$. dissimile in the country was reorganized, showing that this tick is restricted to the Pantanal and Amazon biomes [28]. Therefore, reports outside these biomes are considered misidentifications and must be viewed with caution. Most publications on this species are simple records of occurrence with some authors including data on prevalence and intensity of infestation both in the Amazon biome and elsewhere. According to Luz et al. [29] 12 (54.5\%) out of 22 Rhinella marina toads captured in Amapá state, were parasitized by a total of 97 ticks ( 6 males, 39 females, 31 nymphs, 21 larvae) and mean intensity of 8.1 ticks per infested toad. In the Amazonian biome, $A$. dissimile is common on $R$. marina (Anura) and Boidae (Squamata) (Table 1). The experimental life cycle 


\begin{tabular}{|c|c|c|c|c|c|c|c|}
\hline \multirow[t]{2}{*}{ Host } & \multirow[t]{2}{*}{ Specie } & \multicolumn{3}{|c|}{ A. dissimile } & \multicolumn{2}{|c|}{ A. rotundatum } & \\
\hline & & $\mathbf{L}$ & $\mathbf{N}$ & A & $\mathbf{L} \quad \mathbf{N}$ & A & \\
\hline \multicolumn{8}{|l|}{$\begin{array}{l}\text { Amphibian } \\
\text { (Anura) }\end{array}$} \\
\hline \multirow[t]{5}{*}{ Bufonidae } & Rhinella marina & & 37 & $12 \mathrm{M} ; 16 \mathrm{~F}$ & 164 & $133 \mathrm{~F}$ & {$[23,29-33]$} \\
\hline & Rhinella major & & & $2 \mathrm{~F}$ & 15 & $2 \mathrm{~F}$ & [33-35] \\
\hline & Rhaebo guttatus & & & & 1 & $1 \mathrm{~F}$ & {$[23]$} \\
\hline & Rhinella margaritifera & & & & 3 & $1 \mathrm{~F}$ & {$[23]$} \\
\hline & Rhinella gildae & & & & 1 & & {$[36]$} \\
\hline Leptodactylidae & $\begin{array}{l}\text { Leptodactylus } \\
\text { pentadactylus }\end{array}$ & & & & & $1 \mathrm{~F}$ & {$[23]$} \\
\hline \multicolumn{8}{|l|}{ Reptile } \\
\hline \multirow[t]{3}{*}{ Boidae } & Boa constrictor & & 1703 & $\begin{array}{l}723 \mathrm{M} \\
1346 \mathrm{~F}\end{array}$ & 12 & $\begin{array}{l}1 \mathrm{M} \\
77 \mathrm{~F}\end{array}$ & $\begin{array}{l}{[23,30,32-} \\
34,36-40]\end{array}$ \\
\hline & Corallus hortulanus & & 3 & $1 \mathrm{M}$ & & & {$[31,34]$} \\
\hline & Eunectes murinus & & 305 & $21 \mathrm{M} ; 3 \mathrm{~F}$ & & & {$[31,40]$} \\
\hline \multirow[t]{3}{*}{ Viperidae } & Bothrops atrox & 4 & 11 & $24 \mathrm{M} ; 14 \mathrm{~F}$ & & $\begin{array}{c}1 \mathrm{M} \\
2 \mathrm{~F}\end{array}$ & {$[32,33,36,37]$} \\
\hline & Crotalus durissus & & & $1 \mathrm{M} ; 1 \mathrm{~F}$ & & & {$[34]$} \\
\hline & Lachesis muta & & 1 & & & & [34] \\
\hline \multirow[t]{2}{*}{ Elapidae } & Micrurus averyi & & & $3 \mathrm{~F}$ & & & {$[31]$} \\
\hline & Micrurus lemniscatus & & & $12 \mathrm{M} ; 9 \mathrm{~F}$ & & & [31] \\
\hline \multirow[t]{12}{*}{ Colubridade } & Leptophis ahaetulla & & & & 3 & & [33] \\
\hline & Chironius multiventris & & & & 3 & & [33] \\
\hline & Chironius scurrulus & & & $1 \mathrm{M} ; 1 \mathrm{~F}$ & & & [34] \\
\hline & Chironius laevicollis & & 12 & $15 \mathrm{M} ; 6 \mathrm{~F}$ & & & {$[31]$} \\
\hline & Mastigodryas boddaerti & & & & 1 & & [33] \\
\hline & Hydrodynastes gigas & & & & 1 & $7 \mathrm{~F}$ & [30] \\
\hline & Helicops polylepis & & 1 & & & & [34] \\
\hline & Leptodeira annulata & & 1 & & & & [34] \\
\hline & Phimophis guerini & & & $1 \mathrm{~F}$ & & & [34] \\
\hline & Erythrolamprus reginae & & 1 & & & & [34] \\
\hline & Spilotes pullatus & & 72 & $42 \mathrm{M} ; 9 \mathrm{~F}$ & & & {$[31]$} \\
\hline & $\begin{array}{c}\text { Erythrolamprus reginae } \\
\text { semilineatus }\end{array}$ & & 1 & & & & [34] \\
\hline Dipsadidae & Xenodon severus & & & 8 & & & [40] \\
\hline \multirow[t]{2}{*}{ Testudinidae } & Chelonoidis denticulatus & & & $3 \mathrm{M}$ & 3 & $\begin{array}{l}2 \mathrm{M} \\
42 \mathrm{~F}\end{array}$ & {$[31,41]$} \\
\hline & Chelonoidis carbonaria & & 1 & $1 \mathrm{M} ; 1 \mathrm{~F}$ & 11 & & {$[32,39]$} \\
\hline \multirow[t]{3}{*}{ Podocnemididae } & Podocnemis expansa & & & & & $1 \mathrm{~F}$ & [39] \\
\hline & Podocnemis unifilis & & & & 1 & & [39] \\
\hline & Trachemys dorbigni & & & & 2 & $12 \mathrm{~F}$ & [39] \\
\hline Kinosternidae & Kinosternon scorpioides & & & & & $2 \mathrm{~F}$ & [42] \\
\hline
\end{tabular}


Ticks from the Brazilian Amazon: Species, Distribution and Host-Relations DOI: $h$ ttp://dx.doi.org/10.5772/intechopen.94862

\begin{tabular}{|c|c|c|c|c|c|c|c|c|}
\hline \multirow[t]{2}{*}{ Host } & \multirow[t]{2}{*}{ Specie } & \multicolumn{3}{|c|}{ A. dissimile } & \multicolumn{3}{|c|}{ A. rotundatum } & \\
\hline & & $\mathbf{L}$ & $\mathbf{N}$ & $\mathbf{A}$ & $\mathbf{L}$ & $\mathbf{N}$ & A & \\
\hline Chelidae & Platemys platycephala & & & & & & $5 \mathrm{~F}$ & {$[32]$} \\
\hline \multirow[t]{2}{*}{ Tropiduridade } & Uranoscodon superciliosus & & & & & 7 & $6 \mathrm{~F}$ & [33] \\
\hline & Tropidurus sp. & & & & & & $1 \mathrm{M}$ & [38] \\
\hline Teiidae & Ameiva ameiva & & 4 & & & & $1 \mathrm{~F}$ & {$[31,34]$} \\
\hline Iguanidae & Iguana iguana & & 31 & $\begin{array}{c}118 \mathrm{M} ; \\
69 \mathrm{~F}\end{array}$ & & & $2 \mathrm{~F}$ & {$[31,36,39,40]$} \\
\hline Dactyoloidae & Norops auratus & & 1 & & & & & [34] \\
\hline Gekkonidae & Hemidactylus mabouia & & 1 & & & & & {$[34]$} \\
\hline \multirow[t]{2}{*}{ Alligatoridae } & Paleosuchus trigonatus & & & $9 \mathrm{M} ; 15 \mathrm{~F}$ & & 4 & $12 \mathrm{~F}$ & {$[31,32]$} \\
\hline & Caiman crocodilus & & 3 & & & & & {$[31,39]$} \\
\hline Total & & 4 & 2189 & $\begin{array}{l}983 \mathrm{M} ; \\
1496 \mathrm{~F}\end{array}$ & & 221 & $307 \mathrm{~F}$ & \\
\hline
\end{tabular}

Table 1.

Hosts of Amblyomma dissimile and Amblyomma rotundatum in the Brazilian Amazon.

including pre-attachment periods for each parasitic stage lasts approximately 350 days, as reported by Schumaker et al. [43] who started a colony from one engorged female collected from the Amazonian biome. Ogrzewalska et al. [37] reported Rickettsia bellii and 'Candidatus Rickettsia colombianensi' in ticks collected from Bothrops atrox from Pará state. Luz et al. [29] reported 'Ca. R. colombianensi' in ticks collected on $R$. marina from Amapá state.

The tick $A$. rotundatum is an obligate parthenogenetic species, although there are six reports of adult males, two males in the laboratory [44] and six in the Amazon region parasitizing Tropidurus sp., Boa constrictor, Iguana iguana, Chelonoidis denticulatus and B. atrox [30, 36, 44-47]. Most publications on A. rotundatum are simple records of its occurrence with some additional data on prevalence and intensity of infestation in the Cerrado, Atlantic forest and Amazon biomes [22, 23, 31, 34, 48]. In the Brazilian Amazon, the families Bufonidae (Amphibian) and Boidae (Reptilia) are the most frequently parasitized by $A$. rotundatum, but there are reports on other species of Amphibian and Reptiles (Table 1). Recently, Gianizella et al. [31] reported $A$. rotundatum in different municipalities of the Amazonas state, on $B$. constrictor and several unknown hosts. The bioecology of this species under quasi-natural environment demonstrated a peak of larvae and nymphs in the dry season and females in the rainy season; however, there is a hypothesis of the absence of seasonality in this tick [48, 49]. Although $A$. rotundatum is a three-host tick on amphibians, it can behave as a two-host tick when feeding on snakes [50]. The complete experimental life cycle, including preattachment periods for each parasitic stage, ranged from 126 to 228 days on toads [51] or 56 to 163 days on snakes [50] and ulcerative lesions and hemorrhages after $A$. rotundatum feeding [48] were reported for ticks collected on toads from the Cerrado biome. Transmission of the hemogregarine Hemolivia stellata by $R$. marina collected in Belém, state of Pará was reported by Petit et al. [52]. This tick has also been found infected with $R$. bellii in the state of Amazon in the municipalities of Cacaulândia and Monte Negro, in the state of Rondônia; in the municipalities of Amapá (Ilha de Maracá) and Santana, in the state of Amapá; and in the municipality of Rio Branco, in the state of Acre [29, 53, 54]. 
Most reports of $A$. humerale mention the adult stage parasitizing species of tortoises, namely the "yellow-footed tortoise" C. denticulatus and the "red-footed tortoise" Chelonoidis carbonarius [27, 55]. There is also a record of A. humerale on Rhinoclemmys punctularia in central Amazon [56]. Labruna et al. [27] collected 215 adult ticks from six C. denticulatus and nine Chelonoidis sp. from state of Rondônia, with mean infestation of $14.3 \pm 12.0$ ticks per tortoise. In addition, seven engorged nymphs were collected on lizards. Morais et al. [57] collected 120 adult ticks from 18 (75\%) out of 24 C. denticulatus captured in a transitional area between the biomes Cerrado and southwestern Amazon rainforest, in the state of Mato Grosso. The mean intensity of infestation was 6.7 ticks/tortoise. In both surveys, male ticks were mostly attached in clusters on the carapace whereas females were found attached to the tortoise skin. The sex ratio (males:females) for $A$. humerale were different in both surveys, 10.3:1 [27] and 1.1:1 [57]. There is one additional record of two nymphs on Paleosuchus trigonatus (Crocodylia) [32]. The life-cycle in the laboratory, including pre-feeding periods for each of the parasitic stages, could be completed in an average period of ca. 200 days [58]. Rickettsia bellii and Rickettsia amblyommatis have been detected in $A$. humerale $[42,53]$. The records of $A$. fuscum in association with amphibians and reptiles are rare in Brazil. Dantas-Torres et al. [59] collected one male tick in one out of 490 caimans (Caiman latirostris and Paleosuchus palpebrosus) trapped in the Atlantic rainforest biome in Pernambuco state, northeastern Brazil. Amblyomma goeldii has been recorded only in the Amazonas state. Martins et al. [60] reported two males collected on B. constrictor and recovery of $\approx 100(20 \%)$ engorged larvae out of $\approx 500$ unfed larvae experimentally infested on a B. constrictor.

\section{Hard ticks associated with wild birds}

The importance of birds to maintain biodiversity and ecological balance of nature is notorious [61]. Due to migration, wild birds are of concern to human and animal health worldwide [62] because they can carry infected ticks over long distances, directly influencing the epidemiology of tick-borne diseases in animals and humans. In addition, wild birds themselves can be reservoirs of Borrelia burgdorferi sensu lato, and potentially to Anaplasma phagocytophilum and Rickettsia spp. [62, 63]. Wild birds play an important role in maintaining and dispersing immatures (larvae and nymphs) of several tick species into new locations $[61,64]$.

Of the total genera of ticks described in Brazil, five have at least one species recorded in association with wild birds. The most common are the hard ticks of the genera Amblyomma, Haemaphysalis and Ixodes [61, 64]. There are also occasional reports of the genera Rhipicephalus and Ornithodoros. Ticks of the genus Amblyomma are the most common on wild birds in the Brazil including the Amazon biome, exclusively for the larvae and nymphs [61,64]. Adult ticks are only occasionally found on wild birds, with the exception of Ixodes paranaensis and Ixodes auritulus, which have the entire cycle synchronized with birds [65]. In Brazil, there are no reports of wild birds as a source of pathogens transmitted by ticks to humans, but they can serve as disperser hosts for vectors of Brazilian Spotted Fever (BSF) as Amblyomma sculptum, Amblyomma aureolatum and Amblyomma ovale, in the larvae and nymph stages [64]. Therefore, wild birds act indirectly in the epidemiology of BSF by dispersing and maintaining their vectors in nature.

Over more than 1,900 birds recorded in Brazil, approximately 1,300 reside in the Brazilian Amazon, with a 20\% of endemism [66] (Figure 1). Of these, approximately $7 \%$ are migrants from the northern hemisphere and southern South America, including migrations from other Brazilian biomes [67]. To date, 86 bird species 
of Brazilian Amazonian have been recorded in association with at least one tick species (Table 2). This is equivalent to approximately only $7 \%$ of bird species found in this biome and $5 \%$ of the total birds recorded in Brazil (Table 2). Similar to other studies regarding tick-bird associations in Brazil [73-75], Passeriformes birds were the most parasitized in the Amazon biome, including 14 families and 72 species (Figure 2 and Table 2). In this group, the greatest diversity of parasitized birds was Thamnophilidae (20 species) followed by Dendrocolaptidae (16 species) and Tyrannidade (10 species) (Figure 2). The least parasitized families were Conopophagidae, Furnariidae, Xenopidae, Tityridae, Cardinalidae, Columbidae, Cuculidae, Momotidae, Capitonidae, Ramphastidae, Psittacidae, Accipitridae and Falconidae with only one species of parasitized bird each (Figure 2 and Table 2). Non-Passerines were represented by 10 different orders and 11 families, with

\begin{tabular}{|c|c|c|c|c|c|c|}
\hline \multirow[t]{3}{*}{ Hosts } & & & \multicolumn{3}{|l|}{ Ticks } & \multirow[t]{3}{*}{ References } \\
\hline & & & \multirow[t]{2}{*}{ Species } & \multicolumn{2}{|c|}{ Stages } & \\
\hline & & & & LL & NN & \\
\hline \multirow[t]{30}{*}{ Passeriformes } & Thamnophilidae & Thamnomanes & A. humerale & & 1 & {$[68]$} \\
\hline & & schistogynus & A. nodosum & & 1 & \\
\hline & & Thamnophilus doliatus & A. nodosum & & 2 & [68] \\
\hline & & $\begin{array}{c}\text { Thamnophilus } \\
\text { schistaceus }\end{array}$ & $\begin{array}{c}\text { A. nodosum } \\
\text { Amblyomma sp. }\end{array}$ & 2 & 2 & [68] \\
\hline & & Thamnophilus aethiops & A. calcaratum & & 5 & {$[68]$} \\
\hline & & & A. longirostre & & 1 & \\
\hline & & $\begin{array}{l}\text { Myrmelastes } \\
\text { hyperythrus }\end{array}$ & A. nodosum & & 9 & [68] \\
\hline & & $\begin{array}{c}\text { Sciaphylax } \\
\text { hemimelaena }\end{array}$ & A. nodosum & & 1 & [68] \\
\hline & & Schistocichla & A. humerale & 4 & & [69] \\
\hline & & leucostigma & Amblyomma sp. & 5 & & \\
\hline & & Phlegopsis & A.coelebs & 1 & 5 & {$[68,69]$} \\
\hline & & nigromaculata & A. longirostre & 1 & & \\
\hline & & & A. nodosum & 24 & & \\
\hline & & & Amblyomma sp. & & & \\
\hline & & Hypocnemis subflava & Amblyomma sp. & 3 & & [70] \\
\hline & & Hylophylax naevius & H. juxtakochi & 1 & 1 & [69] \\
\hline & & & A. humerale & 3 & 2 & \\
\hline & & & A. longirostre & 1 & 1 & \\
\hline & & & A. calcaratum & 8 & & \\
\hline & & & Amblyomma sp. & & & \\
\hline & & $\begin{array}{l}\text { Hylophylax } \\
\text { punctulatus }\end{array}$ & Amblyomma sp. & 1 & & [69] \\
\hline & & Thamnomanes caesius & A. geayi & 1 & 2 & {$[69,71]$} \\
\hline & & & A. longirostre & 3 & 1 & \\
\hline & & & A. humerale & 4 & & \\
\hline & & & Amblyomma sp & & & \\
\hline & & Hylophylax & A. geayi & 1 & 1 & [69] \\
\hline & & poecilinotus & A. humerale & 1 & 1 & \\
\hline & & & A. longirostre & 3 & 1 & \\
\hline & & & $\begin{array}{c}\text { Amblyomma sp. } \\
\text { H. juxtakochi }\end{array}$ & 22 & 1 & \\
\hline & & Myrmornis torquata & Amblyomma sp. & 3 & & [69] \\
\hline
\end{tabular}




\begin{tabular}{|c|c|c|c|c|c|c|}
\hline \multirow[t]{2}{*}{ Hosts } & & & \multicolumn{2}{|l|}{ Ticks } & & \multirow[t]{2}{*}{ References } \\
\hline & & & Species & Stages & & \\
\hline & & $\begin{array}{l}\text { Myrmotherula } \\
\text { hauxwelli }\end{array}$ & Amblyomma sp. & 1 & & [69] \\
\hline & & $\begin{array}{c}\text { Myrmotherula } \\
\text { longipennis }\end{array}$ & $\begin{array}{l}\text { A. longirostre } \\
\text { Amblyomma sp. }\end{array}$ & $\begin{array}{l}3 \\
3\end{array}$ & & [69] \\
\hline & & Pyriglena leuconota & $\begin{array}{c}\text { A. coelebs } \\
\text { A. humerale } \\
\text { A. longirostre } \\
\text { Amblyomma sp. }\end{array}$ & $\begin{array}{l}1 \\
1 \\
9 \\
4\end{array}$ & 1 & [69] \\
\hline & & $\begin{array}{l}\text { Myrmoborus } \\
\text { myotherinus }\end{array}$ & A. longirostre & & 1 & {$[69]$} \\
\hline & & $\begin{array}{l}\text { Epinecrophylla } \\
\text { leucophthalma }\end{array}$ & A. longirostre & & 1 & {$[71]$} \\
\hline & & Willisornis poecilinotus & A. calcaratum & & 1 & [71] \\
\hline & Conopophagidae & Conopophaga aurita & Amblyomma sp. & & 1 & [69] \\
\hline & Scleruridae & Sclerurus cf. rufigularis & A. humerale & & 1 & {$[68]$} \\
\hline & & Sclerurus caudacutus & A. humerale & & 1 & {$[69]$} \\
\hline & Furnariidae & Automolus paraensis & Amblyomma sp. & & 1 & {$[69]$} \\
\hline & Dendrocolaptidae & Dendrocincla merula & $\begin{array}{l}\text { A. longirostre } \\
\text { Amblyomma sp. }\end{array}$ & $\begin{array}{c}7 \\
34\end{array}$ & 1 & {$[68,69,71]$} \\
\hline & & Dendrocincla fuliginosa & Amblyomma sp. & 10 & & {$[31,70]$} \\
\hline & & $\begin{array}{c}\text { Deconychura } \\
\text { longicauda }\end{array}$ & $\begin{array}{l}\text { A. longirostre } \\
\text { Amblyomma sp. }\end{array}$ & $\begin{array}{c}4 \\
39\end{array}$ & 1 & {$[69,71]$} \\
\hline & & $\begin{array}{l}\text { Deconychura } \\
\text { stictolaema }\end{array}$ & $\begin{array}{l}\text { A. longirostre } \\
\text { Amblyomma sp. }\end{array}$ & $\begin{array}{l}1 \\
1\end{array}$ & 1 & [69] \\
\hline & & $\begin{array}{l}\text { Dendrocolaptes } \\
\text { hoffmannsi }\end{array}$ & $\begin{array}{c}\text { A. calcaratum } \\
\text { A. geayi } \\
\text { A. humerale } \\
\text { A. longirostre } \\
\text { Amblyomma sp. }\end{array}$ & $\begin{array}{c}1 \\
2 \\
4 \\
39 \\
59\end{array}$ & $\begin{array}{l}2 \\
1 \\
3\end{array}$ & [69] \\
\hline & & Dendrocolaptes certhia & A. longirostre & & 1 & {$[71]$} \\
\hline & & Glyphorynchus spirurus & A. longirostre & & 1 & {$[71]$} \\
\hline & & Glyphorynchus spirurus & $\begin{array}{c}\text { A. geayi } \\
\text { A. longirostre } \\
\text { Amblyomma sp. }\end{array}$ & $\begin{array}{c}1 \\
6 \\
16\end{array}$ & $\begin{array}{l}1 \\
2\end{array}$ & {$[69]$} \\
\hline & & Hylexetastes brigidai & $\begin{array}{c}\text { A. geayi } \\
\text { A. longirostre } \\
\text { Amblyomma sp. }\end{array}$ & $\begin{array}{c}1 \\
6 \\
21 \\
\end{array}$ & 2 & [69] \\
\hline & & $\begin{array}{c}\text { Sittasomus } \\
\text { griseicapillus }\end{array}$ & $\begin{array}{c}\text { A. humerale } \\
\text { Amblyomma sp. }\end{array}$ & 2 & 1 & {$[70]$} \\
\hline & & Xiphorhynchus guttatus & $\begin{array}{l}\text { A. longirostre } \\
\text { A. nodosum }\end{array}$ & & $\begin{array}{l}2 \\
1\end{array}$ & {$[68]$} \\
\hline & & $\begin{array}{l}\text { Xiphorhynchus } \\
\text { guttatoides }\end{array}$ & $\begin{array}{c}\text { A. humerale } \\
\text { Amblyomma sp. }\end{array}$ & 1 & 2 & {$[70]$} \\
\hline & & Xiphorhynchus elegans & $\begin{array}{c}\text { A. longirostre } \\
\text { Amblyomma sp. }\end{array}$ & $\begin{array}{l}3 \\
2\end{array}$ & 2 & {$[69]$} \\
\hline
\end{tabular}


Ticks from the Brazilian Amazon: Species, Distribution and Host-Relations

DOI: http://dx.doi.org/10.5772/intechopen.94862

\begin{tabular}{|c|c|c|c|c|c|c|}
\hline \multirow[t]{2}{*}{ Hosts } & & & \multicolumn{3}{|l|}{ Ticks } & \multirow[t]{2}{*}{ References } \\
\hline & & & Species & Stag & & \\
\hline & & $\begin{array}{c}\text { Xiphorhynchus } \\
\text { ocellatus }\end{array}$ & A. calcaratum & & 1 & [71] \\
\hline & & $\begin{array}{l}\text { Xiphorhynchus } \\
\text { pardalotus }\end{array}$ & Amblyomma sp. & 3 & & [31] \\
\hline & & Dendroplex picus & $\begin{array}{l}\text { A. longirostre } \\
\text { A. nodosum }\end{array}$ & & $\begin{array}{l}3 \\
3\end{array}$ & {$[68,70]$} \\
\hline & Xenopidae & Xenops minutus & A. nodosum & & 2 & [69] \\
\hline & Pipridae & Pipra filicauda & $\begin{array}{c}\text { A.geayi } \\
\text { Amblyomma sp. }\end{array}$ & & 1 & {$[68,70]$} \\
\hline & & Pipra fasciicauda & $\begin{array}{c}\text { A. longirostre } \\
\text { A. nodosum } \\
\text { Amblyomma sp. }\end{array}$ & $\begin{array}{l}1 \\
8\end{array}$ & 7 & {$[68]$} \\
\hline & & $\begin{array}{c}\text { Machaeropterus } \\
\text { pyrocephalus }\end{array}$ & A. longirostre & & 1 & {$[68]$} \\
\hline & & Dixiphia pipra & $\begin{array}{c}\text { A. geayi } \\
\text { A. longirostre }\end{array}$ & $\begin{array}{l}1 \\
1\end{array}$ & $\begin{array}{l}1 \\
1\end{array}$ & [69] \\
\hline & & Lepidothrix nattereri & Amblyomma sp. & 1 & & [71] \\
\hline & Rhynchocyclidae & $\begin{array}{l}\text { Leptopogon } \\
\text { amaurocephalus }\end{array}$ & A. geayi & 1 & & [68] \\
\hline & & Rhynchocyclus olivaceus & $\begin{array}{c}\text { A. geayi } \\
\text { A. humerale } \\
\text { A. longirostre } \\
\text { A. nodosum } \\
\text { Amblyomma sp. }\end{array}$ & $\begin{array}{l}1 \\
1 \\
4\end{array}$ & $\begin{array}{c}2 \\
1 \\
17\end{array}$ & [68] \\
\hline & & $\begin{array}{l}\text { Todirostrum } \\
\text { maculatum }\end{array}$ & A. nodosum & & 1 & [68] \\
\hline & & Poecilotriccus latirostris & $\begin{array}{c}\text { A. nodosum } \\
\text { Amblyomma sp. }\end{array}$ & 6 & 3 & {$[70]$} \\
\hline & & $\begin{array}{l}\text { Hemitriccus } \\
\text { flammulatus }\end{array}$ & Amblyomma sp. & 1 & & {$[70]$} \\
\hline & Tyrannidae & Myiozetetes similis & A. nodosum & & 1 & {$[68]$} \\
\hline & & Empidonax alnorum & $\begin{array}{l}\text { A. nodosum } \\
\text { A. longirostre }\end{array}$ & 4 & 1 & {$[68]$} \\
\hline & & Platyrinchus saturatus & Amblyomma sp. & 1 & & [69] \\
\hline & & Hemitriccus minor & A. longirostre & 1 & & [69] \\
\hline & & Mionectes macconnelli & $\begin{array}{c}\text { A. longirostre } \\
\text { Amblyomma sp. }\end{array}$ & $\begin{array}{l}4 \\
5\end{array}$ & & [69] \\
\hline & & Attila spadiceus & $\begin{array}{c}\text { A.geayi } \\
\text { Amblyomma sp. }\end{array}$ & $\begin{array}{l}1 \\
3\end{array}$ & & [69] \\
\hline & & Myiobius barbatus & A. longirostre & 3 & & [69] \\
\hline & & $\begin{array}{c}\text { Onychorhynchus } \\
\text { coronatus }\end{array}$ & $\begin{array}{c}\text { A. longirostre } \\
\text { Amblyomma sp. }\end{array}$ & $\begin{array}{l}3 \\
6\end{array}$ & & [69] \\
\hline & & $\begin{array}{l}\text { Ramphotrigon } \\
\text { megacephalum }\end{array}$ & $\begin{array}{c}\text { A. nodosum } \\
\text { Amblyomma sp. }\end{array}$ & 1 & 3 & {$[70]$} \\
\hline & & $\begin{array}{l}\text { Knipolegus } \\
\text { poecilocercus }\end{array}$ & Amblyomma sp. & 1 & & [71] \\
\hline
\end{tabular}




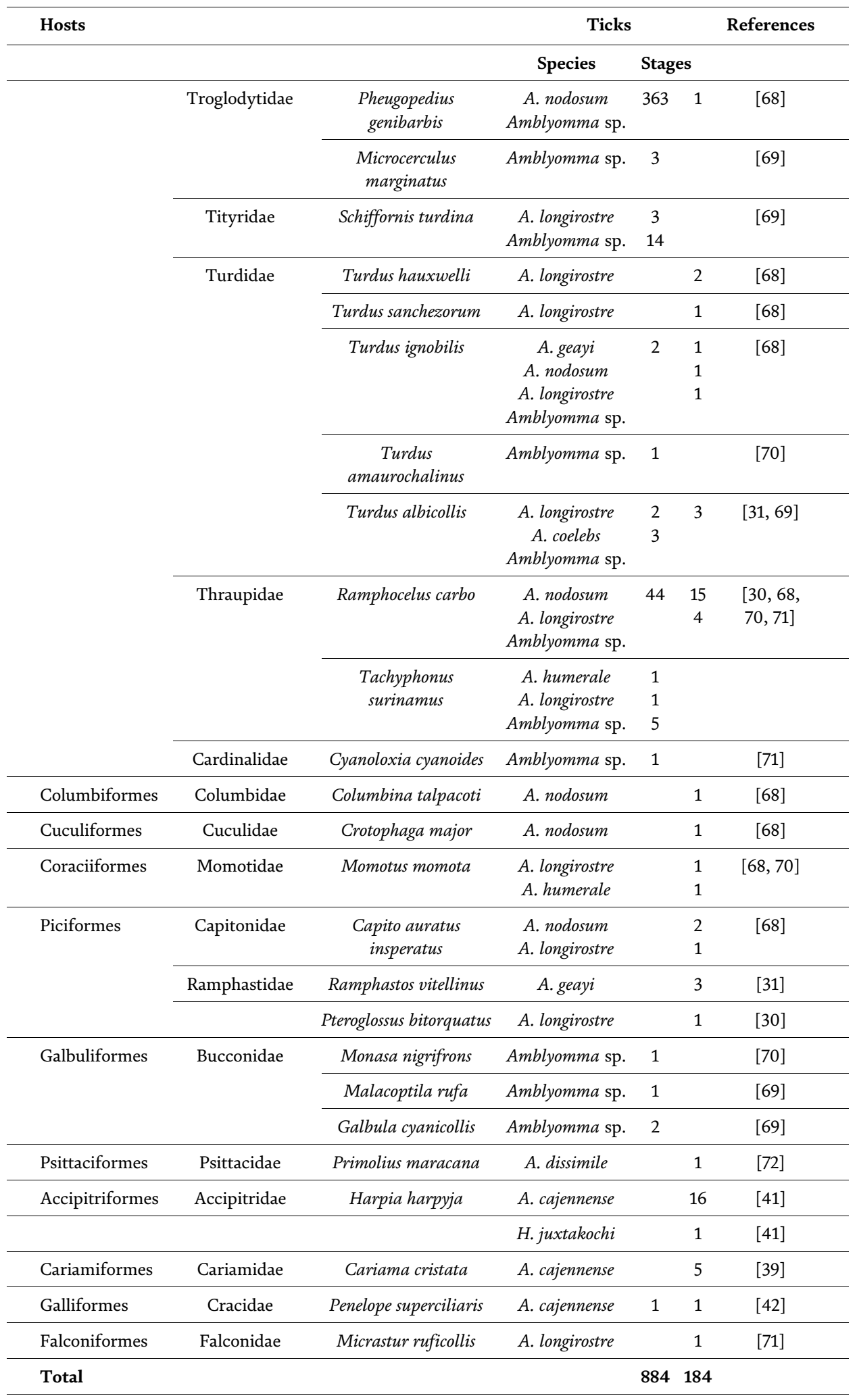

Table 2.

Ticks identified on wild birds in the Brazilian Amazon biome. 
emphasis on Bucconidae with three species (Figure 2 and Table 2). To date, approximately 1,068 specimens of ticks have been collected from birds in the Brazilian Amazon, in the stages of larvae (884/83\%), nymphs (184/17\%) and no adults (Figure 3). These are included in the genera Amblyomma and Haemaphysalis. The genus Amblyomma was the dominant with eight species (Table 2). The greatest diversity of ticks was reported for the Thamnophilidae family with seven species: A. longirostre, $A$. nodosum, $A$. humerale, $A$. calcaratum, A. geayi, $A$. coelebs and Haemaphysalis juxtakochi. The Dendrocolaptidae family was the second with five
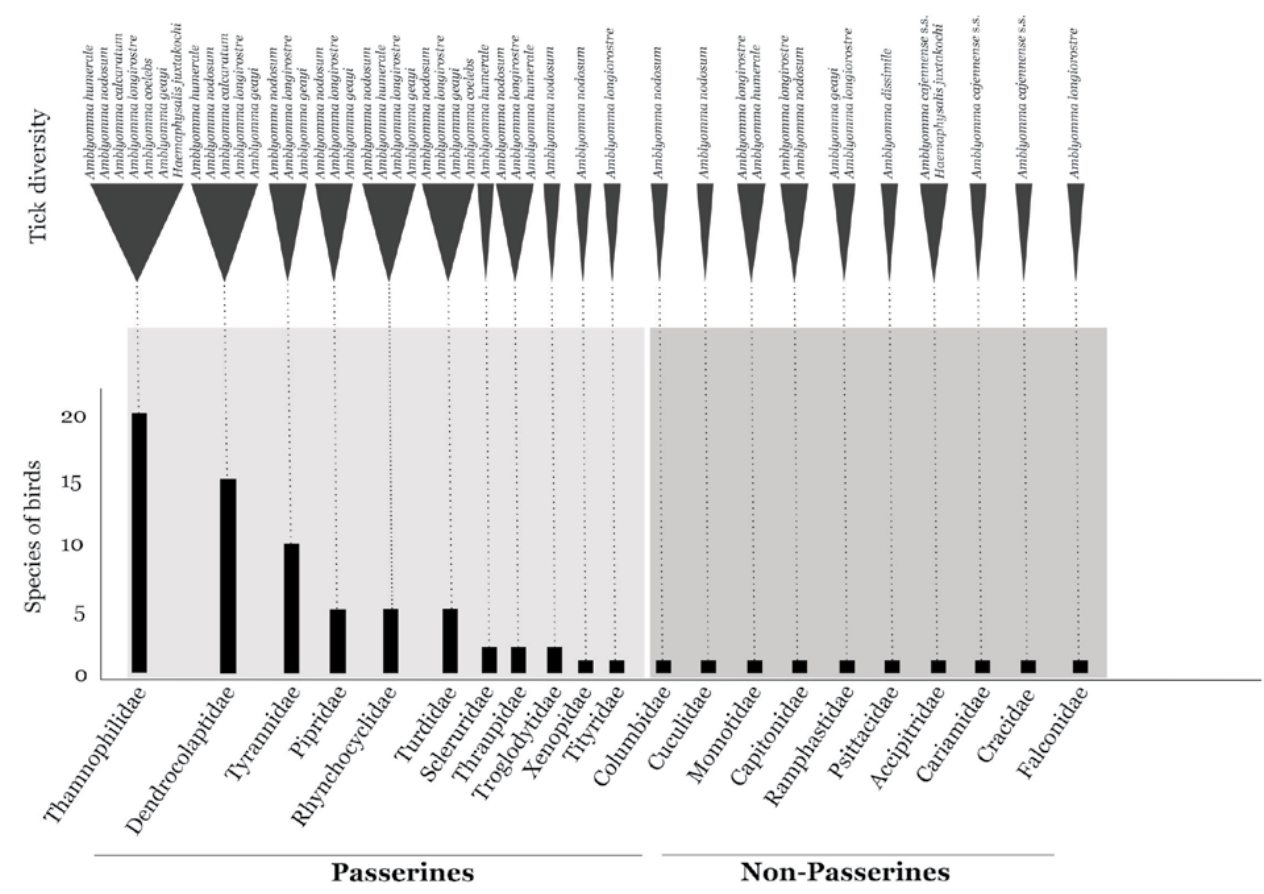

Figure 2.

Diversity of hard ticks parasitizing wild birds from the Brazilian Amazon.

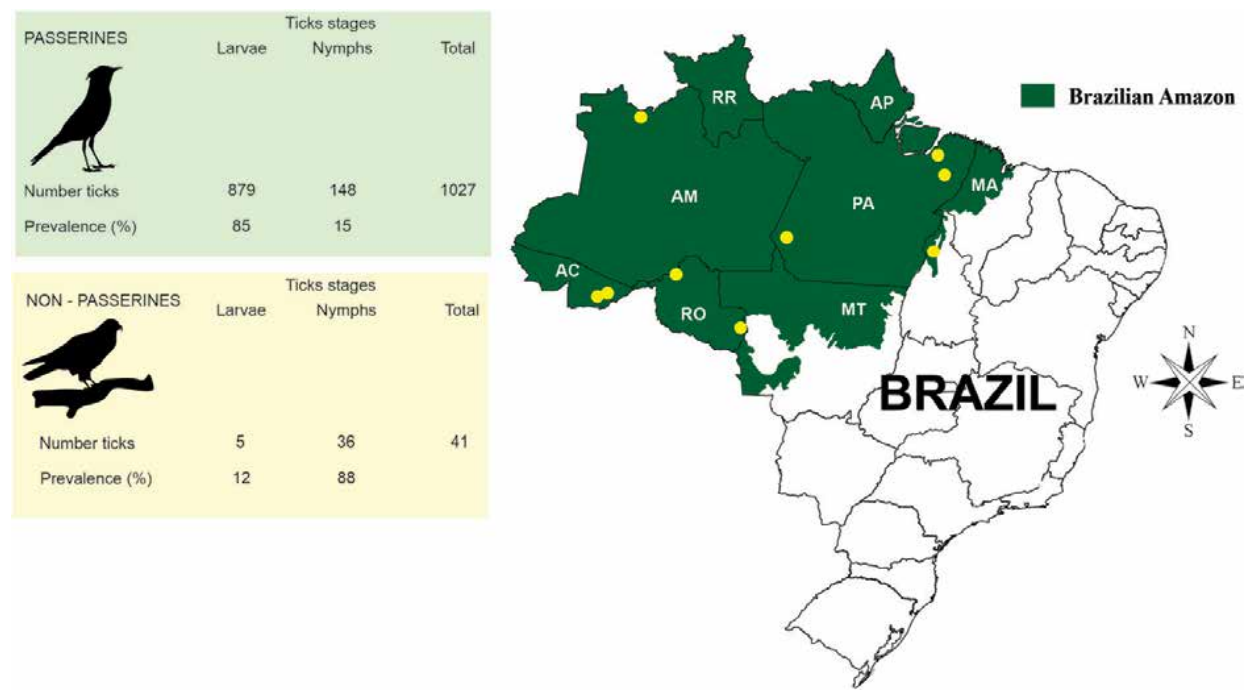

Figure 3.

Distribution of studies reporting the association of hard ticks on wild birds from the Brazilian Amazon. 


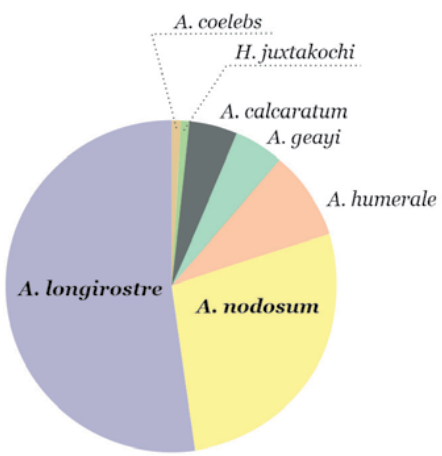

Passerines

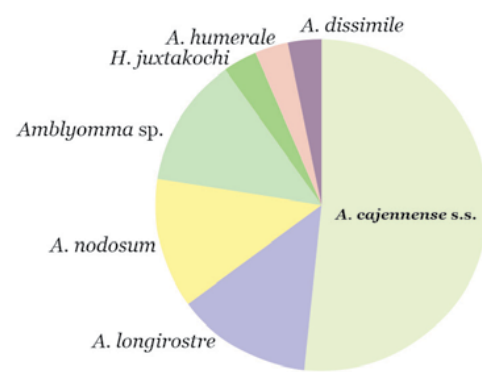

Non-Passerines

Figure 4.

Hard tick species parasitizing wild birds from the Brazilian Amazon.

species: $A$. longirostre, $A$. nodosum, $A$. humerale, $A$. calcaratum and $A$. geayi

(Figure 2 and Table 2).

Overall, $A$. longirostre and $A$. nodosum are the two most common species on wild birds in the Brazilian Amazon [68-71] (Figure 4 and Table 2). The tick A. longirostre was the most common, recorded in 12 families and 40 species of birds (36 Passerines and 4 non-Passerines) (Figure 2). Amblyomma longirostre has been treated as an arboreal tick, with immatures parasitizing birds and adults parasitizing rodents Erethizontidae (e.g., Sphiggurus spp.) [73, 76]. This tick was also the most abundant with 110 larvae and 39 nymphs. Amblyomma longirostre was found in co-infestation with the following species: A. calcaratum, A. nodosum, A. coelebs, A. humerale, A. geayi and $H$. juxtakochi (Table 2). In addition, as it is frequent on birds, A. longirostre is popularly known as "bird tick" or "bird earring" [77]. Amblyomma nodosum was the second most common species collected on 12 families and 22 species of birds. This tick was recorded in co-infestation with $A$. longirostre, A. coelebs, A. humerale and A. geayi (Table 2 and Figures 2 and 4). The birds most infested by $A$. nodosum were Rhynchocyclus olivaceus and Ramphocelus carbo with 17 and 15 nymphs, respectively. These birds inhabit the forest understory and visit the soil occasionally [67]. As Xenartha mammals (Myrmecophaga tridactyla, Tamandua tetradactyla) are the primary hosts of A. nodosum [17], it is believed that the low areas of the understory are a major source of infestation. Interestingly,

T. tetradactyla may have arboreal habits [78], which helps to explain the presence of A. nodosum also on birds of different forest strata.

To date, of the total of ticks collected, $736(70 \%)$ were larvae identified as Amblyomma sp. due to lack of reliable tools for larval identification, thus, indicating that the diversity of ticks on birds of the Amazon may be underestimated. Luz et al. [75], using molecular biology, identified more than $90 \%$ of the larvae collected from birds in the Atlantic Forest biome, reporting the greatest diversity of ticks on birds in a single study in Brazil and description of the new tick Amblyomma romarioi [14]. Therefore, the identification of all larvae by molecular biology in addition to morphological identification is extremely important to ascertain the diversity of ticks in the Amazon biome.

\section{Hard ticks associated with wild and domestic mammals}

The fauna of wild mammals in Brazil is quite diverse and more than half lives in the Amazon biome [79]. Like birds, amphibians and reptiles, mammals play an 
important role in preserved or anthropized ecosystems. Therefore, the knowledge of the local diversity of wild mammals, and their relationship with ticks is considered an important tool for public conservation policies and consequently for public health. The alteration of wild habitats can determine changes in the patterns of parasitic specificity, inducing tick species to seek new groups of hosts, increasing the risk of disease transmission $[79,80]$. Some wild mammals (small, medium and large) are directly or indirectly involved in the transmission cycles of many tickborne pathogens worldwide, including Anaplasma spp., Babesia spp., Borrelia spp., and Rickettsia spp. [80, 81]. In Brazil, the main zoonosis transmitted by ticks is Brazilian Spotted Fever caused by the bacterium Rickettsia rickettsii, which has the rodent Hydrochoerus hydrochaeris as its main amplifier. In addition, there is evidence that marsupials and small rodents can serve as amplifier hosts for $R$. rickettsii in nature [82].

In Brazil there are approximately 755 species of mammals distributed in all its six biomes, including the Amazon biome [78, 79]. Of the total mammal species, $41 \%$ ( 311 species) occur in the Amazon biome (Figure 1) $[2,76]$. These vertebrates are distributed in 11 orders, 51 families and 249 genera [78, 79]. Among the families, Cricetidae is the most diverse, with 144 species $[78,79]$. The vast majority of tick species, including all life stages, in Brazil have records on wild mammals of different sizes [17]. In general, small mammals of the orders Rodentia and Didelphimorphia are those that have a greater number of studies in association with ticks, especially the families Cricetidae and Didelphidae [17, 82]. In general, medium and large mammals are parasitized by ticks in all stages (larva, nymph and adult), while in small mammals the stages of larva and nymph are more common. In this last group of hosts we can highlight the cricetids Akodon spp., Calomys spp., Oligoryzomys spp. and Nectomys spp. as the most parasitized by immature ticks in nature.

Nine orders and 24 families of wild mammals have representatives in association with ticks in the Brazilian Amazon (Figure 5). Rodentia was the most diverse with 16 species of mammals, followed by the orders Carnivora (13 species) and Didelphimorphia (12 species) (Figure 5). However, it was the family Didelphidae that presented a greater number of parasitized species, followed by Dasyproctidae (seven species) and Mustelidae (four species). These records corroborate with numerous studies of tick parasitism on wild animals from South America, with emphasis on the orders Rodentia and Didelphimorphia [17, 82, 83].

Hard ticks parasitizing wild mammals in the Brazilian Amazon are represented by five genera: Amblyomma, Ixodes, Haemaphysalis, Dermacentor and Rhipicephalus. Of these, the genus Amblyomma was more frequently recorded with 23 species (Figure 5). The orders Rodentia, Pilosa and Didelphimorphia are hosts for highest diversity to Amblyomma species 17, 15 and eight, respectively. All these species are also recorded on a variety of wild mammals in Brazil [83-87], except for $A$. rotundatum and $A$. dissimile, which are more specific ticks of cold-blooded animals (Amphibians and Reptiles), although there are occasional reports on mammals in South America [20,83]. Amblyomma humerale, of which the adult stage is more specific to tortoises, immature stages have been found on a variety of small mammals, reptiles and birds [17, 68, 71, 83].

The second most common genus in the Amazon is Ixodes, with six reported species: Ixodes amarali, Ixodes bocatorensis, Ixodes lasallei, Ixodes luciae, Ixodes schulzei and Ixodes spinosus (Table 3). Although there are two exclusive species on birds in Brazil [65], all species recorded in the Brazilian Amazon parasitize mainly wild mammals [13, 16, 31, 32, 88, 99, 102]. Ixodes spp. were found on families Didelphidae, Dasyproctidae, Cricetidae, Myrmecophagidae, Bradypodidae and Cyclopedidae (Figure 5 and Table 3 ). In general Ixodes ticks mainly parasitize 


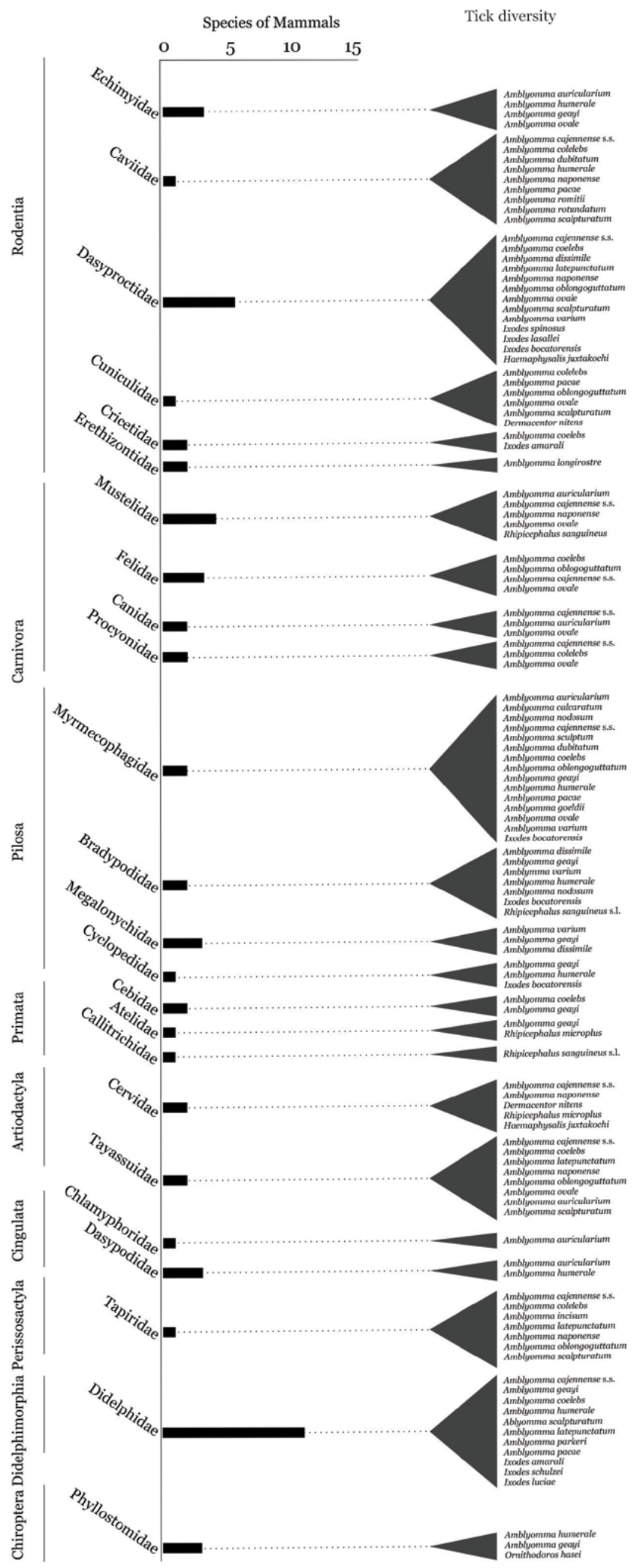

Figure 5.

Diversity of hard ticks parasitizing wild mammals from the Brazilian Amazon. 
Ticks from the Brazilian Amazon: Species, Distribution and Host-Relations

DOI: http://dx.doi.org/10.5772/intechopen.94862

\begin{tabular}{|c|c|c|c|c|}
\hline Tick species & Domestic mammals & Wild mammals & States & References \\
\hline $\begin{array}{l}\text { Amblyomma } \\
\text { auricularium }\end{array}$ & & $\begin{array}{l}\text { Cabassous unicinctus }{ }^{4}, \text { Dasypus } \\
\text { novemcinctus }^{4,5,7}, \text { Dasypus } \\
\text { septemcinctus }^{4,9}, \text { Euphractus } \\
\text { sexcinctu }^{4,9}, \text { Galactis cuja }^{4,9}, \\
\text { Galictis vittata }^{4}, \text { Lycalopex }^{9} \\
\text { vetulus }^{9}, \text { Myrmecophaga }^{9} \\
\text { tridactyla }^{9}, \text { Pecari tajacu }^{9} \\
\text { Tamandua tetradactyla }^{4}, \\
\text { Thrichomys inermis }^{4}\end{array}$ & $\begin{array}{l}\mathrm{MA}^{4} \\
\mathrm{MT}^{5}, \mathrm{RO}^{7} \\
\mathrm{TO}^{9}\end{array}$ & $\begin{array}{l}{[30,32,} \\
36,39]\end{array}$ \\
\hline $\begin{array}{l}\text { Amblyomma } \\
\text { cajennense } \\
\text { sensu stricto }\end{array}$ & $\begin{array}{l}\text { Equus caballus }^{4,5,6,7,8,9}, \text { Sus } \\
\text { scrofa }^{4,9}, \text { Canis } \\
\text { familiaris }^{4,9}, \text { Bubalus } \\
\text { bubalis }^{7}\end{array}$ & 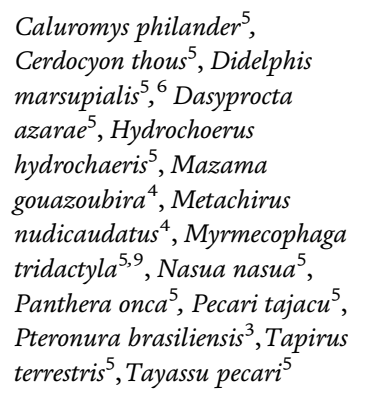 & $\begin{array}{l}\mathrm{AM}^{3}, \\
\mathrm{MA}^{4} \\
\mathrm{MT}^{5}, \mathrm{PA}^{6} \\
\mathrm{RO}^{7}, \mathrm{RR}^{8} \\
\mathrm{TO}^{9}\end{array}$ & $\begin{array}{l}{[32,36,} \\
42,88-91]\end{array}$ \\
\hline $\begin{array}{l}\text { Amblyomma } \\
\text { calcaratum }\end{array}$ & & $\begin{array}{l}\text { Myrmecophaga tridactyla } \\
\text { Tamandua tetradactyla } \\
45,6\end{array}$ & $\begin{array}{l}\mathrm{MA}^{4} \\
\mathrm{MT}^{5}, \mathrm{PA}^{6} \\
\mathrm{RO}^{7}\end{array}$ & {$[36,38,42]$} \\
\hline $\begin{array}{l}\text { Amblyomma } \\
\text { coelebs }\end{array}$ & Equus caballus $^{7}$ & 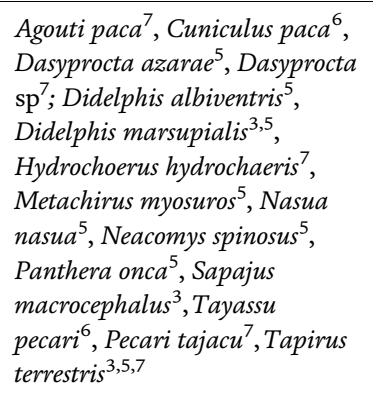 & $\begin{array}{l}\mathrm{AM}^{3} \\
\mathrm{MT}^{5}, \mathrm{PA}^{6} \\
\mathrm{RO}^{7}\end{array}$ & $\begin{array}{l}{[30-32,38,} \\
42,88]\end{array}$ \\
\hline $\begin{array}{l}\text { Amblyomma } \\
\text { dissimile }\end{array}$ & & $\begin{array}{l}\text { Bradypus tridactylus }^{3} \text {, } \\
\text { Choleopus didactylus }^{3}, \text { Coendou }^{3} \\
\mathrm{sp}^{3}, \text { Dasyprocta leporina }\end{array}$ & $\mathrm{AM}^{3}$ & {$[31,36,40]$} \\
\hline $\begin{array}{l}\text { Amblyomma } \\
\text { dubitatum }\end{array}$ & & $\begin{array}{l}\text { Hydrochoerus hydrochaeris }{ }^{1,5,7} \\
\text { Tamandua tetradactyla }^{9}\end{array}$ & $\begin{array}{l}\mathrm{AC}^{1}, \mathrm{MT}^{5} \\
\mathrm{RO}^{7}, \mathrm{TO}^{9}\end{array}$ & $\begin{array}{l}{[30,32,} \\
39,54]\end{array}$ \\
\hline $\begin{array}{l}\text { Amblyomma } \\
\text { geayi }\end{array}$ & & 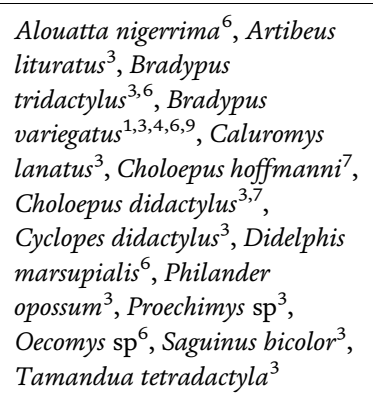 & $\begin{array}{l}\mathrm{AC}^{1} \\
\mathrm{AM}^{3} \\
\mathrm{MA}^{4} \\
\mathrm{PA}^{6}, \mathrm{RO}^{7} \\
\mathrm{TO}^{9}\end{array}$ & $\begin{array}{l}{[30,31,} \\
33,36 \\
39,40 \\
42,92]\end{array}$ \\
\hline $\begin{array}{l}\text { Amblyomma } \\
\text { goeldii }\end{array}$ & & $\begin{array}{l}\text { Tamandua tetradactyla, } \\
\text { Bradypus tridactylus }\end{array}$ & $\mathrm{AM}^{3}, \mathrm{PA}^{6}$ & {$[31,40,42]$} \\
\hline $\begin{array}{l}\text { Amblyomma } \\
\text { humerale }\end{array}$ & & $\begin{array}{l}\text { Bradypus tridactylus }^{3} \text {, } \\
\text { Chrotopterus auritus }^{3} \text {, Cyclopes } \\
\text { didactylus }^{7}, \text { Dasypus } \\
\text { novemcinctus }^{5}, 6 \text {, Didelphis } \\
\text { marsupialis }^{3,5,6}, \text { Hydrochoerus }\end{array}$ & $\begin{array}{l}\mathrm{AC}^{1} \\
\mathrm{AM}^{3} \\
\mathrm{MT}^{5}, \mathrm{PA}^{6} \\
\mathrm{RO}^{7}\end{array}$ & $\begin{array}{l}{[30-33,38-} \\
40,42 \\
54,88]\end{array}$ \\
\hline
\end{tabular}




\begin{tabular}{|c|c|c|c|c|}
\hline Tick species & Domestic mammals & Wild mammals & States & References \\
\hline & & $\begin{array}{l}\text { hydrochaeris }{ }^{1}, \text { Marmosa } \\
\text { constantiae }^{5}, \text { Marmosa } \mathrm{sp}^{3}, \\
\text { Metachirus myosuros }{ }^{5} \\
\text { Philander opossum } \\
\text {, Proechimys } \\
\text { roberti }^{5}, \text { Tamandua }^{3} \\
\text { tetradactyla }^{3,6}\end{array}$ & & \\
\hline $\begin{array}{l}\text { Amblyomma } \\
\text { incisum }\end{array}$ & & Tapirus terrestris ${ }^{7}$ & $\mathrm{RO}^{7}$ & {$[38,93]$} \\
\hline $\begin{array}{l}\text { Amblyomma } \\
\text { latepunctatun }\end{array}$ & & $\begin{array}{l}\text { Tapirus terrestris }{ }^{3,6,7}, \text { Tayassu } \\
\text { pecari }^{3}, \text { Dasyprocta fuliginosa } \\
\text { Didelphis marsupialis }^{3}\end{array}$ & $\begin{array}{l}\mathrm{AM}^{3} ; \\
\mathrm{PA}^{6} ; \mathrm{RO}^{7}\end{array}$ & {$[31,38,93]$} \\
\hline $\begin{array}{l}\text { Amblyomma } \\
\text { longirostre }\end{array}$ & & $\begin{array}{l}\text { Coendou } \mathrm{sp}^{3}, \text { Coendou } \\
\text { prehensilis }{ }^{6,7}, \text { Coendou } \\
\text { nycthemera }\end{array}$ & $\begin{array}{l}\mathrm{AM}^{3} \\
\mathrm{PA}^{6}, \mathrm{RO}^{7}\end{array}$ & $\begin{array}{l}{[30,31,} \\
33,40,42]\end{array}$ \\
\hline $\begin{array}{l}\text { Amblyomma } \\
\text { naponense }\end{array}$ & & $\begin{array}{l}\text { Dasyprocta fuliginos }{ }^{3}, \text { Galictis } \\
\mathrm{sp}^{3}, \text { Hydrochoerus } \\
\text { hydrochaeris }{ }^{1}, \text { Mazama } \\
\text { gouazoubira }^{4}, \text { Myoprocta } \\
\text { acouchy }^{3}, \text { Tapirus terrestris }^{7} \\
\text { Tayassu pecari }^{3,4}\end{array}$ & $\begin{array}{l}\mathrm{AC}^{1} \\
\mathrm{AM}^{3} \\
\mathrm{MA}^{4}, \mathrm{RO}^{7}\end{array}$ & $\begin{array}{l}{[31,36} \\
38,54]\end{array}$ \\
\hline $\begin{array}{l}\text { Amblyomma } \\
\text { nodosum }\end{array}$ & & $\begin{array}{l}\text { Tamandua tetradactyla }{ }^{4,5,6,7,9} \\
\text { Bradypus variegatus }^{9} \\
\text { Myrmecophaga tridactyla }^{9}\end{array}$ & $\begin{array}{l}\mathrm{MA}^{4}, \\
\mathrm{MT}^{5}, \mathrm{PA}^{6} \\
\mathrm{RO}^{7}, \mathrm{TO}^{9}\end{array}$ & $\begin{array}{l}{[30,32,38-} \\
40,42]\end{array}$ \\
\hline $\begin{array}{l}\text { Amblyomma } \\
\text { oblongoguttatum }\end{array}$ & $\begin{array}{l}\text { Canis familiaris }{ }^{4,6,9}, \text { Sus } \\
\text { scrofa }^{7}\end{array}$ & $\begin{array}{l}\text { Agouti paca }{ }^{7}, \text { Cuniculus paca } \\
{ }^{9}, \\
\text { Dasyprocta } \mathrm{sp}^{7}, \text { Myrmecophaga } \\
\text { tridactyla }^{9}, \text { Tayassu tacaju }^{7} \\
\text { Tayassu pecari } \\
\text { Dasyprocta fuliginos }{ }^{3}, \\
\text { Mazama americana }^{3}, \text { Tapirus }^{7} \\
\text { terrestris }^{5,7}, \text { Panthera onca }^{7}\end{array}$ & $\begin{array}{l}\mathrm{AM}^{3} \\
\mathrm{MA}^{4} \\
\mathrm{MT}^{5}, \mathrm{PA}^{6} \\
\mathrm{RO}^{7}, \mathrm{TO}^{9}\end{array}$ & $\begin{array}{l}{[31,32} \\
38,39 \\
42,91 \\
94,95]\end{array}$ \\
\hline $\begin{array}{l}\text { Amblyomma } \\
\text { ovale }\end{array}$ & $\begin{array}{l}\text { Canis familiaris }{ }^{3,4,9}, \text { Sus } \\
\text { scrofa }\end{array}$ & 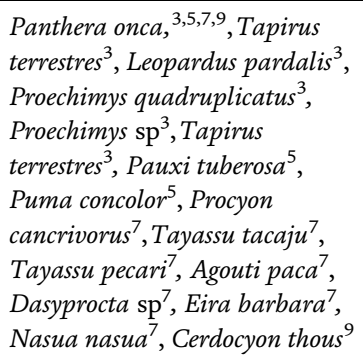 & $\begin{array}{l}\mathrm{AM}^{3} \\
\mathrm{MA}^{4} \\
\mathrm{MT}^{5}, \mathrm{RO}^{7} \\
\mathrm{TO}^{9}\end{array}$ & $\begin{array}{l}{[30-32,38,} \\
39,42 \\
91,94]\end{array}$ \\
\hline $\begin{array}{l}\text { Amblyomma } \\
\text { pacae }\end{array}$ & Canis familiaris $^{7}$ & $\begin{array}{l}\text { Hydrochoerus hydrochaeris }{ }^{1}, \\
\text { Cuniculus paca }^{5}, \text { Tamandua } \\
\text { tetradactyla }^{6}, \text { Monodelphis } \\
\text { glirina }^{6}, \text { Didelphis marsupialis }^{7}\end{array}$ & $\begin{array}{l}\mathrm{AC}^{1}, \mathrm{MT}^{5} \\
\mathrm{PA}^{6}, \mathrm{RO}^{7}\end{array}$ & $\begin{array}{l}{[38,42} \\
54,92]\end{array}$ \\
\hline $\begin{array}{l}\text { Amblyomma } \\
\text { parkeri }\end{array}$ & & Didelphis marsupialis ${ }^{5}$ & $\mathrm{MT}^{5}$ & {$[32]$} \\
\hline $\begin{array}{l}\text { Amblyomma } \\
\text { romitii }\end{array}$ & & Hydrochoerus hydrochaeris ${ }^{5,6,7}$ & $\begin{array}{l}\mathrm{MT}^{5}, \mathrm{PA}^{6} \\
\mathrm{RO}^{7}\end{array}$ & {$[32,41,96]$} \\
\hline $\begin{array}{l}\text { Amblyomma } \\
\text { rotundatum }\end{array}$ & & $\begin{array}{l}\text { Hydrochoerus hydrochaeris }{ }^{i} \text {, } \\
\text { Xenodon merremii }\end{array}$ & $\mathrm{RO}^{7,} \mathrm{TO}^{9}$ & $\begin{array}{l}{[30-33,36,} \\
38,39, \\
41,42,54]\end{array}$ \\
\hline $\begin{array}{l}\text { Amblyomma } \\
\text { scalpturatum }\end{array}$ & $\begin{array}{l}\text { Canis familiaris }{ }^{7}, \text { Sus } \\
\text { scrofa }^{7}\end{array}$ & $\begin{array}{l}\text { Agouti paca }{ }^{7}, \text { Dasyprocta } \\
\text { fuliginosa }^{3}, \text { Didelphis } \\
\text { marsupialis }^{5}, \text { Pecari tajacu }^{5,7}\end{array}$ & $\begin{array}{l}\mathrm{AM}^{3} \\
\mathrm{MT}^{5}, \mathrm{RO}^{7}\end{array}$ & $\begin{array}{l}{[30-32,38,} \\
88]\end{array}$ \\
\hline
\end{tabular}


Ticks from the Brazilian Amazon: Species, Distribution and Host-Relations

DOI: http://dx.doi.org/10.5772/intechopen.94862

\begin{tabular}{|c|c|c|c|c|}
\hline Tick species & Domestic mammals & Wild mammals & States & References \\
\hline & & $\begin{array}{l}\text { Tapirus terrestris } \\
\text { Hydrochoerus hydrochaeris }^{5}\end{array}$ & & \\
\hline $\begin{array}{l}\text { Amblyomma } \\
\text { sculptum }\end{array}$ & Equus caballus ${ }^{4,7,9}$ & Myrmecophaga tridactyla ${ }^{9}$ & $\begin{array}{l}\mathrm{MA}^{4} \\
\mathrm{RO}^{7}, \mathrm{TO}^{9}\end{array}$ & {$[88]$} \\
\hline $\begin{array}{l}\text { Amblyomma } \\
\text { varium }\end{array}$ & & $\begin{array}{l}\text { Bradypus tridactylus }{ }^{3}, \text { Bradypus }^{7} \\
\text { sp }^{3}, \text { Bradypus variegatus }^{7} \\
\text { Choleopus didactylus }^{3,7} \\
\text { Choleopus hoffmanni }^{3,7}, \\
\text { Choloepus } \text { sp }^{7} \text { Dasyprocta } \\
\text { aguti }{ }^{3}, \text { Tamandua tetradactyla }\end{array}$ & $\begin{array}{l}\mathrm{AM}^{3} \\
\mathrm{PA}^{6}, \mathrm{RO}^{7}\end{array}$ & $\begin{array}{l}{[30,31} \\
33,38 \\
40,97]\end{array}$ \\
\hline $\begin{array}{l}\text { Dermacentor } \\
\text { nitens }\end{array}$ & $\begin{array}{l}\text { Bos taurus }^{4}, \text { Canis } \\
\text { familiaris }^{4,7}, \text { Equus } \\
\text { caballus }^{4,7,8,9} \text { Capra } \\
\text { hircus }^{4} \text {, Ovis aires }\end{array}$ & $\begin{array}{l}\text { Agouti paca }{ }^{7}, \text { Mazama } \\
\text { gouazoubira }\end{array}$ & $\begin{array}{l}\mathrm{MA}^{4} \\
\mathrm{RO}^{7}, \mathrm{RR}^{8} \\
\mathrm{TO}^{9}\end{array}$ & $\begin{array}{l}{[36,38} \\
39,95,98]\end{array}$ \\
\hline Ixodes amarali & & $\begin{array}{l}\text { Hylaeamys megacephalus } \\
\text { Monodelphis glirina }^{6} \\
\text { Monodelphis touan }^{6}\end{array}$ & $\mathrm{PA}^{6}$ & [99] \\
\hline $\begin{array}{l}\text { Ixodes } \\
\text { bocatorensis }\end{array}$ & & $\begin{array}{l}\text { Bradypus tridactylus }{ }^{3}, \text { Cyclopes } \\
\text { didactylus }^{3}, \text { Dasyprocta } \\
\text { leporina }{ }^{3}, \text { Tamandua }^{3} \\
\text { tetradactyla }^{3}\end{array}$ & $\mathrm{AM}^{3}$ & {$[16]$} \\
\hline Ixodes spinosus & & $\begin{array}{l}\text { Dasyprocta } \mathrm{sp}^{7}, \text { Myoprocta } \\
\text { pratti }^{1}\end{array}$ & $\mathrm{RO}^{7,} \mathrm{AC}^{1}$ & {$[13]$} \\
\hline Ixodes lasallei & & Dasyprocta variegata ${ }^{7}$ & $\mathrm{RO}^{7}$ & {$[16]$} \\
\hline Ixodes luciae & & $\begin{array}{l}\text { Didelphis marsupialis }{ }^{1,3,4,7}, \\
\text { Marmosa murina }{ }^{6}, \text { Marmosa } \\
\text { demerarae }^{3},{\text { Monodelphis } \mathrm{sp}^{7}}^{7} \\
\text { Oecomys sp. }{ }^{7}, \text { Orysomys sp. } \\
\text { Oligorysomys sp. }{ }^{7}, \text { Philander } \\
\text { opossum }^{6}\end{array}$ & $\begin{array}{l}\mathrm{AC}^{1} \\
\mathrm{AM}^{3} \\
\mathrm{MA}^{4} \\
\mathrm{PA}^{6}, \mathrm{RO}^{7}\end{array}$ & $\begin{array}{l}{[31,36} \\
38,100]\end{array}$ \\
\hline Ixodes schulzei & & Monodelphis touan ${ }^{6}$ & $\mathrm{PA}^{6}$ & {$[92]$} \\
\hline $\begin{array}{l}\text { Haemaphysalis } \\
\text { juxtakochi }\end{array}$ & Canis familiaris $^{4,7}$ & $\begin{array}{l}\text { Mazama americana }{ }^{3,9}, \\
\text { Mazama } \mathrm{p}^{7}, \text { Dasyprocta } \\
\text { azarae }^{5} ; \text { Dasyprocta fuliginos } a^{3}\end{array}$ & $\begin{array}{l}\mathrm{AM}^{3} \\
\mathrm{MA}^{4} \\
\mathrm{MT}^{5} ; \mathrm{RO}^{7} \\
\mathrm{TO}^{9}\end{array}$ & $\begin{array}{l}{[31,36} \\
38,39,42]\end{array}$ \\
\hline $\begin{array}{l}\text { Rhipicephalus } \\
\text { microplus }\end{array}$ & $\begin{array}{l}\text { Bos taurus }^{4,7,8,9}, \text { Canis } \\
\text { familiaris }^{4,7,9}, \text { Felis }^{2} \text { catus }^{7}, \\
\text { Equus caballus, }, 4,7,8,9 \\
\text { Capra hircus }^{4,7}, \text { Ovis aires }\end{array}$ & $\begin{array}{l}\text { Alouatta puruensis }{ }^{7}, \text { Mazama } \\
\text { gouazoubira }^{5,9}, \text { Mazama sp. } \\
\text { Tapirus terrestres }^{7,9}, \text { Tayassu } \text { sp }^{7}\end{array}$ & $\begin{array}{l}\mathrm{MA}^{4} \\
\mathrm{MT}^{5} ; \mathrm{RO}^{7} \\
\mathrm{RR}^{8} ; \mathrm{TO}^{9}\end{array}$ & $\begin{array}{l}{[32,33} \\
36,38 \\
39,95,98]\end{array}$ \\
\hline $\begin{array}{l}\text { Rhipicephalus } \\
\text { sanguineus } \\
\text { sensu lato }\end{array}$ & Canis familiaris ${ }^{1,3,4,7,9}$ & $\begin{array}{l}\text { Bradypus tridactylus }{ }^{3}, \text { Galictis } \\
\text { cuja }^{4} \text {,Saquinus bicolor }\end{array}$ & $\begin{array}{l}\mathrm{AC}^{1} \\
\mathrm{AM}^{3} \\
\mathrm{MA}^{4}, \mathrm{RO}^{7}\end{array}$ & $\begin{array}{l}{[30-33,36} \\
38,39 \\
95,98,101]\end{array}$ \\
\hline $\begin{array}{l}{ }^{1} \text { Acre - AC. } \\
{ }^{2} \text { Amapá - AP. } \\
{ }^{3} \text { Amazonas - AM. } \\
{ }^{4} \text { Maranhão-MA. } \\
{ }^{5} \text { Mato Grosso-MT. } \\
{ }^{6} \text { Pará - PA. } \\
{ }^{7} \text { Rondônia - RO. } \\
{ }^{8} \text { Roraima - RR. } \\
{ }^{9} \text { Tocantins - TO. }\end{array}$ & & & & \\
\hline
\end{tabular}

Table 3.

Records of ticks in the Amazon biome, Brazil, according to tick species, hosts (domestic and wild animals), states, references. 
rodents (e.g., Cricetidae) in the larvae and nymph stages, with adults feeding mostly on marsupials (e.g., Didelphis spp., Monodelphis spp.) [17, 83], and agoutis (e.g., Dasyprocta ) $[13,16]$. Most species were found parasitizing Monodelphis glirina (I. amarali, I. schulzei, I. luciae) and Monodelphis touan (I. amarali, I. schulzei), with some reports of I. amarali on the rodent Hylaeamys megacephalus [30, 38, 92, 99, 100]. Also on rodents the species I. spinosus, I. lasallei and I. bocatorensis have been recorded $[30,31,38]$, although these previous records referred to them erroneously as Ixodes fuscipes, which according to more recent data, does not occur in the Amazon biome (Figure 5 and Table 3) [13, 16].

In general, the greatest diversity of ticks was recorded on T. tetradactyla with 10 species, followed by the rodent $H$. hydrochaeris with nine species. These records indicates the importance of these hosts for maintaining local tick diversity, in addition to act as dispersers of these ectoparasites. Additional hosts have also been shown to be important in maintaining diversity of tick in the Amazon: Tapirus terrestris, Tayassu pecari, Pecari tajacu, Agouti paca, Dasyprocta fuliginosa, Bradypus tridactylus, Bradypus variegatus, Panthera onca, Nasua nasua, Choleopus didactylus, Choloepus hoffmanni, Cyclopes didactylus, Dasyprocta azarae, Dasyprocta leporina, Philander opossum, M. glirina, M. touan, Mazama gouazoubira, Mazama americana and $M$. tridactyla (Table 3), because they are parasitized by more than one species of ticks. There is also a record of A. cajennense s.s. on Pteronura brasiliensis a semiaquatic animal [89].

Interestingly, three species of ticks commonly found on domestic animals have also been found parasitizing wild animals: Rhipicephalus sanguineus sensu lato, R. microplus and D. nitens. Although occasional, the encounter of these species of ticks on wild animals is possible, especially when wild animals coexist with domestic animals infested by ticks (e.g., pastures, corrals, houses). A total of 11 species of ticks have been recorded parasitizing domestic animals in Amazon (Table 3).

\section{Hard ticks associate with humans}

Spotted fevers caused by $R$. rickettsii and Rickettsia parkeri are currently the only confirmed tick-borne disease affecting humans in the country, and A. sculptum, A. aureolatum, $A$. ovale are the main vectors. The disease is severe and highly lethal when caused by the bacterium $R$. rickettsii (vectors $A$. sculptum and A. aureolatum) and moderate, non-lethal, when caused by $R$. parkeri, vectored mainly by $A$. ovale [10]. Only A. sculptum and A. ovale have been recorded in the Brazilian Amazon, the first in rare reports and the second frequently recorded and populations established in this biome. In fact, considering only the tick adult stage, A. ovale has been reported as the most common human-biting tick in the Amazon [38].

In the last century, papers about ticks on human beings have been published in the Brazilian Amazon, however these studies are fragmented and scarce. At least 14 species of hard ticks have already been found and documented parasitizing humans within the limits of the Brazilian Amazon. Of these, the vast majority (11 species) belong to the genus Amblyomma: A. cajennense s.s., A. coelebs, A. dissimile, $A$. latepunctatum, $A$. naponense, $A$. oblongoguttatum, $A$. ovale, $A$. romitii, $A$. rotundatum, A. scalpturatum and $A$. sculptum. The other three species belong to the genus Rhipicephalus, including $R$. microplus and $R$. sanguineus s.l., and the genus Haemaphysalis with only $H$. juxtakochi. The public health importance of human-tick associations in the Amazon biome is unclear and further research are needed to clarify the issue.

Nymphs of $H$. juxtakochi have been reported on humans in the states of Rondônia (municipality not precisely indicated) and Amazonas, in the municipality 
of Santa Isabel do Rio Negro [31, 38]. H. juxtakochi has been found infected with the bacterium Rickettsia rhipicephali in the Amazon region, more precisely in the municipalities of Monte Negro and Confresa, states of Rondônia and Mato Grosso, respectively $[42,93]$. Human parasitism by $R$. microplus was expected, since this species can parasitize humans when it comes into direct contact with domestic cattle, as reported by [38]. Therefore, its importance is much more economical, causing severe losses to livestock in the country than for public health.

Despite sporadic records of $R$. sanguineus s.l. on humans in Brazil, this association in the Brazilian Amazon requires confirmation. Records of approximately 4,020 R. sanguineus s.l. (larva, nymph, and adult), supposedly collected on humans, in the state of Pará by Serra-Freire et al. [103] do not corroborate the common findings in country. The bioecology of this endophilic and introduced tick is well studied. In other countries, $R$. sanguineus s.l. is vector of some zoonotic agents for humans (Rickettsia conorii, Rickettsia massiliae and $R$. rickettsii) [83]. Adults of $A$. cajennense s.s. have been reported on humans in the municipality of Monte Alegre (Pará state) [90]. Reports of Amblyomma cajennense sensu lato parasitizing humans published by Martins et al. [90] in the municipalities of Sinop and Tucuruí in the states of Mato Grosso and Pará, is possibly A. cajennense s.s. taking into account the area of occurrence of this species. This tick is aggressive to humans. In the Amazon biome the $R$. bellii bacterium was detected in this species in Mato Grosso state and R. amblyommatis in Mato Grosso, Maranhão and Rondônia state [32, 42, 53, 83, $88,90,91,104,105]$.

Nymphs and adult of $A$. coelebs were found on humans in Rondônia state [38]. An adult of this tick was found on human in Roraima state, municipality of Caroebe [106]. The nymph and adult stages of $A$. colelebs were also found on humans in Amazonas state, in the municipalities of Coari, Fonte Boa, Presidente Figueiredo and Santa Isabel do Rio Negro [31, 107]. There are reports of infection by $R$. amblyommatis in A. coelebs in the Amazon region in the states of Rondônia and Mato Grosso, respectively $[32,53,88]$. Adult of $A$. dissimile was recorded on humans in the Maicurú River/Amazon biome, located in Pará state [106]. Adults of the species A. latepunctatum have been reported on humans in Coari and Santa Isabel do Rio Negro, both municipalities located in the state of Amazonas [31].

Adults of the tick A. naponense (published as Amblyomma mantiquirense) were found on humans in the state of Pará (municipality not reported) [108]. Human parasitism also by adults was later reported on the Maicurú River, located in this same state [106]. However, nymphs have been found on humans in the states of Rondônia (municipality not specified precisely) and Amazonas, in the municipalities of Coari and Santa Isabel do Rio Negro $[31,38]$. The bacteria $R$. bellii and Rickettsia sp. strain PA were identified in this species in the Amazon region of the municipalities of Santarém and Rurópolis, in the state of Pará [42]. Rickettsia sp. strain Tapirapé was found in this tick in the municipalities of Confresa and Rio Branco, in the states of Mato Grosso and Acre, respectively [42, 54].

Adults of the species A. oblongoguttatum were recorded parasitizing humans in the state of Pará, in the Maicurú River and in the municipality of Uruará [106, 108, 109]. Human parasitism by nymphs and adults of this tick was recorded in the state of Rondônia (municipality not specified with precision) [38]. However, the nymphal stage of this species was later recorded on humans in the municipality of Monte Negro in the same state [106]. Human parasitism by adult of this tick was also recorded in the municipality of Caroebe, state of Roraima [106]. Nymphs and adults of this species have been recorded parasitizing humans in three municipalities (Coari, Manacapuru and Santa Isabel do Rio Negro), all located in the state of Amazonas $[31,106,107]$. On the other hand, the life cycle of this tick has already been studied under laboratory conditions [110]. The bacteria $R$. bellii and 
R. amblyommatis were detected in this species in the Amazon in the municipalities of Governador Jorge Teixeira and Pimenta Bueno, in the state of Rondônia [53, 105].

Adults of the tick $A$. ovale have been reported to parasitize humans in several areas of the state of Rondônia [38]. As previously reported in this chapter, adults of A. ovale parasitize mainly domestic and wild carnivores, while immature (larva and nymph) parasitize rodents of the families Cricetidae and Echimyidae, with sporadic reports on wild birds $[17,75,83]$. This preference for such host groups was observed in the laboratory [111]. This tick is a vector of the protozoan Hepatozoon canis and the bacterium $R$. parkeri, agents of importance in veterinary and human medicine, respectively [83]. In the Amazon region, the bacterium $R$. bellii was identified in this species in the municipalities of Governador Jorge Teixeira and Monte Negro, in the state of Rondonia; and in the municipality of Cururupu, in the state of Maranhão [53, 91].

The adult stage of the species $A$. romitii (published as Amblyomma tasquei) was found parasitizing humans in the north of the state of Pará (municipality not reported) [108]. In this same state, the larval and adult stages of this tick were found on humans in the municipality of Rurópolis $[96,112]$. The life cycle of this tick was studied under laboratory conditions [113].

Parasitism by adults of $A$. rotundatum was recorded in the municipality of Belém in the state of Pará on a human who worked in frequent contact with reptiles in the Zoobotanical Park of the Museu Paraense Emílio Goeldi [114].

Adults of the A. scalpturatum have been reported to parasitize humans in the state of Pará (municipality not reported) [108], and in the Maicurú River located in this state $[93,106]$. Human parasitism by the nymphal and adult stages of this species has been reported in the states of Mato Grosso (municipality of Jauru) and Rondônia (municipality not precisely indicated), however in this latter state it was not specified whether these adult ticks were fixed or walking on humans $[38,93]$. The nymphal stage was also collected from a human who was probably infested with this tick in the municipality of Porto Velho in the state of Rondônia [115]. The nymph and adult stages of this species were also found parasitizing humans in the state of Amazonas, in the municipalities of Coari, Fonte Boa, Jutaí, Presidente Figueiredo and Santa Isabel Rio Negro [31, 107]. In the Amazon biome, two species of rickettsiae ( $R$. bellii and $R$. amblyommatis) were detected in A. scalpturatum, in the municipalities of Governador Jorge Teixeira and Sinop, states of Rondônia and Mato Grosso, respectively [53, 88].

Human parasitism by adults of $A$. sculptum was recorded in the municipality of Jauru in the state of Mato Grosso [90]. The Jauru territory comprises $90 \%$ of the Amazon biome and $10 \%$ of the Cerrado biome, so this human record in this region is in accordance with the transition area of the occurrence of this species in sympatry with $A$. cajennense s. s. [90]. The bioecology of this native tick has been extensively studied due to its aggressive parasitism towards domestic animals and humans in the Brazilian territory. In the geographical area in which this species occurs, it completes an annual generation, with larvae occurring mostly during autumn, nymphs during winter, and adults during spring and summer, with larval behavioral diapause being the main regulating factor of its life cycle $[116,117]$. Besides being considered a pest for domestic animals (dogs, cattle and horses), the species can transmit to humans the Brazilian Spotted Fever caused by the bacterium $R$. rickettsii, being this the most important zoonotic disease transmitted by ticks within the limits of the National territory. Additionally, A. sculptum has also been identified with the bacterium $R$. amblyommatis in the municipality of Pium, state of Tocantins [118].

There is a trend of seasonal behavior for some species of Amblyomma in the Amazon biome, with immatures predominating in the dry period (June to October), 
and adults in the rainy period (October to March) [119]. Similar to the pattern observed for A. sculptum in areas outside the Amazon biome [116].

\section{Soft ticks in the Brazilian Amazon}

Taxonomy of Argasidae is currently questionable and relies on five schemes that divide the family in up to ten genera [120]. Achieving a consensus between soft tick taxonomists depends now chiefly on the molecular characterization of early collected type specimens for some genera. For instance, elucidating the status of pivotal taxa such as Alectorobius is mandatory if we are to understand the systematics of the Argasidae, particularly in the American Continent. Considering a practical approach, in this chapter we adopt but not necessarily endorse the classification of soft ticks into five genera, namely: Antricola, Argas, Nothoaspis, Ornithodoros, and Otobius [121].

The fauna of argasid ticks in Brazil is currently composed by 24 species [15]. Ticks of this family parasitize terrestrial vertebrates including amphibians in this country $[25,26]$. With the exception of larvae from an undetermined Ornithodoros sp. collected on Potus flavus (Procionidae) [84], reports of soft ticks parasitizing mammals in the Brazilian Amazon are few and almost restricted to larvae collected on bats. Adults and nymphs have been collected either inside bat-inhabited caves or over massive rock formations where bats shelter (Table 4).

The first record of a soft tick in the Brazilian Amazon was published by North American entomologists Robert A. Cooley and Glen M. Kohls back in 1941. They received a tick collected inside a bat-inhabited three hole at Marajó Island (Pará state) and identified it as female of Ornithodoros hasei (mentioned as Ornithodoros dunni) [126]. Nowadays, we know that $O$. hasei is a wide spread species in Brazil and that three-roosting bats Artibeus planirostris and Noctilio spp. could act as main hosts [87, 130-132]. With the exception of recent collection of larvae on $A$. planirostris [87], knowledge on the distribution of $O$. hasei along the Brazilian Amazon is still poorly vague.

Tadarida laticaudata were the first bats reported to be parasitized by soft ticks in the Brazilian Amazon [133]. This report referred to Ornithodoros setosus, which was recently reclassified as Nothoaspis setosus [124]. In 1972, the bats Noctilio labialis and T. laticaudata were reported to be parasitized by Ornithodoros stageri in the Brazilian Amazon [129], which was recently confirmed [11]. A report in the Brazilian Amazon is a remarkable fact for $O$. stageri, since it also has distribution in Southern United States and Mexico [126, 134].

Bat inhabited caves constitute excellent niches to find argasid ticks. In particular, special, large colonies of insectivorous bats dwelling inside small chambers create high temperature conditions $\left(28-40^{\circ} \mathrm{C}\right)$ where hundreds of Antricola, Nothoaspis and Ornithodoros ticks might occur [135]. Between 2004 to 2010 collections of ticks performed in hot caves from Porto Velho (Rondônia) fostered the description of two novel species (e.g., Nothoaspis amazoniensis and Ornithodoros rondoniensis) [122, 123]; the redescription of larvae and description of postlarval stages of Ornithodoros marinkellei [127], and the expansion of geographical distribution of Antricola delacruzi and Antricola guglielmonei into Brazilian Amazon [122]. At least for two species, O. marinkellei and O. rondoniensis, further collections performed in caves from Pará state underpined a larger distribution along the Amazon ecosystems [128].

Most amazing feature of soft ticks inhabiting hot caves, is that adaptation to this particular milieu seems to have modified their morphology and biology drastically. For instance, evidence showing that adults of Antricola ticks lack the capacity to 


\begin{tabular}{|c|c|c|c|c|}
\hline Species & State & Locality & Milieu of collection/Host & Reference \\
\hline $\begin{array}{l}\text { Antricola } \\
\text { delacruzi }\end{array}$ & Rondônia & Porto Velho & Bat inhabited cave/Pteronotus spp. & {$[122]$} \\
\hline $\begin{array}{l}\text { Antricola } \\
\text { guglielmonei }\end{array}$ & Rondônia & Porto Velho & Bat inhabited cave/Pteronotus spp & {$[122]$} \\
\hline $\begin{array}{l}\text { Nothoaspis } \\
\text { amazoniensis }\end{array}$ & Rondônia & Porto Velho & $\begin{array}{l}\text { Bat inhabited cave/Pteronotus } \\
\text { parnellii }\end{array}$ & [123] \\
\hline $\begin{array}{l}\text { Nothoaspis } \\
\text { setosus }\end{array}$ & Rondônia & Monte Negro & $\begin{array}{l}\text { Rock formation/ } \\
\text { Molossus molossus }\end{array}$ & {$[124]$} \\
\hline $\begin{array}{l}\text { Ornithodoros } \\
\text { cavernicolous }\end{array}$ & Rondônia & Monte Negro & Bat inhabited caves/Unknown & {$[125]$} \\
\hline \multirow[t]{2}{*}{$\begin{array}{l}\text { Ornithodoros } \\
\text { hasei }\end{array}$} & Amapá & unknown & $\begin{array}{l}\text { Mistneted bat Artibeus } \\
\text { planisrostris }\end{array}$ & {$[87]$} \\
\hline & Pará & Marajó Island & $\begin{array}{l}\text { Bat-inhabited three hole/ } \\
\text { Unknown }\end{array}$ & [126] \\
\hline $\begin{array}{l}\text { Ornithodoros } \\
\text { kohlsi }\end{array}$ & Rondônia & Monte Negro & $\begin{array}{l}\text { Mistneted bat Molossops } \\
\text { mattogrossensis }\end{array}$ & {$[30]$} \\
\hline \multirow{2}{*}{$\begin{array}{l}\text { Ornithodoros } \\
\text { marinekellei }\end{array}$} & Rondônia & Porto Velho & Bat inhabited cave/Pteronotus spp & {$[127]$} \\
\hline & Pará & $\begin{array}{l}\text { Carajás, Paraupebas, } \\
\text { Canaã dos Carajás }\end{array}$ & Bat inhabited caves/Unknown & {$[128]$} \\
\hline $\begin{array}{l}\text { Ornithodoros } \\
\text { peropteryx }\end{array}$ & Rondônia & Monte Negro & Bat inhabited cave/Unknown & {$[125]$} \\
\hline \multirow{2}{*}{$\begin{array}{l}\text { Ornithodoros } \\
\text { rondoniensis }\end{array}$} & Rondônia & Porto Velho & Bat inhabited cave/Unknown & {$[122]$} \\
\hline & Pará & $\begin{array}{l}\text { Carajás, Paraupebas, } \\
\text { Canaã dos Carajás }\end{array}$ & Bat inhabited caves/Unknown & {$[128]$} \\
\hline $\begin{array}{l}\text { Ornithodoros } \\
\text { stageri }\end{array}$ & Rondônia & Unknown & $\begin{array}{l}\text { Unknown/Noctilio albiventris, } \\
\text { Nyctinomops laticaudatus }\end{array}$ & $\begin{array}{l}{[129]} \\
{[11]}\end{array}$ \\
\hline
\end{tabular}

Table 4.

Soft ticks and their respective hosts occurring in the Brazilian Amazon.

digest blood has been gained after transcriptomic analyses of their saliva [136]. In fact, scoop-like short mouth parts suggest that adults of Antricola do not suck blood [137]. Moreover, adults of Antricola, O. marinkellei and O. rondoniensis possess huge spiracular plates [122, 127, 137], perhaps necessary to thrive in such hot and extremely humid environments.

Except for larvae of Ornithodoros kohlsi collected on the bat Molossops mattogrossensis [30], prospections performed by our group between 2016 and 2019 focused mainly in the search for soft ticks inside natural cavities over massive rock formations. During these expeditions, Ornithodoros cavernicolous and Ornithodoros peropteryx were collected for the first time in caves from Monte Negro (Rondônia), extending their distribution of both species to the Brazilian Amazon [125]. Furthermore, analyses performed on large larvae isolated from Molossus molossus bats clarified that $O$. setosus was incorrectly classified in its original description. Indeed, $O$. setosus matches morphologically and molecularly within the genus Nothoaspis therefore the statement of $N$. setosus $n$. comb. was proposed [124]. It is important to note that our last collections performed at Monte Negro included several morphotypes of Ornithodoros pending formal description. Consequently, the fauna of soft ticks occurring in the Brazilian Amazon is likely to increase soon. 


\section{Conclusion}

Ticks parasitize a wide variety of vertebrates around the world such as amphibians, reptiles, mammals and birds, including humans. Although there are a variety of studies of parasitism by ticks on animals and humans in the different ecoregions of Brazil, in the Amazon biome they are scarce and fragmented. Because of this, it is possible to infer that the diversity of ticks in the Brazilian Amazon is underestimated. In the Amazon, amphibians and reptiles were important hosts for A. rotundatum, $A$. dissimile and $A$. humerale, hard ticks common in these hosts in other regions of the country. Birds and mammals, on the other hand, proved important for the maintenance and dispersion of over 30 species of hard ticks in the Amazon, but there are still many gaps between hosts and their ticks in this region. Interestingly, immature $A$. humerale appears to be frequent on wild birds in this biome. No soft ticks have been reported parasitizing amphibians, reptiles, birds and/or non-flying mammals (except for a single record of Ornithodoros sp. on $P$. flavus), possibly due to scarcity of more studies in this biome. Some studies show that bats seem to have an important role spreading soft tick populations along Amazonian caves and that the diversity described for this group is still very poor. Two vector species of spotted fevers were found in the Amazon biomes parasitizing humans (A. sculptum and A. ovale). However, to date, there are no reports of BSF in humans in the region. Finally, it is of paramount importance that researchers (acarologists and epidemiologists) direct their attention to the Amazon biome, in order to fill the numerous existing gaps in the diversity of ticks in Brazil and prevent possible outbreaks of diseases transmitted by these ectoparasites to animals and humans.

\section{Conflict of interest}

No conflict of interest declared. 


\section{Author details}

Hermes R. Luz ${ }^{1,2 *}$, Thiago F. Martins ${ }^{3,4}$, Sebastián Muñoz-Leal ${ }^{5}$, Francisco B. Costa ${ }^{6}$, Sérgio L. Gianizella ${ }^{7}$, João Luiz H. Faccini ${ }^{8}$ and Marcelo B. Labruna ${ }^{3}$

1 Faculdade Florence, São Luís, MA, Brazil

2 Programa de Pós-graduação em Biotecnologia (RENORBIO), Universidade Federal do Maranhão - UFMA, MA, Brazil

3 Departamento Medicina Veterinária Preventiva e Saúde Animal, Faculdade de Medicina Veterinária e Zootecnia, Universidade de São Paulo, SP, Brazil

4 Departamento de Laboratórios Especializados, Superintendência de Controle de Endemias, Secretaria de Estado da Saúde de São Paulo, São Paulo, SP, Brazil

5 Departamento de Patología y Medicina Preventiva, Facultad de Ciencias Veterinarias, Universidad de Concepción, Chillán, Ñuble, Chile

6 Departamento de Patologia, Curso de Medicina Veterinária, Universidade Estadual do Maranhão, São Luís, MA, Brazil

7 Laboratório de Zoologia, Departamento de Biologia, Instituto de Ciências Biológicas, Universidade Federal do Amazonas, Manaus, AM, Brazil

8 Departamento de Parasitologia Animal, Universidade Federal Rural do Rio de Janeiro, RJ, Brazil

*Address all correspondence to: hermesluz@globomail.com

\section{IntechOpen}

(C) 2020 The Author(s). Licensee IntechOpen. This chapter is distributed under the terms of the Creative Commons Attribution License (http://creativecommons.org/licenses/ by/3.0), which permits unrestricted use, distribution, and reproduction in any medium, provided the original work is properly cited. (cc) BY 


\section{References}

[1] Silva JMC, Rylands AB, Fonseca GAB. The fate of the Amazonian areas of endemism. Conservation Biology. 2005; 19: 689-694

[2] MMA. Ministério do Meio Ambiente. 2018. Acessed: 03/10/2120

[3] Vieira ICG, Toledo PM, Silva JMC, Higuchi H. Deforestation and threats to the biodiversity of Amazonia. Brazilian Journal of Biology. 2008; Suppl 0.

[4] Evans KL, Newson SE, Storch D, Greenwood JJ, Gaston KJ. Spatial scale, abundance and the species-energy relationship in British birds. Journal of Animal Ecology. 2008; 77: 395-405

[5] Rylands AB. Amazonia. In: Wilderness: Earth's last wild places. Agrupación Serra Madre, S. C. Mexico: CEMEX, 2002; 56-107

[6] Parrotta JA, Wildburger C, Mansourian S. Understanding relationships between biodiversity, carbon, forests and people: the key to achieving REDD+ objectives. A global assessment report prepared by the Global Forest Expert Panel on Biodiversity, Forest Management and REDD. 2012; 31: 161, 2012

[7] Duscher GG, Fuehrer HP, KübberHeiss A. Fox on the run - molecular surveillance of fox blood and tissue for the occurrence of tick-borne pathogens in Austria. Parasites \& Vectors. 2014; 7: 521

[8] de la Fuente J. Controlling ticks and tick-borne diseases looking forward. Ticks and Tick Borne Diseases. 2018; 9: 1354-1357

[9] Massard CL, Fonseca AH. Carrapatos e doenças transmitidas, comuns ao homem e aos animais. A Hora Veterinária. 2004. 135; 1: 15-23
[10] Szabó MP, Pinter A, Labruna MB. Ecology, biology and distribution of spotted-fever tick vectors in Brazil. Front Cell Infect Microbiol. 2013; 3: 27

[11] Dantas-Torres F, Martins TF, Muñoz-Leal S, Onofrio VC, BarrosBattesti DM. Ticks (Ixodida: Argasidae, Ixodidae) of Brazil: Update species checklist and taxonomic keys. Ticks and Tick Borne Diseases. 2019; 10: 101252

[12] Peñalver EA, Arillo X, Delclòs D, Peris DA, Grimaldi SR, Anderson PC. Nascimbene, and R. Pérez-de la Fuente. Ticks parasitised feathered dinosaurs as revealed by Cretaceous amber assemblages. Nature Communications.2017; 8: 1924

[13] LabrunaMB, OnofrioVC, BarrosBattesti, GianizellaSL, VenzalJM, GuglielmoneAA. Synonymy of Ixodes aragao $i$ with Ixodes fuscipes, and reinstatement of Ixodes spinosus (Acari: Ixodidae). Ticks and Tick-borne Diseases. 2020; 11: 101349

[14] Martins TF, Luz HR, Muñoz-Leal S, Ramirez DG, Milanelo L, Marques S, et al. A new species of Amblyomma (Acari: Ixodidae) associated with monkeys and passerines of the Atlantic rainforest Biome, southeastern Brazil. Ticks and Tick-borne Diseases, 2019; 10: 1-10

[15] Muñoz-Leal S, Martins MM, Nava S, Landulfo GA, Simons SM, Rodrigues VS, et al. Ornithodoros cerradoensis n. sp. (Acari: Argasidae), a member of the Ornithodoros talaje (Guérin-Méneville, 1849) group, parasite of rodents in the Brazilian Savannah, Ticks and Tick-borne Diseases. 2020; 11: Issue 5

[16] OnofrioVC, Guglielmone AA, BattestiDM, GianizellaSL, MarciliA, QuadrosRM, et al. Description of a new species of Ixodes (Acari: Ixodidae) and 
first report of Ixodes lasallei and Ixodes bocatorensis in Brazil. Ticks and Tickborne Diseases. 2020; 11: 101423

[17] Guglielmone AA, Robbins RG, Apanaskevich DA, PetneyTN, EstradaPeña A, Horak IG. The hard ticks of the world: (Acari: Ixodida: Ixodidae). London: Springer; 2014; 738 p.

[18] Esser HJEA, Herre R, Kays YL, Jansen PA. "Local Host-Tick Coextinction in Neotropical Forest Fragments." International Journal for Parasitology 2019; 49: 225-233

[19] Ferreira GC, Sturaro MJ, Peloso PLV. Amphibians and reptiles from Floresta Nacional de Pau-Rosa, Amazonas, Brazil: an important protected area at the heart of Amazonia. Acta Amazonica. 2017; 47: 259 - 268

[20] Luz HR, Faccini JLH. Parasitim on anurans in Brazil (in portuguese). Vet Zootec. 2013; 20: 100-111

[21] Horta MC, Saraiva DG, Oliveira GMB, Martins TF, Labruna MB. Rickettsia bellii in Amblyomma rotundatum ticks parasitizing Rhinella jimi from northeastern Brazil. Microbes Infect. 2015;17: 856-858

[22] Alcântara EP, Silva CF, Ávila RW, Pacheco RC, Martins TF, Muñoz-Leal S, et al. Ticks (Acari: Argasidae and Ixodidae) infesting amphibians and reptiles in Northeastern Brazil.

Systematic and Applied Acarology. 2018; 23: 1497-1508

[23] Oda FH, Kitagawa C, Noronha JC, Rodrigues DJ, Martins TF, Valadão MC, et al. Amblyomma species infesting amphibians and reptiles in the seasonally dry Amazon forest, with new host records for Amblyomma rotundatum (Acari: Ixodida: Ixodidae). Systematic and Applied Acarology. 2018; 23: 387-392

[24] Fonseca, MS, Campanharo TB, Borges AAS, Castilho VO, Doria TB,
ParanáSBM, et al. Ticks and Associated Pathogens From Rescued Wild Animals in Rainforest Fragments of Northeastern Brazil. Frontiers in Veterinary Science. 2020; 7: 177

[25] Barros-Battesti DM, Landulfo GA, Luz HR, Marcili A, Onofrio VC, Famadas KM. Ornithodoros faccinii n. sp. (Acari: Ixodida: Argasidae) parasitizing the frog Thoropa miliaris (Amphibia: Anura: Cycloramphidae) in Brazil. Parasites \& Vectors 2015; 8: 268

[26] Muñoz-Leal S, Toledo LF, Venzal JM, Marcili A, Martins TF, Acosta ICL, et al. Description of a new soft tick species (Acari: Argasidae: Ornithodoros) associated with streambreeding frogs (Anura: Cycloramphidae: Cycloramphus) in Brazil. Ticks and TickBorne Diseases. 2017; 8: 682-692

[27] Labruna MB, Camargo LMA, Terrassini FA, Schumaker TTS, Camargo EP, Notes on Parasitism by Amblyomma humerale (Acari: Ixodidae) in the State of Rondônia, Western Amazon, Brazil. Journal of Medical Entomology. 2002; 39: 814-817

[28] Polo G, Luz HR, Martins TF, Regolin AL, Silva HR, Winker G, et al. Distribution modeling of Amblyomma rotundatum and Amblyomma dissimile in Brazil: estimates of environmental suitability. Parasitology Research. 2020; https://doi.org/10.1007/s00436-02006924-9

[29] Luz HR, Silva-Santos E, CostaCampos CE, Acosta I, Martins TF, Munhoz-Leal S, et al. Detection of Rickettsia spp. in ticks parasitizing toads (Rhinella marina) in the northern Brazilian Amazon. Experimental and Applied Acarology. 2018; 75: 309-318

[30] Martins TF, Venzal JM, Terrassini FA, Costa FB,; Marcili A, Camargo LMA, et al. New tick records from the state of Rondônia, western Amazon, Brazil. Experimental and Applied Acarology 2013; 62: 121-128 
[31] Gianizella SL, Martins TF, Onofrio VC, Aguiar NO, Gravena W, Nascimento CAR, et al. Ticks (Acari: Ixodidae) of the state of Amazonas, Brazil. Experimental \& Applied Acarology. 2018; 74: 177-183

[32] Witter R, Martins TF. Campos AK, Melo ALT, Correa SHR, Morgado TO, et al. Rickettsial infection in ticks (Acari: Ixodidae) of wild animals in midwestern Brazil. Ticks and Tick-borne Diseases. 2016; 7, 415-423

[33] Zimmermann NP, Aguirre AAR, Rodrigues VS, Garcia MV, Medeiros JF, Blecha IMZ, et al. Wildlife species, Ixodid fauna and new host records for ticks in an Amazon forest area, Rondônia, Brazil. Brazilian Journal Veteriany Parasitology. 2018; 27: 177-182

[34] Torres AC, Minervino AHH, Santos Júnior AP, Sarturi C, Martins TF, Vale WG, Morini AC, et al. Amblyomma ticks infesting amphibians and Squamata reptiles from the lower Amazon region, Brazil. Experimental \& Applied Acarology. 2018; 75: 399-407

[35] Pedroso-Santos F, Santos ES, Sanches PR, Campos EC, Luz HR, Faccini JLH. First record of Amblyomma dissimile (Acari: Ixodidae) infesting the Granular Toad Rhinella major (Anura: Bufonidae) in the Eastern Amazon region. Herpetology Notes. 2020; 13: 385-387

[36] Costa FB, Martins TF, Muñoz-Leal S, Serpa MC, OgrzewalskaM, Luz HR, et al. Retrospective and new records of ticks (Acari: Argasidae, Ixodidae) from the state of Maranhão, an AmazonCerrado transition area of Brazil Veterinary Plarasitology: Regional Studies and Reports. 2020; 21: 100413

[37] Ogrzewalska M, Machado CR, Forneas T, Cunha DLE, Lemos, ERS. Microorganisms in the ticks Amblyomma dissimile Koch 1844 and Amblyomma rotundatum Koch 1844 collected from snakes in Brazil. Medical and Veterinary Entomology. 2019; 33: 154-161

[38] Labruna MB, Camargo LMA, Terrassini FA, Ferreira F, Schumaker TTS, Camargo EP. Ticks (Acari: Ixodidae) from the State of Rondônia, western Amazon, Brazil. Systematic \& Applied Acarology, 2005; 10: $17-32$

[39] Martins TF, Reis J L, Viana EB, Luz HR, Oda FH, Dantas SP, et al. Ticks (Acari: Ixodidae) on captive and freeranging wild animals in Tocantins State, a Cerrado-Amazon transition region of northern Brazil. International Journal Acarology. 2020; 46: 254-257.

[40] Nascimento KKG, Veríssimo SMM, Raia VA, Guimarães RCS, Seade GCC, Azevedo ACP, et al. Tick fauna of wild animals received and attended at the Santarém Zoological Park, western Pará State, Brazil. Ciencia Rural. 2017; 47: 20170159

[41] Labruna MB, Barbieri FS, Martins TF, Brito LG, Ribeiro FDS. New tick records in Rondônia, Western Brazilian Amazon. Revista Brasileira Parasitologia Veterinária. 2010; 19: 192-194

[42] Soares HS, Barbieri ARM, Martins TF, Minervino AHH, Lima JTR, Marcili A, et al. Ticks and rickettsial infection in the wildlife of two regions of the Brazilian Amazon. Experimental \& Applied Acarology. 2015; 65: 125-140

[43] Schumaker TTS, Barros DM. Note on the biology of Amblyomma dissimile Koch, 1844 (Acari: Ixodidae) on Bufo marinus (Linnaeus, 1758) from Brazil. Memórias do Instituto Oswaldo Cruz. 1994; 89: 29-31

[44] Keirans JE, Oliver Jr JH. First description of the male and redescription of the immature stages of Amblyomma rotundatum (Acari: 
Ixodidae), a recently discovered tick in the U.S.A. Journal of Parasitology. 1993; 79: $860-865$

[45] Labruna MB, Terrassini FA, Camargo LM. First report of the male of Amblyomma rotundatum (Acari: Ixodidae) from a field-collected host. Journal of Medical Entomology. 2005; 42: 945-947

[46] Silva TKS, Blanco CM, Lemos ERS, Ogrzewalska M. Notes on parasitism and screening for microorganism of ticks Amblyomma (Acari: Ixodidae), Amazon, Brazil. Virus Reviews \& Research. 2016; 21:41-44

[47] Gianizella SL, Moraes JJr, Nascimento CAR, Martins TF. Primeiro registro de machos de Amblyomma rotundatum (Acari: Ixodidae) em jabutitinga (Chelonoidis denticulatus) no estado do Amazonas, Amazônia brasileira: relato de caso. Arquivo Brasileiro de Medicina Veterinária e Zootecnia. 2018; 70: 195-198

[48] Luz HR, Faccini JLH, Silva HR. Patterns of parasitism by Amblyomma rotundatum (Ixodidae) on Rhinella schneideri (Bufonidae) in islands of São Francisco River, Minas Gerais, Brazil. Pesquisa Veterinária Brasileira. 2015; 35 : 579-582.

[49] Oliveira GMB, Araújo AC, Santos JR, Silva IWG, Labruna MB, Horta MC. Lack of seasonality of Amblyomma rotundatum (Acari: Ixodidade) on Rhinella jimi (Anura: Bufonidae) in a semi-arid region of northeastern Brazil. Ticks and Tickborne Diseases. 2018; 9: 1350-1353

[50] Rodrigues DS, Maciel R, Cunha LM, Leite RC, Oliveira PR. Amblyomma rotundatum (Koch, 1844) (Acari: Ixodidae) two-host life-cycle on Viperidae snakes. Revista Brasileira de Parasitologia Veterinária. 2010; 19: 174-178
[51] Luz HR, Faccini JLH, Pires MS, Silva HR, Barros-Battesti DM. Life cycle and behavior of Amblyomma rotundatum (Acari: Ixodidae) under laboratory conditions and remarks on parasitism of toads in Brazil. Experimental \& Applied Acarology. 2013; 58: 89-99

[52] Petit G, Landau I, Baccam D, Lainson R. Description et cycle biologique d'Hemolivia stellata, n.g., n. sp., hemogrégarine de Crapauds brésiliens. Annales de Parasitologie Humaine et Comparee. 1990; 65:3-15

[53] Labruna MB, Whitworth T, Bouyer DH, McBride J, Camargo LMA, Camargo P, et al. Rickettsia bellii and Rickettsia amblyommii in Amblyomma ticks from the state of Rondônia, Western Amazon, Brazil. Journal of Medical Entomology. 2004; 41: 1073-1081

[54] Gruhn KD, Ogrzewalska M, Rozental T, Farikoski IO, Blanco C, Freitas L S, et al. Evaluation of rickettsial infection in free-range capybaras (Hydrochoerus hydrochaeris Linneaus, 1766) (Rodentia: Caviidae) and ticks (Acari: Ixodidae) in Western Amazon, Brazil. Ticks and Ticks-Borne Diaseases. 2019; 10: 981-986

[55] Barros-Battesti DM, Jerozolimski A, Onofrio VC, Arzua M. 2002.

Amblyomma humerale Koch, 1844

(Acari: Ixodidade) on tortoises Geochelone denticulatus (L.) and G. carbonarius (Spix) from the Kayapó Indian land, state of Pará, northern Brazil. XI International Congress of Acarology. Program and Abstract Book, Mérida, México. 160 p

[56] Souza AR, Gianizella SL, Roberto IJ. Rhinoclemmys punctularia (Eastern SpotLegged Wood Turtle). Ectoparasites. Herpetological Review. 2018; 49: 713

[57] Morais DH, Carvalho VT, Bonora L, Kawashita-Ribeiro RA, Strussmann C. 
Patterns of Parasitism by Amblyomma

humerale (Acari: Ixodidae) on Chelonoidis denticulatus (Testudines:

Testudinidae) in the Brazilian Midwest. Herpetological Review. 2017; 48: 316-319

[58] Martins TF, Teixeira RHF, Benatti HR, Minervino AHH, Soares HS, Soares JF, et al. Life cycle of the tick Amblyomma humerale (Parasitiformes: Ixodida) in the laboratory, International Journal of Acarology. 2020. https://doi. org/10.1080/01647954.2020.1802510

[59] Dantas-Torres F, MascarenhasJunior PB, Anjos HR, Santos EM, Correia JMS. Tick infestation on caimans: a casual tick-host association in the Atlantic rainforest biome?. Experimental \& Applied Acarology. 2019; 79: 411-420

[60] Martins TF, Gianizella SL, Nunes PH, Faria DC, Nascimento CA, Abrahão CR, et al. New records of Amblyomma goeldii (Acari: Ixodidae) and description of the nymphal stage. Zootaxa. 2015; 3949: 439-444

[61] Luz HR, Faccini JLH. Ticks on brazilian birds: overview. In: Ruiz, L., Iglesias, F. (Eds.), Birds - Evolution, Behavior and Ecology 1. Nova Science Publishers, Inc, New York. 2013; 97-125.

[62] Hasle G. Transport of ixodid ticks and tick-borne pathogens by migratory birds. Frontiers in Cellular and Infection Microbiology. 2013; 3: 48

[63] Comstedt PS, Bergstrom B, Olsen U, Garpmo L, Marjavaara H. Mejlon, A. G. Barbour, and J. Bunikis. Migratory passerine birds as reservoirs of Lyme borreliosis in Europe. Emerging Infectious Diseases. 2006; 12: 1087-1095

[64] Ogrzewalska M, Pinter A. Ticks (Acari: ixodidae) as ectoparasites of Brazilian wild birds and their association with rickettsial diseases Brazilian
Journal Veterinary Animmal Sciense. 2016; 53: 1-31

[65] Barros-Battesti DM, Arzua M, Pichorim M, Keirans JE. Ixodes (Multidentatus) paranaensis $\mathrm{n}$. $\mathrm{sp}$. (Acari: Ixodidae) a parasite of Streptoprocne biscutata (Sclater 1865) (Apodiformes: Apodidae) birds in Brazil. Memórias do Instituto Oswaldo Cruz. 2003; 98: 93-91

[66] CBRO - Comitê Brasileiro de Registros Ornitológicos. 2014. Listas das aves do Brasil. 10 ed. Disponível em $<\mathrm{h}$ ttp://www.cbro.org.br>. Acessed in: 02.10.2020

[67] Sick H. Ornitologia Brasileira. Editora Nova Fronteira, Rio de Janeiro. 1997. $912 \mathrm{p}$

[68] Lima MA, Martins TF, Muñoz-Leal S, Guilherme E, Ogrzewalska M, Labruna MB. Ticks and tick-associated spotted fever group Rickettsia from birds in the Southwestern Brazilian Amazon. Revista Colombiana de Ciencias Pecuárias. 2018; 31: 26-35

[69] Ogrzewalska M, Uezu A, Labruna MB. Ticks (Acari Ixodidae) infesting wild birds in the eastern Amazon, northern Brazil, with notes on rickettsial infection in ticks. Parasitol.

Res. 2010; 106: 809-816.

[70] Souza VL, Martins TF, Guilherme E, Santos FGA. New records of ticks (Acari: Ixodidae) infesting wild birds in a forest fragment in Acre, Brazilian Amazon. 2020. DOI: 10.5433/

1679-0359.2020v41n5Supl1p2163

[71] Martins TF, Fecchio A, Labruna MB (2014) Ticks of the genus Amblyomma (Acari: Ixodidae) on wild birds in the Brazilian Amazon. Systematic and Applied Acarology. 2010; 19: 385-392

[72] Scofield A, Bahia M, Martins AL, Góes-Cavalcante G, Martins TF, Labruna MB. Amblyomma dissimile Koch 
(Acari: Ixodidae) attacking Primolius maracana Vieillot (Psittaciformes: Psittacidae) in the Amazon Region, State of Pará, Brazil. Neotropical Entomology. 2011; 40: 509-511

[73] Labruna MB, Sanfilippo LF, Demetrio C, Menezes AC, Pinter A, Guglielmone AA. Ticks collected on birds in the state of São Paulo, Brazil. Experimental \& Applied Acarology. 2007; 43: 147-160.

[74] Lugarini C, Martins TM, Ogrzewalska M, Vasconcelos NCT, Ellis VA, Oliveira JB, et al. Rickettsial agents in avian ixodid ticks in northeast Brazil. Ticks and Tick Borne Diseases. 2015; 6: 364-375

[75] Luz HR, Faccini JLH, McIntosh D. Molecular analyses reveal an abundant diversity of ticks and rickettsial agents associated with wild birds in two regions of primary Brazilian Atlantic Rainforest. Ticks and Tick Borne Diseases. 2017; 8: 657-665

[76] Luz HR, Martins TF, Teixeira RHF, Terassini FA, Soares HS, Soares JF, et al. Some biological and behavioral aspects of Amblyomma longirostre (Acari: Ixodidae) under laboratory and natural conditions. Systematic and Applied Acarology. 2018; 23:10. 1965

[77] Aragão HB. Ixodidas brasileiros e de algunos paízes limitrophes. Memórias do Instituto Oswaldo Cruz. 1936; 31: 759-843

[78] Reis NL, Perachi AL, Pedro WA, Lima IP. Mamíferos do Brasil. Universidade Estadual de Londrina, Brazil. 2006.

[79] Abreu-Jr EF, Casali DM, Garbino GST, Loretto D, Loss AC, Marmontel M, et al. Lista de Mamíferos do Brasil. Comitê de Taxonomia da Sociedade Brasileira de Mastozoologia (CT-SBMz). Disponível em: < https:// www.sbmz.org/mamiferos-do-brasil/>. Acessed em: 03/10/2020.
[80] Bown KJ, Begon M, Bennett M, Woldehiwet Z, Ogden N. Seasonal dynamics of Anaplasma phagocytophila in a rodent-tick (Ixodes trianguliceps) system, United Kingdom. Emerging Infectious Diseases. 2003; 9: 63-70

[81] Zhan L, Cao WC, Chu CY, Jiang BG, Zhang F, Liu W, et al. Tick-borne agents in rodents, China, 2004-2006.

Emerging Infectious Diseases. 2009; 15 : 1904-1908

[82] Horta MC, Moraes-Filho J, Casagrande RA, Saito TB, Rosa SC, Ogrzewalska M, et al. Experimental Infection of opossums Didelphis aurita by Rickettsia rickettsii and evaluation of the transmission of the infection to ticks Amblyomma cajennense. Vector Borne Zoonotic Diseases. 2009; 9: 109-118

[83] Nava S, Venzal JM, GonzálezAcuña D, Martins TF, Guglielmone AA. Ticks of the Southern Cone of America. Elsevier Academic Press, London, San Diego, Cambridge, Oxford. 2017. 348 p

[84] Labruna MB, Jorge RS, Sana DA, Jácomo AT, Kashivakura CK, Furtado MM, et al. Ticks (Acari: Ixodida) on wild carnivores in Brazil. Experimental \& Applied Acarology. 2005; 36: 149-163

[85] Martins TF, Milanelo L, Krawczak FS, Furuya HR, Fitorra LS, Dores FT, et al. Diversity of ticks in the wildlife screening center of São Paulo city, Brazil. Ciência Rural. 2017; 47: 1-6

[86] Luz HR, Neto SFC, Weksler M, Gentile R, Faccini JLH. Ticks parasitizing wild mammals in Atlantic Forest areas in the state of Rio de Janeiro, Brazil. Brazilian Journal Veterinary Parasitology. 2018; 27:409_ 414

[87] Luz HR, Muñoz-Leal S, de Carvalho WD, Castro IJ, Xavier BS, Toledo JJ, et al. Detection of "Candidatus rickettsia wissemanii" in 
ticks parasitizing bats (Mammalia: Chiroptera) in the northern Brazilian Amazon. Parasitology Research. 2019; 118: 3185-3189

[88] Colle AC, Mendonça RFB, Maia MO, Freitas LC, Martins TF, Muñoz leal S, et al. Rickettsial survey and ticks infesting small mammals from the Amazon forest in midwestern Brazil. Systematic and Applied Acarology. 2020; 25:78-91

[89] Rosas FCW, Sicsu da Cruz TM, Gianizella SL, dos Santos Ramalheira C, Martins TF. A first record of ticks in free-ranging giant otter (Pteronura brasiliensis) in the Brazilian Amazon. IUCN Otter Species Group Bulletim. 2016; 33: 3-7

[90] Martins TF, Barbieri ARM, Costa FB, Terassini FA, Camargo LMA, Peterka CRL, et al. Geographical distribution of Amblyomma cajennense (sensu lato) ticks (Parasitiformes: Ixodidae) in Brazil, with description of the nymph of $A$. cajennense (sensu stricto). Parasites \& Vectors. 2016; 9: 14 $\mathrm{p}$

[91] Costa FB, da Costa AP, MoraesFilho J, Martins TF, Soares HS, Ramirez DG, et al. Rickettsia amblyommatis infecting ticks and exposure of domestic dogs to Rickettsia spp. in an Amazon-Cerrado transition region of northeastern Brazil. PLoS ONE. 2017; 12: e0179163

[92] Leal PF. Distribuição e relação trófica entre carrapatos e pequenos mamíferos da Ordem Rodentia e Didelphimorphia na floresta nacional de Carajás, estado do Pará, Dissertação. Belém, 2014

[93] Labruna MB, Keirans JE, Camargo LMA, Ribeiro AF, Soares RM, Camargo EP. Amblyomma latepunctatum, a valid tick species (Acari: Ixodidae) long misidentified with both Amblyomma incisum and
Amblyomma scalpturatum. Journal of Parasitology. 2005; 91: 527-541

[94] Furtado MM, Metzger B, Jácomo ATA, Labruna MB, Martins TF, O'Dwyer LH, et al. Hepatozoon spp. Infect Free-Ranging Jaguars (Panthera onca) in Brazil. Journal Parasitology. 2017; 3: 243-250

[95] Martins TF, Spolidorio MG, Batista TCA, Oliveira IAS, Yoshinari NH, Labruna MB. 2009. Occurrence of ticks (Acari: Ixodidae) in the municipality of Goiatins, Tocantins. Revista Brasileira Parasitologia Veterinária. 2009; 18:50-52

[96] Sampaio JS, Martins TF, Labruna MB, Onofrio VC, Faccini JLH, Barros-Battesti DM. A second record of Amblyomma romitii Tonelli-Rondelli, 1939 (Acari: Ixodidae) from the State of Pará, Brazil. Systematic \& Applied Acarology. 2010; 15: 184-186

[97] Marques S, Barros-Battesti DM, Faccini JLH, Onofrio VC. Brazilian distribution of Amblyomma varium Koch, 1844 (Acari: Ixodidae), a common parasite of sloths (Mammalia: Xenarthra). Mem Inst Oswaldo Cruz. 2002; 97: 1141-6

[98] Oliveira SVde, Pereira SVC, Pinna FV, Fonseca LX, Serra-Freire NM, Cardoso KM, et al. Vigilância de ambientes da febre maculosa: explorando as áreas silenciosas do Brasil. Revista Pan-Amazônica de Saúde. 2016; 7: 65-72

[99] Martins TF, Bernardi LFO, MunozLeal S, Marcili A, Labruna MB. New records of Ixodes amarali (Acari: Ixodidae) in the Amazon biome, with description of the male. Systematic and Applied Acarology. 2009; 24: 2552-2558

[100] Luz HR, Faccini JLH, Landulfo GA, Sampaio JS, Neto SFC, Famadas KM et al. New host records of Ixodes luciae (Acari: Ixodidae) in the 
State of Pará, Brazil. Revista Brasileira Parasitologia Veterinária. 2013; 22: 152-154

[101] Fernandes MMP, Medeiros FER, Carvalho YK, Ribeiro VMF, Souza SF. Ectoparasitas de cães domiciliados e errantes do município de Rio BrancoAcre. Enciclopédia Biosfera. 2018; 15: 442-450

[102] Onofrio VC, Barros-Battesti DM, Labruna MB, Faccini JL. Diagnoses of and illustrated key to the species of Ixodes Latreille, 1795 (Acari: Ixodidae) from Brazil. Systematic and Applied Acarology. Parasitology. 2009; 72: 143-157

[103] Serra-Freire NM. Occurrence of ticks (Acari: Ixodidae) on human hosts, in three municipalities in the State of Pará, Brazil. Revista Brasileira de Parasitologia Veterinária. 2010; 19: 141-147

[104] Lopes LB, Guterres A, Rozental T, Carvalho de Oliveira R, Mares-Guia M, Fernandes J, et al. Rickettsia bellii, Rickettsia amblyommii, and Laguna Negra hantavirus in an Indian reserve in the Brazilian Amazon. Parasites \& Vectors. 2014; 7: 191

[105] Aguirre A AR, Rodrigues VS, Costa IN, Garcia MV, Higa LOS, Medeiros JF, Andreotti R. Biological parameters of Amblyomma coelebs Neumann, 1906 (Acari: Ixodidae) under experimental conditions. Brazilian Journal Veterinary Parasitology. 2018; 27: $81-86$

[106] Guglielmone AA, Beati L, BarrosBattesti DM, Labruna MB, Nava S, Venzal JM, et al. Ticks (Ixodidae) on humans in South America.

Experimental \& Applied Acarology. 2006; 40: 83-100

[107] Silva TKS, Blanco CM, Lemos ERS, Ogrzewalska M. Notes on parasitism and screening formicroorganism of ticks
Amblyomma (Acari: Ixodidae), Amazon, Brazil. Virus Reviews \& Research. 2016; 21: $41-44$

[108] Aragão HB, Fonseca F. nota de ixodologia. VIII. Lista e chave para os representantes da fauna ixodológica brasileira. Memórias do Instituto Oswaldo Cruz. 1961; 59: 115-129

[109] Labruna MB, Homem VSF, Heinemann MB, Neto JSF. Ticks (Acari: Ixodidae) associated with rural dogs in Uruará, Eastern Amazon, Brazil. Journal of Medical Entomology. 2000; 37: 774-776

[110] Martins TF, Luz HR, Faccini JLH, Labruna MB. Life-cycle of Amblyomma oblongoguttatum (Acari: Ixodidae) under laboratory condition. Experimental \& Applied Acarology. 2017; 71: 415-424

[111] Martins TF, Moura MM, Labruna MB. Life-cycle and host preference of Amblyomma ovale (Acari: Ixodidae) under laboratory conditions. Experimental \& Applied Acarology. 2012; 56: 151-158

[112] Guglielmone AA, Robbins RG. Tick species found feeding on humans. In: Guglielmone AA, Robbins RG, editors. Hard ticks (Acari: Ixodida: Ixodidae) parasitizing humans: a global overview. 1st ed. London: Springer. 2018. 205 p

[113] Landulfo GA, Luz HR, Sampaio JS, Faccini JLH, Barros-Battesti DM. Life Cycle of Amblyomma romitii (Acari: Ixodidae) Under Laboratory Conditions. Journal of Medical Entomology. 2015; 53: $48-53$

[114] Serra Freire NM, Peralta ASL, Teixeira RHF, Gazeta GS, Amorim M. Amblyomma rotundatum parasitando Homo sapiens no parque zoobotánico do MPEG e em Itaboraí. Arquivos da Sociedade de Zoológicos do Brasil. 1995; 16: 20

[115] Aguirre AAR, Rodrigues VS, Costa IN, Garcia MV, Csordas BG, 
Andreotti R, Medeiros JF. Amblyomma scalpturatum Neumann, 1906 (Acari: Ixodidae): confirmation in Acre State, Brazil, and description of parasitism in a human. Brazilian Journal of Veterinary Parasitology. 2019; 28: 473-478

[116] Labruna MB, Kasai N, Ferreira F, Faccini JL, Gennari SM. Seasonal dynamics of ticks (Acari: Ixodidae) on horses in the state of São Paulo Brazil. Veterinary Parasitology. 2002; 19: 65-77

[117] Labruna MB, Amaku M, Metzner JA, Pinter A, Ferreira F. Larval behavioral diapause regulates life cycle of Amblyomma cajennense (Acari: Ixodidae) in Southeast Brazil. Journal of Medical Entomology. 2003; 40: 170-178

[118] Bitencourth K, Amorim M, De Oliveira SV, Caetano, RL, Voloch CM, Gazêta GS. Amblyomma sculptum: genetic diversity and rickettsias in the Brazilian Cerrado biome. Medical and Veterinary Entomology. 2017; 3: 1-11

[119] Labruna MB, Terassini FA, Camargo LM. Notes on population dynamics of Amblyomma ticks (Acari: Ixodidae) inBrazil. Journal Parasitology. 2009; 95: 1016-8

[120] Mans BJ, Featherston J, Kvas M, Pillay K, de Klerk DG, Pienaar R, et al. Argasid and ixodid systematics: Implications for soft tick evolution and systematics, with a new argasid species list. Ticks and Tick-borne Diseases. 2019; 10: 219-240

[121] Hoogstraal H. Mint: Argasid and nuttalliellid ticks as parasites and vectors. Advances in Parasitology. 1985; 24: $135-238$

[122] Labruna MB, Terassini FA, Camargo LMA, Brandão PE, Ribeiro AF, Estrada-Peña A. New reports of Antricola guglielmonei and Antricola delacruzi in Brazil, and a description of a new argasid species (Acari). Journal of Parasitology. 2008; 94: 788-792
[123] Nava S, Venzal JM, Terassini FA, Mangold AJ, Camargo LMA, Labruna MB. Description of a new argasid Tick (Acari: Ixodida) from bat caves in Brazilian Amazon. Journal of Parasitology. 2010; 96: 1089-1101

[124] Muñoz-Leal S, Terassini FA, Marcili A, Oliveira GMB, Camargo LMA, Labruna MB. A third species of Nothoaspis Keirans \&amp; Clifford, 1975 (Acari: Argasidae): Nothoaspis setosus (Kohls, Clifford \& amp; Jones, 1969) n. comb. Systematic Parasitology. 2019; 96 :595-602

[125] Muñoz-Leal S, Terassini FA, Luz HR, Fontana I, Camargo LMA, Labruna MB. First report of Ornithodoros peropteryx in Brazil, and the occurrence of Ornithodoros cavernicolous in the western Brazilian Amazon. Systematic \& Applied Acarology. 2018; 23: 2113-2121

[126] Cooley RA, Kohls GM. The Argasidae of North America, Central America and Cuba, The American Midland Naturalist. Monograph $\mathrm{N}^{\circ} 1$. 1944

[127] Labruna MB, Nava S, Terassini FA, Onofrio VC, Barros-Battesti D, et al. Description of adults and nymph, and resdescription of the larva, of Ornithodoros marinekellei (Acari: Argasidae), with data on its phylogenetic position. Journal of Parasitology. 2011; 97: 207-217

[128] Henrique-Simões M, Bernardi LFO, Ogrzewalska M, Labruna MB, Ferreira RL. New records of rare Ornithodoros (Acari: Argasidae) species in caves of the Brazilian Amazon. Persian Journal of Acarology. 2012; 1: 127-135

[129] Jones EK, Clifford CM, Keirans JE, Kohls GM. The ticks of Venezuela (Acarina: Ixodoidea) with a key to the species of Amblyomma in the Western Hemisphere. Brigham Young University 
Science Bulletin - Biological Series. 1972; 17: $1-40$

[130] Muñoz-Leal S, Eriksson A, Santos CF, Fischer E, Almeida JC, Luz HR, Labruna MB. Ticks infesting bats (Mammalia: Chiroptera) in the Brazilian Pantanal. Experimental \& Applied Acarology. 2016; 69: 73-85

[131] Muñoz-Leal S, Barbier E, Soares FAM, Bernard E, Labruna MB, Dantas-Torres F. New records of ticks infesting bats in Brazil, with observations on the first nymphal stage of Ornithodoros hasei. Experimental \& Applied Acarology. 2018; 76: 537-549

[132] Luz HR, Muñoz-Leal S, Almeida JC, Faccini LH, Labruna MB. Ticks parasitizing bats (Mammalia: Chiroptera) in the Caatinga Biome, Brazil. Brazilian Journal Veterinary Parasitology. 2018; 35: 484-491

[133] Kohls GM, Clifford CM, Jones EK. The systematics of the subfamily Ornithodorinae (Acarina: Argasidae). IV. Eight new species of Ornithodoros from the Western Hemisphere. Annals of the Entomological Society of America. 1969; 62: 1035-1043

[134] Guzmán-Cornejo C, HerreraMares A, Robbins RG, RebolloHernández A. The soft ticks (Parasitiformes: Ixodida: Argasidae) of Mexico: species, hosts, and geographical distribution. Zootaxa. 2019; 4623: 485-525

[135] De La Cruz J. Mint: Bioecologia de las grutas de calor. Mundos Subterraneos, UMAE, Mexico, DF. 1992; 3: 7-21

[136] Ribeiro JMC, Labruna MB, Mans BJ, Marumaya SR, Francischetti IMB, Barizon GC, Santos IKFM. The sialotranscriptome of Antricola delacruzi female ticks is compatible with non-hematophagous behavior and an alternative source of food. Insect Biochemistry Molecular Biology. 2012; 42: 332-342

[137] Estrada-Peña A, Venzal JM, BarrosBattesti DM, Onofrio VC, Trajano E, Firmino JVL. Three new species of Antricola (Acari: Argasidae) from Brazil, with a key to the known species in the genus. Journal of Parasitology. 2004; 90: 490-498 


\title{
Ecology of the Seed Bank in the Amazon Rainforest
}

\author{
Natali Gomes Bordon, Niwton Leal Filho \\ and Tony Vizcarra Bentos
}

\begin{abstract}
The seed bank is directly related to forest resilience because it contributes to the greatest number of regenerants after the occurrence of disturbances. Changes in seed density, floristic composition, and life forms completely alter the successional trajectory of forest environments. These changes are directly related to land use. For example, suppression of the seed bank can occur in pastures, that experience frequent fires with increase of density of seeds and predominance of herbs are typical of highly degraded areas, such as Poaceae, Rubiaceae, Asteraceae, and Cyperaceae. Melastomataceae seedlings are an important component of the seed bank in the Amazon rainforest. On the other hand, Urticaceae has greater representation in forests that exhibit low-impact land use. Any change in seed bank functionality is bound to compromise the diversity, regeneration potential and overall maintenance of tropical forests. Therefore, it is necessary to expand studies that investigate seed banks in the Amazon rainforest. It is as important to prioritize sampling methods and pursue standardization of data presentation, as well as improve the identification of species that occur in the seed bank.
\end{abstract}

Keywords: floristic composition, forest disturbance, anthropic changes, forest regeneration, land use

\section{Introduction}

The seed bank, or stock of viable seeds in the soil, can be defined as a set of latent, or dormant, seeds capable of originating adult plants $[1,2]$. Studying the composition of the seed bank and understanding its role in regeneration are important to the conservation and management of tropical forests, as well as the control and eradication of invasive species in agrosilvopastoral systems [3-8]. The seed bank is influenced by the local plant community, history of land use, and forest matrix in general, it also has spatial and temporal variations [5, 9-12]. Spatial variations occur both horizontally and vertically; however, the greatest amounts of seed are observed in the upper layers [13-16]. Temporal variation occurs as a result of both loss and incorporation of seeds in the soil $[13,17]$. The incorporation of seeds is the result of seed rain, which also presents seasonality owing to the different fruiting patterns of the species $[9,18$, 19]. The rate of seed loss in the soil depends intrinsic loss of viability resulting from dispersal, environmental conditions, predation, and attack of pathogens [17, 20, 21].

Seeds of pioneer species are found in high density in the soils of tropical forests and constitute the main reserve of propagules for the regeneration of areas subject to disturbances [10, 22-24]. Most pioneer species have quiescent diaspores, owing to 
canopy light conditions or temperature variations [25-27], and compound the persistent seed bank [10, 22-24]. Species that compound the transitional seed bank have a lower density and are composed of late species of the forest succession [10, 14, 22], commonly forming a seedling bank [28, 29]. Consequently, floristic composition of the tropical rainforest seed bank does not reflect the composition of species in the arboreal, or regenerating, strata of old-growth forests $[8,14,29]$. Thus, seed bank serve to allow the establishment of a set of species that do not occur in vegetation or that present in low density in old-growth forests, but persist in the seed bank [18, 30-32].

After formation of a clearing by natural or anthropic disturbance, the quantity of seeds in the soil decreases as a consequence of recruitment rates or loss of seed viability $[14,29,33]$. After the establishment of pioneer species and subsequent fruiting, seed density in the soil increases in the initial stages [9, 21, 24, 29, 33, 34]. The, with the advance of forest succession, the number of seeds in the seed bank tends to decrease and return to pre-disturbance equilibrium $[9,21,24,29,33,34]$. The seed bank plays a major role in the re-establishment of plant communities subjected to medium and high-intensity disturbances and can have a wide impact on the dynamics of plant communities during the process of ecological succession [35-38]. For example, in forest areas of the Amazon burned and converted to pasture, almost no vestiges of the seed bank, remain [39]. Nonetheless, pioneer species of Vismia were reported to dominate regeneration $[40,41]$. In contrast, areas with some seed bank left intact were initially reported to already be occupied by pioneer species of Cecropia, allowing a larger set of plant species to regenerate under its canopy [36, 39, 42-44]. In terms of forest management, the role of the seed bank in the regeneration of forests increases in importance, when compared to the seed rain, both in clearings and trails generated by skidders [45].

The seed bank is known for its low contribution to the establishment of late species in the forest succession in which these groups derived from dispersion and stock seedlings $[1,14]$. However, the seed bank can be considered highly diverse in life forms thus contributing to the restructuring of forest strata $[33,46]$. The abundance of herbs and shrubs in the seed bank of forest environments can be a consequence of the surrounding matrix, as well as the history of land use [5, 14, 22]. It is a reflection of vegetation that has already undergone some type of anthropic or natural change [5, 29, 33, 47]. In general, herbaceous and shrub species are more commonly found in altered areas and secondary vegetation [14]. However, disturbances that occur around the forest also contribute to the entry of ruderal, or invasive, species in the seed bank [5]. Notwithstanding this phenomenon, forest areas surrounding pastures or agricultural areas change the density and floristic composition of the seed bank in these areas [5]. This gives rise to the entry of common trees and shrubs into the seed bank of forest areas [5]. The seed bank in tropical forests is, therefore, highly variable. At the same time, studies reporting on this natural component of the Brazilian rainforest are scarce. Therefore, this chapter aims to analyze variations in density, family abundance, and life forms of the seed bank in terra firme forest of the Amazon rainforest, as well as assess the impact of the main changes in land use in this region on seed bank characteristics.

\section{Materials and methods}

Data were obtained from published and unpublished scientific reports and monographs written by undergraduate students under the supervision of Dr. Niwton Leal Filho of the National Institute for Amazon Research (INPA). One dataset contains complete data on density and floristic composition. We used 17 datasets from a seed bank in terra firme forest of the Amazon rainforest, which dataset [48-50] was not included in the floristic composition. Table 1 list all datasets 


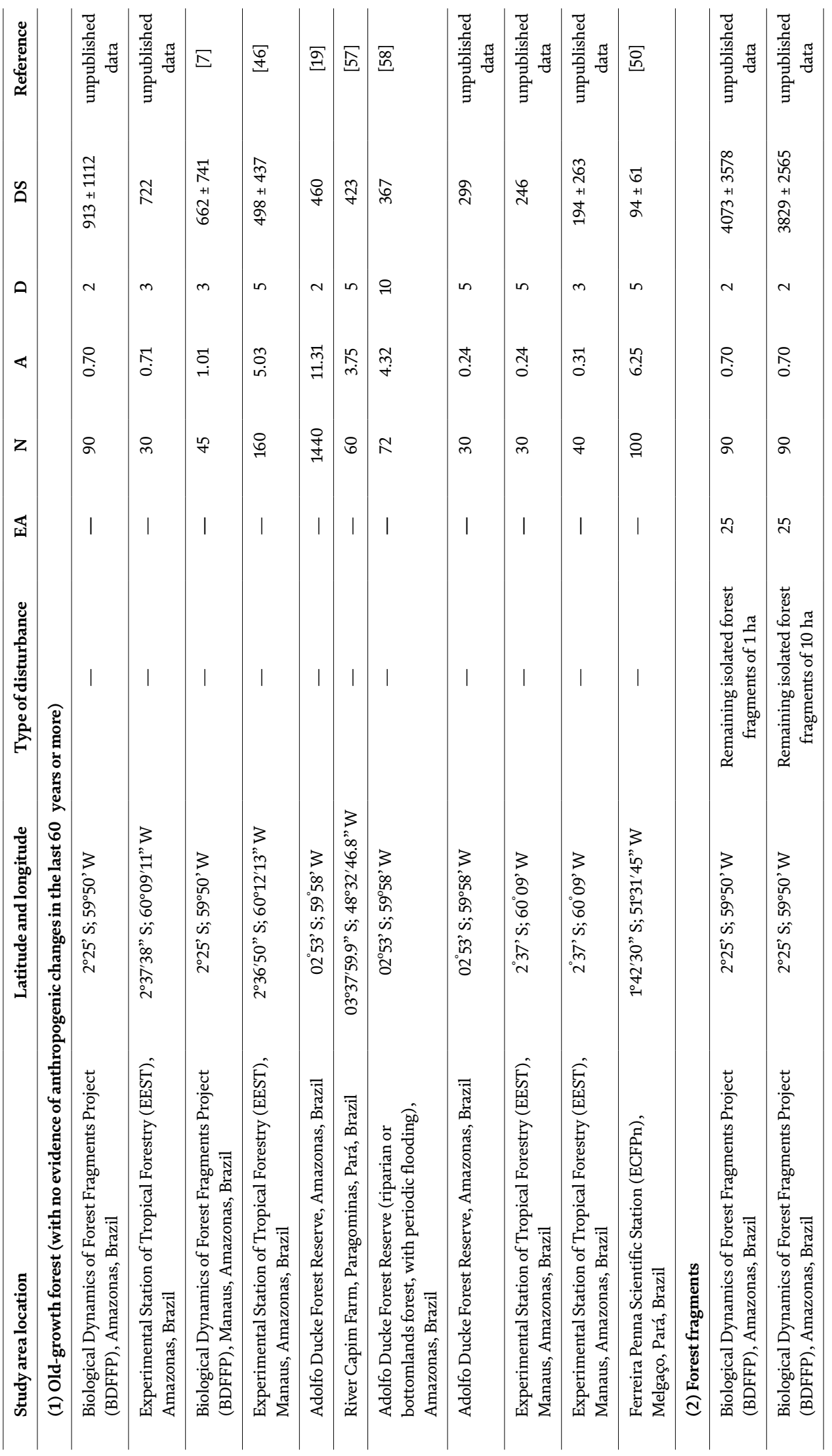




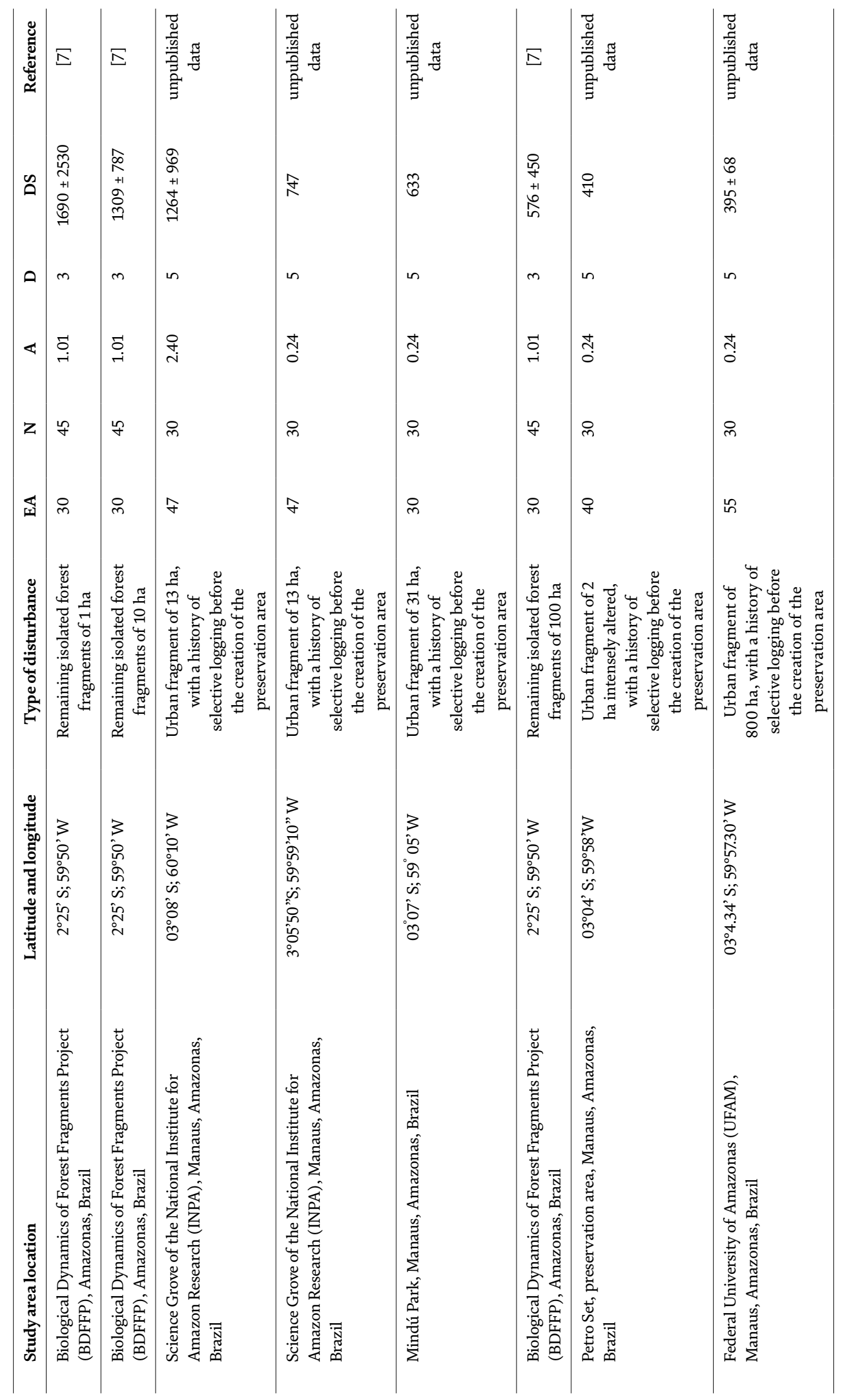




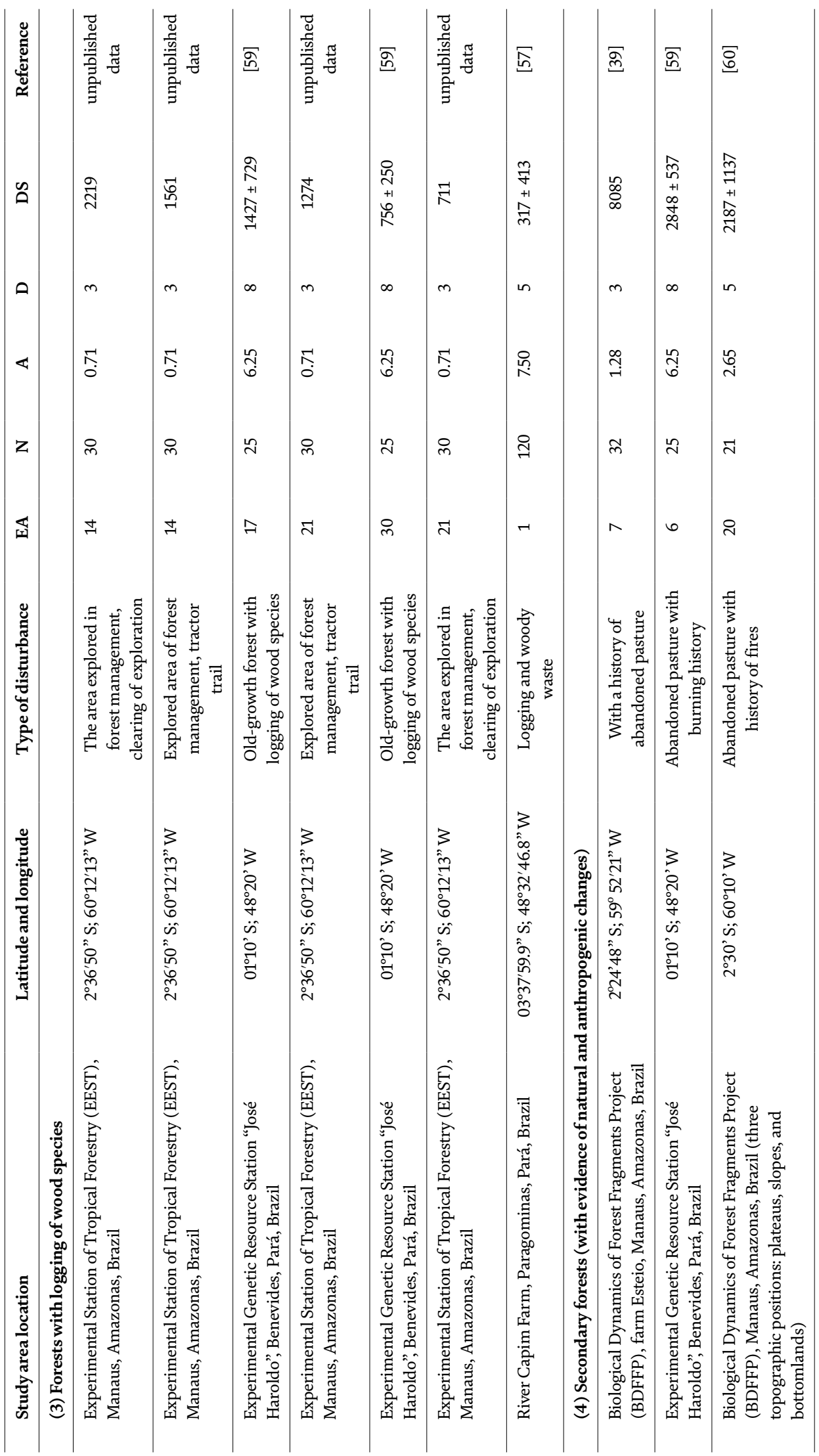




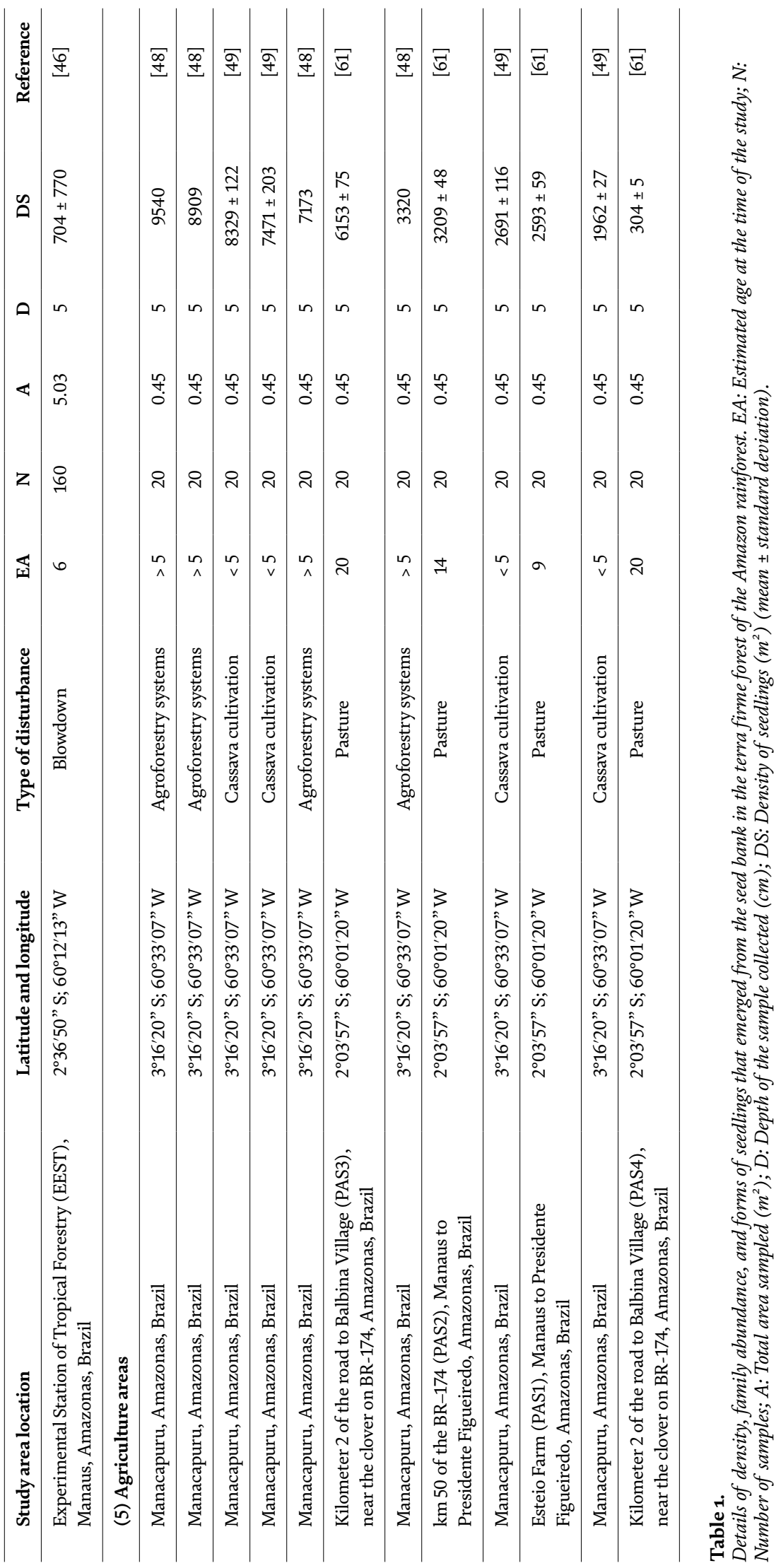


used in this stydy. The datasets involve different types of land use in the Brazilian Amazon rainforest, incluinding (1) old-growth forests, with no evidence of anthropogenic changes in the last 60 years or more; (2) forest fragments with different historical changes; (3) forests with logging of wood species; (4) secondary forests with evidence of natural and anthropogenic changes and (5) agriculture areas.

Seedling density emerging from soil samples is used in all datasets as an indirect estimate of seed density in the seed bank [51-56]. In addition to the highly variation found in the seed banks, even at small distances $[20,54,55]$, we see variation in the methods of soil sampling and sampled area [56], sampling depth and spread of sample in the nursery [15], all of which could influence both density and floristic composition. It should be noted that the tropical region lacks seedling identification guides or floras, making this activity largely dependent on the expertise of parabotanics and researchers involved in the field. It is well known that the seedling stage is one of the most difficult stages to identify, as reflected in the floristic composition of the seed bank. Even the division of seedlings into a life form, is difficult to position and categorize. To compile a file form database, we followed the categories proposed by the authors, but with minor changes. We chose to group emerged seedlings into four major categories, i.e., tree, herb, shrub, and support-dependent plants, which included lianas, epiphytes, and hemiepiphytes. Some species like Miconia serialis DC. can be shrubby to small trees; however, the small tree life form is the most common, and this species was placed in the tree categories.

\section{Results}

In general, the lower density of seedlings that emerged from the seed bank samples was observed in old-growth forests, while the highest density in seedlings emerged in agricultural areas (Figure 1). Seedling density in old-growth forests had less variability, with numbers varying between 94 and 913 seedlings per $\mathrm{m}^{2}$ (Table 1). In the other classes of land use, the density of seeds in the soil was found to be higher and had high variation (Figure 1 and Table 1).

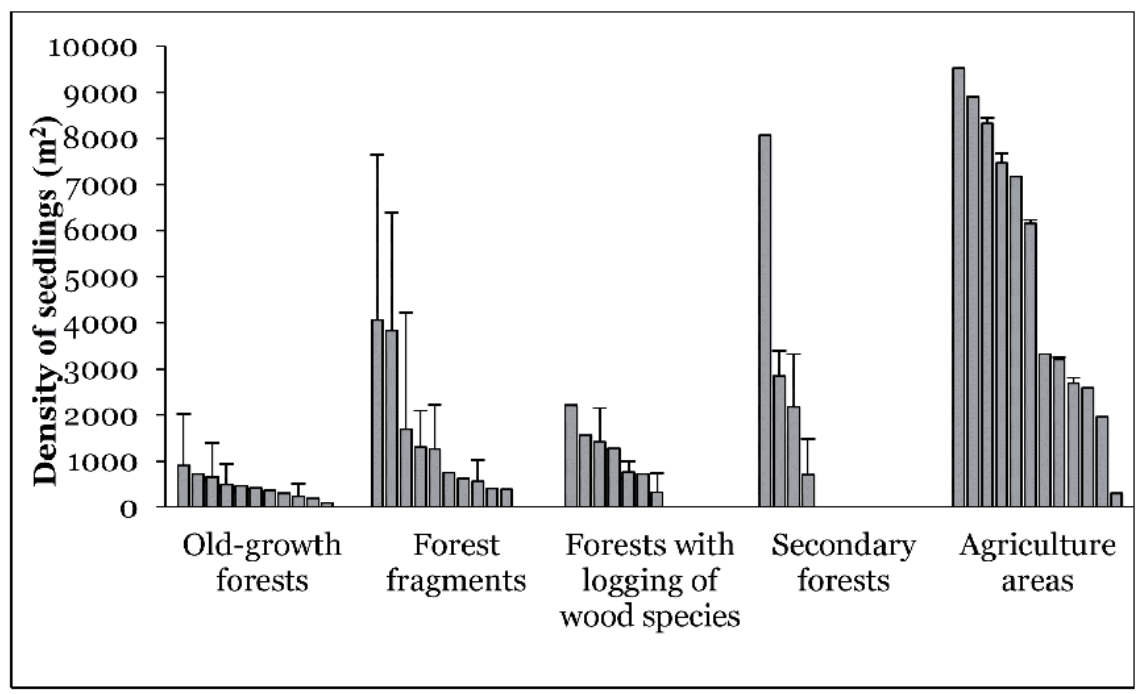

Figure 1.

Seedling density $\left(\mathrm{m}^{2}\right)$ emerged from the seed bank in different classes of land use. The vertical bar shows the standard deviation when cited. The datasets used are those described in table 1. 


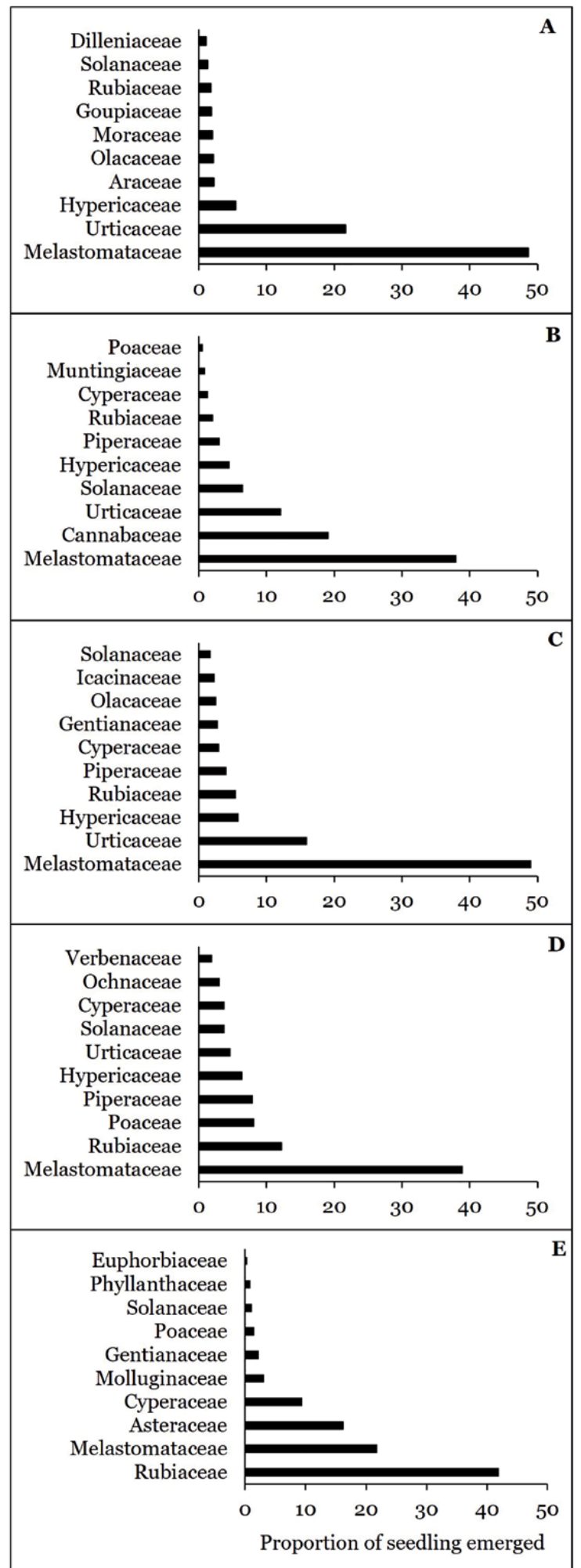

Figure 2.

The proportion of seedlings emerged from seed banks of the ten most abundant families according to different types of land use. A: Old-growth forests, with no evidence of anthropogenic changes in the last 60 years or more; $B$ : Forest fragments with different historical changes; C: Forests with logging of wood species; D: Secondary forests with evidence of natural and anthropogenic changes; E: Agriculture areas. 
The type of land use promotes changes in floristic composition (Figure 2). Melastomataceae seedlings predominated in all land uses, except for agricultural areas where Rubiaceae seedlings were the most abundant (Figure 2). Melastomataceae was represented by the following genera: Aciotis, Adelobotrys, Bellucia, Clidemia, Henriettea, Leandra, Maieta, Miconia, and Tococa. Urticaceae was the second most abundant family in the old-growth forests and the forests with logging of wood species. It was the third most abundant in forest fragments with different historical changes (Figure 2). Here, the following genera predominated: Cecropia, Coussapoa, and Pourouma, with only Cecropia occurring in agricultural areas and with low density. The families Dilleniaceae (Davilla, Doliocarpus, and Tetracera), Goupiaceae (Goupia glabra Aubl.), Moraceae (Ficus, Bagassa, Helicostylis, and Maquira), and Araceae (Philodendron) were present among the ten most abundant families, but only for old-growth forests (Figure 2). Hypericaceae seedlings, as represented by Vismia species, were among the ten most abundant families for all types of land use, except for agricultural areas, and, similar to Urticaceae, they occurred at low density (Figure 2). Cannabaceae seedlings represented an important component in forest fragments. It was represented by a single species, Trema micranta (L.) Blume, with wide distribution, and it serves as an indicator of degraded areas under anthropic use. The Piperaceae family was among the ten most abundant families in the category of intermediate change. It was absent from oldgrowth forests and agricultural areas. Cyperaceae and Poaceae were configured as a common component of altered areas. Poaceae, however, is not among the ten most abundant families for forests with logging of wood species. Solanaceae, as well as Rubiaceae, was present in all forest types; however, the latter had greater abundance in secondary forests and agricultural areas. Asteraceae (Chromolaena, Rolandra, and Vernonia) and Cyperaceae (Cyperus, Rhynchospora, and Fimbristyllis) had greater abundance in agricultural areas (Figure 2). Seedlings of Olacaceae (Heisteria) were among the ten most abundant families, but only for old-growth forests and forests with logging of wood species (Figure 2). Seedlings of Gentianaceae (Coutoubea and Irlbachia) were among the ten most abundant families, but only for forests with logging of wood species and agricultural areas. Muntingiaceae (Muntingia)

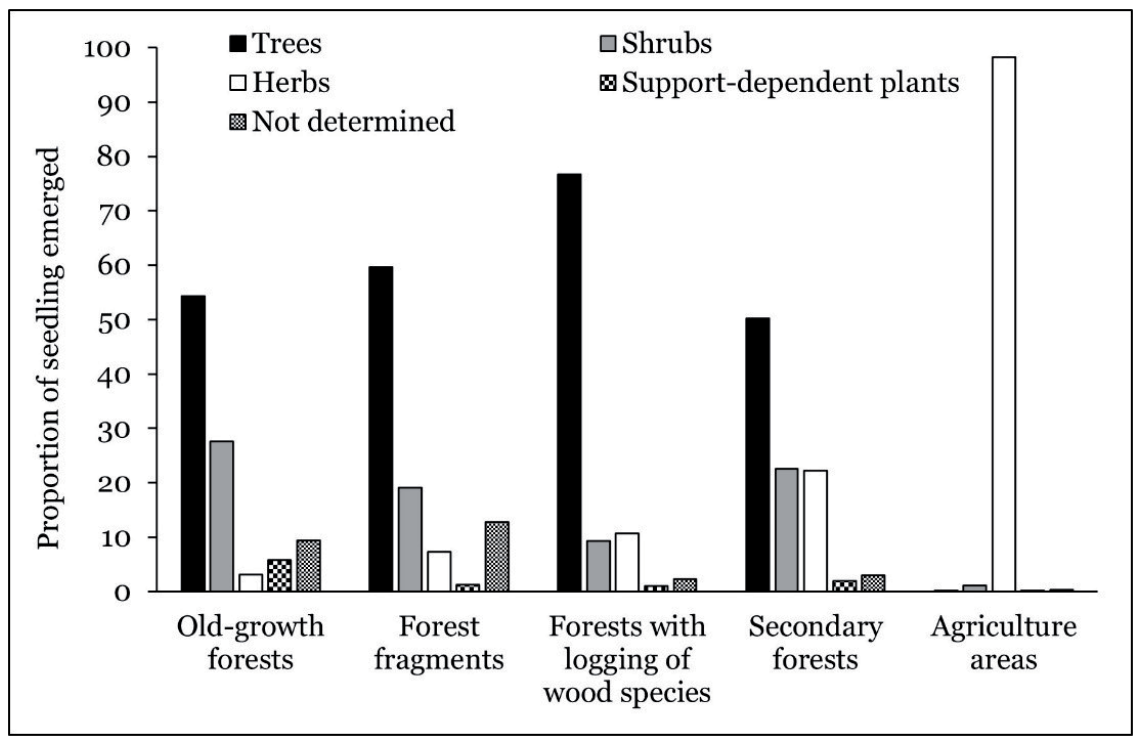

Figure 3.

The proportion of seedlings emerged from seed banks divided into life forms according to different types of land use. 
was configured among the ten most abundant families only for forest fragments, Icacinaceae (Dendrobangia) only for forests with logging of wood species and Verbenaceae (Stachytarpheta) and Ochnaceae (Lacunaria, Ouratea and Sauvagesia) only for secondary forests. Euphorbiaceae (Croton), Phyllanthaceae (Phyllanthus) and Molluginaceae (Mollugo) were also among the ten most abundant families, but only for agricultural areas (Figure 2).

Tree seedlings predominated in all types of land use in the seed bank, except for agricultural areas (Figure 3). Herbs increased in frequency according to land use, with a high proportion in the seed bank in agricultural areas. Despite the low proportion of seedlings classified as support-dependent plants (lianas, epiphytes, and hemiepiphytes) they still showed a higher proportion in the old-growth forests. In the seed bank of agricultural areas, a suppression of other life forms was observed (Figure 3). In the seed bank of forests with logging of wood species, shrubs decreased, while the proportion of tree seedlings increased.

\section{Discussion}

The seed bank has been the subject of studies in different forest types. However, literature surveys carried out in the present study reveal that very few studies reporting on the Amazon rainforest have been published. This highlights the need to expand research on seed banks in natural and anthropized areas. The data used in this chapter account for regions close to the capitals of the states of Amazonas and Pará (Table 1), owing to easy access by highways, in addition to universities and research institutes with a long tradition in ecological studies.

Changing land use in the Brazilian Amazon threatens the extinction of a significant number of species and consequent loss of environmental functions and services of the largest tropical forest on the planet [35, 37, 62-64]. Despite repeated warnings and concerns of conservationists and the scientific community, deforestation continues at an accelerated rate $[63,65]$. The replacement of the forest by pasture has been the main means of occupation and use of the land, as agriculture advances in the region [65-67]. The resilience of the forest and natural regeneration depends on several factors. Among them are type and intensity of the initial disorder, recurrence of disorders, topography, soil type, and the maintenance of accessible propagation sources [3, 36, 40, 68, 69]. The main mechanisms involved in the regeneration of these altered areas occur through the seed bank, dispersion of seeds from nearby areas, and vegetative regeneration, which includes surviving plants capable of sprouting from both the aerial part and the roots $[3,8,69]$.

We generally do find a high density of seeds in the altered areas. Nevertheless, the type and intensity of disturbances and changes occurring around in forest areas contribute to corresponding changes in the floristic composition of the seed bank [5]. Moreover, invasive, or ruderal, species are common and cause the impoverishment of the seed bank [70-74]. Thus, understanding the effects of different types of land use on the seed bank is fundamentally essential to understand the evolution of the landscape, identify obstacles to the restoration of the forest, and, consequently, ensure the regeneration of forest environments and maintenance of environmental services $[41,64,65,69,70,74]$.

Our data support the results of other studies carried out in tropical regions where the density of seeds in the topsoil is highly variable $[5,10,14,21,33,34]$. Seed density has increased from the old-growth forest to the altered areas (Figure 1). The observed variations in seed density in each class of land use (Table 1, Figure 1) reflect differences in forest typology, canopy opening, and sampling time among 
the areas $[9,14,19,21]$. In addition, intrinsic variations are associated with the seed bank $[20,54]$, as well as methodological differences $[15,52,56]$.

The seed bank is characterized by the occurrence and dominance of a limited number of botanical families. These families contribute markedly to common species and genera in secondary forests or the early stages of forest regeneration. Among the ten most abundant families in the seed bank, the presence of a high number of seedlings belonging to the Melastomatacea family stands out. This family has high diversity in the Neotropics, with approximately 3000 species, being composed of shrubs, lianas, herbs, epiphytes, and trees [75]. In the Amazon basin, the family is mainly composed of small tree species and shrubs, and it occurs in high abundance and diversity in the forest understory [76-78].

The Melastomataceae family is an important component of the seed bank of the Amazon rainforest $[7,19,60]$, as well as other forest types in the Neotropical region $[9,23,79,80]$. Its high abundance can likely be attributed to the number of small seeds produced per individual [18, 81], longevity [82], and photoblastic seeds, favoring the recruitment of seedlings in environments with greater luminosity [83-86]. The Melastomataceae family is composed of pioneer species that require high to low light, as well as species tolerant to shading [86-88]. Given the great importance of this family to the seed bank, more detailed studies need to be performed in order to better understand the spectrum and functionality of this group in the process of ecological succession.

Urticaceae seedlings consist of Cecropia, Coussapoa, and Pourouma configured as an important component in forest types with low land-use intensity, such as oldgrowth forests, forest fragments with different historical changes, and forests with logging of wood species (Figure 2). The pioneer species of Cecropia stand out for colonizing secondary areas that have suffered low impact disturbances, those are more important in the succession processes of these areas [39-43].

In the present study, seedlings of tree species predominated in the seed bank, except for agricultural areas where herbs predominated (Figure 3). A decrease in tree seedlings and an increase in herbs can already be observed in secondary forests. Herbs increased density with intensity of disturbance, with low density in old-growth forests (Figure 3). In general, the forest seed bank is dominated by trees (49\% on average), while cultivated areas and secondary forests are dominated by herbs ( $75 \%$ on average) [14]. The high density of herbs in secondary forests and forest fragments results from the occurrence of anthropized areas around these areas $[5,14,22,29,33]$. The importance of shrubs and small trees is little studied in successional processes in tropical forests. Most studies focus on changes in the structure and floristic composition of the woody layer [89-94], but such studies exclude many groups that occur in high density in the seed bank, groups which can play a relevant role in the mechanisms of ecological succession. These groups also respond to different time scales in biological attributes, such as lifetime, reproductive age, and rate of evolution [95].

Secondary forests in the Amazon may result from the abandonment of areas previously used for different purposes, such as shifting agriculture, pastures, and mining $[63,65,96,97]$, which rarely originate from natural disorders [46]. Abandoned pastures occur after years of grazing and cleaning, usually by fire $[65,69]$. These areas usually have a seed bank with high density and composition mainly consisting of locally produced herb seeds $[41,65,69]$. This seed bank is very similar to that with established vegetation cover [39-44], which is not seen in old-growth forests $[14,98,99]$. Among the ten most abundant families in the seed bank, common herbs from high-impact degraded areas, such as Poaceae, Rubiaceae, Asteraceae, and Cyperaceae predominate. However, seedlings of typical families from the seed bank of old-growth forests do occur (Figure 2). Floristic composition 
and seed density in agricultural areas suggest the need to use forest restoration techniques after abandonment, to facilitate and accelerate the return of the forest.

Forest fragments are stretches of forest inserted in a matrix of different types of land uses, typically of anthropic origin [38, 100-102]. The areas used in this study encompass a variety of forest fragments, requiring a more detailed analysis of the characteristics of each. Increase in seed density and changes in the floristic composition of the seed bank intensify in small fragments inserted in a matrix composed of pastures, as well as recurrence of disturbances in these forest fragments [5, 24, $34,74,100]$. While large forest fragments over 100 ha have a density and floristic composition more similar to the seed bank of old-growth forests, the seed bank also contains species typical of anthropized areas [7, 19, 102, 103].

In the areas of forests with logging of wood species, we can find a mosaic of altered and unaltered areas $[45,57,104-110]$ with marked differences between open canopy areas and those that suffered little or no impact $[104,107]$. Thus, a greater number of seeds are found in the soil in the centers of exploration clearings and tractor trails $[45,57]$. Later, with regeneration, seed density declines and approaches pre-exploratory conditions [45]. The density, as well as life forms, of these areas is closer to that of old-growth forests (Figures 1 and 3). For the three most abundant families in the seed bank, floristic composition is very similar to that of old-growth forests. On the other hand, in other families, such as Cyperaceae, Rubiaceae, and Piperaceae, we see higher density of seedlings characteristic of open areas (Figure 2).

The seed bank is directly related to forest resilience which contributes to a large number of regenerants, including species of ecological groups not present in the arboreal stratum of old-growth forests. This means that dramatic changes in the seed bank owing to the use and management of soil will, in turn, promote changes in floristic composition and density in a manner that favors the introduction of species not commonly found in the seed bank of old-growth forests. Ultimately, these conditions cause the impoverishment of the seed bank and consequent loss of its functionality. In extreme cases where total suppression of the seed bank has occurred, its absence completely alters the successional trajectory [39-44]. The seed bank is essential for resilience, forest regeneration, and forest diversity; therefore, any changes in its functionality compromise the diversity, regeneration, and maintenance of tropical forests.

\section{Acknowledgements}

This research is part of TVB's project of the Institutional Training Program of the National Institute for Amazon Research - INPA. TVB acknowledges the financial support of the National Council for Scientific and Technological Development - CNPq, Brazil [process \#301481/2020-2]. To Thaiane Rodrigues de Sousa for providing the worksheets to prepare the review. For undergraduate students: Gisiane Rodrigues Lima, Tamires Ferreira Muniz, Gisele Rodrigues dos Santos and Pedro Cavalcante da Cruz under the supervision of Dr. Niwton Leal Filho, from the research group on forest seeds of the National Institute for Amazon Research - INPA, who proved unpublished data for the preparation of the chapter.

\section{Conflict of interest}

There are no conflicts of interest in the chapter entitled "Ecology of the seed bank in the Amazon rainforest" to be considered for publication in Open Access 
book at IntechOpen in the book Ecosystem and Biodiversity of Amazonia”, ISBN 978-1-83,962-813-9. The data used in the chapter have no conflicting interests since there is no conflict of interest by the authors. All sources of funding were cited in the acknowledgments and all help received in the execution of the research was properly cited. The data used in this chapter refer to previously published articles and theses, as well as the unpublished data, refer to the result of scientific initiation under the supervision of Dr. Niwton Leal Filho.

\section{Author details}

Natali Gomes Bordon ${ }^{1 *}$, Niwton Leal Filho ${ }^{2}$ and Tony Vizcarra Bentos ${ }^{2}$

1 University of Campinas (UNICAMP), Campinas, Brazil

2 National Institute for Amazon Research (INPA), Manaus, Brazil

*Address all correspondence to: natalibordon@yahoo.com.br

\section{IntechOpen}

(C) 2020 The Author(s). Licensee IntechOpen. This chapter is distributed under the terms of the Creative Commons Attribution License (http://creativecommons.org/licenses/ by/3.0), which permits unrestricted use, distribution, and reproduction in any medium, provided the original work is properly cited. (cc) BY 


\section{References}

[1] Barker HG. 1989. Some aspects of the natural history of seed banks, p. 9-21. In: Leck MA, Parker T, Simpson RL, editors. Ecology of soil seed banks. San Diego: Academic Press; 1989. p. 9-21. DOI: 10.1016/B978-0-12-440405-2. X5001-5.

[2] Baskin CC, Baskin JM. 2001. Seeds: Ecology, Biogeography, and Evolution of Dormancy and Germination. San Diego: Academic Press; 2001. 659p.

[3] Castillo LS, Stevenson PR. Relative importance of seed-bank and postdisturbance seed dispersal on early gap regeneration in a Colombian Amazon Forest. Biotropica. 2010; 42: 488-492. DOI: $10.1111 / j .1744-7429.2009 .00605 . x$.

[4] López-Toledo L, Martínez-Ramos M. The soil seed bank in abandoned tropical pastures: source of regeneration or invasion? Revista Mexicana de Biodiversidad. 2011. 82: 663-678. DOI: 10.1111/j.1744-7429.2009.00605.x.

[5] Miranda IS, Mitja D, SILVA TS. Mutual influence of forests and pastures on the seedbanks in the Eastern Amazon. Weed Research. 2009; 49: 499-505.DOI: 10.1111/j.1365-3180.2009.00719.x.

[6] Thompson K. The functional ecology of soil seed banks. In: Fenner M. editor. Seeds: the ecology of regeneration in plant communities. Wallingford: CAB International; 1992. p. 231-258. DOI: 10.1079/SSR2003142

[7] Sousa TR, Costa FRC, Bentos TV, Leal Filho N, Mesquita RCG, Ribeiro IO. The effect of forest fragmentation on the soil seed bank of Central Amazonia. Forest Ecology and Management. 2017; 393: 105-112. DOI: 10.1016/j. foreco.2017.03.020

[8] Vieira ICG, Proctor J. Mechanisms of plant regeneration during succession after shifting cultivation in eastern Amazonia. Plant Ecology. 2007; 192: 303-315. DOI: 10.1007/sl 1258-007-9327-4

[9] Dalling JW, Denslow JS. Soil seed bank composition along a forest chronosequence in seasonally moist tropical forest, Panama. Journal of Vegetation Science. 1998; 9: 669-678. DOI: $10.2307 / 3237285$.

[10] Dupuy JM, Chazdon RL. Longterm effects or forest regrowth and selective logging on the seedbank of tropical forests in northeastern Costa Rica. Biotropica. 1998; 30: 223-237.DOI: 10.1111/j.1744-7429.1998. tb00057.x.

[11] Menalled FD, Gross KL, Hammond M. Weed aboveground and seedbank community responses to agricultural management systems. Ecological Applications. 2001; 11:15861601. DOI: $10.2307 / 3061080$.

[12] Wagner M, Mitschunas N. Fungal effects on seed bank persistence and potential applications in weed biocontrol: A review. Basic and Applied Ecology. 2008; 9: 191-203.DOI: 10.1016/j.baae.2007.02.003.

[13] Harper JL.1977. The Population Biology of Plants. London: Academic Press; 1977. 892 p. DOI: $10.1017 /$ S0376892900005774

[14] Garwood NC. Tropical soil seed banks: a review. In: Leck MA, Parker T, Simpson RL, editors. Ecology of soil seed banks. San Diego: Academic Press; 1989. p. 149-209. DOI: 10.1016/B978-012-440405-2.X5001-5

[15] Dalling JW, Swaine, MD, Garwood NC. Effect of soil depth on seedling emergence in tropical soil seedbank investigations. Funct. Ecol. 1994; 9, 119-121. DOI: 10.2307/2390098 
[16] Pearson TRH, Burslem DFRP, Mullins CE, Dalling JW. Germination ecology of neotropical pioneers: interacting effects of environmental conditions and seed size. Ecology. 2002; 83: 2798-2807. DOI: 10.1890/0012-9658

[17] Baskin CC, Baskin JM. Germination Ecology of seeds in the Persistent seed Bank. In: Seed Ecology, Biogeography, and Evolution of Dormancy and Germination. San Diego: Academic Press; 1998. P. 133-179. DOI: $10.1016 /$ B978-0-12-080260-9.X5000-3

[18] Bentos TV, Mesquita RCG, Williamson GB. Reproductive Phenology of Central Amazon Pioneer Trees. Tropical Conservation Science. 2008; 1: 186-203. DOI: $10.1038 /$ nature 09273 .

[19] Leal Filho N, Sena JS, Santos GR. Variações espaço-temporais no estoque de sementes do solo na floresta amazônica. Acta Amazonica. 2013; 43: 305-314. DOI: $10.1590 /$ s0044-59672013000300006.

[20] Dalling JW, Swaine MD, Garwood NC. Dispersal patterns and seed bank dynamics of pioneer trees in moist tropical forest. Ecology. 1998; 79: 564-578. DOI: 10.1890/0012-9658(1998) 079[0564,DPASBD]2.0.CO;2

[21] Fornara DA, Dalling JW. Seed bank dynamics in five Panamanian forests. Journal of Tropical Ecology. 2005; 21: 223-226. DOI: 10.1017/ S0266467404002184.

[22] Medeiros-Sarmento PS, Ferreira LV, Gastauer M. Natural regeneration triggers compositional and functional shifts in soil seed banks. Science of the Total Environment. 2021; 753: 141934. DOI: 10.1016/j.scitotenv.2020.141934.

[23] Baider C, Tabarelli M, Mantovani W. The soil seed bank during Atlantic forest regeneration in southeast Brazil. Revista Brasileira
Biologia. 2001; 61: 35-44. DOI: $10.1590 /$ S0034-71082001000100006.

[24] Martins AM, Engel VL. Soil seed banks in tropical forest fragments with different disturbance histories in southeastern Brazil. Ecological Engineering. 2007; 31:165-174. DOI: 10.1016/j.ecoleng.2007.05.008

[25] Vázquez-Yanes C, Smith H. Phytochrome control of seed germination in the tropical rain forest pioneer trees Cecropia obtusifolia and Piper auritum, and its ecological significance. New Phytologist. 1982; 92: 477-485. DOI: 10.1111/j.1469-8137.1982. tb03405.x

[26] Vásquez-Yanes C, Orozco-Segovia A. Ecological significance of light controlled seed germination in two contrasting tropical habitas. Oecologia. 1990; 83: 171-175. DOI: 10.1007/BF00317748

[27] Pearson TRH, Burslem DFRP, Mullins CE, Dalling JW. Functional significance of photoblastic germination in neotropical pioneer trees: a seed's eye view. Functional Ecology. 2003; 17: 394:402. DOI: 10.1046/j.1365-2435.2003.00747.x

[28] Brokaw NVL. Treefalls, regrowth, and community structure in tropical forests. In: Pickett STA, White PS, editors. The ecology of natural disturbance and patch dynamics. San Diego: Academic Press, 1985. P. 53-69. DOI: 10.1016/C2009-0-02952-3

[29] Whitmore. T. C.1996. A review of some aspects of tropical rain forest seedling ecology with suggestions for further enquiry. In: Swaine, MD, editor. The ecology of tropical forest tree seedlings. Volume 17. New York: UNESCO; 1996. P. 3-39.

[30] Thompson K. Gap and Seedling Colonization. In: Fenner M, editor. Seeds The Ecology of Regeneration in Plant Communities. 2nd ed. London: 
British Library; 2000. p. 375-395. DOI: 10.1079/9780851994321.0000.

[31] Uhl C. Factors Controlling Succession Following Slash-and-Burn Agriculture in Amazonia. The Journal of Ecology. 1987; 75: 377-407. DOI: 10.2307/2260425.

[32] Uhl C, Buschbacher R, Serrao EAS. Abandoned Pastures in Eastern Amazonia. I. Patterns of Plant Succession. The Journal of Ecology. 1988; 76: 663-681. DOI: $10.2307 / 2260566$.

[33] Young KR, Ewel JJ, Brown BJ. Seed dynamics during forest succession in Costa Rica. Vegetatio. 1987; 71: 157-173. DOI: 10.1007/BF00039168.

[34] Quintana-Ascencio PFM, González-Espinosa; Mirez-Marcial, N.; Domínguez-Vasquez, G.; MartínezIco, M. 1996. Soil seed banks and regeneration of tropical rain forest from milpa fields at the Selva Lacandona, Chiapas, Mexico. Biotropica. 1996; 28:192-209. DOI: : $10.2307 / 2389074$

[35] Jakovac CC, Peña-Claros M, Kuyper TW, Bongers F. 2015. Loss of secondary forest resilience by landuse intensification in the Amazon. J. Ecol. 2015; 103: 67-77. DOI: 10.1111/1365-2745.12298.

[36] Mesquita RDCG, Massoca PEDS, Jakovac CC, Bentos TV, Williamson GB. 2015. Amazon rain forest succession: stochasticity or land-use legacy? Bioscience. 2015; 65: 849-861. DOI: 10.1093/biosci/biv108.

[37] Chua SC, Ramage BS, Potts MD. Soil degradation and feedback processes affect long-term recovery of tropical secondary forests. J. Veg. Sci. 2016; 27: 800-811. DOI: $10.1111 /$ jvs.12406.

[38] Arroyo-Rodríguez V, Melo FPL, Martínez-Ramos M, Bongers F, Chazdon RL, Meave JA, Norden N,
Santos BA, Leal IR, Tabarelli M. Multiple successional pathways in human-modified tropical landscapes: new insights from forest succession, forest fragmentation and landscape ecology research. Biol. Rev. 2017; 92: 326-340. DOI: 10.1111/brv.12231.

[39] Monaco LM, Mesquita RCG, Williamson GB. Banco de sementes de uma floresta secundária amazônica dominada por Vismia. Acta Amazonica. 2003; 33: 41-52. DOI: 10.1590/1809-4392200331052.

[40] Longworth JB, Mesquita RC, Bentos TV, Moreira MP, Massoca PE, Williamson, GB. 2014. Shifts in dominance and species assemblages over two decades in alternative successions in Central Amazonia. Biotropica. 2014; 46: 529-537. DOI: 10.1111/btp.12143.

[41] Rocha GPE, Vieira DLM, Simon MF. Fast natural regeneration in abandoned pastures in southern Amazonia. Forest Ecology and Management. 2016; 370: 93-101. DOI: 10.1016/j.foreco.2016.03.057.

[42] Mesquita RCM, Icke SK, Ganade G, Williamson GB. Alternative successional pathways in the Amazon Basin. Journal of Ecology. 2001; 89:528-537. DOI: 10.1046/j.1365-2745.2001.00583.x.

[43] Williamson, GB, Bentos TV, Longworth JB, Mesquita RCG. Convergence and divergence in alternative successional pathways in Central Amazonia. Plant Ecol. Divers. 2014; 7: 341-348. DOI: 10.1080/17550874.2012.735714.

[44] Jakovac ACC, Bentos TV, Mesquita RCG, Williamson GB. Age and light effects on seedling growth in two alternative secondary successions in central Amazonia. Plant Ecology \& Diversity. 2014; 7: 349-358. DOI: 10.1080/17550874.2012.716088. 
[45] Leal Filho, N. Dinâmica inicial da regeneração natural de florestas exploradas na Amazônia brasileira [thesis]. São Paulo: Instituto de Biociências da Universidade de São Paulo. Departamento de Ecologia Geral; 2000.

[46] Bordon NG, Nogueira A, Leal Filho N, Higuchi N. Blowdown disturbance effect on the density, richness and species composition of the seed bank in Central Amazonia. Forest Ecology and Management, 2019; 453: 117633. DOI: 10.1016/j. foreco.2019.117633.

[47] Saulesi M, Swaine MD. Rain forest seed dynamics during succession at Gogol, Papua New Guinea. Journal of Ecology. 1998; 76: 1133-1152. DOI: $10.2307 / 2260639$

[48] Costa JR, Mitja D. Bancos de sementes de plantas daninhas em sistemas agroflorestais na Amazônia Central. Revista Brasileira de Ciências Agrárias - Brazilian Journal of Agricultural Sciences. 2009; 4: 298-303. DOI: 10.5039/agraria.v4i3a12.

[49] Costa JR, Mitja D, Fontes JRA. Bancos de sementes de plantas daninhas em cultivos de mandioca na Amazônia Central. Planta Daninha. 2009; 27: 665-671. DOI: 10.1590/ S0100-83582009000400004.

[50] Peçanha-Júnior FB. Avaliação do banco de sementes da floresta de Caxiuanã, município de Melgaço, Pará, Brasil [thesis]. Belém: Universidade de Federal Rural da Amazônia e Museu Paraense Emílio Goeldi; 2006.

[51] Gonzalez S, Ghermandi L. Comparison of methods to estimate soil seed banks: the role of seed size and mass. Community Ecology. 2012; 13: 238-242. DOI: $10.1556 /$ ComEc.13.2012.2.14.

[52] Gross KLA. Comparison of Methods for Estimating Seed Numbers in the
Soil. The Journal of Ecology. 1990; 78: 1079-1093. DOI: $10.2307 / 2260953$.

[53] Price JN, Wright BR, Gross CL, Whalley WRDB. Comparison of seedling emergence and seed extraction techniques for estimating the composition of soil seed banks. Methods in Ecology and Evolution. 2010; 1: 151-157. DO: 10.1111/j.2041-210X.2010.00011.x.

[54] Plue J, Goyens G, Van Meirvenne M, Verheyen K, Hermy M. Small-scale seed-bank patterns in a forest soil. Seed Science Research. 2010; 20: 13-22. DOI: 10.1017/S0960258509990201.

[55] Dalling JW, Swaine MD, Garwood NC. Soil seed bank community dynamics in seasonally moist lowland tropical forest, Panama. Journal of Tropical Ecology. 1997; 13: 659-680, 10 Sep. 1997. DOI: 10.1017/ S0266467400010853.

[56] Butler BJ, Chazdon RL. Species Richness, Spatial Variation, and Abundance of the Soil Seed Bank of a Secondary Tropical Rain Forest. Biotropica. 1998; 30: 214-222. DOI: 10.1111/j.1744-7429.1998.tb00056.x. A

[57] Quanz B, Carvalho JOP, Araujo, MM, Francez LMB, Silva USC, Pinheiro KAO. Exploração florestal de impacto reduzido não afeta a florística do banco de sementes do solo. Rev. Ciências Agrárias. 2012; 55: 204-211. DOI: 10.4322/rca.2012.055.

[58] França, AL. Similaridade florística e banco de sementes da zona ripária de igarapés de bacias hidrográficas distintas na Amazônia Central [thesis]. Manaus: Instituto Nacional de Pesquisas da Amazônia; 2018.

[59] Araujo MM, Oliveira FA, Vieira ICG, Barros PLC, Lima CAT. Densidade e composição florística do banco de sementes do solo de florestas sucessionais na região do Baixo Rio 
Guamá, Amazônia oriental. Scientia Forestalis. 2001; 59: 115:130.

[60] Bentos TV, Nascimento HEM, Williamson GB., 2013. Tree seedling recruitment in Amazon secondary forest: importance of topography and gap micro-site conditions. For. Ecol. Manag. 2013; 287: 140-146. DOI: 10.1016/j.foreco.2012.09.016.

[61] Costa JR, Mitja D, Leal Filho, N. Bancos de sementes do solo em pastagens na Amazônia Central. Pesquisa Florestal Brasileira. 2013; 33: 117-125. DOI: 10.4336/2013.pfb.33.74.431.

[62] Zemp DC, Schleussner CF, Barbosa HMJ, Rammig A. Deforestation effects on Amazon forest resilience. Geophysical Research Letters. 2017; 44: 6182-6190. DOI: 10.1002/2017GL072955.

[63] Bullock EL, Woodcock CE, Souza C, Olofsson P. Satellite-based estimates reveal widespread forest degradation in the Amazon. Global Change Biology. 2020; 26: 2956-2969. DOI: 10.1111/ gcb.15029.

[64] Luther DA, Cooper WJ, Wolfe JD, Bierregaard RO, Gonzalez A, Lovejoy TE. Tropical forest fragmentation and isolation: Is community decay a random process? Global Ecology and Conservation. 2020; 23: e01168. DOI: 10.1016/j.gecco.2020. e01168.

[65] Laurance WF, Sayer J, Cassman, KG. Agricultural expansion and its impacts on tropical nature. Trends in Ecology \& Evolution. 2014; 29: 107-116. DOI: 10.1016/j.tree.2013.12.001.

[66] Fearnside PM. Amazonian deforestation and global warming: carbon stocks in vegetation replacing Brazil's Amazon forest. Forest Ecology and Management. 1996; 80: 21-34. DOI: 10.1016/0378-1127(95)03647-4.
[67] Ferraz SFB, Vettorazzi CA, Theobald DM, Ballester MVR. Landscape dynamics of Amazonian deforestation between 1984 and 2002 in central Rondônia, Brazil: assessment and future scenarios. Forest Ecology and Management. 2005; 204: 69-85. DOI 10.1016/j. foreco.2004.07.073.

[68] Seifan M, Seifan T, Jeltsch F, Tielbörger K. Combined disturbances and the role of their spatial and temporal properties in shaping community structure. Perspectives in Plant Ecology, Evolution and Systematics. 2012; 14: 217-229. DOI: 10.1016/j.ppees.2011.11.003.

[69] Robin LC. Tropical forest recovery: legacies of human impact and natural disturbances. Perspectives in Plant Ecology, Evolution and Systematics. 2003; 6: 51-71. DOI: 10.1078/1433-8319-00042.

[70] Wijdeven SMJ, Kuzee ME. Seed Availability as a Limiting Factor in Forest Recovery Processes in Costa Rica. Restoration Ecology. 2000; 8: 414-424. DOI: 10.1046/j.1526-100x.2000.80056.x.

[71] Silva ÚSR, Matos DMS. The invasion of Pteridium aquilinum and the impoverishment of the seed bank in fire prone areas of Brazilian Atlantic Forest. Biodiversity and Conservation. 2006; 9: 3035-3043. DOI: $10.1007 /$ s10531-005-4877-z.

[72] Gioria M, Jarošík V, Pyšek P. Impact of invasions by alien plants on soil seed bank communities: Emerging patterns. Perspectives in Plant Ecology, Evolution and Systematics. 2014; 16: 132-142. DOI: 10.1016/j.ppees.2014.03.003.

[73] Gioria M, Pyšek P. The Legacy of Plant Invasions: Changes in the Soil Seed Bank of Invaded Plant Communities. BioScience. 2016; 66: 40-53. DOI: 10.1093/biosci/biv165. 
[74] Alvarez-Aquino C, WilliamsLinera G, Newton AC. Disturbance effects on the seed bank of Mexican cloud forest fragments. Biotropica. 2005; 37: 337-342. DOI: 10.1111/j.1744-7429.2005.00044.x.

[75] Clausing G, Renner SS. Molecular phylogenetics of Melastomataceae and Memecylaceae: implications for character evolution. American Journal of Botany. 2001; 88: 486-498. DOI: $10.2307 / 2657114$.

[76] Tuomisto H, Ruokolainen K, Aguilar M, Sarmiento A. Floristic patterns along a 43-km long transect in an Amazonian rain forest. Journal of Ecology. 2003; 91: 743-756. DOI: 10.1046/j.1365-2745.2003.00802.x.

[77] Tuomisto H, Ruokolainen K. Yli-Halla M. Dispersal, Environment, and Floristic Variation of Western Amazonian Forests. Science. 2003; 299: 241-244. DOI: 10.1126/science.1078037.

[78] Duque AJ, Duivenvoorden JF, Cavelier J, Sánchez M, Polanía C, León A. Ferns and Melastomataceae as indicators of vascular plant composition in rain forests of Colombian Amazonia. Plant Ecology. 2005; 178: p. 1-13. DOI: 10.1007/s11258-004-1956-2.

[79] Pereira-Diniz SG, Ranal MA. Germinable soil seed bank of a gallery forest in Brazilian Cerrado. Plant Ecology. 2006; 183: 337-348. DOI: 10.1007/s11258-005-9044-9.

[80] Franco BKS, Martins SV, Faria PCL, Ribeiro GA. Densidade e composição florística do banco de sementes de um trecho de floresta estacional semidecidual no campus da Universidade Federal de Viçosa, Viçosa, MG. Revista Árvore. 2012; 36: 423-432. DOI: 10.1590/ S0100-67622012000300004.

[81] Bentos TV, Mesquita RCG, Camargo JLC, Williamson GB. Seed and fruit tradeoffs - the economics of seed packaging in Amazon pioneers. Plant Ecology \& Diversity. 2014; 7: 1-2. DOI 10.1080/17550874.2012.740081.

[82] Silveira FAO, Ribeiro RC, Soares S, Rocha D, Oliveira C. Physiological dormancy and seed germination inhibitors in Miconia (Melastomataceae). Plant Ecology and Evolution. 2013; 146: 290-294. DOI: 10.5091/plecevo.2013.817.

[83] Carreira RC, Zaidan LBP. Germinação de sementes de espécies de Melastomataceae de Cerrado sob condições controladas de luz e temperatura. Hoehnea. 2007; 34: 261-269. DOI: 10.1590/ S2236-89062007000300001.

[84] Silveira FAO, Ribeiro RC, Oliveira DMT, Fernandes GW, LemosFilho JP. Evolution of physiological dormancy multiple times in Melastomataceae from Neotropical montane vegetation. Seed Science Research. 2012; 22: 37-44. DOI: 10.1017/ S0960258511000286.

[85] Godoi S, Takaki M. Seed germination in Miconia theaezans (Bonpl.) Cogniaux (Melastomataceae). Brazilian Archives of Biology and Technology. 2007; 50: 571-578. DOI 10.1590/S1516-89132007000400002.

[86] Silveira FAO, Fernandes GW, Lemos-Filho JP. Seed and Seedling Ecophysiology of Neotropical Melastomataceae: Implications for Conservation and Restoration of Savannas and Rainforests. Annals of the Missouri Botanical Garden. 2013; 99: 82-99. DOI: $10.3417 / 2011054$.

[87] Ellison AM, Denslow JS, Loiselle BA. Seed and Seedling Ecology of Neotropical Melastomataceae. Ecology. 1993; 74: 1733-1749. DOI: 10.2307/1939932.

[88] Putz FE. Treefall Pits and Mounds, Buried Seeds, and the Importance 
of Soil Disturbance to Pioneer Trees on Barro Colorado Island, Panama. Ecology. 1983; 64: 1069-1074. DOI: 10.2307/1937815.

[89] Lu D, Mausel P, Brondízio E, Moran E. Classification of successional forest stages in the Brazilian Amazon basin. Forest Ecology and Management. 2003; 181: 301-312. DOI: 10.1016/ S0378-1127(03)00003-3.

[90] Van Breugel M, Bongers F, Martínez-Ramos M. Species Dynamics During Early Secondary Forest Succession: Recruitment, Mortality and Species Turnover. Biotropica. 2007; 39: 610-619. DOI 10.1111/j.1744-7429.2007.00316.x.

[91] Pena-Claros M. Changes in Forest Structure and Species Composition during Secondary Forest Succession in the Bolivian Amazon. Biotropica. 2004; 35: 450-461. DOI 10.1111/j.17447429.2003.tb00602.x.

[92] Saldarriaga JG, West DC, Tharp ML, Uhl C. Long-Term Chronosequence of Forest Succession in the Upper Rio Negro of Colombia and Venezuela. The Journal of Ecology. 1998; 76: 938-958. DOI:10.2307/2260625.

[93] Finegan B. Pattern and process in neotropical secondary rain forests: the first 100 years of succession. Trends in Ecology \& Evolution. 1996; 11: 119-124. DOI 10.1016/0169-5347(96)81090-1.

[94] Marra DM, Chambers JQ, Higuchi N, Trumbore SE, Ribeiro GHPM, Santos J, NegrónJuárez RI, Reu B, Wirth C. Large-Scale Wind Disturbances Promote Tree Diversity in a Central Amazon Forest. PLoS ONE. 2014; 9: e103711. DOI 10.1371/journal.pone.0103711.

[95] Lanfear R, Ho SYW, Davies J, Moles AT, Aarssen L, Swenson NG, Warman L, Zanne, AE, Allen AP. Taller plants have lower rates of molecular evolution. Nature Communications. 2013; 4: 1879. DOI: $10.1038 /$ ncomms2836.

[96] Lapola DM, Schaldach R, Alcamo J, Bondeau A, Msangi S, Priess JA, Silvestrini R, Soares-Filho BS. Impacts of Climate Change and the End of Deforestation on Land Use in the Brazilian Legal Amazon. Earth Interactions. 2011; 15: 1-29. DOI: 10.1175/2010EI333.1.

[97] Aldrich SP, Walker RT, Arima EY, Caldas MM, Browder JO, Perz S. Land-Cover and Land-Use Change in the Brazilian Amazon: Smallholders, Ranchers, and Frontier Stratification. Economic Geography. 2009; 82: 265-288. DOI: 10.1111/j.1944-8287.2006.tb00311.x.

[98] Cui L, Li W, Zhao X, Zhang M, Lei Y, Zhang Y, Gao C, Kang X, Sun B, Zhang $Y$. The relationship between standing vegetation and the soil seed bank along the shores of Lake Taihu, China. Ecological Engineering. 2016; 96: 45-54. DOI: 10.1016/j. ecoleng.2016.03.040.

[99] Hopfensperger KN. A review of similarity between seed bank and standing vegetation across ecosystems. Oikos. 2007; 116: 1438-1448. DOI: 10.1111/j.0030-1299.2007.15818.x.

[100] Hill JL, Curran PJ. Area, shape and isolation of tropical forest fragments: effects on tree species diversity and implications for conservation. Journal of Biogeography. 2003; 30: 1391-1403. DOI: 10.1046/j.1365-2699.2003.00930.x.

[101] Turner IM. Species Loss in Fragments of Tropical Rain Forest: A Review of the Evidence. The Journal of Applied Ecology. 1996; 33: 200-209. DOI: $10.2307 / 2404743$.

[102] Laurance WF, Lovejoy TE, Vasconcelos HL, Bruna EM, Didham RK, Stouffer PC, Gascon C, Bierregaard RO, Laurance SG, 
Sampaio E. Ecosystem Decay of Amazonian Forest Fragments: a 22-Year Investigation. Conservation Biology. 2001; 16: 605-618. DOI 10.1046/j.1523-1739.2002.01025.x.

[103] Lippok D, Walter F, Hensen I, Beck SG, Schleuning M. Effects of disturbance and altitude on soil seed banks of tropical montane forests. Journal of Tropical Ecology. 2013; 29: 523-529. DOI 10.1017/ S0266467413000667.

[104] Greguš C. Principles of longterm sustainable forest development implemented as the background for ecological forest management. Folia Oecologica. 2013; 40: 146-152. DOI: 91836966.

[105] Lindenmayer DB, Franklin JF, Fischer J. General management principles and a checklist of strategies to guide forest biodiversity conservation. Biological Conservation. 2006; 131: 433445. DOI 10.1016/j.biocon.2006.02.019.

[106] Macdicken KG, Sola P, Hall JE, Sabogal C, Tadoum M, Wasseige C. Global progress toward sustainable forest management. Forest Ecology and Management. 2015; 352: 47-56. DOI: 10.1016/j.foreco.2015.02.005.

[107] Hartshorn GS. Application of Gap Theory to Tropical Forest Management: Natural Regeneration on Strip Clear-cuts in the Peruvian Amazon. Ecology. 1989; 70: 567-576. DOI: 10.2307/1940208.

[108] Summers PM, Browder JO, Pedlowski MA. Tropical forest management and silvicultural practices by small farmers in the Brazilian Amazon: recent farm-level evidence from Rondônia. Forest Ecology and Management. 2004; 192: 161-177. DOI: 10.1016/j.foreco.2003.12.016.

[109] Bonilla-Bedoya S, EstrellaBastidas A, Ordoñez M, Sánchez A,
Herrera MA. Patterns of timber harvesting and its relationship with sustainable forest management in the western Amazon, Ecuador case. Journal of Sustainable Forestry. 2017; 36: 433-453. DOI 10.1080/10549811.2017.1308869.

[110] Piketty MG, Drigo I, Sablayrolles P, Aquino EA, Pena D, Sist P. Annual Cash Income from Community Forest Management in the Brazilian Amazon: Challenges for the Future. Forests. 2015; 6: 4228-4244. DOI 10.3390/f6114228. 



\title{
The Nymph Architect of the Cicada Guyalna chlorogena: Behaviours and Ecosystem
}

\author{
Claude François Béguin
}

\begin{abstract}
At the beginning of the last year of its larval life, the nymph of Guyalna chlorogena builds, from a vertical well, which is the result of a verticalization process from a deep horizontal gallery, a clay turret 20 to $40 \mathrm{~cm}$ high which appears as a regulating device of the physico-chemical conditions inside the burrow. The construction of the turret is remarkable for its finish. The nymph maintains, repairs and rebuilds it if necessary. It opens and closes it under certain circumstances. Before moulting, the nymph comes out at the top, opening it according to a set protocol and time schedule, using its chitins' forelegs. The burrow is associated in a commensal relationship with arborescent Fabaceae species (of the Tachigali genus) through its nutrition mode, the suction of the elaborated sap in fine roots, close to the meristems.
\end{abstract}

Keywords: behavior, building, burrow, cicada, clay, forelegs' hooked end, molt, nymph, regulating device, turret, urine, well, commensalism

\section{Introduction}

Over a large area of the Amazon rainforest, extending from the Brazilian state of Para to the south-east of Peru (Madre de Dios department), passing through Surinam, one can observe curious clay buildings, having the shape of turrets, or chimneys (Figure 1a), with a height of 20 to $40 \mathrm{~cm}$ and an internal diameter at their base of about $2 \mathrm{~cm}$ (Figure 1b). The turret surmounts a vertical well (Figure 1c) with a depth of up to about a meter, i.e. the thickness of the fertile soil layer. The surface inside the turret is perfectly smooth (Figure 1d).

Each turret is the visible part of the pupal burrow of the cicada Guyalna chlorogena (Figure 2), or Fidicina chlorogena, according to its old taxon [1]. Endoscopic exploration made it possible to observe the nymph in the well (Figure 3) and to verify that each burrow is occupied by a single nymph, male or female [2], which builds its turret (between December and February) a few months before moulting into a winged imago, and reproducing (between late July and early September).

Our research was conducted at the Museu da Amazônia (MUSA) ${ }^{1}$, installed in the Botanical Garden of Manaus, on the edge of the Adolfo Ducke Reserve (Figure 4), in the northern area of Manaus, State of Amazonas, Brazil, in an area of about twenty hectares, around $59^{\circ} 56^{\prime} 21.5^{\prime \prime} \mathrm{WO}$ and $3^{\circ} 0^{\prime} 19.7^{\prime}$ S. A total of more than 250 burrows were observed, between November 2013 and September 2019. About 60 buildings

\footnotetext{
${ }^{1}$ Av. Margarita, 6305 - Cidade de Deus, Manaus - AM, 69088-265, Brésil.
} 

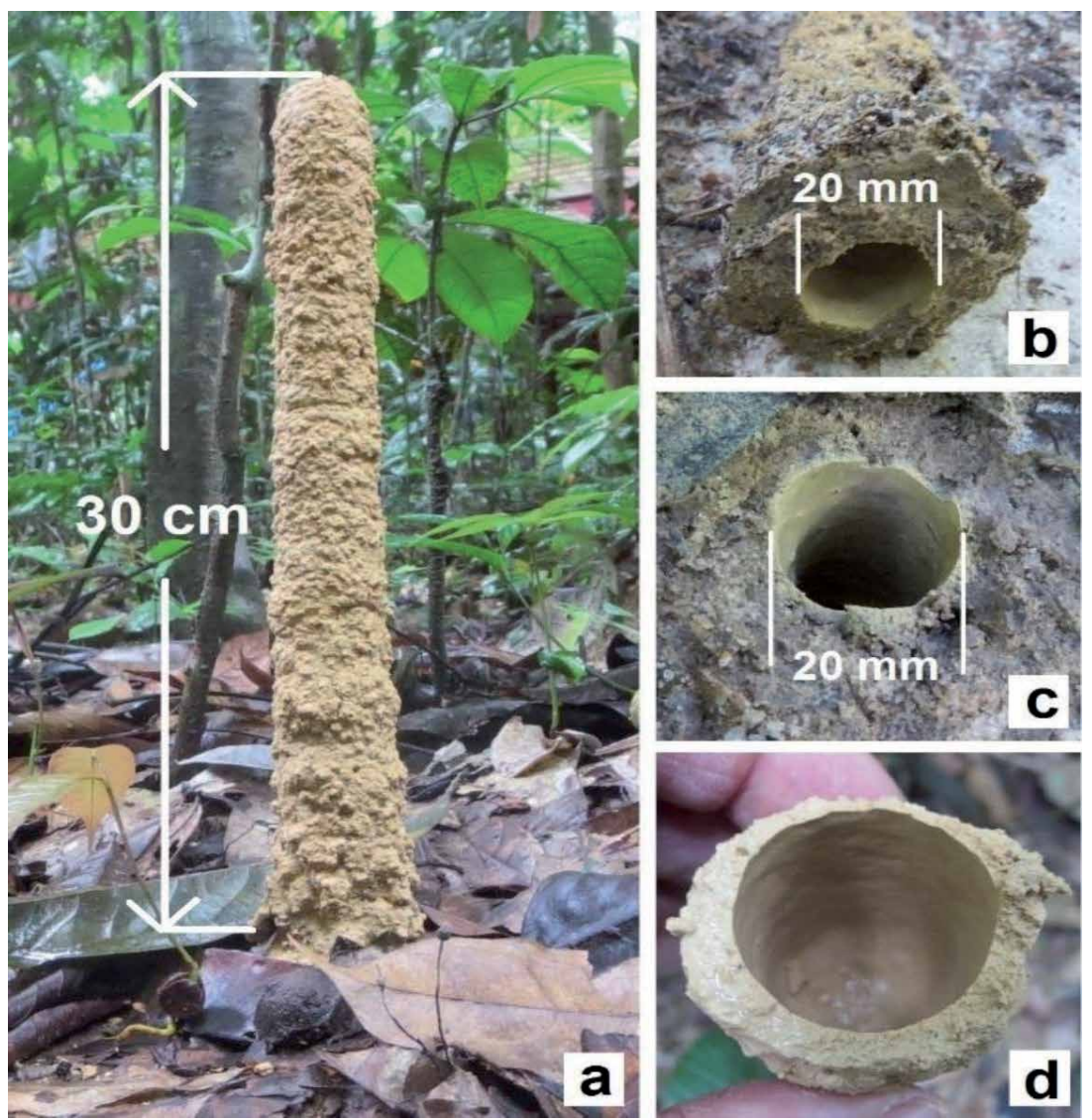

Figure 1.

(a) View of a turret. (b) Turret removed. (c) Entrance to the well. (d) Inner surface of the summit.

were monitored daily. The observations made up to 2016 have been published [2]. The results obtained subsequently will be the subject of a second publication (Béguin, Gama and Ribamar Mesquita Ferreira, to be published).

\section{Construction of the turret}

The turret is constructed from the well, which has a double curvature near the ground surface (Figure 5a) and a single one in depth (Figure 5b), as revealed by cement casts.

From the moment it appears, the night-time growth of the turret is very rapid; 3-4 cm per night. The nymph uses a special technique that allows it to lengthen the top without ever opening it, so without exposing itself to predators. It softens the top with a mixture of its urine and clay drawn from the bottom of the well and loaded on its clypeus; then it pushes everything upwards [2].

When the nymph encounters obstacles, it continues its construction obliquely, but restores the verticality as soon as possible, manifesting an acute perception of gravity (Figure 6).

The monitoring of many buildings, after the construction of the turret and until the nymph abandons its burrow before moulting into a winged imago, has made it possible to identify various maintenance and rehabilitation behaviours, as well as to make hypothesis about the role of the turret. 
The Nymph Architect of the Cicada Guyalna chlorogena: Behaviours and Ecosystem DOI: http://dx.doi.org/10.5772/intechopen.94106

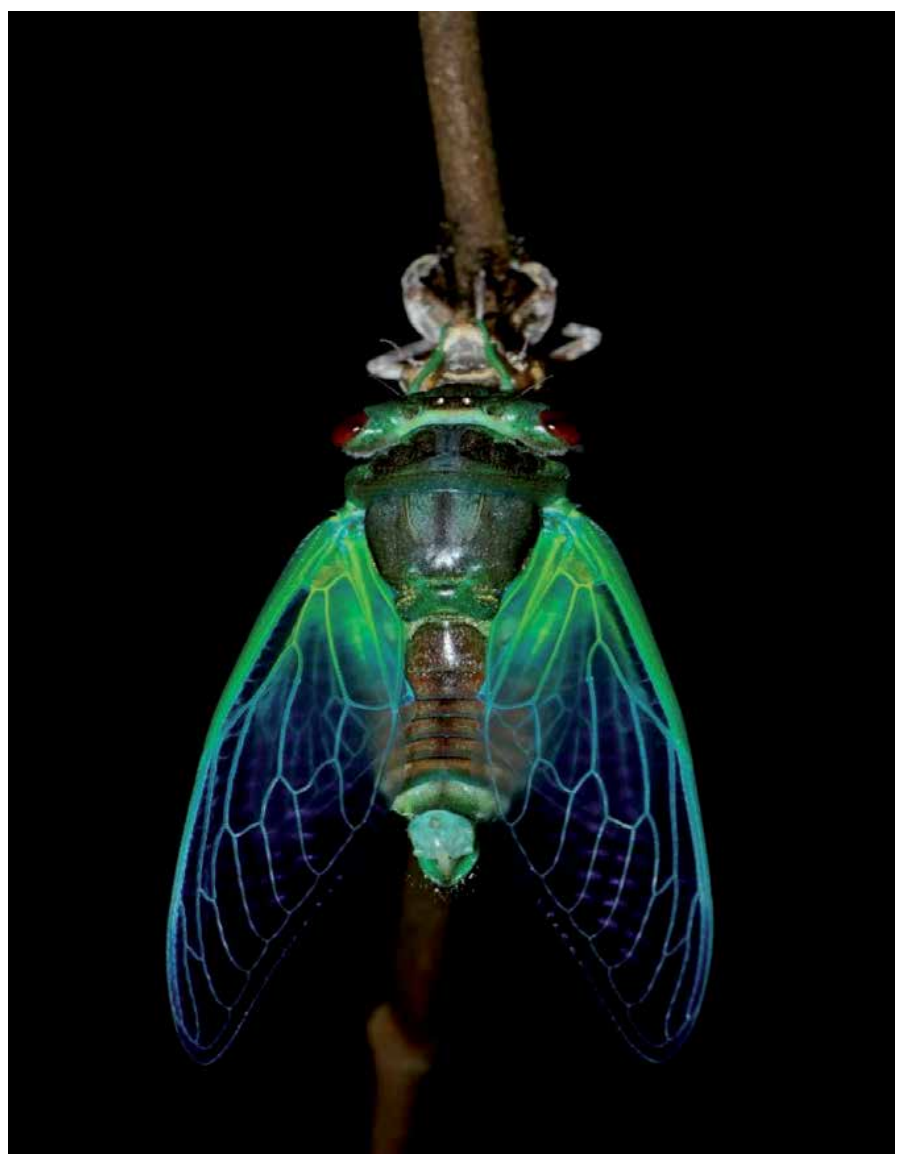

Figure 2.

The cicada Guyalna chlorogena; young imago after moulting (photography Vanessa Gama).

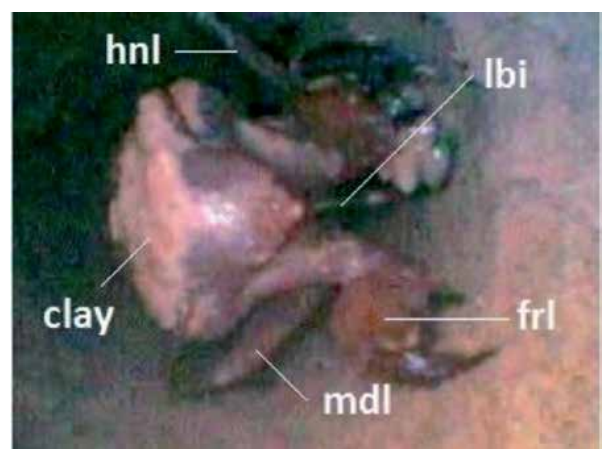

Figure 3.

Endoscopic images of the nymph in its well; lbi: Labium, frl: Foreleg, mdl: Middle leg, hnl: Hind leg. Clay can be seen on the head of the nymph.

\section{Maintenance and rehabilitation}

If a turret is damaged, the nymph fixes it without delay. It performs an occlusion with a mixture of clay and urine (Figure 7) if its turret was severed, before restoring the initial height (see below). Maintaining the sealing of the building appears to be a priority for the nymph; if one experimentally fractures a turret and then re-stack 


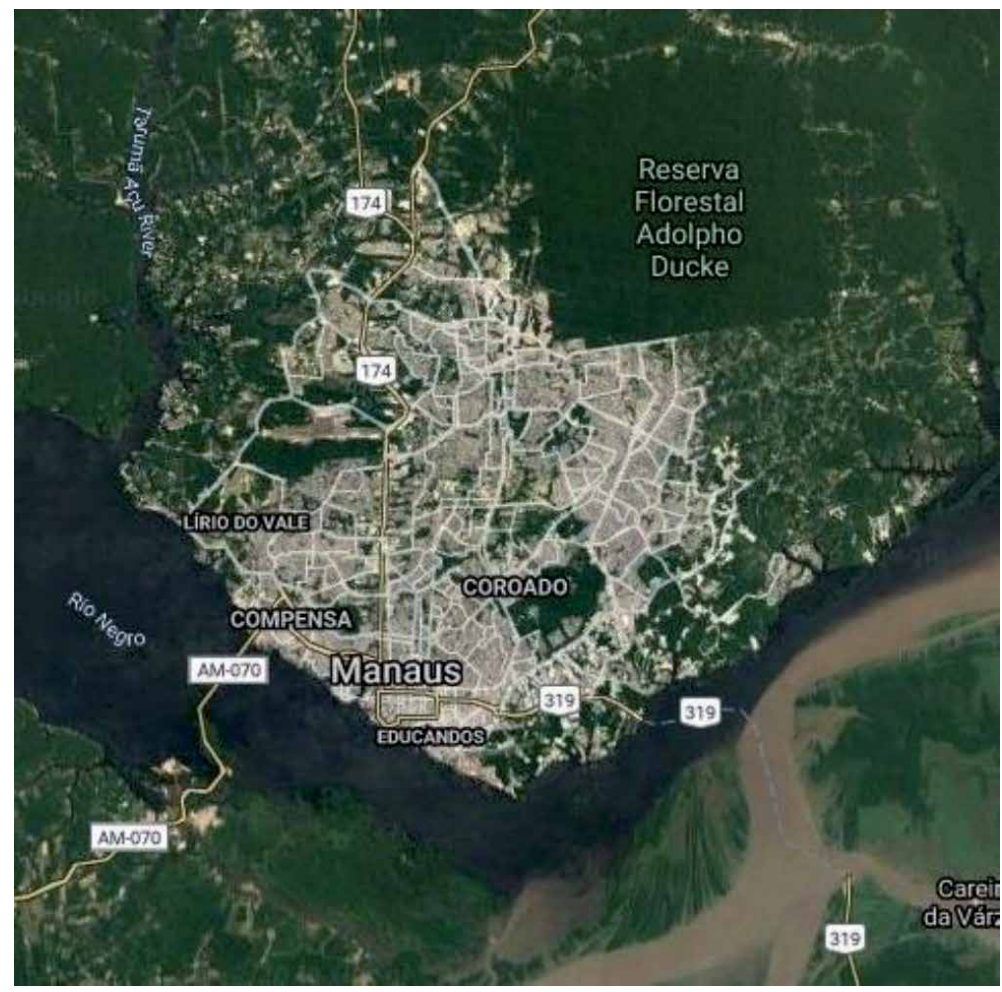

Figure 4.

Manaus and the Adolfo Ducke Reserve. Google Maps https://www.google.ch/maps/place/Reserva+Florestal+ Adolpho+Ducke/@-2.8580657,-60.0242213,71,452 m/data =!3 m1!1e3!4 m5!3 m4!1sox926c1ec4d40d48b7:0x897d $42 e 519777 e b 2 ! 8 m 2 ! 3 d-2.9633439 ! 4 d-59.9228331$.
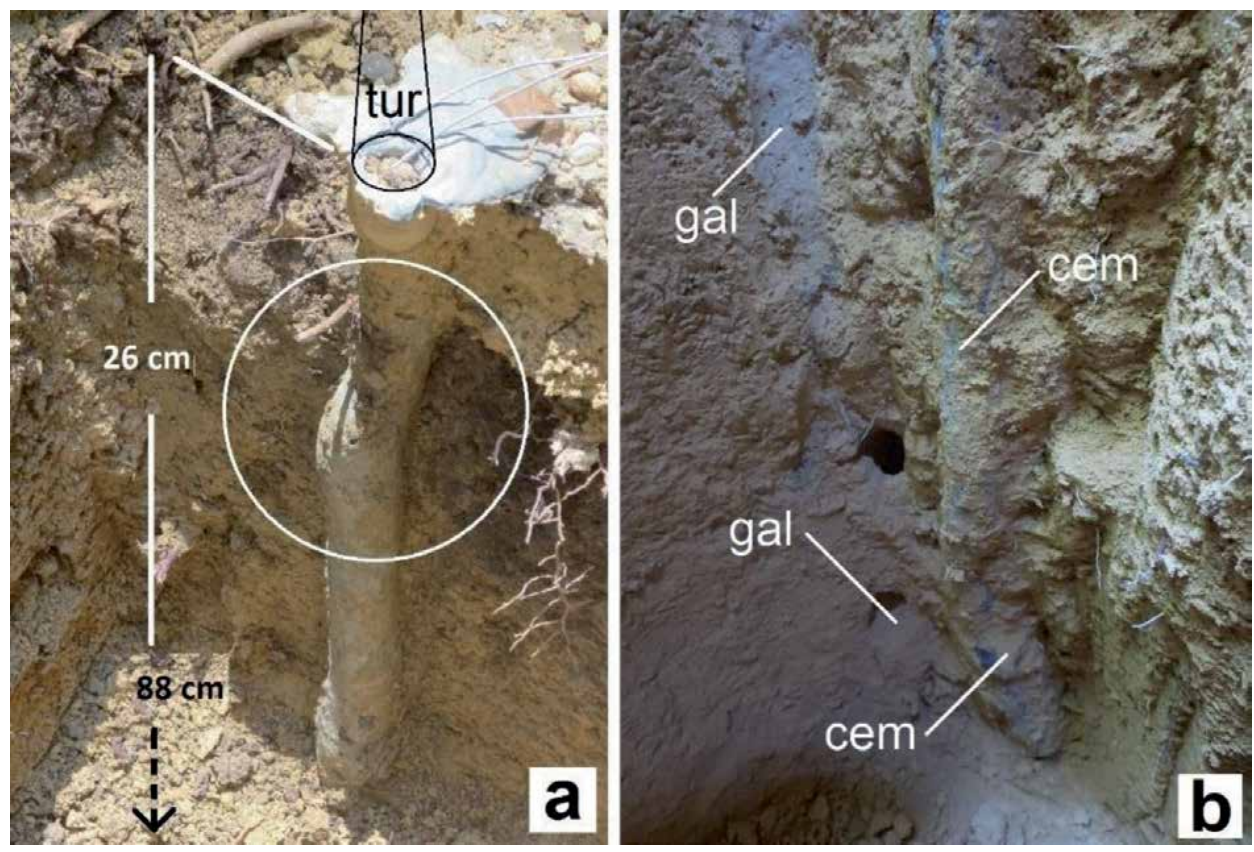

Figure 5.

(a) concrete moulding inside an $88 \mathrm{~cm}$ deep well, $26 \mathrm{~cm}$ of which have been excavated. The curvature (circle), just below the ground level, is clearly visible. The turret is traced (tur). (b) oblique galleries (gal) at the base of the well, oblique as well, up to a curvature at $15 \mathrm{~cm}$ from the bottom; cem: Cement moulding. 
The Nymph Architect of the Cicada Guyalna chlorogena: Behaviours and Ecosystem DOI: http://dx.doi.org/10.5772/intechopen.94106

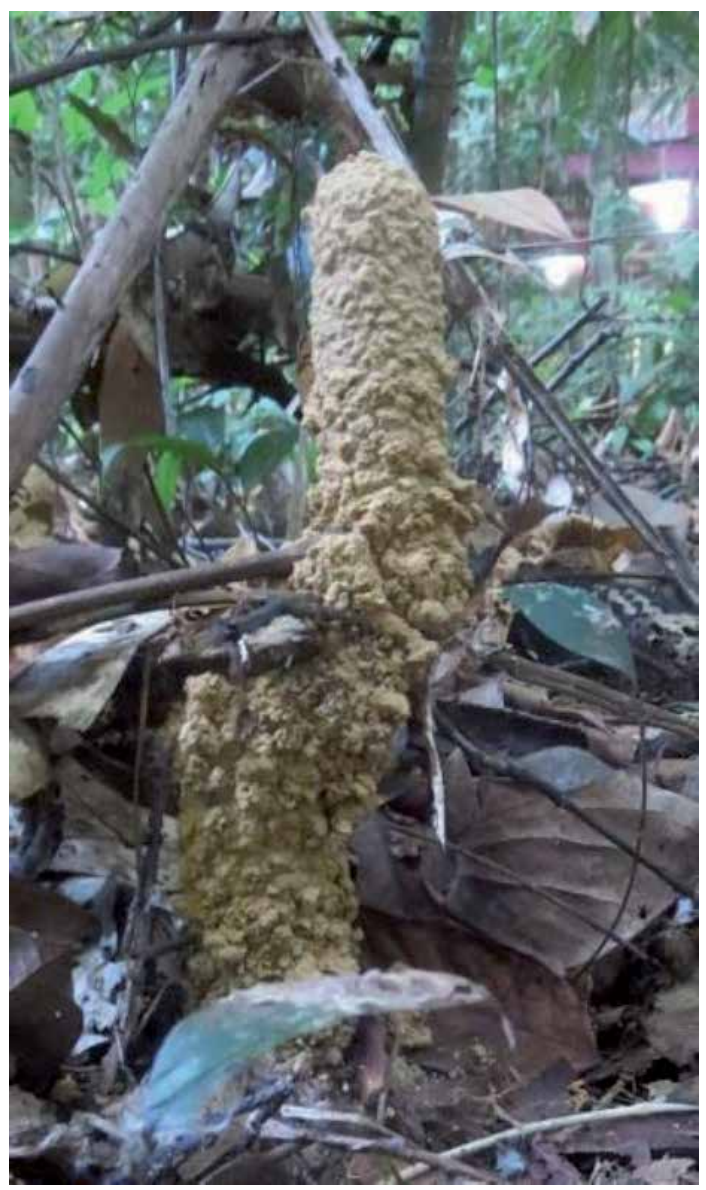

Figure 6.

A pile of stems and leaves became an obstacle during the construction of this turret; the nymph avoided it by raising the turret obliquely, but it reestablished the verticality as soon as the obstacle was passed.

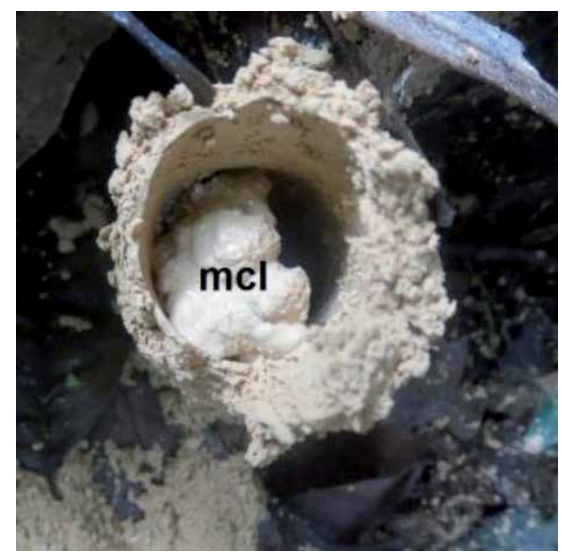

Figure 7.

Occlusion in progress by the nymph with clay mixed with its urine (mcl) after its turret has been severed.

pieces over the base, the nymph plugs the interstices (Figure 8) by injecting soggy clay with its urine.

When a turret has been destroyed, or even when it tips over (Figure 9), the nymph rebuilds it completely. 

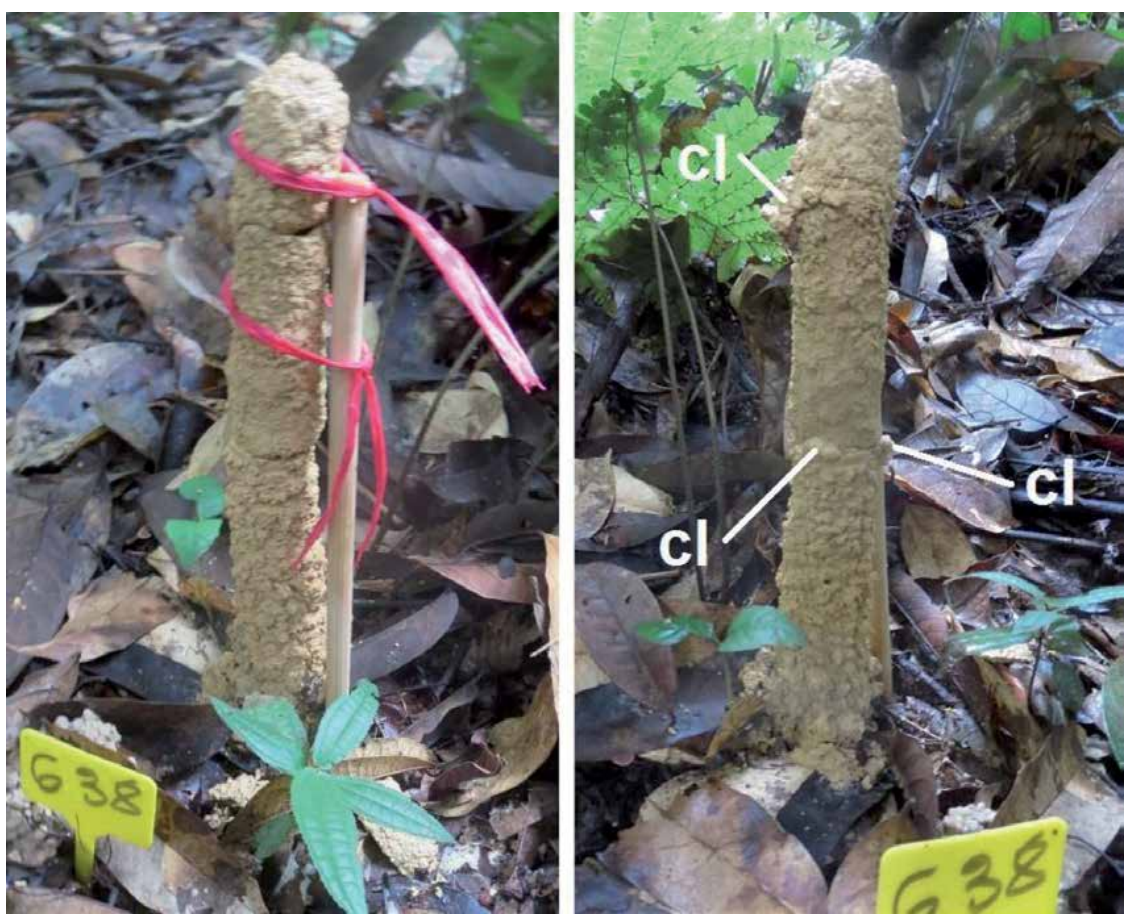

Figure 8.

Sealing of interstices by injection of soaked clay $(\mathrm{cl})$.

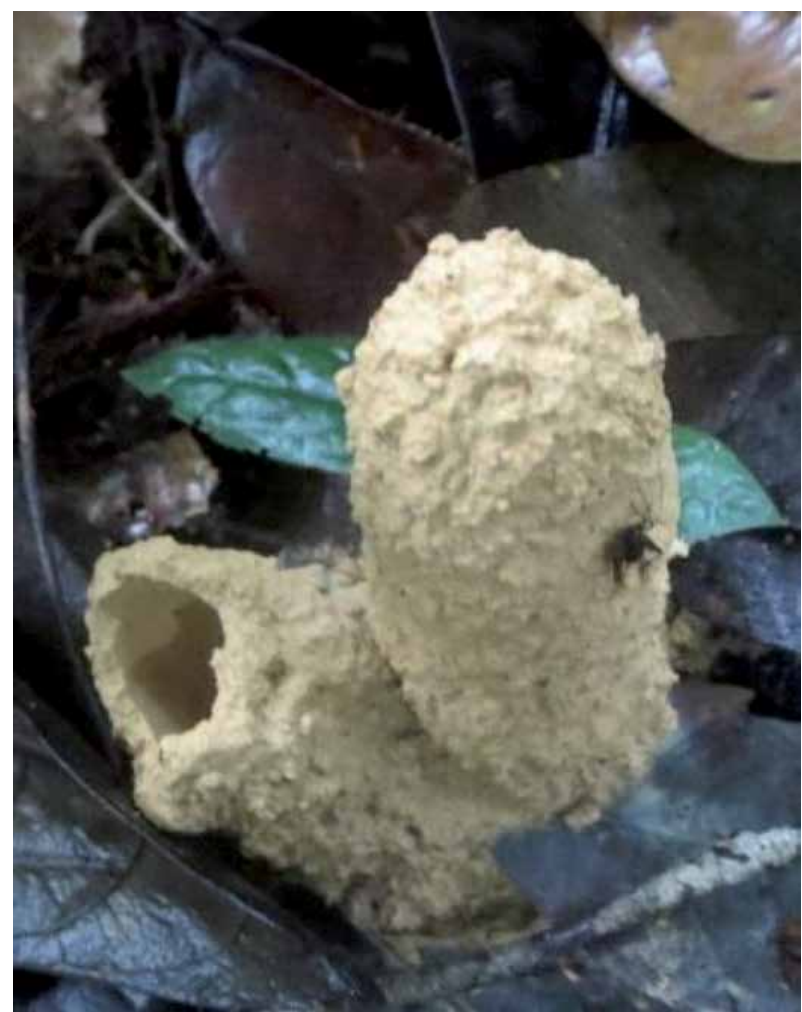

Figure 9.

Reconstruction of the turret after failover. 
The experiment was carried out [2] to section a turret experimentally and to continuously monitor the repair; the nymph clogs the section and restores the original height within days using the same lengthening technique as when growing, and at the same rate of about $3 \mathrm{~cm}$ per night. The result of this experiment gives credence to the idea of the requirement of a minimum height necessary to maintain appropriate parameters (humidity, pressure, and $\mathrm{O}_{2}$ and $\mathrm{CO}_{2}$ levels) for the survival of the nymph in its burrow.

\section{Spontaneous changes in height}

A spontaneous increase in turret height to a value held constant thereafter has occasionally been observed, reflecting an increase in the minimum required height discussed above.

A spontaneous decrease in the height of the turret can also be observed, resulting from building a summit inside the turret, below the existing one, which, probably because it is no longer in contact with the moisture inside the burrow, dries up and crumbles (Figure 10), revealing the new top. After a few days, the parts above the new summit have completely disappeared and the result is a turret with reduced height.

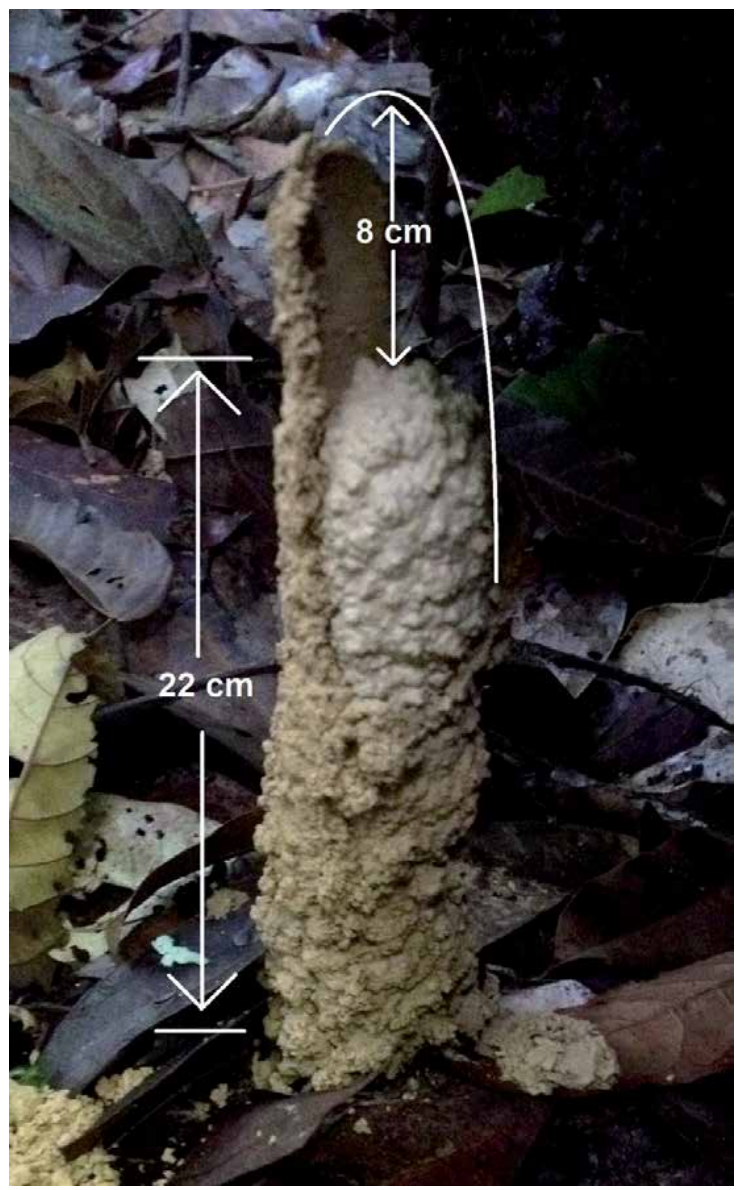

Figure 10.

Spontaneous reduction in the height of the turret by construction of an internal top and drying out of the old one. The white line represents the old wall of the upper part of the turret. 
The reasons leading to the performance of this operation by the nymph remain to be elucidated because, during experiments of artificial lengthening of a turret by transplanting fragments from another one, a nymph does not manifest a requirement of a maximum height; in the long run, it accommodates a higher turret than the one it has built itself; it does not practice the technique which has just been described, nor any other. On the other hand, it ensures the sealing of the modified turret by plugging with soaked clay the interstices between the base of its turret and the implants received, in the same way as described above (Figure 8).

\section{Moving the turret}

This action of the nymph is rarely observed, but its peculiarity makes it worthy of presentation. A turret emerges near another which later tips over and lies down on the ground. The communication with the well is either completely closed or in the process of being sealed with clay (Figure 11a). The hypothesis can be put forward (Figure 11b) that the new turret is built over a deviation made by the nymph from the exit of its well.

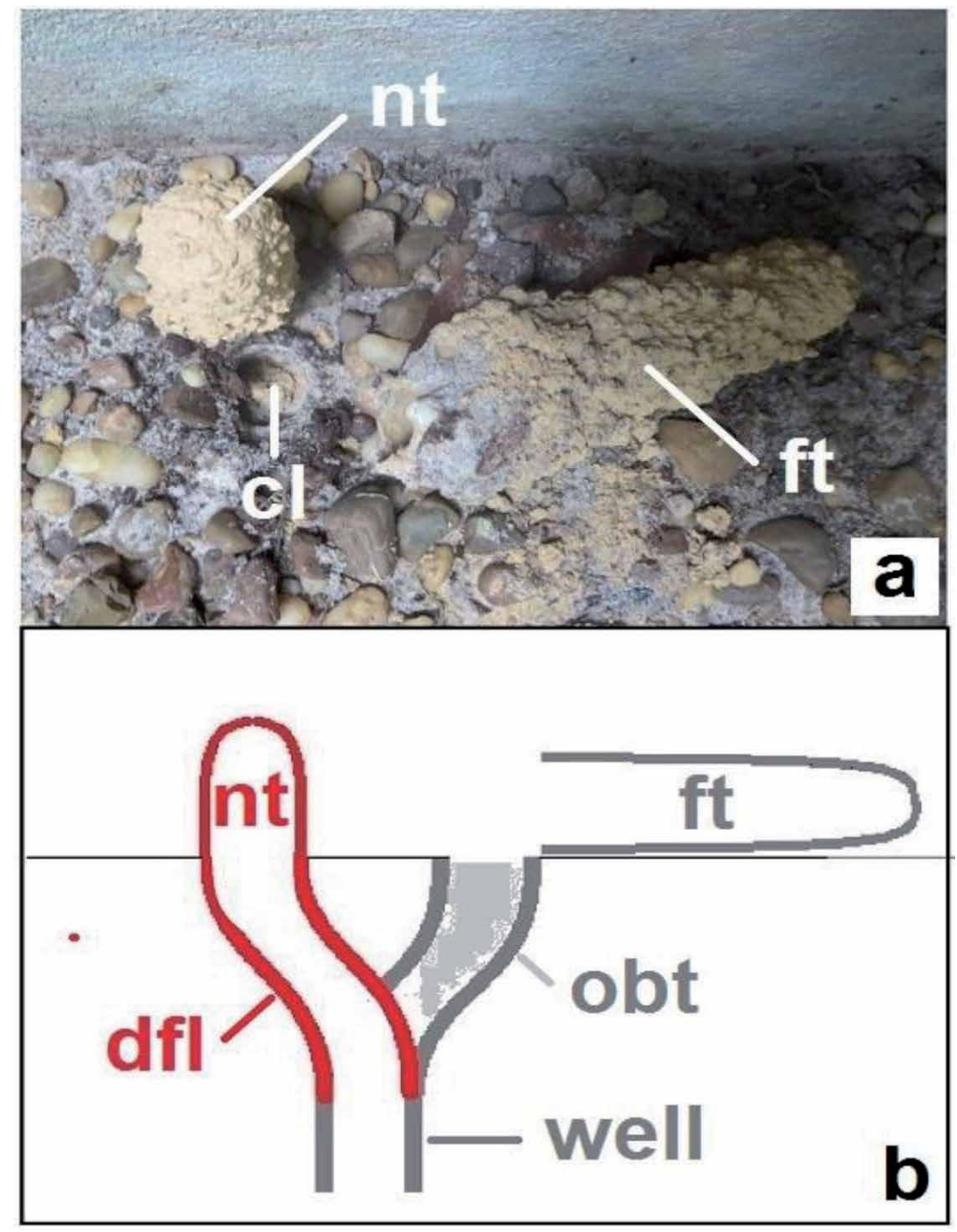

Figure 11.

(a) Spontaneous reconstruction of a new turret. (b) Diagram of deviation by the nymph of the outlet of the well: obt: Filling with clay of the old outlet, dfl: Deviation made for a new outlet, ft: Former turret, nt: New turret. 
The Nymph Architect of the Cicada Guyalna chlorogena: Behaviours and Ecosystem DOI: $h$ ttp://dx.doi.org/10.5772/intechopen.94106

\section{Role of the turret}

A correlation has been established [2] and confirmed later (Béguin, Gama and Ribamar Mesquita Ferreira, to be published) between the appearance of intense rains and the simultaneous temporary opening of the turrets at their top. A succession of 3 episodes, between July 19 and 23, 2016, turned out to be particularly significant; many openings (Figure 12) appeared, which were then closed when the precipitation stopped (Figure 13). The openings vary in shape, from a small hole about $5 \mathrm{~mm}$ in diameter (Figure 12a) to a larger opening where the contour of the clypeus, eyes or anterior part of the pronotum (Figure 12b) can frequently
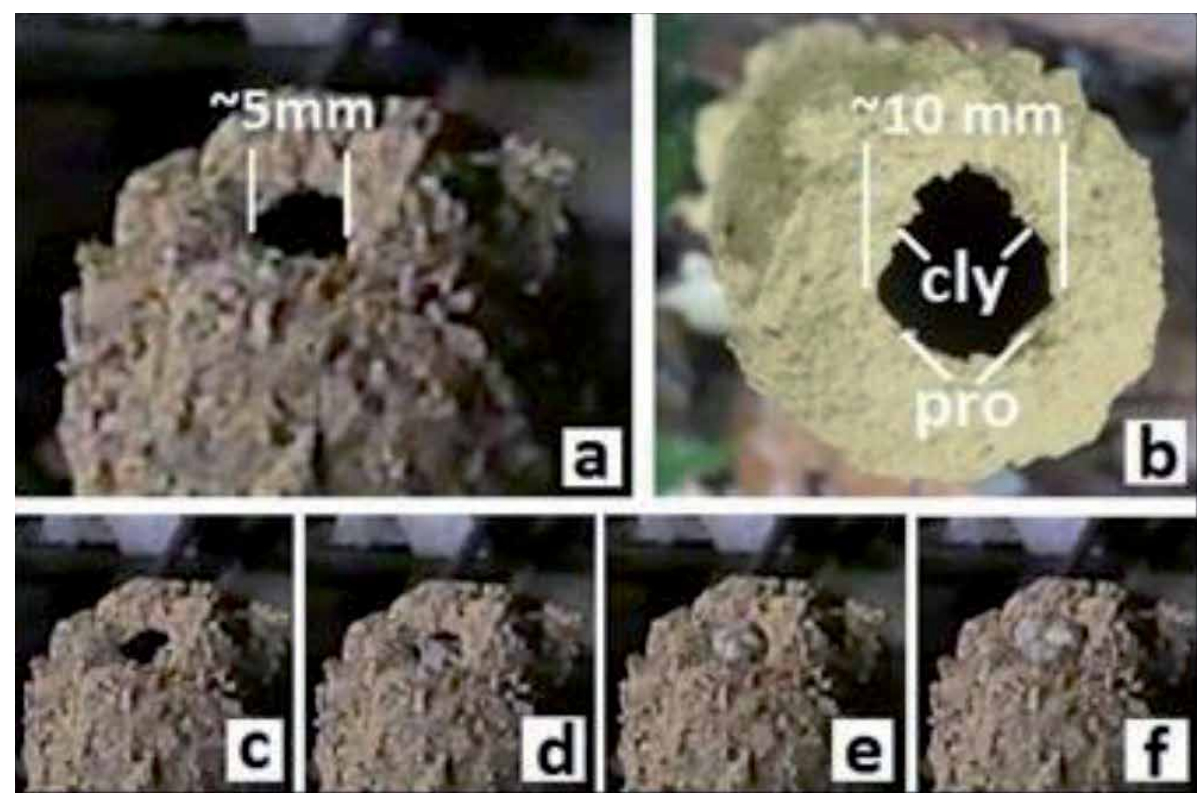

Figure 12.

(a) Circular orifice resulting from a slight pressure of the mass of soggy clay against the wall of the summit. (b) Orifice with imprint of clypeus (cly) and pronotum (pro) covered with soggy clay. (c-f) occlusion of the orifice shown in Figure 12a after end of rainfall, by injection of soggy clay (captured images with the automatic camera Brinno timelapseTLC20o Pro).

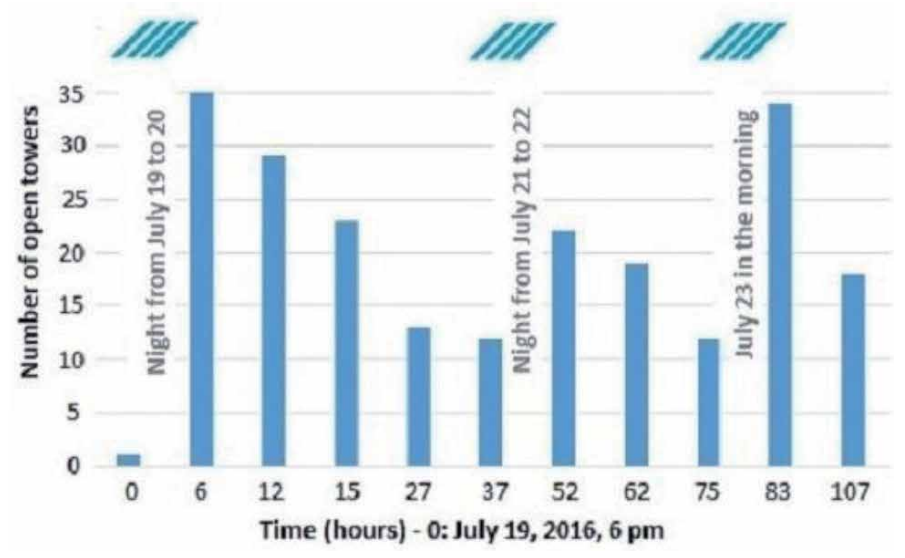

Figure 13.

Correlation between intense rainfalls (////) and temporary and simultaneous opening of 35 turrets, during 3 episodes, between July 19 and 23, 2016. 
be observed, as a consequence of the liquefaction of the clay from the top wall by applying these parts covered with clay wet with urine. After the rain has stopped, the nymph closes these openings by injecting moist clay (Figure 12c-f).

When rainfalls are heavy, the soil becomes very wet and the moisture level in the burrow increases dramatically. In addition, rainwater in some places passes through a rapidly decomposing litter [3]. We can therefore imagine that the level of $\mathrm{CO}_{2}$ also increases. The temporary opening of the turret would therefore lower these rates, as well as the concomitant increase in pressure. The turret would thus appear as a regulating device of the physical-chemical conditions prevailing inside the burrow.

\section{Opening of the turret, exit and moulting}

From the end of July begins the period of moults. The nymphs emerge from their turret after having opened it at the top, moult into a winged imago, on their own turret (Figure 14a, b) or on neighbouring vegetation (Figure 14c), then fly away for a brief adult life, during which males and females will mate.

We have identified three opening modes (Béguin, Gama and Ribamar Mesquita Ferreira, to be published), each accomplished using the hook-shaped end of the forelegs. It is therefore important to note that the opening behaviours of the top of the turret before moulting are totally distinct from those described above for the temporary opening of the top during intense rainfalls, and which are practiced by liquefaction of the top with soaked clay, without ever involving the front legs. For the opening
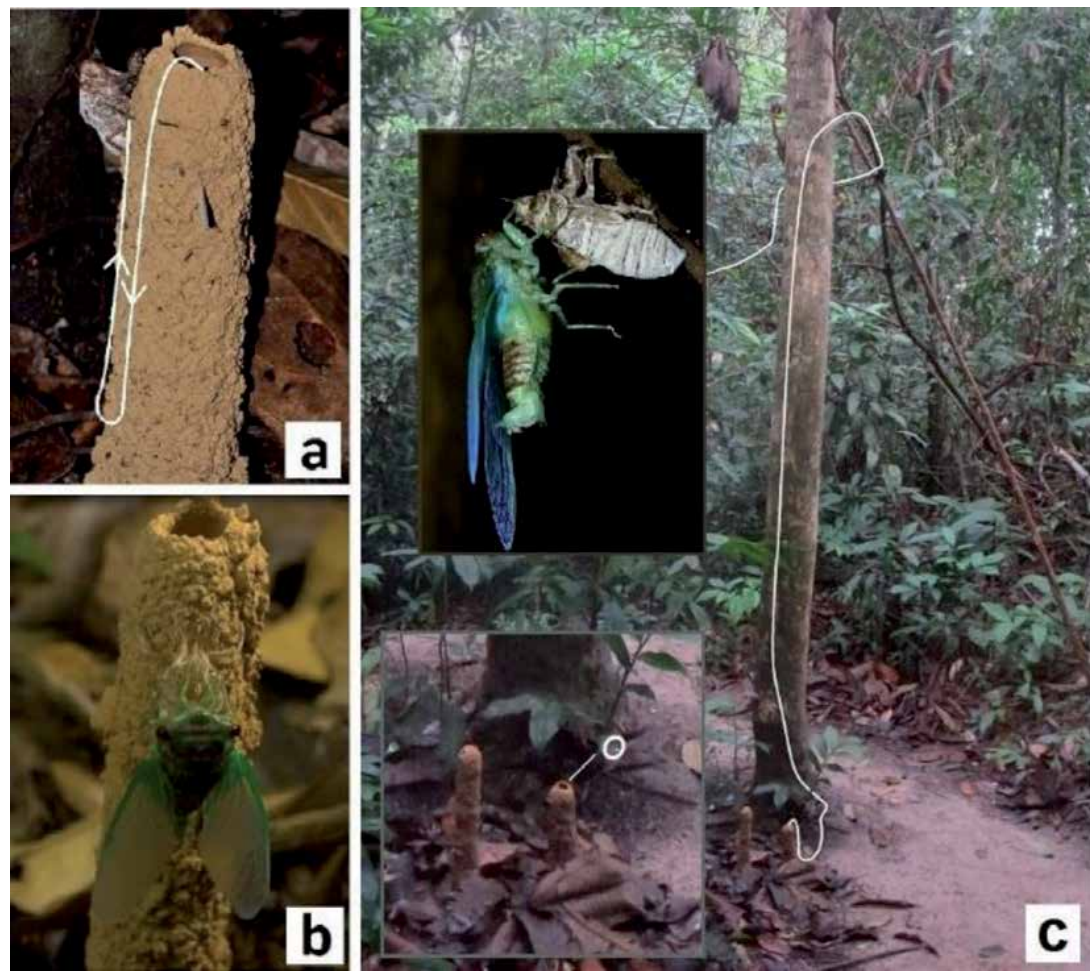

Figure 14 .

(a) Exuvia attesting for the moulting of a nymph on its own building (photos Vanessa Gama). The white line represents the trip of the nymph between the opening at the top of the turret and the place where the moult took place. Note the rotation made by the nymph at the bottom of its turret. (b) imago from another nymph drying its wings after moulting on its own building. (c) Migration of a nymph from its turret to the branch where it has moulted. o: Opened turret. 
The Nymph Architect of the Cicada Guyalna chlorogena: Behaviours and Ecosystem DOI: http://dx.doi.org/10.5772/intechopen.94106
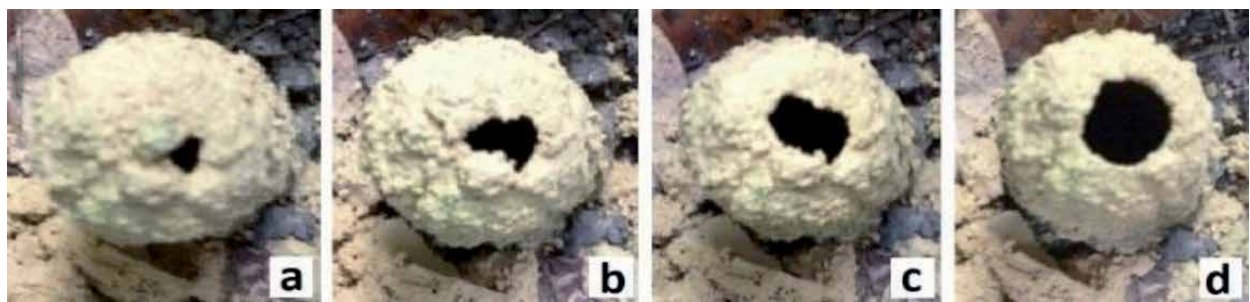

Figure 15.

Four stages of opening a turret. (a) Beginning of the draft work (6:21 a.m.). (b) draft in progress (9:58 a.m.). (c) Draft completed (10:43 a.m.). (d) Equalisation of the border completed (11:35 a.m.). Observation on 19.08.2019.
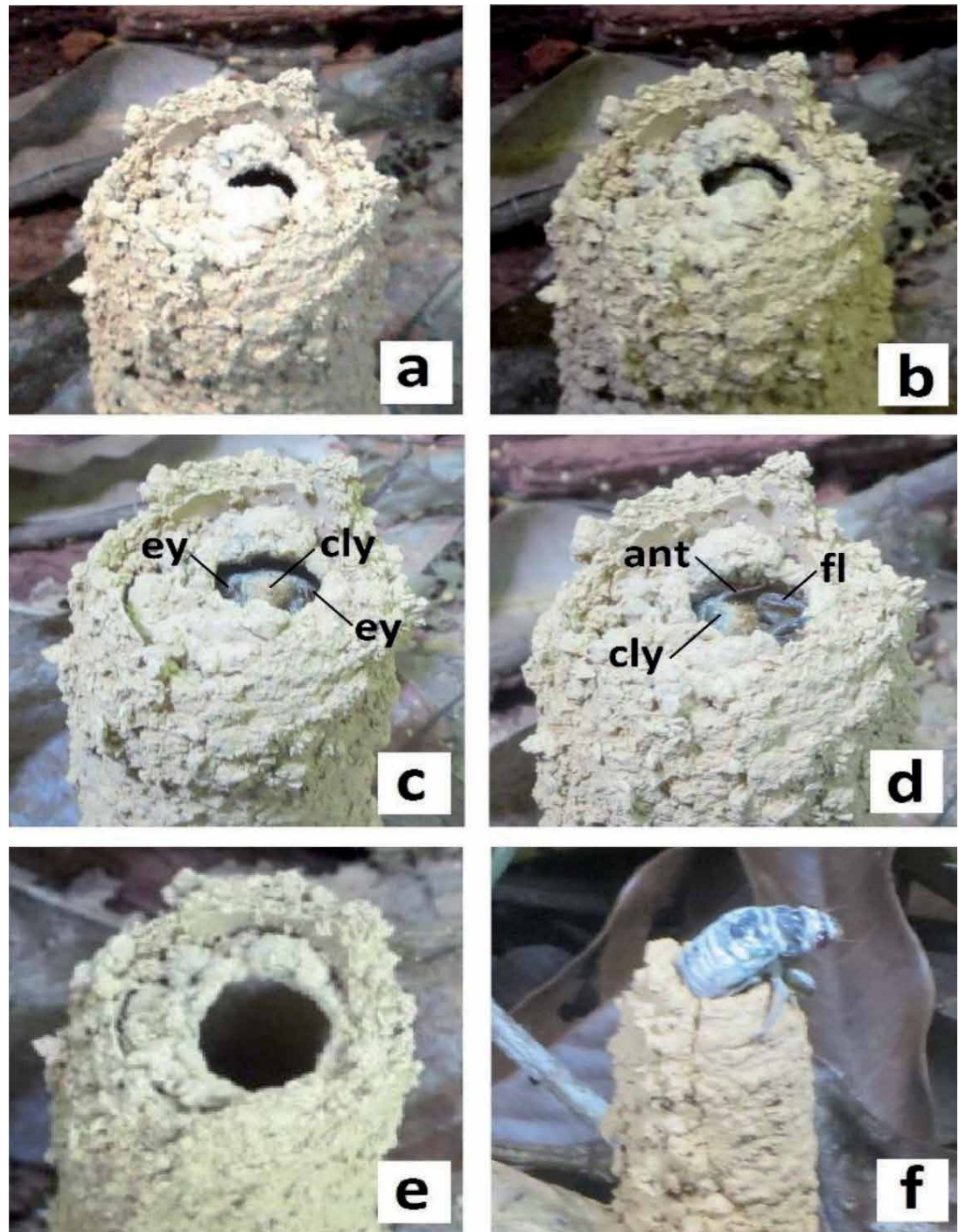

Figure 16.

(a) 6:59 a.m.: Opening resulting from the enlargement of a small perforation, such as that shown on

Figure 15a. (b) 7:03 a.m.: Continuation of the enlargement; the nymph is discernible. (c) 8:44 a.m.: The enlargement is finished; the nymph appears, on can distinguish its eyes (ey) and its clypeus (cly).

(d) 9:38 a.m.: The nymph, gripped at the opening, is equalising the edge by scratching with the hook-shaped end of its forelegs ( $f l$ ); one distinguishes also an antenna (ant) and the clypeus (cly). (e) 10:05 a.m.: The equalisation of the edge is complete, the opening is perfectly circular and the nymph withdrew. $(f)$ 6:08 p.m.: The nymph leaves its building. Observation on 01.09.2019. 

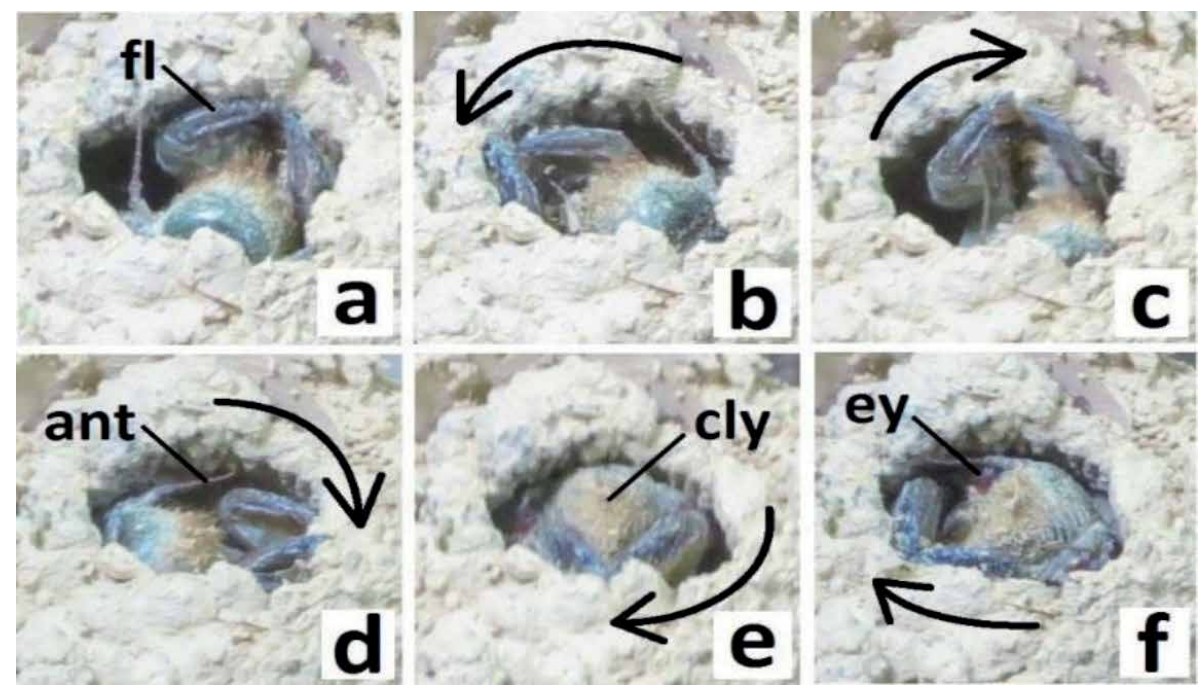

Figure 17.

Six snapshots illustrating the nymph's rotations when equalising the edge of the opening with its forelegs. (a) 9:15 a.m. (b) 9:35 a.m. (c) 9:37 a.m. (d) 9:38 a.m. (e) 9:41 a.m. (f) 9:45 a.m.. Arrows represent the rotations from the previous snapshot; ant: Antenna, fl: Foreleg, cly: Clypeus. Observation on 01.09.2019.

\begin{tabular}{ll}
\hline Moulting period & $\begin{array}{l}\text { Late July - early September (maximum frequency } \\
\text { during the first week of August) }\end{array}$ \\
\hline $\begin{array}{l}\text { First perforation for the opening of the top of the } \\
\text { turret }\end{array}$ & Before 7:00 a.m. \\
\hline $\begin{array}{l}\text { End of opening (before equalising the edge) - } \\
\text { program } A\end{array}$ & Between 8:30 and 11:00 a.m. \\
\hline Equalisation of the edge completed - program $A$ & Between 10:00 and 12:00 a.m. \\
\hline $\begin{array}{l}\text { Exit of the nymph through the opening at the top } \\
\text { of its turret }\end{array}$ & Between 6:00 and 6:10 p.m. \\
\hline Immobilisation before moulting & Between 6:45 and 7:00 p.m. \\
\hline Downtime to moult & About 2 hours \\
\hline Downtime after moulting (drying the wings) & About 5 hours \\
\hline Taking flight & After 2 a.m. \\
\hline
\end{tabular}

Table 1.

Work schedule of the nymph during its moult to imago.

of its turret, the nymph therefore has a register of behaviours specific to the function performed.

The most common method of opening before moulting (named program A) is worth explaining here. It takes place in two phases: a draft of the opening (Figure 15a-c), then an equalisation until the opening is remarkably circular (Figure 15d).

Continuous monitoring makes it possible to describe in detail the behaviour of the nymph which creates the roughing by enlarging (Figure 16a-c) the initial perforation (Figure 15a) by a scraping carried out with the chitins' end of its forelegs, up to obtain an elongated opening with irregular edges (Figure 16c). Working from the inside, the nymph is almost invisible. When the roughing is complete, the nymph appears (Figure 16c) and undertakes the work of equalisation, which is accomplished by scraping the edge with the chitins' end of its forelegs 
(fl) also (Figure 16d), at the same time as it performs rotations. During this phase, the nymph's head is clearly visible, and one can easily recognise its antennae (ant), front legs (fl) and clypeus (cly). Once the equalisation is complete (Figure 16e), the nymph disappears until its exit (Figure 16f) which takes place with a remarkable precision between 6 p.m. and 6:10 p.m. (local time). The 6 pictures in Figure 17 illustrate the rotations that the nymph performs at the same time as it levels the edge of the opening with its forelegs.

The monitoring of two individuals, from the exit of the nymph from its turret, until the flight of the imago, made possible to establish a detailed time schedule (Table 1).

\section{Ecosystem}

Each time an edifice of G. chlorogena was discovered on the site we studied, an arborescent Fabaceae of the genus Tachigali has been identified in the vicinity (Béguin, Gama and Ribamar Mesquita Ferreira, to be published). The building of the nymph is usually the much farther from the tree the larger this one is. This fact is not surprising when one takes into account: $1^{\circ}$ ) that a cicada nymph can plant its tiny rostrum [4] to suck up the elaborate sap on which it feeds, only in radicular extremities of comparable size, close to the meristems; $2^{\circ}$ ) that the root ends of trees, in the Amazon rainforest where the layer of fertile soil is very small (of the order of 1 meter), instead of plunging in depth, spread out [5], forming a "root disc" whose radius is all the greater as the size of the tree is large.

During the 2 years 2018 and 2019, we identified 132 buildings of G. chlorogena distributed among 14 trees of the genus Tachigali; 11 from the species chrysophyllum and 3 from the species venusta. We therefore measured, for each building, the distance separating it from the tree ${ }^{2}$, as well as the diameter of the trunk of this latter ${ }^{3}$.

The results were reported on two graphs relating the diameter of a tree with: a) the distances to all the buildings associated with it (Figure 18a); b) the average distance to them (Figure 18b). The trend lines calculated with Excel by the smallest squares indicate clearly, on each of the graphs, a proportionality between the diameter of the trunk of the tree and its distance to a building of G. chlorogena, thereby providing a logical-mathematical support to the association between the nymphs of G. chlorogena and these Fabaceae ${ }^{4}$. G. chlorogena apparently being the main, if not the only, beneficiary of this relationship, we admit that this is a case of commensalism [6].

The graph with plotting of all distances (Figure 18a) shows that part of the buildings are located near the trunk. We will be re-examining our statistics to determine if the location of the buildings is related to the Tachigali species (chrysophyllum or venusta). One thing is obvious; nymph buildings (i.e. nymphs feeding) close to the trunk involve root ramifications down to the level of the meristems from the proximal roots, particularly the buttresses. We recently discovered, at another place in the Adolfo Ducke reserve, a Tachigali station of a species (yet to be identified) which is neither chrysophyllum nor venusta, with nymph buildings (the species to which their hosts belong has not yet been confirmed as $G$. chlorogena) close to the trunk. In Santarém (Pará, Brazil), edifices of Fidicina chlorogena, a taxon since identified with G. chlorogena [1] have been described [7] near the base of the trunk; the

\footnotetext{
${ }^{2}$ More precisely of the estimated center of its implantation surface.

${ }^{3}$ If the trunk is connected to a buttress by its base, its diameter is measured above.

${ }^{4}$ It is due to this situation to meet, at the Botanical Garden of Manaus for example, buildings in a built area near the forest. This is the case with the one shown in Figure 11.
} 

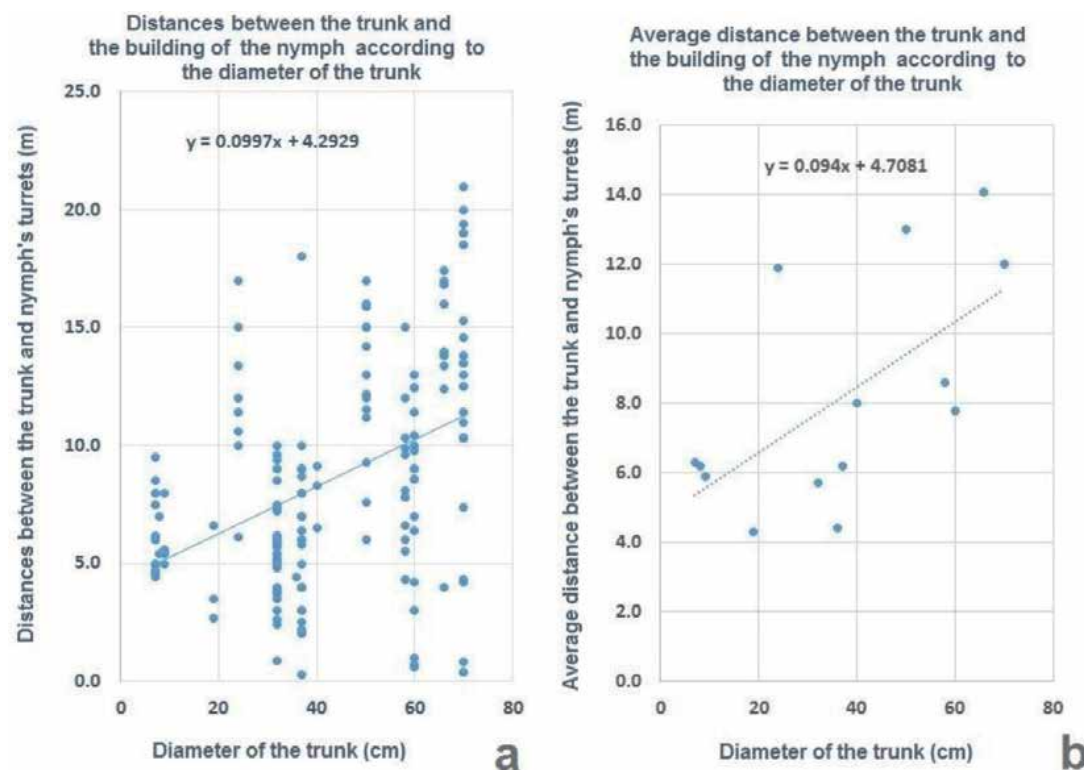

Figure 18.

Relationship between Tachigali's trunk diameters and distances to G. chlorogena's edifices. (a) Plotting distances to all the buildings associated with a given tree. (b) Plotting the average distance to the buildings associated with a given tree.

species name of the tree was not reported. The same disposition was observed [8] for Orialella aerizulae (Boulard), which could also feed on Tachigali sp. as well as possibly on Tabebuia sp. This aspect of the dependency relationship between cicadas and their foster trees has to be explored in more detail.

\section{Reproductive cycle}

The nymphs spend several years underground, moving to reach the fine roots (less than $2 \mathrm{~mm}$ ) from which they suck, with their rostrum, the elaborate sap on which they feed (see above). They move forward by digging galleries with their forelegs, throwing the excavated material behind them.

On can consider [9] the beginning of the reproductive cycle at the time of mating (Figure 19a), after the nymph has emerged from its burrow and moulted into an imago (Figure 19h, i). The winged adults, stimulated by singing males, mate in trees. Then the females search for a stem in which they will plant their ovipositor several times [10] to deposit their eggs under the bark (Figure 19b). The larvae hatch on the twigs and then fall to the ground (Figure 19c) where they sink (Figure 19d). No one has yet observed their behaviour during this first phase of underground life. No one either knows the duration of the underground life until the exit to moult into a winged imago; it is estimated at several years.

From excavations undertaken after moulding with cement (see above), which revealed an inclination of the deepest zone of the well, as well as in its vicinity traces of oblique galleries of intermediate inclinations (Figure 5b), one can envisage the upwards digging of a vertical well from a deep horizontal gallery (Figure 19e) by digging successive oblique galleries more and more inclined (Figure 19f).

The digging of deep horizontal galleries giving access to fine roots that the nymphs can use to feed themselves (see above), is consistent with the presence of a 


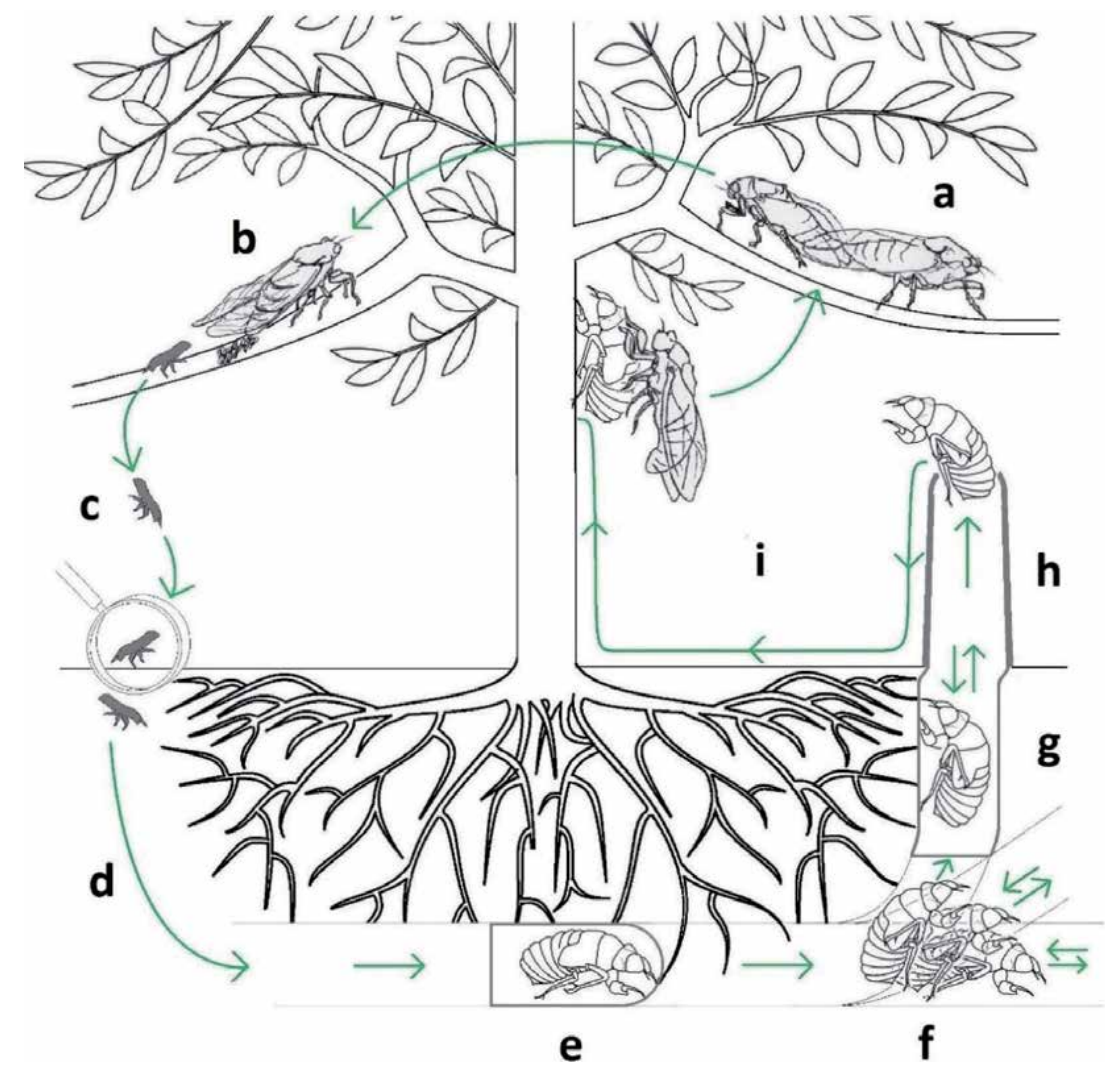

Figure 19.

Life cycle of G. chlorogena. (a) Mating. (b) Lay eggs. (c) After hatching, the tiny larvae ( $2 \mathrm{~mm}$ ) fall to the ground. (d) They bury themselves in the ground. (e) The nymph digs its gallery at the same time as it feeds on the sap of the roots. $(f)$ As it moves forward and back, the nymph changes direction until it is vertically oriented. $(g)$ The nymph digs the well which is a vertical gallery. ( $h$ ) the turret is built from the well. (i) The nymph comes out of the turret to turn into an imago.

significant biomass of fine roots in the deep soil layer of the Amazon rainforest, as recent research has shown [11]. The digging of successive oblique galleries more and more inclined implies a capacity of the nymph to back up into an already dug burrow. Such a capacity is observed when one surprises, by the withdrawal of its turret, a nymph near the exit of its well. It can also be observed in experiments where the nymph is placed in a glass tube.

\section{Role of urine}

The key role mentioned above of urine in G. chlorogena, has been underlined in connection with the construction of the turret and the various maintenance activities described; in experiments where the turret was replaced by a glass tube [2], the observation was made of the rise of the urine soaked mass of clay that the nymph loads on its head. The role of urine, in European species of cicadas, was demonstrated [12] for digging underground burrows; abdominal gutters redirect urine to the anterior part of the body and allow the nymph to use it to soften the soil with its forelegs. In the case of $G$. chlorogena, urine is used to soften the clay [2]. Urine from cicadas also contains mucin, a glycoprotein, which strengthens the walls of burrows after drying [13]. 

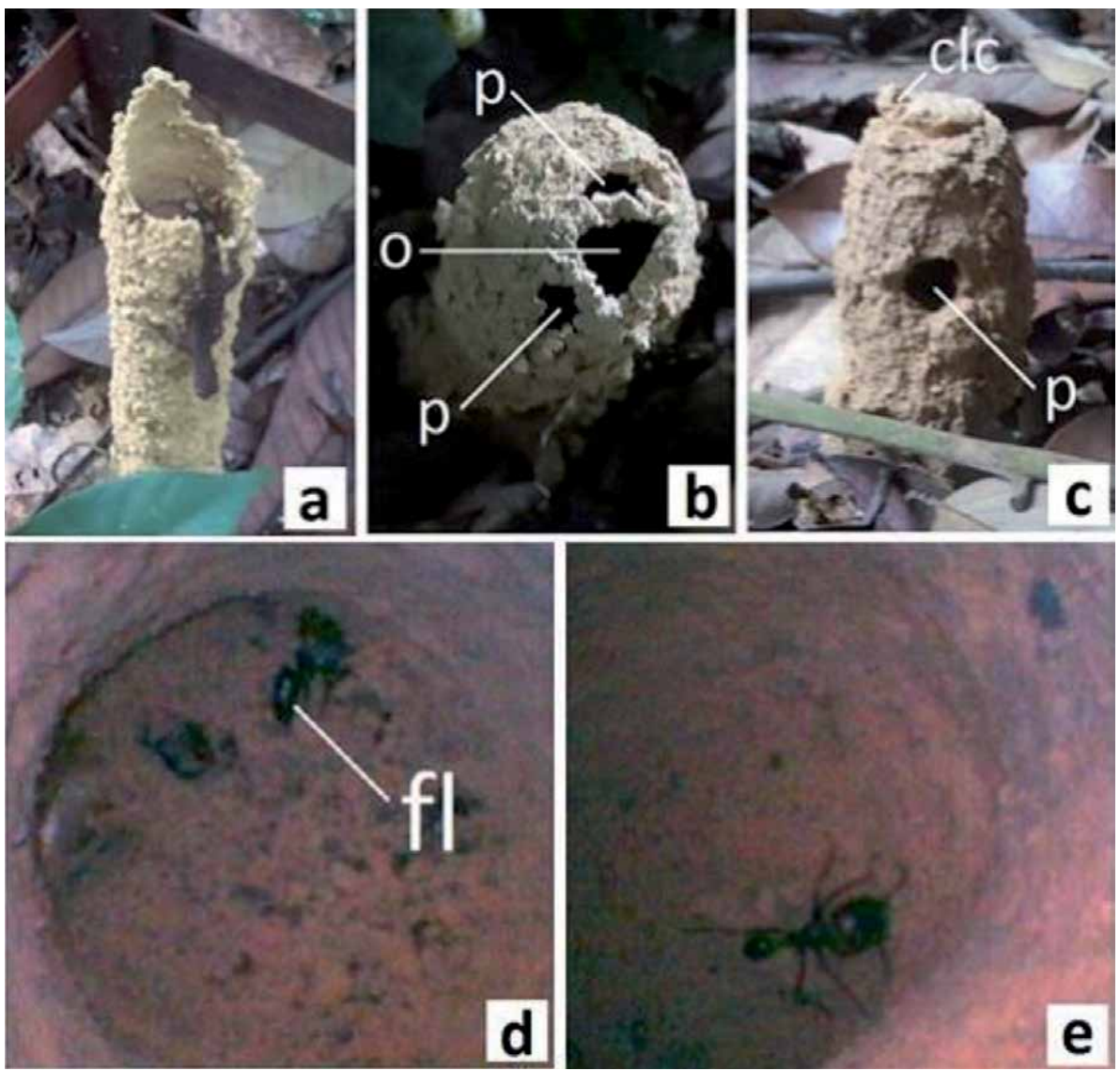

Figure 20.

(a) Lacertilian on an open turret. (b) Perforations ( $p$ ) following passage of Legion ants on an open turret after an episode of heavy rainfall; o: Opening in the shape of its clypeus practiced by the nymph in response to rainfall. ( $c$ ) Perforations ( $p$ ) following a passage of army ants on a turret that the nymph closed with a clay occlusion (clc) after the cessation of precipitation. (d) Bottom of a well after passage of ants; the remainder of the hook of the end of a front leg ( $f l)$ is visible. (e) Ant in the bottom of a well.

\section{Predators}

Different reptiles, such as Lacertilians (Figure 20a), can be supposed as predators when a nymph opens or leaves its building. However ants, known by the vernacular name of Legion ants, or Formigas de coreção according to the local name, are the most dangerous (Figure 20b-e). They invade (Figure 20e) towers which have been opened (Figure 20b) following heavy rainfalls (see above: the role of the turret), and even manage to perforate the walls (Figure 20c). Entering a building, they devour the host, leaving only the chitins' organs, such as the hook-shaped ends of the forelegs (Figure 20d).

\section{Conclusions}

This article has presented the activities of the nymph of the cicada G. chlorogena during its last year of larval life, in relation to its burrow, the visible part of which is a clay turret built from a well whose depth can reach one meter. The clay with which the turret is built probably comes from the base of the well, from the volcanic 
bedrock on which the fertile soil rests. The nymph mixes this clay with its urine and transfers the mixture to its forelegs and then to its clypeus, through its abdominal and thoracic "gutters" [9]. It can then climb this mortar to the surface and build its turret. By replacing a turret with a glass tube, it was possible [2] to observe the rise of a nymph with a mass of soggy clay on its clypeus.

The existence of a one meter deep well, dug vertically from the bottom thanks to a process of verticalization of a horizontal gallery (Figure 19f), validates the representation of the digging by the nymph of paths below the root base of the tree with which it is associated, in order to find appropriate roots to introduce its rostrum and feed on elaborated sap [10], which is confirmed, as mentioned above, by the recent demonstration [11] of a significant biomass of fine roots in the deep soil layer of the Amazon rainforest. To dig, the nymph shovels with its chitins' forelegs, tears off earthy fragments which it impales on the bristles of its clypeus and deposits behind it [12]. It thus advances in a short gallery, which it opens in front of it and closes behind (Figure 19e). One question remains to be clarified; at what moment, and consecutively to which signals (external and/or endogenous), does the nymph begin its process of verticalization.

The well therefore has the status of a gallery, from which it is however distinguished by the fact that, after closing off the bottom, it is not closed as the nymph digs it, vertically and from bottom to top, until reaching the ground surface. The turret, for its part, is an additional device. Maintained sealed by the nymph (Figure 8), it appears to be devoted to maintaining appropriate conditions for the survival of the nymph in its burrow (see above; Role of the turret). As already mentioned, a minimum height of the turret is required by the nymph, which repairs or rebuilds it if necessary.

A behaviour, considered as motor coordination, involves [14, 15] stimuli (external and/or endogenous), as well as a recognition mechanism which is a neuronal structure. The observed richness of the nymph's behaviours is therefore concomitant with an important perceptual component in its nerve system. The realisation of similar tasks (opening the top of the turret, for example) by different behaviours according to the circumstance, can be considered as falling under an elementary cognitive system. The execution, without learning, of complex motor sequences, such as the opening of the top of the turret before moulting, according to a straight defined time schedule, is the result of highly perfected innate programming.

The dependence of G. chlorogena on arboreal Fabaceae of the genus Tachigali is a very important aspect of its reproductive cycle. In this regard, an important question arises: do the very young larvae which have just burrowed (Figure 19b), have the same mode of nutrition? If so, are they also related to Tachigali to find fine root ends near the soil surface?

Many questions still remain open about cicadas, insects as popular as their biology is poorly understood.

\section{Acknowledgements}

I wish to express my gratitude to Prof. Ennio Candotti, who entrusted me with this research and constantly supported me, to Vanessa Gamma and José Ribamar Mesquita Ferreira for technical assistance, to Dr. Nállarett Dávila for the determination of the Tachigali, and to Olga Béguin for critical reading. The work was supported by the Conselho Nacional de Desenvolvimento Científico e Tecnológico (CNpq), grants no 385612/2014-1 et no 310012/2015-5, by the Fundação de Amparo à Pesquisa do Estado do Amazonas (FAPEAM), grant no 462/2018, and by Museu da Amazônia (MUSA), 69060-060 Manaus, AM, Brasil. 


\section{Author details}

Claude François Béguin

Museu da Amazônia (MUSA), 69060-060, Manaus, AM, Brasil

*Address all correspondence to: claude.beguin@gmail.com;

claudefb@museudaamazonia.org.br

\section{IntechOpen}

(C) 2020 The Author(s). Licensee IntechOpen. This chapter is distributed under the terms of the Creative Commons Attribution License (http://creativecommons.org/licenses/ by/3.0), which permits unrestricted use, distribution, and reproduction in any medium, provided the original work is properly cited. (cc) BY 


\section{References}

[1] Sanborn A F (2013) Catalogue of the Cicadoidea (Hemiptera:

Auchenorrhyncha). Elsevier, London, p. 207

[2] Béguin C F (2017) An Architect Cicada in Brazilian Rainforest: Guyalna chlorogena (Walker). Neotropical Entomology 46 (2): 159-168 (DOI 10.1007/s13744-016-0464-0)

[3] Melo L (2014) Personal communication. Museu da Amazônia, 69060-060 Manaus, Brazil.

[4] Myers J G (1928) The morphology of the Cicadidae (Homoptera).

Proceedings of the Zoological Society of London 98:365-472

[5] Coco Magnanville (2012) La forêt amazonienne : Une forêt tropicale humide. http://cocomagnanville.overblog.com/ accessed 2020-08-25

[6] Breton S and Carrière A (2018) Notions sur la biodiversité. http:// www.biodiversite-poitou-charentes. org/Relations-entre-les-especes.html / accessed 2020-08-25

[7] Ginzberger A (1934) Die bauten der larve der singzikade Fidicina chlorogena Wlk. Sitzungsberichte der Akad. d. Wissenschaften. Wien, math.-natunv. 143:91-94 A (1934). https://archive. org/details/sbaww_143_0091-0094/ mode/2up / accessed 2020-08-31

[8] Wood Z (2020) Personal communication. University of California, Santa Barbara, CA 93106, USA

[9] Ibanez M (2003) Les Cigales, Cycles de vie, caractéristiques et symbolique. Invertébrés continentaux des Pays de la Loire. Gretia, Hérouville-Saint-Clair, France, pp 208-212

[10] Guyard A (2010) Les cigales du sud de la France. http://baladesnaturalistes. hautetfort.com/apps/search/?s=cigales / accessed 2020-08-25

[11] Magrini L (2020) Estoque de carbono subterrâneo da Floresta Amazônica é maior do que se pensava, UNICAMP. https://www.unicamp.br/ unicamp/noticias/2020/08/11/estoquede-carbono-subterraneo-da-florestaamazonica-e-maior-do-que-se-pensava/ accessed 2020-08-25

[12] Boulard M (1988) Biologie et comportement des cigales de France. Insectes 69:7-13

[13] Boulard M (1991) L'urine des Homoptères, un matériau utilisé ou recyclé de façons étonnantes. Insectes $80: 2-4$

[14] Eibl-Eibesfeldt I (1972) Ethologie, biologie du comportement. Naturalia et Biologia Editions scientifiques, pp 15-44

[15] Tinbergen N (1980) Leétude de l'instinct. Petite bibliothèque Payot, Paris, pp 21-23 

Section 2

\section{Human Culture and History}





\title{
Shipibo Conibo and Chilean Diaguita Visual Art: Cognitive Technologies, Shamanism and Long-Distance Cultural Linkages
}

\author{
Paola González Carvajal
}

\begin{abstract}
Pre-Columbian art in all its varied forms offers rich terrain for furthering our insights into the cultural and symbolic lives of Amerindian peoples. This paper studies decorative patterns of Diaguita origin which present a visual logic characterized by the use of complex symmetries, illusory optical vibration, endless variability stemming from simple geometric forms, horror vacui, and gradual structural complication, among other techniques. The features described, the association of this visual art to an animal alter ego (jaguar), and the evidence of hallucinogen use together suggest a cultural link with specific ethnographic (Shipibo-Conibo) and archeological (Mojocoya) visual art. In this case, we are dealing not with a notation system but with visual "technologies of enchantment" (sensu Gell 1998) that are used to produce decorative patterns with social agency that captivate viewers with their visual artifice-the non-mimetic appearance of animation. In 2015, a large cemetery was excavated at the Diaguita site of El Olivar. The graves therein belong to an early Diaguita cultural period, during which the Diaguitas created a techno-stylistic material identity, expressed in visual languages rooted not only in the Andean world, but in ancient cultural traditions of the eastern lowlands of Bolivia and the Peruvian Amazon.
\end{abstract}

Keywords: Chilean Diaguita culture, Shipibo-Conibo culture, South American shamanic art, cultural symmetry, long-distance cultural linkages, indigenous art concept

\section{Introduction}

Structural analysis of Diaguita visual art [1] revealed certain decorative patterns (the predominance of abstract designs, the heavy use of symmetry, and the presence of spotted feline representations). The designs' minimal units and symmetrical structure have been shown to be sensitive to issues of group identity and cultural interaction processes [2], in which each culture selects and appropriates a limited number of symmetries that form a specific universe of socially recognized forms, and only these are approved for use.

Pre-Inca Diaguita art displays a series of traits that allow it to be considered representative of a specific South American shamanic art tradition. Notable among these traits are the association of the designs with an alter ego (jaguar or spotted feline), the 
practice of hallucinogenic consumption, and the development of non-figurative visual art featuring complex symmetry. The image of a spotted feline (jaguar) has been recorded from the Diaguita II phase on duck-shaped pitchers, zoomorphic serving bowls (Figure 1), and spatulas used for the consumption of hallucinogenic substances.

Evidence that Diaguita culture engaged in this practice includes tubes and spatulas, as well as the scallop shells that held the psychoactive substance itself (Figure 2).

The Diaguita culture developed in the semi-arid region of what is now Northern Chile, between the Elqui and Choapa rivers. The Diaguita were skilful potters who developed an abstract, symmetrical visual art style that was tremendously complex and beautiful. The variety, extraordinary complexity, and intricate composition of Diaguita ceramic designs comprise one of the most stunning visual universes of the pre-Colombian Americas (Figure 3). Two phases can be clearly identified in the development of this pre-Colombian people-a pre-Inca period (900-1470 A.D.) and a period of Diaguita-Inca contact (1470-1536 A.D.) —each with its own characteristic style of visual art.

Before Inca contact, the Diaguita were a peasant society with little social stratification, in which the family served as the basic social unit. The Diaguita of this phase practised small-scale farming and adapted to their environment without altering it significantly. They had a disperse settlement pattern, which suggests that they managed space through kinship-based residential units that occupied the transverse

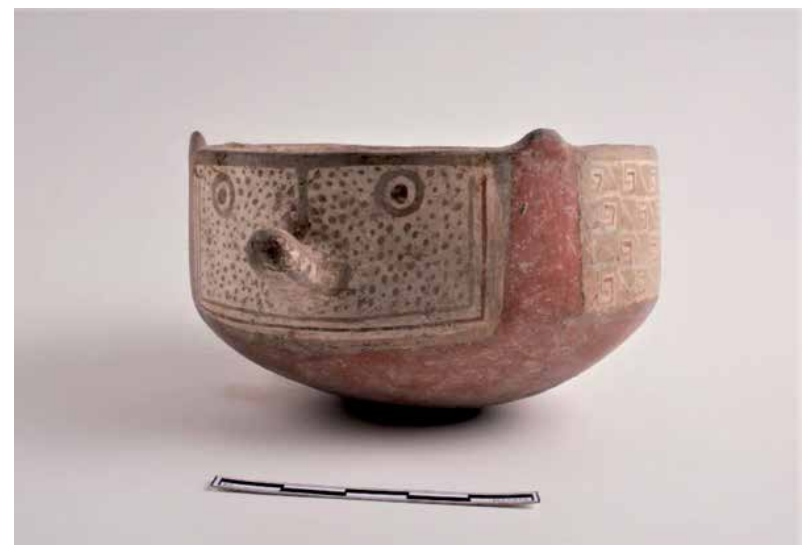

Figure 1.

Diaguita zoomorphic serving bowl (spotted feline). Grave 62, El Olivar site.

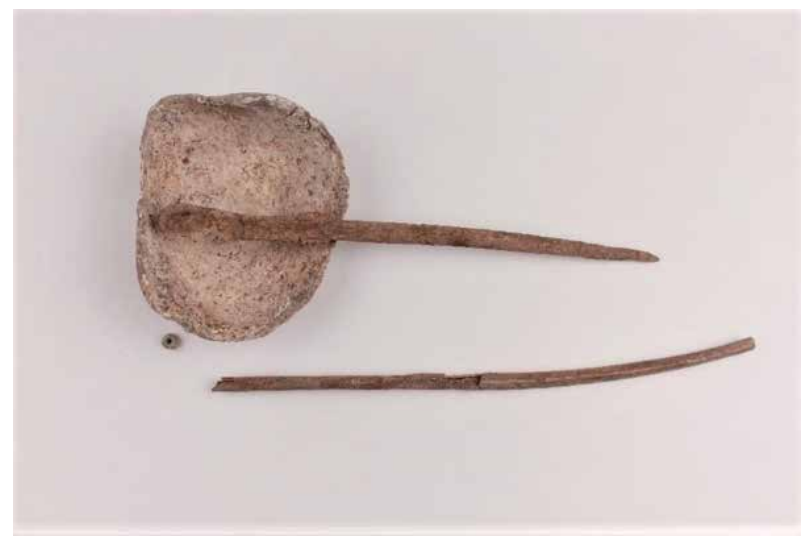

Figure 2.

Spatula, tube, and shell used for consuming psychoactive substances. Grave 99, El Olivar site. 


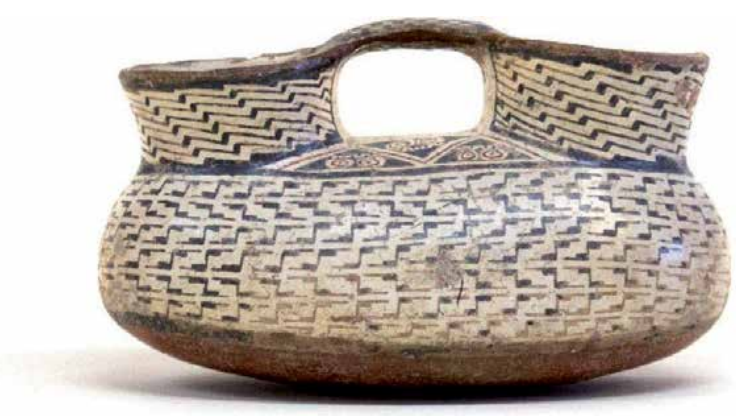

Figure 3.

Duck-shaped pitchers (Diaguita II phase). Museo del Limarí ${ }^{\circ} 31$.

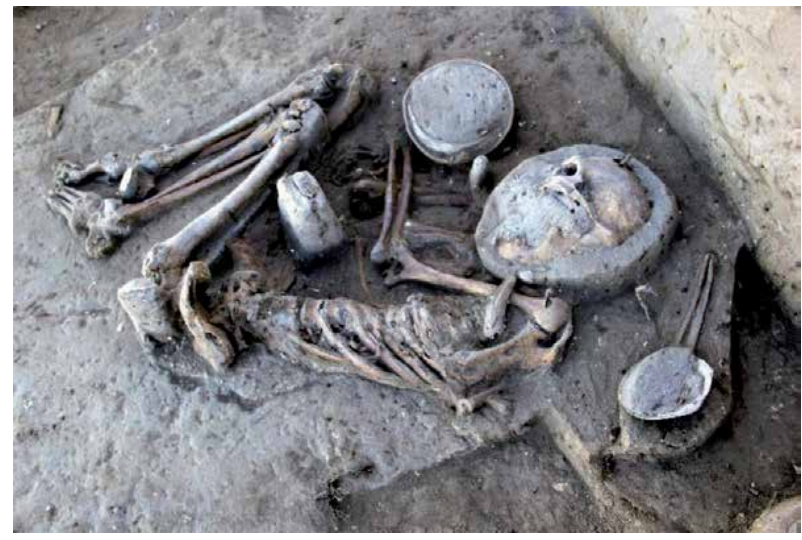

Figure 4.

Male accompanied by spatula, tube, and shell for consuming psychoactive substances. Grave 99, El Olivar site.

(East-West) valleys of their territory. As the basic social units, individual families practised small-scale farming to provide for their members, forming communities that were both economically self-sufficient and politically autonomous.

Evidence from pre-Inca Diaguita burial contexts in the Choapa Valley [3] has shown that there was little social differentiation in these communities, at least in regard to burial practices, as the nature and distribution of ceramic grave goods was largely homogeneous across age and gender. However, the presence of offerings associated with the consumption of hallucinogenic substances (spatulas and scallop shells) indicates that certain males-who have been interpreted as shamans-seem to have occupied a slightly different social category (Figure 4).

In terms of social organization, researchers have affirmed [4] that the Diaguita had a dual social structure, with groups organized in complementary halves, similar to several pre-Hispanic and present-day Andean and Amazonian societies. Ethnohistoric evidence indicates that, at the time of the Spanish arrival, the Diaguita were organized into dual señoríos (chiefdoms).

\section{Diaguita Pre-Inca visual art and South American shamanic art tradition}

Aspects such as the optical illusion of movement and vibration (Figure 5); interminable variability based on simple geometric forms (Figure 6a-c); horror vacui (Figure 7); hypnotic attraction (Figure 8); positive/negative views (Figure 9), and 


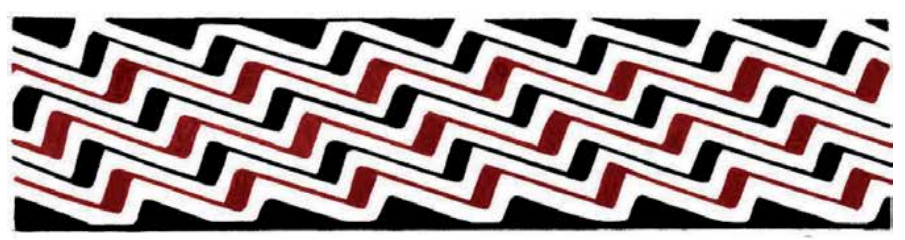

Figure 5.

Optical illusion of movement and vibration. Diaguita F2-2 wave pattern ([1], p. 118).
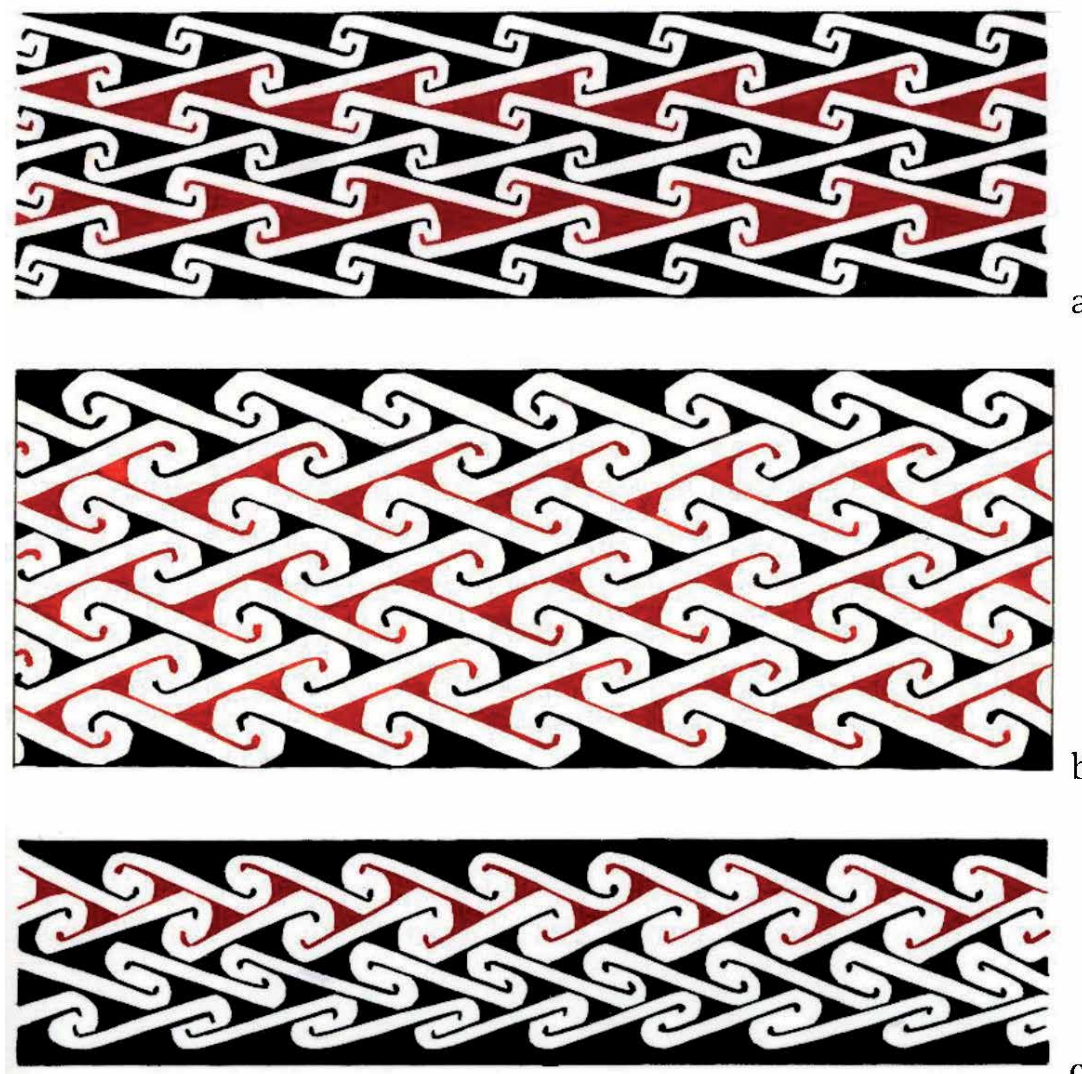

Figure 6.

Interminable variability based on simple geometric forms. (a) Diaguita $C_{5}$ wave pattern ([1] p.111); (b) Diaguita C6 wave pattern ([1], p.111; (c) Diaguita C7 wave pattern ([1], p.112).

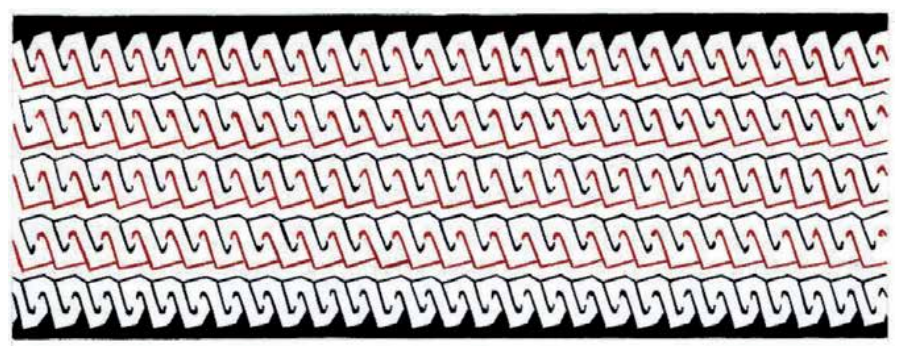

Figure 7.

Horror vacui. Diaguita J 1-1 wave pattern ([1], p. 123). 


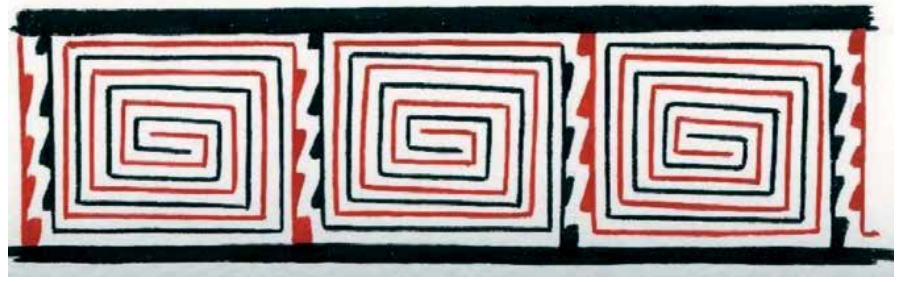

Figure 8.

Nearly hypnotic attraction. Diaguita A2 labyrinth pattern ([1], p. 152]).

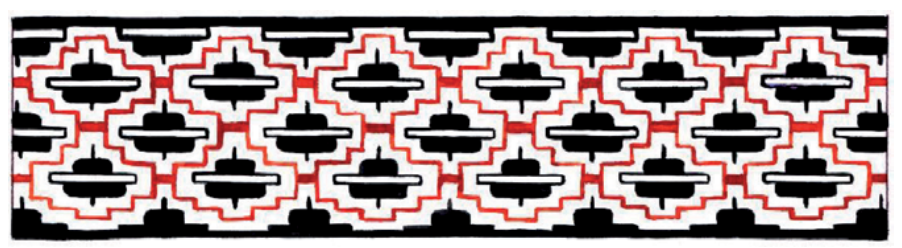

Figure 9.

Positive/negative designs. Diaguita stepped motifs, reflection B ([1] p. 149).

designs organized according to the principle of gradual structural complexification, among other features.

Recent investigations have made headway in identifying Diaguita rock art in the Limarí and Choapa river basins [5, 6]. Certain rock art representations (petroglyphs) have been attributed to the Diaguita culture on the basis of their formal similarities with Diaguita ceramic designs, both in terms of motifs and minimal units (labyrinth, stepped designs and stepped fret borders, for example) as well as in regard to the complex symmetrical operations performed by the creators. On this rock support we find the same visual logic that is recorded on Diaguita ceramic decoration, which is marked by its abstract character and complex symmetry (Figure 10).

Our comparative examination of Diaguita art and other South American ethnographic visual art styles linked to shamanic religions, especially those of the Amazonian Tukano [7], Shipibo-Conibo [8], and Caduveo [9] cultures, reveals a set of shared characteristics [10]. Two common external associations of these visual art traditions are the reference to an animal alter ego (jaguar, anaconda, feline) and the practice of hallucinogenic consumption (Figure 11).
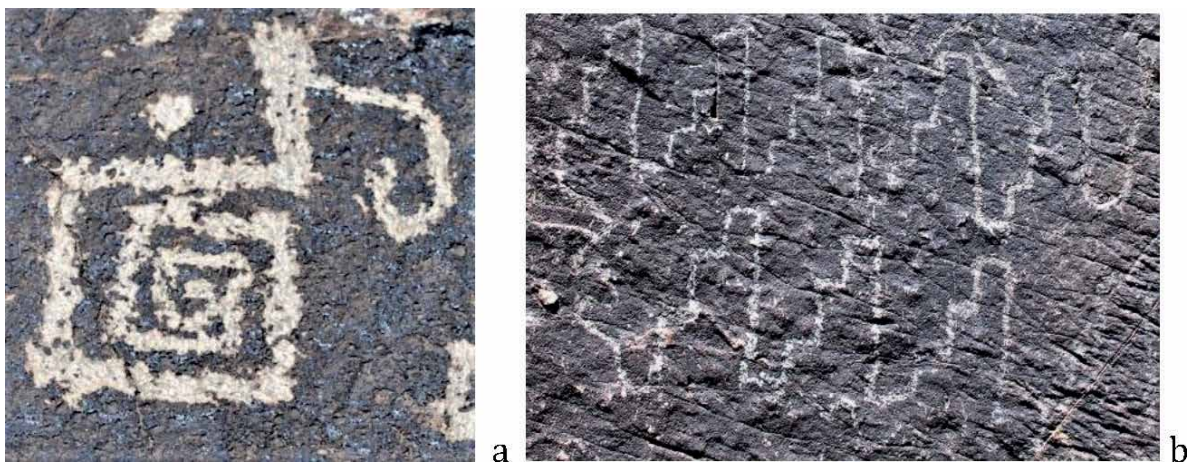

Figure 10.

Diaguita rock art. (a) Diaguita labyrinth pattern, Choapa Valley; (b) Diaguita double zigzag pattern, Choapa Valley. 


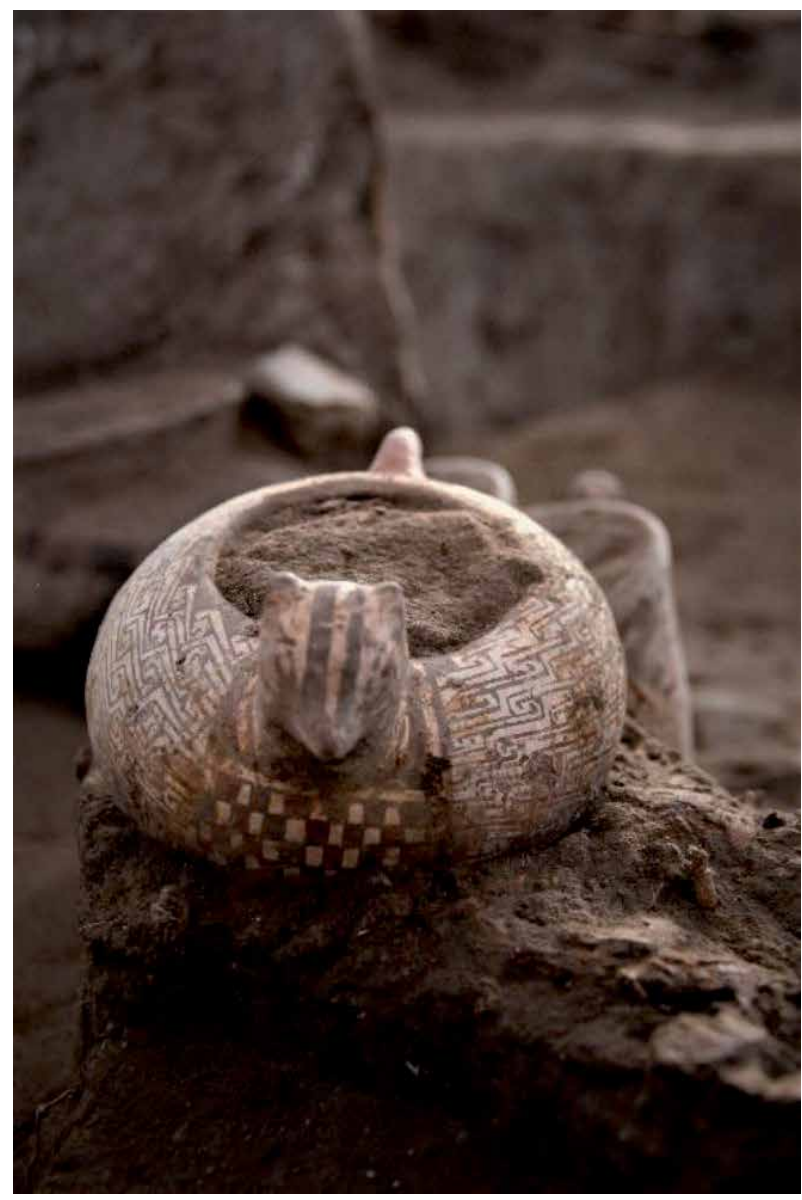

Figure 11.

Polychrome vessel with feline representation. Diaguita-Inca phase. Grave 59, El Olivar site.

Diaguitas and Shipibos also share the practices of ceramic urn burials, intentional cranial deformation, and the use of "sacrificial" objects in burial contexts. But the most prominent similarities are found in the styles of these South American indigenous art traditions, which employ complex symmetry to articulate the motifs, using three or more inter-operational symmetrical principals, and the frequent use of mirror reflection [10] (Figure 12).

For instance, in relation to Shipibo art, De Boer [11] affirms

“...the basic cross is mastered first. This element is then successively submitted to a number of increasingly complex operations that entail concatenation, repetition, compounding-first in one, then in two dimensions-and finally various partitioning and orientational transformations. The strength of this sequential pattern suggest that a powerful maturational program of the kind famously diagnosed by Piaget [12] is at work."

Another trait is the endless continuation or the self-generative power of the compositions, which endows them with an outstanding rhythmic quality. In contrast, the principle of horror vacui and the sectioning of the designs in delimited fields are also present. Yet another characteristic is the interplay between positive and negative perspectives. The use of (strictly abstract) geometric motifs, 
Shipibo Conibo and Chilean Diaguita Visual Art: Cognitive Technologies, Shamanism and Long... DOI: http://dx.doi.org/10.5772/intechopen.93984

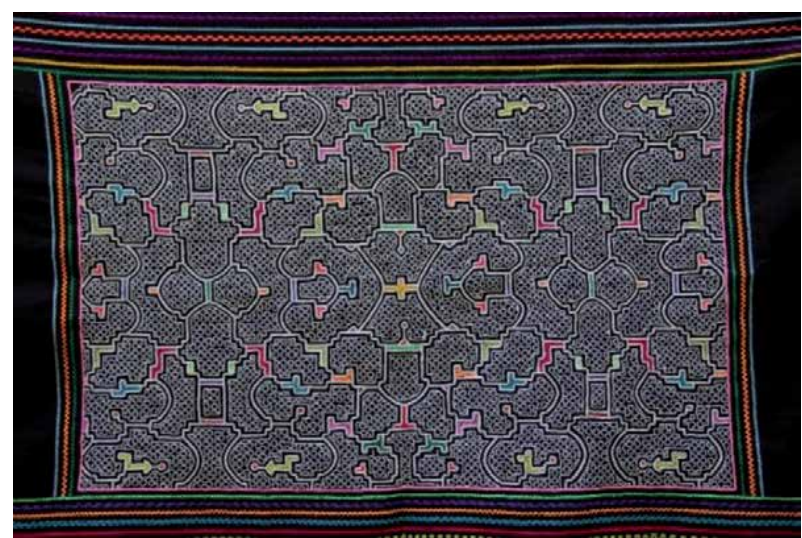

Figure 12.

Mirror reflection. Shipibo textil, Panaillo community.

combined with complex symmetrical structures that makes them barely intelligible, is another characteristic feature of Shipibo visual art [10].

These are elaborate and systematic procedures of graphic creation, visual litanies that generate a hypnotic attraction (Figure 13) through designs executed in different media such as facial paint, textile decoration, ceramics, and home decor.

In relation to this specific class of South American visual art, present in ethnographic contexts and associated with shamanic practices, Reichel-Dolmatoff ([7], p. 292) has linked the ingestion of psychoactive substances to geometric designs. The author highlights how the hallucinatory experience offers a potentially rich array of symmetrical images, which are then reproduced by the Tukano people in their art. He comments:

one of the most important discoveries in the last decades, in the ethnology field consists in the confirmation that art and shaman religions are closely related to the use of hallucinogenic drugs"..."the ingestion of hallucinogenic drugs represents the principal mechanism that induced states of shaman visions, accompanied by the

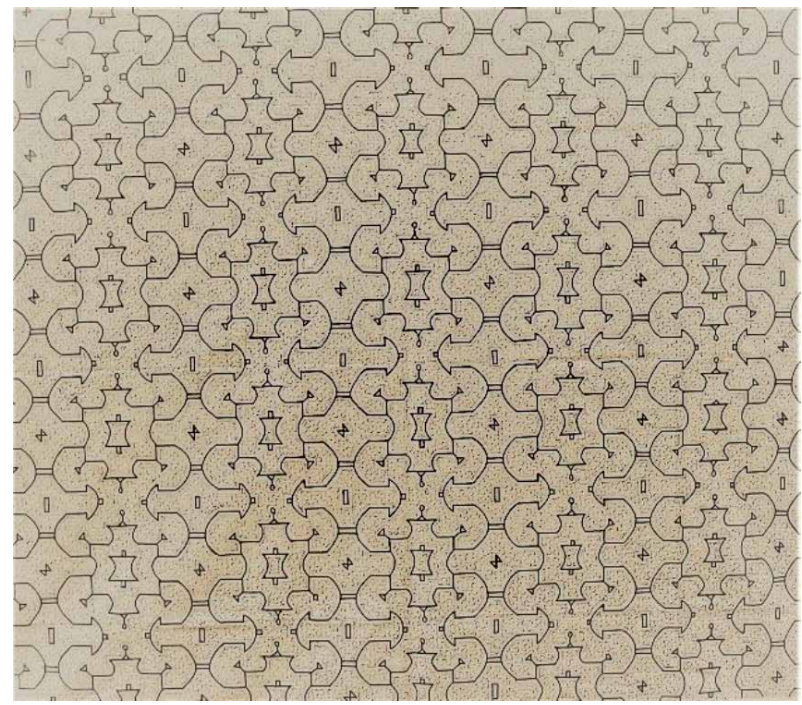

Figure 13.

Nearly hynotic attraction. Shipibo textil. Paola González collection. 
illusion of flying through the air, animal transformations and the penetration into other cosmic dimensions, out of this world

Similarly, among the Shipibo-Conibo people, kené designs left on a material support (ceramic, fabric, or wood) suggest designs perceived during shamanic visions resulting from the ingestion of Ayahuasca and believed to hold great healing power. Thus, these symmetrical, non-figurative designs have a therapeutic as well as an esthetic function. For the Shipibo people, the execution of these complex and extraordinarily beautiful designs constitutes a collaboration with the sacred, spiritual realms, erasing the dividing line between religious and esthetic experience. Thus, there is an evident link between shamanic practices, the consumption of hallucinogenic substances (Ayahuasca), and synesthetic healing therapies, which range from the artistic to the musical [8]. Gehbart-Sayer ([6], p. 161) points out:

\section{the visions of the designs are described as non analytical impressions on "pages" or "sheets", organized in a pattern that flicker rapidly in front of the eyes of the shaman then disappear as soon as he tries to take a closer look.}

This synesthetic quality of South American shamanic art also includes the transition between visual art and music, with the use of symmetry being a common feature in both. Gehbart-Sayer ([8], p. 170) comments, "symmetry prevails in the formal, melodic, and rhythmic characteristics of the songs. An example of a more complex consonance is the lateral symmetry of melodic inversion."

In these communities, artistic activity goes hand in hand with the sacred; shamans and female artisans create magical-religious objects, in which esthetic beauty is not an end in itself. For example, the Shipibo-Conibo people believe that individuals are "marked" at birth with invisible decorative patterns. When an individual becomes ill, the healing designs are spiritually projected upon the patient by the shaman to bring them back to a healthy state. The attributing of agency to the symmetrical pattern is evident in the story of Netén Vita (a Shipibo shaman from Caimito), as related by Illius ([13], p. 197). Netén Vita affirms that, in order to heal, the shaman must contact the guardian spirits, who are "the bands of drawings from my heaven (noco naina kené)." Furthermore, recent studies of Amazonian peoples have revealed the existence of a series of pan-Amazon beliefs $[14,15]$, expressed in different stylistic traditions. Such commonalities include the representation of specific animals, particularly jaguars and snakes, as well as abstract art, shamanic practices, and the consumption of hallucinogenic substances. These findings point to a longstanding shared ideology, the common elements of which can be found in both present-day cultures and in the archeological record [14]. Also on the basis of archeological and ethnographic evidence, Roe proposes the existence of a common cosmology within the South American tropical forest, pointing out that, "with its vast interconnecting web of waterways knitting together similar microenviroments, the Amazonian region is a perfect highway of ideas" ([14], p. 26).

In terms of the temporal depth of this shamanic art tradition in South America, Taylor ([16], p. 16) affirms that "it is possible that what we see in the contemporary Amazonian graphic tradition is only the preservation of a tendency present since preColombian times, the fruit of an ancient cultural tradition, of an eminently intellectual, cerebral, elaborate and complex form of art".

In the paragraphs below, we will examine archeological information which suggests the existence of long-distance relations that played a determining role in Diaguita ethnogenesis. These cultural relations will also explain the cultural linkages that one observes between the Shipibo-Conibo and pre-Hispanic Diaguita peoples, despite their separation in both space and time. 


\section{The Mojocoya culture, a nexus for understanding the cultural linkages between the Chilean Diaguita and Shipibo-Conibo peoples}

Affirming the linkages between the Chilean Diaguita and Peruvian Amazon Shipibo-Conibo peoples (which considers stylistic aspects, social practices, and material culture), and following the arguments of Lathrap [17], González [8] proposed the existence of a common antecedent between the two cultures, namely the Mojocoya culture of the Bolivian lowlands. As the cultural ancestor of the Shipibo people, Lathrap proposes the Cumancaya culture (Alto Ucayali), which also displays evident parallels with Chilean Diaguita culture.

González [8] confirmed the presence of patterns in Mojocoya iconography that were previously identified in Diaguita iconography, including the Wave A, stepped vertical reflection, and Chain C [1] patterns. The coincidences observed are not limited to the identification of minimal units (stepped borders, triangles combined with scrolling, simple stepped motifs, etc.), but also include symmetrical principles (or groups of them) that make up these units (reflection, displacement combined with translation, double specular reflection, horizontal reflection, rotation, and translation, among others). This structural similarity is a very good indicator of cultural interrelatedness [2].

According to Brockington et al. ([18], p. 4), the Mojocoya culture originated in the Amazon-Chaqueñas lowlands of Bolivia expanded into the areas around the highlands of Cochabamba and Chuquisaca. Based on their ceramics, two phases have been identified: an early, pre-Tiwanaku one (ca. 1-600 A.D.) and a later one (600 - 900 A.D.) that displays the influence of Tiwanaku. Mojocoya designs are executed in black and red on orange, with some use of white. The most frequent motifs include triangles; triangles with scrolling; stepped and triangular stepped motifs with scrolling; and zig-zagging lines in alternating colors, very often organized in bilateral or quadrilateral symmetry. We add to this list recorded examples of the labyrinth pattern A2 [1]. The main ceramic forms include simple convex bowls, tripod bowls, kero cups, and "effigy pieces" [18]. Monochrome ceramics include urns and other large vessels.

For the Mojocoya culture, archeologists have noted the practices of child burial in urns, cranial deformation, and the consumption of psychoactive powders. At the El Tambo site (1-600 AD), researchers have found copper bells with folded bases [18], which have also been recorded at Diaguita sites in Chile's semi-arid north. The authors emphasize that the Mojocoya sites are located near traffic routes connecting the Andean and Amazon regions, which would have facilitated the movement of people and goods among different ecozones. Along the same lines, Pereira and Brockington ([19], p. 2) hypothesize that the area southeast of Cochabamba would have operated as a focal point for social complexity, a place where a variety of social processes emerged over time, making it "an area of historic interplay between environmental factors and Andean, Amazonian, and Chaqueño peoples, with a dynamic that had major repercussions and wielded significant influence even beyond its sphere of interaction as a zone."

\section{New research on the origins of Chilean Diaguita culture: El Olivar archeological site}

In light of the above information about the Mojocoya culture and its ceramic tradition, it is interesting to examine analyses of recent discoveries at the Diaguita site of El Olivar [20, 21], which have identified more stylistic coincidences between 
the Diaguita and Mojocoya representational universes [8], while at the same time shedding light upon the genesis and development of the Diaguita culture itself in Chile's semi-arid north.

An extensive cemetery was discovered during construction of a highway between the Chilean cities of La Serena and Vallenar, and excavated between 2015 and 2017 [20, 21]. The funerary contexts recovered correspond to 212 individuals in primary graves, 39 of which contained one or two camelids, along with another 44 secondary graves. Among the whole, 86 burial contexts correspond to the period in which Diaguita culture was emerging, which we have called the Early Diaguita phase [21]. The evidence unearthed suggests that it was during this stage that the Diaguitas created their own techno-stylistic material identity. And although there was some degree of interaction with neighboring communities in the semi-arid North, Diaguita ceramics forged an identity all its own, developing visual languages with roots that were linked not only to the Andean world, but with the ancient cultural traditions of the Eastern Bolivian lowlands.

Included among the discoveries associated with those Early Diaguita funerary contexts were novel polychrome vessels, including an anthropomorphic bi-globular polychrome pitcher, which bears a rather crude version of the Wave A pattern on the back of its "head" (Figure 14a,b). Also outstanding among the grave goods found is a polych-rome anthropomorphic cup decorated with a labyrinth pattern on both sides of the face and body (Figure 15a,b). Yet another notable vessel is the polychrome globular pitcher with a flared neck, which displays the minimal units of the Chain B pattern (triangle combined with a rectangular hook), also present in Mojocoya iconography (Figure 16). Lastly, we wish to highlight the four-footed anthropomorphiczoomorphic vessel (Figure 17) found at the site, for both its shape and the designs molded and incised on its "face" (nose, eyes, ears), both of which qualities bear evident similarities to the "effigy pieces" illustrated by Brockington et al. [18].

It is interesting to note that, as Diaguita culture consolidated over time, these early motifs gradually transformed and became more complex, until achieving the esthetic and geometric virtuosity characteristic of the Classic Diaguita style and the Diaguita-Inca phase. Clearly, the Wave pattern remained a point of reference throughout Diaguita development, acting as an "axis of formal coherence" [22], an essential formative aspect of Diaguita identity. In effect, when we look at how Diaguita ceramics has evolved over time, we observe the persistence of certain

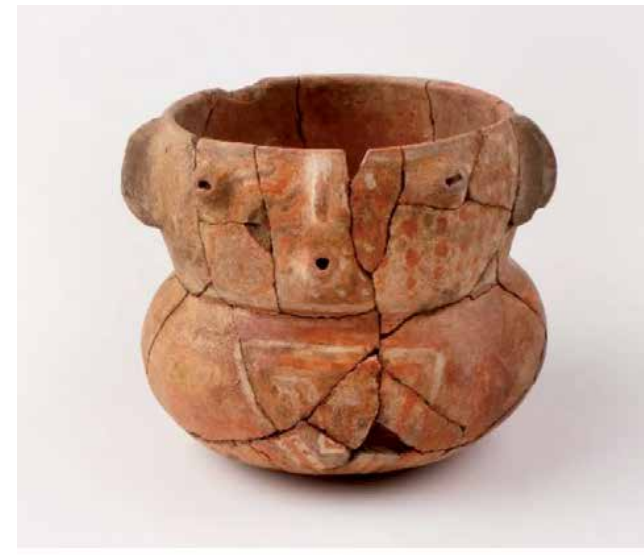

a

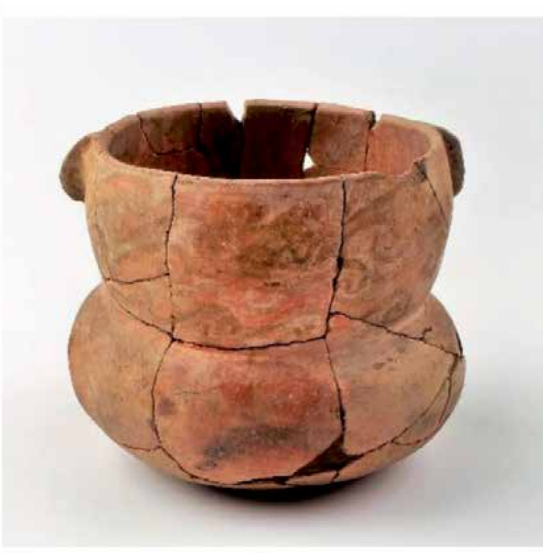

b

Figure 14 .

Bi-globular anthropomorphic polychrome pitcher with wave A pattern A. Grave 182. El Olivar Site; (a) Front section; (b) Back section. 
Shipibo Conibo and Chilean Diaguita Visual Art: Cognitive Technologies, Shamanism and Long... DOI: http://dx.doi.org/10.5772/intechopen.93984

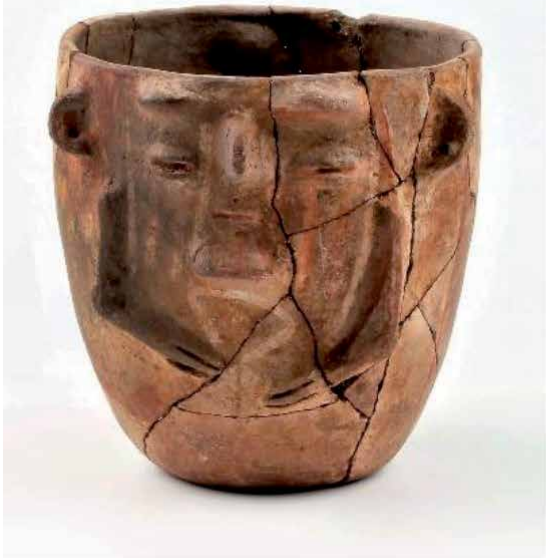

a

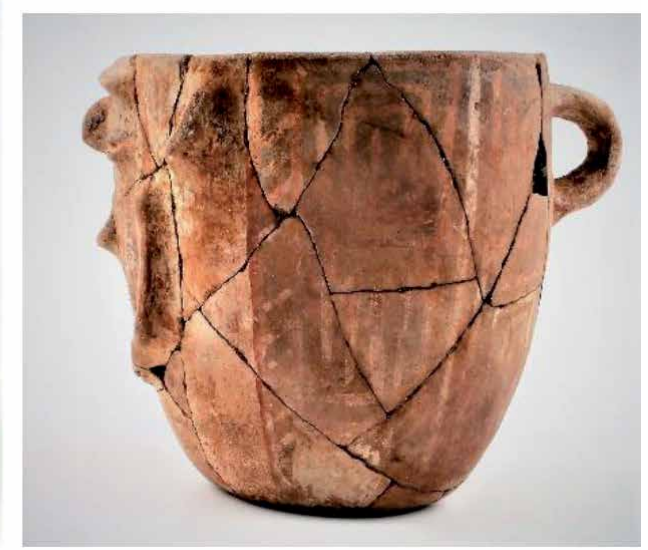

b

Figure 15.

Polychrome anthropomorphic cup decorated with labyrinth pattern. Grave 182, El Olivar site. (a) Front section; (b) Lateral section.

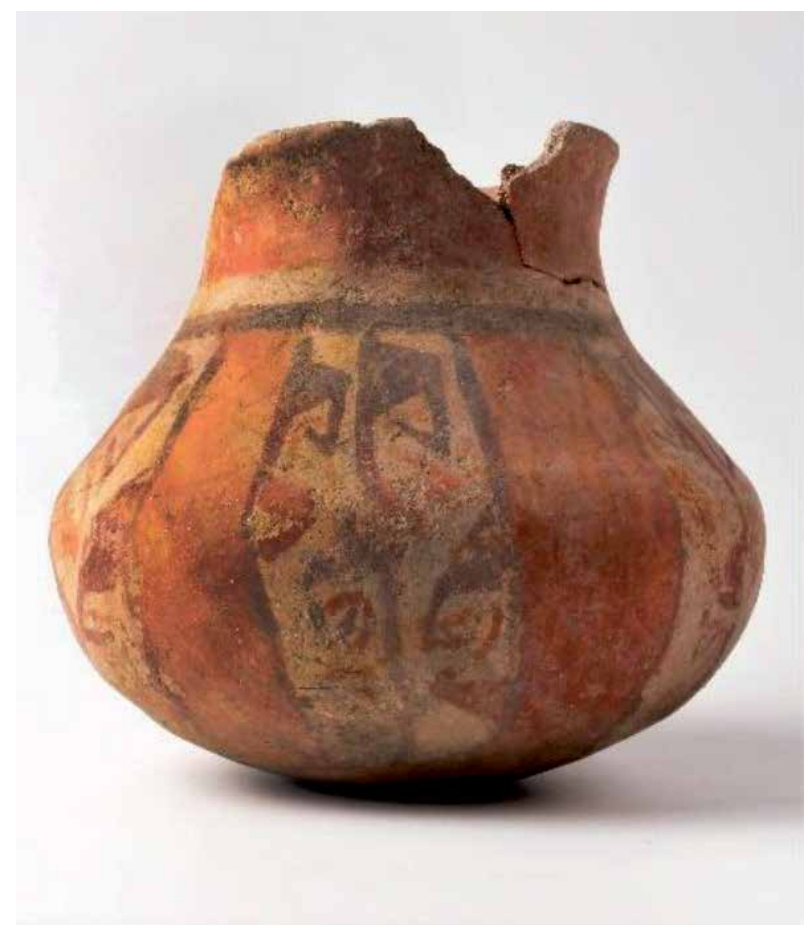

Figure 16.

Globular polychrome pitcher with flared neck, displaying the minimal units of the chain B pattern. Grave 58 , El Olivar site.

complexly structured designs, expressed in a simpler version in the Early Diaguita phase (the Wave A pattern, for example). These decorative patterns were taken up and enhanced time and time again by the Diaguita people in a kind of ongoing sequence that withstood the passage of time. This insistent reproduction of a set of specific designs is a clear expression of how memory constructs and establishes identity. In this sense, we propose that designs like the Wave A pattern, which can 


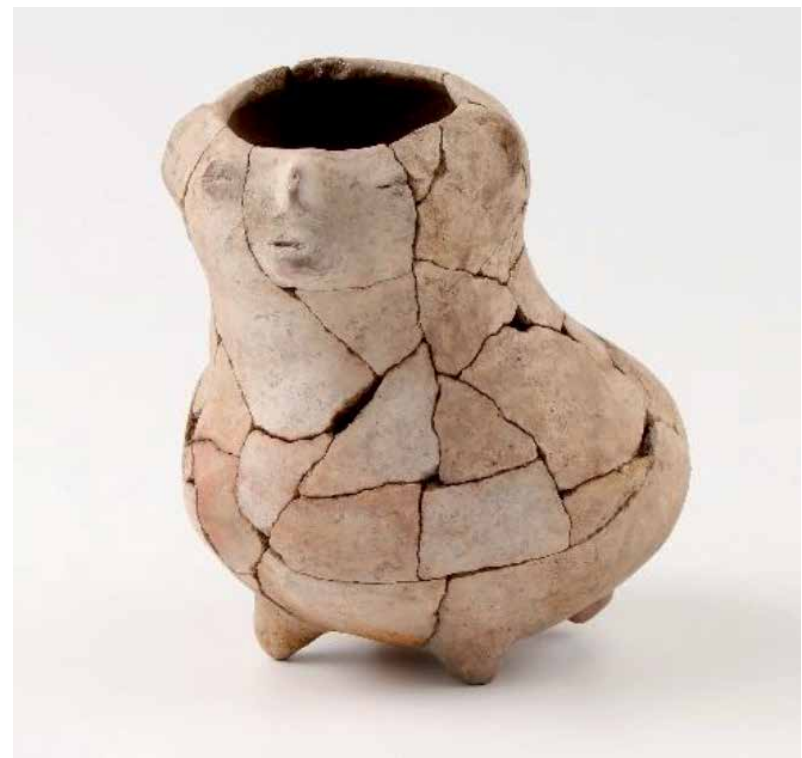

Figure 17.

Four-legged anthropomorphic-zoomorphic vessel. Grave 186, El Olivar site.

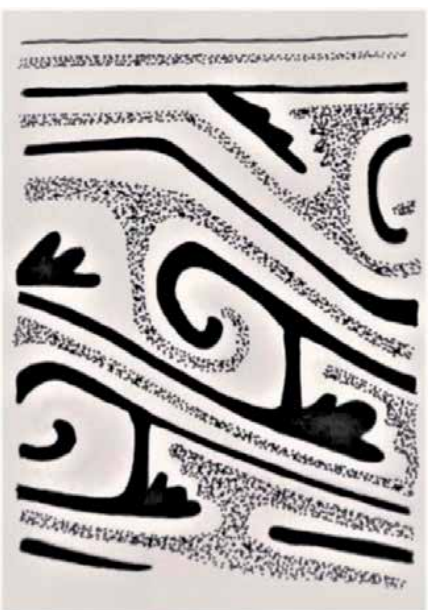

a
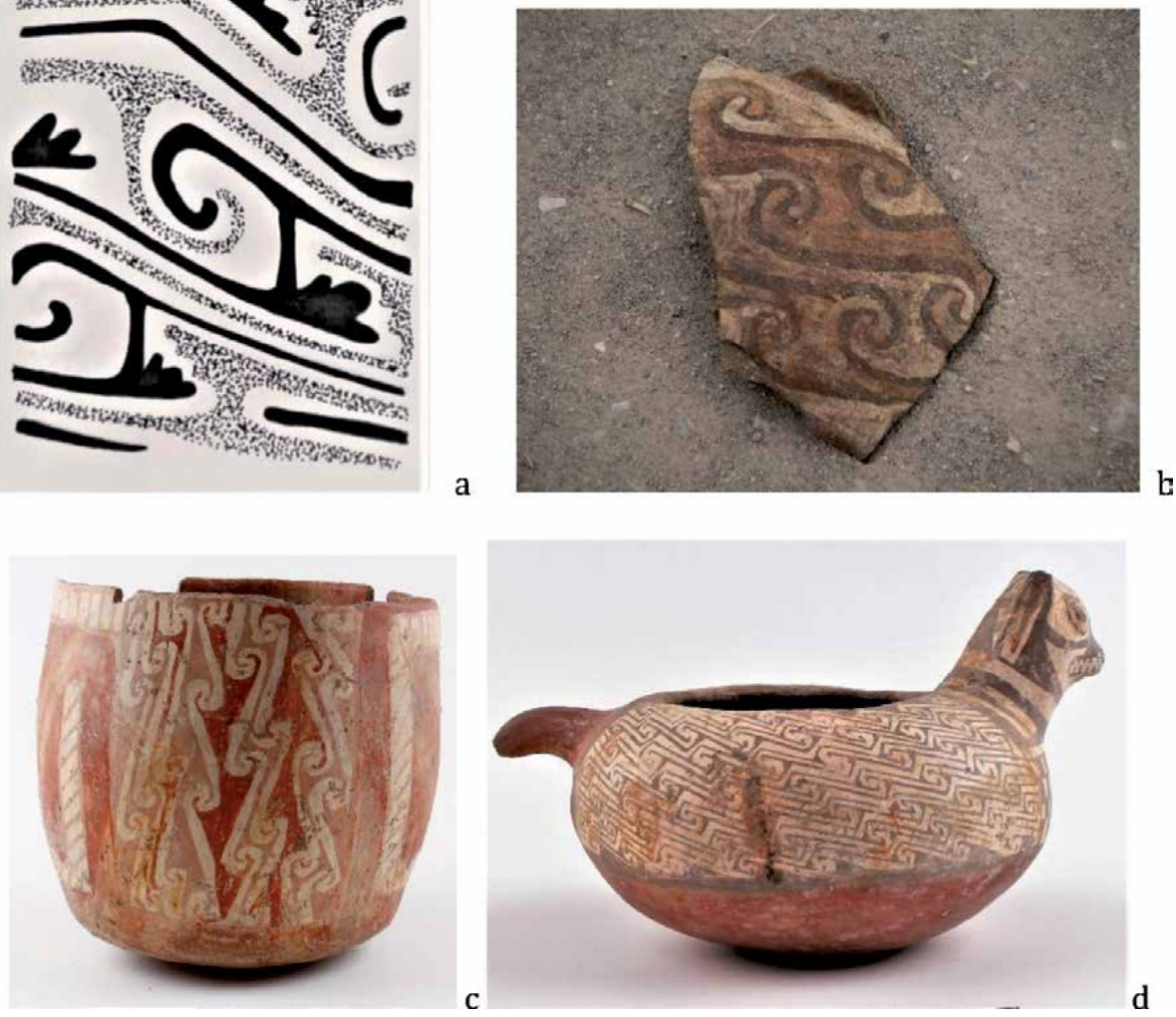

Figure 18.

Evolution of Wave A pattern over time: (a) Mojocoya trichromatic design (Lathrap 1970, p.143); (b) Sherd of the Wave A pattern, Early Diaguita period, El Olivar site; (c) Wave A pattern in trichromatic cup, Diaguita pre-Inca period, Grave 149, El Olivar site; (d) Wave A1 pattern in felinomorphic bowl, Diaguita-Inca period, Grave 59, El Olivar site. 
be traced back to the earliest times of the Mojocoya culture and is represented in Diaguita culture without interruption from its origin to the Inca stage, is an "axis of formal coherence" [21]. These particular forms and designs are used by a group of people as a means of their own social reproduction (Figure 18a-d).

Obviously, the Mojocoya and Chilean Diaguita cultures are separated by a major gap in both time and space, making it difficult to speak of a direct link between the two. Perhaps the latter can be thought of as an original source of the concepts and designs that spread, albeit with some variations, over a geographically extensive area that stretched to the eastern lowlands and likely into the Amazon uplands as well.

\section{Pre-Inca Diaguita art: the agency of art and technologies of enchantment}

A detailed examination of pre-Inca Diaguita visual art [1] from the perspective of its motifs, formal logic, and symmetrical structure suggests that this representational universe does not seek to communicate specific concepts of any kind. Notably, the hyper-concentrated visual litanies of that period were crafted by artisans highly skilled in intricate, complex symmetrical operations. For us, it appears that their aim was more likely the creation of what Gell [22] has termed "technologies of enchantment."

In turn, the same author considers decorative art a special form of technology. Gell comments [23],"the decoration of objects is a component of a social technology, which I have elsewhere called the technology of enchantment" [22], and continues, "this psychological technology encourages and maintains the motivations 6necessitated by social life. The world is filled with decorated objects because decoration is often essential to the psychological functionality of artifacts, which cannot be dissociated from the other types of functionality they possess, notably their practical or social functionality" ([23], p. 74).

As Gell explains, work of art captivate the viewer with the difficultly of their conception and execution. Their uniqueness and beauty transform them into active agents in the social sphere. In particular, abstract art exploits our perception of internal agency because

\footnotetext{
"Patterns, by their multiplicity and the difficulty we have in grasping their mathematical or geometrical basis by mere visual inspection, generate relationships over time between persons and things, because what they present to the mind is, cognitively speaking, always "unfinished business" ([23], p.23)
}

The author goes on to argue that this "sets up a biographical relation - an unfinished exchange - between the decorated index and the recipient" ([23], p. 81), and thus attributes this "cognitive stickiness" of abstract patterns "to this blockage in the cognitive process of reconstructing the intentionality embodied in artefacts."

Thus, by employing these visual strategies, the abstract patterns acquire properties, such as the illusion of movement and vibration, that help to captivate the viewer and enhance the agency of the pattern. In the words of Gell ([23], p. 77), "nothing could be more animated than the tessellations (tiling patterns) devised by Islamic decorative artisans...it seems, to inspire ever more effective inducements to captivation by visual artifice, the non-mimetic appearance of animation".

In this regard, Taylor [16] notes that in the Amazonian representational universe, figurative representations of the entities of the cosmovision are virtually absent, while abstract and geometrical representations abound. The author concludes, "any surface with geometric motifs can evoke subjectivity or personality. Even 
paintings themselves can be treated as persons. For example, the Jibaro people have ritual songs that are sung directly to body paintings to ask them for a certain type of intervention" [14 p. 6]. The author therefore proposes that the abstract body painting of Amazonian groups was intended to "represent complete beings as "incarnations." This suggests that this geometric, non-figurative Amazonian art was not "iconophobic," but rather played a major role "in the perpetuation of this tradition of figuratively imagining supernatural beings" ([16], p. 13).

\section{Conclusions}

In this article we have attempted to build our understanding of the visual logic deployed by the Chilean Diaguita people, as expressed in the designs of Diaguita polychrome ceramics. The use of symmetry in Diaguita culture is remarkable. In their pre-Inca designs the highly skilled Diaguita artisans managed to create complex abstract constructs that were highly symmetrical and capable of producing optical effects such as vibration and movement. Without a doubt, these reinforced the active social role of their visual art, in association with a shamanic belief system. Current reflections about Amazonian animism offer extensive opportunities for interpreting pre-Inca Diaguita art, which, as we have previously proposed, seems to be part of a larger cultural tradition that remains alive in different parts of South America, particularly among indigenous groups of the Amazon region.

Furthermore, the surprising similarities observed in both the visual art and certain social practices of the Chilean Diaguitas and the Shipibo-Conibo people, despite their spatial and temporal distance, can be better understood by observing the dynamic long-distance cultural contact that likely took place between peoples living in the Bolivian, Andean, and even Amazonian lowlands. If we are to better understand the pre-Hispanic past of the southern cone of the Americas as well as its ethnographic present, we must broaden our perspective and grasp that in the distant past, cultural traditions possessed of a clearly recognizable identity exercised their influence over extensive geographic areas and diverse ecosystems. 3 In the case presented, the analysis of symmetry was crucial in demonstrating that cultural contact did exist, and has proven to be an approach well suited to detecting processes of cultural inter-relatedness and exchange.

It is also interesting to examine the esthetic facet of symmetry, and how it helped define the elusive concept of beauty. In the pre-Inca Diaguita representational universe, its function in the creation of highly complex abstract images is evident. At the same time, the painstaking display of symmetry in a significant number of designs from across the entire Diaguita territory demonstrates the social importance that Diaguita artisans attributed to managing and comprehending symmetry. Indeed, the use of symmetry enabled communities in different valleys to affirm their individual identities, while marking Diaguita identity as a whole.

So, how did the Diaguita people conceive of such vessels loaded with symbolic content? We find it difficult to believe that they were simple, everyday pieces crafted to hold food. Instead, based on their complex iconography and rich esthetics, it would appear that they were invested with an active social role. 
Shipibo Conibo and Chilean Diaguita Visual Art: Cognitive Technologies, Shamanism and Long... DOI: $h$ ttp://dx.doi.org/10.5772/intechopen.93984

\section{Author details}

Paola González Carvajal

Sociedad Chilena de Arqueología, Santiago, Chile

*Address all correspondence to: paoglez@gmail.com

\section{IntechOpen}

(C) 2020 The Author(s). Licensee IntechOpen. This chapter is distributed under the terms of the Creative Commons Attribution License (http://creativecommons.org/licenses/ by/3.0), which permits unrestricted use, distribution, and reproduction in any medium, provided the original work is properly cited. (cc) BY 


\section{References}

[1] González P. Arte y cultura Diaguita Chilena: simetría, simbolismo e identidad. Santiago: Ucayali Editores; 2013, 349 p.

[2] Washburn D, Crowe D. Symmetries of Culture. Theory and practice of plain pattern análisis. 2nd ed. Seattle: University of Washington Press, 1992. 294 p.

[3] Becker C, Rodríguez J, González P, Troncoso A, Pavlovic. Arqueología en el río Chalinga. Informe Final. Proyecto Fondecyt N¹000039. 2003 MS.

[4] Hidalgo J. Diaguitas Chilenos Protohistóricos. In: Hidalgo J, SchiappacasseV, Niemeyer H, Aldunate C, Solimano I, editors. Prehistoria. Desde sus orígenes hasta los albores de la Conquista. Santiago: Editorial Andrés Bello, 1989. p. 289-293.

[5] Troncoso A. Arte rupestre, prácticas socio-espaciales y la construcción de comunidades en el Norte Semiárido de Chile (Valle del Limarí). In: Falabella F., Sanhueza L, Cornejo L, Correa I, editors. Distribución Espacial de Sociedades No Aldeanas. Serie Monográfica de la Sociedad Chilena de Arqueología $\mathrm{N}^{\circ} 4$. Santiago: Ediciones On Demand; 2014. p. 89-115.

[6] González P. Arte rupestre de origen Diaguita-Inca en los valles de Choapa y Limarí: su importancia en las estrategias de interacción política Inca en territorio Diaguita. In: Actas XIX Congreso Nacional de Arqueología Chilena; 8-12 October 2012; Arica: Andros Impresores; 2015. p. 214-223

[7] Reichel-Dolmatoff G. Aspectos chamanísticos y neurofisiológicos del arte indígena In: Museo Chileno de Arte Precolombino, editors. Estudios en Arte Rupestre. Santiago: Editorial Museo Chileno de Arte Precolombino, 1985. p. 291-307
[8] Gehbart-Sayer A. The geometric designs of the Shipibo-Conibo in ritual context. Journal of Latin American Lore. 1985; 11 (2): 143-175.

[9] Levi-Strauss C. Tristes Trópicos. Barcelona: Ediciones Paidós, 1988 [1955]. $468 \mathrm{p}$.

[10] González P. La tradición de arte chamánico Shipibo-conibo (Amazonía peruana) y su relación con la cultura Diaguita chilena. Boletín del Museo Chileno de Arte Precolombino. 2016; $21 \mathrm{~N}^{\circ} 1$ : 27-47

[11] De Boer W. Interaction, imitation and communication as expressed in style: the Ucayali experience. In: Conkey M, Hastorf C, editors. The uses of style in Archaeology. Cambridge: Cambridge University Press; 1990. p. 82-104.

[12] Piaget J. Structuralism: Translated by Chaninah Maschler. New York: Basic Books. Harper \& Roe; 1970. 16 p.

[13] Illius B. La Gran Boa: Arte y cosmología de los Shipibo-Conibo. Amazonía Peruana 1994; 24 (12): 185-212.

[14] Roe P. The cosmic zygote. Cosmology in the Amazon Basin. New Brunswick: Rutgers University Press; 1982. 400 p.

[15] Barreto C. Meios místicos de reproducao social: Arte e estilo na cerámica funeraria da Amazonia antiga [thesis]. Sao Paulo: Museo de Arqueologia e Etnologia, Universidade de Sao Paulo; 2008.

[16] Taylor A. Arte y mito en las culturas amazónicas. Universidad Pompeu Fabra. Centre Investigador en Art Primitiv i Primitivisme. Jornada Arte y Miti en las culturas primitivas. Conference on 10 March 2008. Available from: 
http://www.upf.edu/ciap/_pdf/

Conference_Taylor_Amazonas_peq.pd [Accessed 2015-08-15]

[17] Lathrap D. The Upper Amazon. Southampton: The Camelot Press Ltd; 1970. 256 p.

[18] Brockington D, Pereira D, Sanzetenea R. El sitio El Tambo y la tradición Mojocoya: Cambios, Tiempo y Espacio en el Sur-Este de Bolivia. In: Pereira D, y Brockington D, editors. Mojocoya y Grey Ware: Interacción espacial e intercambio entre la Amazonía, Chaco y Andes. Cuaderno de Investigación $\mathrm{N}^{\circ} 10$. Serie Arqueología. Cochabamba: Universidad Mayor de San Simón. Dirección de Investigación Científica y Tecnológica, Instituto de Investigaciones Antropológicas y Museo Arqueológico. 2005. p. 3-58

[19] Pereira D, Brockington D. Mojocoya y Grey Ware: Interacción espacial e intercambio entre la Amazonía, Chaco y Andes. Cuaderno de Investigación $\mathrm{N}^{\circ} 10$. Serie Arqueología. Cochabamba: Universidad Mayor de San Simón. Dirección de Investigación Científica y Tecnológica, Instituto de Investigaciones Antropológicas y Museo Arqueológico; 2005. 91 p.

[20] González P. Sitio El Olivar: su importancia para la reconstrucción de las comunidades agroalfareras del norte semárido chileno. Colecciones Digitales. Subdirección de Investigación. Colecciones Digitales. Subdirección de Investigación DIBAM. 2017. Available from: http://www. museoarqueologicolaserena.gob. $\mathrm{cl} /$ sitio/Contenido/Coleccionesdigitales/83495:El-sitio-arqueologicoEl-Olivar [Accesed: 2020/07/15]

[21] Cantarutti G, González P. Boletín de la Sociedad Chilena de Arqueología. Santiago: Nuevos antecedentes sobre la cultura Diaguita Chilena en el valle del Elqui a partir del sitio El Olivar. Journal article (forthcoming)
[22] Gell A. The Technology of Enchantment and the Enchantment of Technology. In: J. Coote J. Shelton A, editors. Anthropology, Art and Aesthetics. Oxford: Clarendon Press; 1992. p. 40-67.

[23] Gell A. Art and Agency: An Anthropological Theory. Oxford: Oxford University Press; 1998. 271 p. 



\title{
From the "Terra Preta de Indio" to the "Terra Preta do Gringo": A History of Knowledge of the Amazonian Dark Earths
}

\author{
Klaus Hilbert and Jens Soentgen
}

\begin{abstract}
The anthropogenic origin of the Amazonian dark earths (Terra Preta de Índio) was first verified more than 70 year ago. However, the last 30 years have seen a massive wave of scientific investigation, public interest and an ever-expanding intensification of commercial activity toward all things connected to "Terra Preta." Today, the dominant concept, which drives current research, is that of binding atmospheric carbon with artificially concocted dark earths. The large-scale production of Terra Preta is said to be an effective tool in efforts to mitigate global warming. This text attempts to provide a history of the knowledge on Amazonian dark earths. It not only focuses on scientific aspects but also considers traditional indigenous knowledge. The position is taken that without indigenous knowledge, modern Terra Preta research would not exist; a view, which has profound implications for the ethical evaluation of all further, applied Terra Preta Nova research and commercial endeavors.
\end{abstract}

Keywords: Amazonia dark earths, Terra Preta de Índio, traditional indigenous knowledge, biochar, history of knowledge, global warming, carbon storage

\section{Introduction}

Today, the term Amazonian dark earths (Terra Preta de Índio-Amazonian dark earths) refers to a dark soil most often found in limited zones in the lowland areas of Amazonia. These soils are, as a rule, concentrated near rivers and located on bluff zones above the floodplains (várzea) [1]. This unique soil has a significantly higher nutrient content, especially phosphorus and nitrogen, and a much higher $\mathrm{pH}$ value (around 6.7) when compared to other Amazonian soils [2, 3]. These soils are-as the name indicates-very visually dark and all of them contain some quantity of prehistoric material cultural remains. For this reason, all ancient Terra Preta sites are nowadays considered archeological in character and protected by Brazilian law.

According to Woods and Denevan [4], the Terra Preta sites cover an area of $0.1-0.3 \%\left(6000-18,000 \mathrm{~km}^{2}\right)$ of the wooded Amazonian lowlands. As these soils are characterized by a long-term fertility, many of them are used by the local population, known as caboclos, in their agricultural practices [5-7].

The baseline, "non-Terra Preta," primary forest soils (especially oxisols) are generally extremely nutrient-poor, unless modified significantly through the 
introduction of artificial fertilizer. These primary forest soils have a low $\mathrm{pH}$ value, which means they are extremely alkaline and suited for long-term agricultural use. The usual agricultural workaround, known as slash-and-burn, produces ash and coal, which provide for a temporary fertility. Immediately thereafter, the areas are generally abandoned as the soil fecundity declines and much waste in biomass and land use is the overall result in this highly inefficient approach [8].

The indigenous knowledge of Terra Preta, their location and qualities are still invaluable to the current discussion (for a more in-depth discussion on the subject see Manuela Carneiro da Cunha [9]). Simply taking into consideration solely peerreviewed scientific journal publications is, in our opinion, insufficient [4]. Such a limited approach creates a distorted perspective. Such a selective corpus might inspire the conclusion that only Western-based scientists and 21st century business concerns discovered and developed the fundamental benefits of the Terra Preta de Indio. Such a clearly simplified historically misinformed view might even be used for legitimizing claims to the economic exploitation of this important indigenous knowledge [10].

\section{Dark earth as anthropogenic soil: the legacy of Curt Nimuendajú}

Foreign researchers and travelers first learned about the existence of this uniquely fertile soil by local informants. Herbert Smith [11], for example, had this description to give after his visit to Santarém, “...the rich terra preta, 'black land', the best on the Amazon (...) is a fine, black loam, a foot, and often two feet thick. Strewn over it everywhere we find fragments of indian pottery, so abundant in some places that they almost cover the ground." Friederich Katzer [12], a German geologist, gave the "Schwarze Erde" (black earths) a natural origin and interpreted them, as they were located near the rivers, as ancient lake deposits (igapó). He analyzed three soil samples from Terra Preta and was surprised by their exceptionally high content of organic matter. He noticed a great quantity of potsherds as well of indigenous origin and concluded from this observation that these "ancient lake deposits" were once cultivated by the ancient Amazonians, when the region was much more densely populated.

Curt Unkel (1883-1945) went beyond the mere confirmation of the existence of the Amazonian dark earths and the understanding that these were places in which archeological objects could be found. Beyond a doubt, Unkel (later receiving his Indian-sanctioned moniker "Nimuendajú") is one of the most important 20th century researchers of Amerindian cultures and has done invaluable work for the investigation and protection of Brazilian indigenous populations [13].

In his research on Terra Preta, Nimuendajú started from the widely-understood fact, that wherever a certain earth was found (locally called Terra Preta de Indio), ceramic fragments of earlier indigenous cultures were always present. Following this premise, near the city of Santarém, at the confluence of the Rio Tapajos and the Amazon, Nimuendajú registered the location of 63 previously unknown Terra Preta sites (Figure 1) [14].

In 1945, in a letter to the ethnologist Herbert Baldus, Nimuendajú outlined his ideas about the origin of the Terra Preta. This letter, summarizing the considerations of many earlier studies, was a watershed publication in Terra Preta knowledge and major hallmark of Nimuendajús personal research legacy, as it contains nearly all the keys ideas of all subsequent Terra Preta research [15].

His systematic analysis of the locations of the Terra Preta led him to reject the previously prevailing opinion that the special soil was of a natural origin and the result of flooding, the remnants of lake sediments or even volcanic ash [16]. Nimuendajú concluded, by comparing the spatial distribution of the Terra Preta that the soils were totally anthropogenic, did not occur naturally and clearly 


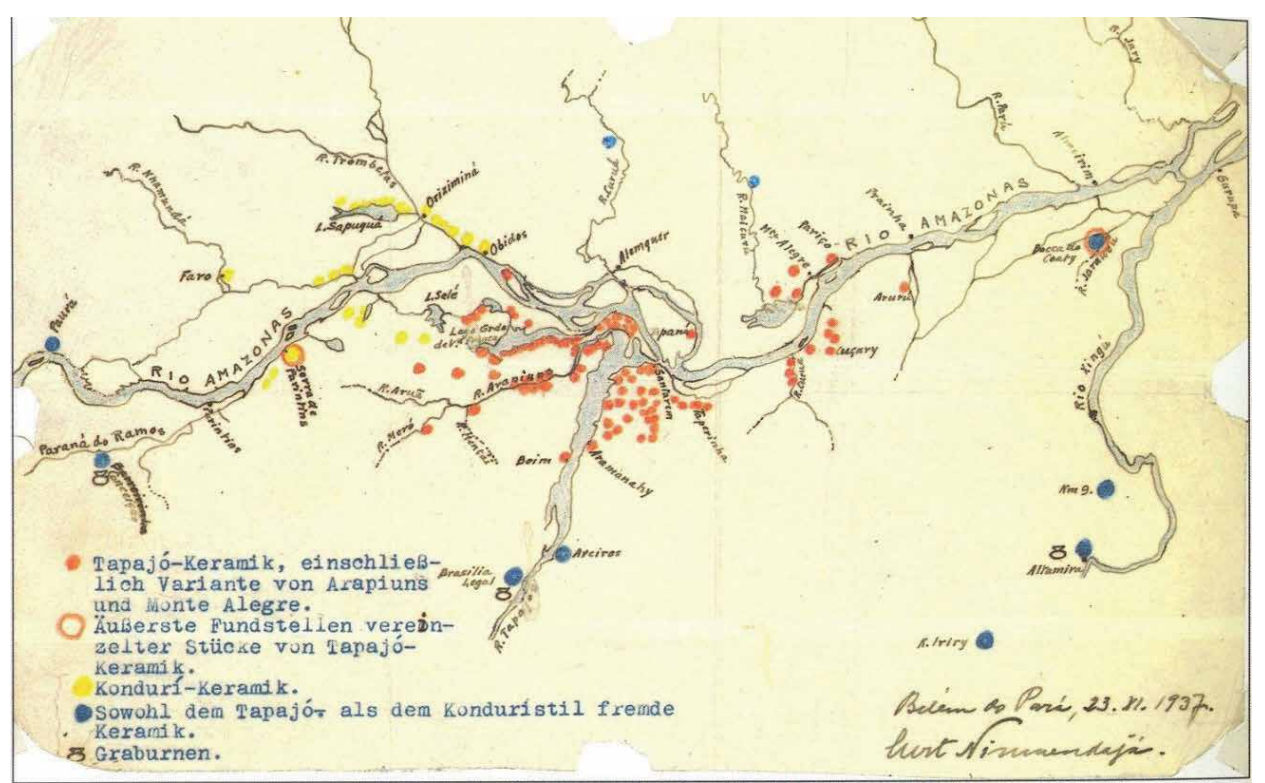

Figure 1.

Map of Terra Preta sites located in the Rio Tapajós area, drawn by Curt Nimuendajú in 1937 (property: Klaus Hilbert).

an outcome of indigenous production. Nimuendajú did not, however, mention whether he assumed this soil was created intentionally or unintentionally. What he did say with certainty and much authority was that all Terra Preta in Amazonia was of indigenous origin. Their formation, he explained, was due to the burning of wood in hearths and not the product of slash-and-burn techniques. He concluded that all dark earth sites were necessarily archeological sites, because of their clear association with Amazonian peoples. He was thereby squarely positioning himself in opposition to the prevailing interpretation that presumed a natural production process at work in Terra Preta genesis.

\section{Terra Preta as an archeological site}

Nimuendajú bequeathed, so to speak, Terra Preta, as a serious research topic to the archeological community. Nevertheless, the academic community was slow to ascertain the value of his contributions.

Betty Meggers and Clifford Evans [17], who eventually picked up where Nimuendajú research had left off, initially began their research inquiries following the work of Charles Hartt [18] and Orville Derby [19] by conducting their research on Marajó Island. They were more interested in the artificial mounds of the Marajoara culture, located on the eastern part of the island, than in Terra Preta.

Initially, the researcher to most fully grasp the gravity of Nimuendajús conclusions regarding Terra Preta was Franciscan priest Protásio (Günther) Frikel. He, in turn, bestowed upon fellow researcher Peter Paul Hilbert [20] the location of more than 40 Terra Preta archeological sites found in the vicinity of the Nhamundá and Trombetas rivers, where Frikel happened to hold a parish seat. Both Hilbert and Frikel associated the potsherds found in and about these sites, again following Nimuendajús groundwork, with the Konduri natives, mentioned in the earliest European chronicles. It is likely that this was the time and place when truly systematic archeological research on Terra Preta first began. 
During the subsequent 10 years, Peter Paul Hilbert located, sample and excavated Terra Preta sites along the middle Amazon River [21]. Later, archeologists associated with the Museu Paranse Emilío Goeldi in Belém, such as Mario Simões, continued Hilbert's work and even intensified the systematic approach towards treating Terra Preta soils as bonafide archeological sites.

Under Betty Meggers' intellectual supervision and financial support, Mário Simões and his assistants, located and pit-tested hundreds of Terra Preta sites, mostly along the Amazonian tributary rivers, such as Rio Negro, Rio Madeira and Rio Tocantins [22]. Recognizing these Terra Preta sites mainly as deposits of discarded refuse (kitchen middens), these archeologists were largely interested in the material cultural remains, such as fragmented ceramic vessels and some rare polished stone implements "thrown away" by their original, ancient owners.

Quantifying and classifying the ceramic fragments by their diagnostic features, such as decoration, style, technique and form of vessel, this group of researchers created a chronology-based model of site categorization and orientation. According to the dominant typological pattern of the ceramic fragments, four cultural traditions were pronounced: Zone-Hachured, Incised Rim, Polychrome and Incised-Punctuated [23].

As most of these habitation sites had a multi-compositional sequence of archeological remains, it was concluded that the ancient Amazonians had a semi-nomadic strategy of survival. This was necessitated, it was argued, by the poor soil conditions [24] which could not support extended agricultural use and therefore, neither a complex society nor a high population rate. Despite the extraordinarily high biodiversity of the Amazon region, it was claimed, the habitants had to change their settled areas periodically, which on one hand, explained the great number of Terra Preta sites and, on the other, their frequent reoccupation by varying archeologically displayed cultures. Betty Meggers elaborates on this paradoxical situation contrasting the Amazonian environment and archeological record with the idea of a "counterfeit paradise" [25].

Donald Lathrop [26], José Brochado [27] and Anna Roosevelt [28] questioned this model of environmental restraint and soil poverty, and its inherent relationship to a low level of social complexity. They defended the opposite scenario of a rich and fertile Amazonian environment, which supported a large population and complex societies, based on powerful and interrelated chiefdoms.

Eduardo Neves, observing a gradually waning academic interest in these debates and marked shift away from topics involving ancient Amazonia as important research terrain, felt impelled to develop an interdisciplinary-driven and internationally-inclusive research strategy. Initially located in the lower Rio Negro and Rio Solimões region, he united a group of scientists from soil sciences, anthropology, biology, ecology, geography, geology and sociology and set out to reinvigorate the research topic of Terra Preta. This wave of researchers made pivotal contributions to the knowledge of Amazonian Archeology, focusing most recently on the question of the origins of early crop domestication [29-35].

Contemporaneously, Michael Heckenberger [36], Denise Schaan [37, 38] and Denise Gomes [39] reignited discussion on the social-power relations expressed by the construction of the monumental structures of the ancient Amazonians. Their primary focus being the massive vertical constructions and their reflection of a high social and cultural complexity. Some examples include the mound builders of Marajó Island, the road builders of the Tapajos, in Alter do Chão, near Santarém, the village builders of the upper Rio Xingu or the geoglyph builder in Rondônia and Acre.

Despite all of these advances in the knowledge of Terra Preta, the subject was generally, yet again, abandoned as a serious research focus and the idea of the "dark earth" as a socio-cultural phenomenon, a massive public works project of horizontal monumentality, or as an expression of high social organization and cultural complexity, was again, relegated to the academic shadows. 


\section{The scientific characterization of Terra Preta de Índio}

While archeologists, and to some extent anthropologists, were becoming more deeply involved in the discussions about the relatively high or low fertility of the Amazon region, investigations into the soil's relation to social complexity, sedentary or semi-nomadic lifestyles or population density remained secondary at best. Other scientists took up the subject of Terra Preta and ran with it. Soil scientists more and more gained international public interest and headlines from prestigious and highly visible publications.

In the early 1980s, research on the "natural scientific character" of the Terras Pretas began in earnest, with the investigations of Eije Erich Pabst and Gerhard Bechtold. They demonstrated, for the first time, that the "black earth" differed dramatically in chemical composition from the typical, reddish oxisols of Amazonia. They re-confirmed the soil's higher $\mathrm{pH}$ value, abundance of organic substances, and much higher nitrogen and phosphorus levels $[2,3]$.

How the Terra Preta de Indio could have come about what the leading question of Eije Erich Pabst, who not only explored the soil properties, but also ethno-pedological aspects. Pabst posited that if one could determine how the Terra Preta was arose from the oxisol, then one could recreate such improved soil enhancements today. As part of his strategy, Pabst visited several ethnic groups in the Amazon region. Here he found quite diverging opinions expressed, including their natural provenance by the Assurini, divine origin, as expressed by an Arawete: "the forest God threw them down from heaven," and an anthropogenic or "man-made" origin. Finally, some Waiapi natives simply explained that they just did not know how the soil came to be [3].

Despite efforts, Pabst was not able to track down a definitive indigenous "recipe" for the manufacture of Terra Preta during his oral interview investigations. Pabst emphasizes, however, that this knowledge once existed, but was lost in the course of the population collapse the Amazonian people suffered during and since the European colonization. The indigenous populations were largely displaced from any favorable localities and generally forced into non-sedentary modes of survival. It is stressed that this historic and unmerited loss of cultural expertise should in no way be equated with native inventive capacity, agricultural competence or claims thereof.

Whether Amazonian black earths were intentionally produced or not, continues to fuel debate. On the one hand are the positions that exclude all intentionality and assume that the Terra Preta resulted to the indigenous lifestyle. This was more or less the opinion of the earliest archeologists and anthropologists conducting research in the twentieth century. On the other hand, positions exist that presume a very clever technique for the deliberate production of humus, even going so far as to suggest specific ceramics were created and then used in the process [40].

Ethnopedological research has shown that there still do indeed exist Amerindian groups whose lifestyle leads directly to the production of Terra Preta [41]. Even without this evidence, it would seem plausible to presume that at least some of the groups formerly living in the Amazon had consciously carried out soil improvement measures by adding a combination of plant charcoal, ceramics and organic matter [42]. Considering the many innovations of the Amazon Indians [43], it is highly unlikely that such a vital adaptive measure and its life-improving results would have totally escaped the conscious awareness of the indigenous population living in Amazonia prior to the arrival of the Europeans.

Moreover, historical studies have shown in other important cases that the ahistorical perspective, that the indigenous products are results of pure happenstance, stems from the faulty view of native peoples as "children of nature"-a perspective 
no longer seriously tenable $[44,45]$. On the contrary, it is almost certain that at least some central components of the Terra Preta required deliberate actions with the purpose of soil enhancement at play. The introduction of charcoal on fields and plantings could be one such element which is current in Amazonia even today, where hearth ashes are strewn on house gardens.

The discovery of the black earths has far-reaching significance for the history of the American continent, as it forces a total revision in estimating number of inhabitants in Amazonia prior to 1492. Because of the high and enduring fertility of Terra Preta, it now seems plausible that the area, before European invasion, would have had a population of several times the currently accepted approximate figure of one million people [46]. Currently a pre-colonial population of 8-10 million is considered quite plausible, based on estimates of the currently known acreage of Amazonia Terra Preta [29].

This also corresponds to historical accounts of the conquistador Francisco de Orellana (1511-1546), whose chronicler Gaspar de Carvajal reported sighting "numerous huge settlements," in the first trip along the Amazon in 1542, especially above the confluence of the Rio Negro. Retrospectively Carvajal specifically praised the people of the Amazon for their extraordinary intelligence and inventiveness, demonstrated in their "wonderful works" [47].

\section{The black earth as climate savior: Wim Sombroek's vision}

In 1992 the Dutch soil scientist Wim Sombroek, who had previously devoted his doctoral thesis to the soils of the Amazon [48], outlined what would prove to be a watershed conceptual breakthrough in the on-going "Terra Preta” story.

In contrast to previous researchers who had enjoined Terra Preta research to ethnological, historical and archeological data, Sombroek infused climatic sciences and concerns into the Terra Preta dialog [49]. Sombroek sought to manufacture Terra Preta Nova or "new" black soil through the introduction of plant charcoal to nutrient-poor soils.

The addition of "Biochar" (plant charcoal) into the soil, sequesters carbon, diminishes the release of carbon dioxide and methane and provides for the soils' extended usefulness. The enhanced soils' new fertility, it was hoped, would provide a nutritional benefit to Amazonian farmers and could also be replicated elsewhere in the tropics.

Sombroek hoped this strategy could act as a counterweight to some of the pressures created by man-made global warming on extant agricultural practices. This combination of Terra Preta research with "climate change" concerns proved to be very ripe recipe indeed for both academic and public consumption and interest. It brought an otherwise obscure issue, a specific soil type, into the international spotlight.

Sombroek's new approach seemed to coincide with a new, global reckoning and awareness of the general climate change issue. In 1990 the United Nation's first IPCC (Intergovernmental Panel on Climate Change) report was issued, followed 2 years later by the U.N.s Rio de Janeiro Earth Summit in June of 1992.

Existing elegantly at the intersection of environmental concern and hard science Terra Preta research took on a new life, birthing a robust research network and garnering unsuspected mainstream media attention. At the helm of this wave of interest was always the charismatic Wim Sombroek, who was duly recognized for bringing attention and funding to the fledgling world of Terra Preta research, he was even honored with a poem at his posthumous memorial service. He died in December 2003 [50]. 


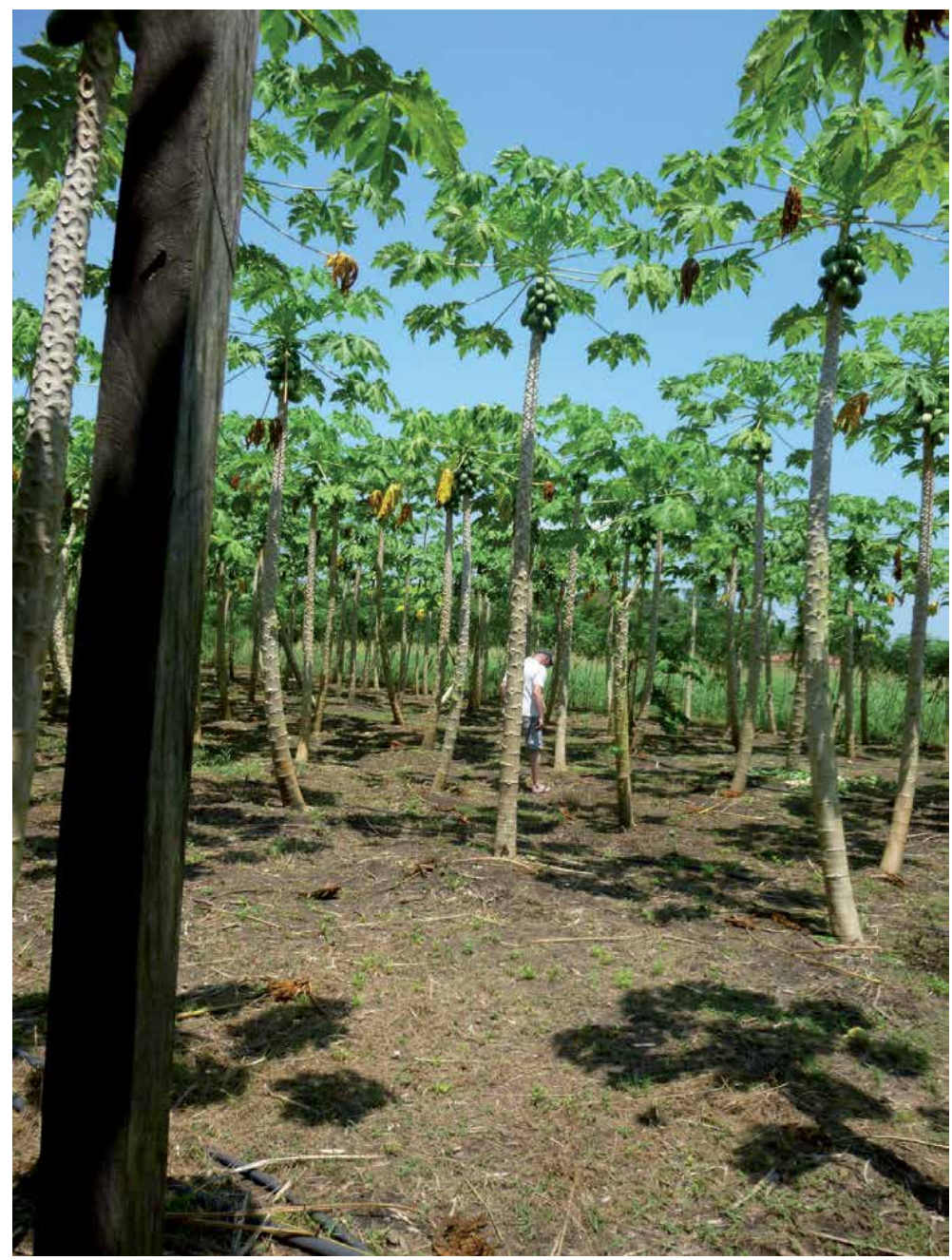

Figure 2.

A Terra Preta site used as papaya-plantation by the local population at the Rio Negro

(Photo: J. Soentgen, 2015).

At the core of Sombroek's research initiative was the goal of providing the inhabitants of Amazonia with a means to bring greater, more reliable harvests by reinstating native soil improvement techniques (Figure 2) [51].

\section{Terra Preta Nova}

Wim Sombroek would probably be a great deal befuddled, if not downright dismayed, by the surprising direction his groundbreaking research has since taken. The Terra Preta Nova, as both a concept and a physical substance, has now been seized up by commercial interests and its being offered on the home improvement/horticultural market right alongside the more widely known "enhanced" home gardening soils.

The rapid and profound proliferation of the Terra Preta model to large-scale commercial and agricultural uses has been supported by organizations like the International Biochar Initiative (BCI). Founded in July 2006 this body aims to support research on and commercialization of biochar suitable for the manufacture of black earth (www.biochar-international.com). 
By promoting the spread of Biochar's use, BCI and its proponents, hope to limit the effects of climate warming through long-term carbon sequestration and increased soil fertility. Their strategy includes political lobbying in addition to their commercial investment. One principal aim is to insert biochar, as sequestered carbon, squarely into global political climate decisions, particularly in the Kyoto protocol and its successor agreements. Further discussion in Bruges [52].

Clearly, the Terra Preta Nova community and its adherents have expanded well beyond the ideas Sombroek originally outlined. Carbon in the form of plant charcoal became more and more the central focus, largely because of the relation to the conversations about the climate issue.

However, it is important to take note that the climate-saving Terra Preta Nova is in many respects much different from the Terra Preta de Indio. First and foremost, it is not simply a "special soil type" that has formed over hundreds of years, but rather a substance, a stuff, that can be deliberately produced through a very specific technical process. Both the incorporation of plant charcoal, but also ceramic components (potsherds), whose porous properties act as a water retainer, were essential to the original Terra Preta recipe. By highlighting only certain characteristics of the Terra Preta properties, (those strictly relatable to climate change) and reframing the soil as a universally applicable and easily "manufacturable" substance, Terra Preta Nova is less an archeologically localized soil and more a commodity.

Through this change of meaning, the redefined Terra Preta can be industrially produced in a manner similar to what Bavarian writer Walter von Molo once imagined in his Murnau diaries as "earth factories." These factories "would produce wonderful wheat soil or whatever was desired, that then would be poured out over swamps, deserts, barren or stony areas of all types. Rains of earth would be allowed to occur with great transport aircraft, earth cloudbursts" [53].

\section{Mythologizing Terra Preta}

Another major component and catalyst for the dispersal of Terra Preta recognition in the public arena was the concurrent "mythologizing" of Terra Preta itself. Some aspects of the history told in this paper have been previously been published in: 'Terra preta de indio': Commodification and Mythification of the Amazonian dark earths [54]. Key phrases, with very little specific meaning, like "ancient knowledge," "from the rainforest" and the like were peppered throughout the commercialization and discussion process. Thus, a "black revolution from the rainforest" was announced, showing the "way out of the world-wide climate and hunger crisis [40]. Likewise, the website of the "international Biochar Initiative reads: "Sustainable biochar is a powerfully simple tool to fight global warming. This 2000-year-old practice converts agricultural waste into a soil enhancer that can hold carbon, boost food security, and discourage deforestation.” (www.biochar.org, accessed August 25, 2018).

German producer PALATERRA emphasizes the aura of mystique and arcane wisdom in their advertising slogan: "The gold of the earth-after the example of the Indians." Another commercial text reads: "More than 1,000 years old-'Terra Preta', the most fertile soil in the world, was produced by the advanced Indian culture of the Amazon from organic material and charcoal. This ancient form of a sustainable recycling economy enables an effective foodstuff cultivation on the infertile rainforest soils (oxisol) for an enormously large population. The production method lapsed into obscurity with the disappearance of the ancient culture years ago. Only around the end of the 20th century archaeologists discovered this 'gold of the earth"' (Figure 3) [55]. 


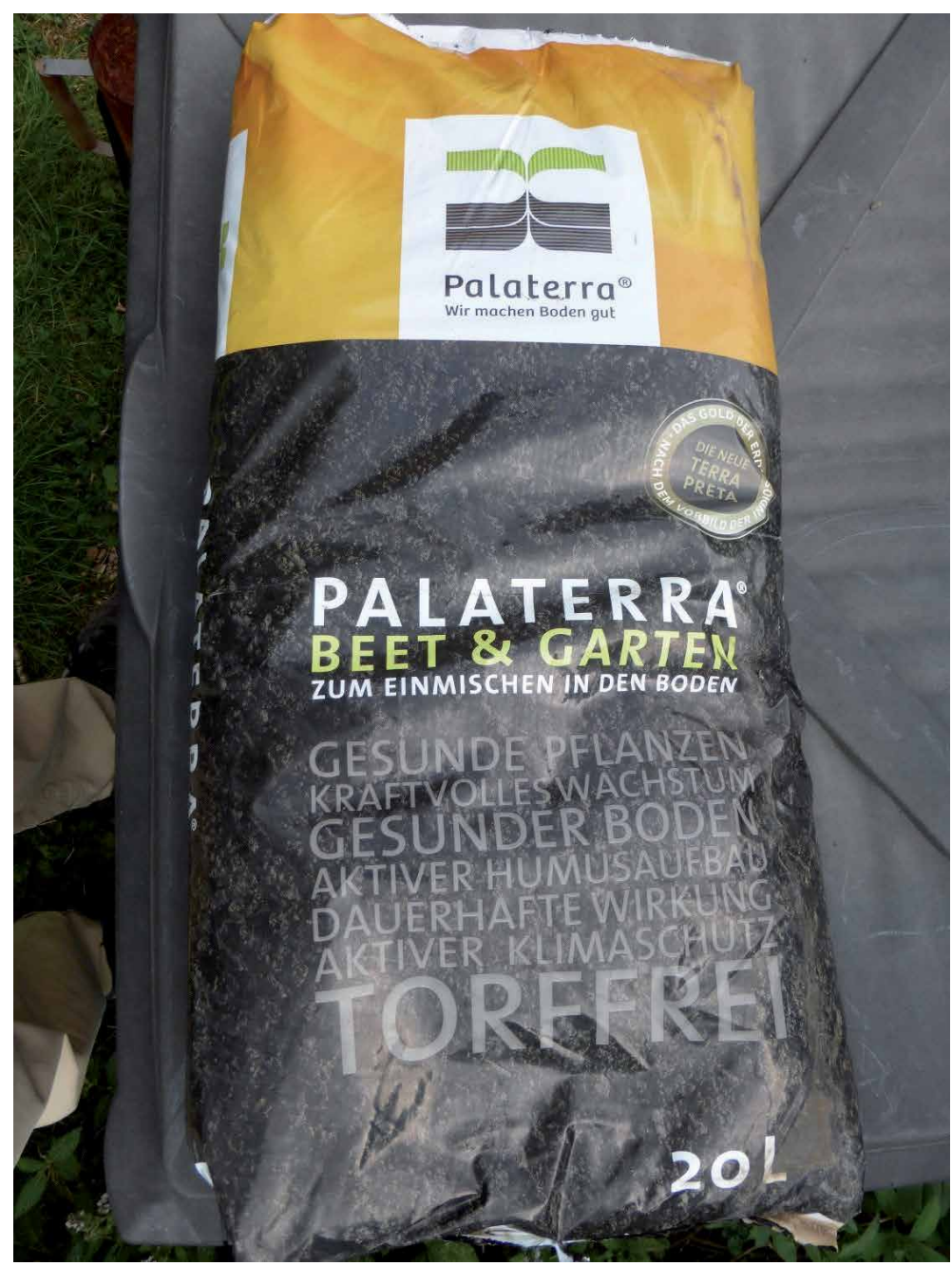

Figure 3.

Terra Preta Nova, produced by PALATERRA (BB-mbh): "The Gold from the Earth, created after the model of the Indians." Provides healthy plants, powerful growth, healthy soil, activates the building of humus, lasting effects, active climate protection, and peat-free soil (Photo: J. Soentgen, 2015).

No doubt, one expects such an enigmatically rich dramatization to improve sales of any commercial product. Nevertheless, similarly “enchanted" language and descriptions are also found in scientific papers, usually in the abstract or introduction.

One of the most renowned Terra Preta researchers in Germany, Bruno Glaser, explains in a scientific article published in the Philosophical Transactions of the Royal Society, that Terra Preta could contribute simultaneously to three of the "Millennium Development Goals. These include mitigating desertification and global warming, as well as maintaining 'biodiversity hotspots" in tropical rainforests [56]. Large-scale use of the "black stuff" would reduce the pressure on primary forests, thereby limiting further degradation of the rainforest while also benefiting the climate.

North American soil researcher Johannes Lehmann likewise considers the introduction of biocharcoal into soils as a "win-win approach" [57] and his colleague David A. Laird goes a step further, describing it as a "win-win-win scenario" [58]. It is worth noting that biocarbon production itself is big business, especially when its manufacture and incorporation as $\mathrm{CO}_{2}$-sequestration becomes part of the emissions certificates market. 
Thus the "vision" of the soil pioneer Wim Sombroek has in some sense become a reality. Carbon storage via the production of Terra Preta is unique amongst strategies being implemented in the fight against climate. Whether it's pumping $\mathrm{CO}_{2}$ underground or the deliberate dispersal of aerosols into the environment, the Terra Preta strategy holds a unique persuasive power by being a modern adaptive measure from ancient pool of knowledge. Not only is a practical strategy being promulgated, but a myth and narrative is constructed that functions alongside the researchdirecting paradigm [45].

For such narratives and meaningful tales, it is characteristic to frame the saving agent as a return or resurrection of something ancient, prehistoric. It harkens back, painting a picture of archaic conditions, people, and gods in order to orient and motivate the act and agency of present-day protagonists [59], (on the term "myth" see also Christine Schmitz [60]). In our case, it is the ancient Amazonian indigenous population who was in possession of the secret to make fertile soil out of infertile ground. However, the ability of the traditional societies was based not only on knowledge, but also on wisdom. Therefore, it is valid to reactivate this now in order to find a way out a potential ecological crisis.

The conundrum presented by suggesting Terra Preta, or any other technical means, as a quick-and-easy, one-size-fits-all way solution in the combat against the steady on-set of global warming is that is relegates the role of politics and political will to the sidelines. If the political will to implement these technical solutions is not extant, then they can do very little on their own merit. Nevertheless, at the same time, the mythologizing is functional and can have real practical results. For one, it might help in convincing funding agencies. However, more importantly can spur the research community and inspire younger generations of researchers to enter the academic fray (see Jürgen Frese [61] on the function of myths in groups).

A report on a Terra Preta symposium, published in Nature, one of the most prestigious scientific journals, commented on a meeting of soil scientists researching Terra Preta describing how: "more than one eye in the room had a distinctly evangelical gleam" [62].

The same journal, Nature, is gladly supportive of spinning the Terra Preta mythos. In 2015, for example, an extended article was published [63] in which Terra Preta was praised for not only being a remedy for climate change, but also a nutrient and water reservoir and even an absorbing medium for poisons. It worth noting that Terra Preta Nova is now being produced in the United States and Europe (a report by the International Biochar Initiative names of 326 firms that are active in production: http://www.biochar-international.org/State_of_Industry_2015, accessed on June 22, 2019).

As an area of scientific research, Terra Preta is firmly established. By the end of September 2018, 1.230 scientific papers with titles containing the keywords "Terra Preta" and "biochar" had been published (online research in the ISI Web of Science on 24 September 2018). The academic fervor is not groundless, for it is now well documented that the introduction of biochar does indeed have soil-improving traits and does increase agricultural yields. In a limited sense, it contributes to climate protection, especially in Europe, if biocharcoal replaces compost [64]. Terras Pretas have also inspired research into novel methods of waste-water treatment [65].

The claim that newly-produced Terra Preta Nova can sequester carbon in massive amounts has not yet been sufficiently confirmed by studies. Now, there are only a few concrete field studies proving that the carbon particles really do remain in the soil for a substantial period and that the carbon bonding is not overcompensated through other processes [66]. Health is another concern when discussing the implementation of biochar, due to increased smoke levels (see a new analysis of smoke from burned plant material: Iinuma et al. [67], and products from the pyrolysis 
processes can cause adverse health effects. In addition, there are other competing uses of biomass to consider $[68,69]$.

In addition to these aforementioned concerns there is the need to stress the enormous profit incentives many large companies inevitably take into consideration when championing the integration of Terra Preta Nova and, respectively, biocharcoal in the $\mathrm{CO}_{2}$ markets [66].

However, one enormous critically concerning issues is that it is often not possible to verify that biochar production is sustainably produced and does not stem directly from sources of illegal deforestation [52]. Accordingly, the Biochar activists are criticized by other NGOs, most notably Biofuelwatch [70, 71].

From the perspective of a history of knowledge and responsible use thereof, in closing, a consideration of the ethics of knowledge is deemed appropriate.

\section{Indigenous knowledge and ethics}

The modern Terra Preta research would have never begun without indigenous knowledge. There is a clear and direct link between the Terra Preta archeological sites and their characteristics that inform the modern search developments. Even the specific plants most adaptable to Terra Preta practices is delivered to us from traditional indigenous knowledge. Although observational evidence supports the idea that the modern-day indigenous people of Amazonia produce and understand the Terra Preta process, the idea remains debated [41, 72]. In addition, it is highly unlikely that the technically proficient indigenous people of Amazonia would have left their soil quality and conditions, so important for their very survival, entirely to chance.

Given this state of affairs, it would justify and correct that the intellectual and financial benefit gained through the research and manufacture of Terra Preta goes to not only the researchers and manufacturers, but also to the local inhabitants. Although certainly individual players (in the Terra Preta research and commercial diaspora) have exhibited the moral responsibility and principled outlook of Wim Sombroek and have indeed contributed to the benefit and well-being of the present-day inhabitants of Amazonia, it unfortunately remains the exception in the industry.

As the locally sourced Terra Preta de Indio mutated into the globally distributed and produced Terra Preta Nova, the benefits to the local communities seems to have gone missing in the equation. Generally speaking, the present-day inhabitants of Amazonia are excluded from participating in the profit-sharing made possible by the industrialized production of Terra Preta and biochar. Once might argue that they do indeed also benefit from the fact that climate change is being combatted. This remains a very abstract and long-term benefit however and means much less to generations living today, regardless of the efficacy the native technology does hold for negating the onset of human-caused climate changes.

Participation in both promulgation of and benefits from Terra Preta practices by native groups is essential. The current exploitative and non-collaborative methods used both scientifically and commercially disregard the core principles that were established for the reasonable protection of indigenous knowledge (World Intellectual Property Organization: Wipo Publication 920E). Modern suppliers and producers of Tarra Preta products insist on emphasizing the fact that their product was produced with the insight of "traditional indigenous knowledge". In this instance, therefore, the principle of "equitable benefit sharing" [73] (Wipo Publication 920E, p. 23) must be applied, for there are still remaining native peoples along the Amazon who continue to know and apply this knowledge [74, 75]. 


\section{Conclusions}

At present, it seems that neither the commercial manufacturers nor the science lobbyists have developed any plan of "benefit sharing" with the local populations. The situation takes on an aura of neo-colonial tendencies under the guise of protecting the world climate. In this scenario, the Terra Preta de Indio is today a "Terra Preta do gringo"; a black earth of English-speaking and publishing Northern-hemispheric researchers and for-profit companies. Incredibly, the patent process is now well underway where several companies already applying with the European Patent Office to protect “their" Terra Preta products (see European Patent 2188230B1). In Germany, Terra Preta, and Terra Preta Mulata are already registered words or trademarks (registered with the Terra Preta $\mathrm{GmbH}$, Berlin). Clearly, these are not the product of European ingenuity, but the intellectual achievements of the people of the Amazon.

In blatant, unblushing irony, the same companies racing to register with the patent office continue to advertise the mystical "rainforest" as their products' point of origin. Major adjustments must be in the current profit and knowledge-sharing exchanges surrounding Terra Preta. Although efforts against debilitating climate change is certainly necessary and noble, shorter term economic value-setting and the absolute tangible benefits of disseminating Terra Preta practices should not continue to only benefit a very small and well-educated citizens of North American and European industrialized countries.

\section{Acknowledgements}

We would like to thank Norman Madarasz and John G. O'Donnell for their valuable suggestions as well as the German Academic Exchange Service (DAAD). This study was financed in part by the Coordenação de Aperfeiçoamento de Pessoal de Nivel Superior-Brasil (CAPES)_Finance Code 001 and CNPq for funding research on Terra Preta.

\section{Author details}

Klaus Hilbert ${ }^{1 *}$ and Jens Soentgen ${ }^{2}$

1 Escola de Humanidades, Pontifícia Universidade Católica do Rio Grande do Sul (PUCRS), Porto Alegre, Brazil

2 Wissenschaftszentrum Umwelt (WZU), Universität Augsburg, Augsburg, Germany

*Address all correspondence to: hilbert@pucrs.br

IntechOpen

(C) 2020 The Author(s). Licensee IntechOpen. This chapter is distributed under the terms of the Creative Commons Attribution License (http://creativecommons.org/licenses/ by/3.0), which permits unrestricted use, distribution, and reproduction in any medium, provided the original work is properly cited. (cc) BY 
From the "Terra Preta de Indio" to the "Terra Preta do Gringo": A History of Knowledge... DOI: http://dx.doi.org/10.5772/intechopen.93354

\section{References}

[1] Denevan W. A bluff model of riverine settlement in prehistoric Amazonia. Annals of the Association of American Geographers. 1996;86(4):369-385

[2] Zech W, Pabst E, Bechtolt G. Analytische Kennzeichnung der Terra preta do índio. Mitteilungen der Deutschen Bodenkundlichen Gesellschaft. 1979;29:709-716

[3] Pabst E. Terra preta. Ein Beitrag zur Genese-Diskussion auf der Basis von Geländearbeiten von Tupí-Völkern Amazoniens [thesis]. Gesamthochschule University Kassel; 1993

[4] Woods W, Denevan W. Amazonian dark earths: The first century of reports. In: Woods W, Teixeira CG, Lehmann J, Steiner C, WinklerPrins A, editors. Amazonian Dark Earths. Wim Sombroek's Vision. Springer Science; 2009. pp. 1-14

[5] Fraser J, Clement CR. Dark earths and manioc cultivation in Central Amazonia: A window on pre-Columbian agricultural system? Boletim do Museu Paraense Emílio Goeldi Ciências Humanas, Belém. 2008;3(2):175-194

[6] Harris M. Life on the Amazon. The Anthropology of a Brazilian Peasant Village. Oxford: University Press; 2000

[7] Kawa NC. Amazonia in the Anthropocene. People, Soils, Plants, Forests. Austin: University of Texas Press; 2016

[8] Frikel P. Agricultura dos índios Mundurukú. Boletim do Museu Paraense Emílio Goeldi, nova série, Antropologia, Belém do Pará1959. p. 4

[9] Cunha MC. "Culture” and Culture. Traditional Knowledge and Intellectual Rights. Chicago: Prickly Paradigm Press; 2009
[10] Vale F, Schaefer C, Vieira da Costa JA. Etnopedologia e transferência de conhecimento: Diálogos entre os saberes indígena e técnico na Terra Indígena Malacacheta, Roraima. Revista Brasileira das Ciências do Solo. 2007;31(2):403-412

[11] Brazil SH. The Amazons and the Coast. New York: Charles Scribners; 1879

[12] Katzer F. Grundzüge der Geologie des unteren Amazonasgebietes (des Staates Pará in Brasilien). Leipzig: Verlag von Max Weg; 1903

[13] Baldus H. Curt Nimuendajú, 18831945. American Anthropologist, N.S. 1946;48:238-243

[14] Nimuendajú C. Os Tapajós. Boletim do Museu Paraense Emílio Goeldi, Belém do Pará. 1949;10:93-106

[15] Baldus H. Tonscherbenfunde in Nordparana. Archiv für Völkerkunde. 1951;6:1-19

[16] Falesi IC. Soils of the Brazilian Amazon. In: Wagley C, editor. Man in the Amazon. Gainsville: University Press of Florida; 1974. pp. 201-229

[17] Meggers BJ, Evans C. Archaeological Investigations at the Mouth of the Amazon. Washington D.C: Bureau of American Ethnologie; 1957. p. 167

[18] Hartt CF. Ancient Indian Pottery of Marajó, Brazil. American Naturalist, New York. 1871;5(5):259-271

[19] Derby O. The artificial mounds on the island of Marajó. Brazil. American Naturalist, New York. 1879;13(4):224-229

[20] Hilbert P P. A cerâmica arqueológica da região de Oriximiná. Belém, Pará, Brasil: Instituto de Antropologia e Etnologia do Pará. Museu Goeldi. 1955;9 
[21] Hilbert PP. Archäologische Untersuchungen am mittleren Amazonas: Beiträge zur Vorgeschichte des südamerikanischen Tieflandes. (Marburger Studien zur Völkerkunde). Berlin: Reimer Verlag; 1968

[22] Simões MF. Pesquisa e cadastro de sítios arqueológicos na Amazônia Legal Brasileira 1978-1982. Belém: Publicações Avulsas. Museu Paraense Emilio Goeldi; 1983. p. 38

[23] Meggers BJ, Evans C. An experimental formulation of horizon styles in the tropical forest area of South America. In: Lothrop SK et al., editors. Essays in Pre-Columbian Art and Archaeology. Cambridge, Mass; 1961. pp. 372-388

[24] Sioli H, editor. The Amazon: Limnology and Landscape Ecology of a Mighty Tropical River and its Basin. Dordrecht: Kluwer Academic Publishers Group; 1984

[25] Meggers BJ. Amazonia. Man and Culture in a Counterfeit Paradise. Chicago-New York: Aldine Aterton; 1971

[26] Lathrap DW. The Upper Amazon. London: Thames and Hudson; 1970

[27] Brochado JP. An Ecological Model of the Spread of Pottery and Agriculture into Eastern South America [thesis]. Urbana-Champaign: University of Illinois at Urbana-Champaign; 1984

[28] Roosevelt AC. Moundbuilders of the Amazon. Geophysical Archaeology on Marajó Island, Brazil. Academic Press; 1991

[29] Clement CR, Denevan WM, Heckenberger MJ, Junqueira AB, Neves EG, Teixeira WG, et al. The domestication of Amazonia before European conquest. Proceedings of the Royal Society B: Biological Sciences. 2015;282(1812):32-40
[30] McEwan C, Barreto C, Neves EG. Unknown Amazon. Culture and Nature in Ancient Brazil. London: The British Museum Press; 2001

[31] Pereira E, Guapindaia V, editors. Arqueologia Amazônica. Belém: MPEG; IPHAN; SECULT; 2010

[32] Neves EG. Arqueologia da

Amazônia. Rio de Janeiro: Jorge Zahar Editora; 2006

[33] Hilbert L, Neves EG, Publiese F, Whitney B, Shock M, Veasey E, et al. Evidence for midHolocene Rice domestication in the Americas. Nature: Ecology \& Evolution. 2017;1:1693-1698

[34] Alves DT. Dark Earth Plant Management in the Lower Tapajós [thesis]. Exeter: University of Exeter; 2018

[35] Watling J et al. Direct archaeological evidence for southwestern Amazonia as an early plant domestication and food production Centre. PLoS One. 2018;13(7):e0199868

[36] Heckenberger MJ. The Ecology of Power. Culture, Place, and Personhood in the Southern Amazon, A.D. 10002000. New York and London: Routledge; 2005

[37] Schaan DP. The Camutins Chiefdom: Rise and Development of Complex Societies on Marajó Island, Brazilian Amazon [thesis]. University of Pittsburgh; 2004

[38] Schaan DP. Sacred Geographies of Ancient Amazonia: Historical Ecology of Social Complexity. Walnut Creek: Left Coast Press; 2011

[39] Gomes DC. Padrões de organização comunitária no Baixo Tapajós: o desenvolvimento do Formativo na área de Santarém, PA [thesis]. Universidade de São Paulo; 2005 
From the "Terra Preta de Indio" to the "Terra Preta do Gringo": A History of Knowledge... DOI: http://dx.doi.org/10.5772/intechopen.93354

[40] Scheub U, Pieplow H, Schmidt H-P. Terra preta. Die schwarze Revolution aus dem Regenwald. 4th ed. München: Oekom; 2013

[41] Schmidt M. Amazonian dark earths: Pathways to sustainable development in tropical rainforests? Boletim do Museu Paraense Emílio Goeldi, Ciências Humanas Belém. 2013;8(1):11-38

[42] Brochado JP. Alimentação na floresta tropical. A analogia Etnográfica na reconstrução da alimentação por meio de evidências indiretas, a mandioca na floresta tropical. In: Revista do Instituto de Filosofia e Ciências Humanas. Porto Alegre: UFRGS; 1977. p. 4

[43] Nordenskiöld E. The American Indian as an inventor. The Journal of the Royal Anthropological Institute of Great Britain and Ireland. 1929;59:273-309

[44] Soentgen J. Die Rolle indigenen Wissens in der Geschichte des Kautschuks. Technikgeschichte. 2013;80(4):295-324

[45] Soentgen J, Hilbert K. Terra Preta als politischer Mythos: Das Wunder aus dem Regenwald, Scheidewege. Zeitschrift für Skeptisches Denken. 2016;45:265-275

[46] Smith N. Anthrosols and human carrying capacity in Amazonia. Annals of the Association of American Geographers. 1980;70(4):553-566

[47] de Carvajal FG. In: Medina JT, editor. Descubrimiento del Río de las Amazonas. Según la relación hasta ahora inédita de Fr. Gaspar de Carvajal con otros documentos referentes á Francisco de Orellana y Sus Companeros. Sevilla: Imprenta de E. Rasco, Bustos Tavera; 1894

[48] Sombroek W. Amazon Soils. A Reconnaissance of the Soils of the Brazilian Amazon Region. Wageningen: Center for Agricultural Publications and Documentation; 1966
[49] Sombroek W. Biomass carbon storage in the Amazon ecosystems. Interciencia. 1992;17(5):269-272

[50] Woods W, Teixeira CG, Lehmann J, Steiner C, WinklerPrins A, Rebellato L, editors. Amazonian Dark Earths. Wim Sombroek's Vision. Springer Science; 2009

[51] Sombroek W, Kern DC, Rodrigues T, Silva Cravo M, Cunha JT, Woods W, et al. Terra preta and Terra Mulata, Pre-Colombian Kitchen Middens and Agricultural Fields, their Sustainability and Replication. In: Dudal R, editor. Symposium 18, Anthropogenic Factors of Soil Formation, 17th World Congress of Soil Science, Bangkok; August 2002. 2002. pp. 1-9

[52] Bruges J. The Biochar Debate. Charcoal's Potential to Reverse Climate Change and Build Soil Fertility. Foxhole Dartington, Totnes, Devon: Green Books; 2009

[53] von Molo W. Wo ich Frieden fand. Erlebnisse und Erinnerungen. München: Braun und Schneider; 1959

[54] Soentgen J, Hilbert K, GrooteBidlingmaier C, Herzog-Schröder G, Pabst E, Timpf S. Terra Preta de Índio: Commodification and Mythification of the Amazonian Dark Earths. GAIA: Ecological Perspectives for Science and Society. 2017;26(2):136-143

[55] Palaterra Betriebs-und

Beteilungsungsgesellschaft mbH 2014: Informationsprospekt. Royal Society: Geoengineering the Climate: Science, Governance and Uncertainty. London: The Royal Society; 2009

[56] Glaser B. Prehistorically modified soils of Central Amazonia: A model for sustainable agriculture in the twenty-first century. Philosophical Transactions of the Royal Society B. 2007;362(1478):187-196 
[57] Lehmann J. Biological carbon sequestration must and can be a winwin approach. An editorial comment. Climatic Change. 2009;97:459-463

[58] Laird DA. The charcoal vision: A win-win-win scenario for simultaneously producing bioenergy, permanently sequestering carbon, while improving soil and water quality. Agronomy Journal. 2008;100(1):178-181

[59] Wülfing W. Mythen und Legenden. In: Küttler W, Rüsen J, Schulin E, editors. Geschichtsdiskurs: Die Epoche der Historisierung. Frankfurt am Main; 1997. pp. $159-172$

[60] Schmitz C. Mythos. A.

Begriffsbestimmung. In: Schöllgen G, Brakmann H, de Blaauw S, Fuhrer T, Leppin H, Löhr, W, Speyer W, editors. Reallexikon für Antike und Christentum. Stuttgart: Verlag Anton Hiersemann; 2013. pp. 471-474

[61] Frese J. IntellektuellenAssoziationen. In: Faber R, HolsteC, editors.ZurSoziologiemoderner Intellektuellenassoziation, Kreise, Gruppen, Bünde. Würzburg: Königshausen und Neumann; 2000. pp. 441-462

[62] Marris E. Black is the new green. Nature. 2006;442(7103):624-626

[63] Cernansky R. State-of-the-art-soil. A charcoal rich product called biochar could boost agricultural fields and control pollution scientists is putting the trendy substance to the test. Nature. 2015;517:258-260

[64] Kammann C, Kühnel Y, von Bredow C, Gößling J. Abschlussbericht desProjekts:'C-Sequestrierungspotential und Eignung von Torfersatzstoffen, Hergestellt aus Produkten der Landschaftspflege und Biochar'. Justus-Liebig Universität Gießen, Institut für Pflanzenökologie (Manuscript); 2010
[65] Rakelmann U, Werner T, Li Z, Schonlau H, Giese T, Augustin K, et al. Die Abwasserentsorgung als Kohlenstoffsenke? Wissenschaftliche Zeitschrift für Technik und Ökonomik der Wasserwirtschaft. 2009;6:44-50

[66] Ernsting A. Biochar-a climate smart solution? Report. Aachen: Misereor. Available from: https://www. misereor.org/fileadmin//user_upload/ misereor_org/Publications/englisch/ report-2-biochar.pdf [Accessed: 31 August 2018]

[67] Iinuma Y, Brüggemann E, Gnauk T, Müller K, Andreae MO, Helas G, et al. Source characterization of biomass burning particles: The combustion of selected European conifers, African hardwood, savannah grass, and German and Indonesian peat. Journal of Geophysical Research. 2007;112:D08209. DOI: 10.1029/2006JD007120

[68] Scholz SM, Sembres T, Roberts K, Whitman T, Kelpie W, Lehmann J. Biochar Systems for Smallholders in Developing Countries. Leveraging Current Knowledge and Exploring Future Potential for Climate-Smart Agriculture. Washington DC: The World Bank; 2014

[69] Rattan L. Managing soils for food security and climate change. Journal of Crop Improvement. 2007;19:49-71

[70] Biofuelwatch. 2013. Factsheet. Available from: http://www. biofuelwatch.org.uk/wp-content/ uploads/Biochar-3-pager7.pdf

[Accessed: 28 August 2018]

[71] The BA, Solution B. Carbon Farming and Climate Change. Gabriola Island, Canada: New Society Publishers; 2010

[72] Hecht SB, Posey DA. Preliminary results on soil management techniques of the Kayapó Indians. In: Posey DA, 
From the "Terra Preta de Indio" to the "Terra Preta do Gringo": A History of Knowledge...

DOI: http://dx.doi.org/10.5772/intechopen.93354

Balée W, editors. Resource Management

in Amazonia: Indigenous and Folk

Strategies (Advances in Economic

Botany). Vol. 7. New York: New York

Botanical Garden; 1989. pp. 174-188

[73] Wipo Publication 920E. World

Intellectual Property Organization:

Intellectual Property and Traditional

Knowledge. Booklet No 2. Available

from: http://www.wipo.int/edocs/

pubdocs/en/tk/920/wipo_pub_920.pdf

[Accessed: 23 June 2018]

[74] Posey DA. Biodiversity, genetic resources, and indigenous peoples in Amazonia: $(\mathrm{Re})$ discovering the wealth of traditional resources of native Amazonians. In: Hall A, editor.

Amazonia at the Crossroads. The Challenge of Sustainable Development. London: Institute for Latin American

Studies; 2000. pp. 188-204

[75] Denevan W. Cultivated Landscapes of Native Amazonia and the Andes.

Oxford: University Press; 2002 



\title{
Chapter 8
}

\section{Ecology as Cosmology: Animal Myths of Amazonia}

\author{
Alexandre Guida Navarro
}

\begin{abstract}
Amazonian ethnography is relied on the creation of the world by Animals as the Anaconda, considered an ancestral creator. The history that myths tell is that the Amazon River is the metaphor of an Anaconda because it has meanders like this snake and it is a large reptile-like the river itself. As far as Archaeology, many of these myths were represented in archaeological ceramic as Cosmology metaphor. Some animals like birds were presented as a ceramic rattle which noise is a shamanic trait of Amazonian Indian Cosmology. This chapter shows how the Stilt Villagers of the Eastern Amazonian built their Cosmology based on the Animals of their environment's Ecology.
\end{abstract}

Keywords: cosmology, ecology, prehistoric art, stilt villages, Amazon

\section{Introduction: myths and animals}

Myths provide cultural explanations for understanding the world. It contains creation stories and explains all the elements necessary to understand the universe [1]. They are memory, a vehicle of cosmological message and identity [2]. In Amazon, the myths rely on the animal metaphor as the social component of the cosmology [3]. As far as Archaeology, the myth usually is represented in the ceramic support as Art.

Many archaeologists think that the art should be understood within a much broader semantic significance: (a) artistic manifestations, functioning as symbolism; (b) cosmological message vehicles serving to communicate social, political and religious values of a certain society; (c) or art to be on its own, as a social cohesion form or political control strategy, to demonstrate these same values to other peoples, as a form of ethnic identity [4].

Artistic manifestations filled the precolonial Amazon and invited the archaeologists to study these themes [5]. However, it is still difficult to define the diverse variations of the art types of these societies, partly because there is no conceptual standardisation [6], or partly as the variability is not fully known, yet, due to the complexity and enormous size of the precolonial Amazon [7].

However, many important paths have already been walked. Among the theoretical assumptions about art that found greater development in Amazon is the structuralist school and its variations, mainly through the works of Lévi-Strauss who regarded the art as an expression of communication and sociability [8]. Gell [9] saw the artefacts as social and non-static agents, which highlighted the activities they were involved, such as rituals. In those magic gives a more pronounced property to the objects, what the author called incantation technologies. To understand the 
indigenous art the Amerindian Perspectivism [10], also under structuralist influence, has been used successfully, especially making the shamanistic relationships between men and animals more noticeable.

\section{The stilt houses of eastern Amazon}

Having presented above the definition of art and studies in the Amazon, this text addresses the art in the Brazilian precolonial stilt villages of eastern Amazon societies, temporally between the 8th to the 10th A.D., thus, they no longer existed during the period of European conquest in the 16th century.

The stilt villages were ancient dwellings (palafittes) built on piles over a lake. Stumps or trunks of trees served as a support for the superior buildings of the
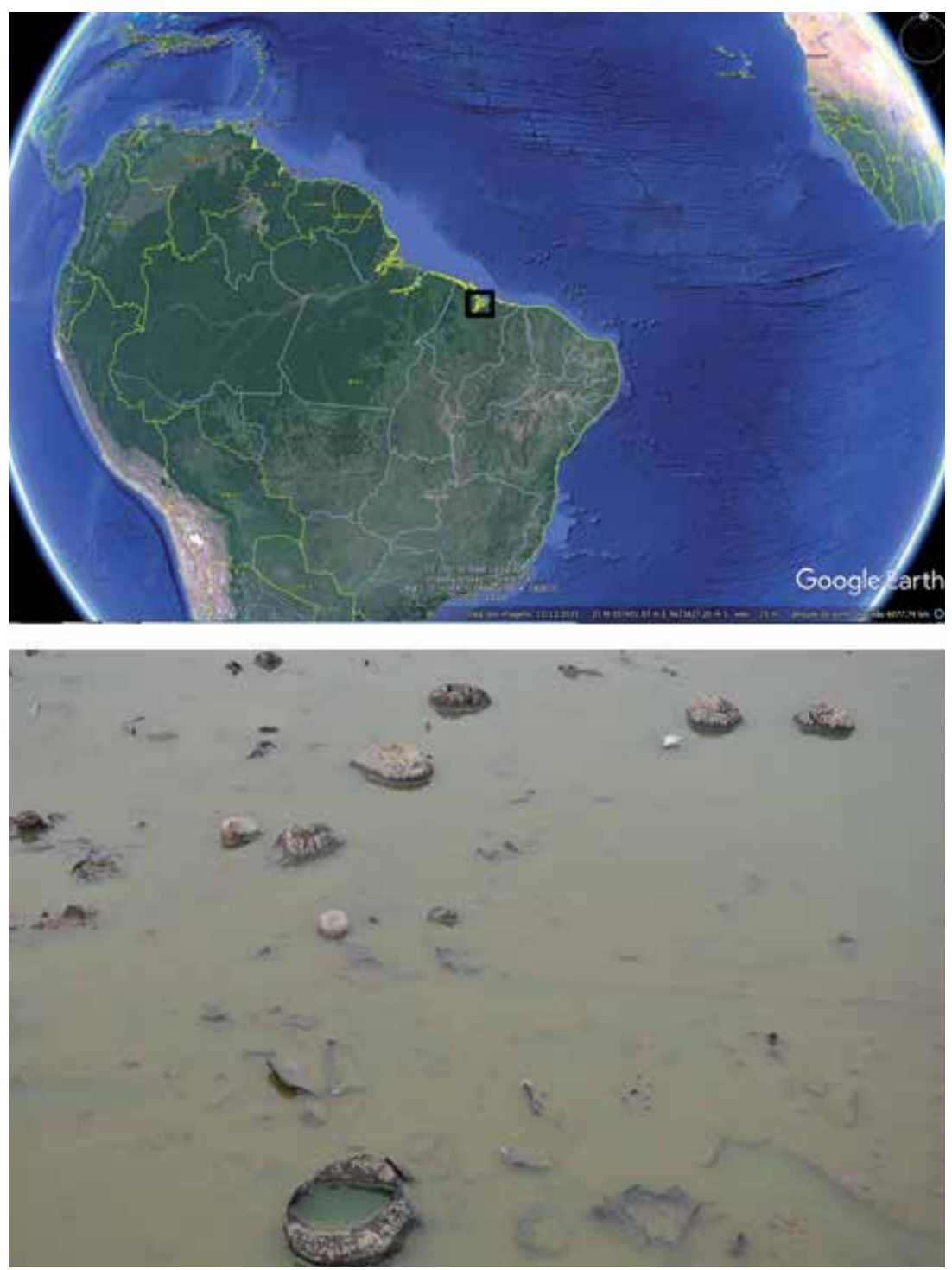

Figure 1.

Map of the stilt villages in eastern Amazon ad apparent stilts at the time of the drought. Photography: Alexandre Navarro. 
villages [11]. Traces of these wooden stilts are located within rivers and lakes and are shown only at the time of drought. This normally corresponds annually to October to December [12]. Rest of the year, the palafittes are submerged. In some of these prehistoric sites, such as Coqueiro, there can be over three thousand stilts [13]. This type of archaeological sites has been described in isolated cases in South America, namely in the reports of Amerigo Vespucci in 1499 on communities that lived in Stilt Houses on the Venezuelan coast. The stilt villages also appear in the reports of Amazon river mouth and from the Upper Amazon, near Peru [14]. However, as known today, the prehistoric palafittes of Maranhão are the only ones preserved, in the entire American continent (Figure 1). The ancient stilt villages have been also common in the prehistory of Europe during the Neolithic age, for instance in northern Italy and Switzerland (Lake Constanza).

In the Amazonian eastern coast, the geographical area where the Stilt Houses are located is called Baixada Maranhense, in the State of Maranhão, Brazil. This region comprises approximately an area of $20,000 \mathrm{~km}^{2}$ within the legal Amazon and has more than 500,000 inhabitants. People are very poor, with the lowest HDI indices not only in Maranhão state but also in Brazil as a whole. Baixada Maranhense population lives from the subsistence of traditional agriculture, fishing, keeping small animals and growing vegetables. Santa Helena, Penalva, Pinheiro, and Viana are the main cities in this area.

It is assumed that the easy availability of food in the form of a rich variety of fish created a favourable situation for the sedentary housing of the human groups that occupied the region. It is also likely that these dwellings had defensive purposes. It also notable that the oxygen-free aquatic environment preserved the artefacts in such a way that even allowed the ink on the artefacts to remain visible. The straws of the cottage walls and roofs and utensils made from the hardwood, like oars and indigenous weapons (bordunas), also resisted the decomposition process over time.

The most striking Stilt House artefacts are the small objects, like plates and bowls, which most likely were used in serving foods or liquids in rituals. These utensils were made of good quality clay burnt at a very high temperature, giving rise to high-quality vessels. These small ceramics had very complex painted decoration with geometric motifs made with precision, indicating also that these vessels were used in rituals.

\section{The animal myths in ceramics}

These pottery utensils formed an information channel of the social and ideological structure among the members of the society. As regards to their form and decoration, these vessels reflect mythical themes and/or were used in rituals [15]. Archaeologists agree that the ceramics reflect the culture of a society and that the main social changes affect the production and types of vessels [16]. So, the ceramics are vehicles of expression of ideological content. The most likely evidence of this is that they were painted, decorated, incised, modelled, with plastic decoration, aiming to reflect mythical or ideological themes.

Therefore, the art interpretations are cultural and in this sense adhere to rigid systems of social conviviality. In prehistory, its main material vehicles are smallscale art that is moveable (mobiliary art), such as decorated figurines and pottery and feather art; the graphic art, with parietal art and rock graphics and body painting, the latter very important, because, in general, it demonstrates the status of the individual, as in the case of chiefs and other leaders who had a high social position [17]. Indigenous art is therefore the result of the identity relationship [18] and social conviviality between the indigenous groups [19]. 
Animal forms are recurring in the art of the Stilt Houses, being the most persistently various birds, but especially owls. The monkey and the jaguar are mostly illustrated Mammals, but also Amphibians (especially frogs) and reptiles (mainly snakes) are common. These animals form the appliques and figurines and are associated with indigenous myths some of which have been described by the missionary chroniclers of the 16th and 17th centuries and by anthropologists when working among indigenous Amazonian communities from the 19th century onward.

The ethnographic analogy shows that myths associating the snake to the creation, such as the canoe-snake, mother of the fish, for example, are recurring in Amazonian cosmologies [20]. Whereas the king vulture is mentioned in Amazonian ethnography as a bird belonging to the realm of the dead.

Anaconda is a shamanic animal in the Amazon. Some peculiar ecological characteristics of these snakes could have attracted the attention of the indigenous people, as the specimens can reach up to $10 \mathrm{~m}$ in length and weigh more than $200 \mathrm{~kg}$, is the heaviest animal in the Amazon. Also, the Anaconda has pale skin with black drawings served as an iconographic orientation, efficient camouflage, speed of attack in the water and lethargy on land, active at night, sensitive tongue for predate [21], powerful teeth and muscles and the females are larger and more aggressive than the males, predator of large mammals such as jaguars, deer and tapirs [22].

The indigenous peoples we mentioned in this text are the Tukano of the Tukano linguistic family who lives in the northwest of the Amazon; the Pano family Shipino who live between the Amazon and the Ucayali river in Peru; the Tupi peoples who have a wide dispersion in the lowlands of South America and countries like Bolivia, Uruguay and Argentina; the Waujá who live in the Xingu and belong to the Arawak family; the Panare and Timbira that are groups of the Jê family of Central Brazil and the already extinct groups of which we only have archaeological material such as the beautiful ceramic pots Tapajó and Konduri from the Lower Amazon in Brazil. Finally, there are the Warao who still live on stilts in Venezuela.

Regarding the cosmological aspects, the characteristics described above could contribute to the association of this powerful animal with the creation myths of the world and humanity. Among the Tukano, Hugh-Jones [23] the songs intoned by the shamans allude to the Amazon River as the terrestrial Anaconda and the Milky Way, the supernatural and creative Anaconda. Many Amazonian peoples compare the supernatural milk of the creative Anaconda with the milky-coloured sap of hallucinogenic plants of the genus Banisteriopsis, whose tree trunk is the metaphor of the body of the creative Great Anaconda [24].

In the polychrome ceramic material of the stilt villages, the principal iconographic element that stands out is the presence of curvy black or hook-shaped designs that fit together (Figure 2). The rim of these polychrome vessels is painted red. This iconography is recurrent in almost all the sites of this river. Although abstract, the iconography has a reading order in horizontal bands, filling the entire internal space of the vessel. The predominance of black colour could corroborate the suggestion that these images correspond to the black spots that the anaconda snake (Eunectes murinus) has on its back, as Roosevelt also interpreted in his study of anacondas and women-shamans in Marajo island.

This magical world is enhanced by music and dance. According to Barcelos [25], the snakes are part of a myth-musical repertoire among the Wauja, in which Kamalu Hai stands out, "the gigantic snake-canoe that carries on its back a long series of singing pots". These ceramic cookwares are of different sizes and have a varied polyphony according to their function. In this sense, the snake-canoe could imply the origin of the ceramic activity among the Wauja, a pristine myth, therefore.

In the Amazon, the anaconda is associated with both the male universe, among the Tukano, as well as the female. Anaconda's association with a shaman woman 


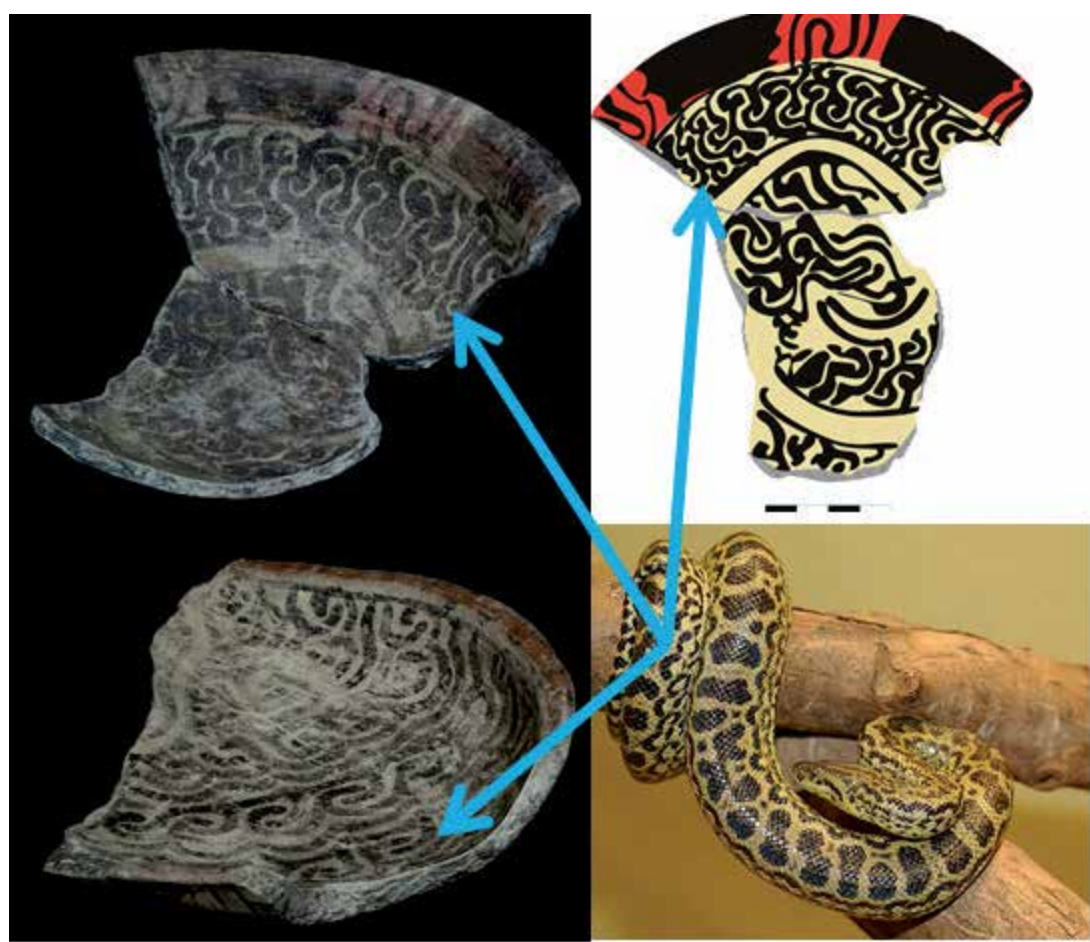

Figure 2.

Vessels with Anaconda skin iconographic pattern. Photograph: Fábio Matta.

and creative deity are common in oral traditions in the Amazon, as among the Shipibo, according to Roosevelt [22]. Indigenous peoples conceive of Anaconda as a dangerous ancestral spirit to the present day. She would be a master who governs the feminine part of the cosmos, which is the aquatic underworld. To Shipibo the anaconda is a woman shaman [26].

According to Roosevelt [22], many Amazonian peoples associate the Amazon River with Anaconda because these snakes dominate the aquatic landscape and because the meanders of the rivers imitate the movement of these reptiles. Thus, it is common for Anacondas drawings to be represented in community houses among the Tukano.

Roe [27] in his classic book The Cosmic Zygote reported among the Shipibo the mythological association of the creation of the world with the Anacondas, is also associated with the rituals of healing, divination, ceremonial dances and the creation of musical instruments. Among other groups, such as the Tupi-Gavião and Panare, Anaconda is a giant animal associated with the rainbow [28] or a celestial phenomenon among the Timbira in which the reptiles ends rest in the mouths of two anacondas [29]. The rainbow would be a symbol of disease [30] and for Weiss [31] it would represent "something demonic, repulsive and detestable, as well as the anaconda". Anaconda, therefore, inhabits a very large number of Amazonian myths, having as main characteristic the shamanic activities which include cosmological creation, under celestial aspects, and cultural properties associated with natural transformations of aquatic life and the water world.

The ceramic figurines indicate the presence of ritual [32]. They are characterised by the representation of animals, especially the owl, the monkey, the turtle and the frog. Some of them are anthropomorphic or zoomorphic design, the zoomorphic being the most recurring. Many of them have a sculptural standard: the legs are open in the shape of a half-moon and some of them possess the feminine genitalia 
on display. A figurine in particular, in the form of an owl, is a rattler and features a small handle that possibly had the function of being hung.

The shamanic nature of these archaeological materials is also evidenced by the production of figurines, generally female, where there are small clay balls inside, which could be a rattle, known in the lowlands of South America as maracas, as communication between the living and the dead. According to Zerries [33], the maracá has always been the most important shamanic instrument in non-Andean South American cultures, since "the noise of the little stone or maracá seeds inside is interpreted as the voice of the spirits". Thus, the maracá was considered an idol for the indigenous peoples of the lowlands of South America (Figure 3). Thus, in many cultures the owl is associated with death [34], and evil spirits [35].

These sound instruments are present in the ethnohistorical records of the colonial period such as Daniel [36], D'Abbeville [37] and D'Évreux [38] and also ethnography by anthropologists from the beginning of the 20th century. The maracá, therefore, is part of the shamanic paraphernalia since it can emit sound, thus, a form of communication between the different worlds in which the shaman acts. In this way, the rattle functions as a musical instrument whose sound together with the hallucinogens induce special sensations that alter their mental and psychological state. For the Warao, who still live in stilt houses in the Orinoco delta in Venezuela, the maracás have spiritual forces and their human forms refer to the ancestral shaman who visited heaven and was gifted with this instrument the Great Spirit of these water peoples [39].

The ceramic figurines were important products of the indigenous art in the Stilt Houses. Sometimes, they represented mainly hand-shaped geometrical figures. Often those represented also animals such as amphibians, fish, mammals and birds, which were similar to those among the Tapajó and Konduri peoples [40]. These animals were represented in a naturalistic style, thus preserving the identifiable traces of the species. A good example is the squirrel monkey (Saimiri collinsi) figurine, in which we can identify its furry ears, and in another piece, the torn mouth, typical of these primates [41] (Figure 4).

In turn, the frogs are associated with fertility, which is most likely due to the aquatic environment in which these societies lived. Themes associated with frogs are also common in the Mesoamerica [42] and the Caribbean [43] (Figure 5).

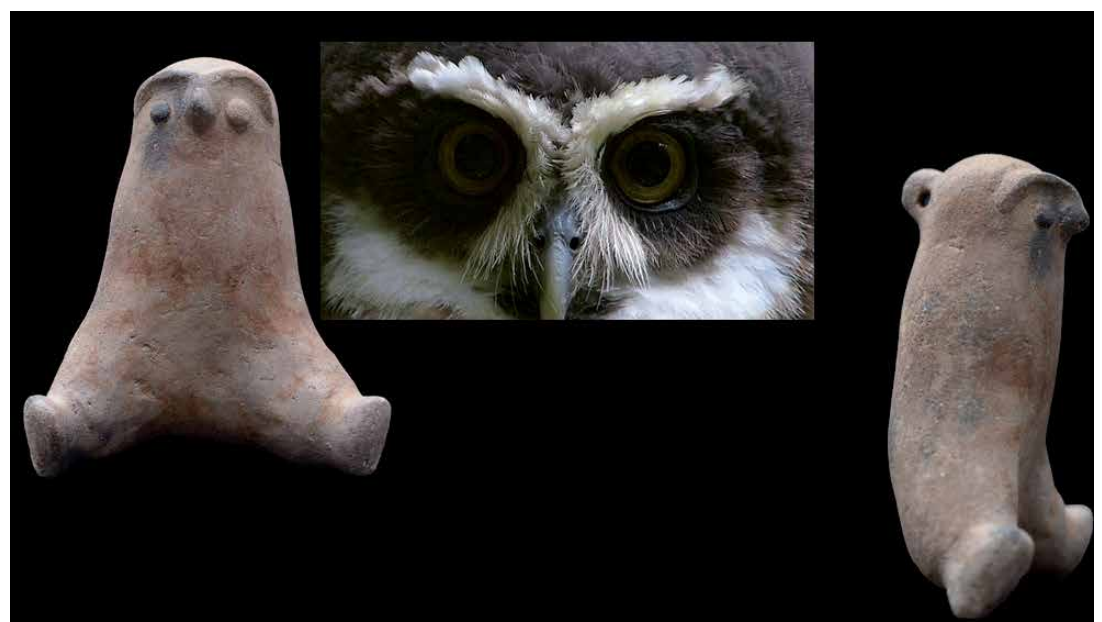

Figure 3.

Rattler-figurine in the form of an owl, a maraca whose sound communicated the living with the dead. In the photo the head of the spectacled owl (Pulsatrix perspicillata). Photograph: Áurea costa. 


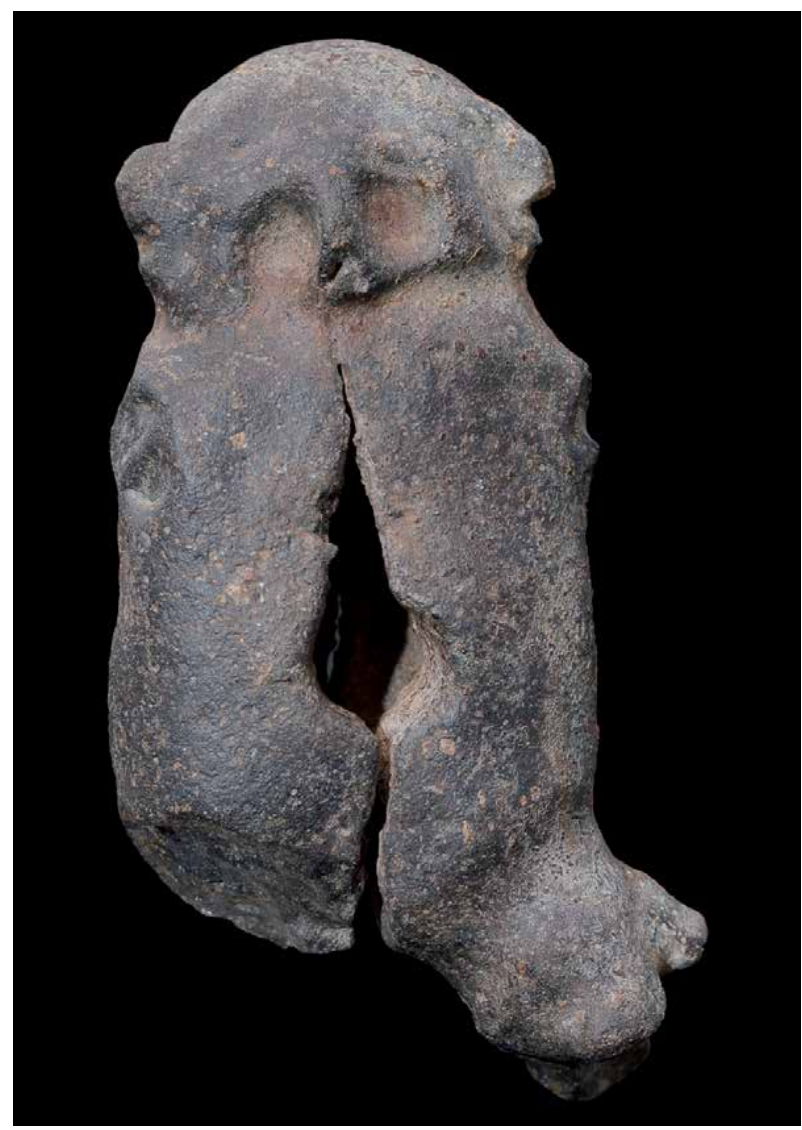

Figure 4.

Figurine in the shape of squirrel monkey (Saimiri collinsi). Photograph: Fábio Matta.

Regard to iconography, it happens through geometric lines or traces that delimit patterns within the stylistic composition of the vase: they are Greeks, zigzags or spirals taking up the interior of the pieces. We can see, that there are two opposite iconographic fields divided by one or two lines across the piece. Mostly the motifs differ in these two fields. For instance, when the square motifs were used in one artistic field, then the circular elements were selected for the opposite one. Red and black were the predominant colours, which were painted on cream engobe or white.

According to Prous [44], some of the motifs resemble the Tupi iconography and he associated them with the custom and practice of eating human flesh (anthropophagic) ritual, such as the representation of the intestine and the brain. However, the pottery shapes at the Stilt Houses, as well as their technologies, such as anti-plastic and quality of clay burning, are very distinct from those of the Tupi. Therefore, Stilt Houses' ceramics show better production control and technological quality.

Perspectivism deriving from structuralism serves the most fruitful theoretical and methodological discussions that apply to the study of archaeological pottery of the stilt villages. The study of the iconographic motifs, as well as their repetition and pattern, in addition to the ethnographic bibliographical revision of the Amazon, show that the geometric motifs of the ceramics are, in general, depictions of the skin or feathers of some animals, especially those of the top of the food chain, such as snakes and owls. 


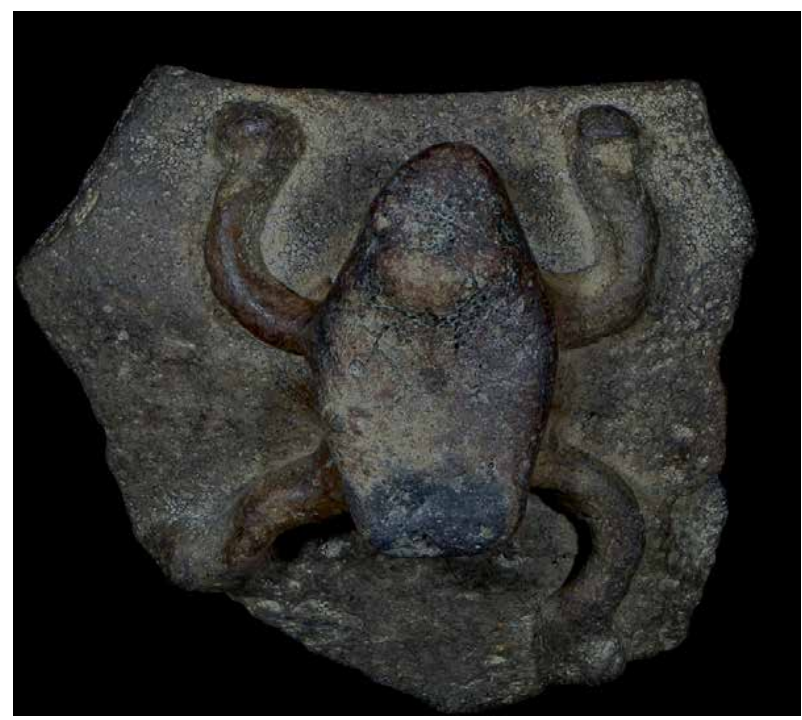

Figure 5.

Vessel frog appliqué of the stilt villages. Photograph: Fábio Matta.

\section{Conclusion}

This chapter has shown that the pre-colonial Amazon peoples were well adapted to the environment and produced a rich art of strong social cohesion. Two types of the artefact of mobiliary art and one of the graphic art stand out in the conception of the indigenous art of stilt villages. The mobiliary art corresponds to the figurines, generally representing animals (zoomorphic design) and sometimes human beings mixed with animals and the appliques showing different animal shapes, especially mammals, amphibians and birds. Therefore, the art reveals the Perspectivism associated with the cosmologies involving mythical concepts. From the graphic art stands out the black and red paintings on white and cream engobe of the ceramic vessels. They contain geometric shapes which take up two distinct geometric fields, forming motifs resembling the skin of predatory animals.

Guss [45] has pointed out when postulating the relationship between myth and artefacts, that objects act as "subtexts" that provide an understanding of the functioning of society bringing them closer to their origins. In this sense, the artefacts imitate primaeval objects, as they are copies of this primordial world. This concept refers to what Gell [9] would call the object's enchantment.

Very likely the representation of animals in appliques and painting of Stilt Houses ceramics have a close connection with the creation myths among the precolonial peoples in Amazon. Snakes are mainly dwelling in the river, and therefore associated with the origin of human life. The Amazonian rivers, on the other hand, have many meanders remembering the shape of the undulating movement of the snakes. Serpents are also associated with fertility and in an aquatic environment where stilts were found, these myths could be very important as social cohesion.

In the river environment of Amazon frogs are other important animals [46]. These amphibians were associated with the fertility and they produce hallucinogenic substances that allowed the shamans to make their spiritual journeys [47]. Many Indian ceramics have frog-shaped appliques and the small size of these vessels indicates their use for the consumption of liquid drinks. Some scholars have argued that the abstract drawings in ceramics paintings and appliques could originate from the view of the visual illusions (phosphenes) caused by hallucination. 
On the other hand, the representation of mammals at the top of the food chain such as jaguars and monkeys may be associated with Amerindian perspectivism. Animals with aggressive characteristics in the ceramic appliques likely represented for the Indians a metaphor of power. It is also possible that these ceramics belonged to the chiefs. Often the animal itself was not represented, but the paintings of the vessels alluded only the skin of these animals.

The bright colours of the Anacondas, as well as their ecological characteristics such as constriction and their large size, played an important role in their choice to symbolise the canoe snake. Nothing better than a strong and large animal to be used as a transport vehicle to populate the villages. The fact of knowing how to swim, like a canoe, corroborates that Anaconda has adequate properties for its appropriation as a narrative. In this sense, the Anaconda had a higher status in the animal hierarchy, appearing only in painting and not in effigies.

Finally, it has to be considered that the contemporary Stilt Houses, most of them comprise the temporality of 800 to $1000 \mathrm{AD}$. So the long-range of their artistic ideologies in an extensive area, indicating firstly a cultural homogeneity of these societies, and, secondly, makes us think, even if hypothetically, that the existences of these chiefdoms of large regional scale between the 8th and 10th AD coincide with the pinnacle of the precolonial Amazonian societies.

\section{Author details}

Alexandre Guida Navarro

Professor of Archaeology at Federal University of Maranhão, São Luís, Brazil

*Address all correspondence to: altardesacrificios@yahoo.com.br

IntechOpen

(C) 2020 The Author(s). Licensee IntechOpen. This chapter is distributed under the terms of the Creative Commons Attribution License (http://creativecommons.org/licenses/ by/3.0), which permits unrestricted use, distribution, and reproduction in any medium, provided the original work is properly cited. (cc) BY 


\section{References}

[1] Sahlins, M. D. (1968). Tribesman. Prentice-Hall, Englewood Cliffs.

[2] Geertz, C. (1989). A interpretação das culturas. Rio de Janeiro: Guanabara Koogan.

[3] Lévi-Strauss, C. (2008). Antropologia estrutural. São Paulo: Cosac \& Naiff, [1958]

[4] Marconi, Marina de A. \& Presotto, Z. M. (2009). Antropologia: uma introdução. São Paulo: Atlas.

[5] Schaan, D.P. (2004). The camutins chiefdom. Rise and development of complex societies on Marajó island, Brazilian Amazon. PhD thesis, Universidade de Pittsburgh.

[6] Neves, E. G. (2006). Arqueologia da Amazônia. Rio de janeiro: Zahar Editora.

[7] Gomes, Denise Maria Cavalcante. (2012). O perspectivismo ameríndio e a ideia de uma estética americana. Bol. Museu. Paraense Emílio Goeldi, vol. 7, n. 1, pp. 133-159. Belém.

[8] Lévi-Strauss, C. (2004). O cru e o cozido. Mitológicas 1. Tradução Beatriz Perrone-Moisés. São Paulo: Cosac \& Naif, [1964].

[9] Gell, A. (1998). Art and agency: an anthropological theory. Oxford: Clarendon Press.

[10] Viveiros de Castro, E. (2002). A inconstância da alma selvagem. São Paulo: Cosac \& Naif.

[11] Navarro, A. G. (2018). New evidence for late first-millennium AD stilt-house settlements in Eastern Amazonia. Antiquity 92 (366): 1586-603.

[12] Navarro, A. G., Gouveia Neto J.C., Marcondes L. da Costa, Abrahão S. N. F. da Silva, Rômulo S. Angélica, Suyanne S.
Rodrigues. (2017). O muiraquitã da estearia da Boca do Rio, Santa Helena, Maranhão: estudo arqueológico, mineralógico e simbólico. Boletim do Museu Paraense Emílio Goeldi 12 (3): 869-894.

[13] Navarro, A.G. (2016). O complexo cerâmico das estearias, Maranhão. Cerâmicas arqueológicas da Amazônia: rumo a uma nova síntese, edited by $\mathrm{C}$. Barreto, H. P. Lima and C. J. Bitencourt, 158-169. Belém: IPHAN/Museu Paraense Emílio Goeldi.

[14] Porro, A. (1992). As crônicas do rio Amazonas. Notas etno-históricas sobre as antigas populações indígenas $d a$ Amazônia. Petrópolis: Vozes.

[15] Arnold, Dean E. (1985). Ceramic theory and cultural process. Cambridge: Cambridge University Press.

[16] Grieder, T. (1975). The interpretation of ancient symbols. American Anthropologist 77:849-55.

[17] Ember, C.R., Ember, M. \& Peregrine, P. (2004). Antropología. Madrid: Pearson Prentice Hall.

[18] Ribeiro, B. (1983). O índio na história do Brasil. São Paulo: Global Editora.

[19] Vidal, L. (1992). A pintura corporal e a arte gráfica entre os Kayapó-Xikrin do Cateté. Vidal, Lux (org.). Grafismo indígena. São Paulo: Studio Nobel/ Fapesp/Edusp, pp. 143-189.

[20] Reichel-Dolmatoff, G. (1971). Amazonian cosmos. Chicago: University of Chicago Press.

[21] Colthorpe, K. (2009). Eunectes notaeus. Yellow Anaconda. accessed July 11, 2020. https://animaldiversity.org/ accounts/Eunectes_notaeus/ 
[22] Roosevelt, A.C. (2014). The great anaconda and woman shaman: A dangerous and powerful ancestral spirit from creation to today. In Colocataires d'Amazonie: Hommes, animaux et plantes de part et d'autre de l'Atlantique, edited by D. Barone-Visigalig, 1-20. Paris: Parution.

[23] Hugh-Jones, C. (1979). From the Milk River: Spatial and Temporal Processes in Northwest Amazonia. Cambridge: University of New York.

[24] Knoll, M. (1963). Effects of chemical stimulation of electricallyinduced phosphenes on their bandwidth, shape, number and intensity. Confinia Neurologia, v. 23, pp. 201-26.

[25] Barcelos Neto, A. (2011). A serpente de corpo repleto de canções: um tema amazônico sobre a arte do trançado. Revista de Antropologia 54 (2): 981-1012.

[26] Gebhart-Sayer, A. (1984). The Cosmos Encoiled: Indian Art of the Peruvian Amazon. New York: Center for Inter-American Relations and Americas Society.

[27] Roe, P. (1982). The Cosmic Zygote: Cosmology in the Amazon Basin. New Brunswick: Rutgers U.

[28] Dumont, J-P. (1977). Musical Politics: On Some Symbolic Aspects of the Musical Instruments of the Panare Indians. In Anthropology and the Climate of Opinion, edited by S. Freed, 2016214. New York: Annals of the New York Academy of Sciences.

[29] Nimuendajú, C. (1946). The Eastern Timbira. University of California Publications in American Archaeology and Ethnology 41. Berkeley: University of California Press.

[30] Basso, E. B. (1973). The Kalapalo Indians of Central Brazil. New York: Holt, Rinehart \& Winston.
[31] Weiss, G. (1975). Campa

Cosmology: The World of a Forest Tribe in South America. Anthropological Papers 52. New York: American Museum of Natural History.

[32] Roosevelt, A.C. (1988). Interpreting Certain Female Images in Prehistoric Art. Miller, Virginia E. (ed.). The Role of Gender in Precolumbian Art and Architecture. Lanham, MD.: U. Press of America, pp. 1-34.

[33] Zerries, O. (1981). Atributos e instrumentos do Xamã na América do Sul não-andina e seu significado. In Contribuições a Antropologia em homenagem ao Prof. Egon Schaden, edited by T. Hartmann and V. C. Penteado, 319360. São Paulo: Coleção Museu Paulista, Série ensaios.

[34] Mikkola, H. (Ed.) (2020). Owls. 97 p. - InTech Open Access, London Print ISBN 978-1-78984-053-7; Online ISBN 978-1-78984-054-4; eBook ISBN 978-183880-461-9 http://dx.doi.org/10.5772/ intechopen.80242

[35] Mikkola, Heimo. Owls of the World: A Photografic Guide. Firelfly Books, 2013.

[36] Daniel, J. (2004) [1757-1776]. Tesouro descoberto no Máximo Rio Amazonas: 1722-1776. 2 Vols. Rio de Janeiro: Contraponto.

[37] D’Évreux, Y. (2008) [1864]. Continuação da História das coisas mais memoráveis acontecidas no Maranhão nos anos 1612 e 1614. Brasília: Senado Federal.

[38] D’Abbeville, C. (1945) [1864]. História da missão dos padres Capuchinhos na ilha do Maranhão e suas circunvizinhanças, em que se trata das singularidades admiráveis e dos costumes estranhos dos indios habitantes do país. São Paulo: Livraria Martins Editora. 
[39] Wilbert, J. (1963). Vestidos y ornamentos de los Indios Warao. Antropologica 12: 6-26.

[40] Guapindaia, Vera Lúcia Calandrini. (2008). Além da margem do rio: a ocupação konduri e pocó na região de porto trombetas, $P A$. PhD thesis. São Paulo: Universidade de São Paulo.

[41] Navarro, A.G. \& Silva Júnior, J.S.E. (2019). Cosmologia e Adaptação Ecológica: o caso dos apliquesmamíferos das estearias maranhenses. Anthropológicas, Recife, vol. 30, n. 2, pp. 203-233.

[42] Coggins, C. C. (1992). Artefacts from the Cenote of Sacrifice, Chichén Itzá, Yucatán. Cambridge, Massachusetts: Peabody Museum of Archaeology and Ethnology, Harvard University.

[43] Boomert, A. (1987). Gifts of the Amazon: green stones pendants and beads as the item of ceremonial exchange in Amazonia and the Caribbean. Antropologia, núm. 67, Caracas, pp. 33-54.

[44] Prous, A. (2005). A pintura em cerâmica tupiguarani. Ciência Hoje, Rio de Janeiro, v. 36, n. 213, pp. 22-28.

[45] Guss, D. (1990). To weave and sing. Art, symbol, and narrative in the South American rainforest. Berkeley: University of California Press.

[46] Wassén, H. (1934). The frogmotive among the South American Indians. Antropos. Revue Internationale d'Ethnologie et de Linguistique, Freiburg, v. 29, n. 3-4, pp. 319-370.

[47] Reichel-Dolmatoff, G. (1976). O contexto cultural de um alucinógeno aborígine: Banisteriopsis caapi. In: Coelho, V.P. Os alucinógenos e o mundo simbólico. São Paulo: EPU/EDUSP, pp. 59-103. 
Section 3

\section{Development \\ Opportunities and \\ Problems}





\title{
Bioeconomic Potential of Sustainability Indicators in a Ceramic Production Center in the Western Amazon
}

\author{
Gelson Dias Florentino, Lucieta Guerreiro Martorano, \\ Sandro Augusto Lima dos Santos, \\ José Reinaldo da Silva Cabral de Moraes, \\ Ires Paula de Andrade Miranda \\ and Maria de Lourdes Pinheiro Ruivo
}

\begin{abstract}
The use of Amazonian biodiversity has great potential to produce bioproducts in diverse production chains and segments of industry. The combination of public policies with biotechnological development represents an important indicator for the implementation of sustainable production chains that adhere to the Sustainable Development Objectives (SDO). The ceramic industries in the Amazon region represent activities that promote local economic development through the use of biological resources that can be transformed into bioproducts that are considered a reference for sustainable production in world markets. The operations of these industries have great potential to incorporate technologies that can be used for fabrication of ceramic products on a biological base that is compatible with bioeconomic guidelines. The principle of a bioeconomy is centered on the possibility of transformation of natural resources into bioproducts that aggregate technologies and contribute to increase incomes and reduce environmental impacts. In this way, the integration of different fields of science should be stimulated to incorporate new technologies that favor business models that comply with the premises of sustainability.
\end{abstract}

Keywords: Amazon, biodiversity, production chain, bioeconomy, bioproducts

\section{Introduction}

The Amazon contains about a third of all tropical forests in the world and forms a mosaic of ecosystems in an area of about 6 million $\mathrm{km}^{2}$ [1]. The extensive variety of species of flora and fauna spread out across widely differing landscape patterns, coupled with a hydrological system that is rich in biodiversity, makes this region the most biodiverse in the world.

The enormous biological diversity and territorial extension of the Amazon makes governance and sustainable management difficult considering the many 
different sources of anthropogenic pressure [2]. However, geological, hydrological, and climatic patterns of the Amazon, allied with its megadiversity favor sustainable use of its natural resources. Provision of inputs and raw materials for production of bioproducts and biofuels, energy generation, and phytotherapeutic products are examples of Amazonian bioeconomic potential.

Biodiversity is defined as the composition of all species of all forms of life and organizational levels present in ecosystems [3], a characteristic that is typical of the Amazon. The ecologic-economic interface at a large scale generally leads to persistent degradation of the natural environment and a loss of ecosystem services and biodiversity [4].

The value of ecosystem services is hotly debated due to the difficulty in establishing a monetary value for intangible goods $[5,6]$. Studies have indicated that one of the largest gaps or deficits in knowledge of biodiversity is the real magnitude and quantity of microorganisms and species that have been formally described by science $[7,8]$. However, the dynamics and multiple facets that characterize the tradeoff between development and sustainability presupposes the necessity to discuss the bioeconomic potential of the Amazon, focused on balancing the magnitude of consumption of natural resources with the capacity to replace them in nature.

Even without knowing the exact quantity of species present in nature, biodiversity has great biological importance for all forms of life [9], such as:

- Ecosystem functionality: biodiversity facilitates the functioning of ecosystems, maintaining the planet habitable through carbon exchange, maintenance of surface- and groundwaters, protection and fertilization of soils, and regulation of temperature and climate.

- A storehouse of values that are intangible and non-monetary: biodiversity offers to humanity values that are universally recognized, such as those of esthetic, scientific and cultural character.

- A storehouse of values that are tangible and monetary: the beauty and uniqueness of many ecosystems provide value in the form of a diversity of recreational activities and ecotourism.

- Provision of inputs and bioproducts that are destined for human consumption: biodiversity is the base for agricultural crops and for the development and improvement of new varieties for human consumption.

- Provision of raw material for production chains and industrial sectors: biodiversity is the source of many products used by contemporary societies, such as fibers, pharmaceutical products, chemical, and is a source of information for the development of biotechnology.

Besides the economic value and biological importance to human survival, biodiversity provides ecosystem services in the form of provision, regulation, and support, and is also important for its contribution to cultures around the world [10-13]. This results in tangible and intangible benefits based on the diversity and functioning of ecosystems.

The challenge presented by the global market is to satisfy the assumptions of the Organization for Economic Cooperation and Development (OECD) in productive sectors in the Amazon, since the expansion of certain industrial activities necessary to meet national and international market demand generally results in loss of biodiversity, and consequently compromises ecosystem services.

Among the diverse initiatives that utilize biodiversity, there is great preoccupation with the sustainability of production chains, and if these adhere to the Sustainable 
Development Objectives (SDO), as adopted by the United Nations Organization (UNO). The conceptual approach of sustainable development as elaborated in its most recent version, incorporates the necessity of adoption of sustainability parameters that take into account aspects that include efficiency (economically sustained), inclusion (socially desirable), and equilibrium (ecologically prudent).

It is understood that the concept of sustainable development is complex, and it is often interpreted imprecisely, ambiguously, or in a contradictory manner based on a complex and dynamic perspective rooted in the relationship between societies and nature [14]. This concept has been gaining strength and political expression, especially during the last quarter century of the twentieth century, due to a worldwide environmental crisis [15].

The trajectory of sustainability demands ethical compromises, ecological conscience, and social respect, and the demand for sustainable products has been intensifying [16]. Consumers now question how a product was made, if it is in compliance with the legislation of its country of origin, and what were the benefits generated for the agroextractivists and communities that obtained these products.

These requirements impose the necessity of introducing technologies and business models that are compatible with the tools of the bioeconomy.

The bioeconomy is organized around the concept of sustainable and innovative use of natural resources and biological knowledge in order to produce food, industrial products, bioenergy, and ecological services [17]. This concept arose as a new paradigm through the extension of new ideas and knowledge in the fields of biology, economics, and the environment in general, with the goal of providing solutions to complex problems. The concept of the bioeconomy integrates different fields of science, sectors of society, and market demands as a function of providing products that are sustainable, competitive and that adhere to policies of sustainability and applied biotechnology.

Ceramic industries in the Amazon are examples of businesses that use biodiversity resources and promote local economic development. However, the manufacturing operations of these companies have been engaged in a growing effort to achieve a pattern of development that incorporates economic, social, and environmental aspects [18].

Preoccupation with depletion of natural resources has increased interest in biologically based products. Productive activities in the Amazon, especially those derived from biological resources, as is the case of ceramic industries, have created a positive perspective with respect to the implementation of developmentalist models that incorporate innovation, technology, and sustainability.

The advance of the "Fourth Industrial Revolution", or Industry 4.0, has integrated technology and sustainability and created new practices and standards for products and services which are based on concepts of a sustainable economy [19].

Market strategies that search for alternatives that can differentiate a product based on its quality and on attributes that respect the environment normally allow for access to new markets that have higher aggregated value and purchasing power. Cluster analysis shows the potential to track and identify the origin of products, thus aggregating value and confidence in products from the Amazon region.

In this context, this research has as objective the analysis of the potential of the principal bioeconomic variables inherent to the production and marketing of ceramic products in the ceramic production center of Iranduba, state of Amazonas.

\section{Characterization of ceramic production in the western Amazon}

In the Amazon, the development of ceramic production techniques was a pioneering effort by indigenous people that was engaged in before agricultural 
activities and plant domestication [20]. The production of utensils and other artifacts was not done to sell them in a market, but rather the focus of this production was to make vases, jars, and plates for domestic use. Beginning with the industrial revolution and the introduction of machines and equipment to production processes, the production of ceramics ceased to be merely an artisanal activity and took on an industrial scale. Population growth and the expansion of large urban centers in the region created a new commercial niche, the civil construction market. The demand created by the civil construction production chain altered production models and required the fabrication of new products and consolidated the ceramic industries involved in production of specialized ceramic products.

In the state of Amazonas there are records that show that the first ceramic production activities were artisanal, especially with respect to production of plates, cups, and other utensils for domestic use by the local indigenous population [21]. Up to the decade of the 1970s, the ceramic sector of the state of Amazonas was concentrated in the region of the city of Manaus. Starting in the 1980s these companies migrated from the capital of Manaus to the district of Cacau-Pirêra, city of Iranduba [22-25].

The factors that contributed to the installation and strengthening of the ceramic sector in this region of the Amazon were: a) the existence of extensive deposits of clay raw material; b) proximity to the principal consumer center, connected by the Manoel Urbano - AM-070 highway; and c) large supply of unskilled labor that receives low salaries $[18,26]$.

\subsection{Geographic and geologic aspects of the study area}

The study area is located in the city of Iranduba, metropolitan region of Manaus, consisting of an aggregation of 18 industries situated on the right bank of the Negro River, in front of Manaus, with access and shipping of production done using the Negro River bridge (Figure 1).

Geologically, the study area is on a dissected plain, where sedimentary rocks of the Alter do Chão formation predominate. This sedimentation occurred in continental, fluvial, and lacustrine environments, constituted by intercalation of sandstones, mudstones, and conglomerates, which are principally composed of clay [27], which is used in the production of red ceramic products. The sandstones have a fine to medium texture and are red in color; the mudstones, massive or laminar,
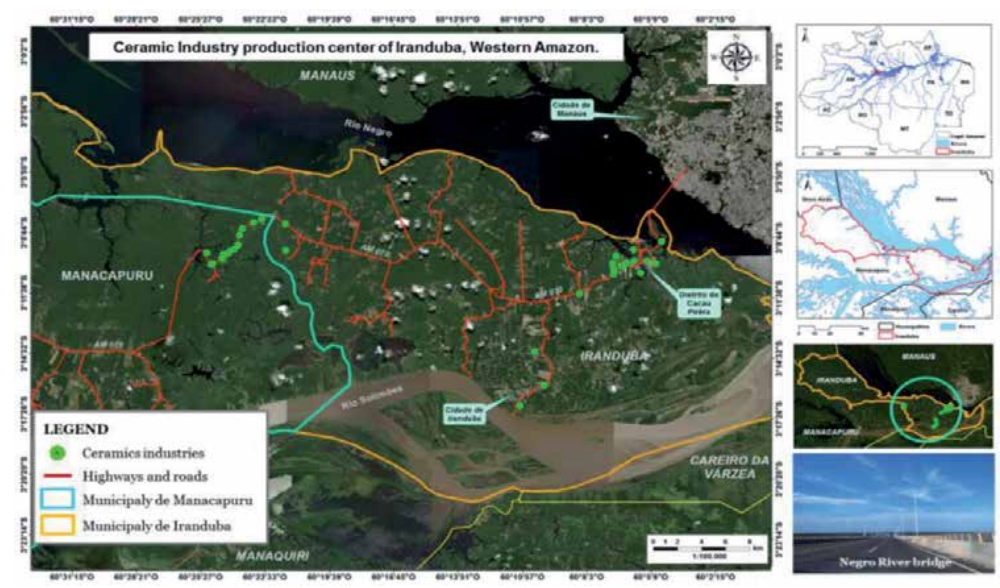

Figure 1.

Location of the ceramic production center of Iranduba, Amazonas, Brazil. Source: Geocartographic data from the Brazilian Institute of Geography and Statistics (IBGE) and ArGis (2020). 


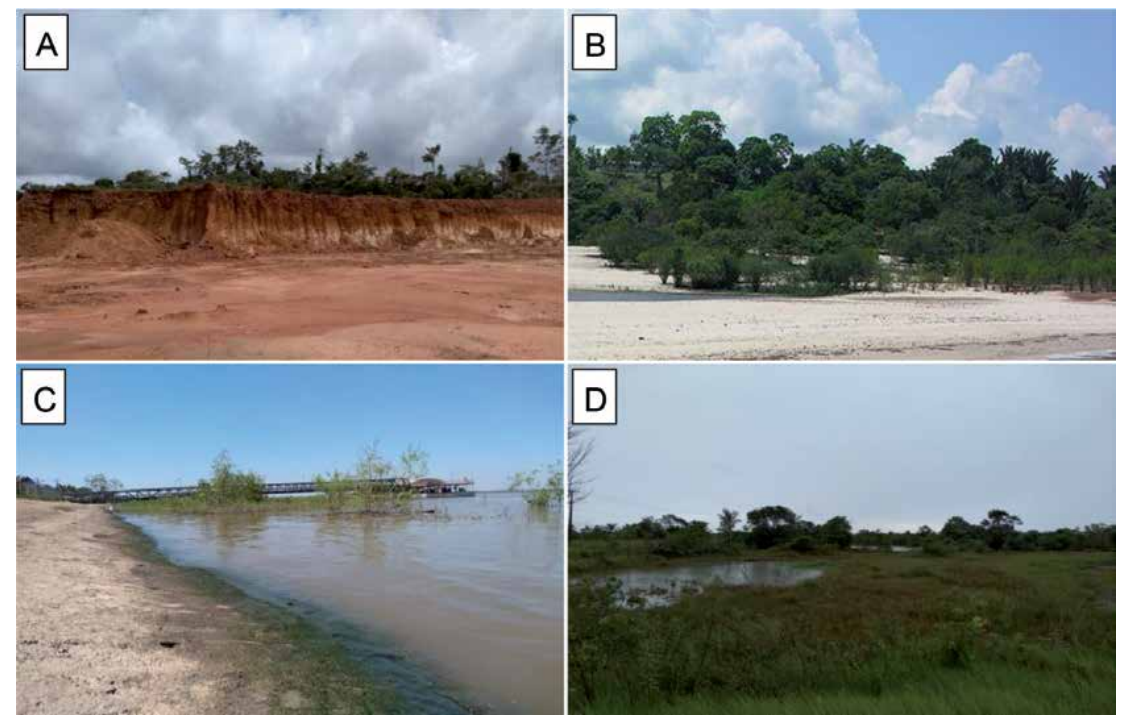

Figure 2.

Landscape heterogeneity of Iranduba: Lateritic profile (A); Sandy deposits (B); fluvial plain (C); floodplain (D). Source: The authors (2020).

are poorly consolidated, and have clasts of sand that are irregularly distributed; the conglomerates are quartz pebbles and silicified sandstone [28].

The ceramic industries are inserted in the Holocene Várzeas pedological sector, which is composed of várzeas (floodplains along riverbanks) that developed over Holocene sediments with a variable mineralogical composition. Geoenvironmental studies have indicated that the city of Iranduba is characterized by a heterogeneous landscape, with different soil types that are classified as a lateritic profile, sandy deposits, fluvial and flood plains [29] (Figure 2). The clay deposits, which are white to rose colored, together with the yellow Oxisols that overlay the Alter do Chão formation, are used as raw material for the production of red ceramics in the ceramic production industries of Iranduba. The principal products of this red ceramics industry are blocks, bricks, roof tiles, hollow ornamental bricks, slabs, floor tiles, encaustic tiles, tubes, ornamental objects, and domestic utensils, all using common clay as raw material.

Recent research conducted in the ceramic production center of Iranduba indicates that the area has a high level of geological diversity and potential for clay extraction at depths of $15 \mathrm{~cm}, 30 \mathrm{~cm}$ and $60 \mathrm{~cm}$, and that this extraction has been occurring without interruption during the last four decades [18]. Even with the obstacles and the technological limitations confronted by this sector the ceramic industry in Amazonas has actively contributed to social and economic development in the region. It has been estimated that at the height of the real estate boom in Brazil between 2008 and 2013 the annual production of ceramics in Amazonas was approximately 35 tons of bricks per month, with the cities of Iranduba and Manacapuru being the principal producers of red ceramics. Just the city of Iranduba was responsible for about $75 \%$ of all brick production in the state, producing between 1700 and 2000 direct and indirect jobs [18, 30].

\section{Bioeconomic and sustainability potential of the ceramic production center of Iranduba}

The market for the ceramics industry in Brazil is highly heterogenous and is formed mostly by small companies that are located near the consumer markets in 
their regions. These companies basically use common clay as their principal source of raw material.

In the Iranduba ceramic production center, production is concentrated in red structural ceramics, with 8-hole bricks being the principal product that is made. With competition and an increasing demand for environmentally sustainable products, it has become of fundamental importance that the ceramics sector promotes biotechnological innovations in its production chain through integration of companies, technology, and sustainability (Figure 3).

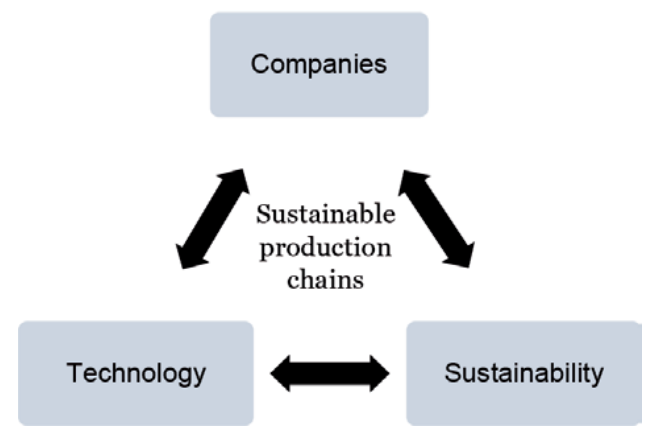

Figure 3.

Structure of sustainable production chains. Source: The authors (2020).

Sustainable production chains seek to improve business models by adding economic and social value to the goods that are produced. For this reason, the bioeconomy is seen as an opportunity to enhance production standards and strengthen relationships between agroextractivists, transformation industries, public authorities and research and development institutions. Companies and governments around the world have been acting to create public policies that strengthen the commitment to use biological resources in a way that favors a more sustainable economic model $[31,32]$.

An important principle underlying sustainable production chains is that they contemplate changes and or a reorientation of productive systems through necessity or opportunity (entrepreneurship), resulting in lower environmental impact (social sustainability), generation of work and income (economic sustainability), and maintenance of urban and rural characteristics (spatial sustainability) [33]. The combination of these elements requires a set of actions that incorporate scientific knowledge, innovation, and organizational experience (tacit knowledge) to produce, market, and distribute products that are competitive and that are sustainable.

As a result of globalization of markets, a growing number of companies has been striving to create technological tools that are able to track commodities and products, with the objective of supplying a consumer market that is becoming more and more demanding with respect to sustainability of productive processes [34]. The creation of tracking mechanisms that display the routes and management schemes of the entire production chain, from the extraction of raw material (inputs) to the final consumer is highly challenging. However, these initiatives incorporate practices and attitudes that represent a technological and sustainable advance for the industries of the ceramic production center at Iranduba.

\subsection{Structural steps that integrate the production chain of the ceramic production center at Iranduba}

The ceramic production chain at Iranduba encompasses three different steps of macroprocesses: extraction of raw material, production of ceramic artifacts, and marketing of the finished product (Figure 4). 


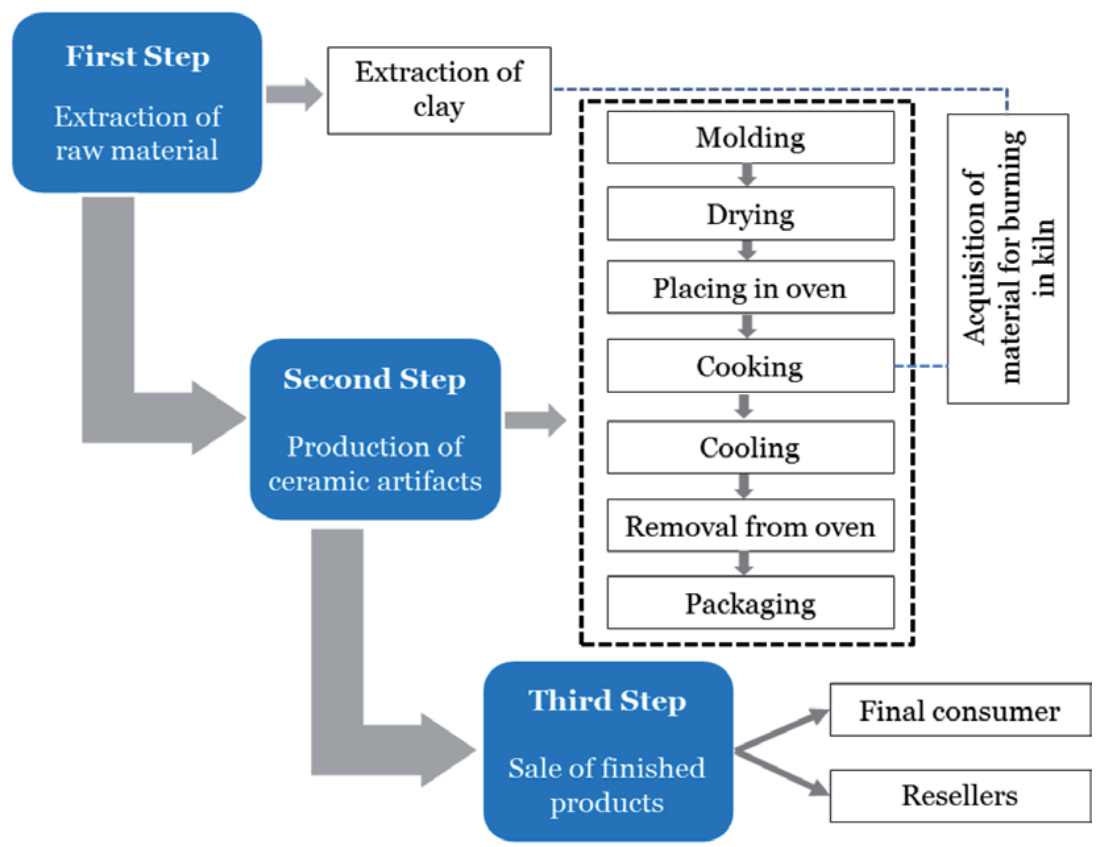

Figure 4.

Structure of the ceramic production chain at Iranduba. Source: The authors (2020).

The first step in the production chain consists of acquisition of raw material, which in this case is clay. The extraction of clay is one of the most important links in the production chain, and is done using machines and motorized equipment, principally a hydraulic backhoe, excavator shovel, and dump trucks (Figure 5A and B). It is important to highlight that before beginning the clay excavation process the excavation sites must be properly licensed to have permission for these activities. In general, these industries do not conduct any specific treatment on the extracted clay, and the clay is simply deposited under the roof of a large hangar or outside in large piles with no covering where it will remain for up to three months (Figure 5C and D). It is thought that this up to three-month period serves to eliminate impurities and microorganisms that can compromise the quality of the final product.

Clay extraction is permitted by law in article $3^{\circ}$ of Law $n^{\circ} 12.651 / 2012$ (Forest Code) and the process of concession/extraction is authorized by different federal agencies, principally the National Mining Agency - ANM, and state and municipal environmental agencies. In the state of Amazonas, licensing of exploitation of mineral substances is done by the Institute of Environmental Protection of the State of Amazonas (IPAAM), by means of three types of licenses that are issued either isolated or in succession, based on the National Environmental Council's (CONAMA) Resolution $n^{\circ} 237 / 1997$ [35], which outlines the rules that organize this activity:

- Preliminary License (LP): issued in the preliminary phase of planning, analysis, and viability of the project in its basic form.

- Installation License (LI): issued in the execution phase of the project and the installation of the infrastructure, as well as during the phase of implantation of an Environmental Control Plan (PCA) which outlines methods of recuperation.

- Operation License (LO): issued during the extraction phase of the project and during the phase of execution of the proposed measures in the Plan for Recuperation of Degraded Areas (PRAD). 

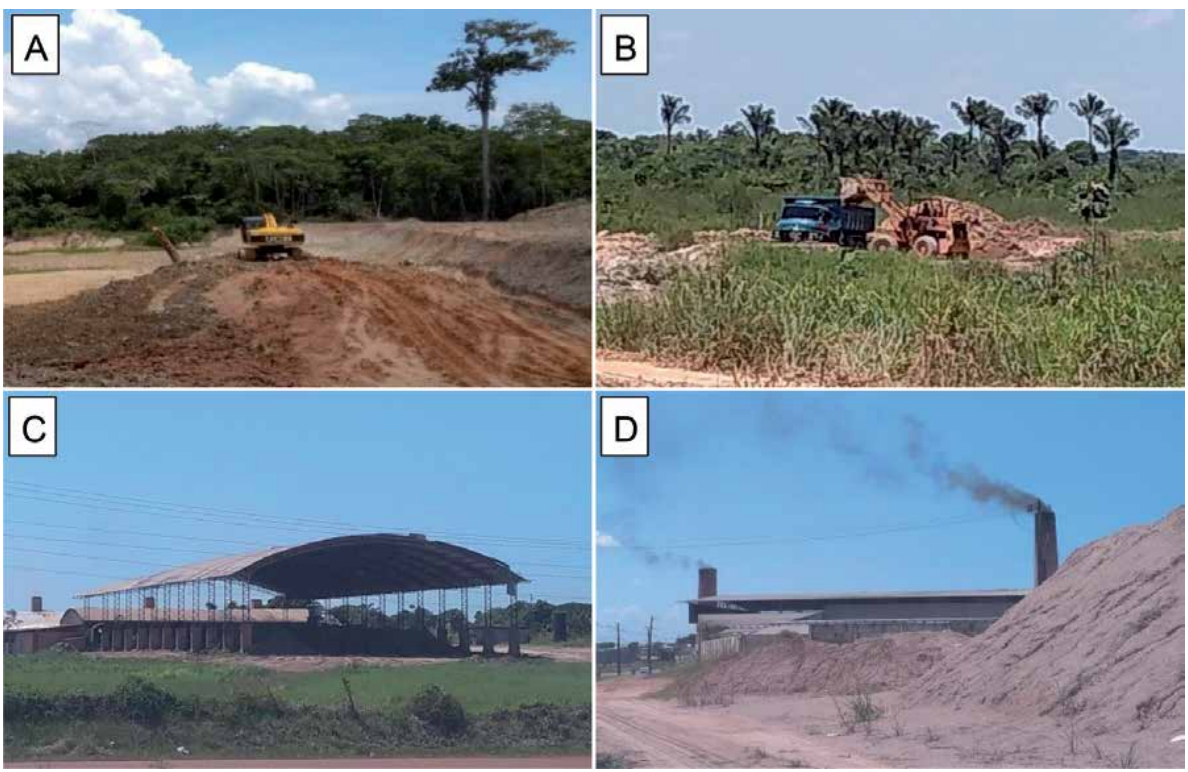

Figure 5.

Processes of extraction $(A)$, transport $(B)$, and storage of clay raw material $(C, D)$ in the study area. Source: The authors (2020).

From the point of view of sustainability, the extraction of clay in open-air conditions without any subsequent processing represents an activity that promotes environmental degradation with significant impacts on biodiversity, which require mitigating actions and/or the reestablishment original ecosystem conditions.

Although the extraction of raw material for the fabrication of tiles, bricks, and other artifacts made of clay cooked in kilns can be considered an activity that causes environmental degradation of medium to strong intensity, the geographic location of the clay extraction sites used by the ceramic industries of Iranduba have high potential for recuperation using strategic mechanisms from bioeconomic principles. The clay extraction sites licensed by IPAAM are essentially situated in areas prone to flooding or are perpetually under water, which therefore have potential to be used for bioeconomic activities such as pisciculture (Figure 6A and B).

Most of the clay deposits are located on the land of the ceramic factory or near them (Figure 6A and B). Clay extraction is done between the months of August to November, which is the dry season where there is a large reduction in rainfall (considered the Amazonian summer). The principal clays that are extracted are kaolinite, with traces of gibbsite, and rarely illite, feldspar, and quartz.
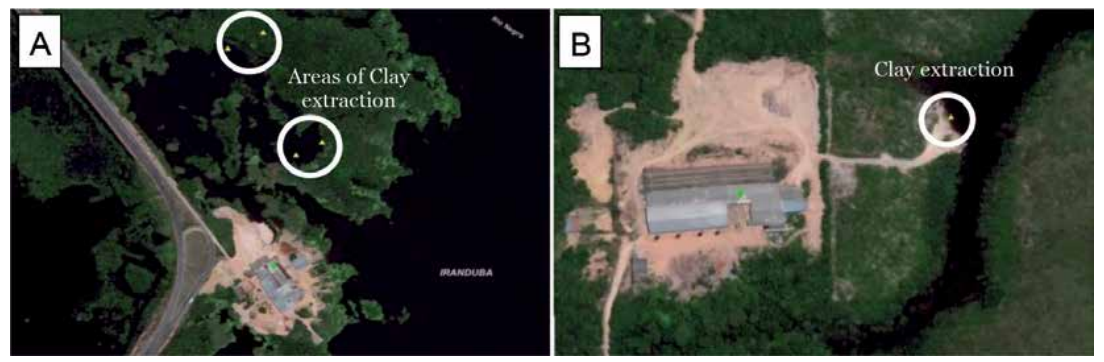

Figure 6.

Clay extraction sites used by the ceramic industries of Iranduba, Amazonas, Brazil: RN Ceramic (A), RO Ceramic (B). Source: Geocartographic data from the Brazilian Institute of Geography and Statistics (IBGE) and ArGis (2020). 
Besides the compensatory environmental recuperation measures, these areas have excellent potential for pisciculture, especially for the species called tambaqui (Colossoma macropomum). Raising tambaqui in captivity is perfectly compatible with the culture, infrastructure, and technology available in the local market. In this context, during the rainy season when river levels are high (Amazonian winter), principally between January to June, the areas used for clay extraction could be reused following a new economic and social perspective. This option would foster additional insertion into local markets incorporating practical aspects of the bioeconomy and would mitigate the environmental impacts of the degraded area (Table 1).

It is important to emphasize that the fishing sector represents one of the most important parts of the local economy, since freshwater fish are one of the natural resources that is most abundant and consumed in the Amazon region [36, 37]. Between the years 2018 to 2019, pisciculture production increased by $34 \%$ in the region, especially for native species such as tambaqui (Colossoma macropomum), matrinxã (Brycon amazonicus) and pirarucu (Arapaima gigas). This points to a scenario of an increase in productive capacity during the rainy season when water levels are high in the region (Figures 7 and 8 ).

Studies indicate that fish is the principal protein source for the populations that live along the river margins in Amazonas, with the upper, middle, and lower regions of the Solimões River having one of the highest levels of fish consumption, a reflection of the strong link that Amazonians have with regional fish populations $[37,38]$. A person from Amazonas consumes, on average, $60 \mathrm{kgyear}^{-1}$ of fish, which represents more than ten times the national average per capitayear ${ }^{-1}$, estimated at $5.8 \mathrm{~kg}[36,37]$. The high rate of fish consumption in the region, besides providing the basic necessities for survival, there are many natural benefits of fish to the health of consumers since fish is rich in protein, mineral, fatty acids, and omega 3 [37]. Furthermore, the introduction or intensification of pisciculture in areas of clay extraction at the ceramic production center at Iranduba will decrease the pressure on natural stocks of fish and will help to meet the guidelines set out in the sustainable development objectives of the UNO.

In this context, the regime high and low water fluctuation over the course of a year in Iranduba represents a bioeconomic alternative that has great potential reconciling several needs in the same natural environment by providing raw material for ceramics production as well as production of fish for subsistence and sale of the excess (Figure 9). These actions will stimulate an increase in income, access to new technologies and a reduction in impacts caused by the extraction of biodiversity resources [25].

The second step in the ceramic production chain at Iranduba occurs internally at the site of the company where the ceramic products are made. The principal changes in the physical-chemical characteristics of the raw material to obtain the finished product occur during this step of the production process. The operational activities are conducted using industrial equipment such as a laminator, extruder, conveyer belt, and cutter, which are operated by the factory workers. Socioeconomic studies done involving managers and workers from ceramic companies in Iranduba have indicated that these activities began in a completely artisanal manner and were then modified over the course of years of operation, to the point today where this process can be considered semiautomatic [21].

The ceramic companies in Iranduba are responsible for about $50 \%$ of all red ceramics produced in the state of Amazonas, generating approximately 1200 direct jobs and 6000 indirect ones, with an estimated production of 4.5 million pieces/month. The portfolio of products consists of bricks (80\%), structural ceramic blocks $(12 \%)$, roofing tiles $(5 \%)$ and floor tiles and accessories $(3 \%)$, as shown in Figure 10. 


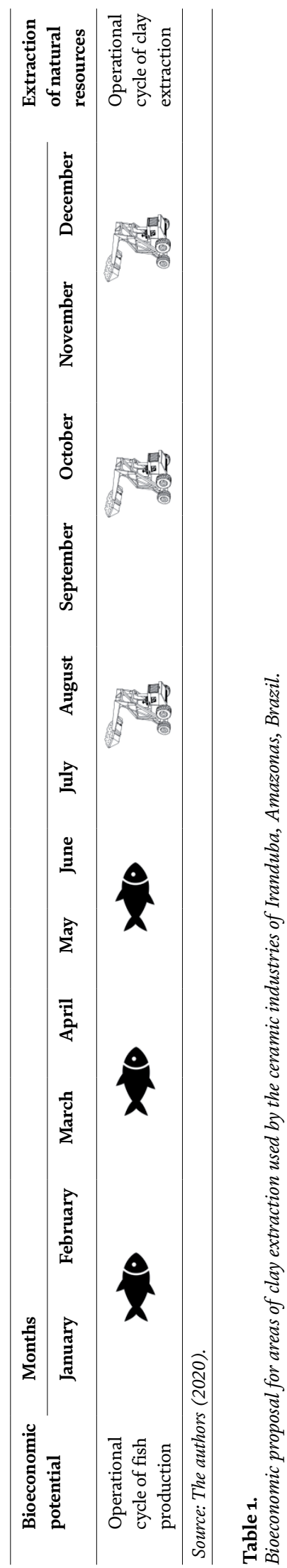


Bioeconomic Potential of Sustainability Indicators in a Ceramic Production Center... DOI: http://dx.doi.org/10.5772/intechopen.94002

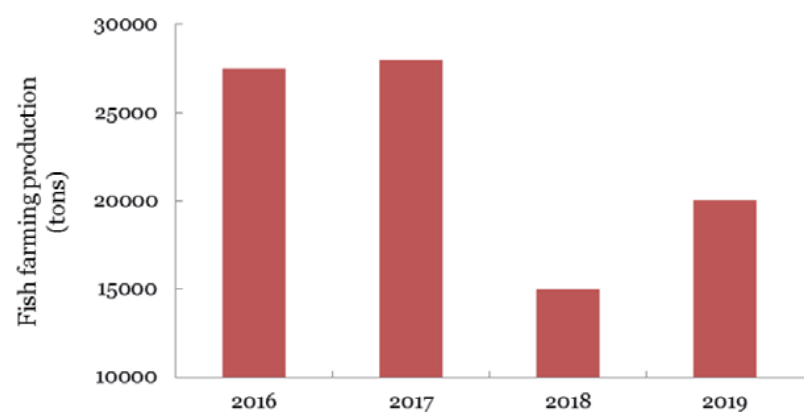

Figure 7.

Pisciculture production in the state of Amazonas (2016 to 2018). Source: Brazilian yearbook of fish farming (2020).
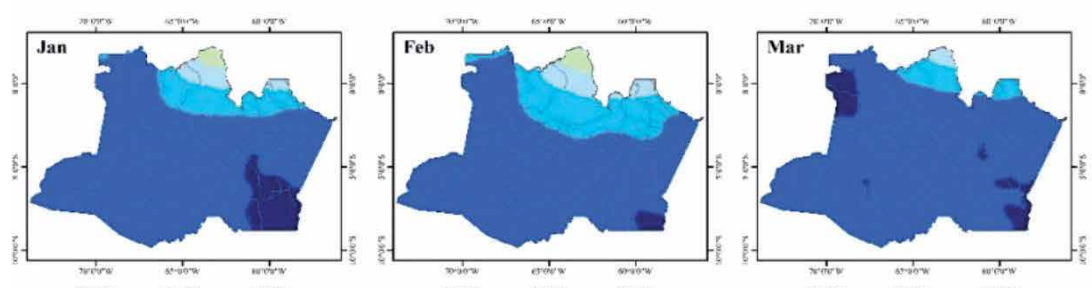

Rainfall (mm)
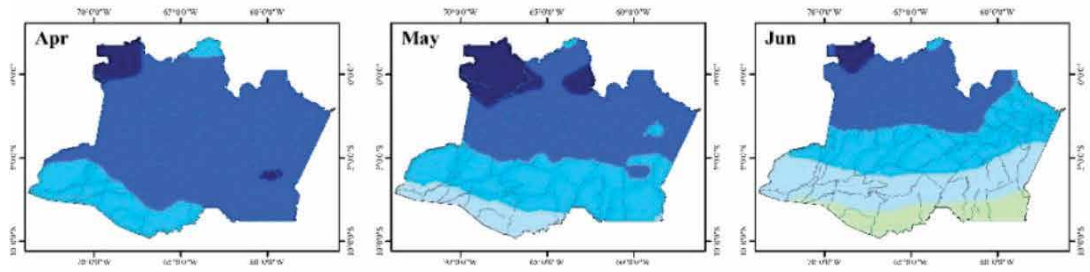

$<60$

$60.01-120$

$120.1-180$
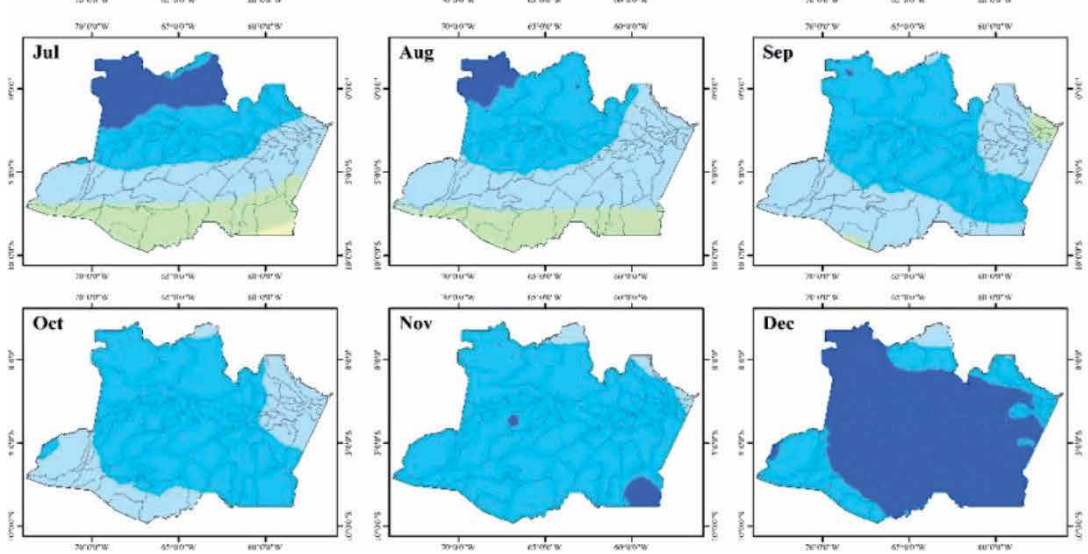

Figure 8.

Characterization of monthly pluviometric in the state of Amazonas (1989 to 2017). Source: European Centre for Medium-Range Weather Forecasts (2020).

As is the case for raw material extraction (clay), the manufacture of ceramic products requires environmental licensing and proof of origin of the input materials used in the ceramic kilns. The generation of thermal energy for heating and baking the ceramics demands creative strategies that adhere to bioeconomic principals. Wood from residuals generated from native forest timber processing is currently the principal fuel used by companies in the ceramic processing sector in the region $[18,39,40]$. However, bioeconomic principals require inclusion of new resources used as fuel for kilns to be based on renewable biomass [17]. In this sense, biomass is generally understood to be 


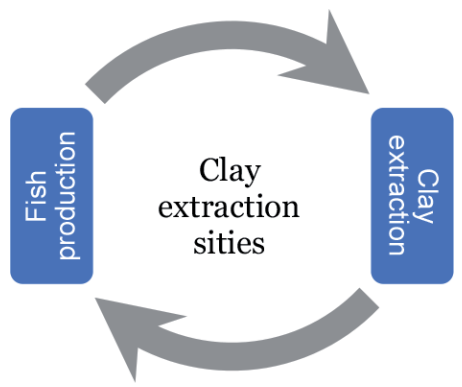

Figure 9.

Operational and bioeconomic cycle of clay extraction at the ceramic production center at Iranduba, Amazonas, Brazil. Source: The authors (2020).

\section{Ceramic products}

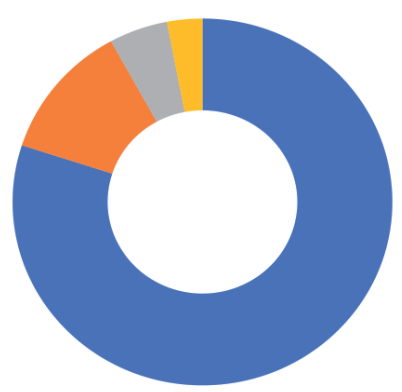

- Sealing blocks

- Structural blocks

Roofing tiles

Figure 10.

Variety of products made at the ceramic production center at Iranduba, Amazonas, Brazil. Source: The authors (2020).

any non-fossil organic matter from plants, animals, or microbes that has economic potential and that can be used to generate energy [41, 42]. For example, residuals generated from silvicultural management in agroforests are normally left on the soil surface and will eventually contribute to $\mathrm{CO} 2$ release to the atmosphere. Alternatively, this biomass could be reutilized and technologically adapted into an energy source by industries, including those that produce ceramics.

The Amazon possesses an extensive variety of sources of residual biomass, whose reutilization could result in tangible and intangible benefits for transformational industries. In the geographic area of the ceramic production center at Iranduba there are agroindustries that produce and process plant fibers such as malva (Urena lobata L.) and juta (Corchorus capsularis L.), whose organic residual wastes are underutilized and discarded into the environment. A mix of these plant fibers and other sources of biomass such as seeds of açaí-do-Amazonas (Euterpe precatória Mart.) could be used as an innovative alternative for burning in the ceramic kilns of the ceramics industry in the region. Despite the rudimentary production system that uses only a low level of technology, the residuals of these plant fibers represent a promising biotechnological solution for thermal energy generation. During the fiber extraction process about $95 \%$ of the plant is discarded at the collection site, and this represents an opportunity to create an alternative destination for this material. A similar situation occurs during the processing of açaí, wherein approximately $83 \%$ of the fruits are discarded due to a lack of an alternative use in the market. These residuals, which are generated in abundance in the Amazon and subsequently disregarded, could become subproducts, such as briquettes, for transformational industries. The manufacture of briquettes through mixing different types of residual 
biomass such as pellets used for products made from açaí, malva and juta, is an innovative biotechnological solution that can provide an alternate destination for residual solids as well as generate thermal energy in the ceramic kilns.

Another regional residual biomass that is commonly and abundantly discarded into the environment is the outer shell that contains the nuts of the Brazil nut tree (Bertholletia excelsa Bonpl.), whose chemical composition is primarily lignin and cellulose. This residual biomass rapidly enters combustion and has a high calorific value, thus being easily converted into thermal energy [43-46]. The use of this source of biomass in the ceramics production process as an alternative source of thermal energy will reduce the demand for wood from residuals of native forest and aid in decreasing deforestation in the western Amazon [18].

From the perspective of innovation, the adoption of a production system based on new types of inputs for energy generation should occur in an integrated manner, with active participation of research institutions, agroextractivist communities, and ceramic industries.

A production chain based on bioeconomic principles requires knowledge and technology to incorporate biomass resources used as an energy source and to manufacture ecological products (bioproducts), and also needs a sustainable business model. Figure 11 summarizes the sequence of activities of a ceramics production chain that will result in bioproducts and a sustainable business model.

The third step in the production chain consists of the process of marketing and distribution of the products to resellers or final consumers.

In terms of market competition, the structural characteristics of a sector are generally affected by an efficient combination of the processes of production, distribution, and sale. In the case of the ceramic industries of Iranduba, there is a certain level of homogeneity in the characteristics of internal processes, suppliers, and clients. These ceramic companies have operational structures like those categorized as Microcompanies (Microempresas (ME)) or small businesses (EPP) by the federal government. The principal characteristics of companies classified as ME or EPP are levels of revenue and tax bracket. According to Brazilian legislation, a company classified as $\mathrm{ME}$ must have gross annual revenue less than or equal to $\mathrm{R} \$ 360,000,00$ and pay taxes through one of the following options: (National Simple Method, Actual Profit Method, or Deemed Taxable Income). The legislation permits that the ME be registered in one of its four subcategories: Ordinary Partnership, Individual Limited Liability Company, Enterprise Corporation, and Sole Proprietorship. Companies classified as EPP gross annual revenue less than or equal to R $\$ 4,800,000,00$, and can opt for either the National Simple, Actual Profit, or Deemed Taxable Income tax payment methods.

The consumers of the products made by the ceramic industry in Iranduba are principally the resellers, with physical store locations in the city of Manaus, and on a smaller scale in the upper Negro River region (Figure 12). These clients are responsible for about 65 to $75 \%$ of the purchases of ceramic production made in Iranduba. The remainder of the production is sold and distributed to endpoint consumers, principally civil construction companies that are responsible for public and private construction projects that used financial resources from the federal government. Among the endpoint consumers is a small proportion of purchases made by individual people who buy products directly from a ceramic company for use in their own homes.

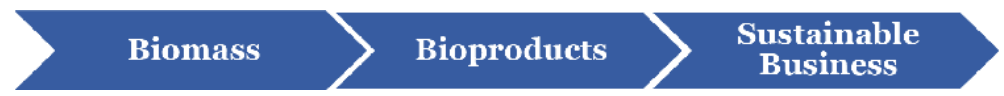

Figure 11.

Aspects of the bioeconomy that should be incorporate into a production chain. Source: The authors (2020). 


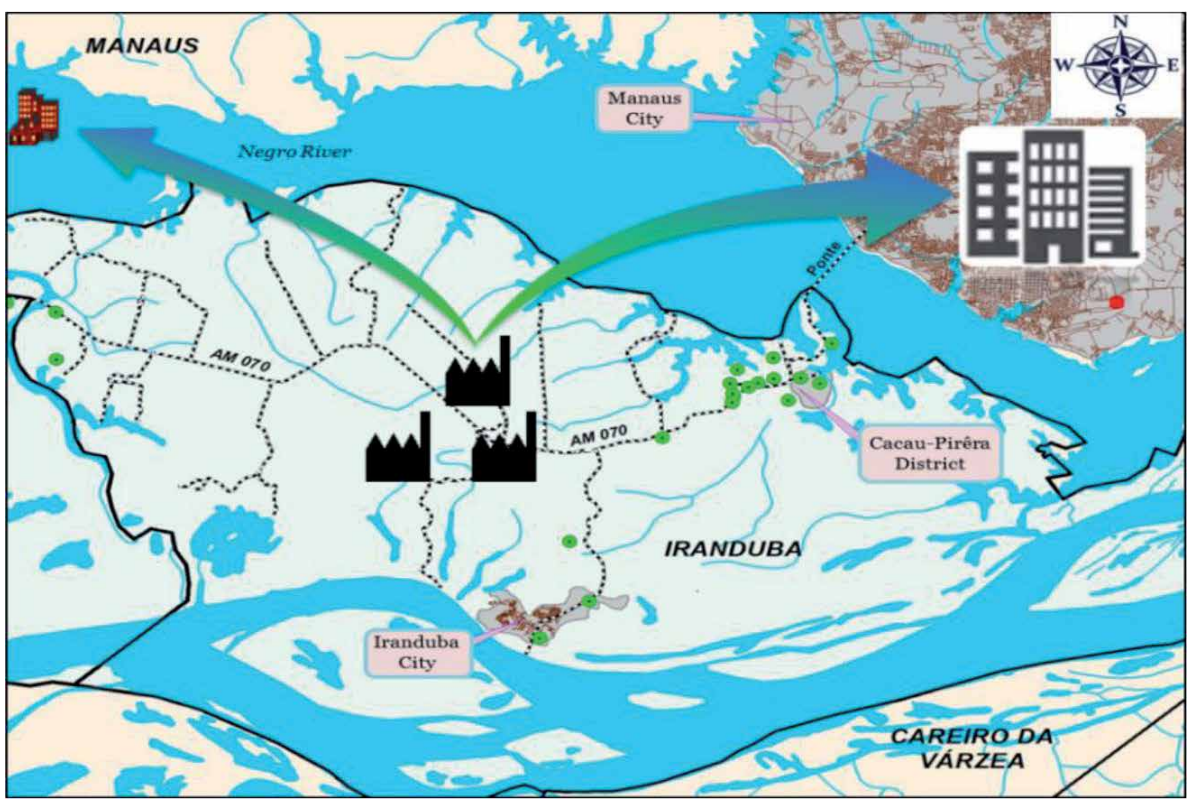

Figure 12.

Routes used to distribute products made in the ceramic production center at Iranduba. Source: ArGis (2020).

Normally, the sectorial or competitive environment in which a company operates is characterized by competing forces that drive companies to reinvent themselves through organizational strategies with the goal of increasing profits. A strategy can be defined as a set of operations that can create a competitive advantage by generating greater economic value compared to competitors. A competitive advantage is perceived through greater profitability, liquidity, leverage, and activity [47].

In the bioeconomy field, a competitive advantage can be related to the perception of the consumer that a certain company is more ecologically correct than its competitors, or that it is completely dedicated to producing and marketing products in harmony with principles of sustainability (Figure 13). This characteristic of ecological products imposes upon production systems the necessity of incorporating technologies that can aggregate value and attenuate impacts on biodiversity.

The search for sustainable competitive advantages has become an objective of all managers who are focused on the global market. The challenge consists in efficiently maintaining the skills that have been acquired over time while searching for novel strategies that will facilitate the manufacture and offer of ecologically

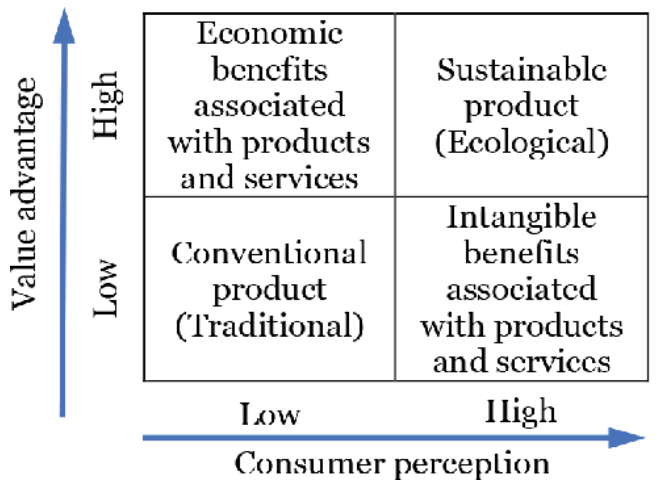

Figure 13.

Competitive advantages associated with biologically-based products. Source: The authors (2020). 
sustainable products. For the ceramic industries of Iranduba, the commercialization and distribution of ceramic products is conducted through a simple, unsophisticated process, without innovative characteristics that would differentiate a product from its competition. In general, the ceramic products that are sold are stored on pallets and wrapped in thin, transparent plastic film (Figure 14).

To maintain a sustainable competitive advantage, companies need to innovate and acquire more highly developed marketing skills than their competitors. Products that have a seal of origin or any characteristic that conveys ecological correctness will normally aggregate intangible values that are translated into a competitive advantage.

In strategic terms, the ceramic industries of Iranduba represent an activity that efficiently transforms natural resources into bioproducts that are a reference for the entire Amazon region. On the other hand, structural changes in the production chain through addition of biotechnology and manufacture of sustainable products, requires a detailed analysis and identification of possibilities and vulnerabilities that involve the ceramics sector in the region.

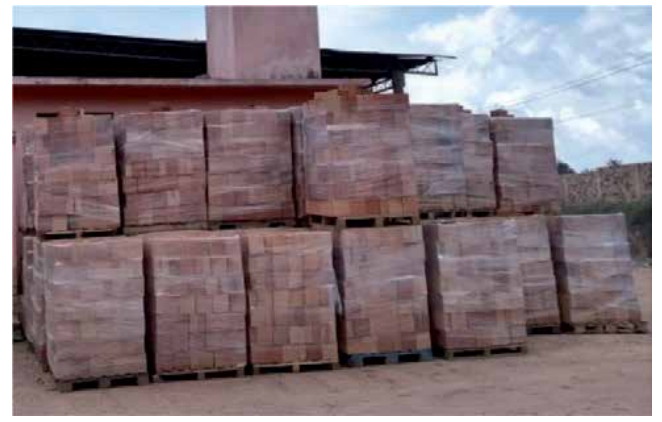

Figure 14.

Finished product, wrapped and ready for sale. Source: The authors (2020).

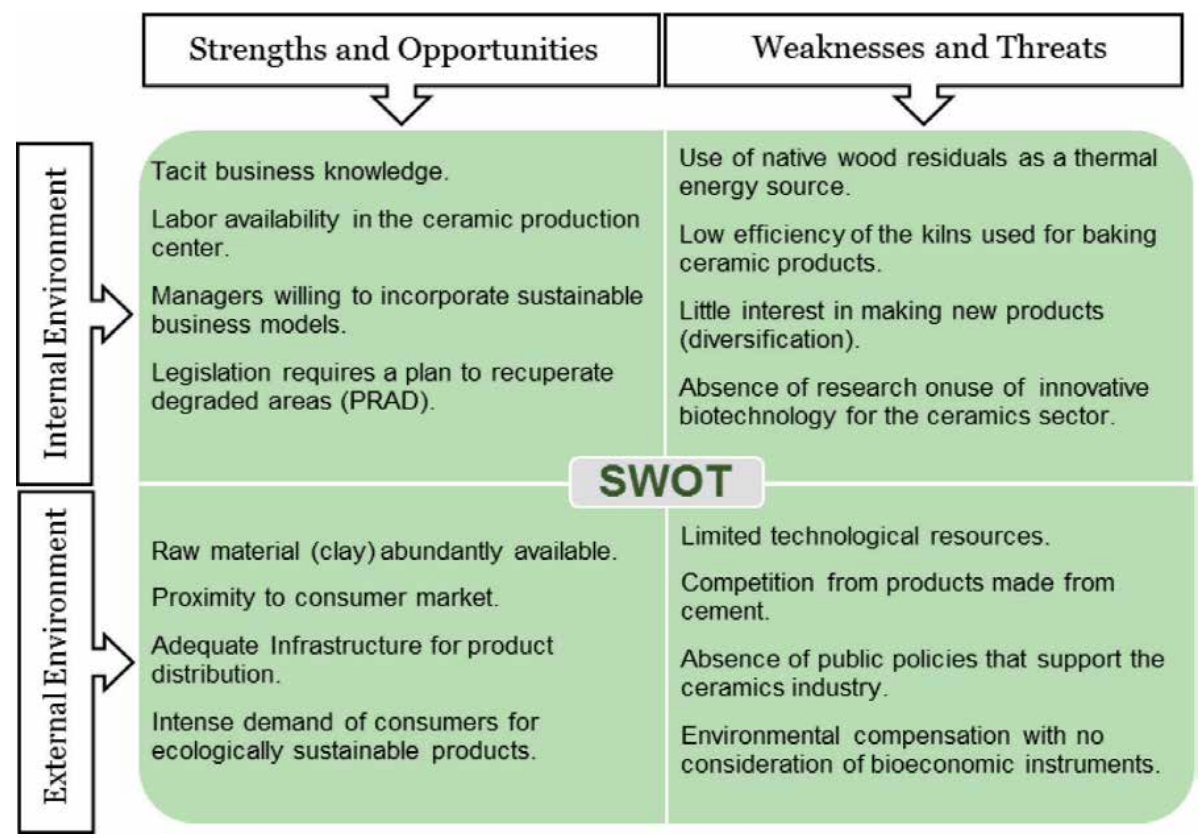

Figure 15.

Possibilities and vulnerabilities identified using the SWOT matrix. Source: The authors (2020). 
In a geopolitical context, the ceramic production center at Iranduba has great economic and social importance for regional development. A redefinition of strategies and objectives together with the creation of participative public policies focused on bioeconomic principles will result in positive results in markets and will generate business models that will have a global impact. An important incentive to foster the implementation of new market strategies is the elaboration of strategic planning that identifies the possibilities and vulnerabilities that involve the ceramics sector. A tool that is commonly used for the elaboration of strategic planning is the SWOT (Strength, Weaknesses, Opportunities and Threats) matrix. The SWOT analysis allows for evaluation of how a company or group of companies behave in relation to competitors, identification of the factors that are responsible for this difference, fragilities, and the market opportunities that can be explored.

The SWOT matrix below synthesizes the principal environmental, economic, and social aspects necessary for the implementation of production of bioeconomic products in the ceramic production center at Iranduba (Figure 15).

Each segment of industry acts in a dynamic environment where companies must concentrate their efforts to establish a set of activities that can explore new markets, balancing development with conservation of biological resources.

The simplified strategic diagnostic in Figure 13 will help ceramic industries identify points of rupture in their production chains and the bioeconomic alternatives necessary for organizational and technological restructuring.

\section{Conclusions}

In the red structural ceramics production chain, there are biotic and abiotic elements that interfere in the conditions of biodiversity. The industries in the ceramic production center in Iranduba have high potential to improve their production standards, strengthen relationships between stakeholders, and offer products that are competitive and ecologically correct.

The geological diversity of clays and the strategic location of the companies favors the manufacture and distribution of sustainable products, principally bricks and tiles, that are based on bioeconomic resources and principles.

The areas where clay is extracted to produce red ceramic products present excellent conditions to be able to, in the same natural environment, extract raw material, and engage in pisciculture to produce fish for subsistence and for sale in markets. These actions will stimulate an increase in income, access to new technologies, and a reduction of the impacts on biodiversity caused by natural resource extraction.

With respect to the production process that occurs at the ceramics manufacture facility itself, the burning of wood derived from native forest timber is currently the principal fuel used by these companies in the region. Strategies based on bioeconomic principles should be adopted so that there is a gradual substitution of this wood source for residual biomass materials. The introduction of different types of biomass including a biotechnological combination of plant fibers with seeds, fruits, and other materials that are discarded from agroforestry operations represent a promising alternative as a fuel source for the kilns of ceramic industries in the Amazon.

The cultural, socioenvironmental, and economic dynamics of the ceramic production center at Iranduba are very complex and challenging. The logic involved with providing incentive to produce red ceramic products based on bioeconomic strategies is not only rooted in the need to increase productive efficiency, but also in the necessity to respect the environment and develop a series of products made in the Amazon that are considered highly sustainable. 
Business strategies that seek excellence and product differentiation normally succeed in obtaining a competitive advantage and greater profits. In this context, well-structured, robust planning should be conducted that strives to make the operational activities of the ceramic industries of Iranduba conform to sustainability criteria and thus make their products a reference for the global market.

\section{Acknowledgements}

The authors thank the Syndicate of the Ceramic Kiln Industry of the State of Amazonas (SINDICER/AM) for the excellent information given on the current situation of the production chain of the ceramic industry center in Iranduba. The authors are also very grateful of the Biodiversity and Biotechnology Network of the Legal Amazon (Bionorte) for financial resources for publication.

\section{Author details}

Gelson Dias Florentino ${ }^{1 *}$, Lucieta Guerreiro Martorano², Sandro Augusto Lima dos Santos ${ }^{3}$, José Reinaldo da Silva Cabral de Moraes ${ }^{4}$, Ires Paula de Andrade Miranda ${ }^{5}$ and Maria de Lourdes Pinheiro Ruivo ${ }^{6}$

1 Doctoral Student, Biodiversity and Biotechnology Network of the Legal Amazon (Bionorte) Belém, College La Salle, Manaus, Brazil

2 Brazilian Agricultural Research Corporation (EMBRAPA) Eastern Amazon (CPATU/NAPT), Santarém, Pará, Brazil

3 Cerâmica Montemar Indústria e Serviço Ltda., Iranduba, Amazonas, Brazil

4 Doctoral Student, Plant Production, University of the State of São Paulo, São Paulo, Brazil

5 National Institute for Amazon Research (INPA), Manaus, Amazonas, Brazil

6 Emilio Goeldi Museum, Belém, Pará, Brazil

*Address all correspondence to: dias.gelson@gmail.com

\section{IntechOpen}

(C) 2020 The Author(s). Licensee IntechOpen. This chapter is distributed under the terms of the Creative Commons Attribution License (http://creativecommons.org/licenses/ by/3.0), which permits unrestricted use, distribution, and reproduction in any medium, provided the original work is properly cited. (cc) BY 


\section{References}

[1] Reis P, Ruschel R, Coelho A, Luz A, Martins da Silva V. Avaliação do potencial madeireiro na floresta nacional do tapajós, após 28 anos da exploração florestal. Pesquisa Florestal Brasileira, v. 30, n. 64, p. 265-281, 2010. DOI: $10.4336 / 2010 . p f b .30 .64 .265$

[2] Blanco-Gutié I, Manners R, Varela-Ortega C, Tarquis M, Martorano L, Toledo M. Examining the sustainability and development challenge in agricultural-forest frontiers of the Amazon Basin through the eyes of locals. Natural Hazards and Earth System Sciences. 2020;20:797-813. DOI: $10.5194 /$ nhess-20-797-2020

[3] Gaston K, Spicer J. Biodiversity. 2. Ed. Oxford. Blackwell Publishing; 2004

[4] De Groot R, Fisher B, Christie M. Integrating the ecological and economic dimensions in biodiversity and ecosystem service valuation (chapter 1 ). In: Kumar P, editor. TEEB Foundations, the Economics of Ecosystems and Biodiversity: Ecological and Economic Foundations. London: Earthscan; 2010

[5] Costanza R. Social goals and the valuation of natural capital. Environmental Monitoring and Assessment, v. 2003;86:19-28. DOI: 10.1023/A:1024045221992

[6] Gomes A, Dantas Neto J, Silva V. Serviços ecossistêmicos: conceitos e classificação. Revista Ibero Americana de Ciências Ambientais.

2018;9(4):12-23. DOI: 10.6008/ CBPC2179-6858.2018.004.0002

[7] Hopkins M. Modelling the known and unknown plant biodiversity of the Amazon Basin. Journal of Biogeography. 2007;34(8):1400-1411. DOI: 10.1111/j.1365-2699.2007.01737.x

[8] Boubli J, Hrbek T. Introdução à Biodiversidade Amazônica. In: Marcon
J [et al.] (Org.). Biodiversidade Amazônica: caracterização, ecologia e conservação. Manaus: Edua. 2012

[9] Veiga J, Ehlers E. Diversidade biológica e dinamismo econômico no meio rural. In: Peter MAY. (Org.). Economia do Meio Ambiente. 3.ed. Campus: Rio de Janeiro; 2018. pp. 289-308

[10] Reyers B, Polasky S, Tallis H, Mooney H, Larigauderie A. Finding common ground for biodiversity and ecosystem services. Bioscience. May 2012;62(5):503-507. DOI: 10.1525/ bio.2012.62.5.12

[11] Mace G. Approaches to defining a planetary boundary for biodiversity. Global Environmental Change. Sep 2014;28:289-297. DOI: 10.1016/j. gloenvcha.2014.07.009

[12] Balvanera P [et al.]. Ecosystem Services (Chapter 3). In: Walters M, Scholes R (Eds.), The GEO Handbook on Biodiversity Observation Networks, SpringerOpen, 2017. ISBN 978-3-31927288-7 (eBook).

[13] Parron L [et al.]. Pesquisa sobre serviços ecossistêmicos no Brasil: uma revisão sistemática. Rev. Ambient. Água [online]. 2019, vol.14, n.3, e2263. Epub May 20, 2019. DOI: $10.4136 /$ ambi-agua.2263.

[14] Raynaut C. Meio ambiente e desenvolvimento: construindo um novo campo do saber a partir da perspectiva interdisciplinar. Desenvolvimento e Meio Ambiente, n. 2004;10:21-32, jul./ dez. Editora UFPR

[15] Michelsen G, Adomßent M, Martens P, Hauff Michael. Sustainable development - Background and context (chapter 2). In Heinrichs $\mathrm{H}$ et al. (eds.), Sustainability Science. London: Springer, 2016. 
[16] Nascimento E. Trajetória da sustentabilidade: do social ao ambiental, do ambiental ao econômico. Estudos Avançados (USP. Impresso), v. 2012;26: $51-64$

[17] Lewandowski I, Gaudet N, Lask J, Maier J, Tchouga B, Vargas-Carpintero R. Context (chapter 2). In: Lewandowski I, editor. Bioeconomy - Shaping the Transition to a Sustainable, Biobased Economy. University of Hohenheim, Stuttgart, Germany: Springer; 2018

[18] Florentino G [et al.]. Dynamics of Space and Time of the Production Chain of the Ceramic Industry Production Center of Iranduba, Amazonas, Brazil. Sustainability, v. 11, p. 5576, 2019. DOI: $10.3390 /$ su11205576

[19] Becker B, Stenner C. Um futuro para a Amazônia. Série inventando o futuro. São Paulo: Oficina de Textos; 2008

[20] Neves E. Duas interpretações para explicar a ocupação Pré-Histórica na Amazônia. In: Tenório M (org.). PréHistória da Terra Brasilis. Rio de Janeiro: Editora UFRJ; 1999

[21] Pinheiro H. Oleiros da vida: trabalho, ambiente e o futuro dos trabalhadores do barro em Iranduba (AM) [Tese] Universidade Federal do Amazonas: Manaus-AM, Brasil, 2015.

[22] AMAZONAS. Plano de

desenvolvimento preliminar: APL de base mineral cerâmico-oleiro. Núcleo Estadual de Arranjos Produtivos Locais - NEAPL/ Secretaria de Estado de Planejamento e Desenvolvimento Econômico - SEPLAN/ AM. In: Governo do Estado. Manaus: NEAPL/SEPLAN; 2009

[23] Chaves S. Estudo de Mercado da Produção de tijolos no Município de Iranduba. Monografia, Faculdade de Estudos Sociais da Universidade Federal do Amazonas, 2001.

[24] Maciel C, Valle M, Moura J. Globalização, reestruturação produtiva e controle do trabalho no Polo oleirocerâmico de Iranduba - AM. Novos Cadernos NAEA. 2012;15:311-331

[25] Florentino G, Martorano L, Miranda I, Silva-Rocha S.

Socioeconomic impacts caused by a center of ceramic manufacturing in the Amazon: Sustainable agrotechnological strategies based on the IrrigaPote technology. In: 7th Brazilian Biotechnology Congress and 2nd Biotechnology Ibero-American Congress. Brasília-DF, Brazil, November 18-21. 2018

[26] D’Antona R, Reis N, Maia M, Nava D. Projeto materiais de construção na área Manacapuru - Iranduba Manaus - Careiro (domínio baixo Solimões). CPRM - Serviço Geológico do Brasil: Manaus; 2007. Available from: http://rigeo.cprm.gov.br/jspui/handle/ doc/1737 Accessed: 12 Jun 2020

[27] BRASIL. Ministério de Minas e Energia. Projeto Argila: Regularização e levantamento ambiental do setor oleiro nos municípios de Iranduba e Manacapuru. Relatório Final. DNPM/ MME, Manaus, 2000.

[28] Campelo N [et al.]. Ensaios tecnológicos em cerâmica vermelha do pólo oleiro dos municípios de Iranduba e Manacapuru, AM. In: Anais do $48^{\circ}$ Congresso Brasileiro de Cerâmica. 28 de junho a $1^{\circ}$ de julho de 2004. Curitiba-PR, 2004.

[29] Abreu N, Silva D, Carvalho D, Sampaio F. Uma abordagem geográfica dos aspectos físicos e dos potenciais econômicos do solo de Iranduba - AM. Eixo Temático: Geomorfologia e cotidiano. Revista Geonorte, Edição Especial, v.2, n.4. 2012:659-667

[30] Maciel C, Valle M, Maciel J. Caminhos cruzados: relação entre empresa, trabalhadores e sindicato em Polo oleiro-cerâmico da Região Metropolitana de Manaus-AM. 
Novos Cadernos NAEA. Suplemento. 2013;16:127-162

[31] Morrison B, Golden J. An empirical analysis of the industrial bioeconomy: Implications for renewable resources and the environment. BioResources, v. 10, n. 3, p. 4.411-4.440. 2015

[32] Silva M, Pereira F, Bomtempo J. A Bioeconomia brasileira em números. BNDES Setorial. 2018;47:277-332

[33] Leripio A, Leripio D. Cadeias Produtivas Sustentáveis. Mix Sustentável. 2015;1:142-159

[34] O'Rourke D. The science of sustainable supply chains. Science. Jun 2014;344(6188):1124-1127. DOI: $10.1126 /$ science.1248526

[35] BRASIL. Ministério do Meio Ambiente. Resolução CONAMA n ${ }^{\circ}$ 237, de 19 de dezembro de 1997. Dispõe sobre a revisão e complementação dos procedimentos e critérios utilizados para o licenciamento ambiental.

[36] SUFRAMA. Superintendência da Zona Franca de Manaus: Projeto Potencialidades Regionais - Estudo de Viabilidade Econômica. Vol. 8. SUFRAMA: Piscicultura. Manaus-AM; 2003. Available from: http://www. suframa.gov.br/publicacoes/proj_pot_ regionais/piscicultura.pdf Accessed: 15 Jun 2020

[37] Florentino G. Caracterização do extrativismo e comércio de pescado no Médio Rio Juruá. [Dissertação] Mestrado em Desenvolvimento Regional. In: Universidade Federal do Amazonas - Manaus: UFAM. 2012

[38] Petrere (Org.). O Setor Pesqueiro na Amazônia: situação atual e tendências. Manaus: IBAMA. ProVárzea; 2004

[39] Azevedo [et al.]. Produção de lenha na região de Iranduba e Manacapuru - Amazonas: Acacia mangium e Acacia auriculiformis. Embrapa Amazônia Ocidental, 2002. Available from: <https://www. embrapa.br/busca-de-publicacoes/-/ publicacao/674334/producao-de-lenhana-regiao-de-iranduba-e-manacapuru--amazonas-acacia-mangium-e-acaciaauriculiformis> [Accessed: 21 Jun 2020].

[40] Barros S [et al.]. Avaliação do potencial energético das espécies florestais Acacia auriculiformis e Ormosia paraensis cultivadas no município de Iranduba/Amazonas, Brasil. Madera y Bosques, v. 15, n. 2, p. 59-69, 2009.

[41] Dias J [et al.]. Produção de briquetes e péletes a partir de resíduos agrícolas, agroindustriais e florestais. Brasília, DF: Embrapa Agroenergia, 2012. 130 p.

[42] Perea-Moreno M, Samerón-Manzano E, Perea-Moreno A. Biomass as renewable energy: Worldwide research trends. Sustainability. 2019;11:863. DOI: 10.3390/su11030863

[43] Oliveira J, Lobo P. Avaliação do Potencial Energético de Resíduos de Biomassa Amazônica. In: $4^{\circ}$ AGRENER, 2002, Campinas-SP. CD-Rom, v. CD-Rom. p. 0-6, $4^{\circ}$ Encontro de Energia no Meio Rural - AGRENER, 2002. Available from: <http://www. proceedings.scielo.br/scielo.php?pid=M SC0000000022002000100026\&script $=$ sci_arttext> [Accessed: 20 Fev 2020]

[44] Freitas J, Naves M. Composição química de nozes e sementes comestíveis e sua relação com a nutrição e saúde. Revista de Nutrição (Impresso). 2010;23:269. DOI: 10.1590/ S1415-52732010000200010

[45] Carmona I, et al. Potencial energético da biomassa e carvão vegetal de resíduos de castanha-dopará (Bertholletia excelsa Bonpl.). III Congresso Brasileiro de Ciência e Tecnologia da Madeira, Florianópolis, 2017. Available from: https:// proceedings.science/cbctem/papers/ 
Bioeconomic Potential of Sustainability Indicators in a Ceramic Production Center...

DOI: http://dx.doi.org/10.5772/intechopen.94002

potencial-energetico-da-biomassa-e-

carvao-vegetal-de-residuos-de-castanhado-para-\%28bertholletia-excelsabonpl.\%29 [Accessed: 10 Ago 2020]

[46] Alves A, et al. Thermal Diagnosis of Heat Conduction and Combustion Time of Fruits of the Brazil Nut Tree (Bertholletia excelsa Bonpl.). Advances in Bioscience and Biotechnology (Impresso), v. 11, p. 60-71, 2020. DOI: 10.4236/abb.2020.112005

[47] Barney J, Hesterly W. Administração estratégica e vantagem competitiva. 5 . São Paulo: Pearson Prentice Hall; 2017. pp. 7-13 



\title{
Neo-Developmentalism and Regional Integration: IIRSA Impact in the Environmental Agenda in the Amazon
}

\author{
Pedro Pablo Cardoso Castro and Nirvia Ravena
}

\begin{abstract}
The regional integration policy in Latin America was based on the premises of the Initiative for the Integration of the Regional Infrastructure of South America (IIRSA), seen as a development strategy adopted by the regional political elites and as an instrument of Brazilian foreign policy. Focusing on the projects undertaken in the Amazon Hub, the article analyzes the integration strategy and its impact on environmental regulation. The paper highlighted the role played by the developmentalism goals in the region regarding the environmental regulation, adopting a model of integration encompassing a reduction of natural resources stock, which is a strategic feature for sustainable development policies. This chapter results from descriptive research, based on secondary data and official documents available from the involved institutions. They analyze the Brazilian government's neo-developmentalism goals to understand how the environmental agenda in Pan Amazon was affected.
\end{abstract}

Keywords: regional integration, neo-developmentalism, Amazon, environmental agenda

\section{Introduction}

The foreign policy of the Initiative for the Integration of the Regional Infrastructure of South America (IIRSA) is one of the key instruments for repositioning South American countries in an environment of global change $[1,2]$. In this context, IIRSA emerged as an initiative of the Inter-American Development Bank (IDB) in August 2000, in partnership with the Andean Development Corporation (CAF) and the River Plate Basin Financial Development Fund (Fonplata), based on a proposal of the then President of Brazil, Fernando Henrique Cardoso (FHC), at the First Summit of South American Presidents (2000).

Originally launched by presidents of neoliberal affiliation (e.g., Andres Pastrana Colombia; Fernando De la Rua - Argentina; Fernando Cardoso - Brazil); IIRSA was subsequently supported by the governments of progressive orientation (e.g., Ecuador, Bolivia, Peru, Chile). In December 2004, the twelve participant Presidents confirmed their commitment to IIRSA initiatives during the Cuzco meeting, approving the "Consensual Implementation Agenda for 2005-2010" that selected the priority projects to be concluded in 2010. 
In that sense, when IIRSA was created, there was a scenario determined by the Washington Consensus that outlined a neoliberal agenda. It recommended (with intense pressure from multilateral lending agencies and developed countries) the privatization of state companies, deregulation of the economy, and unilateral liberalization of the foreign trade in Latin American countries [1, 3, 4]. The declared goals of IIRSA were:

"To promote the development of the regional infrastructure within a framework of increasing competitiveness and sustainability, in order to generate the necessary conditions to achieve a stable, efficient and equitable development pattern in the region; identifying the necessary physical, regulatory and institutional requirements and seeking implementation mechanisms that promote physical integration at the continental level” [5].

IIRSA was conceived to execute the regional integration based on ten "integration hubs" based on territorial planning. Four of them pass through the Amazon Region - comprehending all territories located in the Amazon River basin's watershed area. From a geopolitical perspective, this definition includes the following Amazonian countries: Bolivia, Brazil, Colombia, Ecuador, Guyana, Peru, Suriname, and Venezuela. Thus, in Latin America, Brazil acting as a global player $[6,7]$, together with the Amazon countries, performed the regional dynamics coordination where IIRSA project integration occurred.

This chapter discusses the regional integration in the initial phase implemented by IIRSA in the period between the years 2013 and 2014, as well as the positioning of the integration projects concerning the environmental regulation created by the Amazonian countries highlighting the role played by the sustainability concept regarding the existing environmental regulation. The IIRSA adopted a model of integration encompassing a reduction of natural resources stock, a strategic feature for long term sustainable development policies. The central question that this article wants to answer is: How the implementation of the IIRSA integration projects affected the governance of the sustainability and environmental agenda in the Brazilian Amazon?

The study associates the analysis of the IIRSA Project hubs related to Brazilian Amazon areas and the neodevelopmentalism to understand this economic policy's impacts in the Brazilian environmental scenario [7, 8-14]. The empiric reference of this study, the IIRSA Project, is considered a material expression of the development strategies executed by the Latin American political elites from 2011 to 2014 when an accelerated implementation of the IIRSA took place.

This chapter is organized into three sections: The first one describes the neodevelopmentalism approach and the recent reflections on the post-neoliberal period in the Brazilian Amazon Region. The second section presents the issues related to environmental regulation and sustainability as an arena of interest in the Amazon region. The last section describes and analyzes Amazon's IIRSA projects, the place of the environmental agenda, and the Brazilian foreign policy role in this context.

\section{Neo-developmentalism and the pan-Amazonian context}

The neo-developmentalism supports its interpretation in the governmental strategies assumed by the Latin American governments post-Consensus of Washington, being the broader goals of this strategy summarized by the generic term "macroeconomic" $[15,16]$. The tactics are focused on the combination of stability, which includes inflation control, exchange rate and balance of payments, fiscal sustainability, low-interest rates, and reduction of uncertainties related to future demand, which should provide a more stable environment for investment decisions of these governments [12, 13]. 
The achievement of these goals would require complementary actions of monetary, fiscal, exchange, and wage policies [8-11], aimed at restoring state power to control the currency, facilitate policy implementation, promote competition, and support improvements in income distribution $[8,11,15]$. Also, the adoption of a development strategy that allows domestic firms to seize global economies of scale, and infrastructure and technological updating processes, supported by innovation policy and an activist trade policy targeted at strong intellectual property regimes and investment opportunities for domestic firms. These elements entail a commitment to mobilizing all available labor resources, increasing productivity in each industry, and the steady transfer of finance to high wage and high value-added sectors.

However, neo-developmentalism government strategies insisted on the implementation of neoliberal policies. The politicians conceived the Brazilian economy from 2003 to 2016 as potentially underutilized due to unrealized productivity gains that could be captured through infrastructure development and economic growth. This approach turned areas as Amazon in economies of scale; consequently, opening the region via state support to higher private-sector investment (shifting workers of lower productivity), and expanding the participation in foreign markets as a government goal $[7,17,18]$.

\subsection{IIRSA: Regional integration and developmentalism tool}

The beginning of the XXI century represented a set of global changes, including socialist-oriented governments in many South American countries, which gained influence in the regional political landscape. This was evidenced by the general elections' electoral results in Venezuela, Chile, Brazil, Argentina, Uruguay, Bolivia, Peru, and Ecuador in the first decade of 2000. Programmatically, the elected candidates in these countries had left-wing programs in which the environmental agenda was associated with other electoral strategies based on developmental actions whose legitimacy was based on popular acclaim. The Latin American leaderships, as elected, combined developmentalism policies not considering environmental problems accrued from development strategies and relegated sustainability to a secondary policy level $[19,20]$.

The IIRSA implementation plan did not have a strong administrative and operational bureaucratic body at the multi-local levels. Consequently, after the delay of the integration agendas, some organizational changes occurred at the bureaucratic level in each of the involved territories, and administrative instances emerged to correct systemic inefficiencies in the execution of several projects. In response, the Brazilian government - as the IIRSA paymaster in Latin America - created the South American Council for Infrastructure and Planning (COSIPLAN) to coordinate and accelerate the IIRSA and the developmental premises of leftist governments in the Pan-Amazon countries. The implementation of IIRSA was developing by hubs, and this was how developmentalism politicians could associate diplomatic issues with the necessities of implementation.

Four of the ten IIRSA hubs of action were located in the Amazon territory. Among these, the Peru-Brazil-Bolivia hub concentrates much of the internationalization of the Madeira Complex. From the total IIRSA projects for this area, twenty-one are related to ports and waterways works; twelve to roads; three to works in seaports; five to air transportation and border crossings, and the other two deal with electrical interconnection for various hydroelectric power plants built along the Madeira River. The hubs materialize this complexity and demonstrate the magnitude of the integration and the coordination problems arising from this supranational proposal, as seen in Figure 1. 


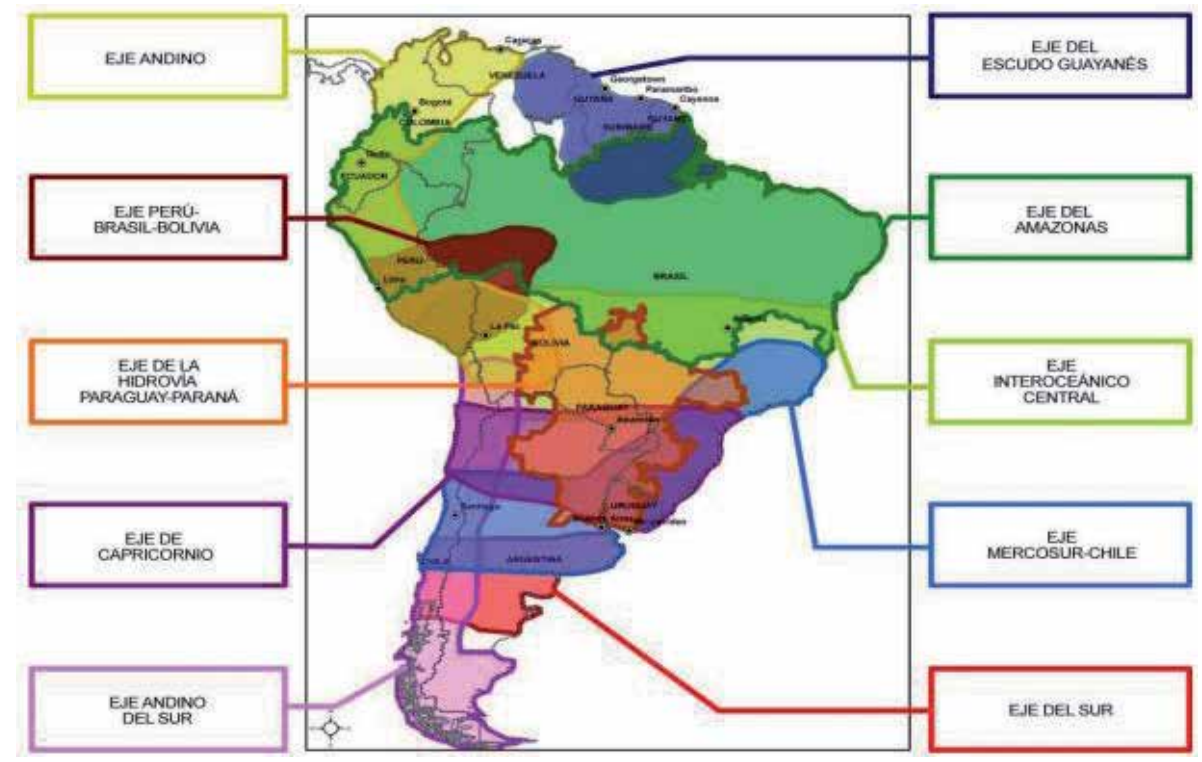

Figure 1.

Map of the IIRSA hubs. Source: GEOSUR, 2018.

\subsection{Integration projects in the Amazon and environmental regulation}

The lack of environmental regulation coordination among the Amazonian countries is notorious in dealing with transboundary water resources management issues. In this regard, an integrated analysis of environmental regulations for the Amazon detects absences and impossibilities of consolidated regulatory arrangements for effective cooperation in the region [21]. This fact certainly has had an impact on the possibility of developing infrastructure on a sustainable basis, as in Amazonian areas, the command and control instruments used by environmental regulation norms have systemic efficiency limits.

In addition to the increasing environmental deregulation in the Brazilian political scenario, IIRSA became an effective instrument for government interests in expanding jobs and increasing economic growth rates and market agents seeking to ensure their investment return in electoral campaigns. An example of this deregulation is the Bill No 1876/1999, which "provides for Areas of Permanent Preservation, Legal Reserve, forest exploitation and other measures" approved in 2013. According to their environmental licensing situation, Table 1 shows the infrastructure projects in the four IIRSA integration hubs located in the Amazon region.

Of the total 191 projects, $54.5 \%$ do not comply with environmental licensing norms. Noteworthy are many unlicensed waterway and railroad projects in the Amazon Hub: 18 of 27 projects, i.e., 66.6\% of those in the same condition. Another situation worth mentioning is the hydroelectric plants and fiber optic transmission lines, mostly found without environmental licenses.

The data presented in the 2013 and 2014 reports - organized in Table 2 - show the projects' typology. Systematized data of each type of integration show the infrastructure projects' situation according to the execution stage and the environmental license condition. The environmental licenses were obtained only for $45.5 \%$ of the projects, and several of them are still being executed or are at the pre-execution stage without an environmental license.

The data presented in Tables 1 and 2, and Figure 2, indicate the fragility of the regulatory actions undertaken at the beginning of the implementation of 
Neo-Developmentalism and Regional Integration: IIRSA Impact in the Environmental Agenda... DOI: http://dx.doi.org/10.5772/intechopen.93983

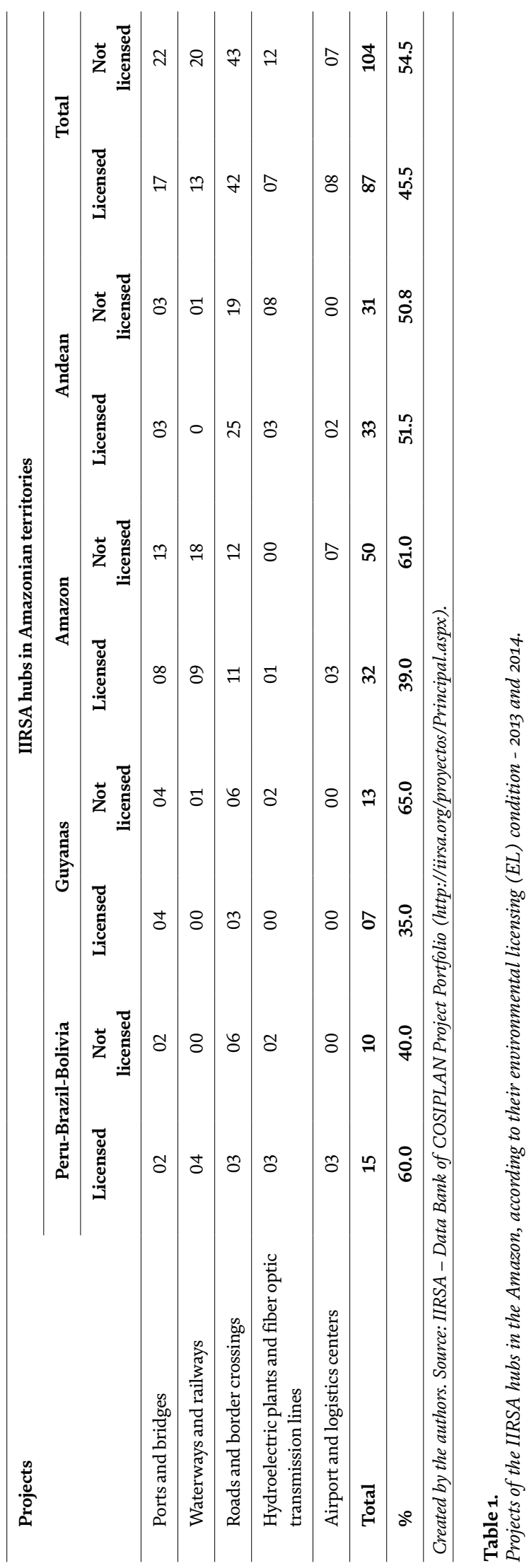


IIRSA projects. Especially projects related to energy generation (63\% without EL), waterways, and railroads (60.6\% without EL) - according to Graphic 1 - express the dysfunctional character between IIRSA and the environmental agenda.

\begin{tabular}{|c|c|c|c|c|c|c|}
\hline \multirow[t]{2}{*}{ Projects } & \multirow[t]{2}{*}{ Project stage } & \multicolumn{4}{|c|}{ IIRSA hubs in Amazonian territories } & \multirow[t]{2}{*}{ Total } \\
\hline & & Peru-Brazil-Bolivia & Guyanas & Amazon & Andean & \\
\hline \multirow{6}{*}{$\begin{array}{l}\text { Ports and } \\
\text { bridges }\end{array}$} & Pre-execution & 2 & 1 & 8 & 1 & 12 \\
\hline & AP. to begin & 1 & 4 & 4 & - & 9 \\
\hline & Execution & - & - & 6 & 3 & 9 \\
\hline & Completed & 1 & 3 & 3 & 2 & 9 \\
\hline & Total & 4 & 8 & 21 & 6 & 39 \\
\hline & With EL & 2 & 4 & 8 & 3 & 17 \\
\hline \multirow{6}{*}{$\begin{array}{l}\text { Waterways } \\
\text { and railways }\end{array}$} & Pre-execution & 3 & & 8 & & 11 \\
\hline & AP. to begin & 1 & 1 & 6 & 1 & 9 \\
\hline & Execution & - & - & 5 & - & 5 \\
\hline & Completed & - & - & 8 & - & 8 \\
\hline & Total & 4 & 1 & 27 & 1 & 33 \\
\hline & With EL & 4 & 0 & 9 & 0 & 13 \\
\hline \multirow{6}{*}{$\begin{array}{l}\text { Roads and } \\
\text { border } \\
\text { crossings }\end{array}$} & Pre-execution & 2 & 2 & 5 & 8 & 17 \\
\hline & AP. to begin & 2 & 1 & 3 & 11 & 17 \\
\hline & Execution & 3 & 4 & 11 & 15 & 33 \\
\hline & Completed & 2 & 2 & 4 & 10 & 18 \\
\hline & Total & 9 & 9 & 23 & 44 & 85 \\
\hline & With EL & 3 & 3 & 11 & 25 & 42 \\
\hline \multirow{6}{*}{$\begin{array}{l}\text { Hydroelectric } \\
\text { plants and } \\
\text { fiber optic } \\
\text { transmission } \\
\text { lines }\end{array}$} & Pre-execution & 1 & - & - & - & 1 \\
\hline & AP. to begin & 2 & 1 & - & 4 & 7 \\
\hline & Execution & 1 & - & - & 3 & 4 \\
\hline & Completed & 1 & 1 & 1 & 4 & 7 \\
\hline & Total & 5 & 2 & 1 & 11 & 19 \\
\hline & With EL & 3 & 0 & 1 & 3 & 7 \\
\hline \multirow{6}{*}{$\begin{array}{l}\text { Airport and } \\
\text { logistics } \\
\text { centers }\end{array}$} & Pre-execution & - & - & 1 & - & 1 \\
\hline & AP. to begin & - & - & 6 & - & 6 \\
\hline & Execution & 3 & - & 2 & 1 & 6 \\
\hline & Completed & - & - & 1 & 1 & 2 \\
\hline & Total & 3 & - & 10 & 2 & 15 \\
\hline & With EL & 3 & - & 3 & 2 & 8 \\
\hline \multicolumn{2}{|l|}{ Grand total } & 25 & 20 & 82 & 64 & 191 \\
\hline \multicolumn{2}{|c|}{ Total projects with EL } & 15 & 07 & 32 & 33 & 87 \\
\hline \multicolumn{2}{|c|}{ \% Projects with EL } & 60.0 & 35.0 & 39.0 & 51.5 & 45.5 \\
\hline
\end{tabular}

Source: IIRSA - Data Bank of COSIPLAN Project Portfolio (http://iirsa.org/proyectos/Principal.aspx).

Table 2.

IIRSA hubs projects in the Amazon, according to the project stage and environmental licensing (EL) condition 2013 and 2014. 
Neo-Developmentalism and Regional Integration: IIRSA Impact in the Environmental Agenda... DOI: $h$ ttp://dx.doi.org/10.5772/intechopen.93983

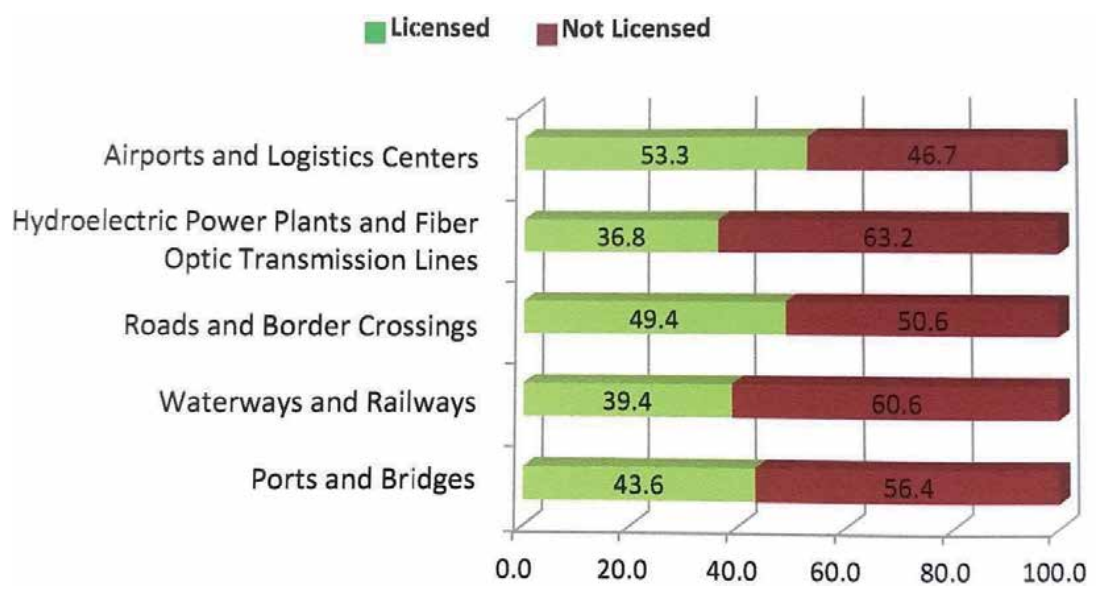

Figure 2.

IIRSA projects in the Amazon hubs, according to the environmental license condition. Source: IIRSA - Data Bank of COSIPLAN project portfolio (<http://iirsa.org/proyectos/Principal.aspx >).

The graphic shows that between the years 2013 and 2014, none of the activities that characterize the integration of IIRSA respected the environmental dimension and sustainability goals, as advertised by the governments. It is important to notice that in Bolivia and Brazil, many voters believed in the proposed administration's developmental agenda, and these popular governments took compliance with environmental laws to second place.

Specifically, in the Amazon countries, environmental regulatory instruments exist without a coordinating scope of environmental policies and have a low level of institutionalization [21,22]. Brazil's actions in the coordination of regional integration projects show this country as a hegemonic power who imposed, at that moment, models of environmental regulation. In the case of IIRSA in the Amazon, these projects would operate throughout the territory where regulatory compliance projects were already underway. For instance, in the Andean Hub runs the Project: Armonización regulatoria: eléctrica, gasífera y petrolera; operating in Bolivia, Perú, Colombia, Ecuador, and Venezuela; and the Amazon Hub, where the largest stocks of natural resources on the planet are located, and the lowest degrees of institutionalization of environmental regulations were imposed (see Figure 3).

The connection of the Amazon region with the execution of projects with preliminary studies of social and environmental impact to subsidize licensing processes and the respective socio-environmental conditions for the projects' execution puts this territory in a degree of vulnerability never experienced before. The conception of development follows an ideology that relegates the environmental agenda to a secondary place. Companies that used to capture the agenda of construction works for IIRSA hubs during the FHC administration were the same at the time of the Latin American popular governments and influenced the decisions of left and center-left governments elected. These companies changed their performance operating in close connection to state structures, introducing their demands and exercising their influence through a plural strategy in supranational arenas as a movement of political capture. They have more flexibility to act due to the redefinition of Latin America's role in the global crisis of 2008 and the conversion of Brazil into a global player in the world scenario in that period $[6,23]$. The dualism environmental regulation and developmentalism started to be obscured, and sustainability stayed as a corporation's discourse.

The World Investment Report indicated that after the 2008 crisis, the most significant increase in foreign investment occurred in South America. Investments were in the order of US\$ 86 billion, with Brazil accounting for $56 \%$ of this amount. 


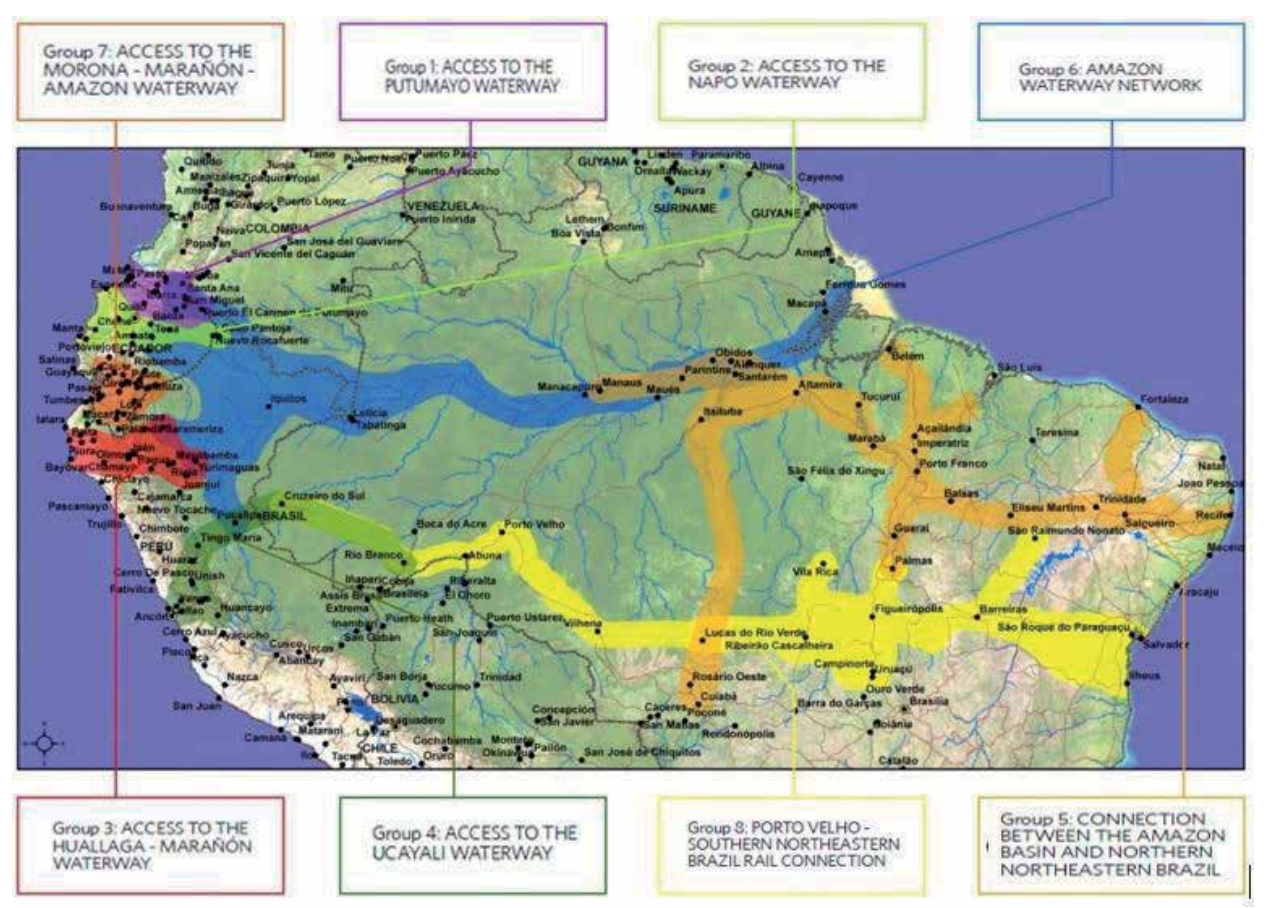

Figure 3.

Map of the IIRSA area of influence in the Amazon. Source: IIRSA, 2014.

Companies such as Vale, Gerdau, Camargo Correa, Votorantim, Petrobras, and Braskem made acquisitions in the iron ore, steel, food, cement, chemicals, and oil refining sectors, as well as other industries in Latin American countries [24]. From a domestic perspective in Brazil, Brazilian companies have met their demands through the association between the Growth Acceleration Program (PAC), a developmental program, and IIRSA actions. In this sense, hydroelectricity gains momentum, given its centrality as a structuring element of regional integration, simultaneously with the violation of environmental sustainability.

\subsection{Foreign policy, South-South cooperation, and IIRSA}

Latin American cooperation started with the Amazon Cooperation Treaty (ACT). The ACT started after the meeting of Brazil and Peru heads of state, who committed to elaborating the initial outline for the cooperation. Since its elaboration in 1978, the ACT was enforced under the premise of preservation and the development of the Amazon region, within the context of territoriality - not the environmental sense. In the same period, the priority sectors were defined for establishing cooperation: Territorial occupation, the development of technology, and scientific knowledge [25].

In 2002, the Amazon Cooperation Treaty Organization (ACTO) creation reinforced the integration purposes initiated with the ACT, emphasizing the environmental dimension. In this context, the ACTO Executive Secretariat - based in Brasilia and disconnected with the Amazonian reality - is now another body that has intensified regional inequalities, emphasizing the competitive dimension between signatories of projects funded by multilateral agencies for the Amazon [22].

This observation is relevant as the IIRSA operated within this context. The neo-developmental legacy that remained in some Brazilian sectoral bureaucracies 
influenced foreign policy towards the Latin American neighbors [26], making the Brazilian Amazon a region where sectoral policies were defined with a high degree of concentration when considering the federative pact. In the other signatory countries of the ACTO, the distance dynamics grows more and more from the centers where the decision-making processes took place [27, 28].

Within this context, the IIRSA actions and the course of the South-South cooperation in the Amazon were materialized by the left government's administrations until 2016 through ACTO's coordination. This organization's role was redefined, leaving it as a standard of regional sustainability associated with a change of political agenda that included development from a different perspective from the one that originated its creation in the ACT.

The development assumptions in the agenda of IIRSA's priority projects in execution and the lack of related licenses also attest that the Brazilian foreign policy indicates to its Amazonian neighbors the extent to which the environmental arena must be included in the South-South cooperation. Against this trend were the social movements emerging from Latin American political institutions. These movements rely on the defense of the environment and on the Amazon's environmental asset [29], where new information and communication technologies gave voice to the groups affected by the actions of IIRSA. The case of the Movimento Xingu Vivo Para Sempre (Xingu Lives Forever movement) illustrates the activism of social movements in the environmental arena. For instance, the Movimento Xingu Vivo Para Sempre - opposing the Belo Monte Hydroelectric Complex installation qualifies itself as "for the awareness of the Brazilian society in defense of the Xingu River and against the hydroelectric of Belo Monte.” Through its activism, the Xingu Vivo Movement put pressure on the Public Ministry of the Union, and 13 sentences to stop the works were issued. However, the judicial sentence succumbed to the power that companies that funded the candidates of the turn-left in Latin America. Many decisions were taken by different judges over ten years to stop licenses due to demonstrate illegalities. However, they were all suspended by the Federal Regional Court of Brasilia in the years of ruling left-wing Latin American candidates from 2005 [30].

\section{Conclusion}

The imbalance and the profound differences between Brazilian government developmentalism goals and the actions to promote sustainability in amazon areas can be understood by the place given to the environmental agenda during the IIRSA implementation. The proposal for regional integration resulted in the process of deregulation and systematic deconstruction of policies for sustainability in the areas of influence of IIRSA. In this perspective, the implementation of IIRSA made evident severe institutional weaknesses, such as independent institutions' existence, as COSIPLAN, enforcing the authorization to implement unsustainable projects. Out of the global environmental regulation, these organizations conducted the rupture of Brazil's environmental legislation - and the IIRSA region in general. The flexibilization and environmental deregulation resulting from the influence of IIRSA contractors and government agents interested in its implementation made the project an example of an environmentally unsustainable regional integration strategy in the Pan Amazon Region.

The dimension of the environmental impacts of the projects carried out are of an intensity never before experienced in the region. The consequences resemble the scenario described by [31] regarding the impact of the Industrial Revolution on the English fields and society. The intensity and frequency of the changes imposed 
by the submission of peasant social logics to the market have profound similarities with the impacts promoted by IIRSA in the Amazon region: Traditional communities, responsible for protecting and maintaining forest integrity, were submitted to lose their autonomy and being pushed to urban areas, with the negative social and economic consequences that such kind of migration brings to both, the forest and the cities; displacement and desolation.

The use of regional institutional arrangements biased towards interest groups promoted the environmental agenda's deconstruction. In this context, regional integration operates as a neo-developmentalist strategy in which the state acts as a coordinator of the market actions and simultaneously works in the regulatory arena by deregulating sectors in which the current and forthcoming projects are not in compliance with the environmental law. Instead of creating synergies between sustainability and regional integration, the Brazilian government began to induce actions at the regional level that bypassed regulatory incompatibilities between pan-amazon countries. The general consequence for the region was the generalization of a shared approach to environmental legislation to facilitate the integration in the supranational perspective, but blind towards the many international commitments made towards the amazon and its global environmental importance. IIRSA lost its fundamental principles and was converted into a framework to carry out environmentally unsustainable projects, with negative consequences for the governability of the amazon countries where it was implemented.

\section{Acknowledgements}

We want to express our gratitude to the Erasmus+ program which facilitated the cooperation between the researchers from Brazil and UK, as well as all the institutions who facilitated access to the documentation of the IIRSA development initiative.

\section{Conflict of interest}

The authors declare no conflict of interest.

\section{Author details}

Pedro Pablo Cardoso Castro ${ }^{1 *}$ and Nirvia Ravena ${ }^{2}$

1 Leeds Beckett University, Leeds, UK

2 Federal University of Para, Belem, Brazil

*Address all correspondence to: p.p.cardoso-castro@leedsbeckett.ac.uk

IntechOpen

(C) 2020 The Author(s). Licensee IntechOpen. This chapter is distributed under the terms of the Creative Commons Attribution License (http://creativecommons.org/licenses/ by/3.0), which permits unrestricted use, distribution, and reproduction in any medium, provided the original work is properly cited. (cc) BY 
Neo-Developmentalism and Regional Integration: IIRSA Impact in the Environmental Agenda... DOI: $h$ ttp://dx.doi.org/10.5772/intechopen.93983

\section{References}

[1] Couto LO. Horizonte Regional do Brasil e a Construção da América Do Sul. Revista Brasileira Política. 2007. 50: 159-176. DOI: $10.1590 /$ S0034-73292007000100009

[2] Caballero S. Brasil y La Región: Una Potencia Emergente y La Integración Regional Sudamericana. Revista Brasileira de Política Internacional. 2011. 54:158-172. DOI: $10.1590 /$ S0034-73292011000200008

[3] Quintanar S, Lopez RO. Plano de Ação para a Integração da Infraestrutura Regional Sul americana (IIRSA): Oportunidades e Riscos. Seu significado para o Brasil e a Argentina. Revista Brasileira de Política Internacional, 2003. 46: 213-221. DOI: /10.1590/ S0034-73292003000100011

[4] Pecequillo C. A Política Externa do Brasil no Século XXI: Os Eixos Combinados de Cooperação Horizontal e Vertical. Revista Brasileira de Política Internacional. 2008. 51: 136-153. DOI: 10.1590/S0034-73292008000200009

[5] IIRSA. COSIPLAN: From old to new developmentalism in Latin America. In: Ocampo, J. A. and Ros, J. Editors. The Oxford Handbook of Latin American Economics, Oxford University Press, London and New York. 2015. pp. 108129. Available at: http://www.iirsa.org/ Event/Detail?Id=145 (Accessed: 20 th August, 2020).

[6] Malamud A. A leader with our followers? The growing divergence between the regional and global performance of Brazilian foreign policy”. Latin American Politics and Society. 2011. 53: 1-24.

[7] Santos FL. Neo-development of underdevelopment: Brazil and the political economy of South American integration under the Workers' Party”. Globalizations. 2018. DOI: 10.1080/14747731.2018.1479016
[8] Bresser-Pereira L. O Novo Desenvolvimentismo.”, Folha de São Paulo. 2004. available at: http://www. bresserpereira.org.br/articles/2004/412. NovoDesenvolvimentismo.pdf .

[9] Bresser-Pereira L. Developing Brazil: overcoming the failure of the Washington Consensus. 1nd ed. Lynne Rienner Publishers, Boulder, CO. 2009.

[10] Bresser-Pereira L. From old to new developmentalism in Latin America. In: José Antonio Ocampo and Jaime Ros. Editors., The Oxford Handbook of Latin American Economics. 1ed.Oxford: Oxford University Press, London. 2011. 108-129. DOI: $10.1093 /$ oxfor $\mathrm{dhb} / 9780199571048.013 .0005$

[11] Bresser-Pereira L. Reflexões sobre o Novo Desenvolvimentismo e o Desenvolvimentismo Clássico. Brazilian Journal of Political Economy. 2016. 36: 237-265. DOI: 10.1590/0101-31572015v36n02a01

[12] Sicsu J, Paula L, Michel R. Introdução, Novo-desenvolvimentismo: Um projeto nacional de crescimento com equidade social. Jornal dos Economistas. 2005. 186: 3-5.

[13] Sicsu J, Paula L, Michel R. Por que um novo-desenvolvimentismo?” Revista de Economia Política. 2007. 27: 507-524. DOI: $10.1590 /$ S0101-31572007000400001

[14] Schutte G. Neodesenvolvimentismo e a busca de uma nova inserção internacional. Revista Brasileira de Estratégia e Relações Internacionais. 2012. 1: 61-97.

[15] Wade R. The Developmental State: Dead or Alive? Development and Change. 2018. 49: 518-546. DOI: 10.1111/ dech.12381

[16] Paiva-Silva J. Pragmatism as a pillar of the New Developmentalism. Brazil. J. 
Polit. Econ. [online] . 2020. 40: 376-397.

DOI: 10.1590/0101-31572020-3099

[17] Morais L, Saad-Filho A. Da economia política à política econômica: o novo-desenvolvimentismo e o governo Lula. Revista de Economia Política. 2011. 31: 507-527.

[18] Carrillo I. The New Developmentalism and the Challenges to Long-Term Stability in Brazil. Latin American Perspectives. 2014. 41: 59-74. DOI: $10.1177 / 0094582 X 14543791$

[19] Ravena N, Texeira E. Usina de Belo Monte: quando o desenvolvimento viola direitos. Ponto de Vista. 2010. 10: 1-16.

[20] Vergara-Camus L, Kay C. The agrarian political economy of leftwing governments in Latin America: Agribusiness, peasants, and the limits of neo-developmentalism. Journal of Agrarian Change. 2017. 17: 415-437. DOI: 10.1111/joac.12216

[21] Sant'Anna F. Inequality and water in the Amazon Basin: the difficulties of cooperation and sustainable management. Kieler Geographische Schriften 2012. 123: 237-261.

[22] Ravena N. Canete, R. Reflexões sobre a Integração Pan-Amazônica: O Papel da Organização do Tratado de Cooperação Amazônica (OTCA) na Regulação da ÁGUA. Revista Brasileira de Estudos Urbanos e Regionais. 2007. 9: 131-144. DOI: 10.22296/2317-1529.2007v9n1p131

[23] Malamud A, Rodriguez J. Com um Pé na Região e outro no Mundo: $\mathrm{O}$ Dualismo Crescente da Política Externa Brasileira”. Estudos Internacionais. 2013. 1: 167-183.

[24] UNCTAD (2011), Word

Investment Report, Geneva, SWI, Available at: https://unctad.org/en/ PublicationsLibrary/wir2011_en.pdf (Accessed: 10th August, 2020).
[25] Roman, M. The Implementation of International Regimes. The case of the Amazonian Cooperation Treaty. Uppsala, Sweden, SE. 1998.

[26] Soares de Lima M. A política externa brasileira e os desafios da cooperação Sul-Sul. Revista Brasileira de Política Internacional. 2005.48 (1):24-59.

[27] Silva L, Ravena N. A Padronização das Políticas de Desenvolvimento na Amazônia. Revista Desenvolvimento Regional. 2012. 17: 168-191.

[28] Neves E. Institutions and environmental governance in Brazil: The local government's perspective. Revista de Economia Contemporânea. 2016. 20: 492-516.

[29] Comegna M, Luchino M. Novas territorialidades e conflitos na Amazônia: a IIRSA e o Eixo PeruBrasil-Bolívia. Paper presented at the Actas del XI Coloquio Internacional de Geocrítica, Universidad de Buenos Aires, Buenos Aires, AR. 2010. Available at: http://www.filo.uba.ar/ contenidos/investigacion/institutos/ geo/geocritica2010/672.htm (Accessed: 10th February, 2020).

[30] Costa A, Ravena, N Oliveira, I. Voz Coletiva para Mobilização pela Amazônia: @XINGUVIVO E BELO MONTE. Contemporanea. 2015. Vol. 13, pp. 542-565. Available at: https://portalseer.ufba.br/index. $\mathrm{php} /$ contemporaneaposcom/article/ view/14614/10886.UFBA (Accessed: 15th June 2020).

[31] Polanyi K. A grande transformação: as origens de nossa época. Fanny Wrabel. 1980. 


\title{
Social Changes in the Peruvian Amazon Due to Foreign Influence
}

\author{
Zoran Stiperski and Tomica Hruška
}

\begin{abstract}
The prehistoric Amazon had low numbers of hunter-gatherers due to poor soil and harsh landscape conditions, due to which it was not able to support advanced cultures. The arrival of Christian missionaries, oil companies, and farmers changed the lifestyle of a specific portion of the population, although some indigenous groups still avoid contact with the outside world. Missionaries stimulated changes in the indigenous medical-religious-political systems. In the Peruvian Amazon, the local government is too weak to carry out the usual functions of the state, and therefore oil companies have replaced the state in terms of various functions such as employment, building wells for the drinking water, healthcare, donation of electric generators, and aircraft transport of local indigenous authorities to meetings in Iquitos or Lima. The policies of the national government are turning the Peruvian Amazon into a productive area and are exploiting its natural raw materials. In modernising the Amazon region, however, the world is permanently and irreparably losing valuable knowledge regarding the nature of tropical areas.
\end{abstract}

Keywords: Peruvian Amazon, foreign influence, indigenous people, missionairies, oil industry, plantation agriculture, deforestation, loss of knowledge regarding the tropics

\section{Introduction}

Migrations of people, especially of the intense variety, bring change to societies and landscapes. The Amazon has historically been sparsely settled, mostly by hunter-gatherers and primitive farmers. Its settlements are small and spread far and wide throughout the vast forests. The largest South American cultures and empires arose in the Andes, along the Pacific Ocean coast, and in the lowlands in the southern part of the continent, while the Amazon was bypassed. Numerous researchers have searched the jungle for signs of highly-developed Amazonian civilisations, but none succeeded in finding anything - their attempts have resulted rather in great stories of adventure and valuable ethnic documentation. Franciscan monks founded a church and monastery in Santa Rosa de Ocopa in the Peruvian Andes 300 years ago to serve as a missionary school and destination for missionary work in the Amazon. During the 20th century, companies and states "discovered" the Amazon as a new area of development. This primarily meant exploitation of natural resources such as oil, natural gas, hydro energy, wood, and agriculture. Today, road networks are spreading along with pipelines, and harbours and airports are being built. Along with the development of business, workers from the Andes and other parts of the world are flocking to the Amazon. Concurrently, indigenous 
peoples are losing their territory and strong deforestation processes are underway. The world also regards the Amazon in ecological terms, referring to it as the "lungs of the world". Numerous politicians of Amazonian states look at the jungle in terms of what it could mean for economic development of their respective states. Many local politicians think that what is happening to the Amazon now is what European settlers did to both Europe and North America over the last several centuries: cut down the forests; developed agricultural land; opened new business opportunities; and spread their civilisation.

In this chapter, our goal is to confirm the reasons for the arrival of settlers in the Amazon, and the significance of individual activities and how they transform nature and society. Special emphasis is placed on logging and the widespread process of deforestation, whereby we are interested in the consequences of cutting down the forest from various aspects: the effectiveness of agricultural activity; maintenance of biological diversity; and the influence of climate change on indigenous communities. Special attention is given to the adoption of the principle of market exchange, i.e. the exchange of money for goods/services, in indigenous communities, as well as key related sociological changes within indigenous societies themselves. Important landscape changes in the Amazon often happen due to deforestation, but in this chapter we explore other types of landscape change that are rarely mentioned in scientific and profession literature: the emergence and spread of networks of modern settlements that are planned in a completely different way than traditional indigenous settlements. In our analysis of modern plans of the Peruvian government, as well as similar projects of Peruvian and foreign companies, we touch on both the strategic and geopolitical dimensions of exploitation of the Amazon. Finally, we also cover the vanishing Amazon forests and indigenous way of life, and with them knowledge regarding the tropics and the Amazon itself-a great loss for the entire world.

\section{Study area}

The territory of Peru can be divided into three parts: the Pacific coast (11\%); the Andes (29\%), and the Amazon (60\%). The area of the Pacific coast (slope) is home to $65 \%$ of the population, while only 5\% reside in Amazonian Peru (roughly 1.6 million). The Peruvian Amazon can be divided into three main landscape wholes: (1) humid, weak drainage areas; (2) drainage areas; and (3) high altitude areas.

1. Humid, weak drainage areas stretch from east of the Ucayali River and the eastern slopes of the Andes, upriver of Atalaya and into the northern Peruvian Amazon. Here the tropical rainforest (Figure 1) is dense and impenetrable, and the area is home to traditional agriculture-practicing tribes such as the Shipibo.

2. Drainage areas stretch from the eastern slopes of the Andes, at an altitude of 200-400 m a.s.l. to west of the upper and middle courses of the Ucayali River. The soil here is easier for hunters to walk on, and better for agriculture and general health. This area is inhabited by agricultural-practicing tribes such as the Ashaninka.

3. High altitude areas are Amazonian drainage areas of low hills, slopes of the Andes below $2000 \mathrm{~m}$ a.s.l. and plateaus such as El Gran Pajonal, which extends at $1000 \mathrm{~m}$ a.s.l. westwards from the point where the Tambo River flows into the Ucayali River (Figure 2). 


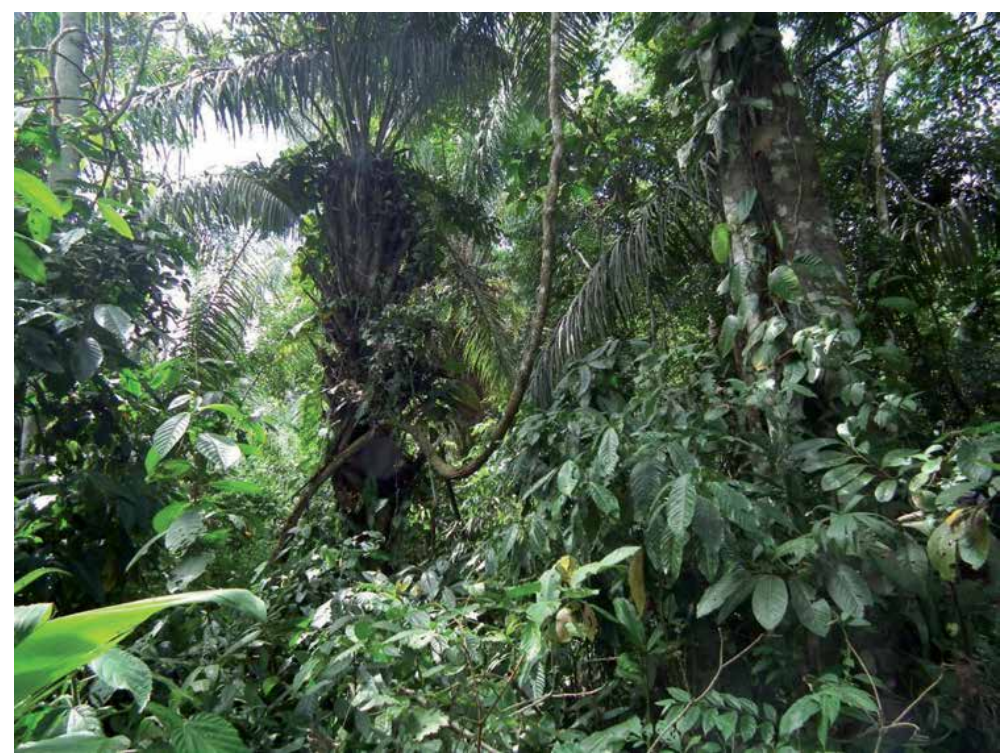

Figure 1.

Tropical rainforest in a drainage area in the Peruvian Amazon along the Tambo River. Picture by the author Zoran Stiperski.

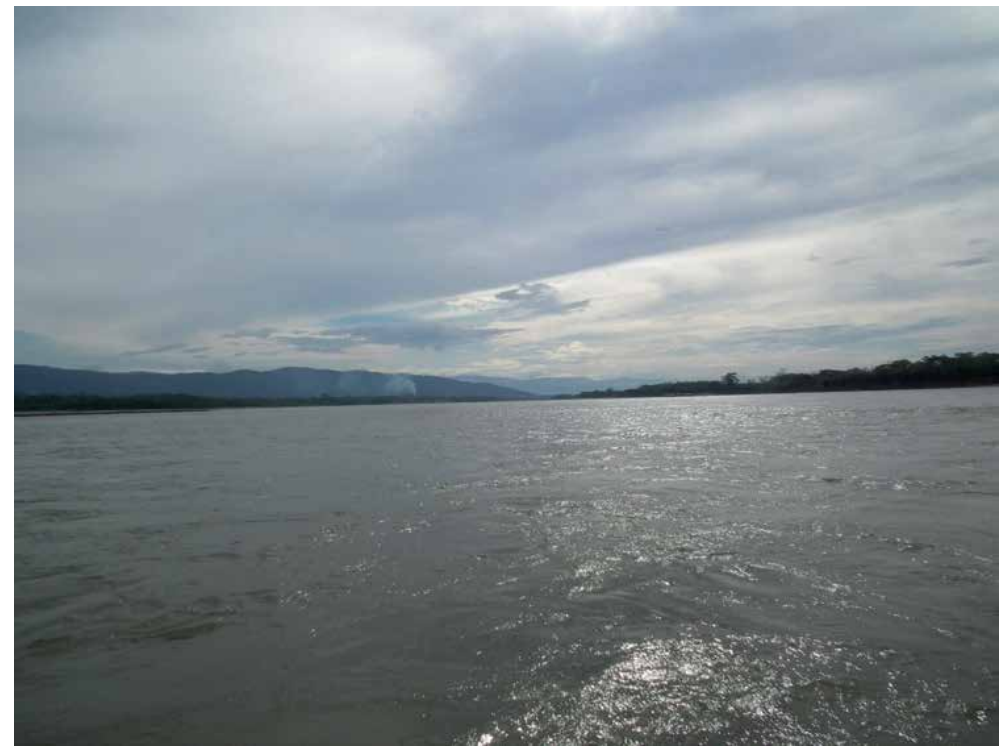

Figure 2.

The Ucayali River near Atalaya. Picture by the author Zoran Stiperski.

\section{Settlement}

Numerous archaeological papers describe how the prehistoric Amazon was sparsely settled by hunter-gatherers because of its poor soil, difficult landscape characteristics, and generally difficult living conditions, which limited population growth and the development of more advanced civilisations [1-5]. Past research of the settlement structure indicated how the permanent population was settled along the main rivers $[6,7]$ due the abundance of fish, which served as a source of animal protein [8]. An additional reason for the presence of population along the main 
rivers was fertile soil [9]. Archaeological data show that the contemporary population of the Amazon is smaller than that of the pre-Colombian era [10-15]. Certain researchers also claim that the population of the Amazon was ten times greater prior to the arrival of Europeans than it is today [16]. The pre-Colombian Amazon was the home of peoples who developed complex forms of social organisations and familial structures [17-40]. Currently, the notion among most archaeologists is that natural limitations preventing the development of agriculture are responsible for the lack of highly-developed civilisations [41], along with insufficient settlement.

The population of the Peruvian Amazon is a complex mix of different peoples and ethnicities: 64 indigenous nations speaking languages from 16 different language families [42], numbering roughly 333,000 according to data from 2007, i.e. roughly $21 \%$ of the population of the Peruvian Amazon. The most numerous indigenous tribes in the Peruvian Amazon have up to 90,000 members, while the smallest nations in remote parts of the forest have as few as 100. Even such small groups have the characteristics of a nation, as they speak their own language. Most such smaller tribes live deep in the forest, and are often nomadic. The two most important autochthonous Amazonian ethnic groups are the Ashaninka (88,700 members) (Figures 3 and 4), and the Aguaruna (55,400 members), followed by the Shipibo and the Chayahuita (both nations have more than 20,000 members), and the Quechuas and the Cocama (each nation has more than 10,000 members). The Peruvian Amazon is a massive area of new colonisation and numerous newcomers from the Peruvian Andes that have come to make a living. These newcomers are not indigenous Amazonian peoples, rather people from the Andes, Pacific coast, or other parts of the world. An important part of the colonisation is led by Peruvian and foreign companies and their respective enterprises. Highly-educated workers from these companies are newcomers to the area and are, as a rule, temporary residents of the Amazon. A smaller share of Peruvians have been sent by the state to work as teachers, doctors, and the like, and come from the Andes or Pacific coast. Missionaries also make up a share of the newcomers.

The main push factors on the Pacific coast and in the Andes are the lack of agricultural land, high poverty rates, and poor prospects for employment, while

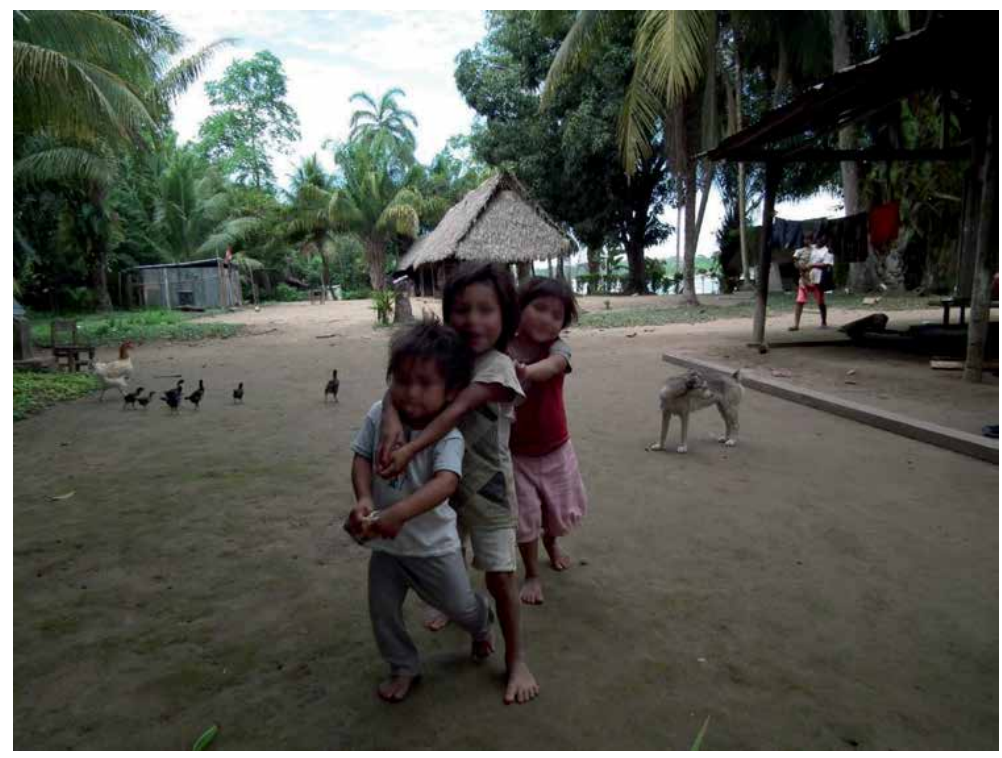

Figure 3.

The indigenous, traditional village Buenos Aires along the Tambo River. Picture by the author Zoran Stiperski. 


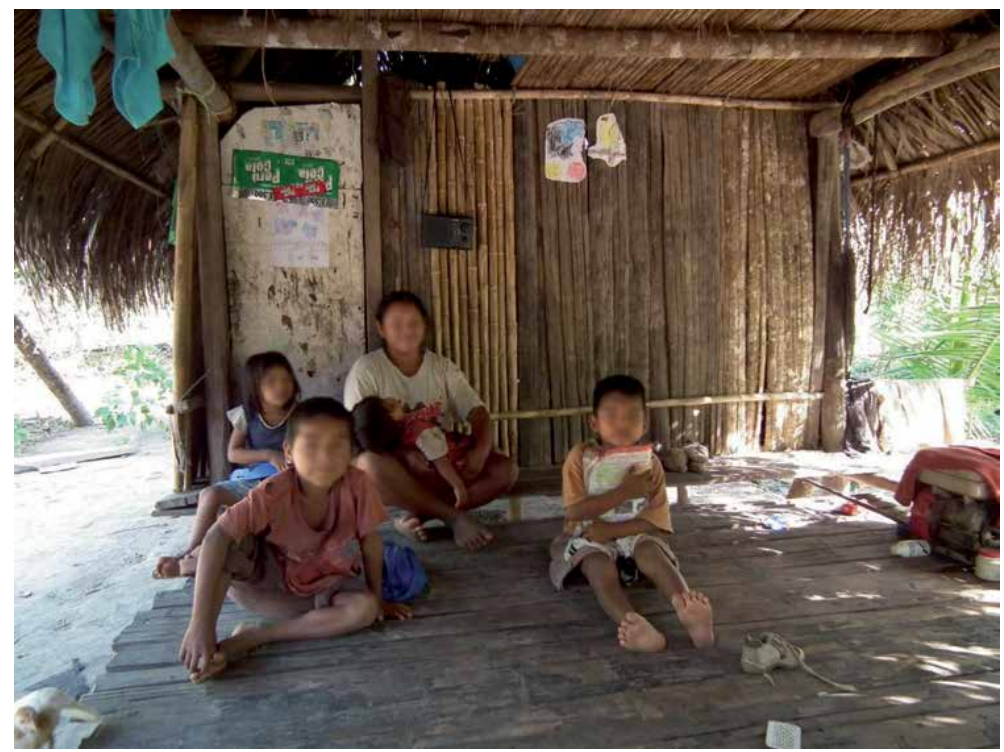

Figure 4.

A stilt house in an indigenous settlement along the Tambo River. Picture by the author Zoran Stiperski.

the main pull factors in the Amazon are cheap and available land, ability to gain ownership of land, perception of economic "climbing", lack of workforce, support from credit programs and tax easements, spread of road infrastructure, and general security [43].

In this vast area, there is a strong process of urbanisation underway (Figure 5). In the Loreto Region and its capital Iquitos (380,000 residents), which is also the largest city in the Peruvian Amazon, a higher share of urban population in relation to rural was first documented in the early 1970s; this trend has continued and in 2017 there were 600,000 urban residents and 280,000 rural residents in the region. Iquitos is the largest city in the world that has no road connections to the outside,

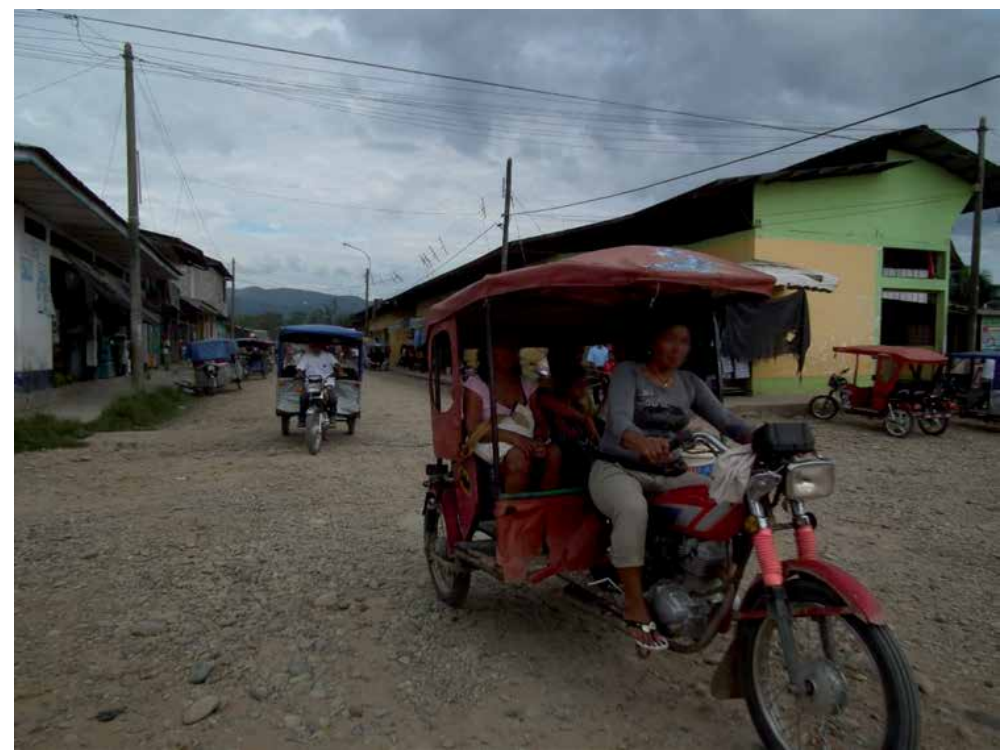

Figure 5.

The City of Atalaya. Picture by the author Zoran Stiperski. 
transit takes place rather by boat and airplane. Likewise, in the Ucayala Region there are 400,000 urban and 100,000 rural resudents (2017). A similar ratio of urbanrural population is also found in the Madre de Dios and San Martin regions [43]. Urbanisation is linked to the development of certain professions and markets, as well as with new settlers arriving in the Amazon.

\section{The arrival of Europeans}

\subsection{Missionaries}

The Spanish put the Peruvian Amazon on the back burner while they were spreading their empire. The Pacific coastal desert area and the Andes were home to advanced indigenous civilisations, while the Amazon showed few such signs. There were researchers who believed that remains of highly-developed indigenous civilisations were hidden in the forest, but no archaeological remains have been found to prove their theories. Near Atalaya, at the headwaters of the Ucayali River, their might be evidence of the remnants of the Inca civilisation in the Amazonian jungle (according to some Peruvian experts) in popular hunting area for local indigenous people. The place in question is called Canuja, and it is a natural stone formation where people carved the likeness of some large tiger-like cat at some point in the distant past, long removed from common memory (Figure 6).

The first Europeans that came to the Peruvian Amazon were missionaries. Franciscan monks built a church and monastery at the beginning of the 18th century in Santa Rosa de Ocopa, near the city Huancayo. Santa Rosa de Ocopa became the base for missionaries who were active in what would come to be called the Peruvian Amazon (Figure 7), but also in parts of Brazil, Bolivia, and Ecuador. Iquitos, the largest city in the Peruvian Amazon, was founded by Jesuit missionaries from Quito in the mid-18th century. Evangelical missionaries arrived in the territory of the Piaroa people during the 1940s [16]. The missionaries set into motion

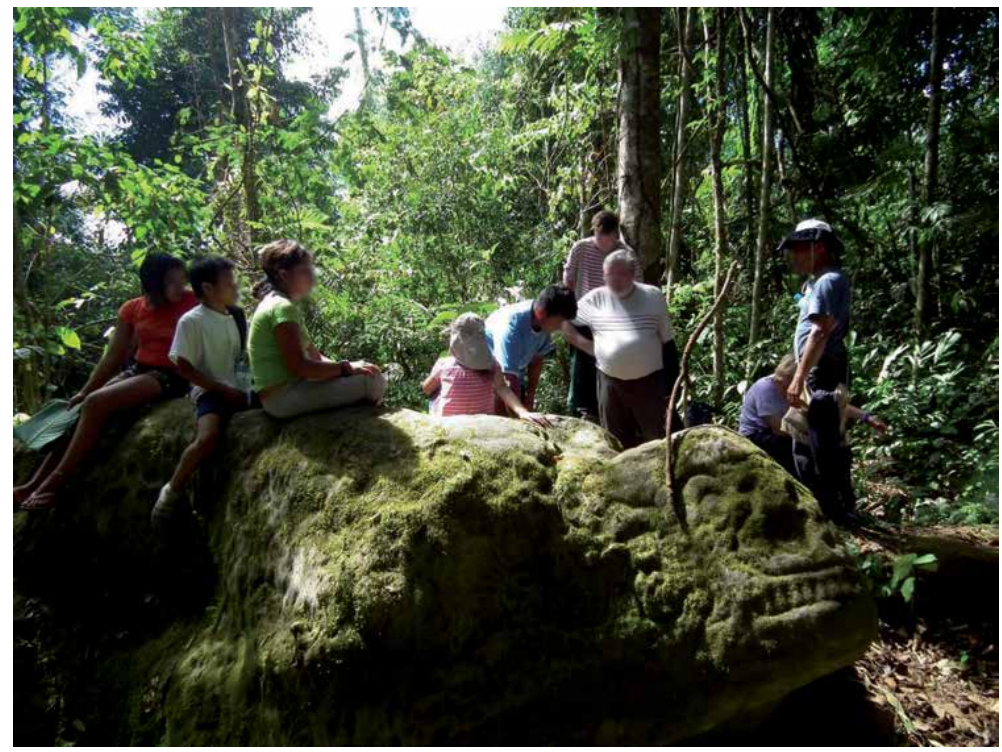

Figure 6.

Canuja stone monoliths are, according to some Peruvian experts, the remains of the Inca civilization. Picture by the author Zoran Stiperski. 


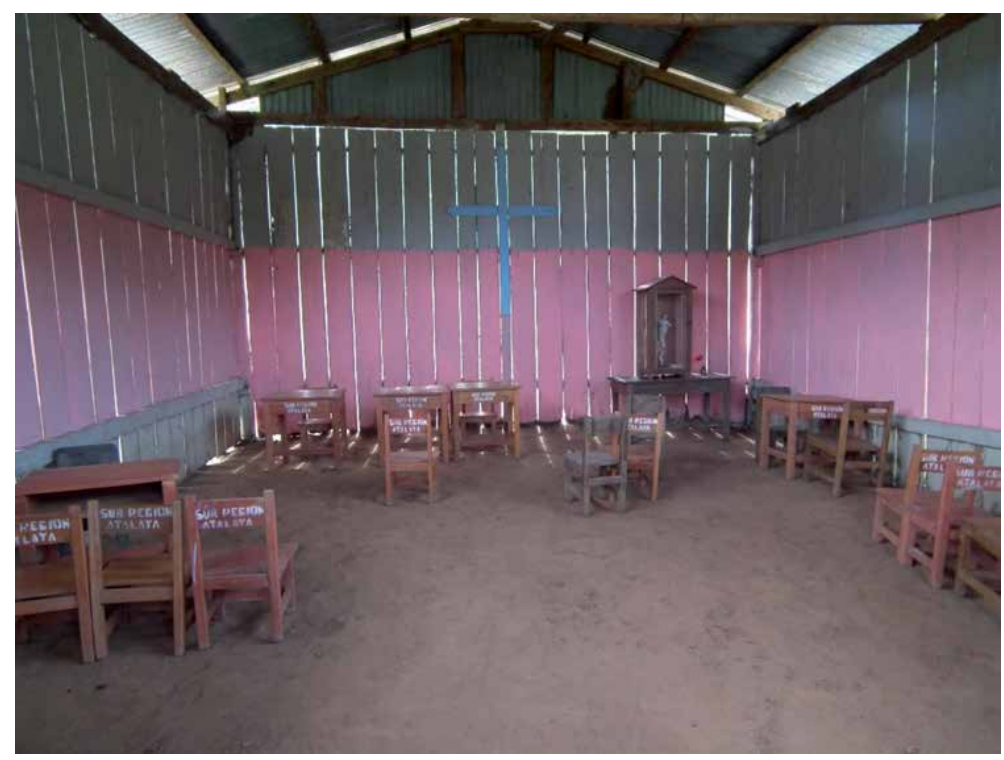

Figure 7.

The interior of a Roman Catholic church in an indigenous village in the Peruvian Amazon. Picture by the author Zoran Stiperski.

radical changes in the indigenous medicinal-religious-political systems [44]. The contemporary influence of missionaries can be seen in the founding of universities and radio stations for broadcasting agricultural advice and farm reports [45]. There are still, however, indigenous tribes that avoid all contact with the outside world [45]. The missionary centre Puerto Ocopa on the Perene River has a church, a youth home, and a school. Until a few decades ago, local shamans would, from time to time, declare that a devil had entered into some poor child, who must be banished from the village into the jungle. Parents were obligated to accept the word of the tribal shaman, but often couldn't bring themselves to leave their child to the mercy of the jungle. Instead, they left them with the Franciscans of the missionary centre where they got a roof over their heads and education. The first encounter between missionaries and the Huaorani people in eastern Ecuador was during the 1950s [46], and the arrival of missionaries and oil companies started a series of changes in the lifestyle of a significant share of the Huaorani population. Some of them now live in newly-founded cities, while some live along rivers, far from roads [45].

\subsection{Oil companies}

In 1939, oil extraction in the Peruvian Amazon began [47]. An intense era of oil hunting took place in the 1970s [48]. Demand and high prices of oil spurred a new boom in oil extraction in the Peruvian Amazon. Today, oil and natural gas extraction is allowed throughout the Peruvian Amazon, except for within the boundaries of national parks and reserves that make up roughly $10 \%$ of the total area of Amazonian Peru. In neighbouring Brazil, the population grew by $10.9 \%$ from 2000 to 2010 (from 170 million to 191 million), while energy demands over the same period grew by $40.7 \%$ [50]. Hydro energy is the dominant energy source in Brazil, but recently-discovered oil and natural gas are also important sources of energy [50].

Lack of sufficient involvement on the part of state agencies and other institutions has led to local communities becoming dependent on oil companies [49]. The Achuar community, for example, is heavily dependent on the Pluspetrol oil company. Oil companies have replaced the state in various fields such as employment, 
construction of drinking water wells, health care centres, donations of electric generators, autostop, air transport for local indigenous authorities to meetings in Iquitos or Lima, and emergency medicine services [50, 51].

Via investment, the oil industry has sped up the process of migration towards areas with western services and goods, which are often located on the edge of traditional indigenous territory [16]. Illegal gold mining, such as the mine in the Madre de Dios region with its 30,000 workers [52], also attracts newcomers to the Peruvian Amazon. Connections to global networks are made with new roads, rail lines, harbours, and communications technology [53], much of which is built for the needs of the oil industry and agricultural activities (ranches, plantations). Activities such as mining, oil and natural gas extraction, and plantation agriculture in Amazonian states_especially Brazil and Peru—have become areas of interest for investment from Chinese state companies. In order to exploit natural wealth, large infrastructural projects like the construction of a highway that would link Brazil to the Pacific Ocean via Peru have been announced [54].

\subsection{Plantation farmers and ranchers}

Bosquesino (forest man) is a name for someone who lives off the forest in rural parts of the Amazon. It is interesting that indigenous Amazonians have named all rivers, creeks, and water sources, but rarely have names for mountains or large hills-waterways are clearly more important to them than mountains. A Bosquesino hunts, fishes, gathers fruit, plants, minerals, nuts, honey, insects, various water creatures, crabs, lizards, and amphibians. The difference between a farmer and a Bosquesino is that a farmer practices cultivation and uses less land, while a Bosquesino does not only grow food, they also hunt and gather over a much wider area [55]. Alluvial plains, which make up $7 \%$ of the area of the Amazon [55, 56], are desirable for cultivation agriculture (horticulture, monoculture), while flood plains and slopes are not. There are exceptions to this such as peanut, rice, corn, and cassava, which are sown in the sand in flood plains along rivers in the dry season.

Agricultural activities are the strongest factor of landscape and social change in the Amazon. Many workers settled the area to extract latex from caoutchouc trees for the rubber industry, creating a vast amount of wealth. This turned parts of the Amazon into a wasteland, useable to indigenous communities, and led to a general cultural and social transformation. The main centres of the rubber boom in the Amazon were Manaus and Belem in Brazil, and Iquitos in Peru. Numerous settlers arrived in Iquitos between 1880 and 1914 to work in the rubber industry.

Traditional Amazonian communities are small and they depend on hunting, fishing, gathering, and primitive agriculture. In various Amazonian communities, the bulk of households practice agriculture (84-99\%), fishing (61-91\%), hunting (4-25\%), aqua culture (14-41\%), and gathering (11-67\%) [57]. Cassava is the main crop for many Amazonian communities, regardless of whether they are indigenous or descendants of European colonists [57]. Indigenous people along the Tambo River, downriver from Atalaya, practice hunting and fishing, and cultivate only bananas-they don't practice any sort of gardening. The last 50 years have seen major changes in food production: rice and jute cultures became common at the beginning of the 1960s, spreading throughout the 1970s and 1980s until the beginning of the 1990s. Production fell drastically thereafter as a consequence of the closure of the Banco Agrario (agricultural bank) and the lack of available credit for rice and jute farmers while Alberto Fujimori was president of Peru [55]. Accordingly, indigenous people from the area of Ampiyacu stopped sowing rice and jute. The fall of the Banco Agrario resulted in a drastic reduction in agricultural production in the Amazon, but reasonable prices for rice were maintained in Iquitos' 
markets, so production in the area around the city continued. Rice production grew significantly in 2000 when Caritas Internationalis offered short-term loans to small businesses [55]. The example of rice, in this case, is a good example of the vulnerability of local producers vis-à-vis availability of financing.

Traditional shifting agricultural cultivation systems practiced by indigenous peoples are sustainable long-term [58] in contrast to typical farm agriculture [59]. Shifting agriculture and cattle ranches are responsible for $80-85 \%$ of deforestation in the Amazon [60] (Figure 8). During the process of making new areas for agriculture at the expense of tropical rainforest, we must bear in mind the high value of the Amazon in terms of bio-diversity, which far exceeds regions with temperate climates. In just 100 ha of the study area in the Peruvian Amazon there are more species than in most individual states of the U.S.A. [61]. This means that roughly half of the planet's species are found in tropical forests. Areas along arterial thoroughfares are more exposed to logging than remote areas, and agricultural activity along trans-Amazon highways is shifting toward herding and multi-year crops [38]. The average cattle rancher from a dynamic village along a transAmazon highway covers 20 times more area than a family with a smaller operation [62]. Both Indigenous people and settlers cleared sections of the Amazonian forests during the 20th century [63]. Some research has indicated a negative link between exploitation of the forest and wealth, such that richer families depend less on extracting raw material from the forest $[64,65]$. There are key differences in the forest clearing techniques of Bosquesinos and plantation farmers. Typically, plantation farmers clear larger areas than Bosquesinos, who only clear enough to allow sunlight to cover the area they want to plant (chakra). Plantation farmers cut trees down and dig up their roots, which makes the soil less fertile, while Bosquesinos leave the roots. Chakras are used for three years and left for nature to reclaim thereafter (Figure 9). Chakras are typically used for one banana harvest and two jute harvests, while other fruit can be harvested longer. Accordingly, this is a form of horticulture with quick and easy recovery, while the typical plantation practices horticulture without land renewal because the degradation of the

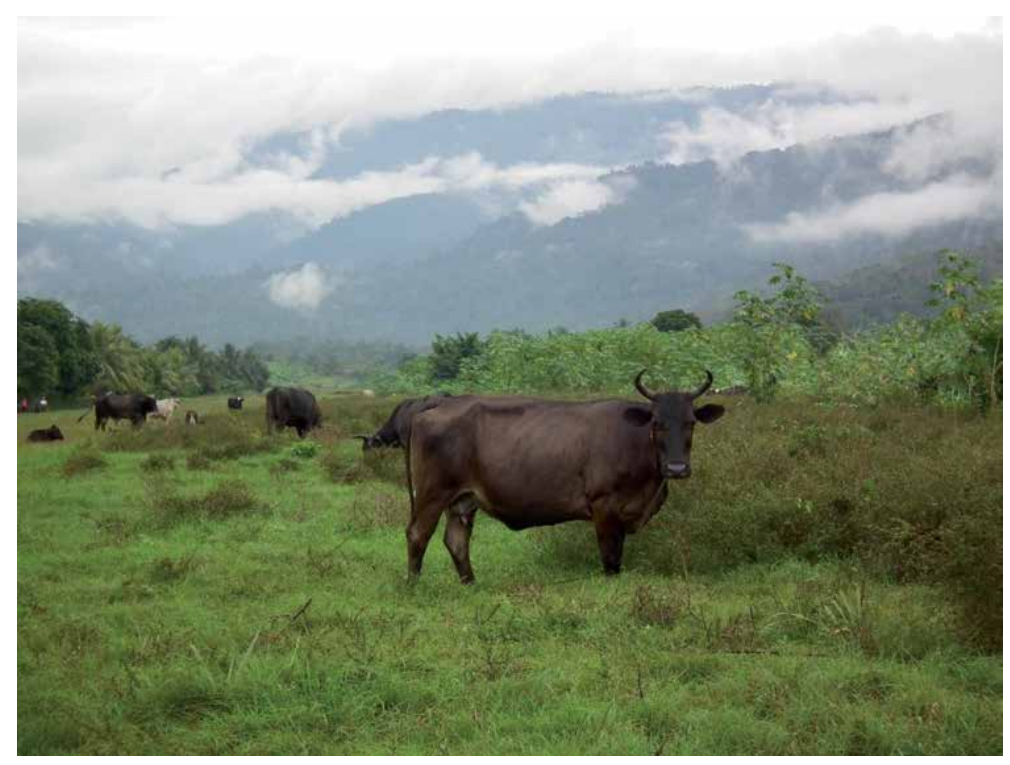

Figure 8.

An area of forest that has been cut down for the purposes of cattle herding along the Perene River. Picture by the author Zoran Stiperski. 


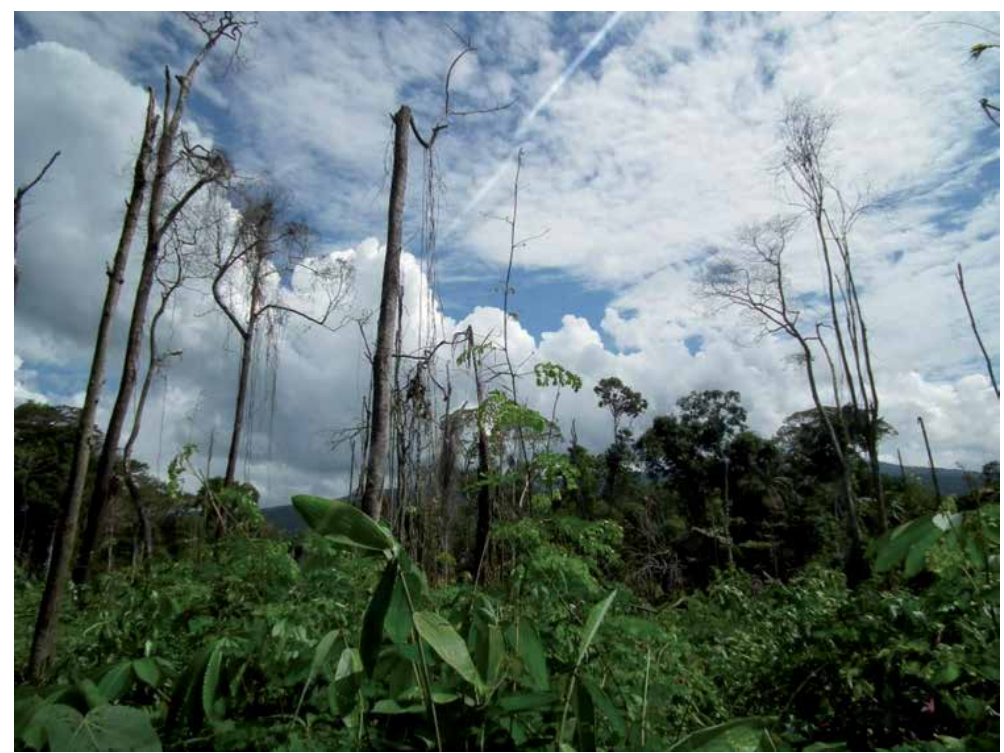

Figure 9.

Tropical rainforest renewal in the area of a fallow chakra. Picture by the author Zoran Stiperski.

forest around the plantation continues. One of the consequences of deforestation is a reduction in precipitation [52]. Climate change has led to increasing average temperatures, larger and more frequent fires during the dry season, more frequent flooding along rivers, and more landslides. In terms of agricultural production amid current climate change trends, there has been a significant reduction in corn and coffee harvests.

\subsubsection{Logging/forest clearing}

Traditional communities like the Ashaninka depend on the land to survive. The greatest threat to traditional ways of life in the Peruvian Amazon comes from farmers who clear the forest to make arable land [58]. Cleared land is quickly exhausted, and cannot be used for longer than two to three years [66]. Ranching, commercial logging, and agricultural activities are the main reasons behind forest clearing in the tropical Amazon, but an important share of deforestation is linked to infrastructure and roadbuilding investment (Figure 10). Deforestation also contributes to uncertain ownership rights, because it encourages the transformation of forests into agricultural and pastoral areas [67]. Poor forest management also encourages logging and export of wood $[68,69]$.

In total, between 8.9 and 10.5 million ha of Peruvian forests, i.e. 11.3-13.4\%, have been cut down [42]. Deforestation in the Peruvian Amazon was below average in relation to other Amazonian states until 2012, but thereafter the rate of deforestation doubled [42]. In the period of 1988 to 2007 , an average of $18,000 \mathrm{~km}^{2}$ of forest were cut down yearly in the neighbouring Brazilian Amazon [67]. Only 5.6\% of the original forest areas in the Bolivian Amazon had been cut down for agricultural use up to 1990, but the rate of deforestation grew afterwards [70]. Lower deforestation rates in the Bolivian Amazon are the result of the fact that settlers gravitate toward cities and areas of coca production, rather than toward the Amazon [70]. A positive and significant link has been established (from 0.35 to 0.47 ) between household income and forest clearing among poor communities in rural areas of the Amazon. The forests in Bolivia's Tsimane area are also faced with growing pressure 


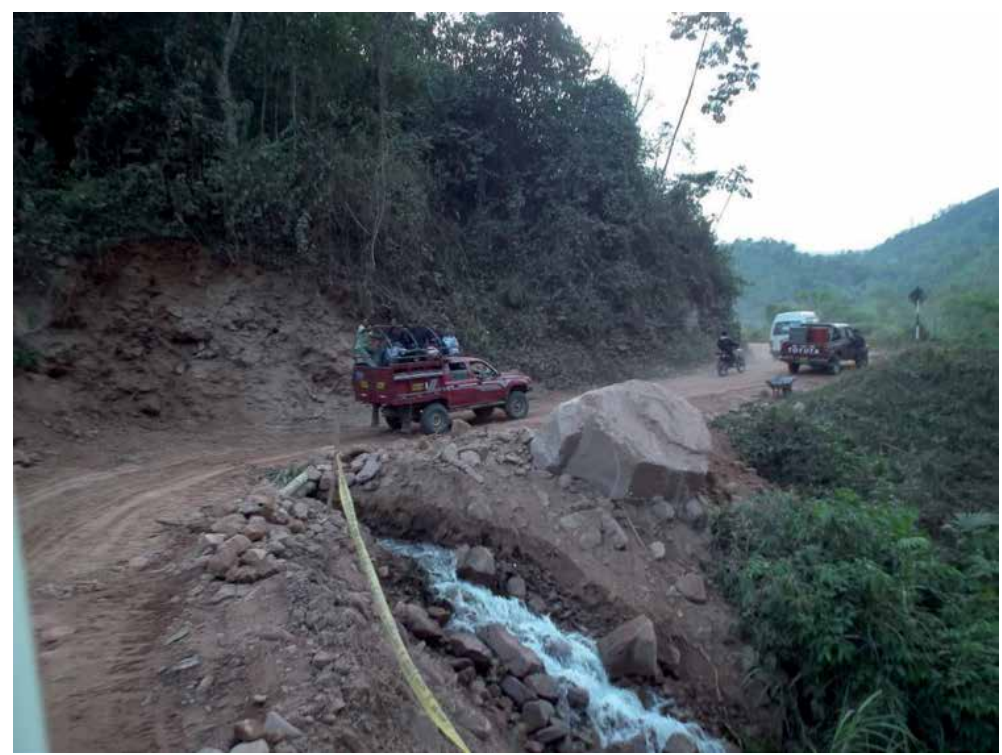

Figure 10.

The road between Puerto Ocopa and Mazamari on the slopes of the Andes in the Peruvian Amazon. Picture by the author Zoran Stiperski.

from indigenous peoples, not just from settlers [63]. Research has shown that the commercialisation of wood and forest products creates good opportunities for local stakeholders and contributes to forest preservation [71].

\subsection{Shotguns}

Game is an important dietary element for traditional communities [72]. Widespread hunting throughout the Amazon threatens the survival of large primates (mammals) and other vertebrates. Shotguns have caused a much greater reduction in the numbers of hunted animals than traditional hunting tools (bow and arrow) of the indigenous Machiguenga, for example. This provides evidence of why pre-Colombian peoples didn't wipe out all the large animals that they huntedbows and arrows are much less effective than shotguns. Furthermore, spider monkeys are quickly being driven toward extinction by shotguns, even around smaller settlements [73]. Hunting with shotguns strips areas of wildlife and consequentially hurts the local population because they end up stripping an ever-larger area of its normal fauna [73]. The usefulness of shotguns in hunting is short-term [74]. The Machiguenga have overhunted their lands near the Urubamba River, where the shotgun is the main means of hunting. This provoked a response from the Peruvian government, which has implemented aquaculture on a small scale to preserve local settlements and reduce the need for hunting [73].

\subsection{Tourism}

The economic effect of strong tourism development is rather small for locals because a large share of the earnings goes to external organisers, who pay indigenous folk meagrely [75]. There are only three areas in the Peruvian Amazon that are seriously involved in tourism: two resorts in the jungle and the City of Iquitos. Manu National Park is touristically attractive and is found on the UNESCO list of Natural Heritage. The Park, however, is faced with rapid population growth as a consequence of settlers from the isolated Machiguenga nation. The consequence of 
this overcrowding is the erosion of bio-diversity and emigration of Europeanised Machiguengas [73, 76]. From this example, we can see that it isn't always clear whether people living in national parks are allies or threats to bio-diversity. 'The forest is full of people and empty of fauna' insist conservationists of bio-diversity of tropical areas who argue that overpopulation or high-volume tourism is a threat to national parks. [77, 78].

In many areas, tourism is not yet practiced. After I returned from the Peruvian Amazon, tourist agents from Lima asked me what it was like-for them it was a totally unknown area. Outside of established paths and large cities, indigenous people are wary of foreigners-particularly white people, who they often associate with criminals, terrorists, or dubious characters. It is not rare for indigenous people to shoot at unknown foreigners, as they have had bad experiences with Shining Path revolutionaries and people involved in the cocaine trade. As there is no presence of state police to protect them, indigenous peoples have to protect themselves with their own weapons and warriors. After indigenous people get to know a foreigner (even a white one), however, they become very warm, friendly, and open.

\subsection{The Market}

A new socio-cultural phenomenon that has been observed over the last 50 years is the specialisation of cooperatives in relation to plurality among people. The activities of the polyvalent bosquesino have begun to commercialise. The use of money has entered into indigenous communities. Huaorani from the upper Amazon trade more with money than barter around larger markets [45]. Existential selfsourced economy and sharing food is common among hunter-gatherer communities [75], but market economy is spreading into traditional areas. In some areas both market and sharing systems operate simultaneously: first comes sharing among the community and the surplus is sold on the market. The advantage of the sharing system is food and material security for those who are unable to provide for themselves. Therefore, the poor favour the sharing system in order to minimise the risk that they might go without [79], while the more affluent easily accept the market system of economy because it maximises income [80].

\section{Modern vs. traditional settlements}

Planimetrics of settlements are a reflection of people's ways of life and the things that they create. Planimetrics of settlements of the Peruvian Amazon show mutual differences between two basic groups of settlements: traditional settlements and modern settlements. Modern settlements have emerged in areas with numerous and varied flows of foreign influence and communication. Traditional settlements are ubiquitous throughout the Amazon, with a noticeable distance from areas of modernity (Figures $\mathbf{1 1}$ and 12). The persistence of modern settlements is a sign of the spread of new lifestyles brought by settlers, and represents a step away from the traditional lifestyle of indigenous Amazonians, which is characterised by fishing, hunting, gathering, and basic agriculture. Newcomers from outside of the Amazon make up nearly $90 \%$ of the total population of the Peruvian Amazon [81]. Settlement density of Amazonian nations is traditionally very low, due to the prevailing hunter-gatherer lifestyle.

Planimetrics of modern settlements is the same as in the rest of the West, i.e. settlements with streets, stores, parks, and squares. Streets are usually laid out in a grid, which is also typical for modern city planning. The planimetric practice 


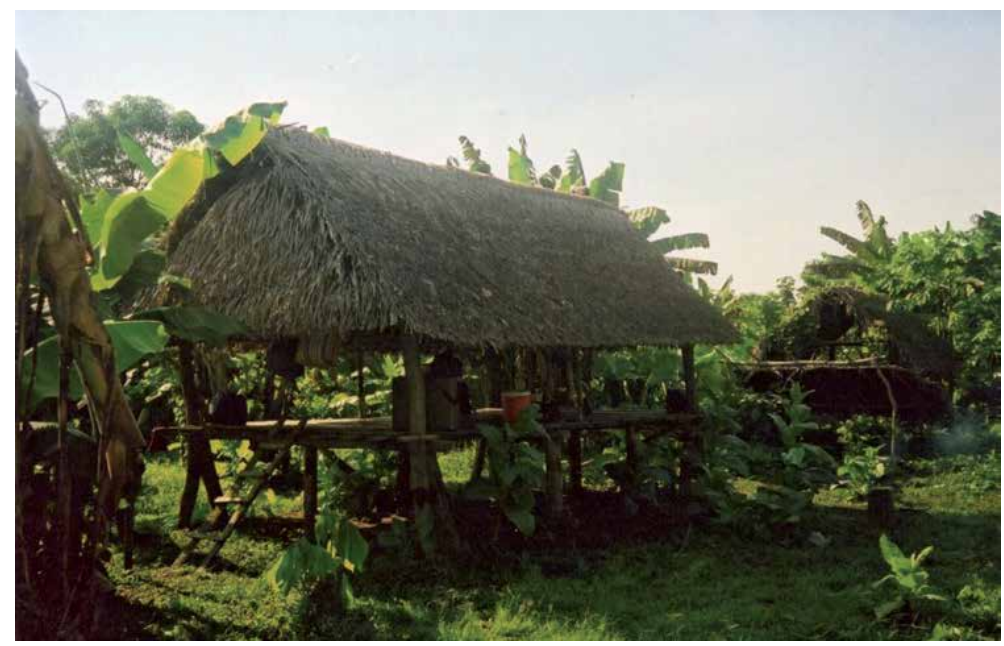

Figure 11.

A traditional indigenous settlement with stilt houses in the lowland area of the Peruvian Amazon along the Ucayali River. Picture by the author Tomica Hruška.

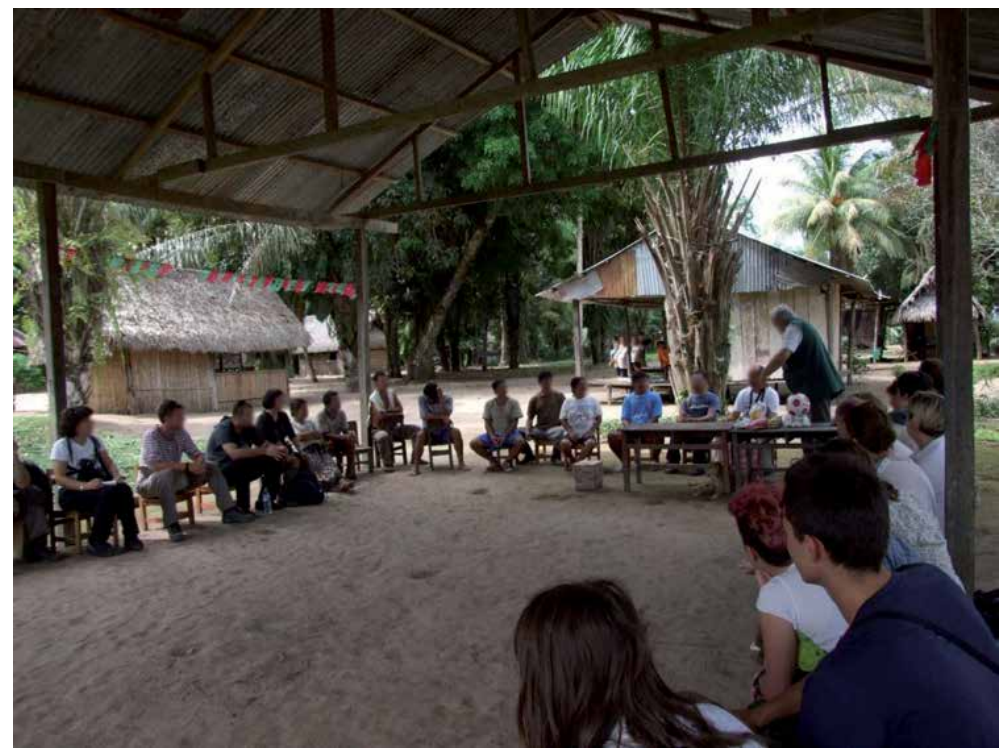

Figure 12.

Gathering in the "village council chamber" in Buenos Aires along the Tambo River. Picture by the author Zoran Stiperski.

of "right angle" planning was brought to Peru by the Spanish. Planimetrics of traditional settlements, however, is reminiscent of an enlarged garden with irregularly-spaced houses. The houses do not have clearly-defined yards or gardens with fences. Modern Amazonian urban settlements name and arrange their central squares according to the standard Peruvian "Plaza de Armas" pattern, which indicates the spread of Peruvian identity in the Amazon (Figure 13). This pattern emerged after the arrival of the Spanish in the 16th century. The first thing built in newly-founded modern Amazonian settlements was often the Plaza de Armas (Figure 14). Traditional settlements have no squares and have not taken up this part of Peruvian identity [82]. 


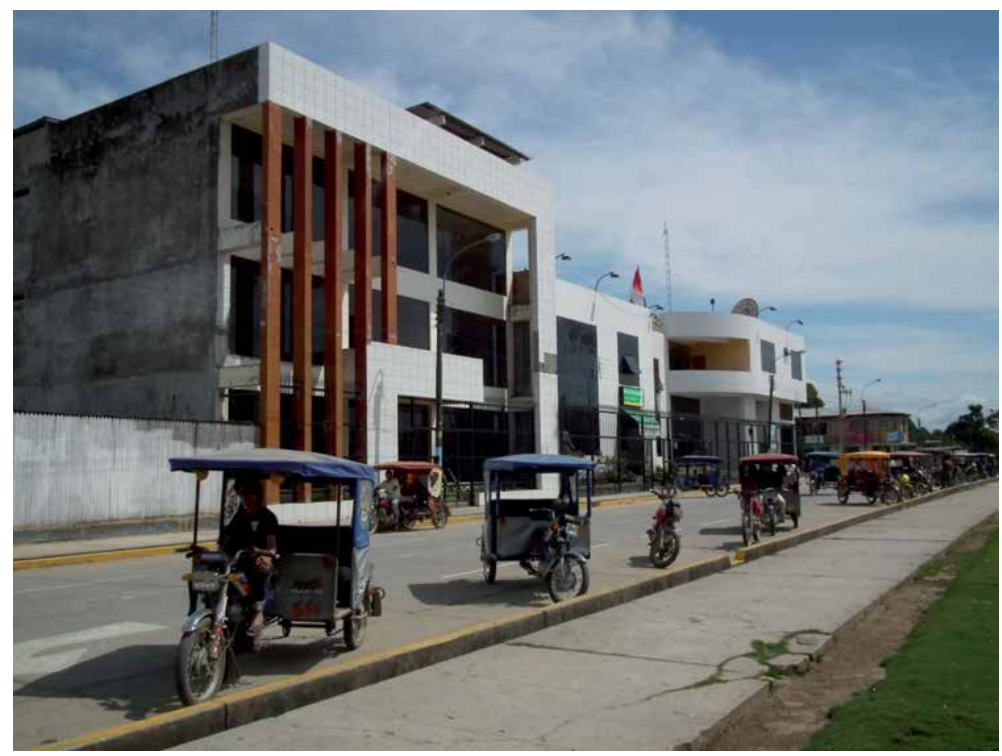

Figure 13.

Business buildings on the main square (Plaza de Armas) in Atalaya. Picture by the author Zoran Stiperski.

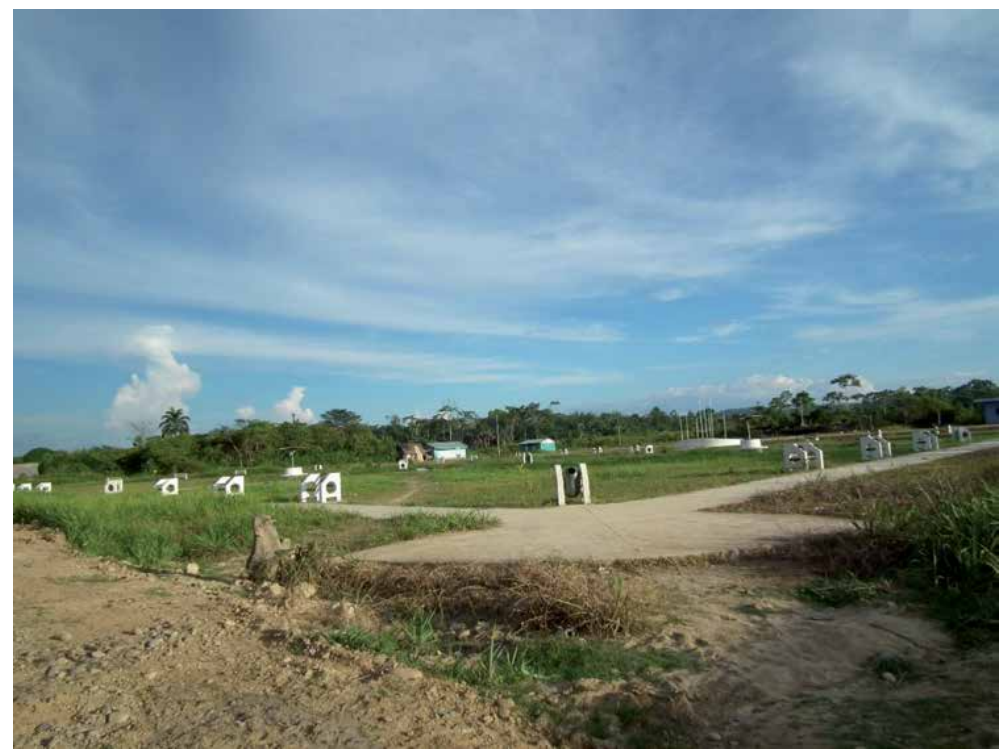

Figure 14 .

The main square (Plaza de Armas) in the design of the emerging settlement of Maldonadillo, being built for the needs of local plantation farmers. Picture by the author Zoran Stiperski.

Larger settlements, in terms of population, are modern, while smaller settlements can be either modern or traditional. Hunters, fishermen, gatherers, and traditional farmers live in traditional settlements. This sort of settlement only works in areas with very low population density, as this kind of lifestyle demands large areas of land, forest, and water resources per resident. Traditional settlements are typically populated by indigenous folk, with very few, if any, outsiders. The few outsiders that do live in traditional settlements are usually married to an indigenous resident or are school teachers. Newcomers to the Amazon mostly live in modern settlements, but there are also numerous indigenous people who have 
accepted the lifestyle [82]. Modern settlements are found along transit corridors, in this case rivers and roads. Traditional settlements are found in all areas, from rivers to very remote areas. Traditional settlements that lack any functions are often semi-permanent. These are mostly newer settlements that become abandoned over time. Hunting, fishing, and gathering require mobility, and the agricultural lifestyle is sedentary. The mobility of the settlement largely depends on the shifting of large river beds, in addition to other logical factors. Settlements that are threatened by river erosion move further from the banks. Another reason for changing the location of settlements can be death within the family, old houses, and the need to create new chakras. The arrival of the first functions, foremost schools, rendered many traditional settlements permanent. With time, such traditional settlements can become modern settlements [82].

\section{Modern plans of the Peruvian government}

Numerous development agencies and national governments around the Amazon encourage market economy for production growth, especially of wood, while simultaneously attempting to sustain the "environment" [83-85]. The policies of national governments are often visible in incentivising the transformation of the Peruvian Amazon into productive land for national or foreign investors, to be used for the purpose of extraction of raw materials and energy, forest plantations, and the production of biofuel [49]. The vast majority of deforestation is a direct consequence of state and corporate policies, aimed to colonise and develop agriculture in the Peruvian Amazon. These policies include road building. The majority of deforestation happens within $20 \mathrm{~km}$ of an arterial road [42]. State planners rarely consider forest communities when creating plans that serve for the extraction of wealth for corporate use; meaning that such plans often come at the direct (or indirect) expense of forest communities. This sometimes leads to conflict in indigenous areas, and indigenous political organisations are emerging and gaining strength. The majority of deforestation (75\%) happens outside of protected indigenous lands. This indicates that the protected status of indigenous lands is also an effective measure against deforestation [42].

Yearly production of oil in the Peruvian Amazon is less than 4 hours of the world's total oil consumption [49] and, even so, the damage to the Peruvian Amazon is immense: indigenous human rights; climate change; loss of biodiversity; and loss of indigenous knowledge of the Amazon itself [49]. From 1970 to 2009, 84\% of the Peruvian Amazon was spoken for via contract or under negotiation, and permits were issued for oil and natural gas extraction on $55 \%$ of indigenous land in remote, pristine areas of the Peruvian Amazon [49]. Oil extraction is a threat to the lifestyle of indigenous folk. Apart from the oil industry, the construction of hydro-electric power plants and powerlines is envisioned. According to expert opinion, the projects for building new hydro-electric power plants will have a negative impact on the local population and biodiversity along the Tambo River. There are also plans to mine, improve and widen the rail and road networks, widen and maintain river channels for water transport, intensify agriculture, and increase exploitation of the forest-in this case export of wood [86]. The most damage is caused by ignoring existing laws, which leads to the negative consequences that exceed what the forest can sustain. Growth in social conflicts over human rights violations, especially of unorganised indigenous folk, is predicted [86].

The Peruvian public on the Pacific coast and in the Andes is generally not interested in and poorly informed about government project in the Amazon. Planners to not attempt to reach harmonious, just, useful, and sustainable development for all 
stakeholders (including indigenous people). The public sector and regional government bodies develop projects in isolation from one another, without mutual agreement. The majority of projects are consequences of inertia in public administration, which recycles old ideas from days past. Projects are mainly taken advantage of by political opportunists, construction firms, bankers, foreigners, and certain interest groups and companies.

The numerous ambitiously-planned, anticipated projects for development of the Peruvian Amazon for the period of 2009 to 2021 include 52 hydro-electric power plants, 53 oil fields, numerous oil and natural gas pipelines, 24,818 permits for new mines (extracting ore), 4486 re-built roads including $880 \mathrm{~km}$ of new roads and $2089 \mathrm{~km}$ of asphalt roads, as well as around $2000 \mathrm{~km}$ of railway, $4213 \mathrm{~km}$ of river channel works, and new plantations for the production of bio-fuel [86]. There have never been so many projects underway at once in Peru's history, but it is likely that some will not come to fruition.

The consequences will be severe and will quickly lead to drastic changes in the Peruvian Amazon. By 2041, it is likely that deforestation and degradation will come to cover at least $56 \%$ of the forest - the more pessimistic projections predict up to $91 \%$. Only $10 \%$ of the Peruvian Amazon is protected. $\mathrm{CO}_{2}$ emissions are expected to rise in proportion to deforestation, putting Peru in a tough position in relation to promises made to the international community. The degradation of natural ecosystems in the process of estuarine water circulation, however, is much more dangerous than rising $\mathrm{CO}_{2}$ levels, as it will cause increasingly expressed droughts and floods, as well as increases in violent erosive phenomena (landslides, torrents, gullies) [86]. The drastic negative influence will be experience foremost by indigenous peoples living in voluntary isolation, who will likely disappear entirely. Social conflicts over violation of human rights and ownership rights are predicted to rise in the future. Five main generators of conflict are often mentioned: (1) conflicts between indigenous leaders and the national government over protection of indigenous territory; (2) conflicts between illegal miners and the greater population; (3) conflicts between illegal coca producers and narco-traffickers; (4) conflicts between indigenous people and oil companies on indigenous territory; and (5) conflicts between those who would be effected by the construction of reservoirs and supporters of hydro-electric power plant projects.

There are also geopolitical motivations found within the Peruvian government's projects, as some of them are intended to forge better connections between the Pacific and Atlantic oceans, which is especially favourable for Brazil due to easing Brazilian foreign trade, producing electricity on the slopes of the Andes, widening the markets of Brazilian firms, and the possibility of investment from the Brazilian National Bank. This all comes, however, at the expense of nature itself, Peruvians who will pay for projects that give them no direct benefit, residents of the forest, and indigenous people. The resulting climate change, reductions in biodiversity, and loss of knowledge of the Amazon itself threaten the entire world.

\section{Conclusion}

The main conclusion of this chapter is that foreign influences have deeply changed the landscape and local societies in the Amazon over the last 60 years. The Amazon is traditionally a sparsely-settled area, in which more-advanced urban civilisations were not able to develop due to harsh landscape conditions. Indigenous people traditionally practice hunting, fishing, gathering, and basic agriculture, as well as a communal "sharing" system in place of a modern system of monetary exchange. 
Missionaries were the first Europeans to spread Christianity and alter traditional indigenous Amazonian society (from the beginning of the 18th century). Oil companies have also left their mark on the Peruvian Amazon by extracting oil and natural gas, building pipelines, employing numerous settlers from the Andes and Pacific coast, and luring indigenous folk to the foreign lifestyle. The strongest causal factor of deforestation and societal change in Peruvian Amazonian societies is modern agriculture: plantation farmers and ranchers. By 2012, a total of between $11.3 \%$ and $13.4 \%$ of the total forest area had been cut down, and this process has only strengthened since then. There is also a risk of overpopulation and over-tourism in some of the area's few tourist resorts and highly-visited areas.

Assuming the arrival of numerous immigrants, the entry of the market, and strong change in the activities of the population, we expect the emergence of new modern settlements and the concentration of the population therein. Reduction in size and disappearance of traditional settlements, and their relocation into remote protected areas away from rivers and arterial roads is also expected. Contemporary settlements in the Amazon planimetrically resemble other settlements in the West with streets and stores, in contrast to traditional indigenous settlements which resemble extended gardens with multiple dwellings. The area of foreign influence, and intense landscape and societal transformation, follows flows of communication: primarily roads and rivers used for transport.

Plans of the Peruvian government are very ambitiously laid out and envision the construction of numerous hydro-electric power plants, oil and natural gas fields, mines, roads, railways, plantations, and river channel works. There are predictions of widening deforestation and forest degradation (estimates range from $56 \%$ to 91\%) of the Peruvian Amazon by 2041. In this context, it is important to stress that only $10 \%$ of the Peruvian Amazon currently has protected status.

The loss of traditional knowledge is linked to the inclusion of the indigenous population in modern market economics, along with the simultaneous exodus from existential hunter-gatherer subsistence [53]. The spread of modernity and the Europeanisation of the population of the Amazon will end up costing the world generations of indigenous knowledge regarding tropical areas.

\section{Author details}

Zoran Stiperski ${ }^{1 *}$ and Tomica Hruška ${ }^{2}$

1 Department of Geography, Faculty of Science, University of Zagreb, Zagreb, Croatia

2 The Franciscan Monastery of the Holy Spirit, Požega, Croatia

*Address all correspondence to: zstiper@geog.pmf.hr

IntechOpen

(C) 2020 The Author(s). Licensee IntechOpen. This chapter is distributed under the terms of the Creative Commons Attribution License (http://creativecommons.org/licenses/ by/3.0), which permits unrestricted use, distribution, and reproduction in any medium, provided the original work is properly cited. (cc) BY 


\section{References}

[1] Gross D. Protein capture and cultural development in the Amazon Basin. American Anthropologist. 1975;77(3):526-549. DOI: https://doi. org/10.1525/aa.1975.77.3.02a00040

[2] Meggers BJ. Environmental limitation on the development of culture. American Anthropologist. 1954;56(5):801-824

[3] Meggers BJ. Amazonia: real or counterfeit paradise? The Review of Archaeology. 1992;13(2):25-40

[4] Meggers BJ. Biogeographical approaches to reconstructing the prehistory of Amazonia. Biogeographica. 1994;70(3):97-110

[5] Meggers BJ. Prehistoric cultural development in Amazonia: an archaeological perspective. Research and Exploration. 1994;10(4):398-421

[6] Denevan WM. A bluff model of riverine settlement in prehistoric Amazonia. Annals of the Association of American Geographers. 1996; 86(4):654-681. DOI: https://doi. org/10.1111/j.1467-8306.1996.tb01771.x

[7] Lombardo U, Prümers H. PreColumbian human occupation patterns in the eastern plains of the Llanos de Moxos. Bolivian Amazonia. Journal of Archaeological Science. 2010;37:18751885. DOI: 10.1016/j.jas.2010.02.011

[8] Carneiro R. The history of ecological interpretations of Amazonia: does Roosevelt have it right? In: Sponsel L, editor. Indigenous Peoples and the Future of Amazonia: an Ecological Anthropology of an Endangered World. Tucson: University of Arizona Press; 1995. pp. $45-70$

[9] Lathrap D. The Upper Amazon Ancient Peoples and Places.

Southampton: Thames \& Hudson; 1970 $256 \mathrm{p}$
[10] Denevan W. The pristine myth: the landscape of the Americas in 1492. Annals of the Association of American Geographers. 1992;82(3):369-385. DOI: https://doi.org/10.1111/j.1467-8306.1992. tb01965.x

[11] Denevan W, Treacy J, Alcorn J, Padoch C, Denslow J, Flores S.

Indigenous agroforestry in the Peruvian Amazon: Bora Indian management of swidden fallows. Interciencia. 1984;9(6):346-357

[12] Heckenberger MJ. The enigma of the great cities: body and State in Amazonia. Tipiti: Journal of Society for the Anthropology of Lowland South America. 2003;1:17-48

[13] McEwan C, Barreto C, Neves E, editors. Unknown Amazon. London: The British Museum; 2001

[14] Uhl C, Nepstad D, Buschbacher R, Clark K, Kauffman B, Subler S. Studies of ecosystem response to natural and anthropogenic disturbances provide guidelines for designing sustainable land-use systems in Amazonia. In: Anderson $\mathrm{AB}$, editor. Alternatives to deforestation: steps toward sustainable use of the Amazon rain forest. New York: Columbia University Press; 1990. pp. 24-42

[15] Zent S. Historical and ethnographic ecology of the Upper Cuao River Wothiha: clues for an interpretation of native Guianese social organization [thesis]. New York: Columbia University; 1992

[16] Freire GN. Indigenous Shifting Cultivation and the New Amazonia: A Piaroa Example of Economic Articulation. Human Ecology. 2007;35:681-696. DOI: 10.1007/ s10745-007-9120-y

[17] Dougherty B, Calandra HA. Excavaciones arqueológicas en la Loma 
Alta de Casarabe, Llanos de Moxos, Departamento del Beni, Bolivia. Relaciones de la Sociedad Argentina de Antropología. 1981-1982;14(2):9-48

[18] Dougherty B, Calandra HA. Prehispanic human settlement in the Llanos de Mojos, Bolivia. In: Rabassa J, editor. Quaternary of South America and Antarctic Peninsula. Vol. 2. Rotterdam: Balkema; 1984. pp. 163-200

[19] Erickson C. The domesticated landscapes of the Bolivian Amazon. In: Balée W, Erickson C, editors. Time and Complexity in Historical Ecology: Studies in the Neotropical Lowlands. New York: Columbia University Press; 2006. pp. 235-278

[20] Erickson C. Amazonia: the historical ecology of a domesticated landscape. In: Silverman H, Isbell W, editors. Handbook of South American Archaeology. New York: Springer; 2008. pp. 157-183

[21] Heckenberger MJ. Manioc agriculture and sedentism in Amazonia: the Upper Xingu example. Antiquity. 1998;72(277):633-648. DOI: https://doi. org/10.1017/S0003598X00087056

[22] Heckenberger MJ. History, ecology, and alterity: visualizing polity in Amazonia. In: Balée W, Erickson C, editors. Time and Complexity in Historical Ecology: Studies in the Neotropical Lowlands. New York: Columbia University Press; 2006. pp. 311-340

[23] Heckenberger MJ. Amazonian mosaics: identity, interaction, and integration. In: Silverman H, Isbell W, editors. Handbook of South American Archaeology. New York: Springer; 2008. pp. 941-961

[24] Heckenberger MJ. Lost garden cities: pre-Columbian life in the Amazon. Scientific American. 2009:64-71
[25] Heckenberger M, Kuikuro A, Kuikuro UT, Russell C, Fausto C, Franchetto B. Amazonia 1492: pristine forest or cultural parkland? Science. 2003;301(5640):1710-1714. DOI: 10.1126/science.1086112

[26] HeckenbergerMJ, RussellJC, FaustoC, Toney JR, Schmidt MJ, Pereira E, et al. Pre-Columbianurbanism, anthropogenic landscapes, and the future of the Amazon. Science. 2008;321(5893):12141217. DOI: $10.1126 /$ science. 1159769

[27] Mann CC. Ancient Earthmovers of the Amazon. Science. 2008;321(5893): 1148-1148. DOI: $10.1126 /$ science. 321.5893 .1148

[28] Neves EG. hanging perspectives in Amazonian archaeology. In: Politis GG, Alberti B, editors. Archaeology in Latin America. London and New York: Routledge; 1999. p. 219-249.

[29] Barreto C, McEwan C, Neves EG. Unknown Amazon - Culture in Nature in Ancient Brazil. London: British Museum; 2001. 304 p.

[30] Pärssinen M, Schaan D, Ranzi A. Pre-Columbian geometric earthworks in the upper Purús: a complex society in western Amazonia. Antiquity. 2009;83:1084-1095. DOI: https://doi. org/10.1017/S0003598X00099373

[31] Porras PI. Investigations at the Sangay mound complex. National Geographic Research. 1989;5(3):374-381

[32] Roosevelt AC. The rise and fall of the Amazon chiefdoms. L'Homme. 1993;33(126-128):255-283

[33] Roosevelt AC. The development of prehistoric complex societies: Amazonia, a tropical forest. Archaeological Papers of the American Anthropological Association. 1999;9(1):13-33. DOI: https://doi. org/10.1525/ap3a.1999.9.1.13 
[34] Roosevelt AC. Late Amazonian. In: Peregrine PN, Ember M, editors. Encyclopedia of Prehistory. New York: Kluwer Academic/Plenum Publishers and H.R.A.F; 2002. pp. 289-293. DOI: 10.1007/978-1-4615-0525-9

[35] Salazar E. De vuelta al Sangay investigaciones arqueológicas en el Alto Upano. Amazonía Ecuatoriana. Bulletin de l'Institut Français d'Études Andines. 1998;27(2):213-240

[36] Schaan DP. The nonagricultural chiefdoms of Marajó Island. In:

Silverman H, Isbell W, editors. Handbook of South American Archaeology. New York: Springer; 2008. pp. 339-358. DOI: 10.1007/978-0-387-79407-5

[37] Walker J. The Llanos de Mojos. In: Silverman H, Isbell W, editors. Handbook of South American Archaeology. New York: Springer; 2008. pp. 927-939. DOI: 10.1007/978-0-387-79407-5

[38] Walker R, Perz S, Caldas M, Silva LGT. Land use and land cover change in forest frontiers: the role of household life cycles. International Regional Science Review. 2002;25:169-199. DOI: https://doi. org/10.1177/016001760202500202

[39] Wüst I. Continuities and discontinuities: archaeology and ethnoarchaeology in the heart of the Eastern Bororo terrritory, Mato Grosso, Brazil. Antiquity. 1998;72:663675. DOI: https://doi.org/10.1017/ S0003598X0008707X

[40] Wüst I, Barreto C. The ring villages of central Brazil: a challenge for Amazonian archaeology. Latin American Antiquity. 1999;10(1):3-23. DOI: $10.2307 / 972208$

[41] Grann D. Izgubljeni grad Z - Priča o pogubnoj opsesiji Amazonijom. Profil: Zagreb; $2011281 \mathrm{p}$

[42] Valqui M, Feather C, Espinosa Llanos R. Revealing the hidden - Indigenous perspectives on deforestation in the Peruvian Amazon The causes and the solutions. Lima: AIDESEP (Inter Ethnic Association for the Development of the Peruvian Amazon) and Moreton-in-Marsh: FPP (Forest Peoples Programme); 2015. 127 p.

[43] Menton M, Cronkleton P. Migration and forests in the Peruvian Amazon. Bogor City: Center for International Forestry Research (CIFOR); 2019. p. 25. DOI: $10.17528 /$ cifor/007305

[44] Zent S. Donde no Hay Médico: las consecuencias culturales y demográficas de la distribución desigual de los servicios édicos modernos entre los Piaroa. Antropológica. 1993;79:43-84

[45] Sierra R, Rodriguez F, Losos E. Forest resource use change during early market integration in tropical rain forests: the Huaorani of upper Amazonia. Ecological Economics. 1999;30:107-119. DOI: https://doi. org/10.1016/S0921-8009(98)00101-3

[46] Cabodevilla M. Misión Capuchina y Huaorani. In: Jass J, editor. Naúfragos del Mar Verde. La Resistencia de los Huaorani a una Integración Impuesta. Quito: Editorial Abya-Yala. 1992. pp. $74-76$

[47] MEM. Anuario Estadístico de Hidrocarburos 1976-1985. In: Lima: Ministerio de Energía y Minas de Perú. 1986

[48] Finer M, Orta-Martínez M. A second hydrocarbon boom threatens the Peruvian Amazon: trends, projections, and policy implications. Environmental Research Letters. 2010;5(014012):1-10. DOI: 10.1088/1748-9326/5/1/014012

[49] Orta-Martínez M, Finer M. Oil frontiers and indigenous resistance in the Peruvian Amazon. Ecological Economics. 2010;20:207-218. DOI: 10.1016/j.ecolecon.2010.04.022 
[50] Pottmaier D, Melo CR, Sartor MN, Kuester S, Amadio TM, Fernandes CAH, Marinha D, Alarcon OE. The Brazilian energy matrix: From a materials science and engineering perspective. Renewable and Sustainable Energy Reviews.

2013;19:678-691. DOI: http://dx.doi. org/10.1016/j.rser.2012.11.063

[51] Pluspetrol Norte SA. PampaHermosa. Convenio suscrito entre la empr esa PLUSPETROL NORTE S.A. y la Comunidad Nativa PAMPA HERMOSA.

CN Pampa Hermosa. 2003:4

[52] Hoffman M, Grigera AI. Climate Change, Migration, and Conflict in the Amazon and the Andes - Rising Tensions and Policy Options in South America. Washington, DC: Center for American Progress; 2013110 p

[53] Kramer DB, Urquhart G, Schmitt K. Globalization and the connection of remote communities: A review of household effects and their biodiversity implications. Ecological Economics. 2009;68:2897-2909. DOI: 10.1016/j. ecolecon.2009.06.026

[54] Wegner RC, Fernandes MP. The Amazon and the Internationalisation of Chinese Companies. Contexto Internacional. 2018;40(2):361-385. DOI: http://dx.doi.org/10.1590/ S0102-8529.2018400200006

[55] Suess JG, Mendoza NV. Sociedad Bosquesina - Tomo I: Ensayo de antropologia rural amazónica, acompańado de una crítica y propuesta alternative de proyectos de desarrollo. Iquitos: Jong DW (collaborator) Instituto de Investigaciones de la Amazonía Peruana (IIAP), Lima: Consorcio de Investigaciones Económicas y Sociales (CIES), Kyoto: Center for Integrated Area Studies, Kyoto University (CIAS); 2011. 292 p.

[56] Coomes OT, Barham BL, Takasaki Y. Targeting conservation-development initiatives $\mathrm{n}$ tropical forests: insights from analyses of rain forest use and economic reliance among Amazonian peasants. Ecological Economics. 2004;51:47-64. DOI: https://doi. org/10.1016/j.ecolecon.2004.04.004

[57] Pinton F. Traditional knowledge and areas of biodiversity in Brazilian Amazonia. International Social Science Journal. 2003;55(178):607-618. DOI: https://doi.org/10.1111/j.00208701.2003.05504010.x

[58] Brady NC. Alternatives to slash-andburn: a global imperative. Agriculture, Ecosystems \& Environment. 1996;58:3-11. DOI: https://doi. org/10.1016/0167-8809(96)00650-0

[59] Serrao EAS, Nepstad D, Walker R. Upland agricultural and forestry development in the Amazon: sustainability, criticality and resilience. Ecological Economics. 1996;18(1):3-13. DOI: https://doi. org/10.1016/0921-8009(95)00092-5

[60] Salisbury DS, Schmink M. Cows versus rubber: Changing livelihoods among Amazonian extractivists. Geoforum. 2007;38:1233-1249. DOI: 10.1016/j.geoforum.2007.03.005

[61] Wilson EO. The current state of biological diversity. In: Wilson EO, editor. Biodiversity. Washington, DC: National Academy Press; 1988. 538 p. DOI: https://doi.org/10.17226/989

[62] Godar J. The environmental and human dimensions of frontier expansion at the Transamazon highway colonization area [thesis]. León: University of León; 2009

[63] Godoy R, Reyes-Garcia V, Vadez V, Leonard WR, Tanner S, Huanca T, et al. TAPS Bolivia Study Team. The relation between forest clearance and household income among native Amazonians: Results from the Tsimane' Amazonian panel study, Bolivia. Ecological Economics. 2009;68:1854-1871. DOI: 10.1016/j.ecolecon.2009.01.001 
[64] Godoy R, Brokaw N, Wilkie D. The effect of income on the extraction of nontimber tropical forest products: model, hypotheses, and preliminary findings from the Sumu Indians of Nicaragua. Human Ecology. 1995;23(1):29-52. DOI: https://doi.org/10.1007/BF01190097

[65] Gavin MC, Anderson GJ. Socioeconomic predictors of forest use values in the Peruvian Amazon: A potential tool for biodiversity conservation. Ecological Economics. 2007;60:752-762. DOI: $10.1016 / j$. ecolecon.2006.01.010

[66] Sanchez PA. Properties and management of soils in the tropics. New York: Wiley and Sons; 1976.686 p. DOI: https://doi.org/10.2307/1297555

[67] Araujo C, Araujo Bonjean C, Combes J-L, Combes Motel P, Reis EJ. Property rights and deforestation in the Brazilian Amazon. Ecological Economics. 2009;68:2461-2468. DOI: 10.1016/j.ecolecon.2008.12.015

[68] Pimental D, Floyd B, Teel W, Bourns J. Deforestation, biomass depletion, and land degradation: Linkages to policy reform in sub-Saharan Africa. Ithaca: Cornell University, Department of Natural. Resources. 1991

[69] Tchoungui R, Gartlan S, Mope Simo JA, Sikod F, Youmbi A, Ddjatsana M, et al. Structural adjustment and sustainable development in Cameroon. London: Overseas Development Institute; 1995 $132 \mathrm{p}$

[70] Kaimowitz D, Thiele G, Pacheco P. The Effects of Structural Adjustment on Deforestation and Forest Degradation in Lowland Bolivia. World Development. 1999;27(3):505-520. DOI: 10.1016/ S0305-750X(98) 00146-6

[71] Pokorny B, Johnson J, Medina G, Hoch L. Market-based conservation of the Amazonian forests: Revisiting win-win expectations. Geoforum. 2012;43:387-401. DOI: 10.1016/j. geoforum.2010.08.002

[72] Peres CA, Lake IR. Extent of nontimber resource extraction in tropical forests: accessibility to game vertebrates by hunters in the Amazon basin. Conservation Biology. 2003;17:521-535. DOI: https://doi. org/10.1046/j.1523-1739.2003.01413.x

[73] Levi T, Shepard GH Jr, Ohl-Schacherer J, Peres CA, Yu DW. Modelling the long-term sustainability of indigenous hunting in Manu National Park, Peru: landscape-scale management implications for Amazonia. Journal of Applied Ecology. 2009;46:804-814. DOI: 10.1111/j.1365-2664.2009.01661.x

[74] Peres C. Effect of hunting on Western Amazonian primate communities. Biological Conservation. 1990;54:47-59. DOI: https://doi. org/10.1016/0006-3207(90)90041-M

[75] Franzen M, Eaves J. Effect of market access on sharing practices within two Huaorani communities. Ecological Economics. 2007;63:776-785. DOI: 10.1016/j.ecolecon.2007.02.001

[76] Terborgh J. Requiem for Nature. Washington, DC: Island Press; 1999. 246 p. DOI: $10.2458 /$ v6i1.21439

[77] Redford KH. The empty forest. BioScience. 1992;42:412-422. DOI: 10.2307/1311860

[78] Terborgh J, van Schaik C. Minimizing species loss: the imperative of protection. In: Kramer R, van Schaik C, Johnson J, editors. Last stand: protected areas and the defense of tropical biodiversity. New York: Oxford University Press; 1997. p. 15-35.

[79] Fafchamps M. Cash crop production, food price volatility, and rural market integration in the Third World. American Journal of 
Agricultural Economics. 1992;74:90-99.

DOI: https://doi.org/10.2307/1242993

[80] Angelsen A, Kaimowitz D.

Rethinking the causes of deforestation:

lessons from economic models. The

World Bank Research Observer.

1999;14:73-98. DOI: https://doi.

org/10.1093/wbro/14.1.73

[81] Mikkelsen C, editor. The Indigenous World 2012. Copenhagen: International Work Group for Indigenous Affairs; $2012591 \mathrm{p}$

[82] Stiperski Z, Hruška T, Heršak E, Lorber L. Planimetry of settlements as a confirmation of transformation in the Atalaya region in Peruvian Amazonia. Anthropological Notebooks. 2018;24(2):75-96

[83] Homma AKO. Amazônia: como aproveitar os benefícios da destruição. Estudos Avançados. 2005;19(54): 115-135. DOI: https://doi.org/10.1590/ S0103-40142005000200007

[84] Almeida E, Sabogal C, Brienza S. Recuperação de áreas alteradas na Amazônia Brasileira: Experiências locais, lições aprendidas e implicações para políticas públicas. Belém: CIFOR; 2006. 204 p. DOI: https://doi. org/10.17528/cifor/002119

[85] Hoch L, Pokorny B, de Jong W. How successful is tree growing for smallholders in the Amazon? International Forestry Review. 2009;11(3):299-310. DOI: https://doi. org/10.1505/ifor.11.3.299

[86] Dourojeanni M, Barandiaran A, Dourojeanni D. Amazonia Peruana En 2021. Explotación de recursos naturales e infraestructuras: Qué está pasando? Qué es lo que significan para el future? Lima: ProNaturaleza - Fundación Peruana para la Conservación de la Naturaleza; 2009. 162 p. 



\title{
Quilombo Communities and Opportunities for Market-Driven Mechanisms for the Protection of the Amazon Forest
}

\author{
Anna Kanele and Pedro Pablo Cardoso Castro
}

\begin{abstract}
Quilombos are communities created since colonial times by emancipated African-descendants who located their free communities in the deep forest north of the Amazon in Brazil. These vulnerable communities are still oppressed and neglected. Paradoxically, their actual economic activities based on Amazon products' extraction are becoming key for protecting the rainforest in the north of Brazil (state of Para). In this chapter, the analysis of Honey production illustrates their socio-economical context, organizational capabilities, and the potential of their economic activities to preserve the rainforest's integrity. It also illustrates the challenges and limitations that they face to access markets where the value of their products' attributes is appreciated based on the profile of blue businesses (e.g., fair trade, organic, rainforest friendly).
\end{abstract}

Keywords: Quilombo, Amazon, Para, Rainforest, Honey

\section{Introduction}

The state of Para in the north of Brazil is part of the official Amazon region [1, 2]. Its territory is mostly composed of savannas, wetlands, and hundreds of islands in the Amazon River's delta, including the world's largest fluvial island, attributes that, together with its seasonal weather, made it iconic for the study of the Amazon region $[3,4]$. In terms of population, out of the 211.38 million habitants, $0.4 \%$ are indigenous, and 2.5\% Quilombola [5-7]. However, - and yet as another form of neglection and discrimination - despite being the Quilombola six times higher than the Indigenous people, this community is underrepresented in the academic literature. This fact was evidenced using Google Scholar under the search term "Indigenous Communities," obtaining 2,990,000 results. In contrast, the search term "Quilombola Communities" only showed 17,400 results in a search made in July 2020 [8, 9].

Historically, the state was occupied by Indigenous tribes. Later, with the arrival and interbreed of Portuguese colonists, different communities developed, varying on the kind of labor and stile of living they developed (e.g., riveirinhos, occupying the riversides of the Amazon delta, working on fishing and seasonal crops). Adding to the racial mixture, the import of African slaves was made early during the colonial times to substitute the decreasing population of Indigenous people. 

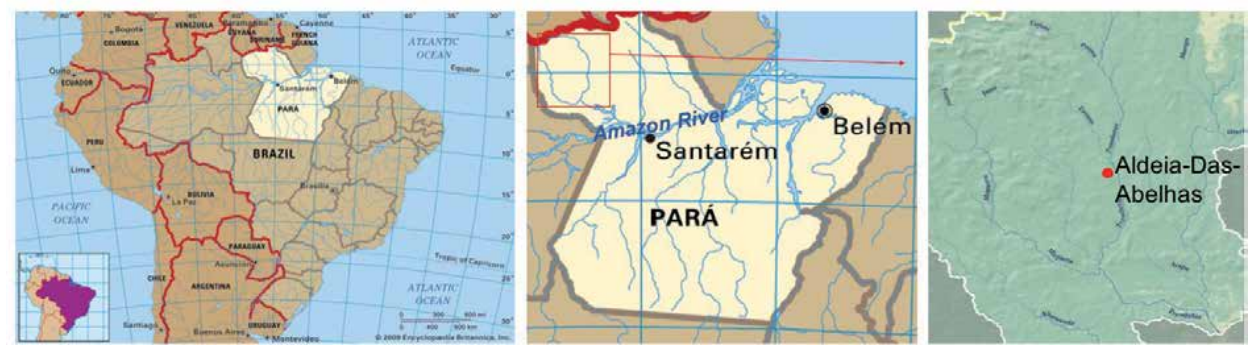

Figure 1.

Location of the district of Santarem - where many Quilombolas are located, and ubication of the archetypical Quilombo of "Aldeia-Das-Abelhas" (modified from [1, 14]).

In this colonization process, African slaves revealed and emancipated, escaping their captors and moving from the plantations to forest areas of difficult access, funding free autonomous colonies/communities (Quilombos, inhabited by Quilombolas), in a process that lasted until the abolition of slavery in 1888 [7, 10-12]. Consequently, many villages are located along the Upper Trombetas, Erepecuru, and Cumina Rivers [13], at the north of Santarem. To consolidate the description of the numerous Quilombos in the region, in this document, we will present an archetypic - fictional - Quilombo named "Aldeia-Das-Abelhas" located in the middle of the Trombetas River (Figure 1).

Due to their location and the nature of their social organization, these communities developed productive activities that did not demand large areas of terrain, with positive side effects for preserving the forest, as its integrity was key for the protection of the community. Also, their use and commercialization of local products is favored by good levels of (bio)diversity, which provides a diverse range of products. In this context, ironically, the discrimination towards these communities - and consequently, their limited access to technology - impose constrains to the level of transformation of their products. Consequently, their offer to the market is composed of natural products that can fit within the categories or organic or rainforest friendly, being Honey one of those with high potential for their socio-economic inclusion and forest production.

\section{The Quilombola context}

From their origins, the Quilombola founded various smaller villages as it made it more difficult for the government troops to find them, making the Quilombola more flexible and mobile as they could quickly relocate individual villages if they were in danger [10]. The National Institute for Colonization and Agrarian Reform has figures from Quilombola communes regarding the number of large families and hectares used. In these figures, it is noticeable that almost the same number of families in Belem and Santarem are listed, but Belem's area is less than $10 \%$ of Santarem's area. Within this context, the "Aldeia-Das-Abelhas" composed of 70 families, would have as much land as the municipalities in Santarem, occupying 4177 ha [15]. A large part of this Quilombo can hardly afford to eat and therefore live in deplorable conditions [16]. Some houses of the Quilombo have been built provisionally from mud and bamboo [17]. Also, the village partly shows problematic sanitary conditions, with limited access to sanitation [18].

In terms of land, the Quilombola community "Barro Vermelho" illustrates these communities' general situation when only after a long struggle, they received the official status as Quilombola land [19]. The recognition of the Quilombola land is 


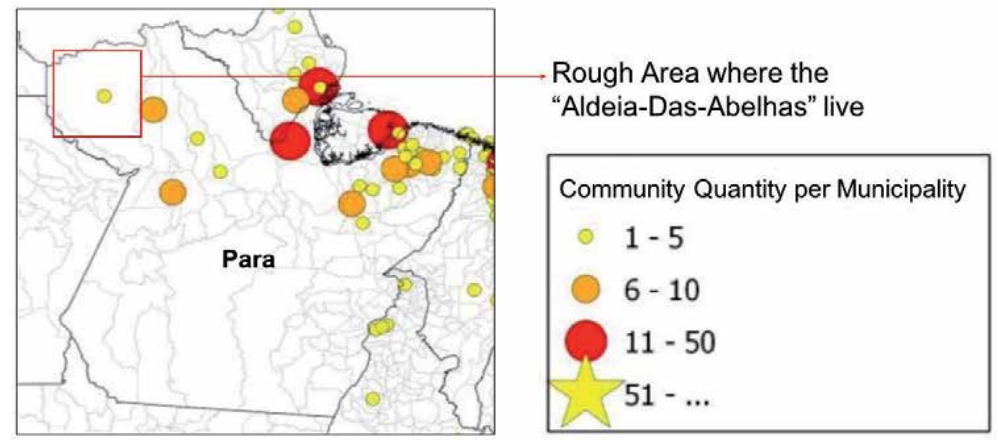

Figure 2.

Quilombola communities certified by municipalities (modified from [23]).

sometimes a very long process. Only $9.4 \%$ of the applications were recognized, and $44 \%$ of them still-open applications, which have been pending for more than ten years [6]. However, this title does not automatically imply the recognition of official land titling, as the example of the "Comunidade Quilombola do Saco Barreiro" shows [20]. The relevance of the land title comes from the fact that through the land title, the area where the Quilombola lives would be officially protected so that no clearing or mining would be allowed. According to title conservation, deforestation has decreased by $66 \%$ in areas where legal rights on the land have been granted [21]. However, Para is the only state in Brazil with more titles of Quilombola land than the land-titling processes of Quilombola lands; about a third (66 out of 181) of all pronounced Quilombola land titles fall on Para [22]. However, in the registers of CAISAN, the "Aldeia-Das-Abelhas" area has hardly been recognized as an official Quilombola community - see Figure 2 [23]. Although the recognition of land in Para is generally relatively high, based on the data of CAISAN, for this document, we assumed that the "Aldeia-Das-Abelhas" have neither the official recognition as Quilombola or a land title.

It should be noted that even villages that have been granted the land continue to struggle for it, and their livelihood is still threatened. No one, except the government, can dispute the land after receiving the land title [17]. In this sense, Bolsonaros' administration plans to dispute these lands to introduce mining and agriculture in protected areas [21], as well as the legalization of deforestation in the Amazon. However, Bolsonaros' administration is not the first to adopt and to implement this approach. Previously, President Michel Temer abolished the Renca Reserve, which lies on the border between Amapa and Para [24]. The consequences of such systemic clearance of land by deforestation were defined by Mauricio Voivodic (executive director of WWF-Brazil) as irreversibly damaging local cultures, and it would also “... lead to an intensification of land conflicts and threats to indigenous peoples and traditional populations" [24]. Within this context of conflict between the communities protecting their land and the political and criminal interests who want to make the most lucrative use of the land and its resources in the short-term, gun violence would not deter economic interests. On the contrary, as reported by the nut collector Antonio Marcos de Lima: tractors, chainsaws, and gunfire now dominate a once quiet and peaceful jungle [25]. There has been a steady increase in direct violence against the villages and their inhabitants in the recent past [26].

\section{Current situation}

Bolsonaros' administration policy is to use the rainforest area to expand industrial agriculture developments, incentivizing the deforestation - legal and illegal - of the 
Amazon [27]. In this context, and adding the historical process of displacement from their lands and neglection from state protection and recognition, the traditionally living people who claim their land [22] are a thorn in the side. This policy was first illustrated in Bolsonaro's election campaign in which he spoke out for the possession of weapons and against the lands claiming of the Indigenous and Quilombola [25, 28]. Bolsonaro said, "You can be sure that there will not be money for NGOs if I get there (Presidency of the Republic). If it is up to me, every citizen will have a firearm. There will not be a centimeter marked for an Indigenous reservation or a Quilombola." [29].

After winning the presidential election, Bolsonaro's policy focused on shortterm profit maximization. To this end, the policy uses the high yield of rainforest land without regard to the long-term consequences for the environment and people [30]. Concerning as it is, Bolsonaros' administration continued to pursue this goal weakening the support of Indigenous and Quilombola. Accordingly, the Brazilian office FUNAI, which protects primarily the Indigenous and supports the Quilombola, has had its funds cut. Its management changed several times and was moved under the Ministry of Agriculture administration, which in line with governmental direction, has no interest in protecting the territories of traditional peoples living in the rainforest $[31,32]$. Bolsonaro also tried with the appointment of Ricardo Lopes Dias (an evangelical missionary who has set himself the goal of evangelizing everyone, including the Indigenous and Quilombola) as head of FUNAI in February 2020, to weaken the social organization of Indigenous and Quilombola communities. However, in May 2020, the court ruled that the appointment of Lopes Dias was illegal because the judges have seen an apparent conflict of interest between Lopes Dias's believes and the mission of FUNAI. Consequently, Lopes Dias was dismissed with immediate effect [11]. Furthermore, as registered by Sarah Shenker (from Survival International): "It was an essential part of Bolsonaro's explicit policy to destroy the country's Indigenous peoples - to dissolve the teams protecting their territories and sell their land to loggers, miners, and ranchers." [11].

Russau describes Brazilian Indigenous/Quilombola politics as submissive assistentialist welfare state thinking and explicit paternalism, further saying that the current situation of the Brazilian Quilombola can be summarized as poverty, dependence, and exclusion [33]. These affirmations ignore - particularly for the Quilombolas - their long history as emancipated communities and their development of autonomous governance and social structures that made them self-sufficient communities. Since colonial times, they have been prosecuted, neglected, and systematically excluded from socio-economic development, and yet, able to coordinate their activities, survive and preserve their identity, culture, and traditions.

\section{Quilombola production and logistics}

Many Quilombola living in rural areas work on collectively-owned land with natural resources [7]. Within this form of productive organization, some Quilombos produce traditional jewelry and sell the surplus of their agricultural production to third parties $[18,34]$. Their offer is mostly composed of Cassava (Manihot esculenta) - and domestically processed from it, farinha; raw fruits like Acai (Euterpe oleracea), Cupuassu (Theobroma grandiflorum), Nuts (Bertholletia excelsa); Honey, and other seasonal Amazon fruits. The product in many Quilombolas that is less dependent on the tenure of the land and seasonal changes and more suitable to the communities' sporadic mobility is Honey. Despite the popularity of products as Acai in the local (and now in the international) market, and Brazil Nuts that demand intense labor to collect, peel and prepare to present to the end consumer. 
Honey production requires little labor and maintenance, low technology for the production and processing - adding value - of the final product, and can be delivered almost directly to the end consumer without processing, making it less susceptible to intermediaries' occurrence. Opposite to Acai, that needs treatment/ processing to add value to the product, and refrigeration once processed. Also, due to the Acai's fragility and the lack of the communities' logistic resources, the product makes them more susceptible to depend on intermediaries to deliver to the market. It also demands a long-term settlement to develop the crop - hence, stability and clear rights on the land, if investment in adding value technologies is required. The case of Brazil Nuts demands a considerable extension of territory to provide commercial volumes of raw product, being a disadvantage, the intensive labor required to peel the Nut, and prepare it for the final consumer.

Concerning Honey production, mostly the two native bee species Melipona flavoneata and Melipona fasciculate, are used in Para for Honey production, as well as Apis mellifera [35], which is one of the most frequently used Honeybees worldwide. Of these, Melipona fasciculate has been identified as the best adapted and most productive in the Amazon context, standing out, among the native bees, for Honey production [36]. The native stingless bees are also highly adapted to “... the different soils, geographical location, good climatic conditions and the large diversity of plants and, in particular, flowering plants" [35], p. 1136. With these references, we can assume that the "Aldeia-Das-Abelhas" use Melipona fasciculate for Honey production.

Within this context, the Quilombola are partly dependent on selling their products in the nearest town or even directly in Belem, traveling by boat on a journey that can last several hours. For instance, for the "Aldeia-Das-Abelhas," Porto Trombetas is the nearest town, covering a distance of about $300 \mathrm{~km}$ on the Trombetas River, on a trip that can last up to 8.5 hours. Considering this logistic challenge and the characteristics summarized for the "Aldeia-Das-Abelhas," the community cannot afford a small fleet of boats to mobilize large amounts of products and keep fishing or other subsistence activities. Thus, they sell a significant part of their production to intermediaries; and trade directly in the city products that demand less labor, have more added or perceived value per unit of volume, and do not require refrigeration or any special treatment (e.g., Honey). These facts lead to the assumption that the "Aldeia-Das-Abelhas" have experience in selling to the middleman, limited experience in direct sales in the city. Therefore, their trading know-how is limited to local trade without the administrative or logistical experience for regional, national, or international trade.

As a counter-example, the "Itunuvico" historical development is presented. The "Itunuvico" started producing Honey in 2006 with nine people, and in thirteen years, they have grown to 180 small producers in Oaxaca-Mexico. The "Itunuvico" exported about 600 tons of organic Honey to Germany in 2018. The Mexican community further reports that they had their Honey certified organic through "Naturland," which has significantly increased yield. However, such certification is very costly [37]. This case also suggests developing skills in international trade and logistics - via partnerships with international ONGs, and the existence of logistics that facilitate the consolidation of production and its preparation for international distribution.

Without a reliable census in the region, due to the convenient size of the "Aldeia-Das-Abelhas," it is safe to assume that the community has around seven small producers. Each producer consists of the union of two families. About $20 \%$ of the population of the "Aldeia-Das-Abelhas" are trained in beekeeping. A total of 3 tons of Honey can be sold per year. This figure assumes that "Aldeia-DasAbelhas" uses part of the Honey for own consumption, and they are not yet as efficient as the "Itunuvico"; as the "Itunuvico" can fall back on many years of experience, and have a different logistic context for the commercialization of their 


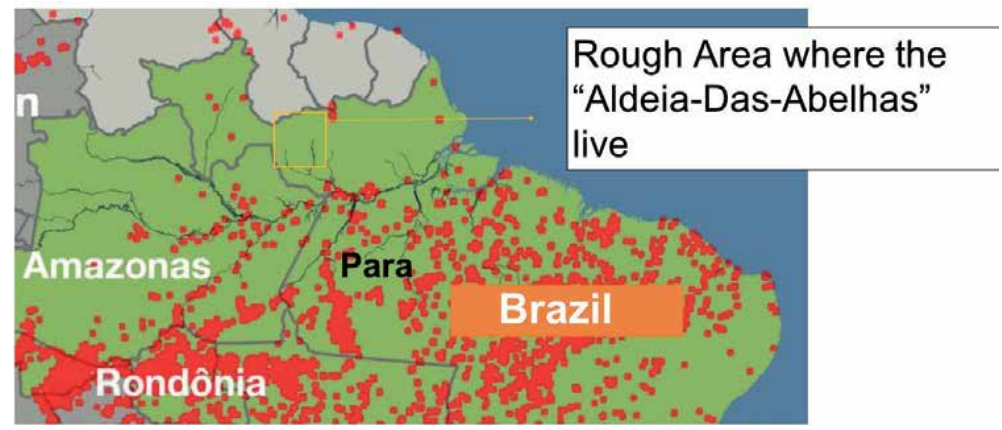

Figure 3.

Wildfire in Para, August 2019. Each red dot represents a fire (modified from [43]).

production. Considering the production context, we can assume that the Honey from the "Aldeia-Das-Abelhas" would satisfy the certification criteria for fair trade, rainforest friendly, and organic, but such certifications do not exist.

However, there is a danger that Honey production is unsteady, and even the bees are endangered. From December 2018 to February 2019, high bee mortality (about 500 million) became known, especially in the south and adjacent regions of the southeast and central west of Brazil $[38,39]$. Fast-tracked approval of almost 300 pesticides, together with the acceleration of the green frontier's expansion, might cause high bee mortality [39]. Particularly when known, these pesticides were already banned in other countries for their toxic effect on bees - among other effects on other species. In contrast, the counter-case of "Itunuvico" demonstrates that they do not have any problems with bee mortality due to strict organic certification regulations. This normative control restricts the boundaries and growth of the expansion of commercial crops, based on the trade-off that Honey production brings to the planning of the local rural economic development [37]. Adding to the threats to Honey production in the region, dos Santos and de Oliveira have found that temperatures in Para have risen in recent years and see the change in the natural landscape as the cause for the increased temperatures [40]. Clearing of the rainforests will increase the dry seasons [41], which harms the flora and, therefore, impacts the Honey production negatively [19].

Looking at the vast wildfires at the end of August 2019, although Para was severely affected, the "Aldeia-Das-Abelhas" area was not under risk (Figure 3). An early assessment of the impact of these recent changes in the region determined that weather conditions have become more extreme, which leads to the assumption that this trend has further increased in recent years [42]. Consequently, the wildfires do not directly threaten the "Aldeia-Das-Abelhas," but that they are already slightly affected by the extent of the rising temperatures and the resulting prolongation of the drought periods. In turn, they are being at risk of not being able to increase or maintain their Honey production.

\section{The Quilombola case for honey as economic activity}

Between 29 and $39 \%$ of the carbon dioxide $\left(\mathrm{CO}_{2}\right)$ released by deforestation is caused by international trade [44]. Forests are cut to make room for pastures and agricultural land. Based on the current demands of international investors [45] and in line with the Quilombola culture [25], clearing the rainforest for economic use and thus as a source of income is not an option. Additionally, Manoel Santiago (a Quilombola resident of "Pedras Negras") reports that some villages have lost their livelihoods 
due to the pandemic because they lived on tourism, selling homemade jewelry or traditional food [18]. Therefore, in the sense of the Quilombola, a sustainable basis of income should be created, where they can live independently from tourism.

Beekeeping offers an excellent alternative source of income compared to the sale of woodland to commercial enterprises or the commercialization of non-timber forest products. In connection with climate change, forest destruction can have devastating effects such as droughts or the deterioration of water supply [46, 47]. Accordingly, beekeeping is not only protecting the rainforest, but it is also an important income source, especially for small communities $[48,49]$. The environmental richness emerging in Brazil, including pollen and nectar, is favorable to Honey production and positively impacts the socio-economy development of a state living in impoverished circumstances - considering the local low human development index of 639 [36]. In this context, the Honey production chain has a favorable trade balance based on the low capital input and the activity's fast financial profitability. This activity generates income for small and medium-sized farms [50, 51]. Successful beekeeping, as demonstrated by the communities of "Barro Vermelho" in northeast Brazil [19] and "Itunuvico" Mexico [37], both exporting their Honey to the EU; can provide effective economic integration of marginal communities to - even international - markets.

Since previous publications do not indicate which areas are particularly suitable for Quilombola beekeeping in the rainforest, a suitable area is determined based on the Quilombo's location and the conditions there. Unlike the Indigenous people, who are widely distributed in Brazil [52], the Quilombolas are relatively centralized. The Quilombola, with official titles of their land living primarily in Maranhao and Para [7]. Silva et al. see Para as “... one of Brazil's most promising regions for the production of distinct types of Honey...” [35], p. 1135. Another argument for Para is that the population density in Para (about 8.67 million inhabitants on $1,248,000 \mathrm{~km}^{2}$ ) is lower than in Maranhao (about 7.10 million inhabitants on 331,982 $\mathrm{km}^{2}$ ) [53] the area per inhabitant is more significant in Para and therefore offers more space for beekeeping. Para's significantly larger area is crucial concerning other farmers who may use pesticides, which may cause a significantly increased bee mortality rate [38,39].

Furthermore, the latest figures from INPE show that Para requires especially strong support, as it accounted for around $40 \%\left(3862 \mathrm{~km}^{2}\right)$ of all clearings in Brazil in 2019 (Figure 4) [54]. The impact of forest reduction can already be seen today in Belem's increasingly extreme weather conditions [42].

An additional - but omnipresent - issue affecting the possibility of integration to the market of the Quilombola is racism. Since most Brazilians of African origin are still at the bottom of the social pyramid [12], it means being invisible, poorly paid,
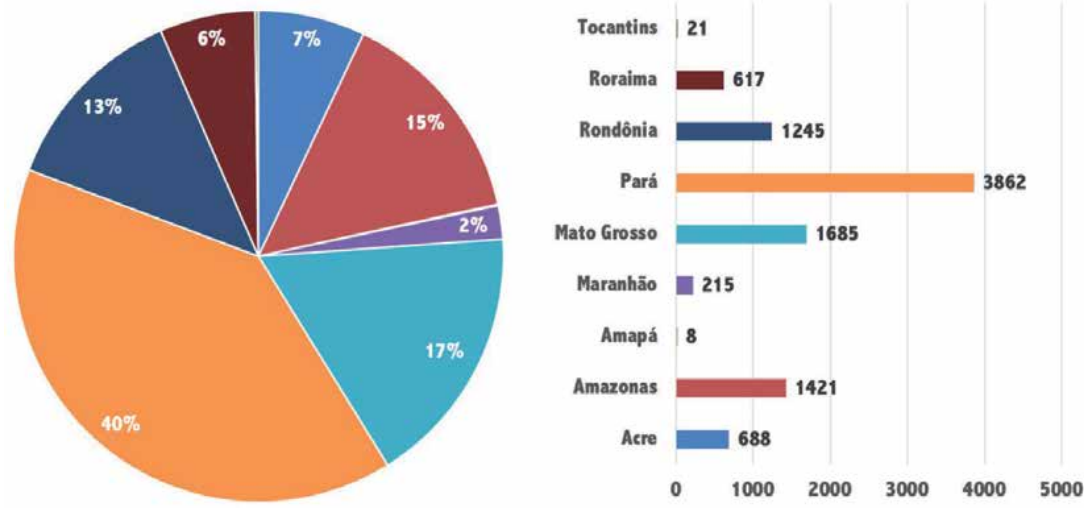

Figure 4.

Deforestation $\left(\mathrm{km}^{2}\right)$ by state in the Brazil Amazon in 2019 (from [54]). 
and deprived of the most basic civil rights. To counter the racism of the Quilombola, the Brazilian government must create instruments that focus on both class and racial inequalities [55]. Brandao et al. describe that "There is a high degree of institutional distance between state and local governments and the Quilombola communities." [56], p. 10. Due to the prevailing structural racism, i.e., the social system, with its legal concepts, and its political and economic structures, causes minorities [57]. Due to the segregation often associated with this, i.e., in the context of the Quilombola, a separation of the different living spaces and the resulting social status and stigmas, e.g., black and rural poor, there are unequal life chances $[34,58]$. This idea leads to the fact that it is difficult for Quilombola to sell their products on the Brazilian market. Because the population living in cities considers the people living in the Amazon (forest) as inferior [59], which can lead to a lower willingness to buy or fairly pay for their products. To bypass this barrier to access the market, one option could be to export Quilombola Honey - or any of the other traditional products such as Acai, Brazil Nuts, or fruits as Cupuassu, with similar benefits for protecting the rainforest. However, there are no reports or technical studies on assessing its viability, despite its enormous potential to provide economic inclusion and the positive consequences in protecting the rainforest and its biodiversity.

\section{Analysis of the potential export market for Quilombola honey}

Honey is a trendy product nowadays [60]. This trend is illustrated by the global Honey market, where Honey's international production is continuously increasing $[61,62]$. Garcia (President of the International Organization of Honey Exporters)

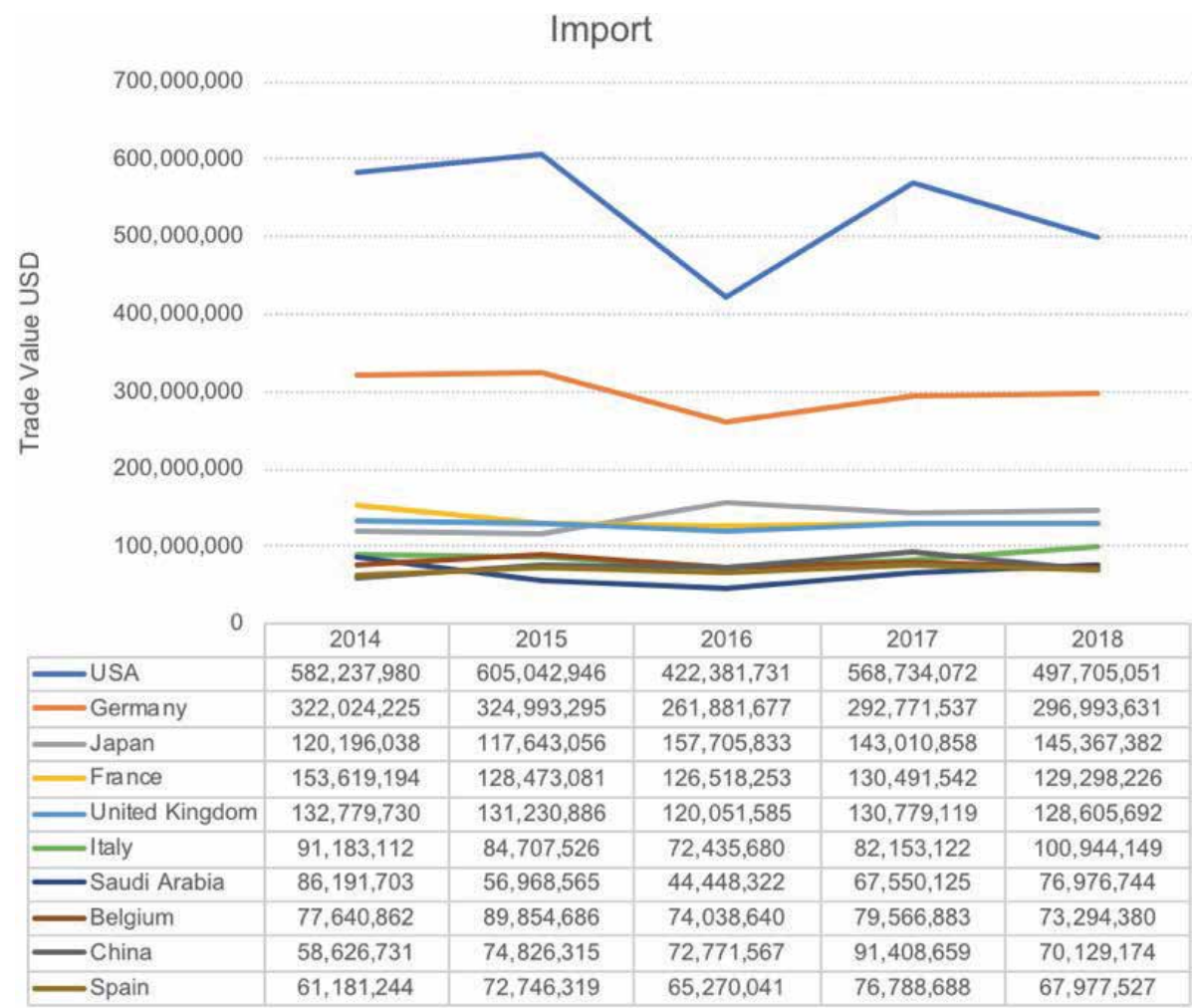

Figure 5.

Trade import value of honey 2014-2018. Top ten importing countries measured by 2018 [68]. 
attributes the rise in production to the increased demand. Garcia explains the increase in consumption by the increased world population and interest in natural nutrition [63]. The growing consumption of Honey can be explained to its image as a natural product that is not directly linked by society as a source of sugar and is, therefore, not associated with obesity [64]. However, Honey is rich in sugar and is not necessarily healthier [65]. Furthermore, Honey is also very popular within home medicine remedy $[66,67]$, contributing to increased consumption.

Many countries are no longer able to cover their domestic production needs and import Honey [63]. The trade import value from 2014 to 2018 is shown in Figure 5 and illustrates the high demand. By far, the USA had the highest import rate in 2018, followed by Germany and Japan, France, and the UK. The chart also displays that the USA and Germany's ranking remained constant over the period shown [68].

However, to answer which export market is the most promising for the Brazilian community, no reports exist in the literature. Thus, adopting a pragmatic approach, we will concentrate on the two largest importers, the USA and Germany.

\section{The US and German honey market}

With imports of $197,866,579 \mathrm{~kg}$, the USA offers a higher volume than Germany with 82,483,285 kg, in 2018, which makes the market opportunities in the USA appear more promising. However, comparing the revenues it in the USA (EUR 2.14/kg) was gained less than in Germany (EUR 2.85/kg) [68] and looking at the EU import prices of Brazil Honey (EUR 3.34/kg) is even higher in 2018 [69]. However, depending on the use, quality (e.g., conventional, organic), and distribution channel of the Honey, a substantial price differentiation occurs in Germany [70-72]. In contrast, the USA has little or no price differentiation between conventional and organic Honey [73]. Also, the United States Department of Agriculture shows a significant drop in organic Honey prices in 2018; it shows a price alignment within the US market [74].

In 2019, the EU concluded a free trade agreement with the Mercosur states (Argentina, Brazil, Paraguay, and Uruguay), under which around 92\% of taxes on imported goods are to be abolished. Accordingly, it can be presumed that revenues from sales to the EU will increase further. However, within the agreement, the Mercosur states have committed themselves to sustainable forest management [75]. Klöckner (Federal Minister of Agriculture from Germany) emphasized under the current rainforest clearing that if Brazil does not meet its commitment to sustainable forest management, the German government will not accept it inactively [76]. Germany also supports Brazil within the framework of the "bilateral development cooperation," which (as of 20 February 2020) supports 104 projects and programs with a total of EUR 1.76 billion [77]. Nevertheless, it should be noted that the EU is in favor of stringent product safety regulations [78-85]. Thus, the barriers to selling a food product on the EU market are correspondingly high.

Guaranteeing the safety of products is also essential in the USA. The Food and Drug Administration (FDA) regulates the guidelines for food. Production facilities and dealers must be registered with the FDA [86]. The USA also has Honey specific regulations such as proper labeling "FDA-2006-P-0207" [87]. In 2014, the Agricultural Marketing Service had asked: "How a Federal standard of identity for Honey would be in the interest of consumers, the Honey industry, and US agriculture?" [88]. Moreover, it responds to various petitions that demand such clarification [88]. In principle, there is also significant economic cooperation between the USA and Brazil. The USA claims to be the second largest trading partner of Brazil, which resulted in an overall trade surplus of more than USD 20 billion on the part of the USA in 2017 [89]. 
On the fact sheet "Bilateral Relations between the USA and Brazil," it is pointed out that both countries have, among other things, “...respect for human rights,..." as a shared commitment and refer to the Partnership for Conservation of Amazon Biodiversity (PCAB). The PCAB intends to strengthen Brazil's vast protected area systems with USD 80 million over 2016-2024, including Indigenous territories to support the “...sustainable forest-friendly value chains..." [89]. However, because of the previously presented policy of Bolsonaro [29,33], and Trump's trade wars, which reinforces Bolsonaro's clearing policy [90], the achievement of the project's objectives is questionable.

This paper suggests concentrating on the German market as an export country. Firstly, because Germany financially values Brazilian Honey in its conventional and organic form. Secondly, Germany's political attitude is an advantage for Quilombola, as it is the opposite of Trump's policy indirectly supporting the deforestation of the rainforest. Thirdly, Germany, together with the EU, is facilitating the export of many products through tax cuts. Lastly, concentrate on the German market on the first-hand makes it is easier to expand the export market to other EU countries such as France and Italy, which also have high imports. Therefore, the German market is for the export of Quilombola Honey more interesting.

\section{Protection of the rainforest in the international trade}

In the international context, Brazil is under increasing pressure concerning deforestation in the Amazon region. Since president Bolsonaro initially refused to accept the G7 countries' offer of help to fight the forest fires in the Amazon in August 2019, Brazil's governors had feared international punitive measures [76]. Within this context, afraid of the implications of the neglecting attitude from the national government and its aggressive promotion of extractivist production policies for the Amazon; Barbalho (Governor of Para) said: "I think we should now address our problems and send a signal to the world of environmental diplomacy because it is fundamental to (our) agriculture. Otherwise, we will suffer serious damage to our image, which is already a cause for concern." [76].

To understand the rate of deforestation concerning the country's total area, Brazils' forest area was around $67 \%$ of the territory in 1990 and only around 60\% in 2010 [91]. According to Brazil's National Space Research Institute [92], which is publishing the official numbers of rainforest deforestation, estimates around $10,129 \mathrm{~km}^{2}$ for the period from August 2018 to July 2019, which is 3.8\% higher than the government estimated in November 2019 (Figure 6). This dynamic is aggravated by the fact that the rainforest's clearing will prolong the drought periods [41]. This behavior creates a vicious circle because, with increasing periods of drought, the effect of self-reinforcing forest loss would occur, estimating that the self-reinforcing forest loss could cause up to 10-13\% additional rainforest death [94].

Despite these warnings, the Brazilian government does not seem to care about international pressure to reduce or even wholly refrain from clearing [76]. Evidence of this challenging - and even displacing - attitude is the fact that the Brazilian government is planning to step up its deforestation efforts. Ricardo Salles (current Brazilian Minister of the Environment) wants to take advantage of the COVIT19 pandemic to change and simplify rainforest deforestation regulations so that mining, agroindustry, and lumberjacks would get even easier and legal access to the rainforest [30]. INPE [92] has accordingly established a record number of $1200 \mathrm{~km}^{2}$ of deforestation from January to April 2020; this is over 50\% more than in the same period in 2019. 


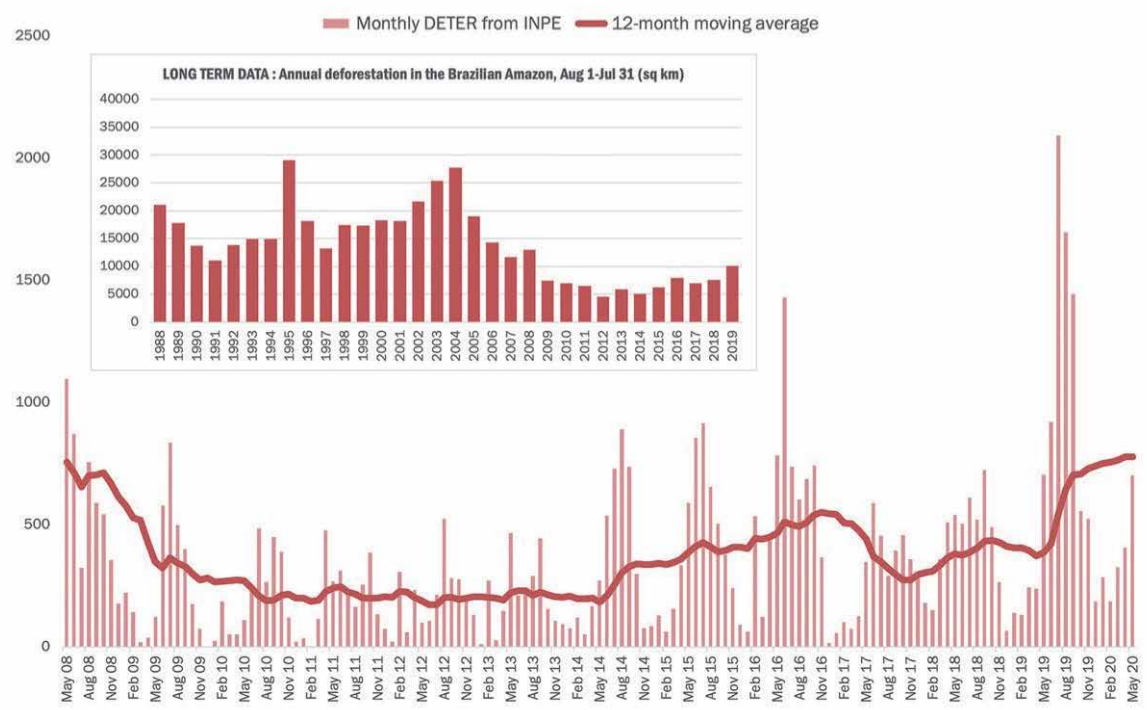

Figure 6.

Monthly deforestation alert data 2008-2020 plus yearly data 1988-2019 (from [93]). Note the peaks on the years 1995 and 2004 and their coincidence with the period of expansion of the green frontier, and the IIRSA plan for the development of big projects of infrastructure in the Amazon region.

In July 2020, 39 Brazilian companies, including some of the country's largest, have started to build up further pressure on the region - towards refraining the deforestation in the Amazon. The reason for the companies' reaction is that their international investors are threatening to withdraw their funds if the Brazilian government does not stop the rapid destruction of the country's forests [45]. Relevant to the case of the north and northeast of Brazil, Coe et al. [41] say that "...indigenous lands, sustainable-use production forests and reserves, and strictly protected forests..." are core elements of rainforest conservation. Especially Amazon's traditional peoples are rainforest protectors, as they live in and from the rainforest [25].

\section{Final remarks}

Some elements of the economic activity of the traditional people of the Amazon seem to be of practical use for the preservation of the rainforest. For instance, cultural practices that do not demand large extensions of territory and do not substantially affect the forest and its biodiversity. In particular, the Quilombola communities are of interest due to their focal ubication in the north of the Amazon, their family structure, and their forms of use of the land; concentrated in the production of food, the development of crops, and harvest of Amazon fruits (e.g., Acai) and the production of Honey. Out of these products, Honey seems to be the one that benefits the most from the existence of a healthy forest. Moreover, its development does not affect the forest and plays an essential role in its preservation (e.g., pollination services); Honey production does not compete with other agroforest products; it actually complements and benefits from them.

Economically, Honey has been documented in other communities as a successful product able to induce economic inclusion, even with the potential to bypass local constrains by targeting and gaining receptivity in international markets. Additionally, due to their production's biophysical characteristics, it has the potential to be certified as organic, fair trade, rainforest friendly, and many other 
certification schemes such as forest-friendly value chain. These certifications provide the possibility of better reception and value in some international markets. However, the development of such initiatives in Para presents some challenges: the formalization of these communities' land ownership and legal security is a significant deterrent to investment. Also, these communities' location in areas with difficult access and no infrastructure makes the logistics cost of developing a reliable provision to international markets too risky and expensive.

Politically, despite the current hostile environment under Bolsonaros' administration, it is evident that such policies are not sustainable in the middle/long-term. These practices depend on the prevalence of an ideology losing support both in the national and the international arena. Additionally, intense pressure is being made by international investors and governments from which Brazil depends to activate and support its economic development. This fact adds to the reaction of local governments in Brazil who are starting to act in opposition to Bolsonaro's policies as a consequence of the international pressure. Adding to these limitations is the fact that these communities do not have experience in international trade. However, historically they have proved to be adaptable and resilient. Also, considering the examples of other communities with similar products in Mexico and Brazil, it is reasonable to believe that this issue is not an impediment.

From the market perspective, there is an opportunity to position Honey in the international market as demand increases, particularly in the two biggest markets. In general, the case for Honey suggests that the development of commercial opportunities for traditional Amazon products, directly from the traditional people of the Amazon is not just feasible but desirable. Considering the potential for the development of socio-economic inclusion, the protection (and eventually the regeneration of) in some areas of the Amazon, and preserving the culture and biodiversity; the promotion of plans to capitalize on these productive activities should be better articulated among interested parties internationally - especially from countries interested in importing such products.

\section{Author details}

Anna Kanele and Pedro Pablo Cardoso Castro*

Leeds Beckett University, Great Britain

*Address all correspondence to: p.p.cardoso-castro@leedsbeckett.ac.uk

IntechOpen

(C) 2020 The Author(s). Licensee IntechOpen. This chapter is distributed under the terms of the Creative Commons Attribution License (http://creativecommons.org/licenses/ by/3.0), which permits unrestricted use, distribution, and reproduction in any medium, provided the original work is properly cited. (cc) BY 
Quilombo Communities and Opportunities for Market-Driven Mechanisms for the Protection... DOI: http://dx.doi.org/10.5772/intechopen.93976

\section{References}

[1] Encyclopaedia Britannica (2020). Para state, Brazil. [Online]. Available from: https://www.britannica.com/ place/Para-state-Brazil [Accessed 5 August 2020].

[2] IBGE (2019). Areas Territoriais. [Online]. Available from: https://www. ibge.gov.br/geociencias/organizacaodo-territorio/estrutura-territori al/15761-areas-dos-municipios. html?=\&t=downloads [Accessed 5 August 2020].

[3] Pereira, L., Mendes, C., Monteiro, M. and Asp, N. (2009). Morphological and Sedimentological Changes in a Macrotidal Sand Beach in the Amazon Littoral (Vila Dos Pescadores, Pará, Brazil). Journal of Coastal Research, 56 (1), pp. 113-117, [Online].

Available from: https://www.jstor.org/ stable/25737548?seq=1\# metadata_ info_tab_contents [Accessed 11 August 2020].

[4] Furtado Gonçalves, M., Cavalcante Blanco, C., dos Santos, V., dos Santos Oliveira, L. and Lira Pessoa, F. (2016). El Niño and La Niña and Rainfall Decrease in the state of Pará, Brazilian Amazon. Acta Scientiarum, 38 (2), pp. 209-216, [Online]. Available from: https://www.redalyc.org/ pdf/3032/303245370010.pdf [Accessed 5 August 2020].

[5] IMF (2019). Population: Brazil. International Monetary Fund, October, [Online]. Available from: https://www. imf.org/external/datamapper/LP@WEO/ BRA [Accessed 28 March 2020].

[6] Burns, N. (2019). Indigenous and Quilombola Land Demarcation in Brazil. Wilson Center: Brazil Institute, January, [Online]. Available from: https://www. wilsoncenter.org/article/ indigenous-and-quilombola-landdemarcation-brazil [Accessed 28 March 2020].
[7] Prado, M. (2018). Quilombola Communities of Brazil. Wilson Center: Brazil Institute, August, [Online]. Available from: https://www. wilsoncenter.org/article/quilombolacommunities-brazil [Accessed 28 March 2020].

[8] Google Scholar (2020a). Indigenous Communities. Available from: https:// scholar.google.com/scholar?hl=de\&as_ $\mathrm{sdt}=0 \% 2 \mathrm{C} 5 \& \mathrm{q}=$ indigenous + communiti es\&btnG $=$ [Accessed 23 July 2020].

[9] Google Scholar (2020b). Quilombola Communities. Available from: https:// scholar.google.com/scholar?hl=de\&as_ $\mathrm{sdt}=0 \% 2 \mathrm{C} 5 \& \mathrm{q}=$ Quilombola + communit ies\&btnG = [Accessed 23 July 2020].

[10] Salles, V. (1988). O Negro no Pará sob o regime de escravidão. Cited in: Andrade, L. (2002) THE QUILOMBOS OF THE TROMBETAS RIVER BASIN: BRIEF HISTORY. [Online]. Available from: https://www.academia. edu/34345324/THE_QUILOMBOS_OF_ THE_TROMBETAS_RIVER_BASIN_ BRIEF_HISTORY [Accessed 7 August 2020].

[11] Survival International (2020). Brazilian Indians. [Online]. Available from: https://www. survivalinternational.org/tribes/ brazilian [Accessed 5 March 2020].

[12] Ruffato, L. (2013).

Rassendemokratie ist ein Mythos. Festrede zur Eröffnung der Buchmesse 2013. Faust Kultur, Translation: Kegel, M. Available from: https://faustkultur. de/1456-0-Festrede-von-Luiz-Ruffato. html\#.U9H_trXlpdg [Accessed 7 July 2020].

[13] Andrade, L. (2002). The Quilombolos of the Trombetas River Basin: Brief History. [Online]. Available from: https://www. academia.edu/34345324/THE_ 
QUILOMBOS_OF_THE_TROMBETAS_ RIVER_BASIN_BRIEF_HISTORY [Accessed 7 August 2020].

[14] WCS (2020). Trombetas. Wildlife Conservation Society. [Online]. Available from: http://amazonwaters. org/basins/great-sub-basins/trombetas/ [Accessed 10 August 2020].

[15] INCRA (2019). Andamento dos Processos - Quadro Geral. Casa Civil da Presi-dência da República Instituto Nacional de Colonização e Reforma Agrária Diretoria de Ordenamento da Estrutura Fundiária Coordenação Geral de Regularização de Territórios Quilombolas - DFQ, January, [Online]. Available from: http://www.incra. gov.br/media/docs/quilombolas/ andamento_processos.pdf [Accessed 11 August 2020].

[16] Gubert, M., Segall-Correa, A., Pedroso, J., Campos Coelho, S. and Perez-Escamilla, R. (2017). Household food insecurity in black-slaves descendant communities in Brazil: has the legacy of slavery truly ended?. Public Health Nutrition, 29 (8), pp. 1513-1522, [Online]. Available from: https://www.cambridge.org/core/ journals/public-health-nutrition/ article/household-food-insecurityin-blackslaves-descendantcommunities-in-brazil-has-the-legacyof-slavery-truly-ended/486C22F 7D836B6ECBCB16BC3AD61F98D/corereader [Accessed 11 August 2020].

[17] Planas, R. (2017). Brazil's

'Quilombo' Movement May Be The World's Largest Slavery Reparations Program. Huffpost, updated December, Original: October, 2014, [Online]. Available from: https://www.huffpost. com/entry/brazil-quilombos_n_557 2236? guccounter $=1$ [Accessed 7 July 2020].

[18] Campos Lima, E. (2020). Brazil is the epicenter of the Covid-19 pandemic in Latin America. Rural communities have it worse. America Magazine, May, [Online]. Available from: https://www.americamagazine. org/politics-society/2020/05/27/ brazil-epicenter-covid-19-pandemiclatin-america-rural-communities-have [Accessed 4 August 2020].

[19] Dancey-Downs (2018). How beekeeping has turned around the lives of a community in Brazil. Ecologist: The Journal for the Post-Industrial Age, May, [Online]. Available from: https:// theecologist.org/2018/may/04/howbeekeeping-has-turned-around-livescommunity-brazil [Accessed 18 March 2020].

[20] Berr, K. and Jenal C. (2019).

Landschaftskonflikte. Chapter written by Neuburger, M. and Rau, R. Die Kolonialität der brasilianischen Energielandschaft. Wiesbaden: Springer, [Online]. Available from: https://books. google.co.uk/books?id=XiaeDwAAQBA $\mathrm{J} \& \mathrm{pg}=\mathrm{PA} 495 \& \mathrm{lpg}=\mathrm{PA} 495 \& \mathrm{dq}=$ bedrohu ng +quilombola\&source $=$ bl\&ots $=$ BKjpbf zhBu\&sig=ACfU3U1wZkR0muq0s70P0 90kieDKg26CHA\&hl=de\&sa $=X \& v e d=2-$ ahUKEwjv37a4s7_oAhVRqHEKHZfLC jYQ6AEwA3oECAoQAQ\#v=onepage \& $\mathrm{q}=$ bedrohung\%20quilombola $\& \mathrm{f}=$ false [Accessed 29 March 2020].

[21] Moloney, A. (2020). Deforestation in Brazil's Amazon two-thirds lower on titled indigenous land. Reuters, August, [Online]. Available from: https://www.reuters.com/article/ us-brazil-forests-indigenous-rights/ deforestation-in-brazils-amazon-twothirds-lower-on-titled-indigenous-landidUSKCN2562GH [Accessed 12 August 2020].

[22] CPISP (2019). Quilombolas communities in Brazil. Comissao Pro-Indio de Sao Paulo, [Online]. Available from: https://cpisp.org.br/ direitosquilombolas/observatorioterras-quilombolas/quilombolascommunities-in-brazil/ [Accessed 7 August 2020]. 
[23] CAISAN (2013). Direitos territoriais e patrimoniais dos povos indígenas e quilombolas - contribuições ao debate da XI Plenária do Consea - agosto de 2013. Interministerial Chamber for Food and Nutrition Security, [Online]. Available from: http://www.mds.gov. br/webarquivos/arquivo/seguranca alimentar/caisan/caisan_nacional/ documentos/terra_territorio/Subsidio_ CAISAN_Plenaria_CONSEA_Direitos_ Territoriais_agosto_2013.pdf [Accessed 12 August 2020].

[24] Watts, J. (2017). Brazil abolishes huge Amazon reserve in "biggest attack" in 50 years. The Guardian, August, [Online]. Available from: https://www. theguardian.com/environment/2017/ aug/24/brazil-abolishes-huge-amazonreserve-in-biggest-attack-in-50-years [Accessed 4 August 2020].

[25] Harris, B., Cowie, S., Schipani, A. and Gross, A. (2019). Powerful interests pose threat to Amazon's forest communities. Financial Times, December, [Online]. Available from: https://www.ft.com/ content/355966ba-e539-11e9-b8e0026e07cbe5b4 [Accessed 28 March 2020].

[26] Campos Lima, E. (2019). What the Catholic Church is doing to protect the Amazon in Bolsonaro's Brazil. America Magazine, October, [Online]. Available from: https://www.americamagazine. org/politics-society/2019/10/22/whatcatholic-church-doing-protect-amazonbolsonaros-brazil [Accessed 7 August 2020].

[27] Sullivan, Z. (2018). Illegale Abholzung und Bergbau bedrohen Gemeinde im Amazonasgebiet. Deutsche Welle, October, [Online]. Available from: https://www. dw. com/de/illegale-abholzung-undbergbau-bedrohen-gemeinden-imamazonasgebiet/a-45656372 [Accessed 7 August 2020].

[28] Cowie, S. (2018). Präsident Bolsonaro bedroht Brasiliens Regenwald
- Schlechte Nachrichten für Brasiliens Umwelt: Der gerade gewählte, rechtsradikale Präsident Jair Bolsonaro möchte Umweltagenturen schließen und industriellen Großprojekten im Amazonas-Regenwald den Weg ebnen. Deutsche Welle, [Online], October. Available from: https://www.dw.com/ de/präsident-bolsonaro-bedrohtbrasiliens-regenwald/a-46079231 [Accessed 1 February 2020].

[29] The Intercept Brasil (2017).

Bolsonaro faz discurso de ódio no Clube Hebraica. April. Available from: https:// www.youtube.com/watch?v=zSTdTjsio5g [Accessed 7 July 2020].

[30] Käufer, T. and Samuel, R. (2020). Die Welt schaut weg - und Brasilien holzt ab. Welt.de, June. Available from: https://www.welt.de/politik/ausland/ article2090 76003/Regenwald-Die-Weltschaut-weg-und-Brasilien-holzt-ab.html [Accessed 5 July 2020].

[31] Boadle, A. (2019). Brazil's Bolsonaro hands indigenous land decisions back to farm sector. Reuters, June, [Online]. Available from: https://www.reuters.com/article/ us-brazil-politics-indigenous/ brazils-bolsonaro-hands-indigenousland-decisions-back-to-farm-sectoridUSKCN1TK37O [Accessed 12 August 2020].

[32] Senpinar, R. (2019). Die Indigenen müssen um ihr Leben fürchten Goldgräber und Sojafarmer verdrängen Einheimische im Amazonas. Wie die Indigenen unter den Bränden leiden, erzählt die Mitarbeiterin einer Hilfsorganisation. Zeit Online, [Online], August. Available from: https://www.zeit.de/2019-08/brasilienindigene-voelker-waldbraendesurvival-international-ngo [Accessed 1 February 2020].

[33] Russau, C. (2020). Schwerer Verbalangriff der FUNAI auf Indigenemissionsrat CIMI und 
internatile Geldgeber. Kooperation Brasilien, May. Available from: https:// www.kooperation-brasilien.org/ de/themen/landkonflikte-umwelt/ schwerer-verbalangriff-der-funaiauf-indigenenmissionsrat-cimi-undinternationale-geldgeber [Accessed 5 July 2020].

[34] Penna-Firme and Brondizio, E. (2007). The risk of commodifying poverty: rural communities, Quilombola identity and nature conservation in Brazil. Habitus, 5 (2), pp. 355-373, [Online]. Available from: http://seer. pucgoias.edu.br/index.php/habitus/ article/view/541/431 [Accessed 11 August 2020].

[35] Silva, A., Alves, C., Fernandes, K. and Müller, R. (2013). Classification of Honeys from Pará State (Amazon Region, Brazil) Produced by Three Different Species of Bees using Chemometric Methods. Journal of the Brazilian chemical society, 24 (7), pp. 1135-1145, [Online]. Available from: http://static.sites.sbq.org.br/jbcs.sbq. org.br/pdf/v24n7a07.pdf [Accessed 13 August 2020].

[36] Fernandes, R., Rosa, I. and ContiSilva, A. (2020). Honey from Tibua stingless bees (Melipona fasciculata) produced in different ecosystems: physical and sensory studies. Journal of the Science of Food and Agriculture, 100 (9), pp. 3748-3754, [Online]. Available from: https://onlinelibrarywiley-com.ezproxy.leedsbeckett.ac.uk/ doi/epdf/10.1002/jsfa.10415 [Accessed 13 August 2020].

[37] DW (2019a). Mexiko: Tonnenweise Bio-Honig für Deutschland. Deutsche Welle, February, [Online]. Available from: https://www.dw.com/de/ mexiko-tonnenweise-bio-honig-fürdeutschland/a-47406856 [Accessed 7 March 2020].

[38] Hanson, T. (2019). Why have $500 \mathrm{~m}$ bees died in Brazil in the past three months?. The Guardian, August, [Online]. Available from: https://www. theguardian.com/commentisfree/2019/ aug/29/500-million-bees-brazil-threemonths [Accessed 28 March 2020].

[39] Grigori, P. (2019). Half a billion bees dead as Brazil approved hundreds more pesticides. Mongabay, August, [Online]. Available from: https://news.mongabay. com/2019/08/half-a-billion-bees-deadas-brazil-approves-hundreds-morepesticides/ [Accessed 28 March 2020].

[40] dos Santos, C. and de Oliveira, V. (2017). Trends in Extreme Climate Indices for Para State, Brazil. Revista Brasileira de Meteorologia, 32 (1), pp. 13-24, [Online]. Available from: https:// www.scielo.br/pdf/rbmet/v32n1/01027786-rbmet-32-01-0013.pdf [Accessed 5 August 2020].

[41] Coe, M., Marthews, T., Costa, M., Galbraith, D., Greenglas, N., Imbuzeiro, H., Levine, N., Malhi, Y., Moorcroft, P., Muza, M., Powell, T., Saleska, S., Solorzano, L. and Wand, J. (2013). Deforestation and climate feedbacks threaten the ecological integrity of south-southeastern Amazonia. Philosophical transactions of the royal society, 368 (1619), June, [Online]. Available from: https:// royalsocietypublishing.org/doi/full/ 10.1098/rstb.2012.0155 [Accessed 6 August 2020].

[42] Martorano, L., Vitorino, M., da Silva, B., de Moraes, J., Lisboa, L., Sotta, E. and Reichardt, R. (2017) Climate conditions in the eastern amazon: Rainfall variability in Belem and indicative of soil water deficit. African Journal of Agricultural Research, 12 (21), May, pp.1801-1810, [Online]. Available from: https://pdfs. semanticscholar.org/ 6a41/07d4b38 12f212a407fc18c7ed526a9b0f1c4.pdf [Accessed 28 March 2020].

[43] FIRMS and NASA (2019). Cited in: ZDF (2020). Zerstörung des 
Amazonas-Walds nimmt stark zu. January, [Online]. Available from: https://www.zdf.de/nachrichten/ panorama/amazonas-wald-zerstoerungdrastisch-zugenommen-100.html [Accessed 12 August 2020].

[44] Pendrill, F., Persson U., Gobar, J., Kastner, T., Moran, D., Schmidt, S. and Wood, R. (2019). Agricultural and forestry trade drives large share of tropical deforestation emissions. Global Environmental Change, 56, pp. 1-10, [Online]. Available from: https://reader. elsevier.com/reader/sd/pii/S0959378018 314365?token $=2$ F8B4E74FAB2F0F21CC 1A14A0E619DC516B728FB569FA44ECE 38523608B1C58CE45C86B96961795DD CEA7CBB19145C6F [Accessed 7 August 2020].

[45] Spiegel (2020) Brasilianische Firmen machen Druck gegen Regenbwaldzerstörung. Spiegel Wirtschaft, July, [Online]. Available from: https://www.spiegel. de/wirtschaft/unternehmen/ brasilianische-firmen-machen-druckgegen-regenwald-zerstoerung-a10143ab9-0918-4525-aff8-52095bd85c58 [Accessed 6 August 2020].

[46] Bosma, W., Suti, S. and Deeks, P. (2017). Beekeeping as Pro-forest Income Diversification in Solomon Islands. Part of the Climate Change Management book series, Springer, February, [Online]. Available from: https://link.springer.com/ chapter/10.1007/978-3-319-50094-2_23 [Accessed 18 March 2020].

[47] Lowore, J., Meaton, J. and Wood, A. (2018). African Forest Honey: an Overlooked NTFP with Potential to Support Livelihoods and Forests. Environmental Management, 62, pp. 15-28, [Online]. Available from: https://link.springer. com/article/10.1007/s00267-018-1015-8 [Accessed 18 March 2020].

[48] Watts, J. (2019). Bees in Amazon 'are greatest ally to halt rainforest destruction'. The Guardian, December, [Online]. Available from: https://www. theguardian.com/society/2019/dec/06/ bees-in-amazon-are-greatest-ally-tohalt-rainforest-destruction [Accessed 18 March 2020].

[49] Mavhunga, C. (2017). Ein süßer Neuanfang in Simbabwe - Bäume retten mit Honig. Deutsche Welle, June, [Online]. Available from: https:// www.dw.com/de/ein-süßer-neuanfangin-simbabwe-bäume-retten-mithonig/a-39430726 [Accessed 6 August 2020].

[50] Carvalho, G., Ribeiro, M., Araujo, A., Barbosa, M. Oliveira, F. and Albuquerue, P. (2016). Flora de importancia polinica utilizada por Melipona (Melikerria) fasciculata Smith, 1854 (Hymenoptera: Apidae:Meliponini) em uma area de foresta amazonica na regiao da baixada maranhense. Brasil Oecologia Australis, 20, pp. 58-68. Cited in: Fernandes, R., Rosa, I. and Conti-Silva, A. (2020) Honey from Tibu stingless bees (Melipona fasciculata) produced in different ecosystems: physical and sensory studies. Journal of the Science of Food and Agriculture, 100 (9), pp. 3748-3754, [Online]. Available from: https://onlinelibrary-wileycom.ezproxy.leedsbeckett.ac.uk/doi/ epdf/10.1002/jsfa.10415 [Accessed 13 August 2020].

[51] Bezerra, F., Bernardo, T., Ximenes, L. and Valente Junior A. (2015). Perfil socio-econômico do Maranhão. Banco do Nordeste do Brasil, Fortaleza. Cited in: Fernandes, R., Rosa, I. and ContiSilva, A. (2020) Honey from Tibu stingless bees (Melipona fasciculata) produced in different ecosystems: physical and sensory studies. Journal of the Science of Food and Agriculture, 100 (9), pp. 3748-3754, [Online].

Available from: https://onlinelibrarywiley-com.ezproxy.leedsbeckett.ac.uk/ doi/epdf/10.1002/jsfa.10415 [Accessed 13 August 2020]. 
[52] Rodgers, C. (2018) Indigenous People of Brazil. Wilson Center: Brazil Institute, January, [Online]. Available from: https://www.wilsoncenter.org/ article/indigenous-peoples-brazil [Accessed 28 March 2020].

[53] IBGE (2020) Projeção da população do Brasil e das Unidades da Federação. Istituto Brasileiro de Geografia e Estatistica, [Online]. Available from: https://www. ibge. gov.br/apps/populacao/projecao/ index.html?utm_source=portal\&utm medium=popclock\&utm campaign=novo_popclock [Accessed 28 March 2020].

[54] INPE (2019). cited in: Butler, R. (2019) Amazon deforestation rises to 11 year high in Brazil. Mongabay, November. Available from: https:// news.mongabay.com/2019/11/amazondeforestation-rises-to-11-year-high-inbrazil/ [Accessed 7 July 2020].

[55] Silva, N. (2000) Extensão e natureza das desigualdades raciais no Brasil. In A. S. A. Guimarães \& L. Huntley (Orgs.), Tirando a máscara: ensaios sobre o racismo no Brasil, pp. 33-51. São Paulo: Paz e Terra. Cited in: Costa, E. and Scarcelli, I. (2016) Psychology, public policy for quilombola populations and racism. Psicol, 27 (2), [Online]. Available from: https://www.scielo.br/scielo. php?script=sci_arttext\&pid=S010365642016000200357\&lng=pt\&tlng=pt [Accessed 6 August 2020].

[56] Brandao, A., da Dalt, S. and Gouveia, V. (2010). Comunidades quilombolas no Brasil: características socioeconômicas, processos de etnogênese e políticas sociais. Cited in: Costa, E. and Scarcelli, I. (2016) Psychology, public policy for quilombola populations and racism. Psicol, 27 (2), [Online]. Available from: https://www.scielo.br/scielo. php?script=sci_arttext $\&$ pid $=$ S010365642016000200357\&lng=pt\&tlng=pt [Accessed 6 August 2020].
[57] Hormel, U. and Scherr, A. (2010). Diskriminierung - Grundlagen und Forschungsergebnisse. Wiesbaden: Springer VS.

[58] Rotondano, R. (2019). Brazilian apartheid: racism and segregation in Salvador, Brazil. International Journal of Sociology and Social Policy, 39 (11/12), pp. 950-961, [Online]. Available from: https://www-emerald-com.ezproxy. leedsbeckett.ac.uk/insight/content/ doi/10.1108/IJSSP-12-2018-0228/full/ pdf?title=brazilian-apartheid-racismand-segregation-in-salvador-brazil [Accessed 8 August 2020].

[59] Behrman, J., Gaviria, A. and Szekely, M. Social Exclusion in Latin America. In: Behrman, J., Gaviria, A. and Szekely, M. (2003). Who's in and Who's out - Social Exclusion in Latin America. Washington: IDB Publications, [Online]. Available from: https://books.google.de/books?hl=en\& $\mathrm{lr}=$ \&id=LvEzYAfbSh0C\&oi=fnd \&pg = PP5\&dq=social+status+segregation + in digenous\&ots=IJtecdMX1L \&sig=8U5V 9nytIn-ohb9MvVwf_tz_UFvE\&redir_ esc $=\mathrm{y} \# \mathrm{v}=$ onepage $\& \mathrm{q}=$ social $\% 20$ status $\% 20$ segregation $\% 20$ indigenous $\& \mathrm{f}=$ false [Accessed 7 August 2020].

[60] Firmenich (2015) FIRMENICH NAMES HONEY THE 2015 'FLAVOR OF THE YEAR'. December, [Online]. Available from: https://www.firmenich. com/en_INT/company/news/flavorof-the-year.html [Accessed 14 March 2020].

[61] FAO (2019). Food and Agriculture Organization of the United Nations. February. Cited in: Shahbandeh, M. (2020). Global production volume of natural honey in 2000-2017. Statista, February, [Online]. Available from: https://wwwstatista-com.ezproxy.leedsbeckett. ac.uk/statistics/755215/natural-honeyproduction-volume-worldwide/ [Accessed 6 March 2020]. 
[62] Orbis Research (2018). Cited in: Shahbandeh, M. (2018) Forecast value of organic honey market worldwide from 2017 to 2023. Statista, October, [Online]. Available from: https://wwwstatista-com.ezproxy.leedsbeckett.ac.uk/ statistics/933490/global-organic-honeymarket-value/ [Accessed 6 March 2020].

[63] Garcia, N. (2018). The Current Situation on the International Honey Market. International Bee Research Association, Bee World, 95 (3), July, pp.89-94, [Online]. Available from: https://www.tandfonline.com/doi/abs/1 0.1080/0005772X.2018.1483814?journal Code=tbee20 [Accessed 6 March 2020].

[64] Carreck, N. (2018) Special issue: Honey. Journal of Apicultural Research, 57 (1), January, [Online]. Available from: https://www.tandfonline.com/ doi/full/10.1080/00218839.2017.1412565 ?src=recsys [Accessed 10 March 2020].

[65] Menn (n.d.) Honig: Gesund essen. Bundeszentrum für Ernährung, [Online]. Available from: https://www.bzfe.de/ inhalt/honig-gesund-essen-33942.html [Accessed 8 March 2020].

[66] Pasupuleti, V., Sammugam, L., Ramaseh, N. and Gan, S. (2017) Honey, Propolis, and Royal Jelly: A Comprehensive Review of Their Biological Actions and Health Benefits. Oxidative Medicine and Celluar Longevity (Oxid Med Cell Longev), July, [Online]. Available from: https:// www.ncbi.nlm.nih.gov/pmc/articles/ PMC5549483/ [Accessed 8 March 2020].

[67] Hery-Moßmann, N. (2017). Honig als Heilmittel - so funktioniert's. Focus Online, August, [Online]. Available from: https://praxistipps.focus.de/honigals-heilmittel-so-funktionierts_95273 [Accessed 8 March 2020].

[68] U.N. (2020) Comtrade. [Online]. Available from: https://comtrade. un.org/data/ [Accessed 6 March 2020].
[69] CMO (2019) Honey Market

Presentation. European Commission, April, [Online]. Available from: https:// ec.europa.eu/info/sites/info/files/ food-farming-fisheries/animals_and_ animal_products/presentations/marketpresentation-honey_en.pdf/ [Accessed 6 March 2020].

[70] ProFound (2015a). Cited in: CBI (2015a) CBI Product Factsheet: Industrial honey in Germany. Center for the Promotion of Imports, November [Online]. Available from: https://www.cbi.eu/sites/default/ files/market_information/researches/ product-factsheet-germany-industrialhoney-2015.pdf [Accessed 14 March 2020].

[71] ProFound (2015b). Cited in: CBI (2015b) CBI Product Factsheet: Organic honey in Germany. Center for the Promotion of Imports, November [Online]. Available from: https://www. cbi.eu/sites/default/files/market_ information/researches/productfactsheet-germany-organic-honey-2015. pdf [Accessed 15 March 2020].

[72] CBI (2015b) CBI Product Factsheet: Organic honey in Germany. Center for the Promotion of Imports, November [Online]. Available from: https://www. cbi.eu/sites/default/files/market_ information/researches/productfactsheet-germany-organic-honey-2015. pdf [Accessed 15 March 2020].

[73] Phipps, R. (2018) International Honey Market. American Bee Journal, November. Available from: https:// www.apiservices.biz/documents/ articles-en/international_honey_ market_report_november_2018.pdf [Accessed 13 July 2020].

[74] USDA (2018) National

Honey Report. Cited in: NHB (2020) International Bulk Prices. National Honey Board, [Online]. Available from: https://www.honey. com/honey-industry/statistics/ 
international-bulk-prices [Accessed 13 July 2020].

[75] EC (2019). EU and Mercosur reach agreement on trade. European Commission, June, [Online]. Available from: https://ec.europa.eu/ commission/presscorner/detail/en/ IP_19_3396 [Accessed 14 March 2020].

[76] DW (2019b) Widerstand gegen Bolsonaros Amazonas-Politik. Deutsche Welle, August, [Online]. Available from: https://www.dw.com/ de/widerstand-gegen-bolsonarosamazonas-politik/a-50190837 [Accessed 6 August 2020].

[77] BMZ (2020) Brasilien: Bilaterale Entwicklungszusammenarbeit. Bundesministerium für wirtschaftiche Zusammenarbeit und Entwicklung, [Online]. Available from: https://www. bmz.de/de/ministerium/zahlen_fakten/ transparenz-fuer-mehr-Wirksamkeit/ iati/index.jsp [Accessed 7 March 2020].

[78] BMEL (2020) Sichere Lebensmittel. Bundesministerium für Ernähung und Landwirschaft [Online]. Available from: https://www.bmel.de/DE/ Ernaehrung /Sichere Lebensmittel/ sichereLebensmittel_node.html [Accessed 14 March 2020].

[79] EC (2002a) REGULATION (EC) No 178/2002 OF THE EUROPEAN PARLIAMENT AND OF THE COUNCIL of 28 January 2002: laying down the general principles and requirements of food law, establishing the European Food Safety. Official Journal of the European Communities, L31, pp. 1-24, February, [Online]. Available from: https://mobil. bfr.bund.de/cm/343/2002_178_en_efsa. pdf [Accessed 14 March 2020].

[80] EC (2002b) COUNCIL DIRECTIVE 2001/110/EC of 20 December 2001

relating to honey. Official Journal of the European Communities, L10, pp. 47-52, December, [Online]. Available from: https://eur-lex.europa.eu/legal-content/
EN/TXT/PDF/?uri=CELEX:32001L01

$10 \&$ from $=$ en [Accessed 14 March 2020].

[81] EC (2004). REGULATION (EC) No 852/2004 OF THE EUROPEAN PARLIAMENT AND OF THE COUNCIL of 29 April 2004: on the hygiene of foodstuffs. Official Journal of the European Communities, L139, April, [Online]. Available from: https://eurlex.europa.eu/LexUriServ/LexUriServ. do?uri=OJ:L:2004:139:0001:0054:en: PDF [Accessed 14 March 2020].

[82] EC (2011). REGULATION (EU) No 1169/2011 OF THE EUROPEAN PARLIAMENT AND OF THE COUNCIL of 25 October 2011: on the provision of food information to consumers, amending Regulations (EC) No 1924/2006 and (EC) No 1925/2006 of the European Parliament and of the Council, and repealing Commission Directive 87/250/EEC, Council Directive 90/496/EEC, Commission Directive 1999/10/EC, Directive 2000/13/EC of the European Parliament and of the Council, Commission Directives 2002/67/ EC and 2008/5/EC and Commission Regulation (EC) No 608/2004. Official Journal of the European Communities, L304, November, [Online]. Available from: https://eur-lex.europa.eu/ LexUriServ/LexUriServ.do?uri =OJ:L:2011:304:0018:0063:EN:PDF [Accessed 14 March 2020].

[83] EU (2018) REGULATION (EU) 2018/848 OF THE EUROPEAN PARLIAMENT AND OF THE COUNCIL of 30 May 2018: on organic production and labelling of organic products and repealing Council Regulation (EC) No 834/2007. Official Journal of the European Union, L150, June, [Online]. Available from: https://eur-lex.europa. eu/legal-con-tent/EN/TXT/?uri=u riserv:OJ.L_.2018.150.01.0001.01. ENG\&toc=OJ:L:20 18:150:TOC [Accessed 15 March 2020].

[84] EU (2019) COMMISSION IMPLEMENTING REGULATION 
(EU) 2019/2164 of 17 December 2019: amending Regulation (EC) No 889/2008 laying down detailed rules for the implementation of Council Regulation (EC) No 834/2007 on organic production and labelling of organic products with regard to organic production, labelling and control. Official Journal of the European Union, L328, December, [Online]. Available from: https://eur-lex. europa.eu/legal-con-tent/EN/TXT/?uri= uriserv:OJ.L_.2019.328.01.0061.01. ENG\&toc=OJ:L:2019:328:TOC [Accessed 15 March 2020].

[85] HonigV. (2020). Honigverordnung. Bundesministerium der Justiz und für Verbraucher, [Online]. Available from: https://www.gesetze-im-internet.de/ honigv_2004/BJNR009200004.html [Accessed 7 March 2020].

[86] FDA (2018a) Importing Food Products into the United States. Food and Drug Administration, March, [Online]. Available from: https://www. fda.gov/food/food-imports-exports/ importing-food-products-united-states [Accessed 18 March 2020].

[87] FDA (2018b) Proper Labeling of Honey and Honey Products: Guidance for Industry. Food and Drug Administration, February, [Online]. Available from: https://www.fda.gov/ files/food/published/PDF---Guidancefor-Industry--Proper-Labeling-ofHoney-and-Honey-Products.pdf [Accessed 18 March 2020].

[88] Federal Register (2014) United States Standard of Identity for Honey. August, [Online]. Available from: https://www.federalregister.gov/ documents/2014/08/20/2014-19770/ united-states-standard-of-identity-forhoney [Accessed 18 March 2020].

[89] State.Gov (2019) U.S. Relations with Brazil - Bilateral Relations Fact Sheet. October. Available from: https://www. state.gov/u-s-relations-with-brazil/ [Accessed 19 July 2020].
[90] Cullen, A. (2019) How Trump's trade wars are fueling the Amazon fires. The Guardian, September. Available from: https://www.theguardian.com/ commentisfree/2019/sep/01/brazilamazon-wildfires-trump-trade-wars [Accessed 19 July 2020].

[91] Imöhl, S. (2020) Die zehn größten Länder der Welt nach Fläche. Handelsblatt, January, [Online]. Available from: https://www. handelsblatt.com/politik/international/ top-ten-die-zehn-groessten-laenderder-welt-nach-flaeche/24428374. html?ticket=ST-563453iKegeqAR516Z207MZtAG-ap4 [Accessed 28 March 2020].

[92] INPE (2020) cited in: Gurk (2020) Der Regenwald als Beute. Süddeutsche Zeitung, May, Available from: https://www.sueddeutsche.de/ politik/brasilien-regenwald-bolsonaroabholzung-landraub-indigenecoronavirus-1.4906376 [Accessed 8 July 2020].

[93] INPE and DETER (2020) cited in: Butler, R. (2020) Brazil revises deforestation data: Amazon rainforest loss topped 10,000 km in 2019. Mongabay, June, [Online]. Available from: https://news.mongabay. com/2020/06/brazil-revisesdeforestation-data-amazon-rainforestloss-topped-10000-sq-km-in-2019/ [Accessed 4 August 2020].

[94] Zemp, D., Schleussner, C-F., Barbosa, H., Hirota, M., Montade, V., Sampaio, G., Staal, A., WangErlandsson, L. and Ramming A. (2017) Self-amplified Amazon forest loss due to vegetation-atmosphere feedbacks. Nature Communications, 8, Document nr. 14681, March, [Online]. Available from: https://www.nature.com/articles/ ncom ms14681.pdf [Accessed 6 August 2020]. 
